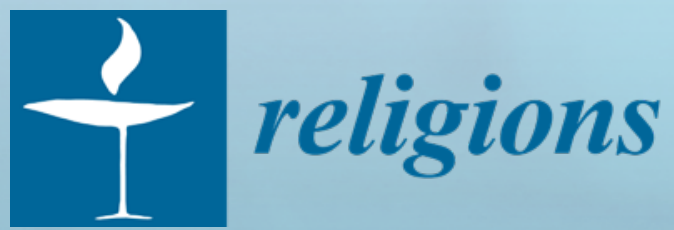

Leadership,

Authority and

Representation

in British Muslim

Communities

Edited by

Sophie Gilliat-Ray and Riyaz Timol

Printed Edition of the Special Issue Published in Religions 


\section{Leadership, Authority and Representation in British Muslim Communities}





\section{Leadership, Authority and Representation in British Muslim Communities}

Editors

Sophie Gilliat-Ray

Riyaz Timol 
Editors

Sophie Gilliat-Ray

Riyaz Timol

Cardiff University

Cardiff University

UK

UK

\section{Editorial Office}

MDPI

St. Alban-Anlage 66

4052 Basel, Switzerland

This is a reprint of articles from the Special Issue published online in the open access journal Religions (ISSN 2077-1444) (available at: https://www.mdpi.com/journal/religions/special_issues/ bmc\#published).

For citation purposes, cite each article independently as indicated on the article page online and as indicated below:

LastName, A.A.; LastName, B.B.; LastName, C.C. Article Title. Journal Name Year, Volume Number, Page Range.

\section{ISBN 978-3-03943-741-2 (Hbk) \\ ISBN 978-3-03943-742-9 (PDF)}

Cover image courtesy of Mark Bryant.

(C) 2020 by the authors. Articles in this book are Open Access and distributed under the Creative Commons Attribution (CC BY) license, which allows users to download, copy and build upon published articles, as long as the author and publisher are properly credited, which ensures maximum dissemination and a wider impact of our publications.

The book as a whole is distributed by MDPI under the terms and conditions of the Creative Commons license CC BY-NC-ND. 


\title{
Contents
}

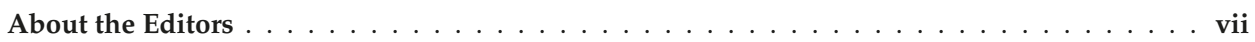

\section{Sophie Gilliat-Ray and Riyaz Timol}

Introduction: Leadership, Authority and Representation in British Muslim Communities

Reprinted from: Religions 2020, 11, 559, doi:10.3390/rel11110559 . . . . . . . . . . . . . . 1

\author{
Abdul-Azim Ahmed and Mansur Ali \\ In Search of Sylhet-The Fultoli Tradition in Britain \\ Reprinted from: Religions $2019,10,572$, doi:10.3390/rel10100572 . . . . . . . . . . . . . 13

\section{Hira Amin} \\ British Muslims Navigating between Individualism and Traditional Authority \\ Reprinted from: Religions 2019, 10, 354, doi:10.3390/rel10060354 . . . . . . . . . . . . . . 3 \\ Amin Al-Astewani \\ Loci of Leadership: The Quasi-Judicial Authority of Shariah Tribunals in the British \\ Muslim Community \\ Reprinted from: Religions 2019, 10, 406, doi:10.3390/rel10070406 . . . . . . . . . . . . . . .
}

\section{Sariya Cheruvallil-Contractor}

Women in Britain's First Muslim Mosques: Hidden from History, but Not Without Influence Reprinted from: Religions 2020, 11, 62, doi:10.3390/rel11020062 . . . . . . . . . . . . . 61

\section{Harun Khan, Hassan Joudi and Zahraa Ahmed}

The Muslim Council of Britain: Progressive Interlocutor or Redundant Gatekeeper?

Reprinted from: Religions 2020, 11, 473, doi:10.3390/rel11090473 . . . . . . . . . . . . 73

\section{Giulia Liberatore}

Guidance as 'Women's Work': A New Generation of Female Islamic Authorities in Britain

Reprinted from: Religions 2019, 10, 601, doi:10.3390/rel10110601 . . . . . . . . . . . . . . .

\section{Michael B. Munnik}

Answering for Islam: Journalistic and Islamic Conceptions of Authority

Reprinted from: Religions 2019, 10, 435, doi:10.3390/rel10070435

\section{Line Nyhagen}

Mosques as Gendered Spaces: The Complexity of Women's Compliance with, And Resistance to, Dominant Gender Norms, And the Importance of Male Allies

Reprinted from: Religions 2019, 10, 321, doi:10.3390/rel10050321 . . . . . . . . . . . . . . . 11

\author{
Alison Scott-Baumann, Alyaa Ebbiary, Shams Ad Duha Mohammad, Safiyya Dhorat, \\ Shahanaz Begum, Hasan Pandor and Julia Stolyar \\ Towards Contextualized Islamic Leadership: Paraguiding and the Universities and Muslim \\ Seminaries Project (UMSEP) \\ Reprinted from: Religions 2019, 10, 662, doi:10.3390/rel10120662 -

\section{Jawad Shah} \\ Assessing Muslim Higher Education and Training Institutions (METIs) and Islamic Studies \\ Provision in Universities in Britain: An Analysis of Training Provision for Muslim Religious \\ Leadership after $9 / 11$ \\ Reprinted from: Religions 2019, 10, 623, doi:10.3390/rel10110623 . . . . . . . . . . . . . . . 149
}




\section{Haroon Sidat}

Shedding Light on the Modalities of Authority in a Dar al-Uloom, or Religious Seminary, in Britain

Reprinted from: Religions 2019, 10,653, doi:10.3390/rel10120653 . . . . . . . . . . . . . . . . 165

\section{Riyaz Timol}

Structures of Organisation and Loci of Authority in a Glocal Islamic Movement: The Tablighi Jama'at in Britain

Reprinted from: Religions 2019, 10,573, doi:10.3390/rel10100573 . . . . . . . . . . . . . . . . . 181

\section{Matthew Vince}

"I Feel as Though I'm Doing the Job of the Imam for Them": Considering 'Tactical' Muslim Leadership Through the Case of 'Muslim RE Teachers'

Reprinted from: Religions 2019, 10,420, doi:10.3390/rel10070420 . . . . . . . . . . . . . . 203

\section{Amin El-Yousfi}

Conflicting Paradigms of Religious and Bureaucratic Authority in a British Mosque

Reprinted from: Religions 2019, 10,564, doi:10.3390/rel10100564 . . . . . . . . . . . . . . . . 219

Yahya Birt

Fuad Nahdi, Q-News, and the Forging of British Islam: Some Personal Reflections

Reprinted from: Religions 2020, 11,220, doi:10.3390/rel11050220

\section{Ron Geaves}

Afterword

Reprinted from: Religions 2020, 11,550, doi:10.3390/rel11110550 . . . . . . . . . . . . . . . 247 


\section{About the Editors}

Sophie Gilliat-Ray is Professor of Religious Studies at Cardiff University, and the founding Director of the Islam-UK Centre, established in 2005. She is the former Chair of the Muslims in Britain Research Network, and current Chair of the BSA 'Sociology of Religion Study Group'. From 2018-2022 she is on the REF panel for Theology and Religious Studies in the UK. Sophie is the author of numerous books, journal articles and edited book chapters relating to Muslims in Britain, with particular focus on the work of Muslim chaplains.

Riyaz Timol is Research Associate in British Muslim Studies at the Islam-UK Centre, Cardiff University. His Ph.D. was shortlisted for the 2018 BRAIS-De Gruyter Prize in the Study of Islam and the Muslim World. He is the Principal Investigator of a major three-year research project 'Understanding British Imams' and an academic expert on the international Islamic revivalist movement Tablighi Jama'at.

The Islam-UK Centre at Cardiff University specialises in the contemporary social scientific study of Islam and Muslims in Britain, with emphasis on qualitative research methodologies, and particular expertise in the area of Muslim religious professionals and leadership. Our approach is strongly community-orientated, and our programmes and agenda are shaped by our engagement with British Muslim organisations, professional academic associations, stakeholders at local and national level, as well as the publications/research within the field of 'British Muslim Studies'. By now, the Centre has a reputation for the integrity and quality of its research, and its focus on work that 'makes a positive difference' to improving public understanding of Islam and benefitting Muslim communities in Britain. 



\title{
Editorial \\ Introduction: Leadership, Authority and Representation in British Muslim Communities
}

\author{
Sophie Gilliat-Ray * and Riyaz Timol * \\ School of History, Archaeology and Religion, Cardiff University, Cardiff CF10 3AT, UK \\ * Correspondence: Gilliat-RayS@cardiff.ac.uk (S.G.-R.); TimolR1@cardiff.ac.uk (R.T.)
}

Received: 12 October 2020; Accepted: 22 October 2020; Published: 28 October 2020

Keywords: Islam; Muslims in Britain; leadership; authority; representation; mosques; religious institutions; darul uloom; islamic education; imams; ulema

\section{Introduction}

Since its launch in 2005, the Islam-UK Centre at Cardiff University has initiated a range of projects concerned with issues of leadership, pastoral care, and the training of religious professionals working in British Muslim communities (Gilliat-Ray 2006; Gilliat-Ray 2010; Gilliat-Ray 2011; Ali and Gilliat-Ray 2012; Gilliat-Ray et al. 2013; Gilliat-Ray 2018). When we were approached with an invitation to act as guest editors of the international peer review journal Religions, this seemed a good opportunity to invite others to contribute to a focussed scholarly discussion of the debates around these topics.

However, rather than simply putting out a 'call for papers' that would reach primarily academics, we decided to host a one-day conference as a stimulus to the submission of contributions from as broad a range of audiences as possible. In keeping with the grassroots, community-orientated ethos of the Islam-UK Centre, we extended invitations to a broad spectrum of Muslim leadership 'professionals' and activists who could bring much-needed practitioner perspectives to the themes of the conference. The result was an event held on 21st January 2019, which explored some of the following questions: 'Who speaks for British Muslims?'; 'How is authority construed, constructed, and exercised in an age of mass media and the Internet?'; 'What internal and external factors shape leadership structures and modalities of representation for British Muslims living as a minority in a culturally Christian but largely secular social context?'; 'Where do leaders come from in a decentralised religious tradition lacking a priestly hierarchy?'; 'How do government discourses and media representations impact upon dynamics of leadership and authority in British Muslim communities?'.

We were clear that the term 'leadership' should be interpreted widely given that it takes many forms. It includes liturgical and ritual leadership from imams (who may be paid, unpaid, or low-paid) and educational leadership from academics or those serving in madrassahs, seminaries, and other kinds of private establishments. It encompasses both women and men and is exercised in increasingly diverse ways, such as virtual forums online or Islamic television channels. Religious leadership is also provided by an elite group of professionals with expertise in Islamic law, who may carry the title 'mufti' or 'ayatollah', or by Sufi shaykhs who provide guidance for their disciples.

Political leadership has emerged via a number of British Muslims taking up positions within local and national governance, some of whom have acquired senior government positions, such as the current Mayor of London Rt. Hon. Sadiq Khan or Baroness Sayeeda Warsi (Peace 2015). Alongside this, a range of regional and national organisations have developed to 'represent' the interests of Muslim communities in civil society, often headed by those with skills derived from a variety of public service and charitable roles. Bodies such as the Muslim Council of Britain and their affiliates exercise national influence while various councils of mosques advocate on behalf of broad regional congregations. Muslim leadership roles have seen further diversification in recent decades through incorporation 
into professions such as chaplaincy and youth work, while those British Muslims in senior positions within the media (such as Mehdi Hasan) or the third sector often function as influential spokespeople. Others who have succeeded in the public eye, such as Sir Mo Farah, CBE, Nadiya Hussain, MBE, or most recently, Liverpool footballer Mohamed Salah, act as 'role models' garnering followings among a wide cross-section of British society.

Arising from our conference, which brought together academics and practitioners with both theoretical and hands-on knowledge, this Special Issue explores the myriad ways in which British Muslims exercise leadership in a range of sectors. We are pleased that the articles gathered here explore issues of leadership from an interdisciplinary perspective, enabling scholars of religion, sociology, political science, history, and Islamic Studies to bring synergistic focus to a topic of current academic and political debate.

\section{Academic Contributions}

In considering the articles in this Special Issue, it may be useful to conceptualise British Muslim leadership as operating on the basis of two distinct yet complementary roles. These reflect the migratory history of a minority identity group defined on the basis of religion in a residually Christian but operationally secular legislative and cultural milieu (Cesari and McLoughlin 2005). On the one hand, leadership and authority are exercised internally within the community and enacted primarily for a confessional Muslim audience seeking educational, pastoral, moral, spiritual, or other types of instruction and guidance. On the other hand, leaders represent that self-same community-in all its diversity - to the wider society functioning as interlocutors with a wide range of external stakeholders, including media, government, or non-Muslim colleagues. The demands and expectations of each audience are different and consequently, as the contributions to this Special Issue illustrate, the skillsets, life experiences, accumulated social and cultural capital and, indeed, theological proficiency of different types of Muslim 'leaders' can vary greatly.

Let us reflect on each leadership orientation in turn. Religious authority within the community tends to be correlated with theology. Ultimate authority in Islam, from a purely religious perspective, derives from Allah, the Prophet Muhammad, and the constellation of Words-revealed and inspired-which entered history, so Muslims believe, through divine intervention in Arabia fourteen centuries ago. Fidelity to and intimacy with these primary sources, captured in the Qur'an and collections of Hadith, imbue both individuals and institutions with religious authority. When lay Muslims seek religious guidance, they often turn to those deemed to be well-versed in scripture who function as the embodiments and carriers of a tradition that reaches back through time to the founding moment of Islam. This proficiency in the Qur'an and the Hadith, along with a pious comportment and an ability to connect with the particular needs of a community or congregation in a given time and place, have perhaps been the key ingredients of Islamic authority through the ages (Zaman 2009; Bano 2019). A consistent theme of the papers presented in this Special Issue concerns the ongoing vitality of the ulema-both male and female-in shaping the religious subjectivities of British Muslims. Clearly, tradition matters to many British Muslims and, rather than being locked in a zero-sum game with modernity, various contributions that follow chronicle how it is nurtured, appropriated, negotiated, filtered, and engaged in accordance with the complex demands of their social context.

Other papers in this Special Issue focus on the outward engagement of the community with the wider society. Here the authority of the ulema is less pronounced as other Muslim actors with more social and cultural capital become positioned-sometimes inadvertently-as community spokespeople. Reciprocally, the state also seeks to influence the selection of interlocutors it is willing to engage (Abbas 2005; Archer 2009; Stjernholm 2010). In a wide-ranging study of state-Muslim relations across seven European countries, Jonathan Laurence (2012) proposes that the early decades of immigration-specifically 1960-1990 — constituted a period of 'Embassy Islam', in which governments adopted a largely "hands-off" laissez-faire attitude to their newly established minorities by outsourcing their management to extant religious infrastructures in the countries of origin. The principal rationale behind this was what British 
sociologist Muhammad Anwar (1979) has termed The Myth of Return; the idea that the Muslim presence in Europe was essentially functional and transient, motivated by economic gain, for which a set of temporary policy measures would suffice. The advent of a diaspora-born generation of Muslims, persistent issues around 'integration', the proliferation of rival networks of 'Political Islam' competing with 'Embassy Islam', and sporadic acts of terrorism committed on European soil collectively persuaded governments from 1990-2010, argues Laurence, to take a more "hands-on" policy approach to their Muslim minorities. In the UK, the Rushdie Affair functioned as a well-documented landmark event which catalysed a shift in community self-conceptualisation from a disparate assortment of ethnic groups to a common Muslim identity (Munnik 2019). Organisations such as the Muslim Council of Britain (MCB) emerged, which, unlike the ulema who speak for 'Islam' as such, instead took on the mantle of advocacy for various 'Muslim community' concerns.

The extent to which the MCB has subsequently been studied and written about in various academic and Muslim community publications is probably reflective of its stature as the most enduring and influential of Britain's Muslim representative organisations (Radcliffe 2004; Birt 2005; McLoughlin 2005; Pẹdziwiatr 2007; Birt 2008a; Elshayyal 2018). This is despite the vicissitudes of its political fortunes as played out in its relations with successive UK governments and the growth of alternative organisations disillusioned with its representative claim-making (Archer 2009; Stjernholm 2010; Jones 2013). Nevertheless, there is no doubt its work has been integral to the development of a corporate Muslim identity in Britain. For this reason, we are delighted that this Special Issue contributes to an important ongoing conversation by including a unique 'insider's perspective' on the formation and evolution of the MCB over its more than twenty years of operation.

Formal engagement with the government, however, is not the only—or even the most important-form of representation. In an oft-cited article, Jones et al. (2015) propose a typology of four leadership modes consisting of delegation, authority, expertise, and standing. While the MCB typifies the delegation mode of leadership, figures such as the late Dr Zaki Badawi or Shaykh Ibrahim Mogra provide examples of Islamic scholars who, based on their explicitly religious authority, have engaged consistently with mainstream community structures, including the media, to represent Islam. Other organisations, such as the controversial counterterrorism think tank Quilliam Foundation, have also staked a claim to authority based on the ostensible expertise conferred by the personal life experiences of the founders. Vince and Munnik's contributions to this Special Issue, however, demonstrate the ongoing importance of standing as a model of leadership through which British Muslims already in the public eye sometimes speak on behalf of the religion.

It may be useful to distinguish here between 'fundamental' and 'incidental' conceptions of religious authority. Figures such as the aforementioned Dr Zaki Badawi or Shaykh Ibrahim Mogra achieved public prominence precisely because their credentials as Islamic scholars qualified them to speak about issues concerning the faith. By contrast, personalities such as the boxer Amir Khan or the baker Nadiyah Hussain were catapulted to fame through high-performance achievements in their respective competitive spheres. Nevertheless, their popularity may sometimes be leveraged to make statements about their faith in ways that resonate with a wider audience beyond their co-religionists. Amir Khan's decision to enter the ring draped in a Union Jack flag following the 7/7 terrorist attacks, for example, showcased him as a 'role model' for integration (Jones et al. 2015, p. 218); while the BBC's choice of Nadiya Hussain to front a two-part television series reporting on the Hajj pilgrimage to Mecca was only made possible by her prior success at The Great British Bake Off (BBC 2017). ${ }^{1}$ For Munnik, such modes of leadership deriving from public 'standing' fit hand in glove with the decentralised nature of Sunni Islam and can act as powerful counterweights to rebalance negative representations of Muslims in the mainstream media. Away from the glare of the celebrity spotlight, Vince also highlights

1 Despite considerable publicity, the series however does not seem to have come to fruition. 
the important yet often overlooked leadership exemplified by ordinary Muslims acting as 'role models' in the micro-contexts of everyday work and life.

The collection of articles presented in this Special Issue brings another point to the fore as revealed by a cursory glance at their titles. Two contain the word "loci"; three the word "mosque"; one references a specific city; three refer to "Islamic seminaries"; and two to "universities". Clearly, place matters in the construction and enaction of British Muslim leadership. To put this differently, the social locations in which authority is incubated, exercised, and transmitted are of significance. Mosques and seminaries, for centuries, have functioned as sites of authority inhabited by imams (despite, as El-Yousfi shows, the mitigating impact of management committees) and ulema, custodians of a cherished theological tradition handed down over generations. Yet their influence has been significantly disrupted most recently through the pervasive impact of a global digital revolution. As Amin's article in particular shows, 'Sheikh Google' offers a quick and easy alternative to the local imam and the technological savviness of contemporary ulema-in tandem with more historical constituents of authority-shapes a new-found ability to access potentially gargantuan virtual congregations. Gender plays a key role here too: Nyhagen's article demonstrates how the physical space of the mosque can enable or constrain women's participation in its religious life while several others-Birt, Cheruvallil-Contractor, Liberatore, Scott-Baumann and Vince-allude to the emergence, in different ways, of 'third spaces' in which female religious agency and leadership have found creative avenues of expression in contemporary Britain.

The training of Muslim scholars, and the different roles that seminaries and universities can play in their intellectual formation, is another key theme of this Special Issue addressed by several authors, namely Liberatore, Scott-Baumann et al., Shah, and Sidat. It also surfaced prominently in the various 'Practitioner Perspectives' that are discussed later in this Introduction. In particular, we are pleased that the Special Issue provided a fitting platform to present the first findings of a new research project-the Universities and Muslim Seminaries Project (UMSEP)—in which Professor Alison Scott-Bauman, along with a team of academics and Islamic scholars, highlights emergent models of Muslim community leadership through exploring issues of collaboration and accreditation in the Darul Uloom (seminary) and university sectors.

This proliferation of sites at which religious subjectivities are cultivated is an important symbol of the appropriation and inhabitation of space fundamental to diaspora communities seeking to establish permanent roots in a new homeland. What Laurence $(2012$, p. 30) terms the "residual paternalism" of Islamic organisations in Muslim-majority contexts toward their diaspora counterparts is perhaps best exemplified in this Special Issue by Timol's chronicling of the local, regional, national, and international structures of authority of the global Islamic movement Tablighi Jama'at, which have facilitated a degree of successful intergenerational transmission in Britain. By contrast, Ahmed and Ali's depiction of the Fultoli movement in Britain paints a picture of steady decline as its transplantation across continents largely fails to bear fruit among a British-born generation. The implications for religious authority are considerable. The individual charisma of Fultolir Sahib, bolstered by his spiritual lineage and a prophetic mandate to teach as relayed in a dream, sparked a distinct religious awakening among twentieth-century Sylheti Muslims. Yet these emblems of authority by themselves, the authors argue, were insufficient for his movement to take root and flourish in the UK. Echoes of Weber can be discerned here: should the charismatic authority of the founder fail to be embedded in institutional constructs, it is unlikely the movement will outlive him. The dynamics of immigration complicate this model but, nevertheless, juxtaposing the Fultoli tradition with the Tablighi Jama'at - two twentieth-century movements of Islamic revival originating in South Asia-yields useful analytical insights into how religious authority 'travels' (Mandaville 2001).

The establishment of Muslim leadership structures in Britain takes place amid older, more historic religious traditions. This raises a question about the extent to which the British Muslim experience should be viewed through the prism of other religious communities. Shah's article detects "the ubiquitous inclination in the academic literature to draw Christian parallels" for Muslim religious life, as exemplified, for example, in the substitution of the word 'seminary' for Darul Uloom: 
"This term too is borrowed from a Christian lexicon, emblematic of the perpetual urge to force Western Christian terms on to Islamic cognates that is so prevalent in this field." On the other hand, Timol explicitly draws upon a model of ecclesiastical hierarchy—the "episcopal polity" of British Christianity - to illustrate the organisational structure of the Tablighi Jama'at. Bringing such divergent perspectives together within this Special Issue highlights the heterogenous ways in which issues of leadership, authority, and representation in British Muslim communities may be approached. Clearly, as a member of the Abrahamic family of faiths, Muslims share much in common-historically and theologically — with the 'People of the Book.' Scholars such as Laurence (2012) and Jenkins (2007) further find grounds for optimism in examining the historical precedence of other religious minority groups-Jews, Catholics, Protestants-whose paths to enfranchisement and incorporation in various European contexts Muslims can usefully draw upon. Equally though, Spickard's speculative recasting of the theoretical underpinnings of the sociology of religion makes the case for taking seriously indigenous epistemologies which, among other things, help displace the universal presumptions of a historically contingent Eurocentric mode of analysis infused with a Protestant ethos (Spickard 2017). As Britain's Muslim communities continue to mature and-as many of the contributions to this Special Issue already demonstrate-confidently take ownership of their own narratives, an organic conceptual apparatus may crystallise that speaks to the authentic core of their experience in ways that segue naturally with the nation's religious heritage (Birt et al. 2011).

\section{Practitioner Perspectives}

In keeping with the ethos of the conference and our wish to incorporate practitioner perspectives into this Special Issue, we proactively sought contributions that reflect the context and experiences of those charged with the practical delivery of Muslim religious leadership education and co-ordination. With the exception of the paper prepared by those associated with the Muslim Council of Britain who chose to write a full-length academic piece, we offered practitioners the opportunity to draft shorter papers of around one thousand words, describing the origins and activities of institutions with which they were associated (in various capacities and at different times), the challenges faced and overcome, and the overall vision for the future. The following paragraphs reflect a systematic analysis by the editors of six such contributions. Having drafted the following paragraphs, we shared them with our contributors, giving them the opportunity to correct any errors of fact or interpretation. Our contributors include, in alphabetical order: Qari Asim (Mosques and Imams National Advisory Board-MINAB, established in 2006); Sheikh Shams Ad Duha (Ebrahim College, established in 2003); Dr Musharraf Hussain (Karimia Institute, established in 1990); Dr Mohammad Mesbahi (The Islamic College, established in 1998); Mufti Dr Abdur Rahman Mangera (Whitethread Institute, established in 2017); and, Muhammad Tajri (Al-Mahdi Institute, established in 1993).

Despite their different histories and priorities, the origins, trajectories, challenges, and priorities of these institutions directly reflect the changing needs and dynamics of British Muslim communities more broadly. They mirror the emergent needs of new generations and the experiences of founding leaders, many of whom have acquired postgraduate degrees from British universities. Common to each there is a clear but gradual shift away from a reliance on overseas institutions for 'endorsement' or teaching staff, alongside the emergence of highly capable and qualified leaders born and educated in Britain. Together, these institutions are 'indigenising' Islamic education for its British context, seeking to find models of education that are true to their origins while being 'fit for purpose' for the future.

Many of those associated with these Institutes have critically evaluated the delivery of Islamic Studies programmes in universities. They have sought to develop their institutions in ways that reflect 'best practice' in the higher education sector while being cautious of replicating aspects of teaching and learning that may not be helpful to their interests. For example, there is a recognition of the value of inter-disciplinary study, research-led teaching, the need to provide flexible programmes for part-time and distance learners, and the benefits arising from research seminars with invited external speakers. Some have responded to the emphasis that many Higher Education Institutions (HEIs) now place 
upon 'employability skills', and have therefore created volunteering, placement, and work experience opportunities within the curriculum. In some cases, degree programmes in Islamic institutions have been validated by local universities, suggesting recognition of the value of transparent processes and standards for admission, assessment, and regulation.

However, programmes of Islamic Studies in many British universities were seen by those from some Institutes as too heavily orientated towards historical, linguistic, and textual approaches, at the expense of attention to Islamic spirituality, personal self-development, contemporary issues, and an appreciation of Islam in its British, inter-religious context. The same sort of criticisms were also voiced in relation to some traditional Islamic Studies programmes within the seminary sector. While appreciating and recognising their invaluable contributions, especially at a particular time of energetic British Muslim community institution-building in the 1970s and 1980s, many of those who contributed to our conference were seeking to create institutions that could build on these foundations in new ways to reflect emergent needs. They were concerned that insufficient contextualisation of Islamic education and leadership training (regardless of sector) can lead to a "disconnect with the changing paradigms of a constantly changing world" (Mangera). Crucially, many of those who have been most directly involved in efforts to develop new institutions have managed to bridge the gap between the confessional and non-confessional study of Islam as graduates of both the traditional seminary and HEI sectors. This makes them pioneering figures who have much to contribute to ongoing developments that seek to close the gap between these sectors (Geaves 2013; Scott-Baumann and Cheruvallil-Contractor 2015). ${ }^{2}$ What this seems to amount to in some cases is a gradual blurring of the distinction between academia and the traditional seminary sector, with "the deep-seated regard for the traditional Islamic sciences ... embedded in a culture of academic critical thinking" (Tajri).

Another indicator of important generational and pedagogical shifts includes the priority that many institutes now place upon the Arabic language. For several decades, Islamic seminaries with origins in South Asia paid particular attention to the advanced acquisition of the Urdu language. This was a natural and inevitable consequence of their history and the background of their founding leaders. However, with the passage of time, it has become clear that proficiency in the language of the Qur'an and the Hadith is now more likely to provide the basis for claims of "scholarship and credibility" (Ad Duha). Similarly, there is a recognition in many institutes that alongside the development of employability skills, the basic literacy of students in written English is a concern. Students enrolling on the training and educational programmes offered by various non-residential Islamic institutions also inevitably bring the daily socio-economic challenges of British Muslim communities with them. This can result in cohorts of students with considerable personal, family, and health problems, making the "contextualisation of the Muslim seminary more a pastoral challenge than an academic one" (Ad Duha).

But in parallel with this, there is sufficient growth and maturity in the Islamic education and training sector for the development of highly specialised, advanced, 'postgraduate-level' study (Mesbahi, Tajri, Mangera). Those who have undertaken their studies in the traditional Darul Uloom sector have, until recently, had few options in terms of developing their knowledge to a higher level within the UK. In relation to the private Islamic education sector, the creation of the Whitethread Institute is a particularly notable development, enabling both male and female 'alims and 'alimas of the highest capabilities to undertake programmes in very advanced Islamic jurisprudence, Qur'anic exegesis, and Islamic Theology. A particular speciality of the Institute is the Ifta course, where deep engagement with advanced juridical texts is allied with close mentoring. The rigours of the course are such that only the most capable students complete it, but the outcome is the production of scholars who can specialise in various aspects of Islamic law at the most advanced level. Such is the sensitivity of issuing fatawa (non-binding religious edicts) that even those who complete the course are required

2 Cheruvallil-Contractor, Sariya, 2012-2013, 'Collaborative partnerships between universities and Muslim institutions: dismantling the roadblocks', UKRI-ESRC research project, University of Derby. 
"to work in various capacities in the field, providing legal responses for another three years before they would be accredited as muftis" (Mangera). The emergence of such a specialist institute is indicative of a likely future trend in relation to Muslim religious leadership in Britain, in terms of the expansion of the 'advanced' traditional Islamic sciences sector.

Alongside the development of 'specialisation', there is also a growing emphasis on 'professionalisation' of private Muslim higher education. The well-established Karimia Institute has a long-standing reputation for its programmes but has recognised the need for graduates to be 'work-ready' as imams, chaplains, youth workers, and so on. This reflects both the expansion in the kind of roles that Darul Uloom graduates might occupy, but also the parallel development of functions that mosque-based imams are expected to fulfil, and the range of external agencies they are likely to have to engage with (e.g., National Health Service, local politicians, police, local religious leaders, interfaith bodies, and so on). "Forty to fifty years ago, when many of the mosques and Muslim institutions started, Muslim communities were smaller and perhaps more insular; the mosque leadership was confined to preaching inside the four walls of the mosque buildings. In present times, sophisticated demands are being made on mosques to represent and lead communities, through an efficient, inclusive, innovative, and sustainable provision of services" (Asim). In view of this, the proposed new Diploma in Imam Training at the Karimia Institute aims to equip Islamic leaders with some key 'competencies', including self-reflective personal development and spirituality; teaching and pedagogy; youth and community work; leadership and management training; mosque governance and management committees; and an ability to undertake effective $d a^{\prime} w a$ (lit: invitation) using social and other media. Underpinning all these is an emphasis on contextualisation of the Islamic tradition, continuous professional development, and the need for the development of a clear 'career-path' for those working in a vocational capacity. In this way, the kind of career-structure and remuneration arrangements of the Christian churches has provided a useful 'model' from which indigenous ones may develop.

A very striking theme to emerge in many contributions was the importance of facilitating the education of Muslim women on a par with their male counterparts. Clearly, this has involved attention to issues of cultural sensitivity and avoidance of free-mixing between the genders, but the important role that women have as educators in the community was consistently acknowledged. Indeed, in some of the institutes, women form the majority of the student body and regularly outperform their male colleagues (Ad Duha). Compared to their brothers, women were sometimes (but not always) found to have more time, opportunity, and inclination to undertake advanced Islamic Studies. But this spirit of inclusivity was also evident in other ways. Several contributors stressed the 'non-sectarian' nature of their institutes (Mesbahi), and the need to engage in both intra- and inter-religious dialogue. In some institutes, there was a clear sense of transcending particular denominational identities and moving toward a broad Muslim one facilitated perhaps through regular contact with Muslim 'others' - especially in cities of 'hyper-diversity', such as London, where Muslims of varied origins mingle closely. Such a culture of inclusivity also manifests in some institutions through questioning and discussion via seminars, conferences, and workshops that host external speakers from a range of academic and denominational backgrounds (Tajri). Far from being internally focused, students are encouraged to consider the ways in which 'traditionally' received Islamic knowledge can be seen through outward-facing contemporary lenses.

\section{Conclusions}

Several common themes of 'contextualisation', 'indigenisation', 'engagement', 'inclusivity', and 'professionalisation' emerge from the various practitioner contributions submitted to this Special Issue. These indicate the successful transmission of models of Islamic educational training and leadership into Britain, and their organic if gradual development to cater to the demands of changing circumstances and new generations. While the institutions and their founders value their relationships with older, more 'traditional' organisations, established in the UK or operating overseas—sometimes their alma maters-it is clear that they seek to draw upon this heritage to address the challenges and 
needs of their own context and lived reality. Deciding 'what counts' as a Darul Uloom or 'traditional' Islamic curriculum is therefore no longer clear; some institutions appear to be walking a tightrope in terms of their underlying purpose, whether this is flexible, locally-delivered Islamic education, the preservation and protection of the Islamic tradition in contemporary Britain, or the training of Muslim faith leaders. Clearly, the cultivation of both a 'Republic of Letters' and a 'Republic of Piety', to use Moosa's terms (Moosa 2015), is important for many of our contributors. There is also a sense, however, of a multitude of disconnected institutions and initiatives, which, despite their overlapping interests, work largely independently of each other. The remit of MINAB and the newly-created BBSI (British Board of Scholars and Imams), alongside organisations such as Faith Associates, for example, is unclear-at least from the outside. There are missed opportunities for the sharing of best practice and experience, more joined-up thinking, and avoidance of pitfalls in a sector that is vulnerable to changing markets, politicisation, and, quite often, negative media scrutiny.

These are perhaps unavoidable factors in the gradual maturation of British Muslim leadership, tied into its essentially privatised role following a range of post-war immigration flows. The UK is unusual among secular democracies for maintaining an established church that continues to have a formal role in UK legislature, and its most senior cleric, the Archbishop of Canterbury, frequently presides over state functions. The Chief Rabbi of the United Hebrew Congregations of the Commonwealth is similarly a formally recognised office providing leadership for British Jews. No such equivalent exists for British Muslims. While there is some evidence that the prominent Victorian Muslim convert Abdullah Quilliam received a (perhaps de facto more than de jure) title of the 'Sheikh-ul-Islam of the British Isles' from the Ottoman caliph Sultan Abdul Hamid II in 1894, this_as Birt (2008b) argues-was a pre-eminently symbolic appointment lacking ratification from the Queen. In 2011, Maulana Shahid Raza, then Chairman of MINAB, suggested there is "strong support from diverse parts of the Muslim community for a Grand Mufti for the UK", further alluding to an "independent appointments committee of leading Al-Azhar scholars" which had allegedly appointed an incumbent to the office (Raza 2011); a claim which "irritated and confused" other British Muslims (Binyon 2011). Both instances indicate the tendency of British Muslim leadership to lean upon overseas centres of religious authority in validating their own credentials. While pioneering migrant ulema from Britain's South Asian communities—such as the late Shaykh Yusuf Motala or Shaykh Muhammad Imdad Hussain Pirzada Sahib, each of whom founded UK institutions that have produced generations of Islamic scholars-are highly revered within their communities, they are largely unknown outside of them. ${ }^{3}$ By contrast, the cultural versatility of converts such as Quilliam-or, more recently, Shaykh Abdal Hakim Murad-provides important 'bridging capital', which allows the development of more prominent public profiles. In any case, the question of whether a single Islamic figure could occupy a formally instituted position within the British establishment, mirroring the roles of the Archbishop of Canterbury and Chief Rabbi, and walk the tightrope of publicly representing Britain's diverse Muslim communities without losing grassroots credibility, remains an open one.

Universities may have little role to play in addressing these issues, but our conference in 2019 was an historic occasion for bringing together key stakeholders in the same place on the same day. The relative 'neutrality' of a university environment provided a context where practitioners from very different kinds of institutions could meet and talk together, sometimes for the first time. Unlike politically sensitive government initiatives to address issues around Muslim faith leader training (Mukadam and Scott-Baumann 2010), our conference was able to draw upon many years of relationship-building across a very wide range of Muslim institutions and long-standing personal connections. It was a privilege to host such an occasion in Cardiff University, and the production of this Special Issue offers an academic landmark for documenting the clear leadership and educational progress of British Muslim communities.

3 For more on Shaykh Yusuf Motala, see Mangera (2020, pp. 190-92); and Shaykh Muhammad Imdad Hussain Pirzada, see MuslimView (2015) or Schleifer (2020, p. 124). 
The papers in this Special Issue should therefore be read alongside the recordings made at the conference itself. These can be found on the Islam-UK Centre YouTube channel and feature presentations from a range of key academics and community activists—such as Dr Usama al-Azami, Professor Gary Bunt, Dr Myriam François-Cerrah, Dr Atif Imtiaz, Dr Shuruq Naguib, Rehanah Sadiq, Professor Ataullah Siddiqui and Shaukat Warraich-who were not able to contribute to the Special Issue. ${ }^{4}$ It was also a pleasure to host a contingent of young Darul Uloom students, many of whom travelled hundreds of miles to attend an academic conference for the first time.

The unfolding of the Covid-19 pandemic in early 2020 coincided with the final stages of this Special Issue's preparation, and the debates it sparked in Muslim communities across the UK, particularly on the question of voluntary mosque closures, brought into sharp relief many of the issues of leadership, authority, and representation addressed herein (Timol 2020). Sadly, one of the earliest fatalities of the coronavirus was a vivacious character of British Islam, Fuad Nahdi (1957-2020), whose larger-than-life personality and myriad contributions to British Muslim community life-including his spearheading of Q-News, "the most consequential UK Muslim publication of its day"-are captured in Yahya Birt's obituary. Figures such as Nahdi represent both the 'inward' and 'outward' orientations of British Muslim leadership suggested earlier in this Introduction. Intimately concerned with Muslim community issues, well-connected with a plethora of international ulema, and particularly committed to nurturing and mentoring a younger generation of talented British Muslims, Nahdi was simultaneously exceptionally well-networked in media, policy, and interfaith circles in the British establishment. In a sense, he was a type of 'Chief Playmaker' of British Islam and it is an honour for us to formally document his life achievements and service to the community within the pages of this Special Issue.

The occasion of our conference also provided an opportunity to introduce a new flagship project at the Islam-UK Centre. 'Understanding British Imams' is the first sustained academic study of the UK imamate, with a clear focus on the role of those responsible for leading worship in British mosques on a day-to-day basis. ${ }^{5}$ The overwhelming response to an initial online survey, and the willingness of a wide cross-section of imams and other stakeholders to contribute their views through interviews, suggests a strong level of grassroots support for rigorous yet empathic social scientific understanding of key Muslim community issues. We hope that our findings will support Muslim communities at all levels by providing an evidence-based assessment of the strengths and weaknesses of the current arrangements for the employment and work of imams. In generating meticulously gathered empirical data, our work can provide an important reference point for the future development of Muslim educational and training institutions and help imams serve their congregations more effectively. This is no less than Muslim communities deserve:

"Muslims who go to their place of worship regularly in an increasingly secular world go because their faith really matters to them-because their religion, and their community, [are] among the most prominent anchors of their life, supporting and sustaining them through times of trial and joy, crisis and celebration. These people deserve to be well cared for, represented, [and] inspired by those who are entrusted with their care" (Asim).

Author Contributions: Conceptualisation, S.G.-R. and R.T.; introduction, S.G.-R. and R.T.; academic contributions, R.T.; practitioner perspectives, S.G.-R.; conclusions, S.G.-R. and R.T. All authors have read and agreed to the published version of the manuscript.

Funding: This research received no external funding.

Acknowledgments: The Editors would like to thank everyone who has been involved with the production of this Special Issue (and the e-book that is due to follow), particularly the contributing authors and various presenters who helped make the related conference in January 2019 such a success. This includes our postgraduate students and colleagues at the Islam-UK Centre at Cardiff University (many of whom are funded via the Jameel Scholarship Programme) who volunteered at the conference. Particular thanks must go to Mark Bryant (Centre Development

4 See https://www.youtube.com/playlist?list=PLr1Tq3qoUBQt9ZJepFCGqi_CBdtW6tMlT (accessed on 23 August 2020).

5 See https://www.cardiff.ac.uk/research/explore/find-a-project/view/understanding-british-imams (accessed on 23 August 2020). 
Officer) for his audio-visual recording of the event, and subsequent upload of the delivered papers to YouTube. We would also like to thank the peer-reviewers who assisted with the production process, ensuring that the papers published were of high standard. Finally, we acknowledge the efforts of Zach Pang and his team at MDPI who supported the swift and meticulous processing of submissions and subsequent publication.

Conflicts of Interest: The authors declare no conflict of interest.

\section{References}

Abbas, T., ed. 2005. Muslim Britain: Communities under Pressure. London: Zed Books.

Ali, Muhammad Mansur, and Sophie Gilliat-Ray. 2012. Muslim Chaplains: Working at the interface of 'public' and 'private'. Edited by Waqar I. U. Ahmad and Ziauddin Sardar. In Muslims in Britain: Making Social and Political Space. London: Routledge, pp. 84-100.

Anwar, Muhammad. 1979. The Myth of Return: Pakistanis in Britain. London: Heinemann Educational Books Ltd.

Archer, Toby. 2009. Welcome to the Umma: The British State and its Muslim Citizens Since 9/11. Cooperation and Conflict 44: 329-47. [CrossRef]

Bano, Masooda, ed. 2019. Modern Islamic Authority and Social Change (Volume 1): Evolving Debates in Muslim Majority Countries. Edinburgh: Edinburgh University Press.

BBC. 2017. Nadiya Hussain to Present The Hajj for BBC One. Available online: https://www.bbc.co.uk/mediacentre/ latestnews/2017/nadiya-hussain-hajj (accessed on 23 August 2020).

Binyon, Michael. 2011. Dispute Underlines Rivalries among Britain's Muslims. The Times, Friday January 28. Available online: https://www.thetimes.co.uk/article/dispute-underlines-rivalries-among-britains-muslims8xcckk6c3v0 (accessed on 24 August 2020).

Birt, Jonathan. 2005. Lobbying and Marching: British Muslims and the State. In Muslim Britain: Communities Under Pressure. Edited by Abbas Tahir. London: Zed Books.

Birt, Jonathan. 2008a. The Next Ten Years: An Open Letter to the MCB. Available online: https://yahyabirt1. wordpress.com/2008/06/27/the-next-ten-years-an-open-letter-to-the-mcb/ (accessed on 23 August 2020).

Birt, Yahya. 2008b. An Enquiry into the Status of the Sheikh-ul-Islam of the British Isles. Available online: https://yahyabirt1.wordpress.com/2008/02/05/an-enqurity-into-the-status-of-the-sheikh-ul-islamof-the-british-isles/ (accessed on 24 August 2020).

Birt, Yahya, Ataullah Siddiqui, and Dilwar Hussain, eds. 2011. British Secularism and Religion: Islam, Society and the State. Markfield: Kube Publishing.

Cesari, Jocelyne, and Sean McLoughlin. 2005. European Muslims and the Secular State. London: Ashgate Publishing.

Elshayyal, Khadijah. 2018. Muslim Identity Politics: Islam, Activism and Equality in Britain. London: Bloomsbury, I.B. Tauris.

Geaves, Ron. 2013. An exploration of the viability of partnership between dar al-ulum and Higher Education institutions in North West England focusing upon pedagogy and relevance. British Journal of Religious Education, 64-82. [CrossRef]

Gilliat-Ray, Sophie. 2006. Educating the ‘Ulema: Centres of Islamic Religious Training in Britain. Islam and Christian-Muslim Relations 17: 55-76. [CrossRef]

Gilliat-Ray, Sophie. 2010. Body-works and fieldwork: Research with British Muslim chaplains. Culture and Religion 11: 413-32. [CrossRef]

Gilliat-Ray, Sophie. 2011. 'Being There': The experience of shadowing a British Muslim Hospital Chaplain. Qualitative Research 11: 469-86. [CrossRef]

Gilliat-Ray, Sophie. 2018. From "Closed Worlds" to "Open Doors": (Now) Accessing Deobandi darul uloom in Britain. Fieldwork in Religion 13: 127-50. [CrossRef]

Gilliat-Ray, Sophie, Stephen Pattison, and Mansur Ali. 2013. Understanding Muslim Chaplaincy. Aldershot: Ashgate. Jenkins, Philip. 2007. God's Continent: Christianity, Islam and Europe's Religious Crisis. Oxford: Oxford University Press. Jones, Stephen H. 2013. New Labour and the Re-making of British Islam: The Case of the Radical Middle Way and the "Reclamation" of the Classical Islamic Tradition. Religions 4: 550-66. [CrossRef]

Jones, Stephen H., Therese O'Toole, Daniel Nilsson DeHanas, Tariq Modood, and Nasar Meer. 2015. A 'System of Self-Appointed Leaders'? Examining Modes of Muslim Representation in Governance in Britain. The British Journal of Politics and International Relations 17: 207-23. [CrossRef] 
Laurence, Jonathan. 2012. The Emancipation of Europe's Muslims: The State's Role in Minority Integration. Princeton: Princeton University Press.

Mandaville, Peter G. 2001. Transnational Muslim Politics: Reimagining the Umma. London: Routledge.

Mangera, Mufti Abdur-Rahman. 2020. Hadhrat Sheikhul Hadith Maulana Yusuf Motala. In The Muslim 500: The World's 500 Most Influential Muslims. Edited by Abdallah Schleifer. Amman: The Royal Islamic Strategic Studies Centre, pp. 190-92.

McLoughlin, Seán. 2005. The State, New Muslim Leaderships and Islam as a Resource for Public Engagement in Britain. In European Muslims and the Secular State. Edited by Jocelyne Cesari and Sean McLoughlin S. London: Ashgate Publishing, pp. 55-70.

Moosa, Ebrahim. 2015. What is a Madrasa? New Delhi: University of North Carolina Press.

Mukadam, Mohamed, and Alison Scott-Baumann. 2010. The Training and Development of Muslim Faith Leaders: Current Practice and Future Possibilities. London: Communities and Local Government.

Munnik, Mohamed. 2019. Salman Rushdie and the 'Sudden Visibilisation' of British Muslims. Islam-UK Centre Blog. Available online: http://blogs.cardiff.ac.uk/islamukcentre/michael-munnik-salman-rushdie-and-thesudden-visibilisation-of-british-muslims/ (accessed on 23 August 2020).

MuslimView. 2015. Interview: Shaykh M. Imdad Hussain Pirzada Founder of Jamia al-Karam. Available online: http://muslimview.co.uk/the-community/interview/interview-shaykh-m-imdad-hussain-pirzadafounder-of-jamia-al-karam/ (accessed on 24 August 2020).

Peace, Timothy, ed. 2015. Muslims and Political Participation in Britain. Abingdon: Routledge.

Pẹdziwiatr, Konrad. 2007. Creating New Discursive Arenas and Influencing the Policies of the State: The Case of the Muslim Council of Britain. Social Compass 54: 267-80. [CrossRef]

Radcliffe, Liat. 2004. A Muslim Lobby at Whitehall? Examining the Role of the Muslim Minority in British Foreign Policy Making. Islam and Christian-Muslim Relations 15: 365-86. [CrossRef]

Raza, Shahid Maulana. 2011. UK Grand Mufti. Letter to the Times (Friday February 04 2011). Available online: https://www.thetimes.co.uk/article/uk-grand-mufti-csss5p6nkkq (accessed on 24 August 2020).

Schleifer, Arabia, ed. 2020. The Muslim 500: The World's 500 Most Influential Muslims. Amman: The Royal Islamic Strategic Studies Centre.

Scott-Baumann, Alison, and Sariya Cheruvallil-Contractor. 2015. Islamic Education in Britain: New Pluralist Paradigms. London: Bloomsbury.

Spickard, James V. 2017. Alternative Sociologies of Religion: Through Non-Western Eyes. New York: New York University Press.

Stjernholm, Simon. 2010. Sufi Politics in Britain: The Sufi Muslim Council and the 'Silent Majority' of Muslims. Journal of Islamic Law Culture 12: 215-26. [CrossRef]

Timol, R. 2020. Mosque Closures and Religious Authority in the British Muslim Community amidst COVID-19. Journal of British Muslim Studies Blog. Available online: https://www.britishmuslimstudies.com/post/ mosque-closures-and-religious-authority-in-the-british-muslim-community-amidst-covid-19 (accessed on 24 August 2020).

Zaman, Muhammad Qasim. 2009. The Ulama and Contestations on Religious Authority. In Islam and Modernity: Key Issues and Debates. Edited by Muhammad Khalid Masud, Armando Salvatore and Martin van Bruinessen. Edinburgh: Edinburgh University Press.

Publisher's Note: MDPI stays neutral with regard to jurisdictional claims in published maps and institutional affiliations.

(C) 2020 by the authors. Licensee MDPI, Basel, Switzerland. This article is an open access article distributed under the terms and conditions of the Creative Commons Attribution (CC BY) license (http://creativecommons.org/licenses/by/4.0/). 

Article

\title{
In Search of Sylhet-The Fultoli Tradition in Britain
}

\author{
Abdul-Azim Ahmed * and Mansur Ali \\ Centre for the Study of Islam in the UK, School of History, Archaeology and Religion, John Percival Building, \\ Cardiff University, Colum Drive, Cardiff CF10 3EU, UK; alimm1@cardiff.ac.uk \\ * Correspondence: ahmedma1@cardiff.ac.uk
}

Received: 24 July 2019; Accepted: 8 October 2019; Published: 12 October 2019

\begin{abstract}
This article presents a case study of the Fultoli tradition, an expression of Islam dominant amongst Bangladeshi migrants to the UK, but which in general terms has failed to communicate itself to British-born Muslims. It is also a denominational identity that has been overlooked in academic literature on British Muslims, and regularly mischaracterized. To correct this, the article presents an overview of Fultolir Sahib, the late founder of the tradition, and the theological distinctiveness of his teachings, before considering its movement to Britain. A varied methodological approach is adopted in order to explore the topic, combining a textual exploration of Fultoli sources with qualitative interviews with members of the Fultoli tradition, and also autoethnography drawing upon the authors' (who were both raised by Fultoli parents) experience of the tradition. The article argues that Fultolir Sahib's authority is constructed in an idiom that is inaccessible to British-born Muslims and that Fultoli institutions have failed to create leaders capable of preserving the tradition. It concludes that despite the diminishing numbers of Fultolis in Britain, it is still important for academics to recognize their unique role in the landscape of Muslim denominational diversity.
\end{abstract}

Keywords: Islam; Muslim; Bangladeshi; Britain; Fultoli; Fultolir Sahib; Sylhet; Shah Jalal

\section{Introduction}

In accounts of British Muslim denominational diversity, the Fultoli ${ }^{1}$ tradition, emerging out of Sylhet in Bangladesh, is consistently overlooked. Despite being the expression of Islam practiced by almost all first-generation Bangladeshi migrants to Britain, it has rarely been given any attention or consideration in academic literature and, when it has been mentioned, it is often mischaracterized. The challenge of understanding the Fultoli tradition is exacerbated in that it faces near-extinction in Britain if its current trajectory continues. Despite being popular in Bangladesh, in Britain, there is a drastic generational drop-off in practicing the Fultoli tradition. The Fultoli tradition provides an important case study for British Muslim denominational diversity, and this article seeks to present a corrective to the under-representation of the Fultoli tradition in academic literature by presenting an empirical description of the theology of its founder (Fultolir Sahib ${ }^{2}$ ) and Fultoli institutions in Britain. In presenting this case study, the question of why the Fultoli tradition has failed to resonate with British-born Muslims is explored. The article argues throughout that Fultolir Sahib's authority is constructed in an idiom and language that is inaccessible to British Muslims. Furthermore, Fultoli institutions in Britain have fundamentally failed to create leaders capable of promoting and preserving

1 There are a number of ways that this word can be spelt, including: Fultoli, Phultoli, Phultali, Foltali, Foltoli and Fultali. Whilst the latter is more correct as far as the standard Bengali spelling is concerned, the authors have decided to go with the spelling 'Fultoli' as this is how it is vocalised by nearly all Bangladeshis.

2 In this article, the phrase 'Fultolir Sahib' (a possessive compound, meaning the Shaykh from the village of Fultoli), refers to the founder of the movement, whilst the term 'Fultoli' refers to the tradition, teaching, instutions and people associated with the movement. 
the tradition, such that with the death of Fultolir Sahib, the movement has ceased to have growth or coherence in Britain. The article concludes with a plea to academics in British Muslim studies to more accurately recognize the specific religious history and identity of Bangladeshi Muslims and the Fultoli tradition.

\section{The Absence and Mischaracterization of Fultolis in Academic Literature}

Despite a burgeoning field of British Muslim studies and a growing list of popular books about Islam in Britain, there has been very little written about Bangladeshi Fultolis, a distinctive and sizeable though diminishing denomination within the British Muslim demographic. One of the few places in which Fultolis are given explicit mention is Ed Hussain's controversial book The Islamist (Hussain 2007), where he juxtaposes the 'kinder and gentler religion' (The Sunday Times 2007) of his parents against his foray into political Islam. His parents were followers of the Sufi Master Shaykh Abdul Latif Choudhury Fultoli (1913-2008), often called Fultolir Sahib, the founder and leader of the Fultoli tradition. In terms of academic research, the Bangladeshi-background scholar Sadek Hamid includes an entry on Fultolis by describing the devotionally orientated Bengali Muslims in the UK (Hamid 2016, p. 74) in his book Sufis, Salafis and Islamists: The Contested Ground of British Islamic Activism. The Fultoli tradition is also mentioned in passing by Bulbul Siddiqi in his doctoral thesis on Tablighi Jama'at amongst Bangladeshis in the UK (Siddiqi 2018). Generally, however, when Bangladeshis are mentioned, for example, in overviews of Muslim history and settlement in Britain, their distinctive denominational identity is not included. This includes both academic works (Ansari 2004; Gilliat-Ray 2010) and journalistic ones (Bowen 2014). Even in studies that explicitly explore British Bangladeshi communities and their religious practice, such as that by Barton (1986), the Fultoli tradition is not mentioned-though the author's meeting with an 'undisputed pir' of the Naqshbandi school (Barton 1986, p. 44) in Sylhet may very well have been with Fultolir Sahib. Elsewhere, academics have mistakenly identified Fultolis as Barelwis (Garbin 2005; Brown and Talbot 2006, p. 129) or classified it as Barelwi-orientated (Eade and Garbin 2006, p. 189). The inaccuracy of the 'Barelwi' label is returned to throughout this article, and some reasons for the confusion are considered also.

Garbin however is accurate in his assessment that the Fultoli movement 'does not appeal to second and third generation British Bangladeshis' (Garbin 2005, p. 9), and, unlike other Islamic movements that have emerged in the UK, it has no appeal beyond its immediate ethnic group. This generational drop-off is no doubt part of the reason why Fultolis have not received much attention in academic literature as it is only accessible and observable as an element of the practice of first-generation Bangladeshi Muslims, who will rarely describe themselves as part of a Fultoli tradition. This generational drop-off will also be explored in subsequent sections.

After a consideration of methodology, the remainder of this paper will explore the denominational and theological distinctiveness of the Fultolis, considering their origins in Bangladesh and their activities in Britain. A key issue returned to is why academia has so consistently overlooked the Fultolis, both in Britain and other diaspora contexts, and, in a similar vein, explore why the Fultolis have failed to establish themselves successfully in Britain.

\section{Methodology}

A varied methodological approach has been adopted by the authors of this paper out of necessity. Both authors, British Bangladeshis, have been raised in the Fultoli tradition and met with Fultolir Sahib as young children. Their denominational identity however, like many other British Bangladeshis, did not remain fixed within this paradigm. Neither, in the course of their careers, has come across an extended consideration of the Fultoli tradition and movement, their teachings, beliefs, or activities. This is despite most Bangladeshi migrants to Britain having a link back to this tradition. The movement has produced very few written texts, in Bengali or English, or codified its distinctiveness in anyway. There is also, as will be explored, a failure to pass on the Fultoli tradition or identity intergenerationally. 
This presents a uniquely challenging topic of study. The authors have thus drawn on a combination of methods. This includes both textual and audio-visual sources. Existing works in academic literature have been consulted, along with hagiographic material posted online, and various sermons delivered by Fultolir Sahib uploaded onto YouTube by his followers. This has been combined with qualitative research undertaken in the last two years. One dimension of this has been surveying and documenting Fultoli institutions in the UK based on research of British mosques one of the authors is currently undertaking. It also includes three unstructured interviews with Bangladeshi Muslims about their knowledge of Fultolir Sahib. The individuals were selected for their specific insight or engagement with an aspect of the Fultoli tradition the authors desired clarification on. It includes a first-generation migrant who organized tours by Fultolir Sahib of mosques in Britain in the nineties and noughties, an older second-generation Muslim who attended several talks by Fultolir Sahib, and a former chairman of a Fultoli mosque. The 'flat' organizational structure of the movement in Britain means other than the late Fultolir Sahib and a small number of key Bangladesh-based leaders, there are no 'key informants'.

The above was guided by and supplemented with an autoethnographic approach influenced by Carolyn Ellis, who describes autoethnography as a qualitative approach intended to 'connect the autobiographical and personal to the cultural, social, and political' (Ellis 2003, p. xix). In practical terms, it involved the authors sharing their knowledge and experiences of the Fultoli tradition with each other and seeking to triangulate it with other empirical sources in order to present a sound understanding of the Fultoli tradition sociologically and theologically.

\section{The Founder: Fultolir Sahib}

Shaykh Abdul Latif Choudhury Fultoli, also known as 'Fultolir Sahib', 'Sahib-e-Qiblah', or 'Shamsul Ulama', was a Bangladeshi Sufi shaykh and pir hailing from the north east region of Bangladesh known as Sylhet. He was born in 1913, in the Bengal region of British India, and died in 2008. Information about the life of Abdul Latif Choudhury is hard to establish. Most details come from short hagiographic excerpts written in Bengali and sometimes in English by his followers. The other details are oral accounts, accessible through the first generation of British Bangladeshis, who themselves usually heard the stories from other devotees and followers of the pir. This ambiguity, however, in which the precise details of his life are not known, is likely partly intentional, and helps maintain an important aura of mysticism and mystery necessary for a pir. Through collected reports and biographies, it is clear that Fultolir Sahib is positioned carefully as an inheritor of the heritage of the Prophet Muhammad, Muslim India, and the Sylheti region itself. The way in which biographic accounts of Fultolir Sahib achieved this will be presented next.

To comprehend the Fultoli tradition requires understanding the person of Fultolir Sahib. His message, activity, and call are, in the context of Bangladesh, as significant as who he is. The messenger and the message are intertwined amongst Fultolis. This can be seen in four areas: Fultolir Sahib and the origins of Islam in the Bengal, Fultolir Sahib and Islam in wider (Mughal) India, Fultolir Sahib's prophetic mandate to teach, and, finally, Fultolir Sahib's spiritual (Sufi) lineage. All four combine to provide Fultolir Sahib with a pre-eminent religious authority amongst Bangladeshi Muslims.

The story of Islam reaching Sylhet is enshrined in an oral tradition that figures remarkably consistently in the paideia of Bangladeshi Muslims. The narrative runs roughly as follows. In the fourteenth century of the Christian era, a Muslim family in the Sylheti region, alone and unsupported, faced persecution from their Hindu neighbors and a local ruler. The father of the family, Burhan ad-Din, on the birth of his son, secretly sacrifices a cow in gratefulness to God. A crow steals a morsel of flesh and drops it in the vicinity of a Brahmin family, or in some accounts, into the court of the Hindu ruler himself, Raja Gaur Govinda-who seeks out the source of the slaughtered cow and then punishes Burhan ad-Din for desecrating Hindu sensibilities by killing his son. Distraught, Burhan ad-Din beseeches help from other Muslims, unsuccessfully, until his pleas reach the legendary Shah Jalal Makhdum Mujarrad (d. 1346 CE), and his 313 disciples. Shah Jalal avenges Burhan ad-Din by conquering Raja Gaur Govinda's palace (through a series of miracles) and then decides to settle in 
Sylhet and, with his disciples, teaches Islam to the locals. The story is included in Barton's study of Bradford Bengali Muslims (Barton 1986), as well as in Metcalf's anthology on Islam in South Asia (Metcalf 2009). It is an important part of the self-conceptualization of Sylheti Muslims. Shah Jalal's intimate link to Sylhet and the region can be observed in the eponymous naming practices prominent in the region. The area of Shah Poran is named after one of Shah Jalal's nephews and disciples who was supposedly banished to the outskirts of Sylhet after consuming one of Shah Jalal's prized pigeons. Another Meccan disciple of Shah Jalal by the name of Khawaja Shah Kamal Qahafan settled on the banks of the Ratna river. This area became known as Shaharpara (lit: Shah by the banks of the river). This eponymic practice, as we shall see, continues with Fultoli Muslims today and the naming of mosques in Britain.

The historicity of the account, when stripped of the miraculous feats included in hagiographies, is largely attestable. Shah Jalal does indeed seem to have been a real figure, as was the toppling of Raja Gaur Govinda (see Metcalf 2009, pp. 138-43). The famous Muslim traveler Ibn Battuta (d. 1377) includes a notice of meeting Shah Jalal in Sylhet in his travelogue al-Rihla (Eaton 1996, 2010).

The role played by Shah Jalal in Sylhet's collective memory is perhaps comparable to the patron saints of Christian countries, or the 'founding-father' in nationalistic myth. Consequently, the reader should appreciate the significance of Fultolir Sahib tracing his lineage back to a disciple and close friend of Shah Jalal, Shah Kamal (Allamah Fultali Sahib Qiblah 2010). This blood-relation with the disciple of Shah Jalal immediately confers upon Fultolir Sahib a sense of inherited piety and places him in the founding narrative of Sylhet and the surrounding region.

The biographic accounts of Fultolir Sahib also often mention that he is a descendant of Shah Alaa Bakhsh who-according to the biographers-was active in Ahmad Sirhindi's (d. 1625) reformist movement ('Family Background' Nadwi 2009). The latter, Sirhindi, was widely celebrated in scholarly circles for resisting and contesting the Mughal Emperor Abu al-Fath Jalal ad-Din Muhammad Akbar (d. 1605)'s heterodox notions of Islam. Whether or not Shah Alaa Bakhsh was involved in Sirhindi's reforms is not clear, but it appears the biographers of Fultolir Sahib are more concerned with anchoring him as a descendant of the religious struggles at the heart of Islamic India and the Mughal empire.

Another account central to Fultolir Sahib's institutional activity and often included in biographies shared about Fultolir Sahib relate to a dream in which he was commended by the Prophet Muhammad. The following story is narrated by Fultolir Sahib's son Najmuddin Choudhury Fultoli (Shafe Ahmed 2019) and has been transcribed and translated into English by the authors of this article. However similar versions of the story have been shared on various biographies online (Hazrat Allama Fultali Saheb Qiblah 2013) and in interviews with Fultoli followers in Britain. The story begins that while Fultolir Sahib was teaching at Badarpur Senior Madrasah one day, he was visited by Shaykh Abd al-Nur Gharkafni, a well-known and celebrated pir from that part of the country. Najmuddin Choudhury Fultoli quotes his father Fultolir Sahib as follows:

I was teaching Tirmidhi Sharif in class one day when Maulana Abd al-Nur Sahib came to visit me. I assumed he came to observe me teaching my students. After class he approached me and said, 'I have come to you regarding an important request.' I replied, 'What is your request?' He said, 'teach me how to recite the Qur'an (qirat) once a week.' I was very busy with teaching hadith and tafsir, as this requires advanced preparation, so I gave him my apologies and refused. He went away and came back the following day. After I finished teaching, he came to me and said, 'I have come back again for the same request.' I, again, told him of my difficulties, but he replied, 'This is not my request, but from someone far greater.' I replied, 'Did my teacher Maulana Badarpuri Sahib send you?' He replied, 'No, someone far greater than him.' I said, 'tell me who it is.' He replied, 'I saw the Prophet in my dream, I requested that I wish to hear him recite the Holy Qur'an. The Prophet recited the Qur'an in the most beautiful manner. I asked, 'O Messenger of God. I wish to recite as you did.' The Prophet pointed towards a man on his right. When I looked at this man, I saw that it was none other than you sat beside the Prophet.' After hearing this I stood up in utmost 
respect and informed him that I would teach one hour per week, God willing. He asked, 'Where will you teach us?' I told him, 'at the shrine of Shaykh Adam Khaki.' We agreed that we would meet every Thursday at midday. The shrine was one mile away, so Maulana Abd al-Nur Sahib brought me a horse to ride there. The word spread that I would be teaching qirat and when I went there, I found that 250 ulema and imams had come to learn. The lesson extended all the way to Isha prayer.'

This story is heavy with meaning. Nile Green observes that such visions and dreams often formed an 'essential element in the rhetoric of sainthood,' and include a component of inter-denominational competition between pirs (Green 2003, p. 210). While pious lineages are important, the dream is an indicator of divine approval and baraka (see Cormack 2013 for an edited collection that explores the concept of baraka in a variety of settings) present in an individual. Not only does the dream narrative serve the function of elevating Fultolir Sahib's teaching of the Quran by receiving Prophetic approval, it also serves to allow lay Muslims an opportunity to access the same Prophetic approval by seeking Fultolir Sahib as their teacher.

In Sufi circles, the core component of an individual's qualification as a pir is his silsila (Bearman et al. 2012). Fultolir Sahib's silsila or spiritual lineage was likewise important in the construction of his authority, tracing its way to Karamat Ali Jaunpuri (d. 1873) (Kazir Bazar 2014). It is also here that the common misconception of Fultolis as similar to Barelwis can be understood in context. Jaunpuri was the spiritual disciple of the scholar, Sayyid Ahmed Barelwi (d. 1831—not to be confused with Ahmed Reza Khan Barelwi (d. 1921), although it is likely some have) and a disciple of the equally conservative scholar Shah Muhammad Ismail (d. 1831). Jaunpuri was sent by Sayyid Ahmad to reform Islam in the Bengal region from what were considered heretical cultural accretions and Hindu syncretism by Sayyid Ahmad (Metcalf 1982, p. 70; Nadwi 2009, p. 37). Jaunpuri's activism led him to be known as Fatih Bangal or the Conqueror of Bengal (Hanif 2000, p. 189). This part of Fultolir Sahib's biography is pertinent as while his biological lineage reaches back to the origins of Islam in the Bengal region, his spiritual lineage has him connected to modern Islamic revival in Bengal.

Fultolir Sahib's silsila also highlights why it is incorrect to label the Fultoli movement as Barelwi-influenced (David 2005) or Barelwi-oriented (Eade and Garbin 2006). The aforementioned Shah Muhammad Ismail, both a disciple of Sayyid Ahmad and a teacher of Jaunpuri (Nadwi 2009, p. 20), was the subject of sustained criticism from Ahmed Reza Khan, the founder of the Barelwi movement. Ahmed Reza Khan laboriously lists seventy reasons as to why Muhammad Ismail had committed heresy based on the latter's work Taqwiyat al-Iman (though Ahmed Reza Khan hesitates from issuing a final declaration of $k u f r$ ) (Sanyal 2005, p. 107). In short, while there are apparent similarities between Fultolis and Barelwis, they are no more significant than the apparent similarities between Deobandis and Barelwis (after all, both groups are South Asian Sunni Hanafis who consider themselves Sufis). Rather, Jaunpuri and Muhammad Ismail represented a scholarly tradition, separate and distinct from Muhammad Qasim Nantauvi (d. 1880, the founder of the Deobandi movement) and Ahmed Reza Khan (d. 1921). Fultoli Islam is the contemporary manifestation of that tradition. The link shared between Fultolis, Barelwis, and Deobandis is that they emerged out of the vibrant and highly charged religious public sphere of India under the Raj, in which calls for religious reforms had both urgency and political relevance.

It may be that the similar names of Sayyid Ahmed Barelwi and Ahmed Reza Khan Barelwi is what led to academics conflating Fultolis and Barelwis. Such confusion occurs between Deobandis and Barelwis too, with the Oxford Dictionary of Islam listing Sayyid Ahmed Reza Khan Barelwi as the founder of the Deobandi movement (Esposito 2004)—despite tracing the lineage correctly in another section (Moosa 2004). As of yet, no academic literature has correctly traced the lineage and history of the Fultoli tradition, or the salience of the divisions amongst Muslims from Bangladesh. This article hopes to begin a process of correction in the representation of Fultolis in literature. 
This section has listed four key ways in which the person of Fultolir Sahib is charged with religious authority, namely: His link to Shah Jalal and the origins of Islam in Bangladesh, as a continuation of the tradition of Islam in Mughal India, his Prophetic mandate, and his spiritual lineage.

\section{Fultolir Sahib's Institutions and Scholarship}

Fultolir Sahib is best-known for founding the Darul Qirat Majidia Fultali Trust Madrasah in Bangladesh, which educated the public in Islamic studies, specializing in the recitation and memorization of the Quran. When it was launched in 1950, it began as a month-long program that ran during the month of Ramadan to teach the correct pronunciation of the Qur'an, and then developed into a fully-fledged seminary (Darul Qirat Majidia Fultali Trust 2019). The success of the seminary in Bangladesh led to the model being adopted in Britain, including the flagship Fultoli institution of Darul Hadis Latifiah in London.

A range of other organizations in Bangladesh are attributed to Fultolir Sahib (British Fultoli organizations will be looked at in the next section), such as Anjumane Madaris e Arabiya (the Association of Arabic Schools), which sought to both preserve the standards of madrassa education while also fighting for employment rights of teachers employed in the madrassa system, and Anjumane Talamije Islamia, an Islamic Students network. The success and activities of these organizations in Bangladesh is hard to establish, with disparate news stories, social media posts, and an unreliable online presence. Without further fieldwork in Bangladesh itself, this paper is unable to answer this question.

Fultolir Sahib was anything but a prolific writer, his primary scholarly output was as a teacher and preacher, delivering lectures and classes. The short list of books he did publish were written in a variety of languages. These include Al-Qawlus Sadeed fil Qirat wat-Tajweed ('True and Accurate Speech in Recitation and Pronunciation'), a short and popular book available in Urdu, Bengali, and English used to teach the correct recitation of the Quran. Anwarus Salikeen is an Urdu language book detailing the Sufi path, and Nek Amal is a short Bengali language book aimed at a popular audience illustrating various actions rewarded and praised in the Islamic tradition. Al-Khutbat al-Yaqubiyyah is one of Fultolir Sahib's most popular publications, it is a collection of short Arabic Friday sermons with Bengali translations, rich and replete with Quranic references and hadith. The book is named after Fultolir Sahib's teacher and father-in-law Shaykh Hatim Ali Yaqub Badarpuri (d. 1958 CE). In the South Asian Hanafi tradition, the Friday sermon is read in Arabic, and as such, pre-written Arabic sermons of this nature are popular, especially in Britain, where it allows non-specialists to lead the Friday prayer.

However, the core of Fultolir Sahib's influence remained within the paradigm of the traditions of the tariqa in which he was a pir. Through personal relationships and sermons, he and his key followers, such as Maulana Nizam Uddin Biskhuti Sahib (d. 2009 CE), would maintain and spread his influence within Britain.

\section{The Theology of Fultoli Tradition}

Fultoli beliefs, theology, and practices are rooted in a Hanafi Sunni expression of Sufism common in the Indian subcontinent. The initial similarity with other expressions of Islam is probably why, hitherto, researchers have confused them with Barelwis, or otherwise overlooked their distinctiveness, especially as both Barelwis and Fultolis place an emphasis on what Gellner calls 'low Islam', the Islam of rural populations with a focus on rituals and concretization of abstract doctrines in the form of Sufi venerations (Gellner 1992). Sufism has been the de facto Islam in the Indian sub-continent even amongst the early Ahle Hadith movement (Metcalf 1982, p. 57).

In accordance with the religious tradition in the Bengal region, Fultolir Sahib was a Sunni, Hanafi, Sufi Muslim. Many of his lectures and works are a defense of his beliefs, or articulation of the practicalities of the Naqshbandi tariqa. As an orator, Fultolir Sahib's sermons are sporadic and unstructured. He often gets side-tracked by tangents, frequently leaving a point unfinished before starting a new one, a story within a story like Cervantes in Don Quixote or the author of the Arabian 
Nights. His sermons are however rarely aimed at providing a coherent or comprehensive lesson. Unlike the university lecture, Fultolir Sahib's aim is to provide a wide array of moral exhortations and wisdom traditions. However, a single theme consistently is returned to within his sermons-that of respecting and recognizing the 'true' status of the Prophet Muhammad.

For Fultolir Sahib, a person cannot be a true believer unless they recognize the status afforded to the Prophet Muhammad by God. Unlike other denominations who frame the discussion of orthodoxy and heterodoxy by using Arabic terms like sunna (prophetic practice) and bid'ah (heresy), Fultolir Sahib takes an approach rooted in Qur'anic rhetoric. He labels an orthodox Muslim as one who is simultaneously a Mu'min and a Muslim, whilst the heretic is only a Muslim (Allama Fultoli Saheb Qiblah 2017). Drawing on a variety of Qur'anic verses, Fultolir Sahib argues that even the Prophet was wooed by the apparent piety of some of the 'hypocrites'; however, God warns him that while they may be Muslims (those who practice Islam), they are not Mu'mins (those who fully believe in Islam) (Allama Fultoli Saheb Qiblah 2017). Moving on from this premise, Fultolir Sahib argues that salvation can only be attained when outer submission (Islam) is aligned with inner conviction (iman). In contrast with the Deobandis and Barelwis, in Fultolir Sahib's view even the Ahmadis are Muslims. Importantly, however, they are not Mu'mins. For Fultolir Sahib, a person's inner conviction will never align with its external manifestation if one's beliefs about the Prophet are incorrect. Thus, believing the Prophet to be just another human is an error, he is a perfected human and thereby something unique and transformative to the rest of creation. Fultolir Sahib's soteriology based on his prophetology has led him to rebuke, refute and mock those who disagree with him, and the Jamaat-e-Islami are selected for particular scorn.

The intercession of the Prophet is an integral part of Fultolir Sahib's prophetology. According to Fultolir Sahib, one can be a Muslim without praying, however, not holding the Prophet in correct reverence will be the cause of being deprived of the Prophet's intercession (Saheb Qiblah Fultali (Muhammad Abdul Latif Chowdhury) - Waz II (2014)). Fultolir Sahib roots this strongly within a sober doctrine of the Prophet's mortality, describing any claims of divinity to be 'extending one's feet in front of the Prophet', a Bengali expression meaning to go beyond what someone has instructed (AAllama Saheb Qibla Fultoli, Moulovi Bazar 2004 2016). Thus, in contrast to Barelwi teachings, the Prophet is not 'Knower of the Unseen' (alim al-ghayb), nor does he attend the mawlid gatherings (hazir o nazir) and to place a chair in anticipation of the Prophet's appearance is to deviate from his sunna. The recitation of salam ala al-Nabi (salutation on the Prophet), also known as mawlid, mawlud sharif, or qiyam, is an integral part of Fultolir Sahib's teaching. Anyone who denies the mawlid is a 'Wahabi' according to him. However, for Fultolir Sahib, unlike the Barelwis, standing up in the mawlid is in remembrance of the Prophet being born into the world and not in anticipation of his appearance at the event (Allama Fultoli Saheb Qiblah 2017). The debate around the personhood of the Prophet, his nature, the extent of his knowledge and presence in the world, are fault lines of identity between Deobandis, Barelwis, and other groups (such as the Jamaat-e-Islami) in contemporary South Asia. Fultolir Sahib navigates these debates, putting forward a unique position on each that aligns with neither the Deobandis, Barelwis, or Islamists such as the Jamaat-e-Islami. Mehmood Naqshbandi, who manages a national database of British mosques (Muslims in Britain 2019) admitted to also finding it difficult to recognize their unique practices, stating that he initially considered Fultoli mosques as potentially 'a typical low-key Deobandi masjid, particularly of the more tassawwuf-inclined variety' until learning about the Fultoli tradition (Naqshbandi, 2017, personal communication, 4th August).

Given Fultolir Sahib's role in establishing schools of qirat and tajweed, it should not come as a surprise that the correct pronunciation of the Quran has become a focal point for Fultolis. In particular, the correct articulation of the letter dāa (ض) has become an idiosyncratic fault-line for Fultoli identity, especially during recitation of the opening chapter of the Quran, the fatiha (which is repeated in every formal daily prayer). So adamant was Fultolir Sahib, and subsequently his followers, on the correct articulation of dād that Fultolis became known amongst Bangladeshis as 'duallin fornay wala', or 'the people who read duallin' (referring to the final verse of the fatiha) as opposed to 'zuallin fornay wala' or 
'the people who recite zuallin. Subsequently, the epithet 'duallin' (which ironically means 'those who have gone astray') has become a marker for true Islamic identity and the title 'zuallin' was reserved for movements and denominations of Islam considered 'deviant'.

Understanding the roots of this debate, which has manifested in conflicts within Fultoli mosques in Bangladesh and Britain, is challenging. The letter dād is the most difficult letter to pronounce in Arabic, and it has long been considered unique to the Arabic language itself, leading to Arabic being referred to as 'the language of dād' (Versteegh 2001, p. 89). Other than native Arabs of a particular dialect, not many people can successfully pronounce it (Brown 2007). The sound for dād' is made when air is forced through the left side of the tongue as it touches the left top and bottom molars. Any minimal gap between the side of the tongue and the molars will result in a sound which is similar to a zầ' sound. Scholars experienced in the recitation of the Qur'an recognized the difficulty of this letter and understood the theological problems that can arise because of a change of meaning caused by substituting one letter for another. Thus, they wrote many works elaborating Islamic guidance on this issue (Shafi 1932).

It is not clear why Fultolir Sahib became exclusively animated over the articulation of dād. One brief account from Fultolir Sahib in 2004 recounts that he was forced to flee to Pakistan due to rioting that took place in the 1950s. While in Pakistan he was told that the mark of a true scholar is to believe that the Prophet Muhammad was subject to human frailties and weaknesses, and to recite the letter dāa as zạa' (Allama Fultoli Saheb Qiblah 2017). Fultolir Sahib explains he took it upon himself to refute these beliefs. Beyond this short narration, the authors have been unable to trace why the dād has emerged as such an important denominational issue for the Fultolis. Nonetheless, the consequence of this is that the average Fultoli Muslim is acoustically trained to perceive whether the imam leading the prayer is reciting duallin or zuallin (even if this Muslim is otherwise amateur in Quranic recitation). For the imam of a Fultoli-aligned mosque, it is a daily job interview, and any minute slip of the tongue (literally) whilst reciting the final verse of the fatiha will lead to censure and rebuke from congregants. This has resulted in a heightened awareness by Bangladeshi imams, Fultoli or otherwise, regarding the correct pronunciation of the letter ḍād in the fatiha (even though there may be lapses in the correct pronunciation of other parts of the Qur'an).

In terms of practice, Fultolir Sahib outlined a simple series of instructions for followers (those who took bay'a from him, or the pledge of allegiance Sufi Muslims offer pirs). It included an exhortation to be 'of assistance to others', to delight in other's successes and not be pleased in other's failures, to diligently observe the five daily prayers, to recite the shahada (Islamic declaration of faith) silently with every breath, and to recite salawat upon the Prophet at least 200 times before sleeping, as well as to seek forgiveness from God at least 100 times in a day. These instructions were delivered to all followers who took bay'a from him, such that other than being recorded in numerous places online (Fultali 2017; Al-Nasiha Al-Latifiyyah 2013), the advice was also recounted by British Bangladeshi Fultolis interviewed as part of the research for this article.

Fultoli theology then is largely synonymous with other Sunni, Hanafi, Sufi Muslim groups. Its idiosyncratic features, an emphasis on correct prophetology and on the pronunciation of dād, are debates that while relevant in Bangladesh, have largely been confined to Bangladeshi Fultolis in Britain.

\section{From Sylhet to Britain}

Having outlined the person of Fultolir Sahib and the theological distinctiveness embedded within the Fultoli tradition, the following section will consider more closely their establishment in Britain.

The Bangladeshi migrants who settled in Britain are part of a wider migration from Commonwealth countries to the United Kingdom following the Second World War. As such, many of the accounts of Bangladeshi migration to the UK are part of wider histories of Muslim settlement, such as Ansari's 'Infidel Within' (2004). A small number of researchers have paid particular attention to Bangladeshis and their history of settlement in Britain (Eade 1990; Eade and Peach 1996; Khanum 2001; Eade and 
Garbin 2006; Peach 2006; Kibria 2008; Lie 2010). In general, Bangladeshis followed the pattern of wider post-war migration-young men seized on opportunities for employment following the Second World War and the British Nationality Act 1948 (which conferred upon them British citizenship as former subjects of the British Empire). Their employment was usually in labor-heavy roles (factories, on ships, and later, the service industry).

Not long after moving to Britain, the single men brought wives and families from Bangladesh and began a period of chain migration. Today, Bangladeshis-like many of their Windrush generation counterparts-have a first-generation community long-settled in Britain, and an adult second-generation population increasingly with families of their own. In some places, this has moved into third, fourth, and sometimes even fifth generations. Kibria identifies two phases of Bangladeshi migration to Britain, the first of Bengali single men travelling for work, and the second of chain migration and reunification of families (Kibria 2008, pp. 247-48). This broad picture however can conceal several unique facets of the British Bangladeshi population.

The first is the singular geographic origin of the migrants. In 1948, many of the migrants we now identify as Bangladeshi would have been from "East Pakistan", formed following the partition of India and the end of the British Raj. The region of East Pakistan is culturally, ethnically, linguistically, and to a certain extent, religiously, distinct from "West Pakistan" (what is now simply Pakistan). East Pakistan became Bangladesh following an armed struggle for independence in 1971. However, Bangladesh itself is diverse, and Sylhet is in many ways an exception to the rest of contemporary Bangladesh. "Historically, Sylhet was in Assam, not Bengal" writes Samuel, and the Sylheti dialect spoken by its inhabitants "is not immediately intelligible to speakers of standard Bangla" (Samuel 2012, p. 142). This distinctiveness of the region is significant when considering the character and profile of Bangladeshi migrants to the UK as it is estimated that between 80\% (Peach 2006, p. 136) and 95\% (Lie 2010, p. 1428) hailed from Sylhet. The Bangladeshi population of Britain is overwhelmingly a Sylheti population. They are bound by their unique dialect of Bengali and their largely rural backgrounds, as well as the religious history of Shah Jalal outlined prior.

The second unique facet of Bangladeshi settlement in the UK is the pattern and timescales of migration. While young men from Sylhet were offered the opportunity to work in Britain like others under the former Raj, Peach considers this migration to be lagging "10 years behind" (2006, p. 137) their Pakistani counterparts. Thus, he argues that while Pakistanis migrated to Britain from the 1950s onwards, Bangladeshi migration only began in earnest in the 1960s. Likewise, Pakistanis began settling with families in the 1970s, whereas Bangladeshis only began this process in the 1980s. In the 1991 census, Bangladeshis were the youngest population amongst Muslim migrants (Eade and Peach 1996). Ansari observes that Bangladeshi migration to Britain increased in the 1970s and 1980s while it was declining from other South Asian countries (2004, p. 155). While it is no longer the case that Bangladeshis are the youngest Muslim migrants in Britain, it is likely that their institutional development is correspondingly also ten years or so behind their Pakistani and Indian counterparts.

Finally, demographically and economically, there are distinctions too. There are fewer Bangladeshis in England and Wales than Pakistanis or Indians. The 2011 census records 447,201 Bangladeshis (compared to 1,124,511 Pakistanis and 1,412,958 Indians), making them a minority within the wider South Asian population (Population of England and Wales-Ethnicity 2019). The Bangladeshi population is less financially well-off than other South Asian counterparts also, with lower levels of home ownership, employment, and educational attainment (Salway 2008; Dale and Ahmed 2011). They are clustered in London, particularly Tower Hamlets, leading Garbin to write the British Bangladeshi population "is a very English urban population-very few live in Scotland or Wales" $(2005$, p. 1). Those Bangladeshis who are in Wales and Scotland are often individuals who first settled in England, and then moved to find new opportunities in the tertiary industry, establishing restaurants and takeaways in rural towns or working in the taxi service.

Relevant to the discussion of Fultoli denominational identity, there are very few ways in which to ascertain numerical data about the tradition. While it is most common amongst first-generation 
Bangladeshis, it is not the denomination followed by all Bangladeshi migrants. The 2011 census recorded that $51.9 \%$ of the Bangladeshi population in the UK is British-born (People Born Outside the UK 2018), however details for where the remaining $48.1 \%$ where born is not available (and it is not uncommon for Bangladeshis to migrate to Britain from other European countries). As such, it is not possible to ascertain a reliable estimate of the number of Fultolis in Britain (usually first-generation migrants from Bangladesh), and, likewise, without further research it is not possible to draw any conclusions about the numbers involved in the generational drop-off discussed prior. A breakdown of Fultoli institutions in Britain in the next section provides some indication of their influence and significance within the wider British Muslim denominational landscape, but without further qualitative and quantitative research, conclusive numbers are currently impossible to ascertain.

In summary then, there are several salient facets of the British Bangladeshi population worth noting. They are generally more recent migrants than other Commonwealth migrants. They are usually more socio-economically deprived than other Muslim migrants. They are numerically significant in Britain as a contingent of the Muslim population (likely hovering around the figure of half a million) but much smaller in number than Pakistani or Indian counterparts (though the Bangladeshi Muslims are more numerous than Indian Muslims in the UK). They are clustered in England, especially in London, particularly in Tower Hamlets. The Bangladeshi migrants are also overwhelmingly from Sylhet, which is a unique part of Bangladesh, distinctive in language and history. These are the migrants then who brought the Fultoli tradition to Britain.

\section{Fultoli Mosques in the UK}

These first generation of migrants from Sylhet brought with them their national-cum-religious history of Shah Jalal, the mystic itinerant warrior-saint who is credited with bringing Islam to the region. The Fultoli tradition, as identified, traces its origin back to one of Shah Jalal's 313 companions (Shah Kamal). One way in which this identity has been recreated is through the establishment of mosques. Like other Muslim migrants in diaspora, the establishment of the mosque became a priority as soon as single Muslim men began marrying and starting families (Ahmed 2019).

Fultoli mosques are often keen to include "Shah Jalal" in the title of the mosque. There are 34 "Shah Jalal" mosques in the United Kingdom, with the majority in England but with 2 in Wales and 1 in Scotland. Alternative names include "Jalalia" (meaning 'of Jalal'), of which there are 5 (all England bar 1 in Wales) or Jalalabad (meaning 'the place of Jalal'), there are 7 such mosques all in England. There are also the similarly named Shah Poran mosques (a disciple of Shah Jalal), with 1 in Wales and 4 in England. This naming convention means that Shah Jalal is the Muslim figure with the most mosques named after him (46 in total, and a further 5 named after his disciple of Shah Poran). No other figure comes close, including the Prophet Muhammad or famous companions (Abu Bakr, Umar, Usman, Ali, or Bilal).

This eponymic naming convention is telling about meaning-making by Fultoli Muslims. To make sense of the naming strategy requires one to be familiar with a particular context. Here, it may be better to speak of 'con-text' than context, drawing on Shahab Ahmed's discursive conceptualization of how Muslims make meaning (Ahmed 2015). Con-text' is the historical, literary, cultural, artistic, and scholarly resources Muslims draw upon to make meaning. Some of these resources may be universal to Muslims, such as the story of the Prophet Muhammad's biography (thus the prominence of mosques named "Madinah"), but others are tied intimately to a locality or ethnicity, such as in the case of Shah Jalal. The challenge, which relates to the generational drop-off amongst Fultoli Muslims, is that British-born Bangladeshis as well as non-Bangladeshi Muslims will find it difficult to access the meanings and significance of such naming conventions.

Naqshbandi identifies 32 mosques belonging to the Fultoli tradition in his database (Muslims in Britain 2019), only some of which overlap with the eponymic naming convention discussed above. Likewise, Garbin (2005) identifies a handful of mosques in Birmingham with Fultoli-links (such as the Jalalabad Sunni Jame Masjid and Islamic Centre or the Muslim Association of Salisbury). 
A comprehensive list of Fultoli mosques is however difficult to compile, not least because the generational drop-off discussed prior means that mosques can change ownership and identity. An example is the Jamia Al-Jalalia, a madrassa and mosque based in Oldham opened in the early noughties, though only officially incorporated as a trust in 2008. The Bangladeshi Fultolis found themselves unable to maintain the running of the madrassa, both financially and following a series of controversies involving trustees. In 2011, the trustees eventually handed over control to Jamia al-Karam, the flagship madrassa for the Barelwis in Britain, to continue running Jamia Al-Jalalia, which was eventually re-opened in 2012 as Oldham Islamic College. This story of a Fultoli institution changing denominational identity is not uncommon, and if the generational drop-off of adherence to the Fultoli tradition continues, it will become increasingly challenging for Fultolis to maintain the identity of mosques, madrassas, and charities.

One of the best-known mosques with a Fultoli heritage is the Brick Lane Jamme Masjid. The establishment of the mosque was ostensibly a reaction to the more reformist tendencies of the East London Mosque nearby, leading to congregants purchasing the building, originally a chapel and subsequently a synagogue, and converting it to a mosque (Saleem 2018, p. 71). Indeed, Eade and Garbin observed how the commitment to Fultoli Islam amongst the mosque congregation was a stumbling block for the recruitment and growth of reformist movements amongst Bangladeshis in East London (Eade and Garbin 2006, p. 189). It remains staunchly Fultoli, and annually hosts an urs on the anniversary of Fultolir Sahib's death.

What is notable about the establishment of Fultoli mosques is that despite the striking uniformity on naming conventions, they are individual, independent, and emerge out of local groups. There is no evidence of any hierarchy or formal relationship between Fultoli mosques in their establishment. Fultolir Sahib did not command his followers to establish mosques in Britain. Nor did the followers of Fultolir Sahib look to him for authority to establish a mosque. Rather they built mosques and recreated the only expression of Islam they knew and were familiar with-a Sunni Islam, of the Hanafi madhab, of the Naqshbandi tariqa, of the Fultoli tradition. Once established, they did become part of a network of Fultoli institutions, hosting Fultolir Sahib, his sons, or other highly regarded preachers and pirs within the Fultoli tradition (such as Maulana Nizam Uddin Choudhury Bishkuti Sahib). Such visits would see the guest delivering a $w^{\prime} a z$ (an Islamic sermon, the word is Bengali though has made its way to the language from Arabic via Persian) followed by fundraising, usually to support Fultoli institutions in Bangladesh (such as orphanages, madrassas, or other charitable development projects). Garbin describes these visits as " $w^{\prime} a z$ mahfil" and taking place in the Fultoli-linked mosques in Birmingham (Garbin 2005, p. 8). The guest would then be hosted in a local Bangladeshi family's home for the night, something both practical but also highly sought after by the family for the baraka of hosting a pious figure. This informal practice bound together the various Fultoli institutions, creating an informal network and also raising important funds for the activities of Fultolir Sahib in Bangladesh. However, it has largely declined following the passing of Fultolir Sahib and Biskhuti Sahib, though still maintained to a lesser degree by his sons.

There are also those institutions established directly as a result of the activism of Fultolir Sahib. One of the most prominent organizations is the Darul Hadis Latifiah Secondary School, College and Title Madrasah. It began as a complimentary educational school for Muslim children, established in 1978 directly by Fultolir Sahib, out of concern for young Bangladeshi children in Bethnal Green (a district within Tower Hamlets in East London), teaching the children a basic Islamic studies syllabus. It has since become a full-time secondary faith school. A similar institution, the Latifiah Fultali Complex was established under Fultolir Sahib's guidance in West Bromwich, a town a short distance from Birmingham in England. The Latifiah Fultali Complex hosts a secondary school, the British Muslim School, as one of its projects. Both of these institutions are modelled after the previously mentioned Darul Qirat Majidia Fultali Trust Madrasah in Bangladesh. Darul Hadis Latifiah is also a base for other organizations founded by Fultolir Sahib, such as the Al-Islah Youth Forum or Anjumane al-Islah. The former is a youth organization, focusing on short Islamic courses and daytrips. The latter, Anjumane 
al-Islah, is modelled on a similar organization founded by Fultolir Sahib in Bangladesh. The website describes it as a 'non-political charity' (About Us 2019) though Garbin describes it as the 'political wing' of Fultolir Sahib's activities, though 'not very influential either in Britain or in Bangladesh' (Garbin 2005, p. 7). Its work in Britain has historically focused on fundraising and attempting to build networks and local chapters of activists. The association is currently largely inactive, especially as similar work is being done by the Fultali Foundation, a registered fundraising charity in Britain.

\section{The British Decline of Fultolis}

The story presented so far of the Fultoli tradition is one of significant growth and activity in Bangladesh. By combining his authority as a descendant of Shah Jalal, a scholar in the tradition of scholars of Mughal India, and hagiographic accounts of Prophetic approval, with a simple message, Fultolir Sahib was successful in reaching many Sylheti Muslims. As these Muslims migrated to Britain, they brought with them their identification and reverence for Fultolir Sahib. The Fultoli institutional landscape of Britain is loose, however. Unlike Deobandi establishments, where authority, tradition, and hierarchy are more clearly defined, Fultoli institutions are more independent and only bound by networks of association and familiarity. Prior to Abdul Latif Chowdhury Fultoli's death, these were sustained through his itinerant preaching and fundraising. However since his passing, and that of Biskhuti Sahib, there are few individuals left to continue this legacy (only Fultolir Sahib's sons have the spiritual capital to do so). There is now very little then to bind together Fultoli institutions, or to continue their association with each other, other than a shared religious identity.

This is not the only challenge however faced by Fultolis in Britain. The tradition is deeply tied to Bengali soil. Returning to a key question in this article, the general failure of Fultoli Islam to successfully propagate itself within Britain, it is possible to identify how the biographical features that make Fultolir Sahib preeminent amongst Bangladeshis fail to resonate with British-born Bangladeshis or to non-Bangladeshis. This effectively turns the Fultoli tradition into an insular one, inaccessible except to insiders. Fultolir Sahib's religious authority and appeal is tightly bound to the geographic and religious space of Bangladesh itself. How relevant is being a descendant of Shah Jalal to a British Muslim? It could be argued that the Prophetic mandate has a potentially wider appeal, however the specific medium in which it is expressed, that of a dream, is a Sufi paradigm that would be rejected by strict textualists (such as Salafis) and viewed with skepticism by conservative Sufis (such as Deobandis). Much of the message, practices, and meaning-making of the Fultoli tradition simply fail to work in a British context. An example of such a practice is the bay'a that would take place at the end of lectures by Fultolir Sahib. The Bangladeshi Sylheti Muslims would queue in front of Fultolir Sahib and commit to following his teachings and preaching. The bay' $a$ is a familiar Sufi practice, and so not unusual. What is unusual is that the bay'a would be offered and received in Urdu-the national language of Pakistan-by Bangladeshis with only limited capability to speak and understand Urdu. It would be an easy mistake to read contemporary national implications into this, but it is more accurate to understand the use of Urdu in the subcontinent as a sacred language of Muslim scholarship, agency, and ambition (Hakala 2016). This resonance of Urdu however is less intelligible in a British context, and while it is easily changed, like much of the Fultoli tradition, its followers have sought to recreate it in Britain with as much fidelity as possible.

Other challenges relate specifically to leadership of Fultoli institutions, most notably, the mosque. With no full-time madrassas producing Fultoli ulema in Britain, there is a dearth of English-speaking Fultoli imams. Fultoli mosques are faced with a number of bounded choices. One option is to hire an imam from Bangladesh, which perpetuates the challenges of connecting with a British-born Muslim congregation (Bangladeshi or otherwise). The alternative is to hire a qualified British-born English-speaking imam but who has graduated from a British institution belonging to another denomination, usually Deobandi, which means to lose their denominational distinctiveness. A third option, often resorted to out of desperation and necessity rather than preference, is to have the religious 
functions of the imam undertaken by Islamically semi-literate and pious laymen rather than trained ulema. All three can be observed in Fultoli (or, sometimes, former Fultoli) mosques.

The future of the Bangladeshi Fultoli tradition in Britain remains uncertain. Its presence is marked by absences. While the Deobandi movement has invested in madrassas and the production of religious professionals (King 1997; Birt 2005; Gilliat-Ray 2006, 2007, 2018; Geaves 2012; Ingram 2018), there is no such activity for the Fultolis. The Tablighi Jama'at have organized activists on the ground recruiting new members and socializing them into the ideals and principles of the movement (see primarily Timol 2017 but also Metcalf 1993; Sikand 1998; Ali 2003); there is no comparable recruitment or activism however amongst the Fultolis. The Salafis have an international network, maintaining transnational links through the internet, television channels, and visiting scholars (Hamid 2016; Inge 2017). The Fultolis have few of these, and while there are Bengali language channels in Britain (such as 'Channel S') which host Fultoli ulema, they remain preachers in the Bengali language and so appeal only to insiders. These factors all contribute towards the generational drop-off amongst Fultolis, with young British-born Bangladeshis often seeking religious fulfilment elsewhere. Sometimes this is by adopting a completely different denominational identity: Salafism, the Deobandis, and various Islamist movements have all become vehicles of religious self-expression for young British Bangladeshi Muslims. For those who seek to maintain some continuity with their parents' overtly Sufi Fultoli Islam, Sufi shaykhs from abroad provide a more attractive and accessible source of guidance than Fultoli pirs from Bangladesh, such as Shaykh Hamza Yusuf, Shaykh Nuh Ha Mim Keller, and Shaykh Muhammad Yacoubi. Hamid describes this new international Sufism as the "traditional Islam movement" (Hamid 2016). The rate of generational drop-off is hard to quantify, and even qualitatively, the nature of the drop-off is difficult to identify. In some cases, younger British Muslim Bangladeshis may outright reject their parents' Islam as heretical, lacking intellectual rigor, or village superstition (all three descriptions have been encountered by the authors). In other cases, they may respect but struggle to access Fultoli Islam. Others still also disengage from a religious identity altogether. Further research on Fultolis in Britain is needed to explore the numbers and nature of intergenerational transmission more closely.

If the Fultoli tradition is to remain a part of the British Muslim landscape, then it will need to reorient itself to be meaningful to younger British-born Muslims. This in no way means abandoning all that makes the Fultoli tradition distinctive, or its relationship to Bengali soil, but it does require ensuring that its meaning-making is intelligible to Muslims outside of Bangladesh, that it can address the theological issues of debate in the Western world (rather than the Indian subcontinent), and that it produces leaders and imams capable of serving and running Fultoli institutions in the United Kingdom. That said, it would be premature to consider the Fultoli movement as irrelevant. Its impact in Britain, through the establishment of mosques, will still shape future developments amongst British Muslims (even if those mosques do not remain Fultoli in denominational identity). It is also worth reflecting on Sikand's predictions that the Tablighi Jama'at will fail to engage or capture the attention of British-born Muslims (Sikand 1998, p. 187). He cites the Tablighi Jama'at's adherence to Gujarati cultural traditions, aversion to 'Western' dress and education, and a general failure to prioritize intergenerational transmission, as reasons for its demise in the United Kingdom. These predictions have largely failed to bear fruit (Timol 2017), with the Tablighi Jama'at not only appealing to British-born Muslims of a Gujarati Deobandi background, but becoming a movement attractive even to Salafis and ethnically diverse British Muslims. Likewise, while the current period is one of decline in Britain for Fultolis, the coming years may see a reversal.

\section{Conclusions}

A key objective of this article has been to correct the representation of Bangladeshis in the literature on British Muslims. Since Geaves' seminal work on sectarian influences within Islam in Britain (Geaves 1996), the study of denominational diversity amongst Muslims in the UK has been a growing field of interest, leading to not only overviews and surveys, such as Hamid's Sufis, Salafis and Islamists (Hamid 2016), but more focused studies of British Muslim denominations themselves. The latter 
include studies of Salafis (Inge 2017), Sufis (Geaves 2000), Deobandis (Birt 2005; Gilliat-Ray 2006), the 'Jamaat-e-Islami' (Geaves 1995), the Tablighi Jama'at (Timol 2017), or the Muslim Brotherhood (Bowen 2013). Fultolis, however, have remained largely absent in this growing picture, and so it is intended that this article contributes towards a more accurate and nuanced picture of British Muslim denominational diversity. It is also the wish of the authors that future scholarship on British Bangladeshis at least recognizes the unique denominational identity of the migrants, and perhaps even studies it further, contributing to our understanding of Fultoli activism in the United Kingdom.

Finally, this article presents a case study of a denomination failing, in general terms, to adapt and grow in Britain. If one looks at the Tablighi Jama'at, who have successfully transplanted their movement from its South Asian origins to multiple new contexts, with appeal not only to the British-born Deobandi diaspora but also (to a more limited degree) intra-religious converts from other ethnicities and denominations (as found by Timol 2015, 2017), the failure of the Fultoli tradition becomes even more pronounced. While this article has highlighted the mechanisms through which Fultolir Sahib attained the religious authority to establish a distinct denominational identity in Bangladesh, it has also argued that the Fultoli tradition has not engaged in the activities that have made co-religionists successful in Britain, through the establishment of networked institutions and production of new leaders. To fully understand the denominational diversity of British Muslims, and the operation of authority within them, it is necessary to account for the less successful groups like the Fultolis, alongside other larger and growing movements within British Islam.

Author Contributions: A.-A.A. contributed to the qualitative, quantitative and sociological sections of the article. Especially the section on Fultolis in Britain. M.A. contributed to the historical and theological sections of the article, which include original research in Bengali, Urdu and Arabic.

Funding: This research received no external funding.

Acknowledgments: The authors would like to thank all those who contributed towards this article, including Mufti Javed Iqbal, Maulana Shams Ad-Duha Muhammad, Maulana Uwais Namazi, Mehmood Naqshbandi, Ayesha Siddika, and all research participants.

Conflicts of Interest: The authors declare no conflict of interest.

\section{References}

About Us. 2019. Anjumane Al Islah UK. Available online: https://anjumane-alislah.org.uk/about-us (accessed on 18 July 2019).

Ahmed, Abdul-Azim. 2019. Conceptualising Mosque Diversity. Journal of Muslims in Europe 8: 138-58. [CrossRef]

Ahmed, Shahab. 2015. What Is Islam? 1st ed. Princeton: Princeton University Press.

Ali, Jan. 2003. Islamic Revivalism: The Case of the Tablighi Jamaat. Journal of Muslim Minority Affairs 23: 173-81. [CrossRef]

Allama Fultoli Saheb Qiblah. 2017. Video Posted by Masum Azad. Available online: https://www.youtube.com/ watch? $=$ G869nsGhpAs (accessed on 18 July 2019).

AAllama Saheb Qibla Fultoli, Moulovi Bazar 2004. 2016. Video Posted by Islam Jindegi. Available online: https://www.youtube.com/watch?v=s5T17BdX1vE (accessed on 18 July 2019).

Allamah Fultali Sahib Qiblah. 2010. Ahl-e Muhabba. Available online: https://ahlemuhabba.wordpress.com/2010/ 01/17/allamah-fultali-sahib-qiblah-rahimahullah/ (accessed on 18 July 2019).

Al-Nasiha Al-Latifiyyah. 2013. Available online: https://www.facebook.com/HazratAllamaFultali/ posts/483071005061410?_xts_[0]=68.ARCnuK0T-z3u5PZUNDWtptabrHuRII6I8upR_ TpRpaO8kLGA1zIXGP0ap7H98MoFeCdQ5OINDlsaVfT4mGhaQvGagKsYt_ mLp27E363El3sM_O-0_uW8ycqNEl7PMQxDbGbrxMPBRrgtDOW5ECUdZbY_ ES9JhW8aObZOWh1Ikt3qNpgEzEXiBW7QvYPjdPfafy3J6B8VueTwQiTkB-Q8XSpkQCuzc9FOjajKoA7Tfez8_GwknFC86aOanIezUqOVMeGhjembUem2Ds2KWd2TkwCDoMNuJKFey0k_ G3HpUkDhoOEYzpHsS6YEnRrkSsZdb0inuKEpdi935Dt3Is\&_tn__=-R (accessed on 19 July 2019).

Ansari, Humayun. 2004. The Infidel Within: Muslims in Britain since 1800. London: Hurst and Co.

Barton, Stephen William. 1986. The Bengali Muslims of Bradford. Leeds: Dept. of Theology and Religious Studies, University of Leeds. 
Bearman, Peri, Thierry Bianquis, Emeri Johannes van Donzel, and Wolfhart Heinrichs. 2012. Sisila. In The Encyclopaedia of Islam, 2nd ed. Leiden: Brill.

Birt, Jonathan. 2005. Locating the British Imam: The Deobandi Ulama between Contested Authority and Public Policy Post-9/11. In European Muslims and the Secular State, 1st ed. Edited by Jocelyne Cesari and Sean McLoughlin. Farnham: Ashgate, pp. 183-96.

Bowen, Innes. 2013. The Muslim Brotherhood in Britain. In The Muslim Brotherhood in Europe. Edited by Edwin Bakker and Roel Meijer. Oxford: Oxford University Press, pp. 111-26. [CrossRef]

Bowen, Innes. 2014. Medina in Birmingham, Najaf in Brent: Inside British Islam. London: Hurst \& Company.

Brown, Jonathan. 2007. New Data on the Delateralization of Dad and Its Merger with Za' in Classical Arabic: Contributions from Old South Arabic and the Earliest Islamic Texts on D/Z Minimal Pairs. Journal of Semitic Studies 52: 335-68. [CrossRef]

Brown, Judith, and Ian Talbot. 2006. Making a New Home in the Diaspora: Opportunities and Dilemmas in the British South Asian Experience. Contemporary South Asia 15: 125-31. [CrossRef]

Cormack, Margaret, ed. 2013. Muslims and Others in Sacred Space. Religion, Culture, and History. Oxford: Oxford University Press.

Dale, Angela, and Sameera Ahmed. 2011. Marriage and Employment Patterns amongst UK-Raised Indian, Pakistani, and Bangladeshi Women. Ethnic and Racial Studies 34: 902-24. [CrossRef]

Darul Qirat Majidia Fultali Trust. 2019. Available online: https://darulqiratfultali.com/ (accessed on 19 July 2019).

Eade, John, and Ceri Peach. 1996. The Bangladeshis: The Encapsulated Community. Population Statistics/Ethnicity in the 1991 Census Vol 2. London: HMSO.

Eade, John, and David Garbin. 2006. Competing Visions of Identity and Space: Bangladeshi Muslims in Britain. Contemporary South Asia 15: 181-93. [CrossRef]

Eade, John. 1990. Nationalism and the Quest for Authenticity: The Bangladeshis in Tower Hamlets. Journal of Ethnic and Migration Studies 16: 493-503. [CrossRef]

Eaton, Richard M. 1996. The Rise of Islam and the Bengal Frontier, 1204-1760. Comparative Studies on Muslim Societies 17. Berkeley, Los Angeles and London: University of California Press.

Eaton, Richard M. 2010. Forest Clearing and the Growth of Islam in Bengal. In Islam in South Asia in Practice. Edited by Barbara D. Metcalf. Princeton: Princeton University Press, pp. 375-89. [CrossRef]

Ellis, Carolyn. 2003. The Ethnographic I: A Methodological Novel about Autoethnography. Walnut Creek: AltaMira Press.

Esposito, John, ed. 2004. Deobandis. In The Oxford Dictionary of Islam. Oxford and New York: Oxford University Press, Available online: http://www.oxfordreference.com/views/BOOK_SEARCH.html?book=t125 (accessed on 5 July 2019).

Fultali. 2017. Available online: https://web.archive.org/web/20171107023614/http://www.fultali.org/biography-inenglish/ (accessed on 19 July 2019).

Garbin, David. 2005. Bangladeshi Diaspora in the UK: Some Observations on Socio-Cultural Dynamics, Religious Trends and Transnational Politics. In Cancer of Extremism in Bangladesh. Proceedings of the European Human Rights Conference on Bangladesh: Extremism, Intolerance \& Violence. Edited by Werner Menski and Biswajit Chanda. Human Rights and Bangladesh Conference. London: SOAS, vol. 17, Available online: https://kar.kent.ac.uk/36052/ (accessed on 5 July 2019).

Geaves, Ron. 1995. The Reproduction of Jamaat-i Islami in Britain. Islam and Christian-Muslim Relations 6: 187-210. [CrossRef]

Geaves, Ron. 1996. Sectarian Influences within Islam in Britain. Leeds: Dept. of Theology and Religious Studies, University of Leeds.

Geaves, Ron. 2000. The Sufis of Britain: An Exploration of Muslim Identity. Cardiff: Cardiff Academic Press.

Geaves, Ron. 2012. The Symbolic Construction of the Walls of Deoband. Islam and Christian-Muslim Relations 23: 315-28. [CrossRef]

Gellner, Ernest. 1992. Postmodernism, Reason and Religion. London and New York: Routledge.

Gilliat-Ray, Sophie. 2006. Educating the c Ulama: Centres of Islamic Religious Training in Britain. Islam and Christian-Muslim Relations 17: 55-76. [CrossRef]

Gilliat-Ray, Sophie. 2007. Closed Worlds: (Not) Accessing Deobandi Dar Ul-Uloom in Britain. Fieldwork in Religion 1. [CrossRef]

Gilliat-Ray, Sophie. 2010. Muslims in Britain. Cambridge: Cambridge University Press. 
Gilliat-Ray, Sophie. 2018. From "Closed Worlds" to "Open Doors": (Now) Accessing Deobandi Darul Uloom in Britain. Fieldwork in Religion 13: 127-50. [CrossRef]

Green, Nile. 2003. The Religious and Cultural Roles of Dreams and Visions in Islam. Journal of the Royal Asiatic Society 13: 287-313. [CrossRef]

Hakala, Walter. 2016. Negotiating Languages: Urdu, Hindi, and the Definition of Modern South Asia. New York: Columbia University Press.

Hamid, Sadek. 2016. Sufis, Salafis and Islamists. London: I B Tauris.

Hanif, N. 2000. Biographical Encyclopaedia of Sufis: South Asia. New Delhi: Sarup \& Sons.

Hazrat Allama Fultali Saheb Qiblah. 2013. Available online: https://www.facebook.com/HazratAllamaFultali/ posts/hazrat-allama-fultali-saheb-qiblah-1913-2008ce-1334-1429ahhe-is-abdul-latif-ibn-/483075751727602/ (accessed on 18 July 2019).

Hussain, Ed. 2007. The Islamist: Why I Joined Radical Islam in Britain, what I Saw Inside and Why I Left. London: Penguin.

Inge, Anabel. 2017. The Making of a Salafi Muslim Woman: Paths to Conversion. Oxford: Oxford University Press.

Ingram, Brannon. 2018. Revival from Below: The Deoband Movement and Global Islam. Oakland: University of California Press.

Kazir Bazar. 2014. Available online: https:/web.archive.org/web/20140809194925/http://www.kazirbazar.com/?p= 13227 (accessed on 18 July 2019).

Khanum, Sultana Mustafa. 2001. The Household Patterns of a "Bangladeshi Village" in England. Journal of Ethnic and Migration Studies 27: 489-504. [CrossRef]

Kibria, Nazli. 2008. The "New Islam" and Bangladeshi Youth in Britain and the US. Ethnic and Racial Studies 31: 243-66. [CrossRef]

King, John. 1997. Tablighi Jamaat and the Deobandi Mosques in Britain. In Islam in Europe: The Politics of Religion and Community. Edited by Steven Vertovec and Ceri Peach. Migration, Minorities and Citizenship Series; London: Palgrave Macmillan UK, pp. 129-46. [CrossRef]

Lie, Mabel. 2010. Across the Oceans: Childcare and Grandparenting in UK Chinese and Bangladeshi Households. Journal of Ethnic and Migration Studies 36: 1425-43. [CrossRef]

Metcalf, Barbara. 1982. Islamic Revival in British India: Deoband, 1860-1900. Princeton Legacy Library. Princeton: Princeton University Press.

Metcalf, Barbara. 1993. Living Hadith in the Tablighi Jama'at. The Journal of Asian Studies 52: 584-608. [CrossRef]

Metcalf, Barbara. 2009. Islam in South Asia in Practice. Princeton Readings in Religions. Princeton: Princeton University Press.

Moosa, Ebrahim. 2004. Deobandi School. In The Oxford Dictionary of Islam. Edited by John L Esposito. Oxford and New York: Oxford University Press.

Muslims in Britain. 2019. Available online: www.muslimsinbritain.org (accessed on 18 July 2019).

Nadwi, Mujibullah. 2009. Tadkhkira Hazrat Maulana Karamat Ali Jaunpuri. Rae Bareli: Sayyid Ahmad Shahid Academy.

Peach, Ceri. 2006. South Asian Migration and Settlement in Great Britain, 1951-2001. Contemporary South Asia 15: 133-46. [CrossRef]

People Born Outside the UK. 2018. Office for National Statistics. Available online: https://www.ethnicityfacts-figures.service.gov.uk/uk-population-by-ethnicity/demographics/people-born-outside-the-uk/latest (accessed on 9 August 2019).

Population of England and Wales-Ethnicity. 2019. Available online: https://www.ethnicity-facts-figures.service. gov.uk/uk-population-by-ethnicity/national-and-regional-populations/population-of-england-and-wales/ latest (accessed on 30 April 2019).

Saheb Qiblah Fultali (Muhammad Abdul Latif Chowdhury)_Waz II. 2014. Video, Posted by Chadraj Ahmed. Available online: https://www.youtube.com/watch?v=OLC-PZaYWSM (accessed on 18 July 2019).

Saleem, Shahed. 2018. The British Mosque: An Architectural and Social History. Swindon: Historic England.

Salway, Sarah. 2008. Labour Market Experiences of Young UK Bangladeshi Men: Identity, Inclusion and Exclusion in Inner-City London. Ethnic and Racial Studies 31: 1126-52. [CrossRef]

Samuel, Geoffrey. 2012. Islam and the Family in Bangladesh and the UK: The Background to Our Study. Culture and Religion 13: 141-58. [CrossRef] 
Sanyal, Usha. 2005. Ahmad Riza Khan Barelwi: In the Path of the Prophet. Makers of the Muslim World. Oxford: Oneworld.

Shafe Ahmed. 2019. History of Darul Qirat Majidia Fultali Trust. Video. Available online: https://www.youtube. com/watch?v=bsoRGTPMZ3k (accessed on 18 July 2019).

Shafi, Muhammad. 1932. Raf' al-Tadad 'an Ahkam al-Dad. Karachi: Maktaba Darul Uloom Karachi.

Siddiqi, Bulbul. 2018. Tablighi Jamaat in the UK. In Becoming 'Good Muslim': The Tablighi Jamaat in the UK and Bangladesh. Edited by Bulbul Siddiqi. Singapore: Springer, pp. 119-28. [CrossRef]

Sikand, Yoginder S. 1998. The Origins and Growth of the Tablighi Jamaat in Britain. Islam and Christian-Muslim Relations 9: 171-92. [CrossRef]

The Sunday Times. 2007. Rediscovering a Kinder, Gentler Islam. April 21. Available online: https://www.thetimes. co.uk/article/rediscovering-a-kinder-gentler-islam-w5hh3jc9rtl (accessed on 18 July 2019).

Timol, Riyaz. 2015. Religious Travel and the Tablighī Jamā'at: Modalities of Expansion in Britain and Beyond. In Muslims in the UK and Europe I. Edited by Suleiman Yasir. Cambridge: Centre of Islamic Studies, University of Cambridge.

Timol, Riyaz. 2017. Spiritual Wayfarers in a Secular Age: The Tablighi Jama'at in Modern Britain. Ph.D. thesis, Cardiff University, Cardiff, UK.

Versteegh, Kees. 2001. The Arabic Language. Edinburgh: Edinburgh University Press.

(C) 2019 by the authors. Licensee MDPI, Basel, Switzerland. This article is an open access article distributed under the terms and conditions of the Creative Commons Attribution (CC BY) license (http://creativecommons.org/licenses/by/4.0/). 

Article

\title{
British Muslims Navigating between Individualism and Traditional Authority
}

\author{
Hira Amin \\ College of Islamic Studies, Hamad Bin Khalifa University, P.O. Box 34110, Doha, Qatar; hfamin02@gmail.com \\ Received: 24 April 2019; Accepted: 25 May 2019; Published: 30 May 2019
}

\begin{abstract}
According to some sociologists, one of the hallmarks of modernity is the end of 'pre-determined' identities and its replacement with bricolage projects in which people literally create 'do-it-yourself' identities. This has also significantly impacted the religious sphere, where it has been argued that traditional authorities are constantly undermined by individualistic cultures, print media, rising literacy rates and, more recently, the internet. Through analysing online discussions, this article explores how some young, devout British Muslims navigate between individualism and their own personal understanding of Islam on the one hand and following traditional religious authority figures on the other. This article argues that British Muslims who are consciously trying to practise their faith are neither following traditional religious authoritative figures or institutions blindly nor fully rationalising and individualising their faith. Rather, they are involved in a complex process of choosing and self-restricting themselves to certain scholars that they believe are representative of Islam and thereafter critically engaging with the scholar and his or her verdicts by adding in their own opinions, experiences and even Islamic textual evidence. While this illustrates how religious authority is transforming in the age of new media, the persistent engagement with scholars also indicates how they still play a significant role in the shaping of Islam in Britain.
\end{abstract}

Keywords: Islam in Britain; British Muslims; religious authority; individualism; rationalisation of religion; representation; leadership

\section{Introduction}

On a Saturday afternoon in August 2015, I received a frantic message on a WhatsApp group with old friends:

Naima: Is beer battered fish halal? Quick I am in a line and about to order!

Zoya: Irfaan [her husband] says its makruh [disliked but allowed]. But I think its halal as the shaykh said if you can't get drunk on it no matter how much you eat, then its fine. Even if Naima eats 50 of them (which she is capable of doing) she still would not be drunk! So just eat it fatty!

Amina: I'm googling fatwas online- - they are saying no.

[Half an hour later]

Naima: I ate it!

This brief conversation on WhatsApp gives us a glimpse into the complex workings of religious authority in our modern age. From 'googled' fatwas, extrapolating general rulings, to individual reasoning — each are part of an intricate mosaic of how religious authority operates in Britain. Amina found that 'googled' fatwas specifically on this issue said no. Zoya had heard a basic principle in an Islamic lecture about food that she extrapolated for this specific context. Ultimately, Naima made her own decision and agreed with the latter. 
This article explores the interconnection of three broad trends discussed widely in the literature: The fragmentation and transformation of religious authority; growing individualisation; and increased religiosity and participation in 'traditional' religious groups amongst British-born Muslims. In bringing together these different strands in the British context, this article argues that British Muslims who are consciously trying to practise their faith are neither following traditional religious authoritative figures or institutions blindly nor fully rationalising and individualising their faith. Rather, they are involved in a complex process of first choosing and self-restricting themselves to certain scholars and thereafter critically engaging with the scholar and his or her verdicts. In other words, it is less about acceptance or rejection but more about critically understanding and partaking in the process of authority by including their personal opinions, experiences and even challenging them with evidence from the Quran and Hadith.

\subsection{Fragmentation of Religious Authority}

The fragmentation and decline of influence of traditional religious authoritative figures and the growth of autodidactic, self-taught amateurs has been a defining feature of modern Islam (Eickelman and Piscatori 2004; Yildirim 2019). While, historically, the ulama played a central role as the 'Guardians of Religion' (Hallaq 2003, p. 258), the crisis of authority, which began in the Muslim world from the nineteenth century, led to the loss of power, the erosion of religious authority structures and the individualisation of belief-with the task of preserving Islam falling on each individual Muslim (Robinson 2009). Instead of Muslims travelling to the Middle East for their studies, they were travelling to Paris, Oxford or Cambridge in favour of secular institutions. In this context, 'new religious intellectuals' who arose 'outside the traditional system for transmitting knowledge' and were educated in secular systems had become increasingly popular (Eickelman and Piscatori 2004, pp. 43-44). As a result, the ulama were gradually side-lined as they became 'less central to the working of Muslim societies' (Robinson 2009). Figures outside the realm of the ulama gained popularity, such as the school teacher Rashid Ghanoushi of Tunisia, the lawyer Hasan At-Turabi of Sudan, the engineers Mehdi Bazargan of Iran and Mahamed Shahrour of Syria, Mawdudi of South Asia, and Al-Banna of Egypt. Even amongst Shia Islam, Jones (2012) highlights the pivotal role of new religious intellectuals in shaping their social transition in colonial India.

Another major development which severely weakened traditional authority was the changes in the legal institutional structure. As Brown (1997) illustrates, this was a gradual process from the end of the nineteenth century, where scholars were cast out of the legal system, ultimately severing the relationship between law and religion, and thus scholars and societal influence.

Furthermore, the growth of mass education, print media and rising rates of literacy further fuelled the fragmentation of religious authority (Eickelman and Piscatori 2004). While the ulama attempted to co-opt the printing press, paradoxically, it also undermined the transmission of knowledge from person to person (Robinson 2009).

Many argue the internet has only exacerbated this trend of fragmentation and transformation (Bunt 2018). Cooke and Lawrence (2005) suggest:

In short, authority is more diffuse now than it was two hundred, or even ten, years ago. Ijtihad used to be the purview of the ulama. The complex language of their religious discourse had blocked access to the amateur. However, the migrant engineer theologians changed all that by distributing authority among Muslim cybernaughts. (p. 23)

\subsection{Individualisation of Belief}

Specifically amongst Muslims in the West, one of the key tropes that has dominated the literature is the shift from an ethnic to a religious identity (Hinnells 2007; McLoughlin and Zavos 2013; Ansari 2004). British-born Muslims primarily define themselves through faith and prefer to use 'religious' identity markers, firmly demarcating and eschewing not only 'ethnic' cultural practices but also their parents' understanding of Islam, which is largely-based on the imams from their country of origin 
(Gilliat-Ray 2010). In other words, young British Muslims are consciously deciding for themselves the role and purpose of religion in their life, which tend to be defined against the practices of their parents' or the first migrant generation more broadly.

Some view this shift as part of the individualisation of Muslims in the West. Cesari (2003), for instance, argues that the individualisation of belief is a distinctive characteristic of European Muslims, due to the declining influence of classical Islamic institutions, such as mosques and imams. This, she claims, is the 'quintessential difference' between European Muslims and Muslims in their countries of origin (ibid., p. 258). She suggests that the 'social adaptation process of Muslim minority groups has placed Islam within the three interrelated paradigms of secularization, individualization, and privatization, which have until recently been distinctive characteristics of Western societies' (ibid., pp. 258-60). Roy (2002), likewise, asserts that the individualisation of faith has also led to the 'delegitimation of religious professionals in favour of religious-minded laypersons' (p. 181).

This can be framed more broadly in the individualisation of modern life. Sociologists such as Giddens (1991), Beck and Beck-Gernsheim (2008) stress that in our 'modern' era, pre-determined identities are largely replaced by bricolage projects in which people literally create do-it-yourself identities.

Tied in with this debate about individualisation is also the phenomenon of the 'objectification of religion', where religion is understood as an object that has to be rationalised. This 'objectification', as Eickelman and Piscatori (2004) argue, is a direct result of the rising literacy rates amongst Muslims, as well as the new media.

\subsection{Rising Religious Trends and the Persistence of the Ulama}

On the other hand, there are a number of other trends that complicate this idea of growing individualisation and dispensing with traditional institutions amongst Muslims in the West. The first is the persistence and even the proliferation of traditional religious groups. Studies show how many 'traditional' trends in the UK are attracting the British-born Muslim generation from different groups, including Salafism, Tablighi Jamaat and Sufism (Abo-Alabbas 2015; Hamid 2009, 2016; Inge 2016; Timol 2015). These movements all have strong traditional religious authority structures, albeit in different forms and hierarchies.

This indicates the continuing presence and importance of the ulama. As mentioned above, some describe the ulama as 'stagnant' and 'anachronistic in the modern world' (Roy 2002, pp. 90-93). However, Zaman (2007) highlights that the ulama have indeed 'enhanced their influence in contemporary Muslim societies' and are in fact 'a crucial part of changes in society' (p. 2). Their claim of representing the 'authentic' Islamic religious tradition is, according to Zaman, central to the persistent strength of the ulama (ibid.). The desire to recapture and revitalise 'authentic Islam' was one of the overarching sentiments that permeated throughout the Muslim world, and it was, and arguably still is, perceived as the panacea to the 'Muslim crisis' from the 19th century until the present day. It is the sense of continuity with the Islamic tradition 'that defines the ulama as ulama', and it 'constitutes the most significant difference between them and their modernist and Islamist detractors' (ibid., p. 10).

The contemporary ulama are not speaking in the language of the medieval ulama. Rather, in an age of new media, they are speaking in a language designed for both the laity and for the ulama using both online and offline mechanisms while remaining embedded within the 'tradition'.

Perhaps one of the most striking manifestations of this is the rise of the modern 'celebrity scholar' and 'edutainment' - a combination of education and entertainment. Similar to popular Evangelical preachers, there are Muslim scholars who also boast large numbers of followers on social media channels and attract huge crowds at their events. Paradoxically, therefore, it seems that rather than simply fragmenting authority, the internet has also bolstered the profile of 'traditional' scholars and allowed them to reach vast and even global audiences. Their popularity has increased to such an extent that Western Muslim bloggers have from the early 2000s, in line with the prevalent usage of social media, coined the derogatory term 'celebrity shaykhs' (Usman 2014; Kamdar 2011). In academia, some 
have called this 'media authority' juxtaposed against state-sponsored traditional figures who do not make use of new media (Herbst 2003; Nielsen 2016).

From another angle, there also appears to be a sentiment amongst average lay Muslims in guarding the sanctity and expertise of traditional scholarship. This is illustrated in certain phrases, jokes and memes that have become widespread amongst Western Muslims, such as the term 'Shaykh Google' (Haq 2015). This term is used in jest to describe those who have not formally trained in Islamic sciences and have simply 'googled' a few articles or fatwas on the internet yet pronounce pseudo-authoritatively on religious issues.

These three trends together indicate that while the traditional scholars and groups no longer have the monopoly they once enjoyed, they are still very much a part of the religious landscape. Using qualitative research, the aim of this article is to discuss how these three strands intersect. In other words, how do British Muslims interact with religious authority figures, institutions and verdicts in an age of growing individualisation and rationalisation of belief?

\section{Methodology}

The research findings in this article came out of another study on sectarianism in Britain, where the primary methodology was the analysis of semistructured interviews, magazines and lectures. During the interviews, many participants, who were British-born Muslims, spoke generally about the importance of learning Islam and rationalising Islamic practices, drawing a distinction between themselves and the first generation who, from their experiences, would practise Islam without an in-depth understanding. Another salient point that came out of the interviews was the importance of online websites for learning more about Islam and engaging with other Muslims. This led to the further research of online spaces.

The online 'Muslim world' in the English-language is continuously growing, but my focus was on any material linked to Salafism and Islamism, which were the two groups in the initial study. It was here where I found online debates over very specific issues (not around sectarianism) that allowed for a more nuanced analysis into the inner contestations of Islamic authority in Britain. To get a range of online material, I chose three different types of online platforms and discussion topics: A forum, a personal blog and a website which regularly published articles and allows anyone to comment.

Online forums and blogs are a relatively new space for research and therefore require different ethical considerations, types of analysis and, most importantly, different advantages in comparison to traditional methods (Snee et al. 2016). Studies have found the anonymity of online interaction reduces social desirability and has a disinhibiting effect on users, which leads to more honest and open responses (Joinson et al. 2008; Edmunds 1999). It allows participants to freely interact with others without physical, geographical or social-cultural barriers which occur in face-to-face discussions or interviews. Furthermore, online ethnography, or 'netnography', as Kozinets (2010) puts it, gives the researcher a 'window into naturally occurring behaviour' (p. 56) in an unobtrusive way (Eysenbach and Till 2001; Paccagnella 2006). This also allows the researcher to analyse the interactions between members or participants.

This, however, raises many issues, namely, consent and lack of background knowledge of each participant. Consent is one of the ethical foundations of research, and there is a debate about whether or not online spaces are considered 'public' or 'private' (Wood and Griffiths 2007; Sveningsson 2004; Griffiths and Whitty 2010). The three online spaces used in this study are all public platforms which do not require any form of login or registration in order to read its content. Anyone is allowed to read and post a comment as long as they follow their rules, which typically exclude extremist or rude language. $\mathrm{I}$, as the researcher, did not participate in any of the discussions or encourage any of the comments. In fact, these discussions occurred a few years before my research and, hitherto, still remain on the sites, indicating that the website owners do not feel the need to remove any of their discussions and are thus comfortable with this information to still remain public. 
The other disadvantage to online studies is the lack of biographical information on the participants. Most people use nicknames and hidden personas, which, as discussed above, encourages honest and open discussion but obscures the participants' backgrounds and context. This also poses an issue when a study specifically wants to focus on Muslims who live in a particular country. While I cannot guarantee that all participants are British Muslims, the websites were carefully chosen where it would be highly likely that they would be the core participants. Each website is discussed below in more detail. To put it here briefly, one of the sites was of a British blogger who had an online altercation with a British Muslim preacher about his speech given at an event that occurred in London. The other website is the platform for a prominent British scholar. While he is also known internationally, he is based in Britain and most of the articles in his site refer to British Muslims in particular, and Western Muslims in general. The third website is a forum and is admittedly the most difficult to ascertain if the Muslims live in Britain. Through language, examples and references, however, one can glean that some of the core participants in this forum are British.

Notwithstanding these limitations, the freedom and openness of the online forums provides a platform for rich analysis where subtle yet important tensions can be carefully examined. While interviewees spoke in generic terms, these online discussions allow the researcher to examine participants engaging directly with the issue of religious authority, leading to insights unattainable by other data collecting methods.

\section{Islam21C and Attractive Hijabs}

Islam21C is a website which discusses latest news items, politics, international affairs and contemporary challenges facing Muslims in the West. However, since the main organisers are based in the UK, there appears to be more of a focus towards matters pertaining to British Muslims. They currently boast 253,000 followers on Facebook and almost 10,000 followers on Twitter (Islam21C n.d.). Their main Shaykh is a well-known senior scholar in Britain, Haitham Al-Haddad, who also serves as a judge for the Islamic Sharia Council (UK \& Eire) (Al-Haddad 2012). His family were originally from Palestine, but Al-Haddad was born and raised in Saudi Arabia, where he studied under prominent Salafi scholars such as Ibn Baz. He also holds a PhD from SOAS, University of London, in Islamic Fiqh and Jurisprudence (ibid.).

The website regularly posts many articles, and one of the most popular articles is entitled, 'Attractive hijabs and Shariah' (Al-Haddad 2011). Published in April 2011, it spawned an intense debate with 152 comments, making it hitherto one of the most-commented-on articles on the website. ${ }^{1}$ In this article, Al-Haddad argues that many Muslim women have misunderstood the concept of the headscarf and modest dress and are wearing 'un-Islamic hijabs' in the form of "[t]ight jeans (also known as 'skinny jeans'), long leather high-heeled boots and tight shirts with a headscarf"(ibid.). He argues that the hijab is more comprehensive than just covering your hair and that it is ultimately an 'act of ibaadah [worship]'; it is 'very much defined by Islamic law ... and not cultural habits or one's idea of what modesty is, or should be' (ibid.). Quoting verses from the Quran, he asserts that the:

main aim of hijab is to stop fitnah [temptation or civil unrest]; females who are attractive by nature attract the gaze of males which then leads to other greater sins such as fornication and adultery. Allah commanded women neither to display their adornment nor to display any form of behaviour that might attract the attention of men. (ibid.)

The article attracted a wide variety of commentators. This is a website where anyone can easily comment without any form of membership or signing up. Comments are not structured as a linear conversation between members, but as a list of people's comments on the article and people reacting to

1 In 2017, it was the second-most commented on, yet they have since removed ranking based on comments; however, browsing through, it is still clearly in the top five most-commented articles. 
other's remarks. Judging on the nicknames used in the comments, 78 women and 49 men commented and there were also 25 people where ascertaining the gender was either unclear or not possible. Generally speaking, women wanted to make clear that they were in fact women and thus speaking from a specific vantage point and so most used clear female names to indicate this. Yet even if we do not assume the unknowns are male, there still seems to be a good mix of male and female commentators, which indicates that this debate went beyond issues simply relating to women and struck a chord amongst both genders.

What is striking in the comments is how many participants constructed their agreement with the article on the basis that it was grounded in Islamic texts, not because of Al-Haddad's scholarly qualifications. For example, Tamam wrote:

I find nothing wrong in what the Shaykh said, all of his points are backed up with Al Quran and Hadith. (ibid.)

Umm salsabeel added:

I completely agree with the shaykh. Hijab has become such a fashion statement! Sisters should realise that wearing the hijab is an act of worship. Wearing skinny jeans and a headscarf is completely contradictory. The prophet (SAW)'s wives and the female companions did not wear a headscarf and tight fitting attractive clothing did they? Why are the sisters attacking the Shaykh? He is stating the facts through the Quran and Sunnah! (ibid. emphasis added)

Umm Khadijah responded to comments insinuating that people were supporting Al-Haddad as they are his 'minions' or 'fans', referring to the 'celebrity shaykh' culture discussed above:

Erm just to clarify these comments in favour of the article is not because its an article by shaykh haitham, rather if any shaykh states something to be done in accordance to the Quran and Sunnah and people come out opposing that, and not only opposing but trying to justify their opposition then yeh you are going to get comments which try and uphold the statement. (ibid.)

By claiming the article only represents the sacred texts, not the scholar, what is obscured is how the scholar is implicated in interpreting the text. By making the scholar invisible, these commentators have also erased his subjectivity. Other people, however, were quick to point this out and underscored his foreign upbringing and gender. Umm Yahya wrote:

I don't blame Sh Haddad for his views, I guess we would all have them if we came from Saudi Arabia, but that's the point, we're not in S.Arabia ... Wearing a colourful hijab there may be temptation for the many perverted Saudi men, but here in the west a colourful hijab does not have a sexual connotation which I believe to be the reasoning behind the shaykh's statement. As I have experienced many times, many Saudi scholars are unfit to talk about feminine issues outside of THEIR country as the rest of the world is quite different.... His views on colourful hijabs are ridiculous, and there are many Hadith that talk about the colour of sahabiyaat's [female companions of the Prophet] outer garments and khimars [long cloaks]. He also assumes many insulting stereotypes for which I'm sure he'll have no fans. Maybe he should should [sic] hang around some iNtelligent [sic] BRITISH people who can maybe give him some cultural learnings [sic]. (ibid.)

In a somewhat lighter tone, Yvonne Ridley-a prominent British journalist and convert to Islam (Ridley n.d.)—wrote:

A Western female perspective-Any sister choosing to cover while living in the West is immediately propelled into the spotlight and attracts attention. That is the reality. In some cases, sisters choosing to wear traditional Arab dress acceptable in Saudi, will draw even more attention to themselves in downtown Luton!... This is not a case of 'one size fits 
all' - what works for sisters in Saudi might not work for those living in Malaysia, Pakistan, France, UK or America. (Al-Haddad 2011)

Therefore, here we see how some are focusing on the scholar and his background, as opposed to his evidence or training. For many commentators, the issue was not his nationality but his gender. Another participant oscillating between respect for Al-Haddad and criticism, wrote:

I take the point being made and agree ... . I thank you also for being so bold ... However the limitation to being a male scholar is of course not having a female mind ... I think it important god fearing women also respond in order to get across another perspective.

In essence I think it needs to be recognised that part of why women like to wear attractive hijabs is a love for pretty things and creativity. In much the same way that some men enjoy looking at the angles of cars and football ... I believe if we are to be effective in channelling sisters towards the Halal we must at the same time advocate halal alternatives for self expression ... (ibid.)

Muslimah 1978, while not questioning his subjectivity and, in her comment, also being careful to be respectful, nevertheless felt that she must provide 'feedback' to Al-Haddad:

Feedback-Jazakumullah khair [thank you] to the Shaykh ... This is a very common problem regarding hijab and it is important to clarify.

However, I would like to give a couple of points of feedback regarding what has been written. I feel that though the majority of points made are correct, there are a few opinions here that I feel should be omitted.... (ibid.)

Here we see that there are those who do not believe Al-Haddad can represent them or understand the Western cultural context. However, even those who do recognise and respect Al-Haddad as a scholar still feel they can criticise, correct, offer their own opinions and give him 'feedback'. This illustrates how religious authority is not simply being accepted or rejected but Muslims are adding their opinions, their experiences and judging the scholar based on his background, upbringing and gender regardless of whether or not they respect the individual as a scholar.

This desire to be 'part of the process' resonates with Jenkin's (2003) concept of 'participatory culture'. He defines this as patterns of media consumption online profoundly shaped by new media technologies that allow the average citizen to 'participate in the archiving, annotation, appropriation, transformation, and recirculation of media content'; it is 'the new style of consumerism that emerges in this environment' (ibid., p. 286). This new consumerism is not passive, but active. This concept of 'participatory culture', I suggest, can also be fruitfully applied to religious authority. Scholar's opinions, articles and books are not only passively circulated, accepted or rejected but also annotated and discussed, often with appended personal references and justifications.

This 'participatory culture' is not limited to personal opinions, but some even challenge the scholar by providing counter-evidence and interrogating his choice of clothing. Samy questioned:

Colorful Hijabs? Perfectly Islamic. Allah is Beautiful and loves beauty. Dr. Haitham, what are YOU wearing? What is that white thingee you have on? Is that the dress of the people you live with? Prophet Muhammad (May Allah bless him and grant him peace) used to wear the dress of the pagans he lived with (Abu Jahal and Abu Lahab.) YOU are being unIslamic by sticking out and putting our lives in danger! Dr. Haitham and the British Salafi ... TAKE OFF that thowb [male Arab dress] or Shalwar khamis [generic Pakistani dress] NOW. (Al-Haddad 2011)

Samy pointed out the Muslims at the time of the Prophet and pagans dressed in the same attire. Therefore, he extrapolates that Al-Haddad, living in Britain, should also wear British clothes and not Arab clothes. He is attempting to use scholarly arguments against him in a stinging personal attack.

Mona demanded proof in support of certain points: 
Being a strong advocate for colourful hijabs, I must say that I feel insulted by your apparant [sic] lack of knowledge in this. Wearing a colourful hjiab is not to entice 'brothers' in some hidden way. ... Until somebody shows me a clear and undisputed Hadith from the Prophet (SAW), CLEARLY stating that hijabs have to be black, I think Sh., you are COMPLETELY out of order for making such a ridiculous statement! ... Anyways, I agree with the skinny jeans and that being completely wrong. But colourful hijabs ENCTICING [sic]? You couldn't have been more wrong Sh. (ibid., emphasis added)

This remark about showing 'clear proof' was common in the discussion and prompted others to list numerous Hadith. Some messages listed 'evidence' that supported the claim that women at the time of the Prophet wore colours, and, in response, other posts sought to show that women only wore black. What these responses show is that the scholar's verdict is no longer sufficient; there is a need to rationalise and see the clear texts for oneself.

The prevalence of personal opinions, accusations and demands for proofs from Al-Haddad led a few people to reprimand the very idea of challenging scholars in the first place. Kezah Revert wrote:

Subhanallah [glory be to God] - I thought that by having worked towards and having earned the deserving title of Shaykh would ensure some credibility and room for benefit of doubt (lots of dubious scholars out there) amongst the readers of this article. The Shaykh is a man of knowledge, part of the trusted ulama, keepers and guardians of the deen [faith]. If we cannot accept advice from our scholars we are in a very troubled place. The ethnicity or nationality of the Shaykh and whether this entitles him to speak about European Muslims etc. is absurd. Islam was revealed for all nations for all times. Any form of compromise is just that. We are no less mocked and ridiculed than the early Muslims, so fitting in, not standing out-making excuses for workplace etc. are irrelevant. (ibid.)

In a similar vein, Abu Abdurrahman wrote:

It is absurd to imply that only a female is entitled to express her opinion on what hijab should constitute....

The people with most knowledge should speak, for they speak from the texts of revelation: the Quran and Sunnah with the understandingf [sic] of the ulama.

The fact that we speak so easily from personal opinion in opposition to those speaking with knowledge of Quran and Sunnah, should be something quite alarming for each and everyone of us, and is the biggest social ill amongst our muslim community, as demonstrated by some of the acrimonious comments. (ibid.)

Throughout these comments, one can see that there is a constant tension between following the scholar as he is a scholar, rationalising, and participating in the verdict by drawing on one's own experience. For the majority of commentators, it was not a simple case of wholeheartedly following the scholar or simply choosing what they want without reference to Islam. These lay Muslims are interacting with this verdict by also quoting other verses of the Quran and Hadith, demanding specific proof and challenging the logic of the scholar's argument. For most of the commentators, it is a process of careful engagement and participation.

\section{Ahl Al Hadith Forum}

The nuances between following different scholars, understanding their rulings and 'participating' in the process are perhaps made clearer through an analysis of some of the discussions on the Ahl-al-Hadith forums - a Salafi forum in the English language. Salafism is a trend in Sunni Islam, which emphasises meticulously following Quran and Hadith in the hopes of emulating the first three 
generations of Islam, known as the salaf (Meijer 2009). It is a growing trend, especially amongst British-born Muslims (see Inge 2016; Hamid 2016). ${ }^{2}$

One long thread dated from March 2009 contains a detailed discussion of particular scholars and opinions. The original post is about an e-book that describes the 'grave mistakes' of Yusuf Qaradawi-arguably one of the most influential Arab scholars and a supporter of the Muslim Brotherhood (Helfont 2009). Immediately, another person posted a book written by Saalih al-Fawzan-a scholar revered by many Salafis and part of the official clerical establishment in Saudi Arabia. Al-Fawzan's book examines Qaradawi's fatwas and 'clarifies the correct opinion on each of the matters' (Ahl-al-Hadeeth Forums 2009). This resulted in a long debate.

A key part of the discussion pivoted on whether or not Qaradawi was indeed a scholar. If he was a scholar, then this would have been a case of legitimate differences of opinion between two reputable authorities; but if he was not a scholar, then his views could be rejected outright. As one member, Basam, posted:

The Salafi position (from respected scholars like Albani, Bin Baz, Fawzaan bin Fawzaan and others) on Qaradawee is that he is not a reliable scholar. That is the Salafi verdict rather you agree with it or not. Brother Hanbali [another member of the forum] and others are free to disagree, but remember that the Salafi scholars have spoken. So if you want to respect Qaradawee just bear in mind and drill it into your head that you are not following Salafi manhaj [path] at this point. (ibid.)

In this post, Basam sees no need to engage directly with Qaradawi's fatwas. Rather, he argues on the basis of the fact that the leading Salafi scholars, whom he lists, do not see Qaradawi as a 'reliable scholar'. Basam is clearly not performing his own ijtihad (individual reasoning), as he is not researching or studying the issue by himself. Instead, he arrived at his position because he is, in his own opinion, a Salafi and thus following the verdict of Salafi scholars.

Another member, 'Hanbali', responded:

I consider Shaykh Salman Al-Oudah to be Salafi, and my favourite one at that. And he is on good terms with Shaykh Yusuf Qaradhawi. ...

If I am not on the Salafi 'manhaj' [path] with regards to that, then good. Al-hamdulillah [praise be to God]. (ibid.)

Here, Hanbali swiftly responded by challenging Basam's definition of 'Salafi'. He says that he does not agree with all of Qaradawi's positions, but he considers him nonetheless to be a reputable scholar since Salman al-Oudah—a popular yet controversial Salaif scholar-is 'on good terms' with Qaradawi, and he respects al-Oudah and considers him to be within the bounds of Salafism.

Basam retorted, in a sarcastic tone:

Thanks for making that clear. I was worried that you would confuse people into making them think that there was a valid difference of opinion amongst Salafis on this issue. Rather, you made it clear that you are just following your own. (ibid.)

In another message, he expounded on his own concept of what was 'valid':

I seriously hope you don't consider every difference of opinion a valid difference of opinion? Something is only a valid difference of opinion when there is [sic] actually good arguments from Quran and Sunnah or qiyas [analogical reasoning] to back up the person's position. (ibid.)

2 Salafism represents a wide variety of groups, some of which are on the opposite ends of the spectrum and fiercely oppose each other. In the UK, there are some Salafi groups that strictly refer to certain Middle-Eastern Salafi scholars, particularly from Saudi Arabia. Other Salafi groups, while they still show respect to these scholars, due to many reasons, are more lenient and prefer to contextualise Islam to the British context. The latter groups are led by some of the Western-born graduates of the University of Medina, who have adapted their Salafi teachings (see Farquhar 2016; Hamid 2016). 
Basam, I suggest, here is seeking to police the boundaries of Salafism. He argued that Hanbali was in fact following his own opinion, which had no validity. Just like the 'Shaykh Google' concept discussed above, there appears to be an underlying consensus on the forum that 'following your own ideas' is a serious error that must be carefully guarded against; the 'correct' method is to follow 'reliable' Salafi scholars. Even Qaradawi is accused by another member of the forum, Abd al-Musin, of not following the 'correct' methodology for seeking knowledge as he 'just follows his whims and desires', as opposed to sound scholarly tradition (ibid.).

Bouncing back from this attack, Hanbali clarified his thought process in the following terms:

I do not know the arguments ... Contrary to your constant accusations, I actually do taqlid [blind following], not just 'speak out of my own whim.' I always keep myself within certain parameters, taking positions on all issues that fall under acceptable views within the Al-Maghrib/Muslim-Matters ${ }^{3}$ circle that I have access to. I don't have access to Saudi scholars, and if I did, I would do taqlid of someone like Shaykh Salman Al-Oudah ...

I use the term 'taqlid' loosely here, since I do try to understand the issues, but I keep in the general realm of acceptable beliefs as understood by the Al-Maghrib/Muslim-Matters type of people. But on issues that I have not studied up myself, I of course do taqlid in a more strict sense of the word. (ibid.)

In this rebuttal, Hanbali revealed how he usually navigates between 'following the scholars' and forming his own opinion. He was at pains to stress that that he does not follow his 'own whim' but remains firmly within the boundaries set by scholars he respects and to whom he has access. He also added that he researches certain topics to improve his own understanding but again quickly reiterated his previous point about restricting himself within a certain circle of scholars and staying within his limits and the 'realm of acceptable beliefs' as understood by the Salafis he follows. In a previous post about differences between the scholars he wrote, 'I like reading both of the two sides, since it gives perspective, and is a blessing' (ibid.). Thus, he explains how he walks a tightrope between abiding by the carefully-selected Salafi scholars on the one hand and forming his own ideas through research on the other. Scholarly opinion coupled with their own personal conviction forms the basis of his understanding of Islam.

In the same rich thread, another discussion centred on Qaradawi's fatwa, deemed by many to be 'controversial', for permitting women to attend mixed-gender universities. It is in this altercation that we see members peppering their responses with the language of the ulama, while also referring to their own experiences and opinions. Responding to the fatwa, the loquacious Hanbali remarked that the:

funny thing is that we all go to mixed universities..., but suddenly when it comes to a scholar just being practical about things and living in the real world, then we blast him. (ibid.)

In response, Muhammad asked a rhetorical but pointed question:

When did our actions become hujjah [proof] for shariah rulings? There is a difference between saying that something incorrect is correct and doing something which is incorrect. (ibid.)

The debate raged on, with a female member, Um Abdullah describing her story of attending a mixed university only to quit a few months later after she was forced to work closely with men. The conversation hinged on the difference between a woman's needs, which were permissible, and wants, which were not. Basam, the same member in the above discussion also enters this debate. 'Islam', he asserted in no uncertain terms, 'excuses needs and not wants'. It is not a necessity for women, he

3 This is a popular Salafi institute based in America but also popular in the UK. Many of their scholars used to write on the blog www.MuslimMatters.org. 
argued, to attend mixed-gender universities while there are alternatives, such as online courses and women-only options available (ibid.).

This thread suggests that individualisation often is accompanied by self-imposed restrictions. For many Salafis, thinking and reasoning of your own accord without reference to the scholars is a grave mistake. While the boundaries of the 'acceptable scholar' category are contested, Salafis restrict themselves to the figures they deem part of this category, as they debate and decide which opinion to take. The very nature of the forum, and their conversations within it, illustrate their desire not simply to copy and paste the fatwas of different scholars but also to 'annotate' them by referring to their own experiences and their own rationalisation of the verdict.

This finding resonates with another study on Salafis in Germany, which examined an essential Salafi belief of al-wala' wa-l-bara' (loyalty and disavowal). When interviewing Tarek, a 55-year-old dental technician who labelled himself as a proud Salafi, he did a quick Google search when asked about this concept. He chose to read the verdict of a prominent Salafi preacher, Ibn Baz. This verdict spoke about hating disbelievers and treating them as enemies for the sake of God. Tarek swiftly reinterpreted this verdict as hating the act of disbelieving but not the person itself. While continuously stressing how he is not a scholar, and not openly criticising Ibn Baz, he still nevertheless expressed his opinion on this matter (Damir-Geilsdorf et al. 2019).

\section{Ali and the Blogger}

Another heated incident which occurred online was the debate between Ahtsham Ali, the former president of the Islamic Society of Britain (Ali 2015) and an anonymous British blogger (Coolness of Hind 2014a). At the 2011 Living Islam conference, Ali had conducted a seminar about gender segregation, at which he argued that there was no evidence in Islam that men and women have to be in separate rooms. The blogger was in fact not present at this seminar; he had read snippets of Ali's arguments in The Times and subsequently wrote a scathing critique of Ali and the Islamic Society of Britain more broadly accusing them of diluting Islam. Ali was informed about this online article and responded in the comments section. A protracted online debate between them ensued.

Ali, despite not being as well-known and distinguished as Al-Haddad (the scholar discussed above), nonetheless had studied for eighteen years under the prominent Iraqi scholar Abdullah al-Judai-one of the founding members of the European Council for Fatwa and Research (ibid.). Nine of those years, Ali mentions in his first few posts, were focused on Usul al-figh (science of legal jurisprudence), and he has been awarded an ijaza (certificate of permission) to teach this subject (ibid.). Nonetheless, despite this, out of deference to other scholars, he refrains from calling himself a 'Shaykh' and instead prefers the term 'forever student' (ibid.).

The blogger, on the other hand, as stated in his biography on his blog, only has a degree in English Law (Coolness of Hind 2014a). While he never claims to be a scholar and describes himself as nonsectarian, the blogger couches his argument in the language of the ulama and meticulously references all his quotes. After explaining how '[f]rom an Usul al-Fiqh [science of legal jurisprudence] point of view, [how] custom is to be taken into account', he reprimands Ali for not using 'correct' methodology:

Had Ali delved into the technicalities of the types of emulation of a particular act of the Messenger (peace be upon), whether it was adah (habitual) or not, and clarifying that the culture of the locality is merely mubah (permissible), as opposed to emulation of actions of the Prophet (peace be upon), which are desirable and rewardable, then the statement could have had some credibility. (Coolness of Hind 2014b)

In response to this blog post, Ali at first wrote that he wanted to meet in person and explain his position clearly, an invitation that the blogger refused, as he wanted the 'confusion' Ali had created to be publicly resolved on his blog, as his initial speech was a public event. Ali agreed and then attempted to explain his position via the comments section; however, the conversation remained stuck on what comprised the basic methodology of Usul-ul-figh. Ali tried to show he was indeed following 
the principles he had learnt in his intensive study and that the blogger was not following the standard procedures by including the opinions of scholars.

The blogger's main contention was that Ali's words were based on nothing but his own 'uninformed personal opinions' and not in line with 'great classical scholars' of the past and the 'mainstream Islamic tradition'. He accused Ali of not being a 'true' scholar and demanded that he specify which teachers had taught him and what books he had studied, even going so far as stating that Ali was confused and was 'studying something else and thought it was Usul-ul-figh?' (ibid.). In the final remark, he charged Ali with acting as though he was a qualified scholar on par with other eminent scholars of the past. With deep sarcasm, he erupted:

... you do not only think you are in the calibre of an Usuli but also a Mufti issuing rulings. Who else has the authority to DERIVE RULINGS and pick and dismiss from the great classical commentators on tafseer [exegesis of Quran] without any justifying explanations?

Oh, I forget the reformation project requires every Amr and Zaid ${ }^{4}$ to perform his or her own heart surgery on their imaan [belief] and then formulate their own personal fiqh [law]! So, of course, in the world of ISB [Islamic Society of Britain] reformation, fervour for this kind of freelance fatwa issuing is acceptable but not in mainstream Islam. (ibid.)

After these allegations, Ali stopped responding and the online debate ended abruptly.

While this online debate is markedly different from the above two examples, the same themes reoccur. First is the issue of representation of Islam and who is a 'true' scholar, and second, lay Muslims critically engaging with the scholar in the process of religious verdicts.

\section{Concluding Remarks}

All three discussions reveal the complex workings and inner contestations of how some young British Muslims strike a balance between traditional religious authority and individual rationalisation and practice of Islam. One central theme that ran throughout was the issue of representation. Who they deem as a 'true' scholar representing Islam in Britain was an essential, if not the most important aspect of the debate, in all three cases. The irony of religious authority is how in these discussions, most lay Muslims felt they could judge and decide for themselves. However, this was fiercely contested as people chose different criteria. For some, it was sufficient quotation from the Islamic texts; for others, the gender and/or nationality of the scholar was deemed central. Other criteria included other senior scholars' opinions within a specific trend of Islam or how they interacted with a certain group of famous classical scholars.

Once the person decides what they deem as the boundaries of 'true' scholarship, there seems to be a process of self-restriction to those scholars. This is perhaps clearer in the second example, where as soon as the fatwa of Qaradawi was posted, rather than discussing the actual content, it was dismissed instantly as the scholar himself was deemed as outside the fold of acceptability. Yet even the blogger had a list of scholars who he deemed only as acceptable, and anyone going against their verdicts were, in his opinion, clearly in the wrong. Likewise, in the first example, some simply dismissed Al-Haddad's opinions due to his gender or nationality.

Probably the most interesting finding in this study is how choice and self-restriction to certain scholars does not lead to deference, but rather critical engagement. Once the scholar is deemed worthy as a 'scholar' who can represent them, it is precisely at this point when young British Muslims begin to rationalise, discuss, annotate and amend the verdict. It was those who respected Al-Haddad who also gave him 'feedback' by adding their own experiences and even textual evidence. Like the example of the proud German Salafi Tarek, he first only searched for Ibn Baz's verdict online and then adapted it to match his own environment without criticising or dismissing the scholar.

4 This is an expression that has the same meaning as 'any Tom, Dick and Harry', but using Muslim names. 
This continuous engagement with traditional figures indicates not their demise but their enduring significance, albeit with transformations. It seems that the expectations of scholars have dramatically increased; not only are they expected to give rulings but also be able to explain the mechanism behind their rulings in a clear fashion in order to gain support, and even acceptance, from the Muslim masses. British Muslims are demanding from their scholars to provide textual evidence yet also link it in a practical sense to life in the modern world. Thus, traditional religious authority has not disappeared in a 'secular' world; rather, it requires deeper clarification and explanation. Referring back to Eickelman and Piscatori's (2004) 'objectification of religion', religious verdicts now need deeper justification, questioning, rationalisation and overall coherence to satisfy the religiously-minded lay-Muslims.

The citations of textual evidence by lay-Muslims, which used to be solely the purview of the trained ulama, either to support the verdict or to go against the scholar also indicates the need for this inner coherence. When textual evidence against the verdict is posed, the implicit question is 'how does this fit with this sacred text, which I have read or heard elsewhere?' When evidence is provided to support the scholar, the underlying statement is the opposite: It is the confirmation that the verdict is coherent and 'fits in' with the overall picture of Islam they have in their minds. Furthermore, the continuous usage of textual evidence also demonstrates the persistent desire for Islamic rulings to be grounded in the texts in order to stay true to the 'authentic' message of the faith. As mentioned above, Zaman argues, it is this desire that keeps the ulama's position in today's society. Yet, now they are being constantly challenged and questioned from below.

Funding: This research received no external funding.

Conflicts of Interest: The author declares no conflict of interest.

\section{References}

Abo-Alabbas, Belal. 2015. Sufism in Britain: How Sufi Orders have Adapted to a Western Context. In Muslims in the UK and Europe I. Edited by Yasir Suleiman. Cambridge: University of Cambridge.

Ahl-al-Hadeeth Forums. 2009. Al-Qaradaawee on the Scales. Available online: http://www.ahlalhdeeth.com/vbe/ showthread.php?s=9f97ec6422b5c5e2099dc821d1bbfda2\&t=4771\&highlight=islamists (accessed on 20 April 2019).

Al-Haddad, Haitham. 2011. Attractive Hijabs and Shariah. Available online: http://www.islam21c.com/islamiclaw/2606-attractive-hijabs-a-shariah/ (accessed on 20 April 2019).

Al-Haddad, Haitham. 2012. Sheikh (Dr) Haitham Al-Haddad. Available online: https://www.islam21c.com/ islam21c-writers/haitham/ (accessed on 20 April 2019).

Ali, Ahtsham. 2015. How Close Is Too Close? A Look at Gender Segregation from the Quran and Sunnah. Available online: https://www.facebook.com/events/899371013420412/ (accessed on 20 April 2019).

Ansari, Humayun. 2004. The Infidel within: Muslims in Britain since 1800. London: Hurst \& Company.

Beck, Ulrich, and Elisabeth Beck-Gernsheim. 2008. Individualization: Institutionalized Individualism and Its Social and Political Consequences. London: Sage.

Brown, Nathan. 1997. Sharia and State in the Modern Middle East. International Journal Middle East Studies 29: 359-76. [CrossRef]

Bunt, Gary R. 2018. Hashtag Islam: How Cyber Environments Are Transforming Religious Authority. Chapel Hill: University of North Carolina Press.

Cesari, Jocelyne. 2003. Muslim minorities in Europe: The Silent Revolution. In Modernising Islam: Religion in the Public Sphere in the Middle East and in Europe. Edited by Francois Burgat John Esposito. London: Hurst \& Company, pp. 251-69.

Cooke, Miriam, and Bruce B. Lawrence, eds. 2005. Muslim Networks from Hajj to Hip Hop. Chapel Hill: University of North Carolina Press.

Coolness of Hind. 2014a. About. Available online: https://coolnessofhind.wordpress.com/about/ (accessed on 20 April 2019).

Coolness of Hind. 2014b. Is ISB Living Islam or Reforming Islam? Available online: https://coolnessofhind. wordpress.com/2014/08/07/isb-and-the-reformation-discourse/ (accessed on 20 April 2019). 
Damir-Geilsdorf, Sabine, Mira Menzfeld, and Yasmina Hedider. 2019. Interpretations of al-wala' wa-l-bara' in Everyday Lives of Salafis in Germany. Religions 10: 124. [CrossRef]

Edmunds, Holly. 1999. The Focus Group Research Handbook. Lincolnwood: NTC Business Books/Contemporary Publishing.

Eickelman, Dale F., and James P. Piscatori. 2004. Muslim Politics, 2nd ed. Oxford: Princeton University Press.

Eysenbach, Gunther, and James E. Till. 2001. Ethical issues in qualitative research on internet communities. British Medical Journal 323: 1103-5. [CrossRef] [PubMed]

Farquhar, Michael. 2016. Circuits of Faith: Migration, Education and the Wahhabi Mission. Stanford: Stanford University Press.

Giddens, Anthony. 1991. Modernity and Self-Identity: Self and Society in the Late Modern Age. Stanford: Stanford University Press.

Gilliat-Ray, Sophie. 2010. Muslims in Britain: An Introduction. Cambridge: Cambridge University Press.

Griffiths, Mark, and Monica Whitty. 2010. Online behavioural tracking in Internet gambling research: Ethical and methodological issues. International Journal of Internet Research Ethics 3: 104-17.

Hallaq, Wael B. 2003. Juristic Authority vs. State Power: The Legal Crises of Modern Islam. Journal of Law and Religion 19: 243-58. [CrossRef]

Hamid, Sadek. 2009. The Attraction of Authentic Islam: Salafism and British Muslim Youth. In Global Salafism: Islam's New Religious Movement. Edited by Roel Meijer. London: Hurst \& Company, pp. 352-79.

Hamid, Sadek. 2016. Sufis, Salafis and Islamists: The Contested Ground of British Islamic Activism. London: I.B. Tauris.

Haq, Muhammad. 2015. The 'Sheikh Google' Phenomenon. Available online: https://www.virtualmosque.com/ personaldvlpt/seeking-knowledge/the-sheikh-google-phenomenon/ (accessed on 20 April 2019).

Helfont, Samuel. 2009. Yusuf Al-Qaradawi: Islam and Modernity. Tel Aviv: Tel Aviv University Press.

Herbst, Susan. 2003. Political Authority in a Mediated Age. Theory and Society 32: 481-503. [CrossRef]

Hinnells, John R. 2007. Religious Reconstruction in the South Asian Diasporas: From One Generation to Another. Basingstoke: Palgrave Macmillan.

Inge, Anabel. 2016. The Making of a Salafi Muslim Woman: Paths to Conversion. New York: Oxford University Press. Islam21C. n.d. Available online: https://www.islam21c.com/ (accessed on 20 April 2019).

Joinson, Adam N., Carina Paine, Tom Buchanan, and Ulf-Dietrich Reips. 2008. Measuring self-disclosure online: Blurring and non-response to sensitive items in web-based surveys. Computers in Human Behavior 24: 2158-71. [CrossRef]

Jones, Justin. 2012. Shi a Islam in Colonial India: Religion, Community and Sectarianism. Cambridge: Cambridge University Press.

Kamdar, Ismail. 2011. Shaykhy Crushes Trials in the Life of Men of Knowledge. Available online: http: //muslimmatters.org/2011/06/06/shaykhy-crushes-trials-in-the-life-of-men-of-knowledge/ (accessed on 20 April 2019).

Kozinets, Robert V. 2010. Netnography: Doing Ethnographic Research Online. London: Sage.

McLoughlin, Seán, and John Zavos. 2013. Writing Religion in British Asian Diasporas. In Research Paper WBAC 009: Diasporas, Migration and Identities Programme. Leeds: White Rose Research.

Meijer, Roel. 2009. Introduction. In Global Salafism: Islam's New Religious Movement. Edited by Roel Meijer. London: Hurst \& Company, pp. 1-32.

Nielsen, Richard. 2016. The Changing Face of Islamic Authority in the Middle East. Middle East Brief 99: 1-8.

Paccagnella, Luciano. 2006. Getting the Seats of Your Pants Dirty: Strategies for Ethnographic Research on Virtual Communities. Journal of Computer Mediated Communication 3: 1. [CrossRef]

Ridley, Yvonne. n.d. About. Available online: http://yvonneridley.org/about/ (accessed on 20 April 2019).

Robinson, Francis. 2009. Crisis of Authority: Crisis of Islam? Journal of the Royal Asiatic Society of Great Britain $\mathcal{E}$ Ireland 19: 339-54.

Roy, Olivier. 2002. Globalised Islam: The Search for a New Ummah. London: Hurst \& Company.

Snee, Helene, Christine Hine, Yvette Morey, Steven Roberts, and Hayley Watson. 2016. Digital Methods for Social Science. London: Palgrave MacMillan.

Sveningsson, Malin. 2004. Ethics in Internet ethnography. In Readings in Virtual Research Ethics: Issues and Controversies. Edited by Elizabeth Buchanan. Hershey: Idea Group Inc., pp. 45-61.

Timol, Riyaz. 2015. Religious Travel and Tablighi Jama'at: Modalities of Expansion in Britain and Beyond. In Muslims in the UK and Europe I. Edited by Yasir Suleiman. Cambridge: University of Cambridge. 
Usman, Omar. 2014. How to Stop Being a Celebrity Shaykh Fanboy or Fangirl and Build Real Relationships with Them. Available online: http://ibnabeeomar.com/stop-celebrity-shaykh-fanboy-fangirl-build-realrelationships/ (accessed on 20 April 2019).

Wood, Richard T. A., and Mark D. Griffiths. 2007. Online data collection from gamblers: Methodological issues. International Journal of Mental Health and Addiction 5: 151-63. [CrossRef]

Yildirim, A. Kadir. 2019. The New Guardians of Religion: Islam and Authority in the Middle East. In Centre for the Middle East: Rice University's Baker Institute for Public Policy. Houston: Baker Institute.

Zaman, Qasim. 2007. The Ulama in Contemporary Islam: Custodians of Change. Princeton: Princeton University Press.

(C) 2019 by the author. Licensee MDPI, Basel, Switzerland. This article is an open access article distributed under the terms and conditions of the Creative Commons Attribution (CC BY) license (http://creativecommons.org/licenses/by/4.0/). 

Article

\title{
Loci of Leadership: The Quasi-Judicial Authority of Shariah Tribunals in the British Muslim Community
}

\author{
Amin Al-Astewani \\ Law School, Lancaster University, Lancaster LA1 4YN, UK; a.al-astewani@lancaster.ac.uk \\ Received: 13 May 2019; Accepted: 24 June 2019; Published: 27 June 2019
}

\begin{abstract}
Leadership and authority were two central themes in the mission statement of the first ever Shariah tribunal to emerge in the UK. When the Islamic Shariah Council was established in 1982, it noted that its founding meeting had been attended by Muslim scholars from a number of mosques in the UK who represented the major schools of Islamic law. This ensured in its own words that it was widely accepted as an authoritative body with regards to Islamic law and that it was therefore able to cater to the basic religious needs of the Muslim community. Since their emergence in the 1980s, Shariah tribunals have played an important role in guiding the Muslim community through the provision of religious services. This paper seeks to enrich the literature on Shariah tribunals by critically assessing how such tribunals have used their expertise in Islamic law to wield quasi-judicial authority in the British Muslim community, within a legal system which does not directly grant legal jurisdiction to religious tribunals. The paper highlights the distinctive characteristics of the authority which Shariah tribunals exercise as religious institutions, which distinguish them from the secular courts of the state despite the judicial functions which both share in common.
\end{abstract}

Keywords: religious authority; religious leadership; religious tribunals; Shariah tribunals; Islamic law; British Muslims

\section{Introduction}

Several religious minorities in England have historically established tribunals to serve the religious needs of their members, with prominent examples being the Catholic and Jewish communities (Malik 2012). These religious tribunals all function on a non-statutory basis and are not considered part of the civil court system (D'Auria 2014). Religious tribunals are nevertheless permitted by law to function on a voluntary jurisdiction and rely on the consent of both parties to submit to a particular decision when resolving disputes (Al-Astewani 2016a). The first Shariah tribunals in England emerged in the 1980s for a number of socio-historical reasons (Bowen 2016). One of the predominant reasons was the plight of numerous British Muslim women whose husbands refused to give them a religious divorce when this was required, leaving them in a limping marriage (Douglas et al. 2011; Bano 2004).

For the first two decades following their formation, Shariah tribunals in England were embraced by the state. In the first ever court-case directly affecting them, an English judge expressed positive sentiments about the complimentary services which they were providing to the Muslim community alongside the civil courts of the state (Al-Astewani 2019a). The government explicitly affirmed on numerous occasions that their presence and activities were legal and that they would be allowed to function based on the British value of religious tolerance (Grillo 2015). The government's resolve in maintaining this liberal attitude was acutely illustrated when a prominent member of the House of Lords, Baroness Cox, failed six times in a row to pass a private member's bill which sought to restrict the activities of Shariah tribunals (Al-Astewani 2017). This situation changed with the entry of the 21st century, which marked a gradual change in public attitudes towards Islamic law following the events of 9/11 that has skyrocketed in recent years following the horrific activities of the Islamic State of Iraq 
and Syria (Davids 2015). Rising levels of public concern and alarm about the existence and activities of Shariah tribunals reached such an extent that the government was eventually forced to change its position and launch the first formal public review of Shariah tribunals (Grillo 2015). This move, along with the decision of the government to leave the European Union, now raises serious question-marks about the future existence of British Shariah tribunals (Al-Astewani 2019b).

Since its inception in the 1990s, the body of literature that has emerged on British Shariah Tribunals has predominantly focused on the compatibility of Islamic law with Western liberal ideals and the consequent impact this may have on members of the Muslim community who use Shariah tribunals (see for example King 1995; Williams 2008; MacEoin 2009; McGoldrick 2009; Reiss 2009; Brechin 2013). Very little research has been done on the judicial nature and function of these tribunals or on the way in which they are regulated by the English legal system. The author was one of the first researchers in the UK to engage in a detailed black-letter law analysis of the legal provisions which relate to Shariah tribunals as part of his doctoral research which took place between 2013 and 2016 (Al-Astewani 2016b). This included an exploration of the impact on Shariah tribunals of the Arbitration Act 1996 and the Divorce (Religious Marriages) Act 2002, as well as the ramifications of important cases involving the legal status of Shariah tribunals such as Al-Midani v Al-Midani, Uddin v Chaudhury and AI v MT. During this period the author conducted fieldwork at four of the most frequently used Shariah tribunals in England and carried out a number of semi-structured interviews with judges and case-workers at each of these tribunals in order to gain an insight into their personal views about the role and function of the tribunals which they serve, as well as the legal status of such tribunals and their relationship with the state legal system. The full set of interview questions were compiled before the interviews took place and participants were all asked the same set of interview questions. The principal inclusion criterion for participants was the professional capacity of the participant as a judge, case-worker or administrator of a Shariah tribunal. The rationale behind this inclusion criterion was the information that such a participant would have about the nature, function and legal status of the tribunal which the participant serves. The participants were identified on the internet via the respective websites of the tribunals which they worked for as employees. Once they accepted to participate, a date was agreed for the interview and the interviews all took place in the official premises of the tribunals under study. ${ }^{1}$ Due to this fieldwork the author was able to develop links with the Shariah tribunals he engaged with and currently acts as the legal adviser for the UK Board of Shariah tribunals, which is the largest umbrella organization for Shariah tribunals in England.

Leadership and authority were two central themes in the mission statement of the first ever Shariah tribunal to emerge in the UK. When the Islamic Shariah Council was established in 1982, it noted that its founding meeting had been attended by Muslim scholars representing the major schools of Islamic jurisprudence who also represented a number of mosques in the UK. This ensured in its own words that it was widely accepted as an authoritative body with regards to Islamic law and that it was therefore able to cater to the basic Shariah needs of the Muslim community (Al-Astewani 2016b). Since their emergence in the 1980s, Shariah tribunals have played an important role in guiding the Muslim community through the provision of religious services. Over the last two decades, a small number of studies have been undertaken analyzing the role which such tribunals play within the British Muslim community from a broad socio-legal perspective (Bano 2004; Douglas et al. 2011; Grillo 2015; Bowen 2016). These studies include the important research of Samia Bano and John Bowen, two scholars who have engaged in extensive socio-legal analyses of British Shariah tribunals, focusing on the social impact which such tribunals have generally had within the religious Muslim communities they were established to serve. This paper seeks to build on such research and enrich the literature on Shariah tribunals by critically assessing how Shariah tribunals have used their expertise in Islamic law to wield quasi-judicial authority in the British Muslim community, within a legal system which

1 Pseudonyms have been used in this paper when referring to the interviewees for the sake of preserving anonymity. 
does not directly grant legal jurisdiction to religious tribunals. The paper highlights the distinctive characteristics of the authority which Shariah tribunals wield as primarily Islamic religious institutions, which distinguishes them from the secular courts of the state despite the judicial functions which both share in common. Understanding the precise nature of the authority which Shariah tribunals exercise and the influence which they enjoy in the British Muslim Community is particularly pertinent for policy makers assessing the future role of such tribunals in the English legal system. It will also more broadly benefit researchers in the human and social sciences as an illuminating case-study of the dynamic ways in which law and religion interact with one another.

The paper is structured into four main sections. Each section captures a particular feature of the quasi-judicial authority which Shariah tribunals enjoy, in order to produce by the end of the analysis a comprehensive and holistic picture of such authority. The first section begins with the socio-religious basis from which the jurisdiction of Shariah tribunals stems by shedding light on two important factors which inspired the formation of such tribunals. The doctrinal basis in Islamic law for establishing quasi-judicial authority in a non-Muslim land represents the first factor, and this is assessed in light of both the views of classical Muslim jurists and the modern British Muslim scholars who pioneered the formation of Shariah tribunals after migrating to Britain. The second factor which is assessed embodies a unique application of this doctrinal discourse and involves the legal environment which South Asian Muslim scholars experienced under British colonial rule, an experience which is particularly relevant to the analysis because of the precedent which it represented for the formation of British Shariah tribunals. The second section explores how the issuing of religious verdicts functions as a manifestation of the judicial authority which Shariah tribunals exercise, and examines the doctrinal distinction in this regard between fatwa (the issuing of religious verdicts) and qada' (judicial adjudication). The third section locates the authority of Shariah tribunals within the context of the English legal system by analyzing how Shariah tribunals have engaged with English law and the English courts. This section begins with investigating the role played by the Muslim Arbitration Tribunal as a pioneering case-study of a Shariah tribunal utilizing the Arbitration Act 1996 to enhance its work. It next considers the important role of Shariah tribunals as expert witnesses in the English courts, in cases featuring an element of Islamic law. The fourth and final section highlights the pastoral and spiritual elements of the services which Shariah tribunals provide, and emphasizes how these elements culminate in a fusion of spiritual and legal authority which distinguish Shariah tribunals from the secular state courts despite the parallels which both share.

\section{The Emergence of British Shariah Tribunals in the 1980s}

\subsection{Quasi-Judicial Authority in a Non-Muslim Land}

The Islamic Shariah Council currently based in the London district of Leyton was the first Shariah tribunal to be established in Britain (Al-Astewani 2016b). A foundational motive for the establishment of the council was to fulfil the Islamic obligation made incumbent on a Muslim community living in a non-Muslim land to provide those religious services which are needed by the community. The basis for this obligation may be found in the thought-provoking discourse of classical Muslim jurists which has been recorded in the classical manuals of Islamic law. The discourse centered on the tricky question of religious authority in the hypothetical situation of Muslims living in a non-Muslim land. The 19th century Hanafi jurist Ibn-Abidin, who enjoyed the patronage of the Ottoman caliphate whilst residing in Damascus, states in his celebrated legal manual Radd al-Muhtar for example:

As for those Muslims who reside in a land which is ruled by non-Muslims, then it is permissible for the Muslims to establish the Friday prayer and the Eid celebration, and the judge should be elected by the general acknowledgement of the Muslim community (Ibn-Abidin 1992, p. 175).

Nine centuries earlier, the 11th century Hanbali jurist Abu Ya'laa had passed a similar judgement in Al-Ahkaam Al-Sultaniyyah, a work which he compiled on the topic of Islamic public law: 
If the people of a land found themselves in a situation where they do not have access to an appointed Islamic judge, then they must agree to appoint an Islamic judge from amongst them (Abu Ya'laa 2000, p. 55).

In the author's interview with a leading judge at the Islamic Shariah Council, this religious obligation for establishing quasi-judicial authority in a non-Muslim land was identified as a key justification for the establishment of Shariah tribunals:

The first thing, which is also a very important question, from where does the authority of the Shariah council come? Because usually judges are appointed by an authority, and in the Islamic state they are appointed by the Islamic government. This is the case in all legal systems. Now in a non-Muslim state, there is no official authority which can elect Muslim judges, as they don't recognise[sic] the Shariah. So what do we do in this case? Muslims are asked to manage their own affairs by themselves, like building a mosque, providing halal meat and so forth. So if the Muslim community set up such a system, we will say the authority comes from the Muslim community itself, and this is how the Shariah council was made. Thereafter, those people who are religiously qualified from prestigious Islamic educational universities or institutions, such as the famous dar al-uloom, or the Islamic University of Madinah-which I am a graduate of-or al-Azhar, or any other institution: [T] hey are eligible to be the judge of such a council. The only condition is that they must be well versed in the Shariah. ${ }^{2}$

On its website, the council describes itself explicitly as a "quasi-Islamic court". ${ }^{3}$ This reveals their understanding from the very beginning of their formation that they were not acting as a formal Islamic court, since their judgments did not have legal authority, as would be the case for an official Islamic court in a Muslim country. The website emphasizes that the participation of representatives from across the country in the formation of the council is a proof that the council was "a manifestation of the will of the Muslim community and a reflection of their collective desire to manage their personal affairs." ${ }^{4}$ It also notes that it bases its judgments on "all of the major schools of Islamic legal thought and is widely accepted as an authoritative body with regards to Islamic law." 5

These two facts are emphasized for several reasons. The council's authority and existence depend entirely on the assent of the Muslim community. The only way the council is able to deliver religious services to the community is because the community recognizes it as a legitimate authority and thus agrees to use and abide by the services it provides. The council is very aware of this fact and hence makes a special point to emphasize the communal authority upon which it relies. As noted above, classical Muslim jurists have also stipulated that institutions in non-Muslim lands should be formed according to the assent of the Muslim community residing in the respective location. This is therefore another reason for the emphasis on communal representation. If the council only judged according to one of the Islamic schools of law, such as the Hanafi school or the Maliki school, this would naturally restrict the pool of clients which the council would have access to and also promote the view that it was not representative of the entire Muslim community. This is part of the reason for the council's emphasis on the fact that it judges according to all the schools of Islamic law.

The quasi-judicial nature of Shariah tribunals and the Islamic legal basis for their authority was significantly acknowledged by an English judge in the case of Al-Midani $v$ Al-Midani, the first ever reported case to consider the legal status of a decision issued by a British Shariah tribunal. ${ }^{6}$ The Islamic Shariah Council in London had in this case issued a decision on the division and distribution

\footnotetext{
Interview conducted by the author with Mohammad Hussain in the Leyton Islamic Shariah Council on 09/10/2014

http://www.islamic-sharia.org/aboutus/ (accessed on 12 May 2019).

http://www.islamic-sharia.org/aboutus/ (accessed on 12 May 2019).

http://www.islamic-sharia.org/aboutus/ (accessed on 12 May 2019).

Al-Midani and another v Al-Midani and others [1999] CLC 904.
} 
of assets in an inheritance dispute between Muslim litigants. Justice Rix decided that the decision had no legal effect because one of the parties had not consented to having the dispute adjudicated by the Shariah Council. The case includes an important account of the nature and function of the Islamic Shariah Council by an English judge. Describing the council during the proceedings of the cases, Justice Rix noted:

The Shari'a Council was, as explained in its own brochure, established in 1982 by scholars representing a number of mosques in the UK. It acknowledges that it 'is not yet legally recognized by the authorities in the UK', but represents itself as gaining recognition and confidence among the Islamic community and at large. It would seem that Islamic divorce and matrimonial questions in general are the focus of its advisory and judicial work ... It can grant Islamic divorce, but it emphasizes that such divorce nullifies only the Islamic marriage and has nothing to do with the civil contract... The bench of the Shari'a Council would seem to provide a welcome facility to the Muslim community of the UK to render decisions on Islamic law, particularly in the matrimonial and family sphere. Its authority appears to rest largely on consent, in as much as it responds to the needs of the community it serves, but it may be that under Shari'a law it has autonomous power, as a religious court, to promulgate decisions in favour[sic] of a claimant even against the will of a respondent. ${ }^{7}$

Not only does Justice Rix affirm from an English law perspective that the decisions of the Islamic Sharia Council are not legally binding, but he crucially also alludes to the quasi-judicial authority of the council under Islamic law, and the authority which it wields based on the assent of the Muslim community.

\subsection{The Colonial Experience}

Another factor which impacted the formation of Shariah tribunals is the legal environment which South Asians experienced under British colonial rule. This factor is particularly relevant considering the fact that the main Muslim group responsible for the establishment of Shariah tribunals in Britain is the South Asian community (Al-Astewani 2016b). South Asians who migrated to Britain and decided to set up Shariah tribunals were merely building on the colonial experience which they had experienced back home, where they had been left to manage their private affairs without intervention from the British authorities. British colonial rulers, unlike their French counterparts, decided to delegate private affairs, such as marriage and divorce to the colonized communities (Kugle 2001). The British governed the affairs of such communities by codifying the communities' own laws and traditions and subsequently appointing judges to apply these personal codes. In the case of a large number of South Asians, this meant a codification and application of private Islamic law. This legal state of affairs encouraged South Asian Islamic scholars to set up their own alternative courts, as they were just as capable as state-appointed judges to apply the law, since it was simply a restatement of Islamic law in statute form (Mullally 2004).

The specific reason South Asian Islamic scholars actually decided to set up alternative courts during British rule in India was the plight of South Asian Muslim women who wanted to end their marriage, but found that the courts which applied Islamic personal law were now occupied by non-Muslim British judges who could not issue Muslim women with a judicial divorce according to Islamic law (Masud 1996). Following intensive lobbying from Islamic scholars, the colonial government passed The Dissolution of Muslim Marriages Act 1939 as a solution to the issue (Khan 2008). Section two of the Act sets out the grounds, many of which are adopted from the Maliki school of law, upon which a South Asian Muslim wife may apply to a court for a judicial divorce. The most significant characteristic of these grounds is their expansiveness. They are far more detailed and extensive than

7 Al-Midani and another v Al-Midani and others [1999] CLC 904, pp. 911-13. 
the narrow and limited grounds available under the old regime dictated by the Hanafi school of law (Abdullah 1997). They make it much easier for a judge to issue a judicial divorce, due to the number of grounds now available for him to identify in any case. The last ground also allows a judge to cite any other ground which the Islamic schools of law have recognized, providing him with even more lee-way when deciding whether to issue a judicial divorce to a Muslim woman. A significant feature of the new grounds was the many parallels they shared with the legal grounds for divorce in English family law (Carroll 1997). South Asian Hanafi scholarsplayed an instrumental role in the passing of the Act by acknowledging that the classical Hanafi jurists permitted applying the provisions of other schools of law if the application of Hanafi law caused hardship on Muslims (Khan 2008).

Bearing this context in mind, South Asian Muslims who migrated to Britain and decided to set up Shariah tribunals were merely building on the colonial experience which they had experienced back home, where they had been able to set up alternative courts and manage their private affairs without state intervention from the British establishment. The 1939 Act and its historical background are particularly pertinent to the emergence of Shariah tribunals in Britain. Both the Act and Section 2 in particular provided a concrete precedent for South Asian Muslims who migrated to Britain and were faced with the dilemma of British Muslim women who urgently needed a judicial divorce. The fact that the reasons set out in section two also had parallels with English family law would have provided a further incentive for using the Act as a precedent, since this fact could be used to give the judicial divorce issued by the Shariah tribunals more legitimacy. The important impact of the colonial experience on the mentality of migrants can be further illustrated by comparing the activities of South Asian British Muslims with North African Muslims who migrated to France. North African Muslims became accustomed to a civil law tradition under French colonial rule where marriage and divorce were public affairs which could only be managed by the civil courts according to French civil law (Bowen 2009). Thus, it was much easier for them to accept on their arrival to France that the law would not allow them to establish Shariah tribunals in order to manage their own personal affairs. This is a limitation which lasts to this day (Al-Astewani 2019a).

\section{Issuing Religious Verdicts}

An important service provided by Shariah tribunals to the communities they serve is that of fatwa, or the issuing of religious verdicts. In Islamic law, fatwa involves a personal non-binding legal ruling issued by an Islamic scholar in response to a specific question raised by a member of the Muslim community (Nadwi 2011). This service was traditionally provided by scholars to members of the Muslim community on a private basis. Thus, the scholar would typically hold a session in the mosque, and members of the public would be free to attend the session and address their question to the scholar. This role traditionally played by Muslim scholars was markedly different from the role which they traditionally played as judges. Scholars acting as judges would rule upon cases between litigants in an official public court, and their judgements would be binding and enforceable by the Islamic state (Al-Khassaf 2004). Whilst commenting on the European Fatwa Council, a judge at the Islamic Shariah Council clarified this difference between fatwa and qada' (judicial adjudication), stating:

The European Fatwa Council is in all senses a council for fatwa, not a council for qada'. Qada' is to give judgement, but the council do not give judgements in a court, they only issue personal legal rulings in all new matters which the Muslim community are affected by. The European Fatwa Council research new matters facing the Muslim community in the west such as the Mortgage. This is a new phenomenon, and the question arises: [W]ill the Shariah accept it? The council therefore researches into these things, then have an annual conference and release papers to inform the Muslims how to deal with these new matters. Some of the 
issues might be very burning issues, upon which the council then issues legal rulings. This is their function; it is different from Shariah councils which are judicial councils. ${ }^{8}$

Since the Islamic Shariah Council employs scholars to deal with religious cases brought before them and gathers them within the bounds of one institution, it became a logical step for the council to also provide the service of fatwa on a professional, institutional basis. This saves a member of the local Muslim community from the burden of trying to gain access to local scholars through their own private means. The website of the Islamic Shariah Council mentions sixteen topics which its fatwa department specifically deals with. It is pertinent to note that many of the topics are novel legal issues in Islamic law which Muslims who migrated to the West are particularly noted to have grappled with, such as pensions, student loans and mortgages. ${ }^{9}$

The Islamic Shariah Council in this regard plays an almost identical role to Islamic fatwa websites online and private fatwa institutions which deal exclusively with issuing personal legal rulings for the Muslim community. Islamic fatwa websites typically receive questions from internet users online, and will then issue the ruling online so it may be viewed by the questioner, as well as other internet users (Bunt 2003). The only difference between the Sharia Council's fatwa service and that of fatwa websites is that the council enables members of the community to physically address Muslim scholars with their questions, which has the additional benefit of allowing the questioner to engage in a discussion with the scholar and seek further clarifications from the scholar to avoid any misunderstandings. Islamic fatwa websites on the other hand do not provide such an opportunity, since they only issue rulings in an electronic format in response to pre-written questions posed by internet users online. It is interesting to note that cases do exist in which clients unhappy with a Shariah tribunal ruling have chosen to resort to a fatwa website in the hope of obtaining a more favorable ruling. ${ }^{10}$

During the author's fieldwork visit to the Islamic Shariah Council, he attended a session arranged between one of the council's senior judges and two young Muslim men which aptly illustrates the nature of this service. The two men asked the judge about the permissibility in Islamic law of working as independent business owners for the new business scheme known as the American Communications Network. The two men explained that this was a scheme which had become popular as a quick way to make money. The judge replied that he had heard about the scheme and was in the process of deriving a legal ruling regarding its permissibility. He told the two men to refrain from getting involved in the enterprise until he was able to issue a ruling on the matter (Al-Astewani 2016b). This episode aptly indicates the authority which Shariah tribunals wield in the domain of fatwa and the power they exerciseto lead the Muslim community by issuing important religious verdicts which can have a significant impact on the lives of British Muslims.

\section{Engagement with the English Legal System}

\subsection{The Muslim Arbitration Tribunal}

Whilst Shariah Tribunals have reiterated on numerous occasions that they are committed to acting within the parameters of the law and complementing the services offered by the state courts, few have attempted to substantively engage with the English legal system (Al-Astewani 2019b). An exception to this is the Muslim Arbitration Tribunal, which enjoys a unique presence in the British Shariah Tribunal landscape. The first of its kind in England, it was formed in 2007 by Faizul Aqtab Siddique, a religious scholar of Pakistani origin who acts as the spiritual leader of a community in Nuneaton known as the Hijaz community (Bowen 2013). Unlike many other religious scholars like him who had decided to set up Shariah tribunals, Siddique was a practicing barrister, as well as being a Muslim scholar. He

\footnotetext{
8 Interview conducted by the author with Mohammad Hussain in the Leyton Islamic Shariah Council on 09/10/2014.

See http://www.islamic-sharia.org/fatwa/ (accessed on 12 May 2019).

See for example http://www.askimam.org/public/question_detail/15522 (accessed on 12 May 2019).
} 
therefore realized that the Arbitration Act 1996 provided a legal framework which he could utilize to enhance the services offered by Shariah tribunals, and it was in this way that the Muslim Arbitration Tribunal was born. In the words of the tribunal itself, it was established to provide a viable alternative for the Muslim community by seeking to resolve their civil disputes in accordance with both English and Islamic law. This could be done via alternative dispute resolution mechanisms, which would have the additional benefit of saving the Muslim community from the burden of resorting to costly and time-consuming litigation in the state courts and tribunals (Al-Astewani 2016b).

Several characteristics are highlighted by the Muslim Arbitration Tribunal which in its own view sets it apart from other Shariah tribunals (Al-Astewani 2016b). The first is the tribunal's access to an expert panel of legal professionals who specialize in English law, as well as Islamic scholars well versed in both English and Islamic law. This aims to ensure that the tribunal is able to reconcile between both English and Islamic legal provisions when reaching decisions in any of its cases. It also ensures that any outcome determined by the tribunal will be binding and enforceable via Section 46 of the Arbitration Act. The second is the British background of the scholars and legal professionals who form a part of the Muslim Arbitration Tribunal's panel of caseworkers. This aims to ensure that the cases are dealt with in an appropriate fashion, especially when the cases demand an intimate understanding and experience of modern British society. The third is a formal set of procedural rules developed by the tribunal which systemize and regulate its work, in much the same way as the English civil procedural rules systemize the work of the English courts (Al-Astewani 2016b). By virtue of the Act, the Muslim community was thus given access to a professional service which could deal with their religious needs in an appropriate and culturally-sensitive environment. At the same time, the Act also protected the interests of those who used the tribunal, as the tribunal was bound by the Act's standards of fairness. The success of the tribunal is illustrated by the fact that it now has a headquarters in Nuneaton with several offices and a number of employees, a fully functioning website and a large number of clientsfrom across the country (Bowen 2013).

The current emphasis in English family law on alternative methods of dispute resolution outside of the courts highlights the potential of the model pioneered by the Muslim Arbitration Tribunal. It is now a well-established principle in modern English family law that it is in the best interests of couples to privately settle their matrimonial disputes rather than become entangled in adversarial litigation (Douglas 2015). This principle has become more firmly enshrined by the English legal system in recent years, with the Family Procedure Rules 2010 obligating courts to encourage parties to use an alternative dispute resolution procedure if the court considers this appropriate. ${ }^{11}$ Justice Baker affirmed this principle in AI v MT, a 2013 High Court case involving a Jewish Beth Din tribunal which had important repercussions for religious tribunals. ${ }^{12}$ He stated that the resolution of the dispute by non-binding arbitration via a religious tribunal during the proceedings of the case was "largely in accordance with the overriding objective of the Family Procedure Rules 2010" and that "it is always in the interests of parties to try to resolve disputes by agreement wherever possible, including disputes concerning the future of children and ancillary relief of the breakdown of a marriage." ${ }^{13} \mathrm{He}$ also highlighted the attractions of arbitration for divorced couples which include "speed, confidentiality and cost... the parties are able to select the arbitrator as opposed to litigation where the parties are obliged to accept the judge allocated to hear the case."14 This increased prominence of private arbitration in English family law gives Shariah tribunals the opportunity to settle disputes between Muslim couples and potentially receive a consent order from the civil courts granting legal status to their decisions

11 The Family Procedure Rules 2010, s 3(2). The Children and Families Act 2014 now also obligates couples to attend a family mediation session before applying to court. Muslim counsellors working at Sharia tribunals could therefore qualify as mediators and thus be eligible to mediate between Muslim couples.

12 AI v MT [2013] EWHC 100

13 Ibid., para 37, 30.

14 Ibid., para 32. 
following the precedent of AI v MT. At the same time the English courts will benefit from such a development, as their own workload will be reduced (Douglas 2015).

\subsection{Expert Witnesses in the English Courts: The Case of Uddin v Chaudhury}

Another avenue through which Shariah Tribunals have had the opportunity to engage with the English legal system has been as expert witnesses in English cases involving Islamic law. This opportunity most prominently arose in the case of Uddin v Choudhury, which involved a financial dispute between a couple who had their marriage dissolved by the Islamic Shariah Council in Leyton at the request of the wife in $2004 .{ }^{15}$ The facts of the case are noteworthy as they depict the typical kind of case that Sharia tribunals receive throughout the year. The marriage had been arranged by the parents of both spouses, who had immigrated to England from Bangladesh. As per the usual practice in South Asian culture, the families exchanged gifts as part of the marriage ceremony, including substantial amounts of gold jewelry. These were completely unrelated to the dower (known in Islamic law as the Mahr), which was stipulated in the marriage contract as $£ 15,000$. This remained unpaid upon completion of the Islamic marriage ceremony.

The couple conducted the Islamic marriage ceremony in 2003 with the intention of conducting a civil ceremony later on, but this never occurred. The marriage did not work out, and so the bride approached the Sharia council a year later to dissolve the marriage. The husband agreed to the procedure as long as the wife agreed to return the jewelry he had given her, as well as the portion of the dower he had paid her. The wife denied she had been paid any dower. The council subsequently dissolved the marriage in December 2004, with its records showing that the decision contained no stipulations concerning jewellry or dower (Bowen 2009). The husband's father, Mr Uddin, decided to pursue the case in the civil courts, and claimed that the bride was obliged to return the gifts and jewellery worth over $£ 25,000$. The wife filed a counter-claim in court that she was owed the $£ 15,000$ of dower stipulated in the marriage contract.

The court decided to appoint Faizul Aqtab Siddique, founder and chief judge of the Muslim Arbitration Tribunal, as the expert witness on Islamic law. This is a sign of the prestige which Siddique's arbitration tribunal enjoyed very soon after its formation in English legal circles. Siddique advised the judge that the gifts were not owed back to the groom's family according to Islamic law as they were not part of the dower. Moreover, he advised that the bride was due the dower in full because the marriage had not been consummated and this was not due to the refusal of the wife. The judge acted on Siddique's testimony, finding that the gifts need not be returned and that the dower was owed to the wife. On appeal, Lord Justice Mummery affirmed the ruling decided at first instance, stating that the marriage was "validly dissolved by decree of the Islamic Shariah Council" and thus activated the obligation of the husband to pay his wife the financial gifts which had been stipulated in the Islamic marriage contract:

On this point it seems to me that, on the basis of the evidence given by Mr Saddiqui [sic] and the findings of fact by the judge, it was a valid marriage under Sharia law and that it was then validly dissolved by decree of the Islamic Sharia council. This was not a matter of English law. There was no ceremony which was recognised[sic] by English law, but it was a valid ceremony so far as the parties were agreed and it was valid for the purposes of giving legal effect to the agreement which had been made about gifts and dower ... Looking to the evidence of Mr Saddiqui [sic] as summarised[sic] by the judge in his judgment, it is not correct to say, as Mr Uddin does, that those gifts should be deducted from the dower or that there is no legal right to enforce the dower in the circumstances in which this marriage was dissolved. As a matter of contract, arising out of the agreement which the parties had made,

15 Uddin v Choudhury [2009] EWCA Civ 1205. 
I think that the judge was entitled in law to say that this was an enforceable agreement, and therefore he was right to grant judgment on the counterclaim. ${ }^{16}$

Mummery LJ's reasoning closely follows that of Justice Winn in Shahnaz v Rizwan, who decided to treat the Islamic dower as a proprietary right for the purposes of contract law, stating that "under Mohammedan law such right to dower, once it had accrued as payable, was enforceable by civil action and was regarded as an assignable proprietary right." 17 Uddin v Choudhury is a landmark case in relation to the decisions of Shariah tribunals. It confirms that English judges are willing to recognize an Islamic decree of divorce issued by a Shariah tribunal as having legal effect for the purposes of contract law. This is a significant judgement as it opens the doors for Muslim women who use Sharia tribunals to have their financial disputes resolved by the English courts despite not legally registering their marriages. Indeed, in Uddin the court was ruling between two litigants who were not married in the eyes of English law, but were simply partners to a financial contract. The case also highlights the important role which Shariah Tribunal judges have the capacity to play in English cases as expert witnesses. In this case the evidence given by Siddique was instrumental in the final decision delivered by the judge.

\section{Spiritual Reform through Private Dispute-Resolution}

Alongside its use of arbitration, another distinctive feature of the services offered by the Muslim Arbitration Tribunal is their spiritual and pastoral dimension. Bowen cites several cases in which he witnessed Siddique infuse the dispute-resolution process with both spiritual and legal advice. He quotes in this regard one of the clients who eventually decided to join Siddique's Hijaz community as stating:

Shaykh Siddique then gave us guidance, business and investment advice, but also said 'if you run the business only for profit where then is the spiritual benefit?' He asked us to give back to the community. He asked us to serve as role models for young people working in Hijaz community (Bowen 2013).

Bowen also noted how Siddique and his colleagues would insist on helping their clients in resolving all aspects of their case, by actively offering pastoral and logistical support (Bowen 2013). This combination between legal, spiritual and pastoral support succeeded in helping to resolve the disputes between the clients involved, and also led to clients joining the Hijaz spiritual community thereafter.

Siddique's insistence as an Islamic judge on incorporating spiritual and pastoral elements within the legal process may be compared to the attitude of judges working in other religious tribunals in Britain. When a priest at a Catholic tribunal was asked by researchers what personal qualities were necessary for him to fulfil his job, he answered:

An ability to blend the two concepts of the judicial and the pastoral because it is an important role within the Church but one has to remember that one cannot, as a religious minister, it's really swimming against the tide by being a purely judicial figure. We can't simply make religion into a system of laws and rules and regulations, Christ himself was very clear about that and he criticised[sic] the Pharisees and the Scribes and the lawyers of his day for doing that. So what one doesn't want to do is to fall into the trap of becoming locked in a legal mindset, you have to have a legal mindset or the ability to adapt to working within judicial structures and disciplines but at the same time you have to retain a pastoral sensitivity and remember that you are also, in your role as a church lawyer, you are trying to help people and you are trying to help people to re-build their lives spiritually speaking and also emotionally

16 Uddin v Choudhury [2009] EWCA Civ, 11, 13.

17 Shahnaz v Rizwan [1965] 1 Q.B. 390. 
and socially after the trauma of the breakdown of a marriage relationship so it requires a certain ability to blend those two skills and to remember that you are a lawyer but you are still a priest and a priest first and foremost (Douglas et al. 2011, p. 23).

This interesting parallel between an Islamic judge working at a Shariah tribunal and a Christian judge working at a Catholic tribunal illustrates the characteristic religious nature of the authority which such institutions harness, and which distinguishes them as a grouping from the secular courts of the state. Indeed, the spiritual and pastoral dimension of the Muslim Arbitration Tribunanl's work, which can also be found in the work of other Shariah tribunals albeit to an arguably lesser extent, has led a number of academic commentators to depict Shariah tribunals as religious and spiritual institutions rather than as purely juridical institutions (Bano 2012; Bowen 2013; Billaud 2013). This unique fusion of legal and spiritual leadership arguably makes Shariah tribunals in some cases enjoy more influence and authority over the communities which they guide than the secular courts of the state.

\section{Conclusions}

This paper set out to critically analyze the multi-faceted nature of the authority and leadership which Shariah tribunals enjoy as British religious tribunals functioning within the contours of the modern English legal system. A number of important themes arose in the course of this analysis in each of the four main sections. An exploration of the socio-historical origins which led to the formation of Shariah tribunals revealed how classical manuals of Islamic law represented the source from which the religious jurisdiction of British Shariah tribunals as quasi-judicial institutions in a non-Muslim land sprang. Within this exploration, the precedent established by Shariah tribunals formed under colonial rule aptly represented the sociological challenges involved in translating this doctrinal guidance into reality within the complex paradigm of human life, engaging as it did a salient partnership between multiple schools of Islamic law and colonial legislation. Next, an examination of the role which Shariah tribunals play in issuing religious verdicts and fusing their dispute-resolution services with pastoral and spiritual elements highlighted the distinctive religious nature in which the authority and leadership of such tribunals manifested itself within the Muslim community which they were formed to serve. Finally, an assessment of how Shariah tribunals have engaged with the state legal system underlined the dynamic ways in which religious and secular law interact with one another and the pragmatic need for religious institutions to engage with secular authority. These themes coalesce together to paint a thought-provoking picture of the distinctive characteristics which Shariah tribunals enjoy as quasi-judicial institutions offering religious guidance to the British Muslim community. Both the doctrinal origins which inspired the rise of the tribunals and the far-reaching impact which their services yield by virtue of the religious elements inherent within them epitomize the powerful role which religion plays in enhancing the authority exercised by religious tribunals. The attempts of Shariah tribunals to constructively engage with the state legal system likewise show how the services offered by religious tribunals have the potential to positively complement those offered by the state courts, thereby augmenting the legal system as a whole.

Funding: This research received no external funding.

Conflicts of Interest: The author declares no conflict of interest.

\section{References}

Abdullah, Raihanah. 1997. Reasons to Dissolve a Marriage through Fasakh. Syariah Journal 1: 1-13.

Abu Ya'laa, Mohammad. 2000. Al-Ahkaam Al-Sultaniyyah. Beirut: Dar Al-Kutub Al-Ilmiyah.

Al-Astewani, Amin. 2016a. Submission of Written Evidence to the Home Affairs Select Committee Shariah Councils Inquiry. Commissioned Report. London: House of Commons Home Affairs Select Committee.

Al-Astewani, Amin. 2016b. Shariah Tribunals in Britain: A Law in Context Study of Their Role as Religious Institutions Which Serve the Needs of the British Muslim Community. Ph.D. dissertation, University of Manchester, Manchester, UK. 
Al-Astewani, Amin. 2017. Reflections on the Rise and Fall of the Arbitration and Mediation Services (Equality) Bill. Public Law 4: 544-52.

Al-Astewani, Amin. 2019a. The Legal Framework for Regulating Shariah Councils in the UK A Potential Model for Ireland? In Minority Religions under Irish Law. Edited by Kathryn O'Sullivan. Leiden: Brill, pp. 193-216.

Al-Astewani, Amin. 2019b. English responses to Shariah tribunals: A critical assessment of populist attitudes toward Islamic Law. Critical Policy Studies 1-21. [CrossRef]

Al-Khassaf, Ahmad. 2004. Adab-Al-Qadi-Islamic Legal and Judicial System. London: Adam Publishers.

Bano, Samia. 2004. Complexity, Difference and "Muslim Personal Law": Rethinking the Relationship between Shariah Councils and South Asian Muslim Women in Britain. Ph.D. dissertation, University of Warwick, Warwick, UK.

Bano, Samia. 2012. An Exploratory Study of Shariah Councils in England with Respect to Family Law. Ministry of Justice Commissioned Project. Reading: University of Reading.

Billaud, Julie. 2013. Ethics and Affects in British Sharia Councils: "A Simple Way of Getting to Paradise". In Islam and Public Controversy in Europe. Edited by Nilufer Gole. London: Ashgate, pp. 159-72.

Bowen, John. 2009. How could English courts recognize Shariah. University of St Thomas Law Journal 7: 411-36.

Bowen, John. 2013. Sanctity and Shariah: Two Islamic Modes of Resolving Disputes in Todays England. In Religion in Disputes: Pervasiveness of Religious Normativity in Disputing Process. Edited by Franz von Benda. London: Palgrave Macmillan, pp. 129-30.

Bowen, John. 2016. On British Islam: Religion, Law, and Everyday Practice in Shari'a Councils. Princeton: Princeton University Press.

Brechin, Jessie. 2013. A study of the use of Sharia law in religious arbitration in the United Kingdom and the concerns that this raises for human rights. Ecclesiastical Law Journal 15: 293-315. [CrossRef]

Bunt, Gary. 2003. Islam in the Digital Age: E-jihad, Online Fatwas and Cyber Islamic Environments. London: Pluto Press.

Carroll, Lucy. 1997. Muslim women and 'Islamic divorce'in England. Journal of Muslim Minority Affairs 17: 97-115. [CrossRef]

D'Auria, Eithne. 2014. The Use of Experts in the Roman Catholic Church with Particular Reference to Marriage Cases. Ph.D. dissertation, Cardiff University, Cardiff, UK.

Davids, Nuraan. 2015. Islam and multiculturalism in Europe: An exposition of a dialectical encounter. American Journal of Islamic Social Sciences 32: 31-50.

Douglas, Gillian. 2015. Who regulates marriage? The case of religious marriage and divorce. In Religion and Legal Pluralism. Edited by Russell Sandberg. London: Routledge, pp. 53-67.

Douglas, Doe, Norman Doe, Sophie Gilliat-Ray, Russell Sandberg, and Asma Khan. 2011. Social Cohesion and Civil Law: Marriage, Divorce and Religious Courts. Report of a Research Study Funded by the AHRC. Cardiff: Cardiff University.

Grillo, Ralph. 2015. Muslim Families, Politics and the Law: A Legal Industry in Multicultural Britain. London: Routledge. Ibn-Abidin, Mohammad. 1992. Radd Al-Muhtaar 'Alaa Al-Darr Al-Mukhtar. Beirut: Dar Al-Kutub Al-Ilmiyah.

Khan, Fareeha. 2008. Traditionalist Approaches to Shariah Reform: Mawlana Ashraf 'Ali Thanawi's Fatwa on Women's Right to Divorce. Ph.D. dissertation, University of Michigan, Ann Arbor, MI, USA.

King, Michael. 1995. God's Law Versus State Law: The Construction of an Islamic Identity in Western Europe. London: Grey Seal.

Kugle, Scott. 2001. Framed, blamed and renamed: The recasting of Islamic jurisprudence in colonial South Asia. Modern Asian Studies 35: 257-313. [CrossRef]

MacEoin, Denis. 2009. Sharia Law or One Law for All? London: Civitas.

Malik, Maleiha. 2012. Minority Legal Orders in the UK: Minorities, Pluralism and the Law. London: British Academy.

Masud, Muhammad. 1996. Apostasy and judicial separation in British India. In Islamic Legal Interpretation: Muftis and Their Fatwas. Edited by Muhammad Khalid Masud, Brinkley Messick and David Powers. Massachusetts: Harvard University Press, pp. 193-203.

McGoldrick, Dominick. 2009. Accommodating Muslims in Europe: From adopting Sharia law to religiously based opt outs from generally applicable laws. Human Rights Law Review 9: 603-45. [CrossRef]

Mullally, Siobhan. 2004. Feminism and multicultural dilemmas in India: Revisiting the Shah Bano case. Oxford Journal of Legal Studies 24: 671-92. [CrossRef]

Nadwi, Akram. 2011. Abu Hanifah: His Life, Legal Method \& Legacy. Leicester: Kube Publishing. 
Reiss, Maria. 2009. The Materialization of Legal Pluralism in Britain: Why Shari'a Council Decisions Should Be Non-Binding. Arizona Journal of International and Comparative Law 26: 739-79.

Williams, Rowan. 2008. Civil and religious law in England: A religious perspective. Ecclesiastical Law Journal 10: 262-82. [CrossRef]

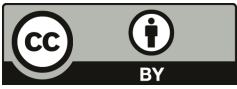

(C) 2019 by the author. Licensee MDPI, Basel, Switzerland. This article is an open access article distributed under the terms and conditions of the Creative Commons Attribution (CC BY) license (http://creativecommons.org/licenses/by/4.0/). 

Article

\title{
Women in Britain's First Muslim Mosques: Hidden from History, but Not Without Influence
}

\author{
Sariya Cheruvallil-Contractor \\ Centre for Trust, Peace and Social Relations, Coventry University, Coventry CV1 2TL, UK; ac0967@coventry.ac.uk
}

Received: 30 November 2019; Accepted: 26 January 2020; Published: 28 January 2020

\begin{abstract}
Two of the earliest Muslim communities in Britain evolved around the first mosques in Liverpool and Woking (both-1889). The history of these early British Muslims is being recovered but little is known about the women (usually converts) in these communities. This article will draw upon original findings from archival research, to examine 'leadership' that women in these communities undertook and their influence in shaping their nascent British Muslim communities. The practical, theological and philosophical negotiations around gender roles, female leadership, and veiling and the social contexts within which they took place are examined. By uncovering historical responses to issues that remain topical in British Muslim communities, this article provides historical grounding for contemporary debates about female Muslim leadership in British Muslim communities.
\end{abstract}

Keywords: Muslim women; leadership; British Muslim history; feminism; feminist history; British Islam; British Muslim studies; mosques

\section{Introduction: Women in Britain's First Mosques}

This article uses archival material linked to the two earliest British Muslim mosques, to examine the everyday lives of women in these historical communities and relates these insights to contemporary concerns about gender roles in Islam.

The earliest Muslim communities in Britain evolved around the first mosques in Liverpool and Woking (both-1889). Muslim communities also emerged in the ports of Liverpool, Cardiff, East London and South Shields where c. 1836 onwards communities of 'lascar' sailors settled. In the Liverpool and Woking communities, women were usually middle-class converts, who encountered Islam through travel, mosque publications or public lectures. In port communities, working-class women converted to Islam to marry Muslim sailors. These conversions often took place in social contexts that viewed Islam and Muslims with suspicion and ridicule (Gilham 2014; Ansari 2004). The histories of early British Muslim communities are being recovered (Ansari 2004, 2011; Geaves 2010; Gilham 2014; Halliday 1992; Lawless 1995; Seddon 2014), but prior to my research extremely little was known about the roles and lives of women in these communities.

Focusing on the first two mosques, this article begins to fill this gap and draws upon original findings from archival research, to examine the lives, roles and social influence of women in these two communities. Women's practical, theological and philosophical negotiations around gender roles, female leadership, modesty and inter-religious relations are contextualized within the historical, social and cultural milieus that these women inhabited.

This article explores the lives of women who lived in social and cultural contexts that were different from contemporary British Muslim communities. They were white and generally middle class, whereas the majority of Muslim women in Britain today are of South Asian heritage, with working-class backgrounds. These differences mean that any comparisons between the historical and the contemporary will at best have significant limitations and at worst be inaccurate. Rather than compare different women, this article uncovers the lives and stories of the historical women, so that contemporary Muslim women and contemporary society, as a whole, may know and recognize them. 


\section{Research Methods: Making Manifest whom History Hides}

A feminist history approach underpins this research that reinstates Muslim women as actors, storytellers and story makers who have shaped the history of what is often described as 'British Islam' (Jones 2013; Jawad 2011; Poole 2002). Feminist history approaches make women visible where they have been hidden within history (Purvis 1992). 'Women's historians, like all other historians, are inescapably dependent on their sources' (Offen et al. 1991, p. xxvi). In its aim to uncover Muslim women's stories, this research necessitated a systematic analysis of writings by, about or for Muslim women written during the period 1890 to 1948 . With the support of a research assistant, I examined and analyzed three sets of archives:

- the Woking Mission archives: available at http://www.wokingmuslim.org/: These Woking Mission archives are now mostly online. It includes photographs, short pathe videos, coverage in the Times newspaper to matters relating to the Woking Muslim community, the guest book of the mosque and, significantly for this research, it contains a nearly complete archive of the Islamic Review and Muslim India—a journal produced by the mosque and which was in print from 1913 to 1971 . This research only covers the period up to 1948

- the Liverpool Muslim Institute (LMI) archive: available at the Islamic Foundation Library, Leicestershire: This includes a nearly complete collection of the Crescent-a journal and newsletter that includes brief commentary of everyday life at the Liverpool Muslim Institute including reports of marriages, deaths and celebrations at the LMI. The Crescent was invaluable in uncovering evidence of Muslim women's roles and lives at LMI. This archive also includes a nearly complete collection of The Islamic World, which describes itself as "a monthly record of Islam around the globe" and which was edited by the president of the Liverpool Muslim Institute, W.H. Abdullah Quilliam

- Private papers of Evelyn 'Zainab' Cobbold (1867-1963): These are now held in London at the Westminster flat of her great-grandson Angus Sladen. These contain personal letters and other correspondence, artefacts from her life and early editions of her books including the book she wrote on the Hajj or her pilgrimage to Mecca.

- Material linked to wider British Muslim contexts including those related to the London Mosque Fund and East London Mosque Trust Ltd (Ansari 2011) were examined. Publications on the history of British Muslim communities, Lascar sailors and related subjects were identified via academic search engines.

A feminist approach is not without limitations and critique, yet for this research, it provides an analytical framework to re-read and re-interpret archival sources to uncover the roles Muslim women played in these communities. The archival materials that I used have been examined many times, yet women's stories remained largely untold as mainstream historians largely concentrate on male lives, experiences and achievements (Purvis 1992). Guided by June Purvis' formative work on feminist history this research on uncovering Muslim women's histories in Britain involves:

“... challenging stereotypical representation of women mainly as wives and mothers [ ... ] and presenting women as actors in their own right; questioning the concepts and analyses offered in malestream historical works [ ... ] that are mainly based on lives of men [ ... ]; exploring the power relationships between the sexes whereby women are oppressed and subordinated to men; and lastly, finding the hidden subjective voices and experiences of women so that their own words can speak to us, even though they may be mediated through the discourses of the day." (Purvis 1992, p. 274)

Through my analysis, I was able to piece together a coherent and compelling narrative of women's lives, contributions and fields of influence within these nascent British Muslim communities. My research is not without gaps. As detailed in the discussion that follows, I would often find an impressive female personality for the trail to then 'go cold'. Some sources simply do not exist and 
where they exist women's voices are often subverted by cultural patriarchies of their time. There are also limitations related to the nature of the content of the archives. Both the journals-'The Islamic and Muslim India' and the 'Islamic Review' - were outward-facing publications, which included discussions about Islam aimed at both Muslim and non-Muslim audiences. Both these contain articles relevant to women, for example around women's rights, women's social roles, marriage, etc. However, other than poetry by women and proclamations by women of accepting Islam, these publications are largely devoid of narratives from everyday life and, therefore, give a sense of how Muslims at the time wanted to represent themselves rather than how they lived. The Crescent however to a certain extent fills this gap by providing a vivid narrative of day-to-day activities within the Liverpool Muslim Institute, including minutes of meetings and records of who attended celebrations and/or prayers at the mosque. Here too there are gaps. For example, there is mention of a 'ladies committee' within the Mosque that met regularly - unfortunately, and rather frustratingly, there is extremely limited evidence relating to the activities of this committee. There is an ongoing need for further research, in the meantime, this article provides glimpses into these women's lives that were shaped both by their Muslim beliefs and their Victorian British sensibilities.

In the presentation of women's lives that follows, I use excerpts from women's and men's writing from that era. For authenticity and to give a sense of the prevailing social milieus, I do not correct grammar or spelling in their writing even where the words that are used appear incorrect or even mildly offensive to modern eyes. So, for example where historical personalities have used 'Moslem' or 'Mahommedan' instead of 'Muslim', I retain their usage. Similarly, I retain a 'ladies committee' and do not change it to 'women's committee'. I refer to the women using the titles that were used to refer to them during their lifetimes, for example, 'Lady' Cobbold, 'Mrs' Keep and 'Madame' Viele.

\section{Women's Everyday Lives}

Both the Liverpool and Woking archives, and the Crescent, in particular, give valuable insights into the everyday lives of the women in the mosque communities. At both sites, women were included in different ways. They were part of prayers, Eid celebrations, debates and other events. This is obvious from Eid celebration photos and videos from Woking and from lists of attendees at the Eid celebrations in Liverpool (as regularly noted in the Crescent). In the photos of the Woking Eid celebrations, women were at the back (see Figure 1); however, there was no physical separation between men and women (which is the norm in most contemporary British mosques), as also noted by Geaves (2010) and Gilham (2014). The photographs also show that a few women and men sat at the back and did not participate in the prayers. This could be because they were not Muslim but were guests who came to observe the prayer and subsequent celebrations. There is a possibility that some of these women may have been in a state of ritual impurity, however, that they are accompanied by men who also did not participate in the prayer suggests that it is more likely that they were guests. 


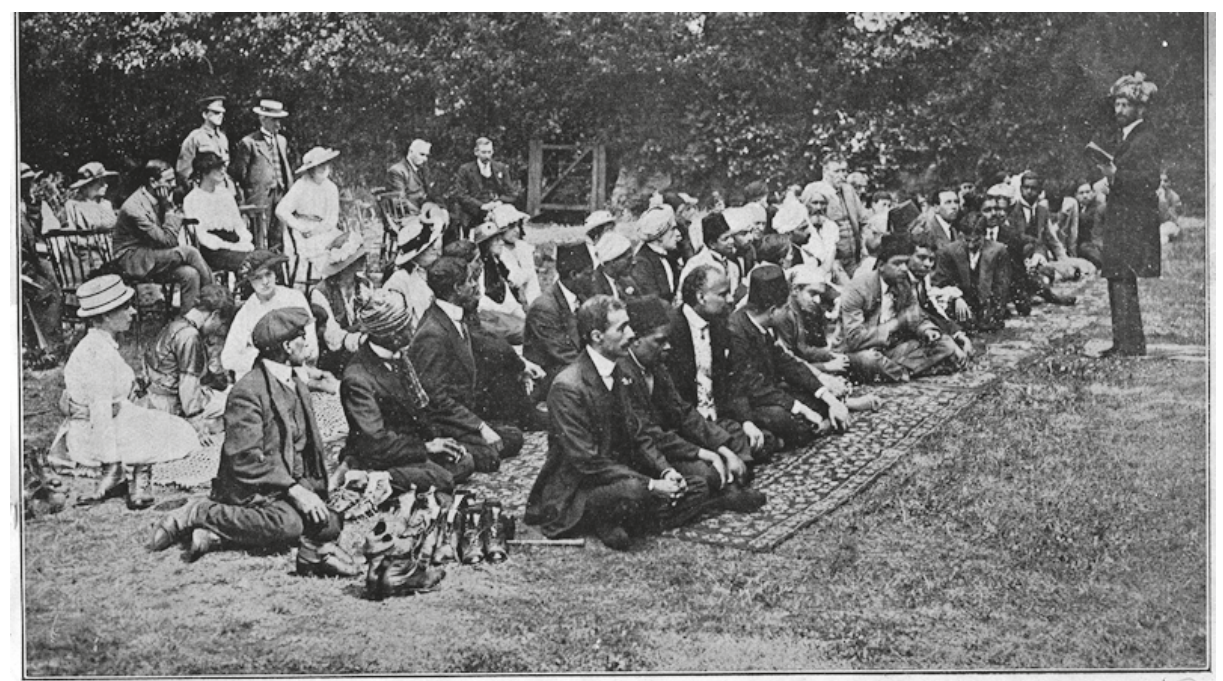

Brotherhood LISTENING to tHE SERMON OF THE IMAM.

Figure 1. This is a photograph of an Eid prayer from the Woking Mosque sometime between 1914 and 1916. Women are clearly visible both as members of the congregation and as observers. Image courtesy www.wokingmuslim.org.

The Crescent also notes that women attended the Annual General Meetings of the mosque. As discussed later in this article women had roles in mosque-leadership. Lady Fatima Cates, an early convert to Islam, was re-elected many times as the treasurer of the Liverpool Muslim Institute. Mrs Nafisa Keep represented the Liverpool Muslim Institute in external social and political events. I examine both women's lives in more detail later in this article. As noted previously there was also a 'ladies committee', although I have found only limited evidence of its activities.

When the Medina Home for Children was established in Liverpool in January 1897, although men were on its committee, women-led the day-to-day management. The first honorary secretary of the home was Miss Emily Mackay. Women managed the everyday running of the home and collected donations for the children. They organized a weekly sewing circle during which they mended the clothes that were donated for the children. In 1898 when the home was struggling for finance, the ladies committee led a fundraising appeal. The edition of the Crescent dated 30 November 1898, included a plea for funds aimed at the Crescent's international readership that was written by the women of the Liverpool Muslim Institute. This publication demonstrates these women's agency and their commitment to the home. It begins,

"The Ladies' Committee of the Medina Home find it necessary to make an appeal to their brothers and sisters abroad for financial aid in order to enhance the value of the Institution, the objects of which are to afford shelter, sustenance and education to friendless and destitute children, orphans and otherwise, who oft-times are left to the mercy of a cruel and pitiless world."

Women wrote for the Crescent, for the Islamic World (the two Liverpool-based publications) and for the Islamic Review and Muslim World (the Woking-based publication). Women like Mrs Nafeesa Keep and Madame Terese Viele wrote about religion, political affairs and personal moral life — subjects that were usually reserved for men. Women regularly wrote travelogues—most notably Abdullah Qulliam's mother Harriet Khadijah Quilliam-Holehouse who wrote a series in the first volume of the Islamic World (1893) entitled 'From Liverpool to the Black Sea'. The publications also include articles by 
women who were not Muslim but who provided sympathetic accounts of Islam, Muslim life in Britain and abroad. Women also regularly wrote poetry.

The Crescent and the Islamic Review regularly made note of a number of women (and men) converting to Islam and the Islamic Review includes statements from women (and men) detailing why they chose to convert. There are records of marriages between members of the mosques including mixed-race marriages usually between white female British converts and wealthy Indian and Middle-Eastern men. The Crescent celebrated women's achievement including those who had no connection to their community. For example, in January 1895 it notes that Mrs Zubeida Ali Akbar had the honour of being presented to the Queen and on 20th March 1895 it notes that Miss Teyba Bilgrami, "a young Mahommedan lady of Hyderabad" has passed the first exam in the Arts at Madras University. Notes like these are found at regular intervals throughout the Crescent. So initial explorations suggest that the first two mosques had an egalitarian ethos at least in relation to including women within the mosque space. Yet as we shall discuss later in this article, they marginalized women in other ways.

The two first British mosques included women in leadership roles as well as in everyday mosque life. In contemporary times, the inclusion of women in the mosque activities and management remains a contested issue (Nyhagen 2019). Although women in Europe are increasing their participation in mosques (Gilliat-Ray 2010; Shannahan 2014), they are often either barred from mosques or relegated to back rooms (Shannahan 2014). Despite initiatives aimed at including women (for example the Muslim Council of Britain's programme on women's leadership in mosques-https: //mcb.org.uk/project/women-in-mosques-development-programme/), mosque leadership and mosque spaces remain overwhelmingly male (Gilliat-Ray 2010). Yet this must be understood in the context of the very different cultural and social contexts within which historical and contemporary Muslim communities, and their mosques, are located. Due to patterns of migration in the 1960s and 70s, contemporary British mosques are culturally situated in Islamic traditions from the Indian subcontinent and to a lesser extent from the Middle-East. In the Indian subcontinent, economic considerations have fused with cultural patriarchies to create a religious narrative that limits women's access to the mosque. When Muslims from the Indian subcontinent came to Britain, they bought with them their culture and their religious traditions (Scott-Baumann and Cheruvallil-Contractor 2015). According to a report published in 2017, 28\% of mosques in Britain do not offer facilities for women, and up to $50 \%$ of all South Asian-run mosques do not accommodate them (MuslimsinBritain 2017).

These Muslim communities of the 1890s that we examine in this article were largely white British communities consisting of middle-class converts who had fairly recently accepted Islam. These communities were also significantly smaller. There were 'foreign gentlemen'-Middle Eastern and South Asian-members of the congregation but they were in a minority and as sailors or travellers, their presence was largely transient. In accounting for their British cultural preferences, these British Muslims were able to find common ground between their Islamic and British values and practices. For example, there was a piano in the mosque that was regularly played at events (music is often banned in contemporary mosques or only instruments that are not string-based or wind are used). Every year the Liverpool Mosque organized a Christmas Breakfast for the poor and destitute of Liverpool, which included free food and entertainment. And the women who attended both the Liverpool Mosque and the Woking Mosque did not usually wear headscarves, but 'dressed as ordinary Englishwomen' (Gilham 2014, p. 95) (please see also Figure 2). 


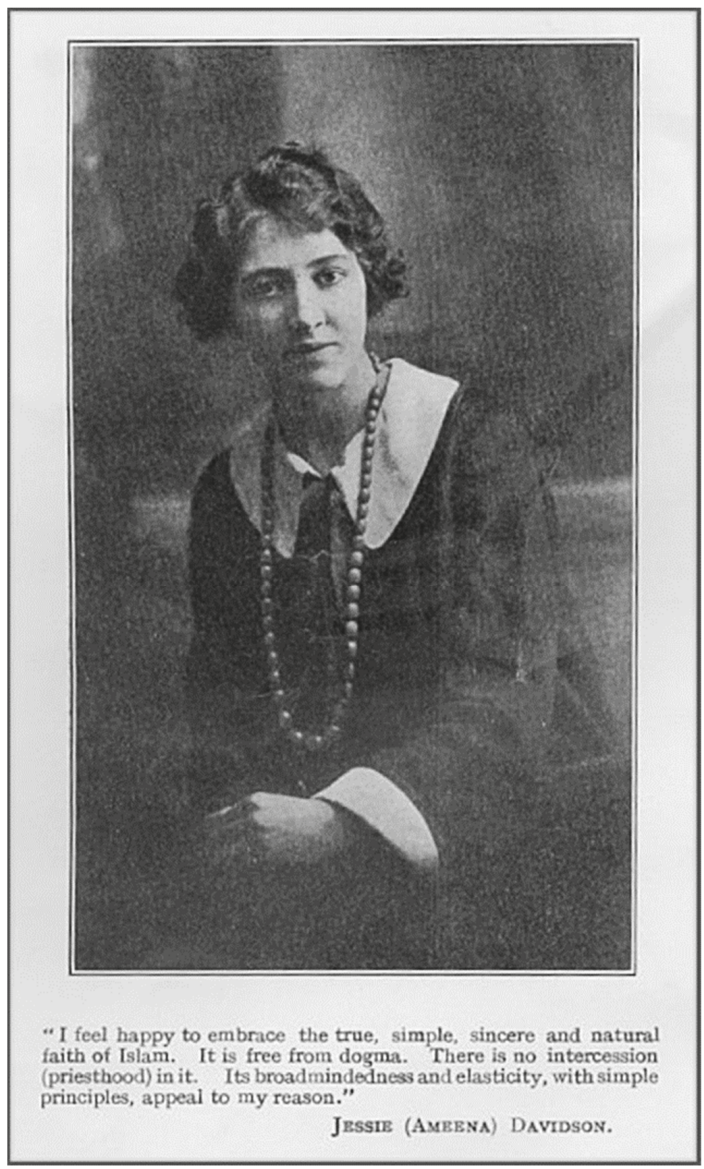

Figure 2. This is a photograph of Jessie Ameena Davidson. Image courtesy www.wokingmuslim.org.

Again bearing in mind their differing social contexts, debates around the women's attire did not take place in the way that they do among contemporary British Muslim communities within which head scarfs, face veils and modest clothing are vested with both religious as well as political meaning (Cheruvallil-Contractor 2012). Women did occasionally wear hijabs and veils, but this was more out of respect for visiting foreign dignitaries than out of religious conviction, as the vignette below demonstrates.

In 1895 Shehzada (Crown Prince) Nasrullah Khan of Afghanistan visited England to pay respects to the Queen. As many Muslim rulers at the time did, after visiting the Queen he came to the Liverpool Muslim Institute. This was a big event for all the people of Liverpool who came out in their droves to see the 'foreign prince' and especially so for Liverpool's Muslims who formed the reception committee. The Mayor consulted with Abdullah Quilliam and they decided that as a mark of respect towards the Shehzada, the Muslim men would wear fezes (a Turkish cylindrical felt hat, usually red) and Middle Eastern-style robes and the women would veil themselves. Mrs Nafeesa Keep wrote about this event in the Crescent, dated 10 July 1895. She writes that when she spoke to them, she detected a sense among the Liverpool people who had gathered that the Muslim women would be heavily veiled. She continues: 
"Much good natured chaff was mingled with the forgoing comment [that the Muslim women would be heavily veiled], meanwhile, we reached the carriage that had been set apart for the ladies dressing-room. Here we ladies rearranged our veils, but we were not shrouded as the spectators had evidently surmised we should have been; white tulle crossed the brow and covered the head, then the fleecy folds were drawn over the lower part of the face, quite concealing the features but leaving the eyes uncovered. The little girls wore white tulle veils over their faces and retained their picturesque hats.

[... ] Several of the spectators who have observed our entrance awaited our regress, and were profuse in exclamations of astonishment at the manner in which the Mohammedans had behaved. I asked, "How did you expect us to behave?" "Well, we thought you'd all rush to the carriage and kiss the Prince's hands and __" I let their hesitation subside, when I replied that we are not altogether devoid of common sense and have besides some little knowledge of the amenities of Society, with a great big "S". Several of the interlocutors called to my attention to the newspaper reports of the manner in which the Shahzada had viewed the low-cut gowns of the London ladies: these persons wished to know if our veils were a concession to the Shahzada's prejudices. I told them we wore veils because we were Muslims and that Shaikh Quilliam had consulted with the Lord Mayor"

For Mrs Keep and the other female Muslims, wearing the veil was something that they recognized as appropriate in respect of the Shehzada's cultural sensibilities but not something that they regularly wore. Yet on this occasion, they also wore veils because they were Muslim. Lady Evelyn Cobbold, who is discussed in detail later in this article, was always dressed in high fashion. For the rituals of her Hajj pilgrimage, she wore a veil that covered her completely, yet when she could not bear the heat she removed it.

Notwithstanding the egalitarian attitudes to mosque access and modesty, there were also delineations in what women could and could not do. Women were nearly always in-charge of refreshments at mosque events including the annual Christmas breakfast that the Liverpool Muslim Institute organized. At the Christmas breakfasts, women also organized the entertainment and played the piano. An example of the exclusion of women is them initially not being included of the Literary and Debating society, this being only for 'young men'. Then in March 1896, for the first time, Rosa Warren gave a talk on the poet Longfellow (The Crescent 8 January 1896). Rosa Warren was a longstanding Muslim member of the congregation and her name is often found among the attendees of the Eid prayer. It is interesting that her talk and indeed those of the very small number of other women who spoke at the debating society never focussed on issues of Islam, religion or even generally on morality, although men regularly spoke about these subjects.

Given the historical nature of this research and our inability to directly access the voices of women like Rosa Warren, it is difficult to gauge why exactly she did not talk about morality or religion. From feminist historical research into women's lives in this era, we know that this could be an expression of Victorian and Edwardian patriarchal attitudes that silenced women in different ways (Purvis 1992). These attitudes gradually seem to change. In his Eid speech in 1899, the chair of the debating society advised, "all our young men and women to join the debating society, they will find its meetings most interesting" (The Crescent, 15 February 1899). It is important also to point out that at this Eid celebration there was no speech by a woman. Furthermore later on that year when Rosa Warren again addressed the Debating Society on the topic 'Dancing-Ancient and Modern', it was described in the Crescent as, "most interesting and certainly the most amusing lecture of the season" (The Crescent, 2 March 1899). Yet it did not receive any further coverage in the Crescent despite a note saying that it would receive more substantial coverage in the following issue and all other lectures in that season being reproduced verbatim.

Articles written by men and often by Abdullah Quilliam himself seems to indicate the convergence of patriarchies that straddled both Muslim attitudes of that time and Victorian attitudes towards 
women and their roles in society. Articles supporting polygamy, for example, indicate women's inferiority from a Muslim perspective. Other articles indicate scepticism of 'the New Woman' who is derided and made fun of. According to the Crescent, the New Woman

"... had studied mathematics [ ... ] knew all about mythology [ ... ] her mind was drilled in science [ ... ] knew all the dates of history [ ... ] Could talk with great loquacity on questions of capacity, but couldn't sew a button on her little brother's pants." (The Crescent, 30 October 1895)

Jokes about women are often made in the Crescent and are illustrative of Victorian attitudes to women and extant tensions around women's changing social roles as a result of their demands for equality (Purvis 1995). There was also a benign form of patriarchy that insisted on protecting and/or idealizing women. This is exemplified in the publicity note for the Medina Home for Children. In looking after children who were 'illegitimate' the 'home' sought to give their mothers a chance to recover their lives in the context of a society in England that 'forgives the man any transgression [ . . but] remembers a woman's slip'(The Crescent, 6 January 1897). Another example of this benign patriarchy is found in an announcement in the Crescent introducing a day school for girls:

"We understand that it is contemplated to still further extend the usefulness of our Institution by arranging for a girls' school to be also commenced, and that a suitable lady has already been engaged. This is also a wise step. Our girls of to-day will in a few years, be the wives and mothers of a future generation. The great Napoleon truly said "Those who rock the cradle, rule the world. " and if the mothers are able to teach their children Moslem prayers and Moslem rules of life, from the first moment that the child is able to lisp a sentence, or understand the difference between right and wrong, then the future of Islam in England is assured. We wish the Institutions, both the boys and the girls schools every success in the future." (The Crescent, 28 January 1893)

The suggestion that the main purpose of women's and girls' education is to educate the next generations mirrors contemporary discussions around women's education in Britain and beyond. Danièle Joly describes how the male scholars she spoke to, considered young women and girls to be the "mothers of tomorrow" who would transmit "a proper Muslim way of life and values to children [of generations] to come" (Joly 1984). Most scholars agree that there is an emphasis within Islamic texts on the 'special status' of mothers (Cheruvallil-Contractor 2016, p.15). In Muslim communities, this translates to an 'over signification' of motherhood (Cheruvallil-Contractor 2016, p.17) which distinctly contrasts with women's desires to be more than 'just mothers' or 'just females' (Liberatore 2019, p. 13).

For Muslim women living in this era, Muslim attitudes of the time and Victorian attitudes converged to marginalise them so that they were excluded from social roles or were often relegated to producing the 'refreshments' and 'entertainment'. Yet in these environs, there were also women who challenged this convergence of patriarchies. The following sections of this article focus on their stories.

\section{Uncovering Significant Female Muslim Personalities}

An example of these significant women is Mrs Nafeesa T Keep, an American convert to Islam, the honorary secretary of the American Islamic Propaganda. After disagreements with Alexander Russell Webb (the controversial leader of this early American Muslim community), she decided to move to Liverpool, arriving here on 14 February 1895. She gave a number of lectures including titles such as "An American Woman's views of Islam", "Women under Islamic Law", "From the Convent to the Mosque: a personal experience'. The Crescent records some of these events in great detail, providing full texts of the talks and in some cases dates too (The Crescent, multiple volumes, February to June 1895). Her lectures demonstrate a confident woman who was not afraid to share her views about Islam and who challenged Western perceptions of her faith. 
"All the privileges which belong to her as a woman and as a wife are secured to her, not by the courtesies that 'come and go', but by the actual text in the book of law [... ] The whole history of Muhammedan legislation is a standing rebuke to those who consider that the position of women under Islamic laws is one of exceptional severity." (Keep 1895)

Mrs Keep nearly always took a stance that defended Islam, but which also insisted on a need to uphold the rights of women as outlined in the foundational Muslim texts. In many ways, Mrs Keep and her campaigning is similar to that of contemporary religious feminist voices emerging from British and Western Muslim communities who seek to strike a similar balance and challenge dichotomies in the representation of women (Cheruvallil-Contractor 2012; Liberatore 2019). Similar to many contemporary European Muslim women, Mrs Keep sought to position herself as an ambassador of her faith (van Es 2019). Mrs Keep continued to live and contribute to the work of the Liverpool Muslim Institute for a few months and she was appointed the assistant superintendent of the Medressah-i-iyyum-al-Sebbah an institution aimed at educating young Muslims on the foundations of their religion (The Crescent, 22 May 1895). In May 1895 she was present at a conference of Muslims held "under the auspices of the London Anjuman-i-Islam" (The Crescent, 22 May 1895). She attended another event organised to "give expression to public sentiment upon the alleged Armenian atrocities" and spoke at this event as a representative of the Liverpool Muslim Institute (The Crescent, 29th May 1895). She also continued to be present for Eid celebrations for a year but after this, no mention of her is found. Singleton notes that she never returned to America (Singleton 2007). It is unfortunate that the Crescent does not contain further information; however, this is an area for further research.

Another significant woman whose stories were uncovered includes Madame Teresa Griffin Viele (1831-1906) who took the Muslim name Sadika Hanoum and wrote for the Islamic World and for the Crescent. She seems to have acted like a news correspondent writing the "Resume of Political Events" in the Islamic World from September 1894 to April 1895. She was planning to translate one of Quilliam's publications into French, although it is not clear if this project was ever completed-that it only ever appeared as 'in press' in the Crescent's advertising pages seems to indicate that it was not completed. In January 1893 the Crescent notes that she was suffering from influenza, although she later recovered. In July 1893 she addressed the World's Congress Auxiliary in Chicago on 'the Women of Turkey'. She too disappears from the pages of the Crescent and the Islamic World and more research is needed to uncover her life.

Other women in this community include Fatima Cates, who was one of the earliest converts, longstanding member and founding treasurer of the Liverpool Muslim Institute. It is significant that a woman was so central to the formation of the Liverpool Muslim Institute and ultimately Britain's first mosque. When considered with the fact that a woman, Begum Shah Jahan of Bhopal (in modern India), funded Britain's first purpose-built mosque in Woking (Lambert-Hurley 2007), this retelling of history puts women at the centre of the establishment of Islam in Britain. It is also unfortunate that the leading roles of both these women have been all but forgotten. The Crescent notes Fatima Cates' death on 27th October 1901 with great sadness:

"Some ten days prior to her demise she contracted a severe cold, and on Wednesday, October 24, was too ill to leave her bedroom. At the time it was not contemplated anything was seriously the matter with her beyond an attack of influenza. [ . . . On the Monday morning, however, acute pneumonia supervened, and at three o'clock the doctor pronounced that there was no hope. Telephonic message was at once sent to the Sheikh-ul-Islam, who proceeded to the house. Sister Cates was perfectly conscious, and expressed to him her wish to be buried as a Muslim, as she would die in the Faith she had embraced, and further desired him to conduct the funeral service over her grave, and to be guardian to her little boy. Half an hour later she expired.

A few moments before she died our sister raised the index finger of her right hand, and slowly, but clearly, repeated the Kaleema in Arabic, then, putting her hand in that of the 
Sheikh, she smiled a sweet smile, and said, 'Good-bye; it is all over,' and without a struggle peacefully yielded up her breath."

There are increasing signs of young British Muslim's interest in these early British communities and their recognition of the significance of the historical contributions of men and women. In memory of Fatima Cates' and as an example of her enduring legacy, a second-generation Islamic scholar set up the Fatima Elizabeth Cates Phrontistery (or institute of learning) in London as an Islamic educational institution: https://www.fatimaelizabethphrontistery.co.uk/.

This section on significant female personalities is incomplete without mention of Lady Evelyn Zainab Cobbold, a high-profile convert from an aristocratic British family. She became one of the first European women to perform the Hajj or pilgrimage to Mecca. Extraordinarily for her time she performed the pilgrimage on her own, in a motor car and then wrote a best-selling book in 1934 about her experiences. Cobbold sought the help of a Saudi theologian in writing the book whose role seems to have been to ensure that the religious facts were correct. Within the book, it is obvious what sections have been written by Cobbold - these are personal and thought-provoking, the sections by the theologian are often formulaic and lacking in personality. Lady Cobbold opens the book with the statement:

"I am often asked when and why I became a Moslem. I can only reply that I do not know the precise moment when the truth of Islam dawned on me. It seems that I have always been a Muslim". (Cobbold [1934] 2009, p. 89)

In writing about her journey to Arafat (one of the stages of the Hajj pilgrimage) Cobbold describes a moment that is humorous yet also underpinned by poignant insight into how she as an aristocratic white British woman perceived her Muslimness and negotiated her identity with other Muslims:

"I had brought an English book with me on my pilgrimage, knowing our progress must be slow in that great procession. The book was Passages from Arabia Deserta by that mighty traveler Doughty, and during a stop I opened it and from under my veil I was soon absorbed in reading, when a voice from a neighboring car asked: "Is that an Arabic book? Suleiman [her driver and guide] answered quickly that of course it was Arabic, and whispered to me to close the book, which I refused to do. Again the voice spoke: "Can you swear by all we hold holy, is it Arabic and a book for the Moslems?" Before the alarmed Suleiman could answer I turned and held the book out to the anxious enquirer saying: "This is an English book and I am an English Moslem and I am here on pilgrimage by permission of the King." After a few seconds of astonished silence he returned the book to me saying "Alhamdullilah!" (Praise be to God)" (Cobbold [1934] 2009, p. 245)

The above narrative from Cobbold demonstrates her sense of identity as an English Muslim woman. She is not alarmed by the enquirer, instead, she describes him as anxious. The intersectional aspects of her identity come into play as she co-opts authority through her own aristocratic heritage and through her networks, most notably the Saudi King!

In their own different ways, these women took on roles of leadership and representation. They negotiated their representativeness at different levels within the social hierarchies that they inhabited. Madame Viele represented her way of believing and practising Islam to global audiences at the World Congress in Chicago. Mrs Keep built local bridges with her neighbours in Liverpool, exemplified in her conversations during the Shehzada of Afghanistan's visit. Lady Cobbold translated cultures when she spoke about her positionality to a Muslim, albeit one from a different culture. Lady Cates contributed to the establishment of her mosque and remained until her death a committed member of its community. These vignettes present the briefest of glimpses into these women's lives and the myriad ways in which during their lives they influenced discourses around Islam. It is imperative that these women's stories of leadership, representation and negotiation are included within historical constructs of British Islam so that their contributions are recognized. 


\section{Conclusions}

Women's contributions are consistently forgotten, lost from the annals of history which perhaps then becomes almost exclusively 'his story'. The research that underpins this article attempts to redress this imbalance in the context of British Muslim history. This article answers the questions: who were the women who lived in these communities? What were their roles in society and how can we learn from them? As we are introduced to Britain's first Muslimahs it is important to note that these are a few stories and a lot more research needs to be undertaken to ensure that women's voices are adequately heard in the annals of history.

These women lived in contexts that socially and culturally were extremely different from the contexts that contemporary British Muslims inhabit. Yet these women's lives, their practice of Islam and their negotiations with multiple patriarchies are not dissimilar to the debates around gender in contemporary British societies. By shining a light on the history of Muslim women in Britain we make contemporary issues seem less insurmountable. These women helped shape the Muslim communities of their time and it is imperative that their stories are known.

Funding: This research was funded by the British Academy and Leverhulme Trust small grants scheme (grant number SG151945).

Acknowledgments: A number of academic colleagues shared their expertise with me - in particular, I would like to thank Humayun Ansari, Ron Geaves and Jamie Gilham. Thank you also to Mandeep Sehmi for his invaluable research assistance on the project. I had valuable feedback from two anonymous peer reviewers-thank you for helping me improve this article. This work would have been much more challenging without the support of Mr Abdul Hayy and other librarians at the Islamic Foundation Library —-thank you.

Conflicts of Interest: The author declares no conflict of interest.

\section{References}

\section{Historical Sources}

The Crescent

The Islamic World

The Islamic Review and Muslim India

\section{Secondary Sources}

Ansari, Humayun. 2004. The Infidel Within', Muslims in Britain Since 1800. London: C. Hurst Publishers. Ansari, Humayun. 2011. The Making of the East London Mosque. Cambridge: Cambridge University Press. Cheruvallil-Contractor, Sariya. 2012. Muslim Women in Britain: Demystifying the Muslimah. London: Routledge. Cheruvallil-Contractor, Sariya. 2016. Motherhood as constructed by us: Muslim women's negotiations from a space that is their own. Religion and Gender 6: 9-28. [CrossRef]

Cobbold, Evelyn. 2009. Pilgrimage to Mecca. With Introduction by William Facey and Miranda Taylor, Notes by Ahmad A Turkistani. London: Arabian Publishing. First published 1934.

Geaves, Ron. 2010. Islam in Victorian Britain: The Life and Times of Abdullah Quilliam. Markfield: Kube.

Gilham, Jamie. 2014. Loyal Enemies: British Converts to Islam, 1850-1950. London: C. Hurst Publishers.

Gilliat-Ray, Sophie. 2010. Muslims in Britain. An Introduction. Cambridge: Cambridge University Press.

Halliday, Fred. 1992. Arabs in Exile: Yemeni Migrants in Urban Britain. London: I B Tauris.

Jawad, Haifa. 2011. Towards Building a British Islam: New Muslims' Perspectives. London: Continuum.

Joly, Danièle. 1984. Making a Place for Islam in British Society: Muslims in Birmingham—Research Papers in Ethnic Relations. Available online: http://web.warwick.ac.uk/fac/soc/CRER_RC/publications/pdfs/Research\% 20Papers\%20in\%20Ethnic\%20Relations/RP\%20No.\%204\%20(checked).pdf (accessed on 29 November 2019).

Jones, Stephen H. 2013. New Labour and the Re-making of British Islam: The Case of the Radical Middle Way and the "Reclamation" of the Classical Islamic Tradition. Religions 4: 550-66. [CrossRef]

Keep, Nafeesa. 1895. The Position of Women under Islamic Law. The Islamic World II 23: 342-51.

Lambert-Hurley, Siobhan. 2007. Muslim Women, Reform and Princely Patronage: Nawab Sultan Jahan Begam of Bhopal. London: Routledge. 
Lawless, Richard. 1995. From Ta'izz to Tyneside: Arab Community in the North-east of England in the Early Twentieth Century. Exeter: University of Exeter Press.

Liberatore, Giulia. 2019. Guidance as 'Women's Work': A New Generation of Female Islamic Authorities in Britain. Religions 10: 601. [CrossRef]

MuslimsinBritain. 2017. UK Mosque Statistics/Masjid Statistics. Available online: http://www.muslimsinbritain. org/resources/masjid_report.pdf (accessed on 29 November 2019).

Nyhagen, Line. 2019. Mosques as Gendered Spaces: The Complexity of Women's Compliance with, And Resistance to, Dominant Gender Norms, And the Importance of Male Allies. Religions 10: 321. [CrossRef]

Offen, Karen, Ruth Pierson, and Jane Rendall, eds. 1991. Writing Women's History: International Perspectives. Basingstoke: Macmillan.

Poole, Elizabeth. 2002. Reporting Islam: Reporting Islam: Media Representations of British Muslims. London: I. B. Tauris.

Purvis, June. 1992. Using Primary Sources When Researching Women's History from a Feminist Perspective. Women's History Review 1: 273-306. [CrossRef]

Purvis, June. 1995. From “Women Worthies" to Poststructuralism? Debate and Controversy in Women's History in Britain. In Women's History: Britain, 1850-1945 - An Introduction. Edited by June Purvis. London: Routledge, pp. 1-22.

Scott-Baumann, Alison, and Sariya Cheruvallil-Contractor. 2015. Islamic Education in Britain: New Pluralist Paradigms. London and New York: Bloomsbury Academic.

Seddon, Mohammed S. 2014. The Last of the Lascars: Yemeni Muslims in Britain 1836-2012. Markfield: Kube.

Shannahan, Dervia Sara. 2014. Gender, Inclusivity and UK mosque experiences. Contemporary Islam 8: 1-16. [CrossRef]

Singleton, Brent. D. 2007. Brothers at Odds: Rival Islamic Movements in Late Nineteenth Century New York City. Muslim Minority Affairs 27: 473-86. [CrossRef]

van Es, Margaretha A. 2019. Muslim women as 'ambassadors' of Islam: breaking in everyday life. Identities 26: 375-392. [CrossRef]

(C) 2020 by the author. Licensee MDPI, Basel, Switzerland. This article is an open access article distributed under the terms and conditions of the Creative Commons Attribution (CC BY) license (http://creativecommons.org/licenses/by/4.0/). 
Article

\title{
The Muslim Council of Britain: Progressive Interlocutor or Redundant Gatekeeper?
}

\author{
Harun Khan, Hassan Joudi and Zahraa Ahmed * \\ Muslim Council of Britian, P.O. Box 57330, London E1 2WJ, UK \\ * Correspondence: media@mcb.org.uk
}

Received: 12 February 2020; Accepted: 10 August 2020; Published: 17 September 2020

\begin{abstract}
Since its inception in 1997, the Muslim Council of Britain (MCB) has evolved to become one of the most enduring British Muslim organisations. It is a representative body for over 500 member bodies ('affiliates') including mosques, schools and charities. During the course of the last two decades, it has been subject to external comment and sometimes critique by academics, media commentators, policy-makers, and others. This special issue of the journal Religions has provided a welcome opportunity for the current leadership of the MCB to write about the organisation from 'within', based on their long-standing time volunteering with it. This paper is based on an oral history methodology involving extended interviews with the oversight of a research director, supplemented by reference to existing academic and other sources. Therefore this paper is essentially a type of 'edited transcript' aggregated wholly from a series of first person interviews undertaken with the current senior elected leaders of MCB; reorganised for clarity and drafted out with added 'prose' allowing for it to be presented in essay form. The result is the first documented 'insider' perspective on the ways in which the MCB has tackled issues such as internal governance, the challenge of 'representation' in view of the diversity of British Muslim communities, changing relationships with government, and policy work. It becomes apparent through the paper that the MCB has matured into a constructively self-critical, pro-active, and more strategically professional body, that contributes to the flourishing of Muslim communities and the place of Islam in British society. The production of the paper is itself an indicator of the growing confidence and capacity of the MCB, and its ability to contribute positively to academic discourse and debate about Muslims in Britain.
\end{abstract}

Keywords: British Muslims; faith-based representation; leadership; umbrella organisation; MCB; civil society; political participation

\section{Genesis and Early Evolution of the MCB}

The MCB was inaugurated on 23rd November 1997 at Brent Town Hall in North London at a conference attended by representatives of more than 250 Muslim organisations from all parts of the UK, including Wales, Scotland and Northern Ireland. It was successful in ensuring representation from bodies reflecting a wide range of ethnic and theological backgrounds, and the interests of extant regional associations at the time, such as the Lancashire Council of Mosques and the Federation of Muslim Organisations of Leicestershire. The launch followed a consultation period that had commenced in 1994 which brought various key individuals and organisations together under the working name NICMU (National Interim Committee on Muslim Unity). This body circulated surveys in English as well as community languages, and held meetings with the major national Muslim organisations at the time, such as the Union of Muslim Organisations (UMO), the Muslim Parliament, the UK Action Committee on Islamic Affairs (UKACIA), as well as with influential Muslim activists.

The nationwide survey conducted by NICMU in 1995 concluded "increasingly, co-ordination and unity is now seen as a question of the very survival of the community" (NICMU 1996, p. 3). 
The community's expectations from a 'co-ordinating body' included lobbying, liaison with the media, leadership, and delivery of specific programmes (ibid). The survey also conveyed a feeling that existing national Muslim bodies were not sufficiently broad-based nor with opportunities for electoral changes of leadership. It arrived at the understanding that:

“... various attempts have been made over the years to achieve some measure of coordination with some positive results. But it is probably true to say that these attempts have not kept pace with the rapid growth and rich diversity of the community ..." (ibid)

Academic analysis of the situation at the time argued that other so-called 'representative' bodies, such as the UMO, were "ahead of their time" (Nielsen 2004, p. 49), or insufficiently linked to the schools of thought that predominated in Britain's largely South Asian Muslim communities (Gilliat-Ray 2010, p. 109). Either way, there were powerful internal and external forces at work that served as a catalyst for renewed efforts to find a new 'voice' for Muslims in Britain, shaped by national and international politics.

The final meeting of NICMU took place in Bradford on 25 May 1996, hosted by Bradford Council for Mosques. At this meeting, an outline constitution was agreed and the name 'The Muslim Council of Britain (MCB)' was chosen from seven proposals. Thereafter a preparatory committee was formed to finalise the constitution, invite more organisations to join and make preparations for the formal launch (Bari 2018). The agreed constitution adopted in November 1997 begins with references to Quranic verses relating to unity (3:103), enjoining what is right (3:110) and supporting one another (5:2). A commitment to being independent, cross-sectarian, broad-based and thereby representative were priorities that $\mathrm{MCB}$ 's founding members drafted into its constitution. There were specific references to the MCB being obliged to "base its policies and decisions on consensus and the largest practicable measure of common agreement" and to have in place a "system of representation and accountability"1.

The representative membership model that emerged in the МСB Constitution was based on an analysis of the constitutions of existing regional and national Muslim representative organisations, both in the UK and the US. Moreover, the constitutions of the umbrella bodies of other faiths groups were also examined. In this way, the MCB's foundations can be regarded as organic, grassroots and bottom-up in origin, and based on existing best practice available at the time (Pẹdziwiatr 2007, p. 270).

Next the challenge of finding consensus amid the diverse communities that make up the British Muslim population was never going to be an easy task, and from the outset, the MCB never claimed to be 'the' only representative body. Rather, it sought to work with a range of Muslim civil society organisations. Sometimes this has led to rivalry, but often partnership and/or membership as an MCB 'affiliate'. Other bodies have taken up specialised niches which have come to complement the MCB's principal efforts, becoming part of the MCB 'ecosystem'. The current MCB Secretary-General (and co-author of this paper) was himself present at the 1997 inauguration as a young volunteer steward, and he is clear that the task of providing a representative, uniting and co-ordinating role for British Muslim communities today remains the MCB's core raison d'etre, as it was from its inception.

In addition to the critique levelled at some of the predecessors of the $\mathrm{MCB}$, it is important to appreciate the wider political climate that saw the leaders of various Muslim communities come together in the period 1994-1997. There was a particular convergence of national and international circumstances that created a driver for the creation of a stronger representative national body, from the Satanic Verses affair, to the ongoing war and genocide in Bosnia. The Muslim periodical ' $Q$ News' reported advice given to Muslim activists at the time by the then Home Secretary, Michael Howard, to the effect that they should "speak with one voice should they wish to exercise more influence over government" (McLoughlin 2005, p. 60). Recognition of the need for a strong organisation at a national level was clear, " ... we felt that we needed to organise otherwise nobody is going to listen to us", asserted one of the early MCB Office Bearers.

1 The Muslim Council of Britain, 'MCB Constitution with Amendments Adopted at Fifteenth Annual General Meeting 2012', 2012, www.mcb.org.uk/wp-content/uploads/2016/03/MCB_Constitution_FINAL-2013.pdf. 
Indeed the landscape of British Muslim communities and how they engaged in public life and social activism was beginning to change from the early 1990s. Much of the important groundwork was laid by the UK Action Committee on Islamic Affairs (UKACIA) which was able to tap into the expertise of a new generation of Muslim professionals (McLoughlin 2005). UKACIA produced well-argued documents such as, Muslims and the Law in Multi-faith Britain: Need for Reform (UKACIA 1993), which was a memorandum submitted to the Home Secretary in 1993. In 1997 UKACIA prepared an eleven-page policy document Elections 1997 and British Muslims-For a Fair and Caring Society. The MCB took up this mantle of well-informed engagement in the British political processes by encouraging voter registration, also publishing Electing to Listen: promoting policies for British Muslims in June 2001 (Pędziwiatr 2007, p. 276).

Internationally major geo-political events and foreign policy continued to overshadow the discourse for British Muslims in the MCB's early years, including the Kosovan War 1998-1999, the 9/11 terrorist attacks in the US and the subsequent invasions of Afghanistan and Iraq. However, this period also saw the emergence of Muslim individuals ${ }^{2}$ and community groups aligning themselves with other non-religious and socio-civic organisations that were united with the sole purpose, for example, of preventing the war in Iraq, with protests including British Muslim men, women and children (as seen with the Million People March) ${ }^{3}$. As Elshayyal explains, many young Muslims turned to grassroots community group and joined the Stop the War Coalition to protest against the Iraq War-thus demonstrating a shift away from communal to national alliances based upon shared values and ideas (Elshayyal 2015). This was a significant development in the political 'coming of age' of British Muslims. Anti-war campaigning mobilised many of them to be active alongside non-religious and even secular actors, thus encouraging many to be political outside Muslim organisations. This is echoed by Elshayyal when she observed, many that moderate thinkers during this period not only explained how the Muslim community felt it needed to provide vision and direction to wider society, but essentially the onus lay upon emphasising and increasing civic participation (Elshayyal 2015, p. 178).

Set against this background, the MCB's early leadership emerged fresh with its own plans to develop the organisation internally, albeit buffeted by events abroad and the need to express the strong feeling of Muslim communities on these issues (MCB 2002, p. xvi). These multiple roles included applying pressure on the Prime Minister at the Commonwealth Institute in 1998 during the ongoing conflict in Kosovo, alongside Muslim parliamentarians and the foreign ambassadors of Muslim majority countries. The issues of human rights abuses in Chechnya, Iraq, Palestine and Kashmir were regularly mentioned in various Secretary General speeches addressing the Prime Minister ${ }^{4}$ and the Foreign Secretary ${ }^{5}$.

The wide range of issues that the MCB's early leadership were concerned about is reflected in the Working Committees that were established. Specialists were brought in to advise on International Affairs, Social and Family Affairs, Women, Business and Economics, Media, and Education, to name a few. These specialist committees led to several successful campaigns. For example, working alongside the Association of Muslim Schools, the MCB was successful in campaigning for Muslim faith schools to have equal access to grant-maintained status. This was finally achieved in 1998 with Islamia Primary School in London and Al Furqan Primary School in Birmingham (despite the first applications

2 A high profile example was Salma Yaqoob a Birmingham psychotherapist who was a member of Stop the War Coalition and later Respect Party.

"'Million" March against Iraq War', 16 February 2003, http://news.bbc.co.uk/1/hi/uk/2765041.stm, accessed 4 June 2019.

4 Iqbal Sacranie, 'Secretary General's Address at Reception for Prime Minister', 5 May 1999. http://www.mcbrestore.org.uk/ secretary-generals-address-at-reception-for-prime-minister/ (accessed 8 May 2019).

5 Iqbal Sacranie, 'Welcome Speech by Iqbal Sacranie, Secretary General Muslim Council of Britain, at a Reception in Honour of Mr Peter Hain MP, Minister of State for Foreign Office and Commonwealth Affairs', London, November 1999. https://mcb.org.uk/press-releases/welcome-speech-by-iqbal-sacranie-secretary-general-muslim-council-of-britain-at-areception-in-honour-of-mr-peter-hain-mp-minister-of-state-for-foreign-office-and-commonwealth-affairs-london-4-no (accessed 8 May 2019). 
being submitted to the Department for Education in 1986) ${ }^{6}$. Another successful campaign was the four-year long lobbying efforts by MCB to include a question on religious affiliation in the 2001 Census (Hussain and Sherif 2014, p. 418). This was a seminal milestone that enabled a significantly greater understanding of faith communities in British society, and provided a data-driven evidence base for future policy makers and researchers (Sherif 2011).

Taken together these initiatives demonstrated sophistication in the way British Muslims were now increasingly engaging in public life, lobbying for their interests and shaping public policy in a way that centred on equal—not preferential—treatment alongside other faith minorities. As Sherif explains, not only did this process demonstrate the "creation of alliances and the importance of interfaith action for social action", but "marked the emergence of new and welcome social developments for the 21st Century" (ibid: 16).

\section{Contemporary Developments, Function and Governance}

Representative umbrella bodies exist in several sectors, whether it is the Confederation of Business Industry (CBI) which represents 1500 direct members from a broad cross-section of the UK business community, to Universities UK which describes itself as an advocacy organisation representing 136 universities nationwide. Thus, what umbrella bodies have in common is that their members are organisations-as opposed to individuals. In any sector, the role of a representative and membership-based body is generally to provide three key functions: (a) represent the voice of its members, (b) advocate on issues that matter to its members and (c) capacity building and sharing of best practice between its members.

In many ways, the strengths and weaknesses of the $\mathrm{MCB}$ - as with any other representative body serving a membership base-are reflective of the strength and weakness of British Muslim civil society as a whole. Despite the long history of Muslim settlement in the UK, it is important to recognise that Muslim communities are still developing their infrastructures and capacities.

The structural arrangements of the MCB play a significant role in its governance and in ensuring fair and equal representation. As a democratic umbrella body, the MCB is reliant on its members for direction and guidance-otherwise known as its affiliates. Affiliates have diverse backgrounds and represent various ethnic and sectarian groups. Since its foundation in 1997, the MCB Annual General Meeting organised every year provides an opportunity for delegates from all member organisations to hold the MCB to account for its actions, and to discuss future ideas and events. Every two years, an election is held at the AGM; positions of governance are allocated through an electoral process whereby all present delegates (representing registered affiliates) are entitled to a vote on who should be elected to the National Council (NC) and the posts of Secretary General (SG) and Deputy Secretary General (DSG).

The National Council is comprised of 50 to 60 individuals who represent the current 500 affiliates that constitute the MCB. These individuals are key to holding MCB to account on a quarterly review basis and they come from a range of backgrounds. The SG and DSG are directly elected at election AGMs with the remaining five office bearers nominated by the SG and then put forward for ratification by the NC. All Office Bearers perform their role in a voluntary capacity. These individuals, alongside an Executive Committee who are responsible for the day-to-day governance of the MCB are therefore held to account by the affiliates through this democratic process. In keeping with the emphasis on consultation (shura) in Islam, MCB's internal decision-making is strongly influenced by a consensus-based ethos, with best endeavours made to genuinely listen to the views of all relevant stakeholders before a practical way forward is proposed and agreed upon. The arrangements that underpin the MCB's structures of governance mean that there are rigorous 'checks and balances' in place to ensure that the organisation delivers on its mandate to its grassroots members.

6 'BBC News|UK|Government Agrees to Fund Muslim Schools'. http://news.bbc.co.uk/1/hi/uk/46069.stm, accessed 7 June 2019. 
MCB affiliates pay an annual membership fee, thus providing a financial base and generating 'buy in' from member bodies. Membership fees are graded from $100 \mathrm{GBP} /$ year for organisations with an annual turnover of less than $£ 100,000$, to $5000 \mathrm{GBP} /$ year for annual turnovers of greater than $15 \mathrm{~m} \mathrm{GBP}^{7}$, although the vast majority of MCB's 500 members fall in the lower membership fee bands. This situation creates interesting challenges of perception. Many might assume the MCB has significant financial and human capacity, but a basic review quickly reveals the reality that income from membership fees barely covers the salary of one full-time administrator and rent for a small office space in London.

Whilst the MCB has always been a democratic body, changes have been implemented over the years to increase the accessibility and transparency of its arrangements. This was most evident in 2010 following criticism of the previously private process through which the Secretary-General was elected by National Council members only. As a result, changes were made to the constitution to ensure that candidates for the SG and DSG roles were publicly announced and voted on directly by delegates of affiliates at election AGMs instead.

Another important change relating to member finances was also initiated in 2012. Whereas affiliate organisations were previously charged a set fee irrespective of size or income, new arrangements were made enabling each organisation to make membership payments depending on their size, resources and revenue ${ }^{8}$. Today, approximately one-third of MCB funding comes from membership fees, with the remainder still coming from community donations, fundraising events and the award of capacity-building and project grants. However as explained by Radcliffe with regards the past, "MCB has consistently suffered from inadequate funding, with its leaders often paying for business expenses out of their own pocket" (Radcliffe 2004, p. 371).

For much of the last 30 years, British Muslim civil society has been dominated by South Asian, Sunni male 'elders'. It has taken time to transit to a more youthful and diverse representation of Muslim community organisations that better reflects demographics such as age, gender and countries of origin. And the profile of the MCB Executive Committee today reflects this progress. The current twelve Executive Committee members who take responsibility for day to day governance include four women, three from a Shia background, and two of African heritage. The average age is significantly younger than those of previous leadership teams; in 2018 the Deputy Secretary General aged 28 years old was the youngest MCB Office Bearer to ever be elected ${ }^{9}$.

Over the course of its history, the MCB has worked hard to ensure that its governance structures continue to accurately reflect the ethnic diversity of British Muslim communities. While nearly two-thirds of British Muslims are of South Asian origin, it remains the case that the MCB has also actively involved Muslims who originate from Arab, African, Afro-Caribbean, and other ethnic backgrounds. Similarly, converts to Islam from white or other ethnic backgrounds are also now finding their place in the structures of the $\mathrm{MCB}$, thereby ensuring that their needs and perspectives are reflected in the work of the organisation. The extent to which the organisation is committed to internal diversity is apparent in its recent efforts to challenge the 'quiet' prejudice that sometimes exists in South Asian communities towards African and Afro-Caribbean groups. The MCBs 'Proudly Muslim and Black' initiative sought in February 2019 to bring the history, heritage and socio-civic contributions of Britain's African and Afro-Caribbean communities from the margins to the mainstream.

As a cross-sectarian representative body, MCB has always taken Sunni-Shia intra-faith relations seriously, from ensuring Shia-led organisations were represented at the MCB's founding consultations,

7 https://mcb.org.uk/join-mcb/.

8 The Muslim Council of Britain, 'MCB Affiliation Pack', 2014, www.mcb.org.uk/wp-content/uploads/2014/09/Affiliation-Pack. pdf, accessed 12 June 2019.

9 'Youngest Deputy Secretary General Elected at Muslim Council's 21st Annual General Meeting (AGM)', Muslim Council of Britain (MCB) (blog), 10 July 2018, https://mcb.org.uk/press-releases/youngest-deputy-secretary-general-elected-at-muslimcouncils-21st-annual-general-meeting-agm/, accessed 22 June 2019 
meetings and affiliate base, to day-to-day working together as Executive Committee and National Council members. In particular, as geopolitical events abroad contributed to rising tensions amongst some communities at home, the MCB issued statements condemning sectarian-driven vandalism of mosques in the UK and led on the symbolic signing of an Intra-Faith Unity Statement at its $2013 \mathrm{AGM}^{10}$.

The election in 2016 of the MCB's first British-born Secretary General was a watershed moment; for the first time the elected Secretary General was a British-born Muslim ${ }^{11}$. This effectively proved a marker for the transition of leadership in British Muslim communities from first generation migrants, to the maturity of second and third generations Muslims born and bred in the UK. As with all Muslim civil society organisations-whether mosques, schools, charities, or professional networks-the transition in leadership from the founding cohort to the successor generation was only a matter of time. Like much organisational change, it was a hard-won and challenging process, and one that is much needed for other Muslim-led civil society organisations to address lingering negative perceptions of being 'old boys clubs'. The MCB is committed to continuing to support the leadership talents of young British-born men and women in order to ensure that it remains representative, forward-facing, and responsive in the service of its affiliates, and by extension, British Muslim communities.

According to the Charity Commission, men outnumber women on the boards of all charities in England \& Wales by two to one, and anecdotally the discrepancy is higher in the Muslim sector ${ }^{12}$. Cultural attitudes amongst many Muslim-led organisations about the role of women have been stubbornly 'conservative'. The MCB sees its role as leading by example in these matters (Jones et al. 2015, p. 12). Notably, aside from a quarter of the current Executive Committee being female, a constitutional amendment in 2012 passed to ensure that at least $20 \%$ of the elected National Council was female ${ }^{13}$. And with the launch of the MCB's annual 'Women in Mosques Development Programme' in 2018 ${ }^{14}$, calls for more Muslim-led organisations in Britain are being reinforced, to ensure they nurture and include talented Muslim women in leadership roles $^{15}$.

These developmental processes continue to evolve today with the social activism of third generation British Muslims. Youthful Muslims such as university students and young professionals, empowered by the tools of social media, are actively lobbying, rallying and campaigning to change society for the better, while using existing faith and non-faith institutions. As Elshayyal explains, the turn of the century saw many more young Muslims mobilising with a greater sense of confidence and sophistication in their identity and actions (Elshayyal 2015, p. 180). One example is young Muslim men and women becoming fundamental to the student politics scene, including two elected Muslim female presidents of the National Union of Students (NUS) ${ }^{16}$.

But the increasingly prominent role of young Muslims in civil society activism, within and outside the MCB is not surprising when the changing demographics of British Muslim communities are taken into account. Figures from the most recent Census in 2011 show that almost $50 \%$ of British Muslims are under 24 years old (compared to $30 \%$ in the general population) and $48 \%$ are born in the UK

10 'Intra-Faith Unity Statement Aims to Provide Common Ground Between Muslims of All Traditions', Muslim Council of Britain (MCB) (Statement), 29 June 2013, https://mcb.org.uk/mcb-updates/british-muslims-sign-historic-intra-faith-unity-statement/.

11 'East End Boy Becomes Muslim Council's First British-Born Leader', The Times, 30 July 2016, sec. News, https://www. thetimes.co.uk/article/east-end-boy-becomes-muslim-councils-first-british-born-leader-7r62x5rr2, accessed 22 June 2019.

12 'Charities Must Do More to Promote Diversity on Their Boards, New Research Shows', GOV.UK, accessed 7 June 2019 , https://www.gov.uk/government/news/charities-must-do-more-to-promote-diversity-on-their-boards-new-research-shows.

13 'Islamic Charity to Impose Quota for Women on Its Decision-Making Committee', accessed 7 June 2019, https://www.civilsociety. co.uk/news/islamic-charity-to-impose-quota-for-women-on-its-decision-making-committee.html.

14 'Muslim Council of Britain to Train Women to Run Mosques', The Guardian, 4 October 2018, sec. World news, https: //www.theguardian.com/world/2018/oct/04/muslim-council-of-britain-women-leadership-training.

15 'Muslim Council Calls for More Muslim Women in Leadership Roles', Muslim Council of Britain (MCB) (blog), 1 April 2019, https://mcb.org.uk/press-releases/muslim-council-calls-for-more-muslim-women-in-leadership-roles/.

16 'Zamzam Ibrahim Elected as NUS President', The Independent, 10 April 2019, https:/www.independent.co.uk/news/ education/education-news/zamzam-ibrahim-nus-president-national-union-students-election-racism-fees-a8863261. html. 
(i.e., second generation onwards) ${ }^{17}$. The total number of British Muslims also increased from $1.55 \mathrm{~m}$ in 2001, to $2.7 \mathrm{~m}$ in 2011, with latest polling data suggesting the number is currently at circa $3.5 \mathrm{~m}$, which amounts to approximately $6 \%$ of the overall British population ${ }^{18}$. It is interesting to note that whilst the Satanic Verses affair is an event often considered a watershed moment in defining the British Muslim experience, an estimated two-thirds of British Muslims alive today were either not born at that time or were still young children.

Internationally, the challenge of providing national representative voices for Muslims has been tackled in different ways across different nations, with the MCB seeking to learn and share lessons from the UK where relevant. For example, the National Mosque Open Day programme run by Australia's Lebanese Muslim Association helped to inform the MCB's \#VisitMyMosque campaign in its early years and vice versa, while members of the Islamic Council of Norway (IRN) attended the most recent Our Mosques Our Future conference in 2019. Further lessons can be learnt between Muslim umbrella bodies internationally from the likes of the Islamic Society of North America and Council on American-Islamic Relations in the US, to the National Council of Canadian Muslims, to closer to home in Europe with the French Council of the Muslim Faith (CFCM) and the Coordinating Council of Muslims (KRM) in Germany.

\section{External and Internal Perceptions}

Over the course of its history, the MCB has had to manage some difficult public relations. These have often centred on presumptions made about its ideological roots. What is most notable about these challenges is the tendency to make selective use of out-of-date information, and the lack of any real supporting evidence for claims that have been made. This indicates an overall lack of nuanced understanding of British Muslim communities and their origins, and insufficient 'religious literacy' when it comes to the Islamic tradition itself. Thus, the MCB has sometimes been accused of being 'Islamist' or dominated by the Muslim Brotherhood. Authors such as Innes Bowen in the book Medina in Birmingham, Najaf in Brent-Inside British Islam, asserts with certainty the that the MCB was dominated by those aligned to the Jamaat-e-Islami (a political party based in Pakistan and Bangladesh) and wonders whether the label moderate is apt to describe MCB (Bowen 2007, pp. 89-90). These accusations were as incorrect then as they are now, with the current MCB leadership team more likely to self-identify by their profession, or where they grew up in the UK, rather than by school of thought or ideology (Pedziwiatr 2007, p. 273). Furthermore, it is notable that during the history of the MCB, imams and religious scholars have in fact had relatively little involvement in core decision-making roles. Limiting their contributions largely to advisory or consultative levels has perhaps helped to ensure that the MCB continues to represent the interests of Muslims from a wide range of theological schools of thought.

Claims such as Bowen's fail to place the MCB in its contemporary context by making proper references to its press statements, its projects, activities and leaders. Media commentators who take time to engage more deeply with the MCB would find an open, progressive civil society umbrella organisation engaged in the spectrum of British social and political life. If it were the case that the MCB was only serving the narrow interests of one particular group within British Muslim communities, its affiliates would have undoubtedly reacted by leaving and/or using its democratic structures to change the leadership (Jones et al. 2015, p. 9).

Prior to 2005, the MCB had good relations with central government. The friendly rapport that the MCB had with the New Labour government in its early years was by no means unique. In fact, according to Radcliffe, many socio-civic and human rights organisations were called upon to provide

17 BMIN, Muslim Council of Britain (MCB) (Special Report), January 2015, http://www.mcb.org.uk/wp-content/uploads/2015/02/ MCBCensusReport_2015.pdf.

18 BMIN, Muslim Council of Britain (MCB) (Special Report), January 2015, http://www.mcb.org.uk/wp-content/uploads/2015/02/ MCBCensusReport_2015.pdf. 
consultations to the government around this time. For example, organisations such as Amnesty International 'provided briefings to new ambassadors on human rights training and respective courses for civil servants' (Radcliffe 2004, p. 366). From 1997-2000, government consultations were relatively common; by encouraging Muslims to get involved in politics, government officials thereby gained access to Muslim communities, in return. As a result of this process, the Labour Party became more dependent upon the Muslim vote in some constituencies, with Muslims making up a significant proportion of their voters. As Elshayyal explains, "the experience of working with the Left served to broaden the political experience of many within the Muslim community and accelerated the pace at which the level of mainstream political engagement intensified" (Elshayyal 2015, p. 186). The extent of this can also be seen with inaugural MCB Secretary General receiving an OBE (1999) and subsequently a Knighthood (2005) in a period when these awards were less common among Muslim and other minority communities. However, the cordial relations that existed changed in the post-9/11 landscape and with the announcement of the Iraq War in 2003. The MCB publicly opposed the war and refused to agree with the Labour Party's foreign policy.

The period after the 7/7 attacks signaled a further turning point in relations between the government and British Muslim communities, including with the MCB. After the attacks, the government established the Countering Violent Extremism group (2005) which was focused on liaising with community groups and organisations around issues relating to radicalisation and extremism. This process saw the MCB and various other Muslim organisations working with the government to create legislation and policy ideas on tackling the risks posed by terrorism and radicalisation. However, as time progressed, it became evident that rather than being a productive relationship, the lens of securitisation was causing Muslim communities to be viewed as suspects rather than stakeholders. This led many Muslim organisations to disassociate themselves from the process.

MCB public relations were also affected by the controversy arising from its early stance to the marking of Holocaust Memorial Day (HMD) given the lack of attention afforded to the genocide of Muslims in Bosnia only a decade earlier, a stance which was rightfully corrected in 2010. Difficulties further increased following Operation Cast Lead in 2008 which saw the 'Istanbul Convention and Declaration' being signed in an independent, personal capacity by the then MCB Deputy Secretary General. This sparked media outrage with elements of the tabloid press wildly extrapolating that this signing meant MCB condoned attacks on or the killing of British troops. This incident led to an exchange of letters between the then Secretary of State at the Department for Communities and Local Government (DCLG), who condemned the signing. She insisted on the DSG's resignation from the $\mathrm{MCB}$ and indicated that refusal would lead to the breaking of ties with the government. Not only did this have an impact on the external perception of the MCB, which led to breakdown of relations, but the incident was also a catalyst for reviewing MCB internal procedures. The MCB prepared additional internal governance protocols on what Office Bearers could and could not do, even in a personal capacity. In a parallel move, the MCB issued a document highlighting the historical contributions of British Muslims to the UK Armed Forces ${ }^{19}$. But it is important to note that this was not done solely in the context of this particular controversy as from its inception, the MCB has campaigned for better Muslim representation in all walks of life, including the Armed Forces. For example, the MCB successfully campaigned for the military to appoint its first ever Muslim Chaplain in 2005 and encouraged the subsequent creation of the Armed Forces Muslim Association.

By 2009, government ties with the MCB were re-established with the appointment of a new Secretary of State at DCLG. During this time, cabinet ministers and senior secretaries of state attended MCB events, such as the inaugural Muslim Leadership Dinner. But after the 2010 election, the situation changed once again under the new Conservative-led coalition government. Even though the MCB met

19 'A report exploring the contributions of British Muslims in the military', Muslim Council of Britain (MCB) (Special Report), Spring 2009, https://mcb.org.uk/wp-content/uploads/2014/04/RememberingtheBrave_MCB.pdf, accessed 12 June 2019. 
several times with several Liberal Democrat ministers up to 2015, the influence of neoconservatives close to 10 Downing Street, and who were dismissive of Muslim representation, meant that government interactions with the MCB scaled down significantly. With several government departments seeking alternative organisations with different 'ideological inclinations' for consultations on matters affecting Muslim communities, and it was felt less attention was placed on grass roots community engagement.

In the last few years, this process has once again changed, with some departments and civil servants consulting with the MCB and engaging with the organisation on a variety of levels, with an example being on conversations surrounding religious slaughter and the issues surrounding religious burials. It seems that rather than maintaining official, high profile and public relationship, as before, there was a more ad hoc approach in which the MCB is consulted on specific issues. However, this raises the question that despite this pattern of casual consultation, why has the government refused to engage with MCB and other Muslim organisations on a more formal and consistent level ${ }^{20}$ ? It is of note therefore that in Wales and Scotland, devolved administrations continue to engage formally with MCB's regional affiliates, the Muslim Council of Wales and Muslim Council of Scotland respectively. It is only the Conservative-led Westminster administration that has more or less maintained a quasi-boycott approach since 2010 .

More recently, the MCB has advocated policy change in relation to extremism and terrorism. When the government finally announced its plans for an Independent Review of Prevent in 2019, the MCB indicated its support for this welcome move. For its part, the MCB undertook a National Listening Exercise in 2019, which involved collating accounts of the myriad ways in which counter-terrorism legislation had affected British Muslim communities at the grassroots level. The intention is that the evidence will feed into improved policy, not only in relation to political violence but also far-right extremism which is likely to be more seriously addressed in any future iteration of counter-terrorism policies.

Alongside the MCB's work in relation to social policy, it has initiated successful projects that go beyond 'identity politics' and address the interests of Muslim communities in civil society more broadly. Recent examples include the national \#VisitMyMosque project, an annual campaign encouraging mosques across Britain to hold open days to welcome visitors and neighbours of all faiths and none. With just 20 participating mosques in 2015, it grew to over 250 mosques getting involved by 2019. The grassroots community engagement that this campaign has cultivated has led to other projects including inviting mosque leaders to meet, network and share best practice at the 'Our Mosques, Our Future' series of conferences.

MCB's media monitoring work, initially a voluntary personal effort by a former MCB Assistant Secretary General ${ }^{21}$, who took on the personal responsibility to submit complaints about factually incorrect reporting of Islam and Muslims in the British media has now been formalised into the Centre for Media Monitoring. This has increased the capacity of Muslim communities to engage with TV, radio, online and print media outlets at both national and local levels in a proactive and constructive way, rather than resort to the 'the media is against us' narrative. Since the summer of 2018, the MCB has led the calls for an inquiry into Islamophobia in the Conservative Party. This has raised the issue up the political agenda and onto the newspaper front pages. This move has been welcomed by many Muslim communities concerned by the continuing rise of Islamophobic sentiment in small pockets of British society, particularly following the Brexit referendum in 2016.

Despite many successes, the MCB recognises that further efforts are required to increase its capacity to act with decisive leadership and to continue to renew how it provides representation in a

20 'Muslim Council of Britain: No one to talk to, A Muslim group falls from favour, The Economist, 18 Oct 2014, sec. Britain, https://www.economist.com/britain/2014/10/18/no-one-to-talk-to, accessed 14 May 2019.

21 'One man's (very polite) fight against media Islamophobia', The Guardian, 18 Oct 2018, sec. The Long Read, https: //www.theguardian.com/news/2018/oct/18/miqdaad-versi-very-polite-fight-against-british-media-islamophobia, accessed 12 June 2019 . 
way that is accurate as well as relevant vis a vis its members (Dobbernack 2017, p. 18). Aspiring to fully empower British Muslim communities in their engagement with public life is a particular challenge in relation to the approximate more than double increase in the size of the Muslim population between 1997 and 2019. The resources required in terms of advocacy, membership engagement, public affairs and media liaison, as well as new projects must scale up accordingly, if the MCB is to keep apace.

In relation to internal Muslim community perceptions, two independent polls in 2015 show that the majority of British Muslims believe the MCB is successful in representing their views. Fifty-five per cent of those questioned in a COMRES poll commissioned by the BBC agreed with the statement, "The Muslim Council of Britain does a good job representing the views of Muslims"22. An ICM poll commissioned by Channel 4 indicated 51 per cent support of the statement: "To what extent do you agree or disagree that the Muslim Council of Britain represents your views?"23. Aside from the data derived from grassroots polls, numerous individuals and activists frequently express support for MCB's work-publicly and privately-despite differences of opinion that may exist on any given topic (Seddon 2014, p. 228). Ironically, the period during which the MCB was out of favour with government may have inadvertently increased Muslim community support for it, reinforcing positive perceptions and understanding of its independence and legitimacy.

In summary, it is evident that the work of the MCB has been integral in shaping aspects of public policy in Britain and making sure that this has a positive impact on the lives of minorities in Britain (Peedziwiatr 2007, p. 274). Following the campaign for inclusion of a question on religion in the 2001 Census, the MCB has subsequently built upon this work by comparing 2001 and 2011 data. This resulted in the report 'British Muslims in Numbers' ${ }^{24}$, which provided a comprehensive picture of the demographics of Muslim communities. The information produced revealed some stark contrasts, from the over-representation of Muslims in prisons and the lowest income levels of any faith community, to the higher than average number of Muslim graduates and doctors. The information produced by the MCB in the report has been useful for a wide range of audiences both within and outside Muslim communities. The report received widespread media attention, providing academics and policy-makers with the data required to ensure evidence-based understanding of the social policy issues facing British Muslims (Pędziwiatr 2007, p. 275).

Discussions surrounding the understanding of 'halal' meat have also been integral in the work MCB has done in recent years. Under former Secretary Generals, extensive ties developed with Jewish community groups to lobby regarding religious slaughter in the UK. Despite being a non-theological organisation, the MCB has managed to understand the sensitivities and issues surrounding halal meat slaughter within its communities and has actively worked to make sure all perspectives are recognised. The MCB has necessarily consulted with religious scholars on this issue as needed, but in keeping with its ethos and role, and mindful of the diversity of its constituent membership, it has not engaged in matters of theological debate as a routine part of its work.

\section{Conclusions}

So are representative Muslim bodies, such as the $\mathrm{MCB}$, progressive interlocutors or redundant gatekeepers? It has often acted successfully as a progressive mediating body, lobbying for the interests of Muslim communities both within and beyond its membership circles. This paper has documented many of its campaigns and initiatives, and equally has attempted to convey the well intentions that have underpinned these efforts. Notably, Muslim communities in Britain have been successful in

22 COMRES, 2015 Muslim Poll—Do You Agree or Disagree with These Statements about British Society ...?', http://comresglobal. com/wp-content/uploads/2015/02/BBC-Today-Programme_British-Muslims-Poll_FINAL-Tables_Feb2015.pdf, accessed 7 June 2019.

23 'Facts about $\mathrm{MCB}^{\prime}$, Muslim Council of Britain (MCB) (blog), https://mcb.org.uk/about/facts-about-mcb/, accessed 7 June 2019.

24 BMIN, Muslim Council of Britain (MCB) (Special Report), January 2015, http://www.mcb.org.uk/wp-content/uploads/2015/02/ MCBCensusReport_2015.pdf, accessed 18 June 2019. 
establishing other civil society and professional bodies that are perfectly capable of 'speaking for themselves', and do so as a matter of course (Jones et al. 2015, p. 14).

Over the course of its history, the MCB has faced critique and misunderstanding from both within and outside Muslim communities. But with growing maturity and confidence, it has come to recognise the value of the 'long view' and the fact that the results of its work are often intangible and long-term. Notably, throughout all its work, MCB continuously strive to ensure it reflects the wide richness of Britain's diverse Muslim communities across the spectrums of age, gender, geographic location, ethnic background and school of thought. Its genesis and subsequent flourishing have taken place against the backdrop of difficult internal and external politics and international events, under a constant and often negative media gaze, and subject to the changing priorities of successive governments. For an organisation with limited resources and driven largely by volunteers, it is a testament to its founding vision and cultivation of a servant-leadership approach that it has managed to remain vibrant, outward-facing, engaged and self-critical. Over the course of time, it has managed to navigate a difficult tension between being responsive to the needs and demands of its affiliates at the grassroots (Bech 2010, p. 17), while also being proactive and forward-thinking in its strategy for the benefit of not only Muslim communities, but British society as a whole. Its efforts continue to be guided by its mission statement, namely, 'empowering Muslim communities towards achieving a just, cohesive and successful British society.'

Author Contributions: H.K. and H.J. contributed equally to the different tasks and parts of the paper, while Z.A. provided research assistance. All authors have read and agreed to the published version of the manuscript.

Funding: This research received no external funding.

Conflicts of Interest: The authors declare no conflict of interest.

\section{References}

Bari, Muhammad Abdul. 2018. A Long Jihad: My Quest for the Middle Way. Leicester: Kube Publishing Limited.

Bech, Emily Cochran. 2010. From Blowback to Incorporation: Muslim Council Consolidation and Influence in Europe. Conference Paper. Chicago: Midwest Political Science Association Chicago.

Bowen, Innes. 2007. Medina in Birmingham, Najaf in Brent: Inside British Islam. London: Hurst \& Company.

Dobbernack, Jan. 2017. Making a presence: Images of polity and constituency in British Muslim representative politics. Ethnicities 19: 292-310.

Elshayyal, Khadijah. 2015. From crisis to opportunity: 9/11 and the progress of British Muslim political engagement. In Muslims and Political Participation in Britain. Edited by Tim Peace. Routledge Studies in Religion and Politics. London: Routledge, pp. 174-92.

Gilliat-Ray, Sophie. 2010. Muslims in Britain: An Introduction. Cambridge: Cambridge University Press.

Hussain, Serena, and Jamil Sherif. 2014. Minority religions in the census: The case of British Muslims. Religion 44: 414-33.

Jones, Stephen H., Therese O'Toole, Daniel Nilsson DeHanas, Tariq Modood, and Nasar Meer. 2015. A 'System of Self-appointed Leaders'? Examining Modes of Muslim Representation in Governance in Britain. The British Journal of Politics and International Relations 17: 207-23. [CrossRef]

MCB, ed. 2002. The Quest for Sanity: Reflections on September 11 and the Aftermath. London: MCB.

McLoughlin, Seán. 2005. The State, New Muslim Leaderships and Islam as a Resource for Engagement in Britain. In European Muslims and the Secular State. Edited by Jocelyne Cesari and McLoughlin Sean. Aldershot: Ashgate, pp. 55-70.

NICMU. 1996. National Interim Committee on Muslim Affairs (NICMU) Survey. London: NICMU.

Nielsen, Jørgen S. 2004. Muslims in Western Europe. Edinburgh: Edinburgh University Press.

Pedziwiatr, Konrad. 2007. Creating New Discursive Arenas and Influencing the Policies of the State: The case of the Muslim Council of Britain. Social Compass 54: 267-80. [CrossRef]

Radcliffe, Liat. 2004. A Muslim Lobby at Whitehall? Examining the role of the Muslim Minority in British Foreign Policy Making. Islam and Christian-Muslim Relations 15: 365-86. [CrossRef] 
Seddon, Mohammad Siddique. 2014. The Muslim Council of Britain: From pious lay preaching to political lobbying. In Islamic Movements of Europe: Public Religion and Islamophobia in the Modern World. Edited by Frank Peter and Ortega Rafael. London: IB Tauris, pp. 226-29.

Sherif, Jamil. 2011. A Census chronicle-Reflections on the campaign for a religion question in the 2001 Census for England and Wales. Journal of Beliefs and Values 32: 1-18. [CrossRef]

UKACIA. 1993. Muslims and the Law in Multi-Faith Britain: Need for Reform. London: UKACIA.

(C) 2020 by the authors. Licensee MDPI, Basel, Switzerland. This article is an open access article distributed under the terms and conditions of the Creative Commons Attribution (CC BY) license (http://creativecommons.org/licenses/by/4.0/). 


\title{
Article \\ Guidance as 'Women's Work': A New Generation of Female Islamic Authorities in Britain
}

\author{
Giulia Liberatore \\ Sociology and Islamic and Middle Eastern Studies, University of Edinburgh, Edinburgh EH8 9LD, UK; \\ giulia.liberatore@ed.ac.uk
}

Received: 17 August 2019; Accepted: 25 October 2019; Published: 30 October 2019

\begin{abstract}
This article is about a new publicly visible generation of female Islamic authorities in the UK and the ways in which they make sense of what it means to be a female authority within largely male-dominated structures of knowledge production. These authorities are setting up their own institutes and emphasising the importance of drawing from within the Islamic tradition while contextualising it in the British context. On the one hand, they stress their unique ability as women to provide personal and collective guidance, based on relationships of empathy and care, that addresses the needs of Muslim women in Britain. On the other hand, they recognise the limitations of presenting guidance as 'women's work', and they seek to pluralise their roles or to present gender as irrelevant in their work. By navigating between accepting, pluralising and transcending female modes of authority, they carve out legitimate spaces for themselves as female leaders while developing and imagining new understandings of Islamic knowledge and plural models of pious leadership. I argue that these multiple ways of making sense of their experiences move us away from theorising female religious leadership solely through binary tropes, such as liberal/orthodox Islam, resistance/compliance, enabling/constraining, which continue to shape research in the field.
\end{abstract}

Keywords: Islam in Britain; authority and leadership; Islamic knowledge; gender and piety; female Muslim authorities; Muslim subjectivities

\section{Introduction}

On 12 August 2016, I made my way from Oxford to North Wales, travelling over five hours through traffic and country roads to reach Glann Llyn, a 600-acre residential activity centre overlooking the beautiful, tranquil Lake Bala in North Wales, and the site of a four-day women's only retreat. Ustadha Iffet Rafeeq $^{1}$ - a young female graduate of Jaamiat Al Karam, a Barelvi darul uloom (seminary) ${ }^{2}$ in Retford, Nottinghamshire, and founder of her own social media platform—had mentioned the retreat to me when we first met at the Cambridge Muslim College, where she was completing her diploma earlier that year. Advertised as an opportunity to 'rejuvenate' participants' spiritual and physical needs, the 'Beacon of Hope' retreat featured three UK-based female authorities delivering classes during the day, dhikr (remembrance) gatherings throughout the night, and a range of sporting activities in the company of roughly eighty young female professionals and students from across the country.

Throughout the retreat, Ustadha Iffet delivered several different classes featuring the lives of female saints and reflecting on how their experiences might relate to the lives of women in the UK. Outside of the formal classes, she spent hours engaging in private conversations with the female

1 Some interviewees asked me to use their real names, whereas others requested a pseudonym. For the small minority who asked to be anonymised, I have changed the details relating to their identity in order to make them non-identifiable.

2 Al Karam is managed by Muhammad Imdad Hussain Pirzada, a Pakistani scholar of the Chisti Nizami Sufi order. 
participants. She barely had time for food, and one night, she spent hours helping one of the women attendees with a personal problem. As she explained to me when we spoke about her role as a female authority, 'You realise when you give a talk that after women come up to you with all sorts of problems, relationship problems, marriage, divorce, trauma ... very personal things, and you think, where is the support network? Why is no one addressing these issues?'

Ustadha Iffet is part of an emerging group of young female teachers and scholars in the UK. Over the last decade, the visibility of female Islamic authorities in Europe and globally has been growing (Bano and Kalmbach 2012; Kloos and Kunkler 2016; Hammer and Spielhaus 2013; Hill 2018). Lewis and Hamid (2018) described this emergence as one of the 'seismic changes' affecting British Islam and the wider Muslim World. In the UK, female authorities are a diverse group in terms of their age, traditional Islamic training, Islamic school of thought, secular education and ethnic and socio-economic background. This diversity is also reflected in the fragmented growth of new initiatives, institutes, and events on the topic of women, leadership and authority.

This article focuses on a new generation of publicly visible teachers and scholars who have been traditionally trained in the UK or abroad and are working from within the Islamic tradition while seeking innovative ways to apply it to the British context. It explores the ways in which these new authorities make sense of what it means to be a female authority within 'orthodox' structures of Islamic education (Asad 1986) and how, in the process, they develop new forms of knowledge and ideals of pious leadership.

Many of these new female authorities present themselves as naturally able to empathise, nurture and care, while adapting knowledge to suit individual circumstances and local community needs. While engaged in diverse teaching, preaching and scholarly activities-as highlighted by the vignette above-many of these young authorities spend a vast amount of their time offering individual or collective advice and guidance to Muslim women on issues ranging from marriage and divorce to mental health, spirituality, faith and Islamic practice. On the one hand, they present guidance as 'women's work', that is, as an area of Islamic knowledge in which women have particular expertise and which complements rather than competes with men's work. They see themselves as fulfilling a need among Muslim women—as Ustadha Iffet's comment above suggests—as well as fulfilling the expectations of their communities, who see them as 'natural guides'. On the other hand, they recognise the irrelevance of gender in matters of faith and spirituality or seek to pluralise ideals of Islamic female leadership.

By navigating between these different positions, these authorities are carving out legitimate and relatively uncontroversial spaces for themselves while also developing and imagining new forms of knowledge and ideals of pious female leadership. Building on recent work on the ethical imagination (Moore 2011) and on my own research on gender and Muslim women's multiple and complex subjectivities (Liberatore 2017; see also Sehlikoglu 2018, forthcoming), I point to the ways in which navigating between these different forms of knowledge can involve new processes of imagination and ethical self-making. In doing so, I bring to the fore the multiple, overlapping and fluid ways in which these emerging Islamic authorities navigate structures of knowledge and make sense of themselves as leaders. Drawing on Stewart's notion of 'weak theory', I suggest that this multiplicity and fluidity of subjectivities means that they can never be fully captured by 'strong' theoretical frameworks, binaries or the linear arguments of academic debate. Stewart (2008, p. 72) experiments with 'theory that comes unstuck from its own line of thought to follow the objects it encounters, or becomes undone by its attention to things that don't just add up but take on a life of their own as problems for thought.' Only a weak theory can account for these moments, she elaborates, because it does not seek to 'judge the value of an analytic object or to somehow get their representation "right"', but rather 'wonders where they might go and what potential modes of knowing, relating, and attending to things are already somehow present in them as a potential or resonance' (ibid. 2008, p. 73). I suggest that the work of female authorities risks being flattened by academic studies or public discussions on Muslim 
subjectivities that are organised around binary tropes such as liberal/orthodox, enabling/constraining or resistance/compliance.

\section{Methods}

This article draws on a larger ethnographic research project on female Islamic authority and guidance in the UK that I conducted between April 2015 and October 2019. The research involved mapping a broad range of female authorities across the country, analysing their online presence, interviewing over twenty-five female Islamic authorities (scholars, teachers, preachers, as well as authorities providing legal advice or counseling), visiting spaces of learning, attending classes and retreats, speaking to audience members and discussing the topic with male Islamic authorities and other experts in the area. ${ }^{3}$ Interviews with female authorities were semi-structured and focused loosely around the following themes: education and training; journeys to scholarship/teaching/preaching; opportunities and constraints experienced in education and work; current work; content and style of any teaching and preaching; ideas about Islamic authority and leadership; Islamic knowledge production and dissemination; engagements with civil society, government or other organisations. While I introduced these topics at various points throughout the interviews, I allowed participants to shape their own narratives wherever possible in order to explore how they wanted to narrate their personal trajectories and to describe the work that they do. Most of the female authorities I interviewed were recruited through personal contacts and networks, and some were contacted via email or through social media platforms. In addition, I spent many hours attending classes, lectures and retreats organised by these authorities, following their engagement on social media and participating in online classes and sermons. Through my involvement in these activities, I was able to build close relationships of trust and friendship over the years.

The following discussion focuses on one of the questions explored during this research: How do female leaders make sense of their female authority? It is based on participant observation and interviews conducted with a sub-group of ten newly emerging female teachers and scholars with traditional training in the Islamic Sciences. This more recent generation is rapidly expanding, and their experiences reveal developing patterns and changes in the fields of Islamic knowledge and gender. Throughout, I prioritise the narrative accounts of female authorities and the ways in which they understand their own authority and gendered subjectivities. Drawing on feminist epistemologies, I treat my interlocutors as theorists and co-producers of knowledge rather than as the subjects of research (see Liberatore 2017, chp. 2). ${ }^{4}$ By juxtaposing their voices and experiences, I explore different perspectives on female authority, bringing out emerging patterns, convergences and contradictions. I also include some of the voices of female audience members and male scholars with whom I discussed the topic. The article also builds on long-term fieldwork with Muslim communities (ibid. 2017) during which I first encountered the work of UK-based female scholars.

The following section (Section 2) introduces this new but highly diverse generation of female authorities and accounts for their recent emergence in the UK, exploring how they make sense of the opportunities and constraints they encounter through their work. Sections 3 and 4 move away from an analysis of opportunities and constraints to explore the multiple ways in which these female authorities make sense of their work by presenting themselves as 'natural guides' while, at the same time, recognising and critiquing some of the limitations of doing so and pluralising or transcending these ideals. Section 5 situates the rise of these new female Islamic authorities among global, regional and local shifts in Islamic knowledge and highlights this article's engagements with the field of Islamic

3 I use the term 'authorities' mostly to talk about women who self-define as teachers, scholars or preachers and who have received some traditional training in the UK or abroad.

4 The female authorities who participated in the project were sent a draft of this article prior to publication. Some replied with suggestions and/or amendments which have been incorporated into the final draft. 
knowledge production and female leadership. The article concludes with a reflection on how these female authorities are shaping knowledge production and notions of leadership and authority.

\section{New Female Islamic Authorities in Britain}

The new generation of Islamic authorities discussed in this article are mostly women whose parents or grandparents settled in the UK from South Asia or, in smaller numbers, from North Africa and the Middle East. Within this diverse group is a small cohort of slightly older but more authoritative women who completed most of their training abroad, in the Middle East. Shaykha Safia Shahid, for example, was born and raised in Glasgow and moved to Syria for five years in 2003, where she studied Arabic at the University of Damascus and earned several ijaza (licenses to teach) with scholars such as the Shadhili Shaykh Muhammad al-Yaqoubi. She is currently completing an MRes in Islamic Studies in the UK. Similarly, Ustadha Nagebah Hayel Muckbel studied Arabic at the University of Damascus and tajweed (Quranic recitation) with the Damascus-based female scholar al-Haja al-Najah for several years. She then moved to Tarim, Yemen where she completed the four-year programme at the female madrasa al-Zahra, where she later taught figh (jurisprudence), aqeedah (creed) and Arabic grammar.

The younger women, who are in their 20s and 30s, are more numerous and have been predominantly trained in the UK, in either the Barelvi or Deobandi institutions. Many have also encountered teachings from other schools of thought that are present in the UK and, in some cases, have incorporated parts of these into their work. Of the ten authorities interviewed, four had trained at an Islamic seminary and had combined their studies with an undergraduate or postgraduate degree or diploma at a British university. For example, Ustadha Iffet, like her fellow Islamic authority Ustadha Noor, had attended the Jaamiat Al Karam. She subsequently spent a year perfecting her Arabic in Egypt ${ }^{5}$ but was forced to return to England in 2011 and enrolled on the Diploma in Contextual Islamic Studies \& Leadership at the Cambridge Muslim College (CMC). Another young authority, Ustadha Khadijah, had enrolled in a part-time alimah (scholar) course with a Deobandi educational institute while finishing her secondary school studies in the early 2000s. ${ }^{6}$ She then travelled to Jordan with her husband to study under Shaykh Nuh Keller, an American convert and the head of the Shadhili order. On returning to the UK, she enrolled on the diploma at Cambridge Muslim College (a year before Ustadha Iffet and Noor) and completed a Masters' at a London-based university. Ustadha Aliya, however, had followed a less linear path to scholarship. She studied Arabic at university in the UK and then travelled to Egypt for a year, to Damascus and Tarim for a few months, and to Morocco for a year, receiving several ijaza in tajweed and hadith in these various locations. Once she returned to the UK, she enrolled at Cambridge Muslim College, and later completed an MSc in Education while studying for an alimah course part-time.

The ways in which differences between the older and younger cohorts overlap with educational opportunities are partly due to the difficulties surrounding studying in the Middle East since the 2011 revolutions, coupled with the opening up of more opportunities for young women to complete their traditional studies in the UK. These different experiences have also led to divergences between schools of thought, with the younger generations trained in Islamic schools that originated in the South Asian sub-continent and that are dominant in the UK because of historic migration and settlement patterns (Bowen 2016). This has also meant that these younger authorities engage with slightly different audiences and communities than their older colleagues and that their experiences of opportunities and constraints are specific to them and not necessarily generalisable across all female authorities. Given the diversity of their scholarly backgrounds, these new female authorities do not form a cohesive

5 The Al Karam seminary has well established connections with Al Azhar, where if often sends its graduates for further study.

6 The institute was one of the first in the UK to offer this programme to women part-time. Ustadha Khadijah, however, mentioned that her part-time alimah course was considered within scholarly circles as less authoritative than full-time courses delivered in boarding schools. 
group, and the women do not necessarily know each other, although they may have heard of each other or been invited to speak at the same events and retreats.

Despite their differences, both sub-groups of this new generation of female authorities differentiate themselves from the much older generation, who tend to be first-generation migrants who teach in Urdu or in languages other than English and focus predominantly on delivering Quranic recitation classes to young children or to small private circles of women. By contrast, the new generation is more publicly visible; its female authorities are setting up their own institutes and are teaching adults as well as children a range of different topics in English. They are distancing themselves from the sectarian Islamic identities (Deobandi/Barelvi) of previous generations and moving towards forms of knowledge that address a broader British Muslim audience. ${ }^{7}$ As Ustadha Iffet summarised in an interview in 2016, 'before it was really about intimate, private circles ... the wives of Shaykhs or young scholars holding meetings in homes or prayer rooms. But over the last five or six years some of us have started to go public.' These new female Islamic authorities are shifting between different modes of establishing authority (Bano and Kalmbach 2012; Kloos and Kunkler 2016) as they navigate between working in formal roles within existing Islamic institutes and teaching in informal spaces or setting up their own organisations, and thus engaging with new audiences.

While some have embraced social media in order to engage with a more diverse national audience, others have a limited presence online and focus instead on working with local audiences. ${ }^{8}$ For example, Shaykha Safia Shahid, with the support of Shaykh al-Yaqoubi, became the Principal of the Women's Muslim College (WMC) in 2017, an organisation that offers certificates, a diploma and a four-year programme in the 'Islamic Sciences in a Modern Context' online and in a range of locations across the UK. It also organises an annual retreat. ${ }^{9}$ The Shaykha is active on social media, where she promotes the work of the College and advertises her events and classes. Her public visibility means that she is very often invited to deliver talks at universities and Muslim and non-Muslim organisations across the globe. Ustadha Iffet is similarly active online. In 2012, she set up 'Dust to Diamonds', a social media platform (available on Facebook, Snapchat, Twitter and Youtube) where she regularly engages in exchanges with her followers and posts advice, quotations from the Quran or hadith or by famous scholars, and information on events. She also regularly tours the UK delivering lectures.

In contrast, Ustadha Khadijah has almost no presence online and works predominantly with her local community in east London. In 2008, she set up her own institute, which now delivers courses on topics ranging from Arabic to Ramadan preparation and holistic health, and occasionally runs tai chi classes or Arabic language toddler groups. Ustadha Khadijah also teaches Arabic and works as a chaplain in an Islamic institute in London, all while caring for her young children. Ustadha Salma, another young authority and darul uloom graduate, is the only authority working formally in a mosque where she runs regular sessions for women and young girls.

In contrast to the first generation of teachers, the legitimacy of these new female authorities is tied not to their husbands or fathers, but to the level and depth of their own scholarship and to their reputation for personal piety. Many have trained alongside their husbands-sometimes enrolling in the same institutions and programmes-and the couple mutually advise and support each other. The depth of the women's scholarship, however, is often assessed according to where and with whom they have studied. Studying in a renowned seminary like, Al-Karam, or receiving an ijaza under a famous male scholar (e.g., Shaykh al-Yaqoubi) is important for the women's futures, as they benefit from the support of the scholars as referees and promoters of their work. These referees act as hosts, 'inviting' female authorities to teach in mosques and other male-dominated Islamic institutions (Kalmbach

\footnotetext{
This is also reflected in the use of titles such as Ustadha or Shaykha rather than alimah or āpā (big sister) in Urdu. Most are assigned the title Ustadha, but out of modesty, they hardly ever claim it themselves.

While the Women's Muslim College is only for women, Shaykha Safia Shahid is one of the only female scholars in the UK to openly lecture both men and women. Most other female authorities prefer to operate in gender-segregated environments and never or only very occasionally deliver talks in mixed settings.
} 
2012). Therefore, while these new female authorities are creating their own spaces and initiatives, their legitimacy is tied in complex ways to that of male scholars, who often dominate the management or boards of mosques and Islamic institutions, and the audiences and communities with whom they engage. Ustadha Noor, for example, greatly benefits from the networks she established while at Al-Karam, as well as from the connections of her father-in-law, a well-respected imam in her local Barelvi community, in attracting students to her classes and receiving invitations to speak across the country.

Some younger female authorities, however, described the frustrating ways in which they continue to be seen by their communities as less authoritative than their male counterparts. As Ustadha Iffet put it, 'scholarship in the UK has been restricted to a male-dominated field and it really feels that we're imposing ourselves'. As mentioned, the large majority of British Muslims have roots in the Indian subcontinent and have brought with them traditions of Islam-in which some of these younger scholars are immersed-that tend to be more restrictive in terms of women's involvement in public affairs. In voicing these critiques, these young authorities often employed a discourse of 'religion versus culture', suggesting that 'cultural norms and practices' were constraining their work in contradiction of an authentic Islam that empowers and encourages women to study and to engage in the public sphere (Ewing 2008). When Ustadha Khadijah first started delivering talks within her local Deobandi community in the mid-2000s, she was forced to conceal her identity by using Ustadha 'bint Muhammad' (daughter of Muhammad) on posters advertising her talks, an attempt at using her name having sparked controversy. She also described the ways in which she had to gain the trust of the local imams and male scholars in her area before she could start delivering classes to women and carving out greater spaces for women in her local mosque. Ustadha Noor also commented on the difficulties of being remunerated fairly for her work when compared to male scholars. She felt that students did not take her seriously as a scholar and did not appreciate the effort, time and money she had invested in her education or the research that she undertook when advising on a particular issue.

Those who have studied in seminaries within the UK are also often seen as less authoritative than those who have studied abroad for long periods of time but also less knowledgeable than male counterparts who studied at the same seminaries. This is because, with the exception of Al Karam, the curriculum for women is considered shorter and less rigorous than that offered to men at the same seminaries (Scott-Baumann and Cheruvallil-Contractor 2015, p. 121). ${ }^{10}$ As a male scholar I interviewed told me, 'until the education they [female scholars] receive is on a par with that of men, they will always be seen as inferior scholars.' Furthermore, studying in major institutions abroad is not only increasingly difficult but is only available to a small minority of women.

For some of this younger generation trained in the UK, legitimacy within their local communities has not only depended on the level and depth of their scholarship, but also on their carefully negotiating their way within existing structures of authority. Other female scholars, however, claim that they have never felt constrained in their work. As Shaykha Safia Shahid elaborated in an interview, 'male scholars have invited me to events and talks.' She claims never to have felt that she was treated differently as a female scholar, and my question on this issue surprised her as she did not find it relevant to her own experiences. ${ }^{11}$ Her remarks were echoed by Ustadha Nagebah, who similarly, felt that she had never experienced barriers or limitations in her learning and teaching. ${ }^{12}$ As I elaborate in more detail below, the only barrier she spoke about in relation to her work was a lack of support networks available in an individualistic society such as the UK. While not all female authorities shared this view, nonetheless,

10 Female scholars who had been to Al Karam reported that teaching now occurs alongside men, with the same male teacher addressing both male and female audiences separated by a large screen.

11 This may due to her high status as well as the particular nature of the communities in Birmingham and London with which she engages, which are more accepting of female scholarship.

12 The female audiences in Liverpool are incredibly diverse, Ustadha Nagebah explained, and less influenced by schools of thought originating in South Asia, which may be why she has experienced fewer obstacles in her work. 
none engaged with a liberal discourse of empowerment or spoke about resisting patriarchal forms of authority. Furthermore, most emphasised that their main concern was not resistance (or compliance) but rather, as I expand on in the next section, to provide guidance and pious leadership to Muslim women who approached them for help.

\section{Women as Guides}

\subsection{Guidance as Women's Expertise}

Female authorities teach a broad range of different topics within their institutes or other Islamic organisations, from tajweed (Quranic recitation), to tasawuuf (spirituality) and figh (jurisprudence). When questioned about the work that they do, however, many new female authorities across the different schools of thought stressed the importance of 'providing guidance' for Muslim women in the UK, and several emphasised that guidance was an area of female expertise. As the following examples demonstrate, guidance involves drawing on different forms of knowledge, ranging from figh to spiritual guidance and counseling support in one-to-one or group sessions.

Advising on marriage and relationships was something Ustadha Iffet found herself having to do on a weekly basis. Consequently, she realised that there was a need to provide advice to larger groups of young women. Her social media platform, Dust to Diamonds, which has over ten thousand subscribers, enables her to do just that, providing, in her words, 'the way to reach so many different kinds of people globally'. The majority of her time is spent answering questions that she receives from her subscribers and preparing YouTube videos that respond directly to their concerns. In her videos, she is not scared to address some of the most 'thorny and taboo' issues of the day: 'these things are normally hidden', she explains in a video on haram relationships. Her YouTube videos are short, typically lasting between five and ten minutes, and each addresses an everyday problem on which she feels her listeners need guidance. Subjects and titles include marriage, study, friendship, love, ' 4 tips for student life', 'getting married or die trying', 'food and soul', 'suffering from anxiety' and 'how to spend holidays like a Muslim'. She takes on the role of a teacher or preacher, but she speaks directly to her listeners, addressing them personally. While she is funny and entertaining, the moral lessons she imparts are conveyed with seriousness and authority, as she cites Islamic sources and alters her tone to reflect this. Her short talks often follow a similar structure: a question or problem is identified at the start (e.g., women's personal insecurities); this is unpacked and the reasons or causes underlying this issue explored (e.g., the role of media in defining beauty and making us feel imperfect). This is usually followed by a critique or admonishment (e.g., the media is not real, you shouldn't let it shape who you are), and a resolution is offered at the end, which most often involves returning to Allah or seeking His help (e.g., Allah has defined us as beautiful; what matters is your personality and actions, what's inside in your hearts). Her videos are carefully edited and as she talks, words or hashtags flash on the screen along with diagrams and images used to illustrate her points. She also occasionally draws on her own experiences (e.g., her own insecurities or mistakes). Her talks often end with 'I am here for you' (addressed to sisters who may need her help), a reminder of her email address, and requests for $d u a$ (prayers or supplications) and for her listeners to act as her witnesses on the Day of Judgment.

In her work at her own east London institute, Ustadha Khadijah is similarly concerned with offering guidance, albeit in a very different setting. During my research, I attended several of her courses and I always did my best to arrive early so as not to miss the first fifteen minutes of the class. Ustadha Khadijah would enter the class, sit at the teacher's desk, lift her niqab and greet us individually, asking each of us about our week. She would then share her own thoughts and experiences of the week, while connecting these with Islamic sources. She might speak about her experience training as a hypnobirthing teacher, impart breastfeeding advice, discuss the importance of keeping children away from screens and devices or talk about the importance of caring and engaging with multiple others, including non-Muslims. She often referred us back to the Quran as a 'book of guidance', as a text that we could turn to for any sort of advice, support, and personal and collective guidance. This was a very 
special moment of intimacy where we could ask questions and seek advice, but also listen and learn through her personal experiences.

As Ustadha Iffet and Ustadha Khadijah's experiences demonstrate, many young Muslims in Britain are in need of personal spiritual and moral guidance. They often find that their parents are unable to provide the support that they need, as their understanding of the British context is limited and their knowledge of their faith is considered-by their children — to be 'cultural' and insufficiently Islamic. School and university teachers or counselors are also considered to know little about Islam and these young people's cultural backgrounds. Research has shown how young Muslims seek support in adapting a virtuous Islamic life to a non-Muslim, Western, secular context, and revealed that they need religious authorities to help them to engage in 'Islamically correct' behaviour (Jouili and Amir-Moazami 2006, p. 636; see also Jouili 2015).

Ustadha Noor found that when she was approached by Muslim women for advice, they most often asked not for figh advice or for a fatwa (non-binding legal judgement) but 'for what is good and moral for them'. She felt she could not refer them elsewhere, as there was no one else in the community with whom they could or would be willing to talk. Similarly, Ustadha Salma explained in an interview: 'It's not possible for women to go to an imam for everything, and imams have lots of other things to do ... ' In the mosque she provides counseling and guidance to women in the community and organises talks on topics she is often asked about by the community (e.g., marriage or the challenges of educating Muslim children in Britain). She has also recently started working as a chaplain in a local hospital. While male scholars and imams do engage in guidance work, as Ustadha Salma suggested, they are often involved in other activities, such as providing teaching, issuing fatwas, leading prayer or delivering Friday sermons, which are traditionally viewed as men's area of authority. For female authorities, therefore, guidance is seen as complementing but not competing with the work that men already do. In the UK, chaplaincy and counselor roles are also increasingly providing opportunities for formal and paid employment for traditionally trained male and female Islamic scholars (Gilliat-Ray et al. 2013). Women are beginning to take advantage of these opportunities: two out of the ten female authorities I interviewed were employed part-time as chaplains in various institutions.

\subsection{Guidance as a Female Mode of Teaching}

As the examples above suggest, guidance work can involve discussing controversial, 'thorny and taboo' subjects, or 'female topics' — such as childcare and menstruation-that are regarded as too personal or intimate to discuss with a male scholar. However, in several of my discussions with female authorities, they also presented guidance as an extension of women's natural skills; many pointed less to the content of the guidance they provided and more to their mode of engaging with students. This was also evident in Ustadha Iffet and Ustadha Khadijah's classes (described above), where the relationship between scholar and audience was based on intimacy, empathy and care and was central to their work. Female authorities claimed that women are naturally caring, compassionate, loving, merciful and more understanding of individual needs, and are particularly skilled at adapting knowledge to different circumstances and contexts. These female characteristics were used to account for, what they deemed to be, distinctly female forms of knowledge and authority. Based on a conception of gender as rooted in biology, these women supported these positions by drawing on examples from within the Islamic tradition.

Ustadha Noor emphasised how female scholars had 'a special aura' about them that men lacked and that enabled them to 'build connections' with their female students. When we met in the summer of 2019, she described a course she had taught alongside her husband in the same mosque. They had prepared the content of the course together, but she had delivered it to women and he had addressed the men. At the end of the session, her female listeners, who had never been taught by a woman before, told her that her sessions were different: 'thank you for making us feel we can approach you, for being so open, we can talk to you on a normal level and there isn't that formality', they told her. As she narrated the incident, Ustadha Noor elaborated: 'it's because of that motherly nature that we have'. 
As an Islamic teacher, it was important for her to empathise with her students and to care for them: 'women are great at making people feel good, making them feel at home so when we speak to them, we open the doors of our hearts to them'.

The idea of naturally female characteristics being the basis for female authority was also furthered by Ustadha Nagebah, who explained to me: 'Women's brains are wired in particular ways. While men might have a spot in their brain for compassion, we have several ... ' She explained how many people came to her and her husband for help with difficult situations and problems. She told me that while her husband feels 'sadness, and does his best to help ... he can then put it aside', she struggles and carries 'the sadness ... for days.' These notions of women being naturally caring are often accompanied references to female role models who exemplify 'mothering' and 'caring' characteristics, such as Khadijah, the first wife of the Prophet, or Maryam the mother of Jesus. Indeed, reflecting Cheruvallil-Contractor's (2016, p. 15) analysis of the Islamic texts, many female authorities stress 'the special status given to mothers', and the value Islam places on motherhood, particularly in the hadith literature (Cheruvallil-Contractor 2016, p. 15).

In claiming guidance as female expertise, some female authorities emphasised not only naturally acquired skills, but also experiential notions of gender. Ustadha Khadijah recognised the shared experience of motherhood, explaining that, as mothers, wives, sisters and daughters, women shared similar life experiences and could use these in imparting knowledge. Similarly to other female authorities, she would often use examples from women's shared experiences, such as child birth or raising and educating children, to illustrate her teachings. She also noted how the experience of managing multiple roles and adapting to changes while responding to the needs of the family had taught her about the importance of contextualising and adjusting knowledge to the different experiences of individuals and communities. 'With women we spend a lot more time with our children, we understand the needs of the community better because we see our very own children going through the challenges. We have to adjust, we can't be textbook or theory based all the time', she elaborated.

My discussions with audience members at women-only classes or gatherings reinforced the sentiments expressed by these female authorities. Many participants noted how these settings were different, more relaxed and intimate than those led by a male scholar. Some explained how they could ask 'intimate' questions that they might not be comfortable discussing with a male scholar. ${ }^{13}$ While their decision to follow a particular scholar was based on their depth and range of knowledge-regardless of gender-the women preferred a female scholar with equal knowledge. 'They [female scholars] understand where I'm coming from ... they connect with you differently ... and I can ask her things a male scholar wouldn't get', a young female audience member told me at a women-only retreat one summer.

\subsection{New Imaginings of Pious Leadership}

For female authorities in the UK, the processes of nurturing and caring are spiritual, experiential and affective, as highlighted by Ustadha Noor and Ustadha Nagebah. But they also involve reasoning, problem solving, application and contextualising. The process of offering practical advice through intimate, empathic and less hierarchical relationships between teacher and student is presented as a distinctly female mode of authority that, as I elaborate in the conclusion, points to the expansion of new understandings of Islamic knowledge that cater to the needs of Muslims in Europe.

In many ways, the experiences of female Islamic authorities in the UK resemble those of the muqaddamas (female spiritual guides) of the Fayḍa Tijāniyya Sufi Islamic movement in Dakar, Senegal, as described by Hill (2018). Muqaddamas present spiritual guidance as a natural extension of motherhood, turn devotional cooking into a form of prestige, and perform wifely obedience, shyness and modesty

13 In her study of al-Qubaysiyyat in Syria, Omar (2013, p. 362) similarly notes how students seek approval and advice on very personal decisions from their female teachers, which they would not feel comfortable addressing with male scholars. 
as acts of 'self-wrapping'. Just as muqaddamas draw on norms of feminine piety to carve out legitimate spaces of authority, emerging female authorities in the UK are establishing legitimacy by developing distinctive areas of expertise through both the content and style of their teaching. They are addressing a growing need in their communities but doing so without contravening dominant understandings of gender segregation and orthodox norms of piety that naturalise women's roles as mothers and carers.

Moreover, guidance for many of these female authorities is not restricted to the individual. Drawing on their work with pious women in France and Germany, Jouili and Amir-Moazami (2006, p. 622) discuss the importance attributed to motherhood in the Muslim community and society at large. Within this conception of motherhood-which emerged in the Ottoman Empire in the second half of the nineteenth century - the domestic sphere is not 'constitutive of processes of individualisation' but is rather 'a space that is largely societal and political' (ibid. 2006, p. 623). In a similar way, female authorities who emphasise guidance as women's natural area of expertise, view their nurturing work as providing more than just individual advice; they see it as guiding the Muslim community, and developing and imagining new models of pious female leadership. Ustadha Nagebah, echoing the sentiments of several other authorities, emphasised how she deliberately chose to spend time 'building a community' rather than touring or travelling to deliver lectures and classes. She stressed the role played by female scholars in community-building: by working with the disadvantaged, caring for nature and the environment, and nurturing the potential of very young children, they were sowing the seeds of a future community. Inspired by Prophetic values, these communities, which placed women at their core, could draw on Islamic frameworks to offer an alternative to-what they perceived as-the problems of 'Western' society, including individualism and the absence of family and societal networks of support. Ustadha Nagebah suggested that the social context in the UK did not facilitate female scholarship, as it was built around the individual instead of being organised in support of a community. Islam, by contrast, offered a model that not only valued motherhood, but also provided societal support for women to engage in the public sphere as leaders in their communities.

\section{Beyond Guidance: Transcending and Pluralising Gender}

While Ustadha Nagebah stressed the unique way in which female scholars were able to guide and connect with their female students, she simultaneously held the seemingly contradictory view that gender was insignificant in her teaching: 'when teaching jurisprudence, theology, the Arabic language... the law is the law, it is absolutely insignificant as to what gender you receive the law from'. The practice of Islam, she explained, is a 'human experience' and therefore constrained within the earthly realm; Islamic knowledge, on the other hand, is based on the unity of the divine. Hill (2018) similarly describes the ways in which muqaddamas are able to hold paradoxical truths simultaneously by treating gender distinctions as an apparent (zahir) truth and absolute equality between genders as a hidden truth (batin). At the same time as performing feminine piety through acts of obedience and self-wrapping, muqaddamas employ mystical discourses to describe themselves as 'spiritual men' or to transcend gender distinctions altogether through unity with a genderless God.

In a similar fashion, Shaykha Safia Shahid preferred not to emphasise her gendered authority in presenting herself as a scholar. While she stressed the importance of 'female empowerment' through her work training a generation of young female scholars at the Women's Muslim College, she also told me that she viewed 'gender as irrelevant'. In her college, women taught and learnt traditional subjects to the same level as those taught in male-led institutions. She also pointed to the diversity of classes and courses she had delivered on a range of different topics. Women might have different experiences, she explained, and 'there are insights that women can offer, for example, about raising children, childbirth, marriage', but when it came to issues of spirituality, Islamic knowledge and scholarship, there was no difference between men and women, she clarified, drawing from the Sufi tradition that emphasises the 'ontological equality of man and woman in the Quran' (Spielhaus 2012). She pointed to Aisha, the Prophet's wife, whom she claimed was a great scholar and transmitter of knowledge: 'Most illustrious male companions of the Prophet (peace be upon him) used to ask for her advice and her counsel', she 
explained, emphasising the ways in which gender could be transcended in scholarly and spiritual pursuits and did not need to be constraining.

In elevating Aisha as a scholar, Shaykha Safia Shahid was not only transcending gender distinctions but seeking to pluralise the tradition from within. Other female authorities, such as Ustadha Iffet, were similarly involved in this struggle to move beyond monolithic models of pious leadership. When I met Ustadha Iffet in Birmingham in early 2019, a few years after the summer retreat, she had grown increasingly frustrated with the restrictive roles assigned to female scholars. She felt that guidance was being relegated to a lesser form of authority and that her work was being downplayed. She suggested that event organisers and audience members were requesting that she and other female authorities provide 'nurturing discussions, to provide spiritual highs, to be an emotional outlet', and were encouraging her to develop a style of teaching that was more 'emotional' than 'academic.' She explained, 'women in the audience don't want to hear my intellectual reasoning on an issue, my explanation of the different legal opinions, they don't want to know that kind of knowledge.' She had also been targeted and criticised for her online presence and her self-presentation: as someone who regularly wears a hijab, a nose piercing and make-up, she has been criticised for being 'liberal', insufficiently modest, and 'overly sexualised'.

In our conversation, she insisted that the Islamic tradition offered many female role models and did not narrowly circumscribe Muslim femininity. She suggested that Aisha, the wife of the Prophet, 'never had children' and 'didn't have that soft, motherly role. She was academic in her approach'. Similarly, while Maryam, the mother of Jesus, was loving and nurturing, she was also 'hard and powerful.' 'Her labour is described in the Quran as really difficult and she endures it with patience', Ustadha Iffet told me. A focus on 'motherly' topics, she felt, was excluding to women who were not mothers or who had no desire to be mothers. She also felt that it forced women to conform to one mode of femininity and to emphasise their emotional rather than intellectual qualities.

According to Ustadha Iffet, it was important to pluralise the tradition and recover a wide range of female pious public figures who were more than just mothers. Her comments echo Cheruvallil-Contractor's (2016, p. 17) observation that within Islamic seminaries and institutions in the UK, some of which rely too heavily on the reformist texts of Thanvi and Maududi, motherhood is 'over-signified'. Through a critical reading of the texts, Cheruvallil-Contractor argues that the Islamic tradition is relatively silent on the necessity of being a mother, what motherhood entails, and its ties to domesticity. Ustadha Iffet similarly problematises the naturalisation of motherhood and the narrowing of women's experiences to the role of wife and mother while also pluralising women's roles and recognising that the Islamic tradition is replete with examples of women who were not 'just mothers' (ibid. 2016, p. 15). She is drawing inspiration from feminist critiques of male-dominated Muslim communities but weaving these back into the tradition. Through her own work and self-presentation, she also seeks to pluralise imaginings of female Islamic leadership without resorting to binaries of liberalism/orthodox Islam or resistance/submission. However, as she confessed to me that afternoon when we met in Birmingham, she is also paying a price for it.

\section{Islam, Gender and Leadership}

The recent emergence of female Islamic authorities in the UK has been shaped by global, regional and national changes in Islamic knowledge production, as well as discourses around gender and Islam. Over the last couple of decades, we have witnessed the greater involvement of women in Islamic education initiatives and piety movements across the globe, as Muslim women from a range of different socio-economic backgrounds have sought Islamic knowledge with the aim of leading more ethical lives (Mahmood 2005; Deeb 2006; Bano 2017). This has led to the emergence or, in some contexts, the re-emergence or expansion of female-only study circles and classes and relatedly, to the 'feminisation of religious authority' (Jouili and Amir-Moazami 2006).

This trend has been accompanied by global discourses on gender equality, women's rights and female empowerment that have generated greater public debate about Muslim women and leadership. 
In the UK, the rhetoric of 'female empowerment' and 'gender equality' is often at the forefront of public discourses, media accounts or policy interventions that celebrate the inclusion of Muslim women as a sign that Islam is becoming more democratic and liberal and therefore, more 'British'. While the authorities discussed in this article do not employ these liberal discourses, the proliferation of these debates and the related rise of Islamic feminism have nonetheless encouraged greater public awareness and debate about female leadership within Islam. Indeed, as I have shown, while female authorities distance themselves from the binary of liberalism vs. orthodox Islam, it continues to be propagated not only through public discourses but also by mainstream Muslim communities, and thus impacts in significant ways on the experiences and claims to legitimacy of female authorities.

This liberal vs. conservative or orthodox trope also often shapes scholarly debates on female leadership. A large body of work has developed around progressive spaces and feminist scholarship, re-interpretation and argumentation (Hammer and Spielhaus 2013; Mir-Hosseini et al. 2015; Petersen 2019). Often, the latter are juxtaposed to conservative, traditional or orthodox ones, but they are also disproportionately represented in the scholarship and policy relative to the percentage of individuals involved in these movements. In Europe, the liberal/conservative or orthodox binary has also played out in public discourse through the ways in which female leadership has been tied to particular opportunities and constraints or enabling and constraining circumstances. For example, a liberalising context is often seen as having enabled the recent rise of female leaders through its values of equality and emancipation and the educational opportunities, spaces, resources and employment opportunities provided for women. In contrast, conservative or patriarchal cultural-religious norms and practices, families and communities are viewed as constraints or impediments to their public engagement. As a consequence, Muslim women are too often portrayed as the objects of male-dominant religio-cultural systems (Ewing 2008) and are positioned as either resisting or accommodating patriarchal norms and practices.

Recent scholarly work has sought to move beyond this liberal/orthodox divide (Bano and Kalmbach 2012; Kloos and Kunkler 2016). In the first significant edited volume on the topic, Bano and Kalmbach (2012) highlighted the varied and expanding work of female Islamic authorities in formal institutions and mosques thanks to growing educational and employment opportunities and broader shifts in Islamic authority and the roles and activities of women in Muslim contexts. Building on this research, Kloos and Kunkler (2016) pointed to the ways in which female leaders operate out of 'informal, relatively unregulated institutions and settings that allows them to compete with male dominated religious establishments' (ibid. 2016, p. 487). By focusing on the importance of 'communities' and the ways in which they react to female religious leaders, the authors expand on Bano and Kalmbach's (2012) tripartite model, which identifies three modes for constituting female religious authority: 'female agency', 'male invitation' and 'state intervention'. Significantly, the authors problematise the equation of liberal spaces with enabling opportunities and conservative communities or norms with constraining ones: just as male authorities may both encourage and limit female leadership, communities are positioned as both enabling and constraining female leadership.

Nonetheless, this emerging research on female Islamic leadership is often structured around questions relating to the enabling and constraining circumstances that shape the work of female scholars, or around their modes of resistance or accommodation within patriarchal environments or secular-liberal settings. ${ }^{14}$ As a consequence, it tends to over-emphasise the importance that gender equality or equity plays in the lives of these authorities. In Section 2, I similarly explored some of the ways in which female leaders understand the opportunities and constraints that they face in their work. While some stress the barriers they experience vis-à-vis their communities, others suggest that they do not encounter constraints and that the 'individualised' culture of the UK is in fact the main barrier they confront in their work. In Section 3, however, I moved beyond questions of opportunities/constraints,

14 For example, see also Nyhagen (2019); Piela (2013) and (Minganti 2012; Ismah 2016; Maritato 2017). 
resistance/accommodation to argue that female authorities do not necessarily view these questions as important or necessarily relevant. Rather, they are more preoccupied with ensuring that they act as good, pious leaders. Their work and complex subjectivities, therefore, cannot be fully captured by engaging solely with 'strong' theories (Stewart 2008), dominant frameworks around gender equality, authority and legitimacy or reductive binary logics that often dominate scholarly work and public debates on Muslim women.

The female authorities in the UK discussed in this article shift between emphasising gendered forms of authority - by stressing their natural abilities to care, empathise and guide young women-and transcending or pluralising gendered ideals. Like the muqaddamas described by Hill (2018), they draw from within the Islamic tradition and distance themselves from liberal discourses of empowerment. They also do not speak about resisting patriarchal interpretations or forms of authority and do not seek to reinterpret the texts by adopting feminist or human rights analytical tools (e.g., Mir-Hosseini et al. 2015; Wadud 2006). Rather, similarly to the women discussed in the literature on pious self-cultivation (Mahmood 2005; Deeb 2006), their starting point is the Islamic tradition and 'orthodox' interpretations. Their ultimate aim is to act as good, pious leaders rather than to contest male authority or to fight for more spaces for female scholars, although this is often one of the effects of their work. Moreover, in their efforts to pluralise the tradition from within, they complicate and move beyond the oppositions between liberal/orthodox Islam, resistance/accommodation and enabling/constraining contexts that dominate public and academic debate on the topic.

In contrast to the muqaddamas described by Hill (2018), the guidance female authorities in the UK provide is not only spiritual but also practical, and it involves contextualising and applying knowledge in the British context. Their legitimacy is gained not solely through their embodied performances, but also, importantly, through their discourse, argumentation and reasoning. As this article has shown, they apply an Islamic framework to 'think of new possibilities' (Bano 2017, p. 23) in their efforts to guide young female Muslims and their communities towards alternative, Islamic-inspired ways of living that contribute to British society while remaining critical of some of its less desirable dimensions. As a result, their teachings and experiences make space for more female scholars, but most importantly, these authorities imagine and develop new ideas on knowledge, and plural ideals for pious public engagement for Muslim women in Britain. By positioning themselves as natural guides while simultaneously transcending and pluralising their roles by drawing on different aspects of the Islamic tradition, female authorities are making possible diverse ideals and imaginings of what it means to be a publicly engaged Muslim woman in Britain that cannot be subsumed within binaries of enabled/constrained or liberal/orthodox Islam. These ideals expand our understandings of female Muslim subjectivities in Europe (Jouili 2015; Fernando 2014; Jacobsen 2011) and contribute to emerging work on changing forms of Islamic knowledge production in Europe (van Bruinessen and Allievi 2012).

\section{Conclusions}

In making sense of their authority, this new generation of leaders is navigating between claiming a distinctly female form of authority and recognising that they are more than 'just mothers' or 'just females'. These leaders both accept and critique not only the idea of guidance as women's natural role, but also the broader structures of Islamic authority within which their work is situated. Some see themselves through a notion of 'gender equity' (Deeb 2006) in which their work is unique and complementary to that of men. At the same time, some present gender as irrelevant, and others pluralise their roles and critique the ways in which their gendered roles position them in inferior positions within structures of authority and within British society. Through their multiple and fluid understandings of themselves, these leaders are able to reconcile seemingly contradictory notions of gender. The ways in which they make sense of gender, therefore, caution against an uncritical celebration of female religious authorities. While these new authorities might celebrate the new visibility and growth of female scholars, some also recognise that over-emphasising their femininity and gender can mask other aspects of their subjectivities and the varied nature of the work that they do. 
Female authorities are creatively engaging with the Islamic tradition by drawing selectively on different gendered ideals embedded within it and problematising a singular and monolithic notion of 'feminine piety', 'Muslim womanhood' or the necessary relevance of gender in matters of knowledge and spirituality. They draw predominantly from notions and role models taken from the Islamic tradition, but also draw inspiration from national and global discourses on women and leadership and structural critiques of patriarchy and weave these back into the tradition. In doing so, they offer plural visions of pious female forms of leadership that are neither liberal nor feminist, nor viewed as forms of resistance or accommodation, but that are rather based within the Islamic tradition, while reworking it in the British context. They navigate between naturalised ideals of pious motherhood, models from the tradition that de-emphasise motherhood, Sufi notions of transcending gender, and critiques of patriarchal structures of power and of individualistic society in the process of imagining new possibilities and ways of being. Even as they clearly separate themselves from feminist positions and transcend the binary between liberal and orthodox Islam, there is always a risk that by pluralising their activities, they are perceived as 'too liberal' within their communities. Ustadha Iffet's experience points to the way in which this dichotomy - which is circulated by mainstream public discourses on Islam but also within Muslim communities_continues to shape representations of female Islamic authorities in the UK and to flatten the nuances and complexities of their work.

Female authorities are not only transforming ideals of pious leadership, but also contributing to the development of new, multiple forms of knowledge in the European context. Through their guidance work, these female authorities join recent efforts to develop a European Islam (Ramadan 2004; Caeiro 2010; Bowen 2009, 2016). New generations of Islamic scholars in Europe, trained in the traditional Islamic sciences, are recognising the need to adapt and contextualise knowledge in the European context by bringing Islamic theology into conversation with secular forms of knowledge and addressing the lived realities and everyday struggles experienced by Muslims in the West (Lewis and Hamid 2018; Scott-Baumann and Cheruvallil-Contractor 2015). While these transformations similarly apply to the work of male and female scholars, they have largely been explored in the literature through the lens of male scholars and imams or the work of large, male-dominated institutions such as the Sharia Councils or European Council of Fatwa and Research (ECFR). As a consequence, juristic authority has also tended to dominate these accounts, reflecting broader public perceptions about dominant forms of Islamic authority (Kloos and Kunkler 2016). Recent research has shown, however, how young Muslims are more likely to approach individual scholars and teachers for advice and guidance with everyday problems rather than attend or consult large institutions such as the Sharia councils or seek a fatwa from a local mufti (Qureshi 2016, pp. 179-81).

Focusing on the varied and fluid nature of the guidance work of female authorities, therefore, highlights the importance of different forms of knowledge, authority and pious public engagement. It points to the increasing relevance of providing more than just legal judgments or fatwas by offering holistic, personal and collective guidance that blurs the lines between figh advice, spiritual guidance and counseling, and is based on trusting, intimate, empathic and less hierarchical relations with Muslim communities. Female authorities are developing new understandings of Islamic leadership as a form of care that is both for individuals and potentially transformative of society at large.

Funding: This research was funded by a Leverhulme Trust Early Career Fellowship.

Acknowledgments: I cannot express my gratitude enough to all the female Islamic authorities who took the time to meet with me and invited me to their many classes, events and retreats over the last few years. Their personal journeys are inspirational, and I continue to learn so much from them. I am also very grateful to Sophie Gilliat-Ray and Riyaz Timol, the editors of this Special Issue, for inviting me to their conference in Cardiff on Leadership, Authority and Representation in British Muslim Communities, and for offering advice on an earlier draft and support throughout the writing process. I also extend my thanks to the two anonymous reviewers, the editorial team at Religions and Kay Celtel for copy-editing the manuscript. I am particularly indebted to Sertaç Sehlikoglu and Zainab Kabba for their invaluable feedback and encouragement on earlier drafts.

Conflicts of Interest: The author declares no conflict of interest. 


\section{References}

Asad, Talal. 1986. The Idea of the Anthropology of Islam. Washington, DC: Center for Contemporary Arab Studies.

Bano, Masooda. 2017. Female Islamic Education Movements: The Re-Democratisation of Islamic Knowledge. Cambridge: Cambridge University Press.

Bano, Masooda, and Hilary Kalmbach, eds. 2012. Women, Leadership, and Mosques: Changes in Contemporary Islamic Authority. Leiden: Brill.

Bowen, John R. 2009. Can Islam Be French? Pluralism and Pragmatism in a Pluralist State. Princeton: Princeton University Press.

Bowen, John R. 2016. On British Islam: Religion, Law, and Everyday Practice in Shari'a Councils. Princeton: Princeton University Press.

Caeiro, Alexandre. 2010. The Power of European Fatwas: The Minority Figh Project and the Making of an Islamic Counterpublic. International Journal of Middle East Studies 42: 435-49. [CrossRef]

Cheruvallil-Contractor, Sariya. 2016. Motherhood Motherhood as Constructed by Us: Muslim Women's Negotiations from a Space That Is Their Own. Religion and Gender 6: 9-28. [CrossRef]

Deeb, Lara. 2006. An Enchanted Modern: Gender and Public Piety in Shi'I Lebanon. Princeton: Princeton University Press. Ewing, Katherine P. 2008. Stolen Honor: Stigmatizing Muslim Men in Berlin. Stanford: Stanford University Press.

Fernando, Mayanthi L. 2014. The Republic Unsettled: Muslim French and the Contradictions of Secularism. Durham: Duke University Press.

Gilliat-Ray, Sophie, Muhammad Mansur Ali, and Stephen Pattison. 2013. Understanding Muslim Chaplaincy. Farnham: Ashgate.

Hammer, Juliane, and Riem Spielhaus. 2013. Muslim Women and the Challenge of Authority: An Introduction. Special Issue of the Muslim World 103: 287-94. [CrossRef]

Hill, Joseph. 2018. Wrapping Authority: Women Muslim Leaders in a Sufi Movement in Dakar, Senegal. Toronto: Toronto University Press.

Ismah, Nor. 2016. Destabilising Male Domination: Building Community-Based Authority among Indonesian Female Ulama. Asian Studies Review 40: 491-509. [CrossRef]

Jacobsen, Christine M. 2011. Islamic Traditions and Muslim Youth in Norway. Leiden: Brill.

Jouili, Jeanette S. 2015. Pious Practice and Secular Constraints: Women in the Islamic Revival in Europe. Stanford: Stanford University Press.

Jouili, Jeanette S., and Schirin Amir-Moazami. 2006. Knowledge, Empowerment, and Religious Authority among Pious Muslim women in France and Germany. The Muslim World 96: 617-42. [CrossRef]

Kalmbach, Hilary. 2012. Introduction: Islamic Authority and the Study of Female Religious Leaders. In Women, Leadership, and Mosques: Changes in Contemporary Islamic Authority. Edited by Masooda Bano and Hilary Kalmbach. Leiden: Brill, pp. 1-30.

Kloos, David, and Mirjam Kunkler. 2016. Studying Female Islamic Authority: From Top-down to Bottom-up Modes of Certification. Asian Studies Review 40: 479-90. [CrossRef]

Lewis, Philip, and Sadek Hamid. 2018. British Muslims: New Directions in Islamic Thought, Creativity and Activism. Edinburgh: Edinburgh University Press.

Liberatore, Giulia. 2017. Somali, Muslim, British: Striving in Securitized Britain. London: Bloomsbury.

Mahmood, Saba. 2005. Politics of Piety: The Islamic Revival and the Feminist Subject. Chicago: University of Chicago Press.

Maritato, Chiara. 2017. Compliance or Negotiation? Diyanet's Female Preachers and the Diffusion of a 'True' Religion in Turkey. Social Compass 64: 530-45. [CrossRef]

Minganti, Pia K. 2012. Challenging from Within: Youth Associations and Female Leadership in Swedish Mosques. In Women, Leadership, and Mosques: Changes in Contemporary Islamic Authority. Edited by Masooda Bano and Hilary Kalmbach. Leiden: Brill, pp. 371-91.

Mir-Hosseini, Ziba, Mulki Al-Sharmani, and Jana Rumminger. 2015. Men in Charge? Rethinking Authority in Muslim Legal Tradition. London: Oneworld Publications.

Moore, Henrietta L. 2011. Still Life. Hopes, Desires and Satisfactions. Cambridge: Polity Press.

Nyhagen, Line. 2019. Mosques as Gendered Spaces: The Complexity of Women's Compliance with, and Resistance to, Dominant Gender Norms, and the Importance of Male Allies. Religions 10: 321. [CrossRef] 
Omar, Sara. 2013. Al-Qubaysiyyat: Negotiating Female Religious Authority in Damascus. The Muslim World 103: 347-62. [CrossRef]

Petersen, Jesper. 2019. Media and the Female Imam. Religions 10: 159. [CrossRef]

Piela, Anna. 2013. "Women are Believers in Their Own Right": One Muslim Woman's Challenge to Dominant Discourses Shaping Gender Relations in Islam. The Muslim World 103: 389-403. [CrossRef]

Qureshi, Kaveri. 2016. Marital Breakdown among British Asians Conjugality, Legal Pluralism and New Kinship. London: Palgrave Macmillian.

Ramadan, Tariq. 2004. Western Muslims and the Future of Islam. Oxford: Oxford University Press.

Scott-Baumann, Alison, and Sariya Cheruvallil-Contractor. 2015. Islamic Education in Britain: New Pluralist Paradigms. London and New York: Bloomsbury Academic.

Sehlikoglu, Sertaç. 2018. Revisited: Muslim Women's Agency and Feminist Anthropology of the Middle East. Contemporary Islam 11: 73-92. [CrossRef]

Sehlikoglu, Sertaç. Forthcoming. Working out Desire: Women, Sport and Self-Making in Istanbul. Syracuse: Syracuse University Press.

Spielhaus, Riem. 2012. Making Islam Relevant: Female Authority and Representation of Islam in Germany. In Women, Leadership, and Mosques: Changes in Contemporary Islamic Authority. Edited by Masooda Bano and Hilary Kalmbach. Leiden: Brill, pp. 437-56.

Stewart, Katheleen. 2008. Weak Theory in an Unfinished World. Journal of Folklore Research 45: 71-82. [CrossRef] van Bruinessen, Martin, and Stefano Allievi, eds. 2012. Producing Islamic Knowledge, Transmission and Dissemination in Western Europe. London: Routledge.

Wadud, Amina. 2006. Inside the Gender Jihad: Women's Reform in Islam. Oxford: Oneworld Publications.

(C) 2019 by the author. Licensee MDPI, Basel, Switzerland. This article is an open access article distributed under the terms and conditions of the Creative Commons Attribution (CC BY) license (http://creativecommons.org/licenses/by/4.0/). 
Article

\title{
Answering for Islam: Journalistic and Islamic Conceptions of Authority
}

\author{
Michael B. Munnik \\ Centre for the Study of Islam in the UK, Cardiff University, Cardiff CF10 3EU, UK; munnikm@cardiff.ac.uk \\ Received: 20 May 2019; Accepted: 7 July 2019; Published: 16 July 2019
}

\begin{abstract}
Media representations of Muslims in Britain have often disappointed both faith practitioners and scholars. Imputed failings include distorting beliefs or practices, essentialising the faith, and amplifying voices that are not representative of Islam. This last factor hinges on questions of authority: what journalists and Muslims recognise as authority can differ in important ways. Drawing on studies of journalism practice, prior professional experience, and ethnographic fieldwork and qualitative interviews in Scotland, I discuss the conventional preference among journalists for "official sources" and the problems this can present in terms of hierarchy in Islam. I contrast this with a less-studied imperative, also present in newsrooms, for "real people". This category matches well with Islam's decentralised tradition and presents an opportunity to understand how different kinds of sources are presented in media coverage. It is possible for journalists to ensure that these differing claims to authority are represented properly, though this requires knowledge and responsibility.
\end{abstract}

Keywords: Muslims in Britain; authority; journalism; journalist-source relations; representation; civic journalism; qualitative methods

\section{Introduction}

Authority is characterised in part by its audience; therefore, authority is relational. Gudrun Krämer and Sabine Schmidtke examine authority in their edited volume Speaking for Islam (Krämer and Schmidtke 2006), and they open with a pair of questions that indicate a shift in audience relevant for this article:

Who speaks for Islam? Who explains to Muslims whether human rights are a legitimate concept 'in Islam,' whether there is such a thing as 'Islamic values' and what they consist of, and whether violence can ever be justified from a religious point of view? (Krämer and Schmidtke 2006, p. 1)

The first question engages the subject—the one invested with authority-but leaves its audience open: the preposition "for" indicates "on behalf of". It is only in the second question that the preposition defines this audience: the one with authority is explaining things "to Muslims", narrowing the addressee to members of the religious community. Authority is thus exercised to articulate the limits of proper belief and practice to the community for which such limits are meaningful.

I am, however, interested in a broader addressee for the first question. Who is authorised to speak for Islam to the wider public, which does not necessarily consider itself Muslim? What this audience desires is not instruction on religious propriety that it can accept or reject for its own life. Rather, it wants information to help it understand an external phenomenon, often but not always with an edge of accountability. "Speaking for Islam" can thus become "answering for Islam", and journalists are often the primary audience through which the wider public is addressed.

The topics that Krämer and Schmidtke suggest Muslims might want explained, such as rights, values, and the justification of violence, are those journalists want explained as well. Studies on 
the representation of Islam and Muslims in Western news media have proliferated since the attacks on the World Trade Center and the Pentagon on 11 September 2001 (Poole 2002; Richardson 2004; Moore et al. 2008; Baker et al. 2013; Bleich et al. 2015). Kerry Moore and colleagues studied a sample of UK coverage of Islam from 2000 to 2008 and found that two thirds of the stories focused "on Muslims as a threat (in relation to terrorism), a problem (in terms of differences in values) or both (Muslim extremism in general." (Moore et al. 2008, p. 3). These preoccupations inform the questions for which journalists expect someone from within Islam to be answerable.

Muslims, in turn, argue that this coverage misrepresents Muslims and focuses on sensational topics, employing language that distorts, obscures, or willfully harms Muslims. Social research identifies dissatisfaction among British Muslims with media narratives (Samad 1998; Kabir 2010; Ali and Hopkins 2012; Al-Azami 2016). Even among sources who speak with journalists and contribute to news coverage, the primary word characterising that coverage is "negativity" (Munnik 2018). Muslim organisations in the UK are now countering this narrative: Muslim Engagement and Development (MEND) provide resources to equip individual Muslims or community groups to monitor and respond to media coverage (Muslim Engagement and Development n.d.); an informal monitoring campaign on social media has evolved into the Centre for Media Monitoring (Subramanian 2018; Muslim Council of Britain 2018).

Part of the problem is owing to different expectations of journalism. Philip Schlesinger (Schlesinger 1980) noted a wry response from journalists to his ethnography of BBC newsrooms in the 1970s, indicating that sociologists hold journalism to a different, even in their view impractical, standard. Barbie Zelizer (Zelizer 2013), herself a journalist before becoming a scholar, has identified poor communication and mistrust between the academy and the institution of journalism. As well, scholars have argued that the UK media has been a significant carrier of Islamophobia, whether incidentally or deliberately (Commission on British Muslims and Islamophobia 1997; Saeed 2007; Ogan et al. 2013).

It is beyond the scope of this paper to address all of the suggested failings of journalistic coverage of Islam and Muslims. I examine one source that accounts for some of this dissatisfaction: sourcing and the representation of authority - who is made to speak for, or answer for, Islam. John Richardson found that in his survey of British broadsheet representations of Islam, sources whom he classes as "illegitimate ('terrorist') organisations are the most frequently quoted Muslim primary source", amplified to the detriment of Muslims who are not terrorists and who might criticise violent activities (Richardson 2006, p. 112). In Salman Al-Azami's study of religion in the media, his focus group of Muslim audiences gave "the overwhelming view ... that the media ... promoted hate preachers like Anjem Chowdhury [sic] (of Al-Muhajiroun) in such a way that they represented the views of all the Muslims in the world." (Al-Azami 2016, p. 131). Both scholars and "everyday Muslims" question the representativity of the sources journalists choose when reporting on Muslims in Britain.

How journalists understand source authority and what expectations they have of sources differs from authority within Islamic structures. In the following two sections, I review the literature-first from journalism studies, paying attention to alternative programmes defined as public or civic journalism and considering whether their incorporation of more diverse sources offers a different model for evaluating authority. I then consider how authority is understood in Islam, including recent challenges to traditionally conceived authority. In the fourth section, I observe how these two conceptions manifest among working journalists, drawing on fieldwork conducted in Glasgow, Scotland. From this, I argue that the bespoke demands of authority in journalism make the presentation of Islamic authority a challenge, but that journalists have the capacity to frame Islam's authority structures within their reporting by making it clear in their stories the ways in which a given source might be authorised. Though this does not account for deliberate, ideological misrepresentations of Islam, it provides some tools for improvements within the broader discussion of religious literacy and responsible journalism (Petley and Richardson 2011). 


\section{Source Authority in Journalism}

Sources are one of several elements that contribute to the selection and construction of news stories, as identified in some of the classic newsroom ethnographies of the 1970s and 80s (Tunstall 1971; Tuchman 1978; Gans 1980; Fishman 1980; Schlesinger 1987). Herbert Gans, writing about US national news media, suggests that of all such contributing elements, "those governing the choice of sources are of prime significance" (Gans 1980, p. 281), and Jeremy Tunstall, looking at specialist correspondents in UK print media, says journalists who report news- "gatherers", rather than editors or, as he calls them, "processors" - are "oriented towards their news sources" above any consideration for audience or rival journalists (Tunstall 1971, p. 30). These observations provide the foundation for research into journalist-source relations, a key element of the study of media production. Beyond their relationship to the news makers, source statements and activities provide the stuff of news itself. Studies have attempted to identify news values to determine what gets covered and what does not (Galtung and Ruge 1965; Harcup and O'Neill 2001, 2017), but such lists are derived from coverage, whereas ethnographic production studies are better equipped to assess the processes of news selection. Richard Ericson and colleagues define news as "a representation of authority. In the contemporary knowledge society news represents who are the authorized knowers and what are their authoritative versions of reality." (Ericson et al. 1989, p. 3). To discuss source authority, then, we must begin by considering sources themselves. Who are they, and what influence do they have on journalists, their practices, and the stories that are eventually published?

Gans defines sources as "actors whom journalists observe or interview ... [and] the most salient characteristic of sources is that they provide information as members or representatives of organized and unorganized interest groups, and yet larger sectors of nation and society." (Gans 1980, p. 80). This definition is broad enough to encompass a range of sources in terms of their authority, as they can be but are not necessarily "representatives" and the groups to which they are attached can be "organized or unorganized".

Yet both journalists and scholars make distinctions within that range. The typical distinction is between official and unofficial sources, and these designations are bound up in power and authority. Gans notes that "[p]owerful or skilled sources know how to make contact with reporters; but many people - perhaps most—lack this knowledge." (Gans 1980, p. 125). Those elite few become effective at advancing the goals and messages of their organisation. Stuart Hall and colleagues call them "primary definers" who enjoy a "structured preference ... [to] establish the initial definition" of an issue or problem in the news media (Hall et al. 1978, p. 58). Journalists, in this analysis, are not mere ciphers who transmit the views of these powerful groups, but they do reproduce these groups' definitions within the debate. David Miller and colleagues from the Glasgow Media Group similarly identified this in reporting about AIDS in Britain: various source communities spoke to the issue, but the scholars found "structural inequality between organisations in the field. These inequalities are the outcome of the financial, institutional and cultural resources available to source organisations." (Miller et al. 1998, pp. 123-24). Schlesinger (Schlesinger 1990) recognises the inequality of resources available to sources, though he rejects the assumption implied in Hall's "primary definition" that powerful, official sources have automatic access to the media narratives; rather, he views access to the news as an accomplishment that sources achieve again and again in the cycle of news.

This characterises the work of source communities to get their messages in the news, but the relationship is two-way: journalists also contact sources for information or comment, whether or not those sources want to be in the news. Nonetheless, whom they prioritise for contact is also structurally supported in favour of official sources. Sociologist Mark Fishman (Fishman 1980) studied the practices of beat reporters at a California newspaper, noting how the demands on their professional time made the routines of official sources key to their success. By having particular bureaucratic sources they could turn to- the city council, the courthouse, the police department-reporters could cover news efficiently. This information was "right" or factual because of its connection to the governmental and state authorities: for a police spokesperson to say a certain individual was charged with a crime 
was correct because the police had done the charging; for a courthouse spokesperson to say that individual was found guilty was correct because the judge had convicted her. The material was trusted because it was true and efficient because it was easy, and so this reliance on official sources became routinised; Oscar Gandy, in a separate but contemporary study, calls such routines "information subsidies" (Gandy 1982). Official sources become, in Fishman's useful phrase, "socially authorized and socially sanctioned knowers" (Fishman 1980, p. 95), distinct from non-bureaucratic sources who cannot benefit from the assumption of the facticity of what they say.

Just as journalists can become socialised into prioritising official sources, scholars can imagine such source relations to be the only ones that matter. In his critique of media production research, Schlesinger finds that "[e]mpirical studies ... have largely failed to investigate the forms of action adopted by non-official sources." (Schlesinger 1990, p. 76). We see this absolutism in the introduction to Ericson and colleagues' comprehensive study of crime reporting in Canada in the 1980s:

It is hard to imagine a mainstream newscast or newspaper that cites only the man on the street, the cop on the beat, the hospital porter, the House of Commons backbencher, the university student, and the clerk of the court. It is thus easy to see why they must cite the executive in his office, the chief of police, the hospital administrator, the cabinet minister, the professor, and the chief justice. These are the people who are recognized socially to be in a position to know. (Ericson et al. 1989, p. 4)

This thought experiment, with the ring of common sense, yields to a naturalistic fallacy. Their rhetoric overstates the case: the word "only" in their first sentence presents a straw man. No one would suggest that news reports "only" focus on everyday workers or other non-official sources. Such reports would lack due attention to the big picture and to events and decisions of communal importance. Ericson and colleagues tell us that journalists "must" include official sources, but we could easily imagine the converse in which news reports "only" publish such voices. Advocates of public or civic journalism, as we see below, criticise reports of this kind as out of touch with the public and limited to a narrow, bureaucratic definition of what matters in society. Similarly, Fishman noted that journalists with a particular beat or specialism might learn things outside the bureaucratic system, such as crime reporters receiving victim or witness testimonies. Yet they hold off reporting such accounts until the events have manifested in the bureaucratic system-a suspect is charged or appears in court. Until such authorised knowers validate the information, it is "officially invisible" (Fishman 1980, p. 76).

\section{More- or Less-Official Sources and "Real People"}

The binary pairing of official and unofficial or non-official sources makes, I believe, too blunt a delineation. Paul Manning defines official sources as those "associated with the apparatus of government and the state"; everyone else is, therefore, unofficial (Manning 2001, p. 140). This restriction ignores the authorisation that comes from being a representative body or holding capital, especially financial capital. Thus the chief executive officer of an international bank-the kind of source Ericson and colleagues would recognise as authorised knowers-sits uncomfortably within the category of "unofficial sources." I suggest that Manning's state associations are better classed as "bureaucratic," a term which features repeatedly in Fishman's study of news routines. Journalist and linguist Allan Bell considers this designation as a threshold of activity: non-bureaucratic sources typically need to be doing something in order to make the news, whereas authorised bureaucratic sources can accomplish things by saying them: "Talk is news only if the right person is talking." (Bell 1991, p. 131; cf. Austin 1975).

David Deacon has noted further that in the sphere of voluntary organisations, to which he accords unofficial status, we can still find a range from "small community-based groups operating on a financial shoestring to large, highly professionalized, international organizations controlling millions of pounds." (Deacon 1996, p. 176). Robert Hackett (Hackett 1985) proposed a "hierarchy of access" which demonstrates this unequal distribution of power in a fine-grained ranking, demonstrating not 
only the greater access and influence of bureaucratic sources but the various uses to which the source types are put. Binary oppositions, then, are insufficient for analysing the distribution of power among journalists' sources. In its place, I propose applying a spectrum of more- or less-official sources, making the conditions of each source a matter of empirical study.

Beyond the spectrum of more- or less-official sources, there are truly unofficial sources. Informed by both scholarship and my prior professional practice, I refer to such sources as "real people". ${ }^{1}$ Research on this topic is sometimes embedded in assessments of what is called civic or public journalism (Glasser 1999; Rosen 1999). The movement "celebrates the absence of clear and precise definitions," but in its various expressions, it attempts to bring institutional journalism closer to the interests, and in many cases the voices, of the people (Glasser 1999, p. 5). Results concerning sources are mixed: Brian Massey (Massey 1998) found numbers of "non-elite" sources in civic journalism experiments increased, but their prominence in stories did not; David Kurpius (Kurpius 2002), however, found that civic journalism practices did improve the diversity of sources. Joyce Nip ventured a list of the broad qualities and preoccupations of civic journalism, including the practice of "giving ordinary people a voice," which includes a reference to "real people", set off in quotation marks as I do (Nip 2008, p. 180). Nip conducted an ethnography of a daily newspaper in Savannah, Georgia, to discover whether the practices of civic journalism were still present in a committed newsroom several years after the movement was first articulated. Some of these practices had been routinised, but others-especially "mechanisms of active listening to the community"-were not (Nip 2008, pp. 191-92). "Real people" also feature as a category of sources in David Kennamer and Jeff South's comparison of civic and traditional news coverage of the 2000 election in the state of Virginia (Kennamer and South 2002, p. 43). More recently, and outside of the US context, where so much of the research on civic journalism has taken place, scholars have noted how technology has increased the presence and prominence of "ordinary people" in Belgian newspapers (De Keyser and Raeymaeckers 2012). A team of Dutch scholars concurred but determined that this presence was largely through the use of "vox pops" and thus not a substantive contribution to the news (Kleemans et al. 2015). Zvi Reich's (Reich 2015) study of sources in Israeli news similarly shows a negligible contribution from "ordinary citizens".

Journalists using the term "real people" are distinguishing a type of source from those with an agenda or a bureaucratic role. Andrew Garbett and colleagues, in evaluating how BBC journalists in London recruited sources from the community, quote one journalist who wanted "'a real people file" in contrast to "the expert file"': such sources made news "more engaging," but their non-institutional character made them difficult to identify and recruit (Garbett et al. 2014, p. 5). They are conceived of as ordinary people to whom things happen or who do particular things that express wider stories in the community. The more organised a group becomes, the less inclined journalists are to consider its members "real people": Garbett and colleagues note that even "citizen journalists" such as bloggers did not fit their participants' definition of "real people", though they were imagined as a potential conduit to such sources (Garbett et al. 2014, pp. 5-6). To the extent that journalists fear the intrusion of "spin" (Sumpter and Tankard 1994; McNair 2004), "real people", in an ideal sense, do not spin stories: they are honest, and they merely relate a narrative from their experience. The quality of honesty allows "real people" to function, for journalists, as a kind of Everyman to which the putative audience connects as it cannot a politician, a committee chair, or an academic expert. "Real people", then, can be understood as a counter-trend to the reliance on bureaucratic or more-official sources.

1 For eight years, I worked in public broadcasting in Canada. The newsroom I worked in adopted a public journalism campaign in the mid-2000s, conducting demographic analysis of the city, comparing this analysis with the categories of voices present in our coverage, and actively cultivating source relationships with categories that were absent from that coverage (Munnik 2016). Even prior to this experiment, producers insisted on the use of "real people" as a valuable addition to stories. 


\section{Authority in Islam}

Authority in Islam starts with the Prophet Muhammad, who embodies, in some ways, an archetype of Max Weber's idea of charismatic authority (Weber 1968). The question facing early Muslims was how to effect this authority after his death. On the one hand, the revealed scripture provides a large measure of guidance: the Qur'an is full of instruction. Furthermore, the sunna or the example of the Prophet gives clarity to the prescriptive nature of Islam. The sayings of the Prophet and stories attributed to him begin an interrogative process of authority, by which Muslims ask for answers concerning what God wants of them in a specific circumstance.

These bodies of knowledge, however, do not speak for themselves, and so the interpreting community becomes an additional source of authority. As Krämer and Schmidtke write, "[t]o deal with the Qur'an and sunna not just as a source of moral guidance but as normative textual proof regulating human activity in all spheres of life requires expert knowledge, a knowledge premised on a minimum level of literacy and the requisite training" (Krämer and Schmidtke 2006, p. 5). The authorisation of individuals is a social process, contingent and developing. Authorising one version closes down another, and competition for primacy characterised the early period of the formation of Islam (Berkey 2003). Hamid Dabashi, following the Orientalist scholar Montgomery Watt, perceives that "'[o]rthodox' and 'heterodox' are polemical, not hermeneutic terms" (Dabashi 2002, p. 71). Dabashi considers different solutions to the continuation of Muhammad's authority and the correct interpretation of scripture that jostled for legitimacy in the first years after the Prophet's death; these would develop, in time, to what we recognise as Sunni and Shi'ite positions, as well as a broad envelope of approaches and doctrines collectively classed as Kharijite. Rather than taking a theological position on the correctness of one branch or another, Dabashi looks urges us to look sociologically at "the particular position that they maintain vis-à-vis Muhammad's charismatic legacy." (Dabashi 2002, p. 72).

The two expressions that comprise the majority of Islam globally have formalised and routinised their positions. Underpinned by the fundamental insistence in Islam on tawhid or the oneness of God, these structures give a certainty and rigidity to the interpretations of the authorised interpreters. Infallibility is attributed in Shi'ite Islam to the Imams, given additional political expression in current-day Iran through the doctrine of velayat-e-faqih (Amirpur 2006); for Sunnis, it is manifest in the idea of consensus of scholars or ulama (Berkey 2003; Zaman 2006). Yet rigid authority is not the only ingredient in effective authority: Dabashi writes that "[n]o claim to authority, in its bid to offer a superseding culture, can survive without a built-in remissive motif that gives the interdictory motif flexibility and thus authority." (Dabashi 2002, p. 154). For the more centralised Shi'ite structures, this flexibility comes from the mystical, hidden knowledge ingredient in the Imam's authority (Robinson 2009, p. 341). For Sunnis, the diffusion of authoritative interpretation across four schools or madahib has fostered "[t]he plurality of Islamic thought" over time and context (Bano 2018a; for practical examples of this, see Zaman 2002). This mixture of rigidity and flexibility has allowed Islamic authority to endure and adapt over fourteen centuries, mutable political environments, and global migration.

Scholars have identified a new set of figures claiming religious authority within Islam, outside the traditional structures. Technology has driven this change- first through the development of print and now through the spread of digital media. Historian Francis Robinson (Robinson 1993) identified print as a disruption to the typical method of transmitting knowledge in Islam: the primacy on oral transmission, memorisation, and the ijaza as the certification of a scholar's knowledge are part of the routinisation described above. Print was adopted late in South Asian Muslim societies, for the purpose of defending against colonialism, and it fostered three religious changes there: what he calls "Islamic protestantism", or a sense of the sufficiency of accurate scriptural knowledge; a wider ummatic consciousness; and "the erosion of the authority of the ulama as interpreters of Islam." (Robinson 1993, pp. 242-44). Books could be consulted and interpreted by, as it were, "real people": in Robinson's memorable phrase, "any Ahmad, Mahmud or Muhammad could claim to speak for Islam." (Robinson 1993, p. 245). Peter Mandaville considers this in the context of transnational Muslim communities in late-twentieth and early twenty-first century Britain, where the increase of digital media 
has "fragment[ed] traditional sources of authority such that the locus of 'real' Islam and the identity of those who are permitted to speak on its behalf become ambiguous." (Mandaville 2001, p. 176). John Esposito and Dalia Mogahed (Esposito and Mogahed 2007), interpreting the findings of a global Gallup poll among Muslims following 9/11, take this to the extreme: the title of their book asks Who Speaks for Islam? The subtitle, What a Billion Muslims Really Think, implicitly answers, "everyone."

Muhammad Qasim Zaman is quick to discourage us from exaggerating this erosion: the ulama have proved capable of adapting to technological changes, with both the early adoption of print and more recently, as with the example of alim Yusuf al-Qaradawi, the Internet (Zaman 2002, 2006). Yet there emerges the challenge of what is called the "new Muslim intellectual" (or "Islamist new intellectual" or "Muslim activist intellectual"; see Roy 1994; Abu-Rabi" 1996; Eickelman and Piscatori 1996; Esposito and Voll 2001; Kersten 2011). In contrasting their status with the rationalised ulama, scholars note that these figures are "Sufi shaykhs, engineers, professors of education, medical doctors, army and militia leaders, and others" (Eickelman and Piscatori 1996, p. 131; cf. Cesari 2004, p. 115). However, while this range of backgrounds can serve tacitly to derogate these scholars, the characterisation can occlude the depth of their study and knowledge base- a base that is not restricted, however, to Islamic tradition but also "Western civilisation, now so freely made available by print, to find answers to contemporary challenges." (Robinson 1993, p. 246). This recourse to a wide base of knowledge and the need to address contemporary challenges distinguishes what authority is increasingly seen to demand.

Masooda Bano attempted to capture both sides in her recent project studying modern Islamic authority. Her research engaged both traditional institutions that train ulama such as Cairo's al-Azhar and the Dar-ul-Uloom in Deoband (Bano 2018a) as well as newer institutions and scholars in non-Muslim-majority contexts such as Zaytuna College and Ebrahim College, Hamza Yusuf and Tariq Ramadan (Bano 2018b). For Bano, authority in Islam is derived from three sources: knowledge of Qur'an and sunna, or ilm; the moral authority of the scholar, or adab; and their ability to relate to the realities of the current context (Bano 2018a, pp. 30-31). It is this third quality, Bano argues that contributes to the increased prominence of these new Muslim intellectuals, though she agrees with Zaman that this does not necessarily mean ulama are irrelevant or failing to adapt to this new environment. However, she notes that the "primary audience" of these new leaders are "university-educated Muslims" living, working, and studying in the West, who are trained to recognise arguments that speak to and reflect their context (Bano 2018b, p. 25).

This attentiveness to audience returns to the point with which I opened this essay, namely that authority is relational and is conditioned by the addressee. Krämer and Schmidtke note that "it is the willingness of others to credit any given person, group or institution with religious authority that ultimately renders it effective." (Krämer and Schmidtke 2006, p. 2, emphasis original). Mandaville, reflecting on British Muslims apart from the Muslim-majority context from which so many came, writes that "[s]ources of social authority are received and understood in a variety of ways by a given political community, and often this reception will be dependent on where they (community and authority) are located within the social discourse of a particular time and place. Social authority is hence never immutable." (Mandaville 2001, p. 80, emphasis original). As we shall see, this can create challenges for journalists who are presented with authority that is not fixed or stable, and these journalists will often lack the training to recognise how these authorities are being received by their political communities.

One final point on the religious and social authority of Islamic leaders needs addressing here, and that is the role of the imam in the contemporary UK context. Jocelyne Cesari identifies a range of leadership types in twenty-first century Islam, and one telling figure is not the "new Muslim intellectual" described above but what she calls the "parochial leader" (Cesari 2004). This type, Cesari finds, has superseded the "bureaucratic leader" who represented diasporic Muslim communities by maintaining links with the Muslim-majority countries from which these people migrated in the second half of the twentieth century. Parochial leaders "are similar to Catholic priests or Protestant pastors, who have traditionally derived their authority from the local parish." (Cesari 2004, p. 127). Imams take-or are given - a central role in affairs surrounding the mosque for which they have responsibility 
and the Muslims who come for worship and community activities. Unlike imams in Muslim-majority contexts, who are more like civil servants and have prescribed activities, such a leader "is imam, cadi, mufti, and teacher all at once; he presides over burials, represents the community in official ceremonies, and so on. The list of his roles both within and without the religious community is potentially endless." (Cesari 2004, p. 130). Though participants in my study suggested "the imam" did not hold such responsibility in Britain, we shall nonetheless see how this construction of authority conditions ways of thinking about representative leadership.

\section{Source and Authority in Reporting Islam: A Fieldwork Example}

I conducted research between August 2012 and March 2014 in Glasgow, Scotland, using interviews and participant observation to examine relations between journalists and sources in the construction of news about Islam and Muslims. Part of my project inquired into how journalists conceived of Islam as a subject and Muslims as sources of or part of the content within their reports. It is from these data that I derive my insights into the question of how journalists understand authority.

Out of thirty interview participants, twelve were journalists. Three others were classed as sources but either had occupied journalistic roles previously or had some measure of news work at the time of my study; to the extent that they spoke in our interviews "as journalists", I have included their insights on sources. They worked for a range of mainstream news organisations in both print and broadcast, tabloid and broadsheet, and occupied both reporter and editor roles. One of the journalists identified as Muslim. My sampling was purposive, seeking to include journalists who had reported on Islam or Muslims at some point in their career. Participation in the study was voluntary, and due to the public nature of their work, I offered to either disclose or anonymise their identity, as they wished. Anonymised participants are given descriptive, general titles, though I have tried as much as possible not to identify any of the participants, as it is irrelevant to this analysis.

During our interviews, I asked specific questions about Muslim sources they spoke with; I also asked about stories they had worked on or might consider as newsworthy, and some source types were generated from these answers. I transcribed the interviews-verbatim for those I had recorded and in summary form for the others-and coded these transcripts. From this, I developed a list of Muslim sources in the journalistic ecosystem of Glasgow and Scotland. The list includes both individuals and groups or institutions, specific sources and generalised types, and actual and hypothetical sources.

\subsection{More- or Less-Official Sources and Authority}

All but one of the specific sources in Table 1 would be classed as more- or less-official (I discuss Faiza Amjid below). They are organised and unorganised interest groups or representatives thereof, following Gans's broad definition. Politicians such as Humza Yousaf and Soriya Siddique, and councillors generally, have bureaucratic authorisation to make things happen. Others, such as lawyer Aamer Anwar and charity director Robina Qureshi, have authority within their professional roles. Few, however, occupy an explicitly religious position. None of the specific or general sources is an alim, and none of the journalists in my study even mentioned the word. Some of the named sources could be described, as one journalist did, as "Muslim commentator", but their authority derives more from their articulateness and identification with Islam than any religious training: Abdel Bari Atwan is a journalist (in London, not Glasgow), and Azeem Ibrahim positions himself as a policy consultant, though he has written about Islamic extremism and the Rohingya Muslims of Myanmar. Institutions such as Radio Ramadhan, Amina, and the Muslim Council of Scotland offer support for a religiously defined community, though the work of the latter two often encompasses social and political matters. Similarly, Osama Saeed was for a time a spokesperson for the Muslim Association of Britain and the Scottish-Islamic Foundation, which took on social and political advocacy for Muslims. I would not class any of these sources as "new Muslim intellectuals" of the kind described above: they do not activate any religious authority, though they may be called upon by journalists to answer for Islam, as I discuss below. Following the terminology from Stephen Jones and colleagues, such sources have 
"standing" in terms of esteem and a social role but not "authority" in a specifically religious sense (Jones et al. 2015, pp. 216-18). It is also worth noting that these sources represent an expansion of source diversity from Richardson's earlier study, notable for its "relative absence of authoritative sources" who were Muslim (Richardson 2006, p. 113); his list, of course, derives from a content study, whereas my list comes from interview data.

Table 1. Muslim sources mentioned by journalists in Glasgow, Scotland.

\begin{tabular}{|c|c|c|}
\hline $\begin{array}{c}\text { Specific } \\
\text { Sources-Groups/Institutions }\end{array}$ & Specific Sources-Individuals & Generalised Types \\
\hline $\begin{array}{l}\text { AMINA-Muslim Women's } \\
\text { Resource Centre }\end{array}$ & Faiza Amjid & $\begin{array}{l}\text { Allison Street residents and shop } \\
\text { owners }\end{array}$ \\
\hline Awaz FM & Aamer Anwar & Councillors \\
\hline East Renfrewshire mosque group & Abdel Bari Atwan & Informal networks \\
\hline Feed Glasgow & Azeem Ibrahim & Mrs. Gupta/Mrs. Gandhi ${ }^{1}$ \\
\hline Glasgow Central Mosque & Robina Qureshi & $\begin{array}{l}\text { Muslim women who do or do not } \\
\text { wear the veil }\end{array}$ \\
\hline Govanhill Baths Community Trust & Osama Saeed & $\begin{array}{l}\text { Second- or third-generation } \\
\text { Muslims }\end{array}$ \\
\hline Govanhill Housing Association & Soriya Siddique & The imam \\
\hline Muslim Council of Scotland & Humza Yousaf & The mosque \\
\hline \multirow[t]{3}{*}{ Radio Ramadhan } & & Women converts \\
\hline & & $\begin{array}{c}\text { Young people breaking Ramadan fast } \\
\text { at McDonald's }\end{array}$ \\
\hline & & $\begin{array}{c}\text { Younger generation who understand } \\
\text { how media work }\end{array}$ \\
\hline
\end{tabular}

${ }^{1}$ Items in italics are hypothetical sources.

Several journalists referred to "the mosque" and "the imam" as a general category, with some also discussing specific communities: the Glasgow Central Mosque and a group attempting to establish a mosque in East Renfrewshire, a suburb of the city. Several of those participants suggested "the mosque" was insufficient for and "the imam" not interested or not able to meet journalists' needs. Two participants caricatured journalists "going to the mosque" or "ringing up the imam" for comment: the former was pitched as a kind of low-hanging fruit, suggesting that their less informed colleagues associate Islam with religion, determine the mosque as "where Muslims go to pray," and think no further about where and how to access Glasgow's Muslims. The typical imam was presented as too old (" 80 "), unversed in English, and not inclined to give any comment to the press anyway. For some, the mosque in general, or the Glasgow Central Mosque in particular, was out of touch with real Muslims, real attitudes, or real events. The East Renfrewshire mosque group was classed as a good story, though a difficult one to tell: one journalist used ideal types to describe it, referring again to the "poor 80-year-old guy" whose "English is poor" and will not speak on the record. The second type he invoked is "the younger set-guys in their forties, fifties, sixties, born in the UK". These sources were deemed good for information but ultimately not useful because of their reluctance to be quoted publicly.

This set of descriptions contrasts with Cesari's depiction of the imam as a parochial leader who accomplishes a range of authorised tasks for Muslims within their notional parish. I attribute some of this attitude to a desire to appear knowledgeable and current in the interview context: some of the journalists may have wished to position themselves as better than others in the industry when speaking with a university researcher on Islam. The role of the British imam has changed significantly, and more research is needed to capture this professional figure. In time, findings may trickle down to the 
consciousness of working journalists. It is also the case, though, that the parochial frame does not reflect the kind of authority these journalists were interested in. One journalist put it to me that "the faith has no phone." He was demonstrating knowledge of Islam's non-hierarchical and decentralised structure. Another mentioned colleagues asking why there was no "Muslim pope." The word "pope" is resonant for Glasgow's Christian sectarian context, where the models of Catholicism and Presbyterianism offer contrasting examples of authority. The Catholic Church is hierarchical: when the archbishop speaks for Catholics, he does so with some clout, because he is institutionally charged with administering faith matters in the archdiocese. Even the press officer at the archdiocese is authorised in a particular way (though see Beaudoin 2012). The Church of Scotland is decentralised: though there is a head office in Edinburgh, it does not speak "for" the denomination or its members. From what participants told me, the simplicity of the strong Catholic structure makes it journalistically useful. ${ }^{2}$

Structurally, Islam resembles Presbyterian decentralisation. Yet some sources from some Muslim groups in the city do position themselves as spokespeople. This is the context in which one journalist told me about "the younger generation, who understand how media work", mentioned on Table 1. He said these sources tired of what they perceived as a fumbling articulation of public views from their elders in the faith and started presenting themselves to journalists, organising voluntary coalitions, and issuing press releases. This work grew in response to 9/11 (Munnik 2017), when journalistic interest in Muslims also grew. He said they were careful not to overstate their authority or representativeness, but they spoke with strength and verve, unafraid of being controversial. Participants compared this expression of Islam to the Catholic archdiocese leaders, who articulate a clear and controversial view on moral matters. They suggested that these kinds of sources are better positioned to control the direction of a story and generate effective and ongoing coverage of an issue.

Thus, out of a familiarity with technology and British media discourse, and responding to a need from journalists for comment, this category of source appropriates authority. These dimensions are similar to what scholars have observed in the "new Muslim intellectual" type described above. Crucially, though, they are not speaking about Islam to Muslims, though they are answering for Islam to the wider public. As much, for example, as Osama Saeed was invited to rebut statements by Anjem Choudaryy in the Scottish media, both are elevated to a representative status that may be more useful for journalists than for Muslims. One journalist spoke of his awareness of the need for caution and information: "I get the impression that a lot of the people we go to as kind of Muslim leaders are not viewed as such by lots of Muslims. That makes it hard." He advocated journalists becoming more familiar with Muslim communities as a way of improving on that tendency, but he also appealed to Muslims to make it "a bit more clear" who the satisfactory spokespeople are. The answer, of course, can be posed as a question: who is satisfactorily representative depends on whom you ask.

\section{2. "Real People" and Authority in Islam}

Several of the sources listed on Table 1 would be classed as unofficial, or what I am calling "real people". They lack the authority markers that officialise them, though they are sought as sources because of the religious dimension of their activity. All but one are generalised types rather than specific individuals or groups, and they were a mixture of actual examples that journalists had engaged for stories, such as "Allison Street residents and shopkeepers" or "women who do or do not wear the veil", or hypothetical examples who could be engaged for an imagined story, such as "young people breaking their Ramadan fast at McDonald's". "Mrs. Gupta/"Mrs. Gandhi" is a hypothetical but concrete construction raised by two different journalists as a counterpoint to an equally hypothetical

2 It is worth noting that the presence of a "Muslim pope" or, less crudely, a phone for the faith, is no guarantee against negative coverage. Though Catholic leaders in Scotland have a clear and distinctive communication protocol, the church has nevertheless been embroiled in reports of scandal and negativity (e.g., Deveney 2013); neither are Muslims in Britain languishing in obscurity and hoping for more presence in the news media. It is the quality, not the quantity, of coverage that concerns Muslims and scholars alike. 
ethnic Scottish woman. In one case, "Mrs. Gupta" was offered instead of "Mrs. Smith" as a local shopkeeper who could be included in a story for which the person's religion was irrelevant. In the other, "Mrs. Gandhi" was counterpoised with "Mrs. Beattie" in a hypothetical news story that would not be news at all if it had happened to a white, Christian person. The specific example is Faiza Amjid, a young Muslim woman commissioned to write an opinion piece on her decision not to wear the veil.

"Women converts" refers to a collection of sources featured by one journalist in profiles for a tabloid newspaper. These sources were quoted concerning their religious feelings or motivations, but they are not religious authorities, and the fact of their conversion is not in itself newsworthy enough to merit the story. One was featured because she was moving with her family to Baghdad in 2004; another received coverage because he had published a memoir. A qualified exception is the profile of Gillian Amin, an "ordinary" Scot whose conversion was used as a local example to follow national news that Lauren Booth, sister-in-law of former prime minister Tony Blair, had converted to Islam. Though the type "second- or third-generation Muslims" seems similar to the younger generation type discussed above, the latter has some authority in the way the journalist described it that places it on the spectrum of more- or less-official sources. The former denotes a "real people" designation which identifies groups of Muslims who are the children or grandchildren of immigrants. Not all of them are familiar with media needs and priorities, and this lack of familiarity may in fact make them more attractive to journalists seeking sources for certain kinds of stories.

As I mentioned above, "real people" have the advantage of being without spin, in the imagination of journalists. One journalist described a story idea proposed in her newsroom during Ramadan that was interesting but "too late" to pursue. Ramadan occurred in the summer in 2013, and the journalists considered school-aged children who might be fasting during the day while taking physical education classes which would require them to run and be active in an unusually hot summer with no opportunity to drink water: how were they coping, and what measures might schools take to accommodate them? I asked how she would have pursued the story if it had been assigned, and the first problem she described was that of finding sources. After identifying schools with a high population of Muslims, she would still face the problem of accessing people. She said she could use "official channels," such as the mosque or the Muslim Council of Scotland, as conduits; but if she wanted "real people," she might devise an elaborate scheme such as visiting McDonald's restaurant at sunset to "see who turns up." Her tone of voice indicated that the "official channels" did not present a satisfactory solution and that although the trip to McDonald's was logistically more complicated and did not guarantee finding an appropriate source, it was her preferred option and worth the effort. What made it worth the effort was authenticity. Sources arranged by a representative body may have been selected and even coached on what to say to provide the desired public representation of Islam. "Real people" were depicted as a guileless alternative.

A second example comes from a journalist discussing the 2007 attack on Glasgow Airport. She said her organisation struggled with the story: journalists did not "misreport" the story, in that they got details correct and were prudent in their assumptions about the perpetrators and their connection to the wider community of Arabs, Asians, or Muslims. However, she said they had none of the added value of human stories and insights that would come from having "close connections" with the city's Muslims. Part of this, she said, was because of the composition of their newsroom: it is hard to get good Muslim contacts if there are no Muslims working for the organisation. Moreover, a large mainstream news organisation can be intimidating, and "real people" and "even experts" may be nervous about commenting on the record. They may not even know how to reach journalists or the newsroom, as email addresses and phone numbers are not readily accessible to the public.

\section{Conclusions}

Considering the range of sources identified by journalists in my study, we can see features that indicate how authority is understood in relation to the production of news about Islam. More- or less-official sources outweighed "real people" by twenty to seven (the type "informal networks" was 
sufficiently vague to stand outside either category), which squares with the literature that indicates a journalistic preference for official sources. Yet the majority of the named groups and institutions, though Muslim, or with responsibility in Muslim communities, are socially authorised to know about things that are not religious. Journalists would be more likely to call Humza Yousaf, a Member of Scottish Parliament and cabinet minister in the Scottish National Party's government, about independence or, given his secretarial role at the time, foreign policy than the appropriateness of schoolteachers wearing a niqab. Conversely, the "real people" mentioned were more likely to be contacted because of the religious dimension of their life and activity-converting, fasting during Ramadan, choosing to wear or not wear the veil. To the extent that they are socially authorised to know things, it is the role of religion in their lives that they know. Jeroen De Keyser and Karin Raeymackers identified this increased authority conferred on "real people" in their Flemish study, calling it "expertise by experience" (De Keyser and Raeymaeckers 2012, p. 828). Journalists in my sample use them as, in their parlance, "case studies" to illustrate the event or idea in their stories.

These sources are not trained scholars-neither ulama or Shi'ite Imams nor "new Muslim intellectuals", and seldom parochial leaders. Though, as Robinson notes, the transfer of Islamic learning to print has democratised access to knowledge, the interpretation of that learning still demands a social context. The apparatus that validates authority in Islam has been shifting, as scholars in this special issue have identified, but this is concerned with authority that addresses a Muslim audience. Journalists, seeking answers on behalf of a wider, largely non-Muslim public, are looking for something else. As the discussion about the preference for hierarchical over decentralised structures shows, journalists may be more receptive to the rigidity of Islamic authority than its flexibility. This is consonant with the majority view in scholarship that journalists favour official, authoritative sources. It means, however, that sources who position themselves thus risk critique from other Muslims that they are not speaking for Islam-or at least not for "their" Islam.

As I have demonstrated in this paper, journalism and Islam make different demands of authority, and it is expressed in different ways. The most authoritative voices in Islam are not represented in most journalistic coverage of the faith, but at the same time, the kinds of questions journalists are interested in are not always ones they need such sources for. The social challenges of building a mosque in East Renfrewshire or fasting during hot summer days and school PE lessons do not require expert knowledge of the Qur'an and sunna or the exemplary conduct of the speaker. Though the best sources for such a story may not be as forthcoming as the journalists would like, the solution does not lie in the shifting terrain of Islamic authority.

When the questions move to topics such as rights, values, and the justification of violence, religious authority is a present concern. My hope with this paper is to indicate the complexity of the question and the necessity of carefully selecting to whom the journalist gives authority. Journalists need a little knowledge and some awareness of the sensitivity of the issue, examining not only who presents themselves as an authoritative voice but how that authority is constructed. Who makes up the political community activated by the speaker, and what is the social discourse of that particular time and place? Journalists in this study spoke to me from their occupational and operational perspective; yet, as scholars, we are able to observe wider patterns concerning sourcing strategies and other considerations that bear on how news is constructed. Understanding their priorities and how they justify their actions does not mean we cannot point out the socially problematic consequences they create. In addition, from within the communities of practice themselves, it may yet be the case that some British Muslims will criticise those whom journalists choose to answer for Islam on a particular question. Fourteen centuries of flexibility, growth, and change suggest that this is a normal state of affairs and one that can be absorbed in the continuum of history.

Funding: This research was funded by a scholarship from the Alwaleed Centre for the Study of Islam in the Contemporary World at the University of Edinburgh. 
Acknowledgments: The author thanks the anonymous reviewers for their comments in shaping this paper and is grateful to Mansur Ali for references and Hannah-Lena Hagemann for helpful comments on the section concerning authority in Islam.

Conflicts of Interest: The author declares no conflict of interest. The funders had no role in the design of the study; in the collection, analyses, or interpretation of data; in the writing of the manuscript, or in the decision to publish the results.

\section{References}

Abu-Rabi', Ibrahim M. 1996. Intellectual Origins of Islamic Resurgence in the Modern Arab World. Albany: State University of New York Press.

Al-Azami, Salman. 2016. Religion in the Media: A Linguistic Analysis. London: Palgrave Macmillan.

Ali, Rahielah, and Peter Hopkins. 2012. Everyday Making and Civic Engagement among Muslim Women in Scotland. In Muslims in Britain: Making Social and Political Space. Edited by Waqar I. U. Ahmad and Ziauddin Sardar. Abingdon: Routledge, pp. 141-55.

Amirpur, Katajun. 2006. A Doctrine in the Making? Velayat-e Faqih in Post-Revolutionary Iran. In Speaking for Islam: Religious Authorities in Muslim Societies. Edited by Gudrun Krämer and Sabine Schmidtke. Leiden: Brill, pp. 218-40.

Austin, John Langshaw. 1975. How to Do Things with Words. Edited by James Opie Urmson and Marina Sbisà. Cambridge: Harvard University Press.

Baker, Paul, Costas Gabrielatos, and Tony McEnery. 2013. Discourse Analysis and Media Attitudes: The Representation of Islam in the British Press. Cambridge: Cambridge University Press.

Bano, Masooda, ed. 2018a. Modern Islamic Authority and Social Change Volume 1: Evolving Debates in Muslim Majority Countries. Edinburgh: Edinburgh University Press.

Bano, Masooda, ed. 2018b. Modern Islamic Authority and Social Change Volume 2: Evolving Debates in the West. Edinburgh: Edinburgh University Press.

Beaudoin, Tom. 2012. Everyday Faith in and beyond Scandalized Religion. In Religion, Media and Culture: A Reader. Edited by Gordon Lynch, Jolyon Mitchell and Anna Strhan. Abingdon: Routledge, pp. 236-43.

Bell, Allan. 1991. The Language of News Media. Oxford: Blackwell.

Berkey, Jonathan. 2003. The Formation of Islam: Religion and Society in the Near East, 600-1800. Cambridge: Cambridge University Press.

Bleich, Erik, Hannah Stonebraker, Hasher Nisar, and Rana Abdelhamid. 2015. Media Portrayals of Minorities: Muslims in British Newspaper Headlines, 2001-2012. Journal of Ethnic and Migration Studies 41: 942-62. [CrossRef]

Cesari, Jocelyne. 2004. When Islam and Democracy Meet: Muslims in Europe and in the United States. Basingstoke: Palgrave Macmillan.

Commission on British Muslims and Islamophobia. 1997. Islamophobia: A Challenge for Us All. London: Runnymede Trust.

Dabashi, Hamid. 2002. Authority in Islam: From the Rise of Muhammad to the Establishment of the Umayyads, 2nd ed. New Brunswick: Transaction.

De Keyser, Jeroen, and Karin Raeymaeckers. 2012. The Printed Rise of the Common Man: How Web 2.0 Has Changed the Representation of Ordinary People in Newspapers. Journalism Studies 13: 825-35. [CrossRef]

Deacon, David. 1996. The Voluntary Sector in a Changing Communication Environment: A Case Study of Non-Official News Sources. European Journal of Communication 11: 173-99. [CrossRef]

Deveney, Catherine. 2013. UK's Top Cardinal Accused of 'Inappropriate Acts' by Priests. The Observer, February 23. Available online: https:/www.theguardian.com/world/2013/feb/23/cardinal-keith-o-brienaccused-inappropriate (accessed on 16 November 2015).

Eickelman, Dale F., and James Piscatori. 1996. Muslim Politics. Princeton: Princeton University Press.

Ericson, Richard V., Patricia M. Baranek, and Janet B. L. Chan. 1989. Negotiating Control: A Study of News Sources. Milton Keynes: Open University Press.

Esposito, John L., and Dalia Mogahed. 2007. Who Speaks for Islam? What a Billion Muslims Really Think. New York: Gallup.

Esposito, John L., and John O. Voll. 2001. Makers of Contemporary Islam. Oxford: Oxford University Press.

Fishman, Mark. 1980. Manufacturing the News. Austin: University of Texas Press. 
Galtung, Johan, and Mari Holmboe Ruge. 1965. The Structure of Foreign News. Journal of Peace Research 2: 64-91. [CrossRef]

Gandy, Oscar H. 1982. Beyond Agenda Setting: Information Subsidies and Public Policy. Norwood: Ablex.

Gans, Herbert J. 1980. Deciding What's News: A Study of "CBS Evening News", "NBC Nightly News", "Newsweek", and "Time". New York: Vintage Books.

Garbett, Andrew, Rob Comber, Paul Egglestone, Maxine Glancy, and Patrick Olivier. 2014. Finding "Real People": Trust and Diversity in the Interface between Professional and Citizen Journalists. Paper presented at the ACM Conference on Human Factors in Computing Systems, Toronto, ON, Canada, April 30. Available online: http://di.ncl.ac.uk/publicweb/publications/Garbett_et_al_FindingRealPeople.pdf (accessed on 3 March 2014).

Glasser, Theodore Lewis, ed. 1999. The Idea of Public Journalism. New York: Guilford Press.

Hackett, Robert A. 1985. A Hierarchy of Access: Aspects of Source Bias in Canadian TV News. Journalism \& Mass Communication Quarterly 62: 256-77.

Hall, Stuart, Chas Critcher, Tony Jefferson, John Clarke, and Brian Roberts. 1978. Policing the Crisis: Mugging, the State, and Law and Order. Houndmills: Macmillan.

Harcup, Tony, and Deirdre O'Neill. 2001. What Is News? Galtung and Ruge Revisited. Journalism Studies 2: 261-80. [CrossRef]

Harcup, Tony, and Deirdre O’Neill. 2017. What Is News? News Values Revisited (Again). Journalism Studies 18: 1470-88. [CrossRef]

Jones, Stephen H., Therese O'Toole, Daniel Nilsson DeHanas, Tariq Modood, and Nasar Meer. 2015. A “System of Self-appointed Leaders"? Examining Modes of Muslim Representation in Governance in Britain. The British Journal of Politics E International Relations 17: 207-23.

Kabir, Nahid. 2010. Young British Muslims: Identity, Culture, Politics and the Media. Edinburgh: Edinburgh University Press.

Kennamer, David, and Jeff South. 2002. Election Coverage Reflects Civic Journalism Values. Newspaper Research Journal 23: 34-45. [CrossRef]

Kersten, Carool. 2011. Cosmopolitans and Heretics: New Muslim Intellectuals and the Study of Islam. London: Hurst \& Co.

Kleemans, Mariska, Gabi Schaap, and Liesbeth Hermans. 2015. Citizen Sources in the News: Above and beyond the Vox Pop? Journalism 18: 464-81. [CrossRef]

Krämer, Gudrun, and Sabine Schmidtke, eds. 2006. Speaking for Islam: Religious Authorities in Muslim Societies. Leiden: Brill.

Kurpius, David D. 2002. Sources and Civic Journalism: Changing Patterns of Reporting? Journalism \& Mass Communication Quarterly 79: 853-66.

Mandaville, Peter. 2001. Transnational Muslim Politics: Reimagining the Umma. London: Routledge.

Manning, Paul. 2001. News and News Sources: A Critical Introduction. London: Sage.

Massey, Brian L. 1998. Civic Journalism and Nonelite Sourcing: Making Routine Newswork of Community Connectedness. Journalism \& Mass Communication Quarterly 75: 394-407.

McNair, Brian. 2004. PR Must Die: Spin, Anti-spin and Political Public Relations in the UK, 1997-2004. Journalism Studies 5: 325-38. [CrossRef]

Miller, David, Jenny Kitzinger, Kevin Williams, and Peter Beharrell. 1998. The Circuit of Mass Communication: Media Strategies, Representation and Audience Reception in the AIDS Crisis. London: Sage.

Moore, Kerry, Paul Mason, and Justin Lewis. 2008. Images of Islam in the UK: The Representation of British Muslims in the National Print Media 2000-2008. Cardiff: Cardiff School of Journalism, Media and Cultural Studies, Available online: http://www.cardiff.ac.uk/jomec/resources/08channel4-dispatches.pdf (accessed on 2 May 2011).

Munnik, Michael B. 2016. When You Can't Rely on Public or Private: Using the Ethnographic Self as Resource. In Advancing Media Production Research: Shifting Sites, Methods, and Politics. Edited by Chris Paterson, David Lee, Anamik Saha and Anna Zoellner. Basingstoke: Palgrave Macmillan, pp. 147-160.

Munnik, Michael B. 2017. From 'Voice' to 'Voices': Identifying a Plurality of Muslim Sources in the News Media. Media, Culture E Society 39: 270-281.

Munnik, Michael B. 2018. Reaching out in a Climate of Negativity: Perceptions and Persistence among Muslim Sources Engaging with News Media. Contemporary Islam 12: 211-227. [CrossRef]

Muslim Council of Britain. 2018. Centre for Media Monitoring. Muslim Council of Britain. Available online: https://mcb.org.uk/project/media-monitoring/ (accessed on 16 April 2019). 
Muslim Engagement and Development. n.d. Mend's Media Toolkit-Resources and Publications. Muslim Engagement and Development. Available online: https://www.mend.org.uk/resources-and-publications/ media-toolkit/ (accessed on 16 April 2019).

Nip, Joyce Y. M. 2008. The Last Days of Civic Journalism. Journalism Practice 2: 179-96. [CrossRef]

Ogan, Christine, Lars Willnat, Rosemary Pennington, and Manaf Bashir. 2013. The Rise of Anti-Muslim Prejudice: Media and Islamophobia in Europe and the United States. International Communication Gazette 76: 27-46. [CrossRef]

Petley, Julian, and Robin Richardson. 2011. Responsible Journalism. In Pointing the Finger: Islam and Muslims in the British Media. Edited by Julian Petley and Robin Richardson. Oxford: Oneworld, pp. 250-74.

Poole, Elizabeth. 2002. Reporting Islam: Media Representations of British Muslims. London: I.B. Tauris.

Reich, Zvi. 2015. Why Citizens Still Rarely Serve as News Sources: Validating a Tripartite Model of Circumstantial, Logistical, and Evaluative Barriers. International Journal of Communication 9: 22.

Richardson, John E. 2004. (Mis)Representing Islam: The Racism and Rhetoric of the British Broadsheet Newspapers. Amsterdam: John Benjamins.

Richardson, John E. 2006. Who Gets to Speak? A Study of Sources in the Broadsheet Press. In Muslims and the News Media. Edited by Elizabeth Poole and John E. Richardson. London: I. B. Tauris, pp. 103-15.

Robinson, Francis. 1993. Technology and Religious Change: Islam and the Impact of Print. Modern Asian Studies 27: 229-51. [CrossRef]

Robinson, Francis. 2009. Crisis of Authority: Crisis of Islam? Journal of the Royal Asiatic Society 19: 339-54. [CrossRef]

Rosen, Jay. 1999. What Are Journalists For? New Haven: Yale University Press.

Roy, Olivier. 1994. The Failure of Political Islam. Translated by Carol Volk. Cambridge: Harvard University Press.

Saeed, Amir. 2007. Media, Racism and Islamophobia: The Representation of Islam and Muslims in the Media. Sociology Compass 1: 443-62. [CrossRef]

Samad, Yunas. 1998. Media and Muslim Identity: Intersections of Generation and Gender. Innovation: The European Journal of Social Science Research 11: 425-38. [CrossRef]

Schlesinger, Philip. 1980. Between Sociology and Journalism. In The Sociology of Journalism and the Press. Edited by Harry Christian. Keele: University of Keele, pp. 341-69.

Schlesinger, Philip. 1987. Putting "Reality" Together: BBC News, 2nd ed. London: Methuen.

Schlesinger, Philip. 1990. Rethinking the Sociology of Journalism: Source Strategies and the Limits of Media-Centrism. In Public Communication: The New Imperatives: Future Directions for Media Research. Edited by Marjorie Ferguson. London: Sage, pp. 61-83.

Subramanian, Samanth. 2018. One Man's (Very Polite) Fight against Media Islamophobia. The Guardian. October 18. Available online: https://www.theguardian.com/news/2018/oct/18/miqdaad-versi-very-politefight-against-british-media-islamophobia (accessed on 16 April 2019).

Sumpter, Randy, and James W. Tankard Jr. 1994. The Spin Doctor: An Alternative Model of Public Relations. Public Relations Review 20: 19-27. [CrossRef]

Tuchman, Gaye. 1978. Making News: A Study in the Construction of Reality. New York: Free Press.

Tunstall, Jeremy. 1971. Journalists at Work: Specialist Correspondents: Their News Organizations, News Sources, and Competitor-Colleagues. London: Constable.

Weber, Max. 1968. Economy and Society: An Outline of Interpretive Sociology. Edited by Guenter Roth and Claus Wittich. New York: Bedminster Press.

Zaman, Muhammad Qasim. 2002. The Ulama in Contemporary Islam: Custodians of Change. Princeton: Princeton University Press.

Zaman, Muhammad Qasim. 2006. Consensus and Religious Authority in Modern Islam: The Discourses of the 'Ulama. In Speaking for Islam: Religious Authorities in Muslim Societies. Edited by Gudrun Krämer and Sabine Schmidtke. Leiden: Brill, pp. 153-80.

Zelizer, Barbie. 2013. Tools for the Future of Journalism. Ecquid Novi: African Journalism Studies 34: 142-52. [CrossRef]

(C) 2019 by the author. Licensee MDPI, Basel, Switzerland. This article is an open access article distributed under the terms and conditions of the Creative Commons Attribution (CC BY) license (http://creativecommons.org/licenses/by/4.0/). 

Article

\title{
Mosques as Gendered Spaces: The Complexity of Women's Compliance with, And Resistance to, Dominant Gender Norms, And the Importance of Male Allies
}

\author{
Line Nyhagen \\ Communication, Media, Social and Policy Studies, Loughborough University, Leicestershire LE11 3TU, UK; \\ L.Nyhagen@lboro.ac.uk
}

Received: 25 February 2019; Accepted: 30 April 2019; Published: 14 May 2019

\begin{abstract}
Women's presence and role in contemporary mosques in Western Europe is debated within and outside Muslim communities, but research on this topic is scarce. Applying a feminist lens on religion and gender, this article situates the mosque as a socially constituted space that both enables and constrains Western European Muslim women's religious formation, identity-making, participation, belonging, and activism. Informed by qualitative interviews with twenty Muslim women residing in Norway and the United Kingdom, the article argues that women's reflexive engagement simultaneously expresses compliance with, and challenges to, male power and authority in the mosque. It contends that a complex practice of accommodation and resistance to "traditional" gender norms is rooted in the women's discursive positioning of "authentic Islam" as gender equal. While men typically inhabit positions of religious and organizational power in mosques, the article also suggests the importance of male allies in women's struggles for inclusion in the mosque.
\end{abstract}

Keywords: authentic Islam; imams; inclusion; mosque governance; mosques; Muslim women

\section{Introduction}

Mosques have become part of the geographical landscape of urban centers in Western Europe, following post-World War II immigration of Muslims from many parts of the world, including Eastern Europe, Africa, and the Middle East. Mosques were initially established in existing buildings, but an increasing number of mosques are purpose-built. Today, mosques provide religious, educational, and welfare services to a well-established indigenous Muslim population in Western Europe, and to migrants and refugees with ties to Islam. Questions about what happens inside mosques and how mosques are embedded within their local communities, and how the wider society relates to mosques, are debated by politicians, news outlets and social media, scholars, and ordinary people, including Muslims. The building of mosques is in itself a contested issue, causing political conflicts in many Western European cities (Cesari 2006). A particularly debated issue is that of women's participation and role in the mosque, which raises questions about equality, citizenship, democratic governance, religious freedom, and self-determination; questions that are central to sociological inquiry beyond the realm of religion.

Despite evidence of emerging scholarship on mosques as gendered spaces in Western contexts, including Europe (Nyhagen Predelli 2008; Bhimji 2009; Gilliat-Ray 2010; Bano and Kalmbach 2012; Shannahan 2014; Lewicki and O'Toole 2017), Australia (Woodlock 2010), and North America (Haddad et al. 2006; Hammer 2012), there is still a dearth of research on women's views on and experiences of mosques. Questions that need addressing are: What kinds of spaces and roles do women occupy within mosques? How do women experience mosque spaces and governance structures? Women's access to 
and use of male imams and other sources of religious authority is another under-explored issue, as is women's views on female imams. This article seeks to address the identified research gap by examining the mosque as a gendered space via a qualitative case-study study of twenty Muslim women residing in Oslo, Norway and Leicestershire, UK, focusing on their motivations for attending, the gendered spaces in which they participate, and their views on the imam role. It suggests that the women's reflexive engagement with the mosque as a physical and social space represents a complex discursive positioning which simultaneously reproduces and challenges established forms of male power. Taking into account wider developments regarding women and mosques in Norway and the UK, the article also highlights evidence of emerging support for more gender-inclusive mosque practices.

\section{Extant Research and Contemporary Developments}

Mosques are houses of religious worship that also function as community hubs for social events, welfare services, charitable activities, and political engagement. As such, the ability to access and use mosque facilities is vital for community participation and belonging. Although only men have a religious duty to attend Friday prayer in the mosque, Muslim women in Western Europe are increasingly participating in mosques, including in Norway (Nyhagen Predelli 2008), the UK (Bhimji 2009; Gilliat-Ray 2010; Shannahan 2014; Lewicki and O’Toole 2017), and elsewhere, e.g., Sweden (Minganti 2012), France, and Germany (Jouili and Amir-Moazami 2006; Spielhaus 2012). Women's increased participation has been accommodated via the introduction of designated, gender-segregated spaces in some, but not all, mosques. Hegemonic Islamic norms dictate the separation of women and men during prayer due to women's childbearing role and a perceived need to control male sexual lust (Mernissi 1991; Ahmed 1992; Hammer 2012); see also (Lehmann 2012) on the mosque as a sexual space). Women's participation is thus conditioned upon the availability of a gender segregated physical space, with a separate room for women, distinct from the main prayer room, and with a separate mosque entrance too. Mosques that are open to women typically afford them physical spaces that are inferior in quality and size compared to men's, thus demonstrating "an overall prioritization of male space and needs" (Shannahan 2014, p. 15). Many mosques also block women's participation by not offering them a designated space (Roald 2001). Furthermore, mosques in Western Europe are typically governed by men, and men occupy the main position of religious leadership, the imam, who leads prayers. Women may be permitted to lead prayer for women, but only men can lead prayers for men and/or mixed gender audiences. Mosque boards and management committees only rarely include women, and if women are allowed any autonomy it tends to be confined to women's own activities. Whether located in Muslim majority or Muslim minority contexts, mosques "remain bastions of male dominance" (Gilliat-Ray 2010, p. 202); see also (Kalmbach 2012; Vogt 2000).

In contrast to public rhetoric about Muslim women as submissive and passive (Abu-Lughod 2002), evidence shows that Muslim women are not absent as sources of religious knowledge and authority. Despite a historical lack of women in mosques, and the barriers this has caused for women's claims to religious authority, Kalmbach (2012, pp. 15-16) notes that a "sizeable number of female religious authorities appear in Islamic sources, especially biographical dictionaries, prior to the sixteenth century, primarily as Companions of the Prophet, hadith transmitters and Sufi saints, but also as scholars, instructors, and patrons of religious endowments". These historical precedents offer legitimacy to contemporary women's claim to religious authority. Kalmbach also observes that competition between an increasing number of stakeholders who claim religious authority, as well as the broadening of women's societal roles, have contributed to a dramatic expansion in women's Islamic leadership in the 20th and 21st centuries (Kalmbach 2012, p. 16). Her view is supported by Jouili (2015, p. 24) who, in her study of Muslim women in France and Germany, noted "the feminization of the Islamic institutional landscape" as a trend. Within mosques, women lead prayers for women and transmit religious knowledge to women and children, thus "solidly establishing, re-establishing, or expanding female leadership in public religious spaces" (Kalmbach 2012, p. 17); see also (Hammer 2012; Jouili 2015). Moreover, feminist Muslim women scholars (e.g., Amina Wadud) advocate re-interpretations of 
Islam that support gender equality at home, in the labor market and in politics (Wadud 2006); see also (Roald 2001); on Islamic feminism, see, e.g., (Mir-Hosseini 2000). Wadud is also known for having led public and private prayers for gender-mixed audiences (including in New York, USA, in 2005 and in Oxford, UK, in 2008), gaining widespread media attention and igniting debates within Muslim communities (see Hammer 2012).

More recent initiatives have seen Muslim women and other stakeholders call for more gender-inclusive mosques. Both in Norway and in the UK, reports by various interlocutors have revealed that many mosques lack spaces for women and that women are overwhelmingly absent from mosque governance. For example, a report published by the Norwegian national newspaper Vårt Land in 2016 showed that only three out of 248 mosque board members were women, and these three were all members of the same mosque board (Lindvåg 2016). Also in 2016, Azhar Ali, a Muslim woman of Somalian background in Arendal, Norway, initiated a campaign for women to become board members in her local mosque. While Ali eventually succeeded, women are still excluded from most mosque boards in Norway. In 2017, on the back of media reports about the lack of women on mosque boards, the Labor Party, the second largest political party in Norway, put forward a policy proposal in Parliament that would have required boards of religious organizations in receipt of state funds (which include mosques) to have a minimum of forty percent representation of women.

In the UK, voluntary organizations that have consulted with Muslim women, including the (Muslim Women's Network 2006; Faith Matters 2010; Citizens UK 2017), have argued that mosques must open spaces for women and include them in governance structures. The Muslim and Imams National Advisory Board (MINAB) and the Muslim Council of Britain (MCB) have issued similar recommendations, as has the Scottish Mosques For All initiative founded by Sahira Dar, a Scottish Muslim woman. In 2018, a House of Lords Committee report observed that mosques have "a preponderance of men on their governing bodies" and welcomed an initiative where Citizens UK and the Muslim Council of Britain are working together towards a third of all mosque board members being women (House of Lords 2018, pp. 93-94). Also in 2018, the MCB launched a programme in which twenty women receive training for leadership roles in mosques and community organizations.

In further developments in Western contexts, some Muslim women have reacted against male-dominated mosques by establishing women-focused and/or women-led mosques. The first women-only mosque in the USA, The Women's Mosque of America, opened in Los Angeles in 2015, mirroring women-only mosques that have existed among the Hui community in China for several hundred years (Jaschok and Jingjun 2000). In the UK, the Muslim Women's Council in Bradford have launched an initiative to establish a new mosque that, whilst open to women and men, will be led and managed by women. Women will, however, not inhabit the imam role; gender-mixed prayers will be led by a man. By accommodating to hegemonic 'gender-normative religious practices' (Darwin 2018), this new mosque initiative has garnered support from male Muslim scholars, including from Imam Zaid Shakir who stated that "[t]he masjid [mosque] will be well run; they're not talking about female imams, and women-led Jummah khutbahs [Friday prayers]" (Muslim Women's Council's Website 2018).

A more "gender-transgressive religious practice" (Darwin 2018) is represented by the Inclusive Mosque Initiative (IMI), established in London in 2012. IMI accepts women leading prayer and welcomes people of diverse gender and sexual orientations. Similar inclusive initiatives have emerged in other Western countries, including the USA, France, Germany, and Denmark. The Ibn Rushd-Goethe mosque in Berlin, for example, was established in 2017 by Seyran Ates, a Muslim woman who also plans to open a mosque in the UK. ${ }^{2}$ In Hamburg, a female imam, Halima Krausen, writes sermons but

1 (Faith Matters 2010) listed five criteria for 'women-friendly mosques': a separate prayer space for women; services and activities for women; an imam or female scholar that women can access; the inclusion of women in decision-making; and women members of mosque committees.

2 See https://www.theguardian.com/world/2017/jul/26/seyran-ates-muslim-feminist-liberal-mosque-london-britain (accessed on 18 February 2019). 
does not lead gender-mixed prayers (Spielhaus 2012). The Mariam mosque in Copenhagen (established 2016) is run by a female imam, Sherin Khankan, who leads Friday prayers for women only (the mosque is open to men on other days; see (Khankan 2018)). In Norway, Thee Yezen Al-Obaide, a gay man, has announced plans to open an inclusive and feminist mosque in Oslo where women and men pray together. ${ }^{3}$

Recent scholarship has also highlighted Muslim women's activism and leadership beyond the mosque. Regarding the UK, Gilliat-Ray (2010, p. 303) notes "a growth of religious gatherings among women" outside of mosques, as well as Muslim women's participation in community organizations. Similarly, Joly and Khursheed (2017, pp. 152-54) describe an increase in Muslim women's organizations and community activism in Britain since 2000, and explain the growth as rooted in women's need to counter Islamophobia and to offer alternative voices to those of Muslim men, as well as the state's co-optation of Muslim women in the so-called war on terror (see also Brown 2008). At a local level, (Lewicki and O'Toole 2017) observe the mobilization of Muslim women in Bristol in a campaign against violence towards women. In the Norwegian context, Muslim women have mobilized in voluntary associations beyond mosques, including in youth and women's associations (Jacobsen 2011a); for other contexts see, e.g., (Hammer 2012; Minganti 2012); for online activism see (Piela 2010).

\section{Research Methods}

This article is based on a thematic analysis of twenty semi-structured interviews with Muslim women; ten in Oslo, Norway (five Sunni and five Shia) and ten in Leicestershire, UK (five Sunni and five Shia). The interviews, conducted in 2009-2010, were part of an EU-funded project that also included Muslim women in Madrid, Spain, as well as Christian women in the same geographical locations. ${ }^{4}$ This article provides an in-depth focus on the Muslim women who were interviewed in Norway and the UK. It offers the first comprehensive and detailed analysis of these women's views on and experiences of mosques (limited findings were reported in (Nyhagen and Halsaa 2016, pp. 142-43). ${ }^{5}$

The first mosques in Norway were established by Pakistani immigrants in the 1970s, and today the country has over 130 mosques representing Muslims from diverse ethnic, national, linguistic, and political backgrounds (see Nyhagen and Halsaa 2016, pp. 10-11). In comparison, the first mosques were established in the UK in the late 19th century (in Liverpool and in Woking, Surrey). Also representing a diverse population of Muslims, the number of mosques in Britain has recently been estimated at between 850 and 1500 (Gilliat-Ray 2010, p. 181).

This research used a purposeful approach (snowball sampling) to recruit Sunni and Shia Muslim women who are active mosque goers. In both Oslo and Leicestershire, Pakistani-dominated Sunni mosques were chosen because Muslims of Pakistani backgrounds form the largest Muslim groups in Norway and the UK. The recruitment of Shia women was more complex; we found that Shia women in Oslo frequent mosques that attract people from diverse ethnic and national backgrounds, and that Shia women in Leicestershire attend either Sunni mosques in Leicester or Shia mosques in nearby cities including Nottingham and Birmingham. The interviewed women in Oslo were all from ethnic minority backgrounds and spoke fluent Norwegian; the Sunni women had origins from Pakistan (three of whom were born in Pakistan and two in Norway) and the Shia women had origins from Iran, Iraq and Afghanistan (two of whom were born in Afghanistan, one in Norway, one in Iran and one in Iraq). The interviewed women in Leicestershire included Sunni and Shia women with origins from Pakistan, India and Iran (of whom three were born in Pakistan, three in Iran and two in the UK; one was born in Malawi and one was a UK-born, white convert); all of them spoke fluent English. Among

See https://www.nrk.no/norge/vil-etablere-feministmoske-i-oslo-1.13567445 (accessed on 15 February 2019 ).

4 Work Package 4, 'Multicultural Citizenship: Intersections between Feminism, Ethnic Identity and Religion' was part of the FEMCIT project (www.femcit.org) funded by the European Commission's 6th Framework Programme (2007-2011).

5 Other themes from the full dataset discussed in (Nyhagen and Halsaa 2016) include identities, citizenship, gender equality at home and in society, and women's movements and feminism. 
the participants were stay-at-home mothers, students, workers in full- or part-time employment, and pensioners. Their ages ranged from the early twenties to the sixties. Some of them wore a headscarf while others did not (for further details about the sample, see Nyhagen and Halsaa 2016, pp. 23-27).

All the interviewed Sunni women attended mosque; most of them attended the same mosque on a regular basis, while others frequented more than one mosque. All five Shia women in Oslo attended mosque regularly; one of them went to a variety of mosques (both Shia and Sunni) but most often to a Shia mosque. Of the five Shia women in Leicestershire, three did not attend mosques in the UK but did so in their country of origin; however, in the UK they participated in religious gatherings for women and families, including weekly women's meetings to study the Quran. Reasons these Shia women gave for why they did not attend mosque in the UK included the lack of a women's room in their local mosque and/or that women are not allowed, or that their local mosque is "too political" with reference to politics in their home country. Two of the Shia women attended mosque in the UK, with one frequenting "any mosque" (Shia and Sunni) and the other attending a Shia mosque in Birmingham.

Several of the interviewed women had leadership roles in their mosque or in the wider Muslim community. For example, a Shia woman in Leicestershire had a central role in a Muslim women's association outside the mosque, and one of the Shia women in Oslo had an important role in her mosque's women's association. Among the interviewed Sunni women, one was a voluntary member of her Leicester-based mosque's main board. A Sunni participant in Norway led her Oslo-based mosque's women's association, while another interviewee had occupied several prominent roles in the same women's association. Notably, the interviews were conducted by non-Muslim researchers, which meant that the participants gave detailed explanations of their faith and practice.

\section{Findings: Analysis and Discussion}

Three prominent themes emerged from the analysis of the research participants' discursive reflections on the mosque: their motivations for attending, their views on gendered religious spaces and practices, and their perspectives on the imam role and the importance of male allies.

\subsection{Motivations for Attending the Mosque}

Previous research has found that mosques are important spaces for Muslim women in Western contexts to learn about Islam, pray, socialize, engage in community activities (e.g., fund-raising), and gain a sense of community and belonging (Nyhagen Predelli 2008; Shannahan 2014). The interviewed women in this study confirmed that they have religious, educational, social, and community motivations to attend the mosque. A prominent motivation was the emotional religious experience afforded by the mosque. Several of the women emphasized the Friday communal prayer as important to them in a religious sense. By praying together, women feel a religious connection to God and to fellow Muslim women. For example, a Shia woman in Oslo described how she feels a sense of urge to go to the mosque; her heart tells her "you must go to the mosque". She achieves a sense of tranquility by listening to the imam's prayer. Another Shia woman in Oslo recounted that she "feels closer to God" when hearing the prayer in the mosque. She experienced the Friday prayer as "a form of therapy" and noted that it helps her cope with everyday challenges related to work and family.

Resonant with findings reported by (Jouili and Amir-Moazami 2006), obtaining religious knowledge for one's own sake was very important, with women recounting how they seek a better understanding of Islam via partaking in mosque sermons and listening to the imam and invited speakers. Some of the women expressed a reflexive, critical engagement with religious knowledge imparted by imams in the mosque; for example, a Sunni participant in Oslo noted how she listens to the imam's instructions and advice and that, when at home, she reads about what he said and checks its accuracy: "So I am completely certain that what the imam says is correct". Similarly, a Shia participant in Oslo observed that she obtains knowledge from the imam and checks what he said by reading the Quran at home: "Is it what Allah has said in the Quran? I can find out". The women are thus actively reflecting on whether to accept the authority of imams and the knowledge imparted by 
them. Women also consulted other sources of knowledge, including television and the Internet. One participant, who noted that learning from the imam is important to her, consults a variety of sources, including other women: "many of the women who attend possess knowledge. So I go to the mosque just to get knowledge [ ... ]. And I have learnt a great deal [from it]; I also watch Islam on the telly, but I also read a lot by myself". The usage and checking of multiple sources of religious knowledge indicates an individualistic and self-reflexive approach to religion that resonates with larger trends towards individualization in Western contexts. One participant also suggested that, although women cannot formally be imams, an individual woman can be an "informal" imam in her own right: "If you have learnt Islam properly, then you are an Imam in yourself. Right?" In her view, through reflexively developing her own pious self, a woman can become her own religious authority, independent of any formal religious authority see also (Mahmood 2005; Jouili and Amir-Moazami 2006; Dessing 2012).

Obtaining religious knowledge and also broader societal knowledge was seen as a tool for empowerment by some of the participants. For example, one interviewee stated that "as long as one has knowledge, one has power", while another highlighted the mosque's ability to bring women in the local community together and provide them with knowledge. Whilst noting her own reflexive engagement with religious knowledge, a further participant also emphasized the mosque as a social space where women can be empowered to participate in society more broadly. The ability to transmit religious knowledge to one's children was also a motivator for some of the women.

The notion that the mosque is a community centre for socialization, learning, support, and belonging shone through several of the interviews. These aspects were highlighted as particularly important to women; the mosque fulfils their needs to meet up with other women, sharing problems, getting to know their community, and learning about Islam and wider societal issues. However, not all the participants expressed the same need for the mosque as a social space. One interviewee, a young Norwegian-born Shia in higher education, noted that, while the mosque is an important "social meeting place for housewives", she herself is not very keen to partake in women's conversations. Her main motivations for attending are to pray and to learn. However, she often finds that the sermons and lectures in her mosque are repetitive and even uninspiring, as they tend to deal with the same topics (e.g., fasting, prayer, and marriage). In her view, this is because "you have to keep it simple so that it fits for everyone". Her account differs markedly from the other participants who emphasize that they learn a lot from attending the mosque, thus illustrating that women have different needs depending on their knowledge about Islam.

The participants in this study were overwhelmingly supportive of the activities run by women's groups in their mosques. A Sunni interviewee from Leicestershire noted that gender relations in the mosque are changing, and that the creation of the women's group is an indication of women's increased participation and influence:

"Ten years ago nobody would have thought of having a sub-committee of women who would have equal voting rights; and look at what we have achieved today. And it is more the [changes in] interpretation of our religion. Unfortunately, the male interpretation sometimes puts our religion in a negative light".

The quote illustrates how women engage in debates about Islam and gender, and that mosques are spaces in which existing hegemonic gender norms and structures are contested. In this example, women fought for their say, and men accommodated their wishes. At the very least, the women's group symbolizes a step towards the religious accommodation of more inclusive practices within mosque governance. That women have voting rights in the mosque (albeit limited to women's own affairs) was viewed as a positive step forward for women's participation and influence. Notably, the male-dominated mosque board is still in charge. The women's group is required to put forward its activity proposals to the main mosque board. One participant saw this requirement as reasonable: "so at least they [the men] know what the women want, we can put forward to the men as well, this is what we want, this is how we are". As the discussion below shows, however, other participants were more critical of the need for men's approval. 
Support for women's groups was widespread, but not uniformly positive. One participant stated that the women's group in her mosque does not give her "much of a good impression" and wanted to distance herself from what she saw as "bad culture". While the participant herself wears the headscarf, she noted that her mother and sister, who do not wear the headscarf, would feel uncomfortable in the mosque due to cultural pressure from other women: "So they, they do not dare to come to the mosque, because they know how the culture is, and they will be looked down upon". The interviewee also mentioned "cultural prescriptions" about the colour and length of clothing as limiting women's freedom. Nevertheless, she also said, "I would feel very lonely if I did not attend these gatherings. Even if I am a bit different from them". For this participant, tensions between what "culture and tradition" appears to demand of women and what "Islam" is perceived to prescribe, are difficult to negotiate see also (Jouili and Amir-Moazami 2006, p. 628). Her experience suggests that the mosque is also a space that may enable "the policing of women's dress, women's voices and women's interactions with men" (Karim 2009, p. 177), as cited in (Shannahan 2014, p. 7).

\subsection{Gendered Religious Spaces and Male Power}

The interviewed women appreciated their local mosques because they offer permanent women-only spaces. Participants observed that mosques without dedicated spaces for women, or with only temporary and/or small spaces for women, produce barriers to women's participation. "Now we have got our own dedicated ladies gallery, it means that the mosque is much more accessible to us than it was perhaps before [ ... ] because we know that space is ours, regardless", noted a Sunni woman in Leicestershire. In her mosque, the women's gallery is accessible via a women-only entrance; men enter the larger and principal prayer room via the main entrance. Sermons (and also lectures by male speakers) are transmitted to the women's room, while prayers or lectures by female speakers are heard by women only. Male voices are thus explicitly privileged in the mosque, echoing the privileging of male voices in Roman Catholic Christianity and Orthodox Judaism (Manning 1999).

Gender segregated prayer rooms is established practice in mosques that are open to women in Europe and elsewhere (Hammer 2012; Nyhagen Predelli 2008). Notably, the participants in this study did not perceive such practice as a barrier to women's inclusion. To the contrary, gender segregation was seen as providing opportunities for women to participate in institutional religious life (see also Nyhagen Predelli 2008; Nyhagen and Halsaa 2016). For example, a Sunni woman in Leicestershire observed that her mosque provides a "ladies gallery and ladies facilities as well, so ladies can also attend the prayers. So that is quite good in that it gives the women the opportunity to pray with the imam in the mosque". Furthermore, gender segregated spatial arrangements were interpreted as providing equality between women and men. A Sunni woman in Oslo recounted that, in her mosque, the imam's Sunday lectures are received by women and men who inhabit different floors. All the men occupy the main prayer room, while the women watch the imam via a video projector in their own room. She noted, "So, we have gender equality, there is no different treatment. There is no oppression, because at the [mosque] there are very educated people, and the imam is very, very good". In this view, despite the gendered spatiality of the mosque, there is equality between women and men. That women are on their own also offers a safe space for women, away from the male gaze.

By inhabiting their own gendered space in the mosque, Muslim women are claiming their own participation and belonging as religiously and socially legitimate, which in turn may challenge the long-standing, overall male domination of mosques in Western Europe. At the same time, by accepting the gender segregated spatial practices that are justified on the basis of religious prescriptions and cultural traditions, including the allocation of smaller and inferior spaces, women are accommodating to 'gender-normative religious practices' (Darwin 2018) that maintain gender inequality. However, women may also engage in 'gender-transgressive religious practices' (Darwin 2018) that contest and transform hegemonic gender norms. For example, a Shia woman in Oslo noted that the noise from conversations in the women's room is so loud that it disturbs her religious experience. She and other women who wish to focus on the religious service have started to occupy back rows in the men's prayer 
room: 'So in our mosque they have introduced a system where you go [and] sit on the men's side. That is, women go and sit down in the men's section so that they can follow what is being said'. When women enter the room, men move forward, and the women occupy rows at the back. About twenty women regularly partake in prayer in this way in the men's room. This practice indicates the increasing and changing role of women in Muslim congregations. It also demonstrates that some Muslim men are willing to accommodate women's presence, also when it contests hegemonic prescriptions about gender segregation during prayer. Nevertheless, this kind of accommodation of Muslim women's participation is highly unusual within mosques in Norway, the UK and Western Europe more broadly. Moreover, while it challenges the male-centeredness of the mosque, it also reproduces a gendered spatiality in which men occupy the front and women are at the back of the room.

Many of the women in this study problematized the relationships among gender, religion, and power. They indicated that men's power in the mosque and in the wider Muslim community is challenged and contested, but also that male power is deeply entrenched and difficult to change. A Sunni participant noted that "now the women are in power as well" in her mosque, while another said that, although women have equal rights in Islam, "at the end of the day we are all human beings and men don't like to give up their power". At times, women offered quite different reflections on specific practices. A further Sunni participant from Leicestershire, for example, questioned the practice that women must obtain men's approval for their activities: "If we [women] need to do anything, we have to ask the chair person, we have to ask him. Why can't we just go ahead and do it? [ ... ] I am always in conflict with the ladies, why do we have to [ask], why can't we decide?" That the male-dominated mosque board requires the women's group to obtain its approval shows that men's power is entrenched. It also suggests that men may be reluctant to relinquish their power. The interviewee was also critical of women who accept the policy that men must have the final say. However, her views contrasted with that of another participant from the same mosque, who framed the consideration of women's plans by the main mosque board as supporting equality and equal rights between women and men, rather than as a case of women having to request permission from the men: "[ . . ] we can have voting rights, we can vote on our own committee, we can make decisions of our own, so we can fundraise for our own activities. Basically, we have equal rights over all decisions made in the mosque". She clarified that each sub-committee (e.g., women; youth) has representation on the main board, and that the voices of sub-committees are heard via their informal board representatives. Although confirming that the women's group must seek permission from men, the participant insisted that "it is a very democratic process". In her view, gender unequal authority and decision-making structures do not negate the value of women's participation and influence in the mosque. Her interpretation thus prioritizes the actual involvement of women, rather than who is making the final decisions. Together, the above examples illustrate that changes in power structures depend on men's willingness to include women and to relinquish some of their power to women. Support from male allies appears crucial to the inclusion of women in mosque governance. However, women's own aspirations (or lack thereof) for leadership and authority should not be discounted.

Reflections about gender, religion, and power were also offered by interviewees from Oslo. Similar to (Jouili and Amir-Moazami 2006, p. 628), findings from their study of German and French Muslim women, Norwegian Sunni and Shia participants talked about tensions between what they perceived as "authentic" Islam and its affordance of equal status and rights to women, versus "cultural-traditional" understandings of Islam which subordinate women to men. A Sunni woman observed that Muslim men seem threated by women's rights:

"They [women] demand their rights. But the men have not learnt a lot [ .. ], they are scared of giving rights. They might think that if we give women freedom, then they might acquire wings and fly away. And that isn't true, because we, if we know about Islam, then we also know our limits. We know how far we can fly. Or how high we can fly. And the men are a bit scared about this". 
According to this interviewee, if men feel threatened by women's rights, they have no reason to do so, as women are only demanding the rights they were originally given by Islam. And because women know their "limits" as prescribed by Islam, they will not pose demands that surpass these rights.

Other Sunni and Shia women in Oslo confirmed that mosque debates about gender relations demonstrate tensions between a perceived "authentic" Islam that affords equality and rights to women, versus "cultural" practices that demand women's subordination. For example, a Sunni participant observed that Islam itself does not oppress women, and that tensions only arise when people interpret the Quran in the wrong way. Noting that women and men are equal in Islam, a Shia participant said: "Men have power. But that is completely wrong. Because Mohammed did not do this himself [he treated his wives equally]. But today, it is like the men are saying 'oh, we have the power', but they don't really have the knowledge". Similarly, another Shia participant noted that "if you go to the Quran, then there is gender equality. But not in the real world [ ... ]. Men always want to be above, [to] have power over women". These interviewees thus adopted a "religion is innocent" discourse, where patriarchy, and not Islam, is the culprit of any infringements to women's rights (see also Nyhagen and Halsaa 2016, p. 208).

\subsection{Views on the Imam Role and the Importance of Male Allies}

Mosques are typically governed by male-dominated boards, and the main religious leadership role is held by the male imam. Many imams have been "imported" to Western Europe from countries in Asia and the Middle East, often lacking necessary language skills and socio-cultural knowledge (Gilliat-Ray 2010; Vogt 2000). In response to demands for "home-grown" imams, imam training is offered at institutions such as the Markfield Institute of Higher Education in the UK. Gilliat-Ray (Gilliat-Ray 2010, pp. 164-65) has noted that "Muslim women seek the counsel of imams on issues concerning marriage, children, education, divorce, and so on, yet few imams have been trained in counselling skills, or have the ability to relate Islamic law to the realities of contemporary Britain". Nyhagen Predelli (2008, p. 250) reported that imams in Norway thought it important for women to attend mosque for learning and social activities, yet recommended that it is best for women to pray at home. There is, however, hardly any existing research on women's access to and use of male imams from women's own perspective (see Taj 2013), nor of women's views on female imams. This study addresses that research gap.

The interviewees imparted a mixture of positive and negative views of their local imams. The Sunni women were particularly appreciative of their local imams and spoke about their admiration and respect for them as providers of reliable and trustworthy religious knowledge and as supporters of women's inclusion and participation in the mosque. A Sunni woman in Leicestershire, for example, said that she attends the mosque as it offers services for women and because the imam is very open and supportive of women's activities. She admires the chief imam as he can be asked any question and always provides good answers: "we ask him, and he puts us straight". Men ask questions directly to the imam, while women put their questions in writing and pass them on to the main prayer room. Another participant spoke of the imam as "brilliant; he answers your questions in a simple way and makes you understand and makes you feel like you want to come back [ ... ]. And every time I am going, I am coming out with more and more strength and knowledge". Similarly, this woman imparted her admiration for the imam: "The imam, every Friday, when I go to the mosque, he does his speech. I only go for the speech; he has a lot of power in his voice and you want to sit there and listen to him". Another participant described her imam as "a very good imam who has always included the women". A Sunni woman in Leicestershire also spoke of the mosque's chair as promoting an inclusive approach towards women; she admires him as someone who "is always pushing the involvement of women, not just in the mosque, everywhere [ ... ]. Most men don't bother, they are just talking for men, or for themselves". Together, these statements demonstrate women's appreciation of imams who possess religious knowledge and are inclusive towards women. They also indicate the importance of male 
allies for women's inclusion in the mosque. Importantly, women do not take such support for granted; it is noted and valued.

Sunni women in Oslo spoke in similar ways about admiration and respect for their local imam as a source of religious knowledge and supporter of women's inclusion. Noting the imam's influence on her faith and her admiration for him, one participant said: "Many people talk about strict imams, but I feel that [my imam] is a very nice person and you get answers to everything you ask. It is very easy to communicate with him". Another Sunni woman in Oslo emphasized her local imam's support for the establishment of a women's group at the mosque. She recalled that the imam came and sat in front of all the women, giving advice on their leadership election. His advice was to elect a leader who "is kind, and that you can cooperate with", regardless of the extent of her religious knowledge. The women went on to elect her-a woman who was "not so much practicing the religion, and I didn't wear the hijab, I wore Western clothing and still do". This imam is viewed as caring and engaged, and that he speaks out against "gender-policing" (Shannahan 2014) of women's clothing is appreciated. The participants emphasize the imam's support for women's inclusion in the mosque; in short, he is perceived as women's ally.

Some of the interviewed women expressed more critical views, especially of imams whom they perceive are supporting conservative views that prescribe male power and authority as representing "true Islam". According to these participants, such conservative views are rooted in "cultural traditions" that have emerged as a result of patriarchal and false interpretations of Islam. These women are engaging in a discursive "politics of authenticity" (Jouili and Amir-Moazami 2006, p. 637); see also (Jacobsen 2011b), where practices that subordinate women are challenged via appeals to a "true", "original" or "authentic" Islam that is seen to afford women's rights and gender equality. Such critical views were expressed by Sunni and Shia women alike in both Oslo and Leicestershire. For example, a Sunni participant from Leicestershire recounted the discrepancies she finds between what she reads in the Quran and what some imams impart about gender relations:

"And when it comes to the Quran a lot of things I do read; and it does say equal things for women and men. But what happens is most of the imams they think no; it is to do with the culture as well and what country you come from, how you understand religion, and they shove the women in the background because they are afraid that the women will come forward and probably take over".

Her practice of self-reflexive knowledge acquisition supports the earlier finding that women seek autonomy and empowerment via multiple routes to knowledge, including their own reading of religious texts. Furthermore, her statements suggest that some imams (and also other men) seek to protect male power and privilege by actively marginalizing women; "But it is the men that don't want the women to step forward. I think they are afraid for themselves". A similar analysis was imparted by a Sunni woman in Oslo: "Men are worse [than women] because they are more dominating. They have learnt religion from their parents, from their local imams. An imam who reads the Quran but does not understand what the Quran says". Again, we see how women actively engage in a discursive positioning of "authentic Islam" as supportive of women's rights and gender equality in order to defend women's inclusion and participation in the mosque and beyond.

Some of the interviewed Shia women also expressed critical sentiments about 'traditional imams', but from a different perspective. A Shia woman in Leicestershire, for example, stated that she is critical of mullahs (imams) who insist that it is women's responsibility to take care of the house: 'it is not their [women's] obligation. You believe this if you don't read Islam, and if you only hear what the mullah says in the mosque'. Her interpretation of 'authentic Islam' was also shared by a Shia woman from Oslo, who stated that a wife's only duty to her husband is to satisfy him sexually. To do housework or raise children are not formally women's duties; however, if they are taken on, they will be rewarded. These views are characteristic of some Shia traditions (see Mir-Hosseini 2000, pp. 61-72). Within traditional Islam, women's place is considered to be in the home, but modernist interpretations of Islam support women's rights to education and employment (Ahmed 1992; Esposito 1982). 
While the interviewees expressed mixed views of imams, they all agreed with the existing hegemonic Islamic norm that only men can be imams and lead prayer for men and gender-mixed audiences. They did, however, support the work of female teachers and scholars towards women and children. ${ }^{6}$ The rule that women cannot be imams was seen as rooted in religious prescriptions that are not up for debate. For example, a Sunni woman in Leicestershire stated that "in our religion we can't have a lady imam, that is strictly no. You have lady priests [in Christian churches] but we can't have, we can't lead the congregation, we have to follow". Similarly, a Sunni woman in Oslo declared that "the imam is he who leads prayer, and a woman cannot lead prayer". Participants noted that women are not obliged to pray in the mosque (as are men), and that they are not allowed to pray during menstruation. These reasons were used to legitimate that women are not suited to become imams. "We are not pure, we are not allowed to pray", said one interviewee, while another noted the inconvenience of having a woman leading prayer when she would have to be regularly absent from the mosque due to her period. These women's views were echoed by a further participant who also noted that women are expressly forbidden to pray during the menstrual cycle: "[women] are not pure, we are not allowed to pray. We can enter the mosque, but we can't pray or lead prayers, so for that reason if there is a woman imam then it is not sure that she will be able to lead prayers as needed". The notion of female "impurity" during menstruation was not challenged by any of the participants, and the possibility of post-menopausal women being imams was not entertained. One participant also mentioned women giving birth and breastfeeding as practical hinders for women.

The last woman quoted above also noted that she had never heard a demand from women "to be able to stand in front of a congregation and be imam". While indicating that the idea of female imams is a "non-issue" among mainstream Muslim communities, this example is also illustrative of a larger point; namely, that the interviewed women are engaging in a complex discourse of equality as difference, where gender equality as "equal value" is compatible with gender differentiation in the religious sphere, in the family, and within society more broadly see (Nyhagen and Halsaa 2016).

In contrast to other women in the study, a Sunni participant from Leicestershire was aware of an event in Oxford, UK, where a woman, Amina Wadud, had led a gender-mixed Salah (prayer) see (Hammer 2012), thus demonstrating that the issue of women leading prayer is at least to some extent debated. Neither she nor her mosque approves:

"So it was literally told to the community that it was going on and a woman [was] performing prayer. And behind the woman, the men and women [were together], this is not right, this is not right. What God and the Prophet's rules were, that the man should be performing, and the men and women came behind to pray, but women can't perform [prayer], because it is not right. God does not allow it, simply, and the priest [imam] doesn't allow you. So, we won't debate about it".

The same participant also suggested that women have all the equality they need and want: "We have got all the freedom [we need], we are going to mosque, we are performing our prayers, we are joining events, we are celebrating everything, we are praying and we are getting chances to express our feelings, how we feel and what should be done". Despite observable gender differences pertaining to spatial segregation in the mosque and the leading of gender-mixed sermons and prayers by men only, the interviewed women claim equality with men. As suggested earlier, within a discourse of equality as difference, it is possible to reconcile notions of equality (as equal value) with difference.

\section{Conclusions}

This study has shown that women have multiple motivations for attending the mosque, including learning about Islam, praying, socializing, engaging in community activities, obtaining emotional support, and a feeling of belonging. Women report profound religious experiences in the mosque, such

6 (Kalmbach 2012, p. 24) argues that the accommodation of Muslim women leaders within religious contexts depends on women's willingness 'to support the status quo with respect to gendered norms'. 
as feeling connected to God and to fellow Muslims. The participants engage in self-reflexive processes of knowledge acquisition; they develop their own religious selves and identities by comparing and contrasting multiple sources of religious information. They articulate a discourse about "authentic Islam" which is juxtaposed to "cultural-traditional" perceptions of Islam. This "authentic Islam" is presented as contributing to the women's development of a "correct" or "true" pious, autonomous self and to their own empowerment vis-à-vis men who are perceived as denying Muslim women their rightful status and equal value due to "incorrect" interpretations of Islam (see also Jacobsen 2011b; Jouili and Amir-Moazami 2006).

The analysis has also demonstrated that unequal gender relations are both maintained and contested in the mosque. The very presence of women constitutes a challenge to the overwhelmingly male-dominated mosque spaces. Moreover, women's groups play a vital role in facilitating women's increasing influence in mosques, including their (slow) inclusion in mosque governance. Despite these developments, however, mosques remain male-dominated, something which the women in this study partly accepted and partly contested. The women accepted and welcomed gender segregated spaces, as it afforded them opportunities for participation. The example of women quietly occupying the back seats of the men's room in a mosque in Oslo, however, shows that women may negotiate the gendering of space and that men might be willing to accommodate women's requests in this regard.

Women in this study were critical of men who cling on to power and who are unwilling to accept more gender-inclusive governance structures. In the words of one participant, men are scared that women "might acquire wings and fly away" if they are given any influence; this would be unlikely, she observed, as when women know Islam, they also "know their limits". Again, women made references to men who invoke "cultural practices" in order to hold women back, whilst the women made discursive appeals to an "authentic Islam" as valuing women's contributions. A notable finding is that women express strong support and admiration for men who accommodate women's participation in the mosque. The importance of male allies in women's fight for inclusion should not be underestimated; it seems to make a real difference in terms of women's participation, women's views on the religious authority of imams and experiences of the mosque as a space for religious learning and prayer, and women's sense of belonging to the mosque and its community.

On the other hand, the interviewed women supported the notion that only men can be imams, and did not perceive this as any hindrance to women's participation in the mosque. Rather, the male privilege of inhabiting the role of imam was portrayed as justified and legitimate based on natural-biological differences between women and men related to reproduction (menstruation, birth, and breastfeeding) and concomitant perceptions of "purity" and "impurity". Moreover, gender differences pertaining to religious authority were interpreted within an overall framework of equality as difference, where the allocation of different roles to women and men can legitimately be interpreted as "equality" due to the equal value assigned to both genders (see Nyhagen and Halsaa 2016).

The findings indicate that a binary reading of Muslim women's religious discourses and practices as representing either subordination or resistance does not capture the complexity of Muslim women's reflexive engagement with sources of religious knowledge and with male power and authority. The interviewed Muslim women engage in a complex discursive positioning of "authentic Islam" as supportive of gender equality and women's rights and of women's inclusion in the mosque, whilst also invoking natural-biological and religious justifications for the ubiquitous unequal allocation of mosque space, power, and authority in men's favor.

In terms of the mosque as a gendered space, the participants were positive towards their own accommodation via segregated spaces for women, the welcoming of women's groups and their autonomy and decision-making, and the dissemination of an "authentic Islam" that values the inclusion and participation of women. In this regard they differ from other Muslim women who seek to expand women's inclusion beyond the allocation of prayer space and inclusion in mosque governance. Some women in Lewicki and O'Toole (2017, p. 163) study from Bristol, for example, supported "equal responsibility in ritual leadership to women, including the delivery of sermons and prayers to mixed 
congregations". Further research is needed on Muslim women's demands for equality and inclusion in mosques and of Muslim men's (including imams') reactions to such demands, and on the effects of current initiatives such as the women-led mosque initiative in Bradford, UK and the Muslim Council of Britain's training scheme for women. Further research should also address the significance of age and generational differences, as well as differences pertaining to national-ethnic identities, when it comes to the issue of gender in mosques.

Funding: This research was funded by the European Commission's 6th Framework Programme (2007-2011) within the project 'FEMCIT: Gendered Citizenship in Multicultural Europe: The Impact of Women's Movements' (www.femcit.org). The FEMCIT research theme 'Multicultural Citizenship: Intersections between feminism, ethnic identity and religion' was led by Line Nyhagen.

Acknowledgments: The author wishes to acknowledge the involvement of Beatrice Halsaa, Hannah Helseth, Esmeranda Manful and Cecilie Thun in the fieldwork for this research, and to thank Thomas Thurnell-Read and participants at the 'Power of the Mosques' workshop at the University of Copenhagen, May 2018, for their comments on an earlier version of this manuscript.

Conflicts of Interest: The author declares no conflict of interest.

\section{References}

Abu-Lughod, Lila. 2002. Do Muslim Women Really Need Saving? Anthropological Reflections on Cultural Relativism and Its Others. American Anthropologist 104: 783-90. [CrossRef]

Ahmed, Leila. 1992. Women and Gender in Islam. New Haven: Yale University Press.

Bano, Masooda, and Hilary Kalmbach, eds. 2012. Women, Leadership and Mosques: Changes in Contemporary Islamic Authority. Leiden: Brill.

Bhimji, Fazila. 2009. Identities and agency in religious spheres: A study of British Muslim women's experience. Gender, Place and Culture 16: 365-80. [CrossRef]

Brown, Katherine. 2008. The Promise and Perils of Women's Participation in UK Mosques: The Impact of Securitisation Agendas on Identity, Gender and Community. British Journal of Politics and International Relations 10: 472-91. [CrossRef]

Cesari, Jocelyne. 2006. Mosque Conflicts in European Cities: Introduction. Journal of Ethnic and Migration Studies 31: 1015-24. [CrossRef]

Citizens UK. 2017. The Missing Muslims. Unlocking British Muslim Potential for the Benefit of All. Report by the Citizens Commission on Islam, Participation and Public Life. London: Citizens UK

Darwin, Helena. 2018. Redoing Gender, Redoing Religion. Gender E Society 32: 348-70.

Dessing, Nathal M. 2012. Thinking for Oneself? Forms and Elements of Religious Authority in Dutch Women's Groups. In Women, Leadership and Mosques: Changes in Contemporary Islamic Authority. Edited by Masooda Bano and Hilary Kalmbach. Leiden: Brill, pp. 217-33.

Esposito, John L. 1982. Women in Muslim Family Law. Syracuse: Syracuse University Press.

Faith Matters. 2010. Meeting the Needs of Muslim Women: A Directory of Mosques in England. Available online: http://www.faith-matters.org/images/stories/publications/Developing_Diversity.pdf (accessed on 25 February 2019).

Gilliat-Ray, Sophie. 2010. Muslims in Britain. An Introduction. Cambridge: Cambridge University Press.

Haddad, Yvonne Yazbeck, Jane I. Smith, and Kathleen M. Moore. 2006. Muslim Women in America. The Challenge of Islamic Identity Today. Oxford: Oxford University Press.

Hammer, Juliane. 2012. American Muslim Women, Religious Authority and Activism: More Than a Prayer. Austin: University of Texas Press.

House of Lords. 2018. The Ties that Bind: Citizenship and Civic Engagement in the 21st Century. Select Committee on Citizenship and Civic Engagement. Report of Session 2017-19. HL Paper 118. London: House of Lords.

Jacobsen, Christine M. 2011a. Islamic Traditions and Muslim Youth in Norway. Leiden: Brill.

Jacobsen, Christine M. 2011b. Troublesome threesome: Feminism, anthropology and Muslim women's piety. Feminist Review 98: 65-82. [CrossRef]

Jaschok, Maria, and Shui Jingjun. 2000. The History of Women's Mosques in Chinese Islam: A Mosque of Their Own. London: Routledge. 
Joly, Daniele, and Wadia Khursheed. 2017. Muslim Women and Power: Political and Civic Engagement in Western European Societies. Basingstoke: Palgrave Macmillan.

Jouili, Jeanette S. 2015. Pious Practice and Secular Constraints: Women in the Islamic Revival in Europe. Stanford: Stanford University Press.

Jouili, Jeanette S., and Schirin Amir-Moazami. 2006. Knowledge, Empowerment, and Religious Authroity among Pious Muslim Women in France and Germany. The Muslim World 96: 617-42. [CrossRef]

Kalmbach, Hilary. 2012. Introduction: Islamic Authority and the Study of Female Religious Leaders. In Women, Leadership, and Mosques: Changes in Contemporary Islamic Authority. Edited by Masooda Bano and Hilary Kalmbach. Leiden: Brill, pp. 1-30.

Karim, Jamillah. 2009. American Muslim Women: Negotiating Race, Class, and Gender within the Ummah. New York: New York University Press.

Khankan, Sherin. 2018. Women Are the Future of Islam. A Memoir of Hope. London: Rider.

Lehmann, Uta Christina. 2012. Women's Rights to Mosque Space: Access and Participation in Cape Town Mosques. In Women, Leadership, and Mosques: Changes in Contemporary Islamic Authority. Edited by Masooda Bano and Hilary Kalmbach. Leiden: Brill, pp. 481-506.

Lewicki, Aleksandra, and Therese O'Toole. 2017. Acts and Practices of Citizenship: Muslim Women's Activism in the UK. Ethnic and Racial Studies 40: 152-71. [CrossRef]

Lindvåg, Andreas W. 2016. 'Knapt en kvinne i moskestyrene' [Hardly Any Women on Mosque Boards]. In Vårt Land. Available online: https://www.vl.no/nyhet/knapt-en-kvinne-i-moskestyrene-1.768560?paywall=true (accessed on 18 February 2019).

Mahmood, Saba. 2005. Politics of Piety. The Islamic Revival and the Feminist Subject. Chicago: University of Chicago Press.

Manning, Christel. 1999. God Gave Us the Right: Conservative Catholic, Evangelical Protestant and Orthodox Jewish Women Grapple with Feminism. New Brunswick: Rutgers University Press.

Mernissi, Fatima. 1991. The Veil and the Male Elite. A Feminist Interpretation of Women's Rights in Islam. Reading: Perseus Books.

Minganti, Pia Karlsson. 2012. Challenging From Within: Youth Asociations and Female Leadership in Swedish Mosques. In Women, Leadership, and Mosques: Changes in Contemporary Islamic Authority. Edited by Masooda Bano and Hilary Kalmbach. Leiden: Brill, pp. 371-92.

Mir-Hosseini, Ziba. 2000. Islam and Gender. The Religious Debate in Contemporary Iran. London: I.B. Tauris.

Muslim Women's Council's Website. 2018. Available online: https://www.womenledmosque.co.uk/testimonials/ (accessed on 14 May 2018).

Muslim Women's Network. 2006. She Who Disputes. Muslim Women Shape the Debate. Available online: http: //www.mwnuk.co.uk//go_files/resources/882054-shewhodisputesnov06.pdf (accessed on 25 February 2019).

Nyhagen, Line, and Beatrice Halsaa. 2016. Religion, Gender and Citizenship: Women of Faith, Gender Equality and Feminism. Basingstoke: Palgrave Macmillan.

Nyhagen Predelli, Line. 2008. Religion, Citizenship and Participation: A Case Study of Immigrant Muslim Women in Norwegian Mosques. European Journal of Women's Studies 15: 241-60. [CrossRef]

Piela, Anna. 2010. Muslim Women's Online Discussions of Gender Relations in Islam. Journal of Muslim Minority Affairs 30: 425-35. [CrossRef]

Roald, Anne Sofie. 2001. Women in Islam: The Western Experience. London: Routledge.

Shannahan, Dervia Sara. 2014. Gender, Inclusivity and UK mosque experiences. Contemporary Islam 8: 1-16. [CrossRef]

Spielhaus, Riem. 2012. Making Islam Relevant: Female Authority and Representation of Islam in Germany. In Women, Leadership, and Mosques: Changes in Contemporary Islamic Authority. Edited by Masooda Bano and Hilary Kalmbach. Leiden: Brill, pp. 437-55.

Taj, Farhat. 2013. Legal Pluralism, Human Rights and Islam in Norway. Making Norwegian Law Available, Acceptable and Accessible to Women in a Multicultural Setting. Ph.D. Thesis, University of Oslo, Oslo, Norway.

Vogt, Kari. 2000. Islam på norsk. In Moskeer og islamske organisasjoner i Norge. Oslo: J. W. Cappelens Forlag. 
Wadud, Amina. 2006. Inside the Gender Jihad: Women's Reform in Islam. Oxford: Oneworld Publication.

Woodlock, Rachel. 2010. The masjid is for men: Competing voices in the debate about Australian Muslim women's access to mosques. Islam and Christian-Muslim Relations 21: 51-60. [CrossRef] article distributed under the terms and conditions of the Creative Commons Attribution (CC BY) license (http://creativecommons.org/licenses/by/4.0/). 

Article

\title{
Towards Contextualized Islamic Leadership: Paraguiding and the Universities and Muslim Seminaries Project (UMSEP)
}

\author{
Alison Scott-Baumann ${ }^{1, *}$, Alyaa Ebbiary ${ }^{1}$, Shams Ad Duha Mohammad ${ }^{2}$, Safiyya Dhorat ${ }^{2}$, \\ Shahanaz Begum ${ }^{2}$, Hasan Pandor ${ }^{1}$ and Julia Stolyar ${ }^{1}$ \\ 1 School of Oriental and African Studies, University of London, London WC1H 0XG, UK; \\ alyaa_ebbiary@soas.ac.uk (A.E.); 655836@soas.ac.uk (H.P.); 657735@soas.ac.uk (J.S.) \\ 2 Shams Ad Duha Mohammad, Ebrahim Community College, London E1 1EJ, UK; \\ shamsadduha@gmail.com (S.A.D.M.); safiyyadhorat@gmail.com (S.D.); shahanaz_b@hotmail.com (S.B.) \\ * Correspondence: as150@soas.ac.uk
}

Received: 26 September 2019; Accepted: 3 December 2019; Published: 5 December 2019

\begin{abstract}
The Universities and Muslim Seminaries Project (UMSEP) addresses three key issues in the narrative of Muslim communal identity and religious leadership in Britain today: firstly, the need for the accreditation of Darul Ulooms (Muslim seminaries) and external validation of their programmes; secondly, understanding the career trajectories of Darul Uloom graduates, and exploring good practice; thirdly, understanding emerging leadership models in the British Muslim community. This project is a community-led, positive response to a large Arts and Humanities Research Council (AHRC)-funded research project (Re/presenting Islam on campus) conducted between 2015-2018, which identified discrimination against Muslim staff and students and the politicization of their identity due to counter terror securitisation measures. The community project summarized here in interim form proposes powerful and informed antidotes to discrimination: pathways to mutual recognition in higher education. We used interviews, workshops, and surveys and triangulated our findings to draw our draft conclusions. Firstly, we found enough interest in universities and Darul Ulooms to proceed with accreditation for an Islamic course with the same standing as a degree. Secondly, we identified barriers to career pathways for Muslims. Thirdly, we developed new models of Muslim community leadership, most notably Muslim chaplaincy with spiritual components: a career path with specific significance for Muslim women.
\end{abstract}

Keywords: Darul Uloom; seminary; chaplaincy; accreditation; servant leadership; paraguiding; the jurisprudence of reality

\section{Introducing Paraguiding and the Jurisprudence of Reality}

The Muslim seminary tradition is often viewed as a version of Islamic spirituality that offers exemplary Islamic scholarship unrecognized by mainstream education: in order to maximize its potential and relevance, this traditional approach requires contextualization so that it can be understood more widely, and its wisdoms applied to daily life. This is a form of the 'jurisprudence of reality' that transcends the divide between theory and practice in order to support all communities to communicate better and function co-operatively (Scott-Baumann 2007; Mukadam et al. 2010). The jurisprudence of reality is translated from the Arabic fiqh al-waqi, a concept used to apply and understand classical Islamic law through the prism of today's world.

Here, we set out for the first time a summary of the achievements of a new project, the Universities and Muslim Seminaries Project, which considers the three major issues outlined above. We draw on the work of Mahmood, Naguib, Bano, Scott-Baumann, Ebbiary (Ebbiary 2017), Vygotsky and 
others to demonstrate project innovation and to address chaplaincy and curriculum improvement. The Universities and Muslim Seminaries Project (UMSEP) project team, guided by Scott-Baumann, has developed documentation that will facilitate various aspects of accreditation. Furthermore, the UMSEP project, guided by the Muslim women scholars in the team, has developed a new form of leadership for women and men that involves working alongside those who wish to learn. We call this 'paraguiding', in the sense of 'para' meaning beside or next to and 'guiding' in the sense of facilitating supporting others by actively using one's own social agency as both teacher and learner. Both learner and teacher may go through a similar process of self-discovery and this is inspired partly by the servant-leader model and partly by Vygotsky's pedagogic zone of proximal development. Paraguiding contains elements of intellectual, spiritual and emotional striving which can be seen in each of the following approaches in different ways: the new Ebrahim College chaplaincy model, the academic improvement of the Darul Uloom female curriculum led by Begum, and analysis and distillation of contemporary women leaders' experiences by Ebbiary.

\subsection{The State of Darul Ulooms and Islamic Higher Education in the UK}

The training of British Muslim faith leaders has been an area of interest and concern for both Muslim communities and governments for decades. The earliest Islamic theological college in the UK was founded in 1975. Since then, such colleges, commonly known as Darul Ulooms, have proliferated across the UK, and the demand for the alimiyyah programmes which they provide has continued to grow. The alimiyyah, a course of approximately 4-6 years duration, is a thorough training in the Islamic textual, legal and theological canon. More recently, with the founding of Ebrahim College (2003), the pedagogy and course structure through which the traditional alimiyyah programme is delivered has been reappraised. It is important to note here that the alimiyyah programme is degree-equivalent training offered in different parts of the Muslim world but, in the UK context, it is taught according to the Dars Nizami syllabus, which has its origins in the clerical training programmes of the Mughal Empire.

Despite the alimiyyah programme not being recognized by most universities, or by most employers, many graduates have progressed onto BA and MA programmes, and some are also PhD holders. Others have realised their potential and fulfilled their talent in other meaningful ways, such as teaching Islamic sciences, running institutes, and community work. Some have trained in professional fields unconnected to their prior education. However, others have found the lack of accreditation limiting. Whilst seminary graduates tend to have the commitment and initiative to find ways of earning, often their salaries are limited by the nature of the labour markets they can enter, and the theological training they have received may not be utilized well to the benefit of their communities and wider society.

\subsection{Definition of Darul Uloom}

The Universities and Muslim Seminaries Project (UMSEP) proposes the following working definition of an Islamic seminary:

'An Islamic seminary is an institution that teaches an alimiyyah or other scholarly training programme, that aligns with the religious authority and curriculum goals of a tradition of higher learning in the Islamic world. Such traditions of higher learning may include the Darse Nizami curriculum, which is popular in the Indian sub-continent, or any model established in other parts of the Muslim-majority world. As institutions of higher education, the training is usually offered to post-16 students whom it trains for scholarship in the Islamic sciences and/or service of the community as faith leaders. These institutions may come under the names Darul Uloom, madrasa, Islamic college (Kulliyyah) or University (Jamia), or others.'

Although this definition falls into the category of Further and Higher Education in the UK context (FE and HE), this does not acknowledge the dozens of institutes across the country that offer the alimiyyah programme to students under 16. For the purpose of this project, we will not be including them. 


\subsection{Why Darul Ulooms, and Why Now?}

In the British government's 2018 Integrated Communities and Strategies Green Paper, the government committed to:

Conven[ing] a working group to identify the barriers to Darul Ulooms (Islamic theological institutes) and other religious seminaries achieving higher education accreditation of the qualifications they offer. ... This working group will identify the barriers to Darul Ulooms and other religious seminaries achieving accreditation for their courses from British universities, which government will then seek to act on. (p.61)

The Ministry of Housing, Communities and Local Government commissioned Scott-Baumann to lead this working group, which became the Universities and Muslim Seminaries Project (UMSEP). Objectives were proposed and agreed by the research team with the Ministry of Housing, Communities, and Local Government (MHCLG) to explore the barriers to accreditation and also to map Muslim seminary graduates' current career trajectories. A particular emphasis was placed on Muslim scholarship and leadership, and a sub-committee was formed in March 2019 to advance understanding and formulate specific proposals for them. This report is the result of a five-month investigation, and constitutes the first phase of what we expect will be a five-year project that will lead to a template and model through which the UK's traditional Muslim seminaries (over 40) will be able to work towards the accreditation of their courses and establish excellent working relationships with regional universities.

Whilst the accreditation of Darul Ulooms has been an area of speculative interest for decades, it would appear that it is now that the idea's time has come. Various factors have made this possible. Firstly, over a decade, Ebrahim College has restructured its alimiyyah programme and pedagogy to align with the National Qualifications Framework, thereby making the Islamic sciences taught in Darul Ulooms intelligible to the university sector, and possible to accredit. Secondly, interest in accreditation in the Darul Uloom sector is growing fast, and the will and energy is, for the first time, increasingly present. Most notable in this respect is the long-established and reputable Jamiatul Ilm Wal Huda (Blackburn), whose rector is very supportive. Furthermore, a Jamiatul Ilm Wal Huda graduate, Haroon Sidat, recently completed his PhD—an ethnographic study entitled Formation and Training of British Muslim Religious Leadership Muslim Scholars (Ulama): An Ethnography of a Dar al-Uloom in Britain (Sidat 2019). A third factor is that St Mary's University, a willing partner, was granted powers to award its own taught degrees in September 2006, and now has over a decade of experience in validating Catholic seminary courses. The aligning of other factors too makes this project well timed, and able to deliver long-term success. These factors include some concerns in some parts of government about the securitisation of public space in an attempt to reduce 'extremism'. Another element is the strength of a few respected and influential agents for change such as Tim Winter (Abdal Hakim Murad, Dean and Aziz Foundation Professor at Cambridge Muslim College) who urges renewal of Islamic higher education:

'The UK Darul Ulooms typically follow a curriculum which represents 19th and early 20th century reforms to a 17th century North Indian curriculum. It was the intention of the reforms to reduce the emphasis on logical, philosophical and jurisprudential topics in order to place more stress on Hadith and Sharia studies. In the UK context where critical intellectual skills are the basis of academic life this transformation has poorly equipped Darul Ulooms to enter the mainstream higher education sector.' (UMSEP archive 2019)

Accreditation has been achieved by Cambridge Muslim College and a few others and is a long term goal for some Darul Ulooms: of immediate use and impact is the toolkit developed as part of the project by Ad Duha Mohammad, Ebbiary, Begum and Dhorat in order to help universities and academics in the field of Islamic studies to understand Islamic seminaries, such as Darul Ulooms, and the nature of their curricula. Finally, in the broader context of the national discussion about Islam, we contextualised 
our work within the findings of the Arts and Humanities Research Council (AHRC)-funded project 2015-18 Representing Islam on Campus (Scott-Baumann et al. 2020). The AHRC project has, at the time of writing, the largest data sets yet collected (both quantitative and qualitative) about Islam on campus and two of the case study institutions are Muslim colleges: analysis shows clearly that the Muslim colleges have a great deal to offer mainstream universities in terms of a range of personal Islamic identities including articulation of citizenship, cultural as well as secular understanding and academic scholarship. These features are corroborated in our current project.

\section{UMSEP Objectives, Methodology and Findings}

Outlined below are the nine objectives that were agreed with the Ministry of Housing, Communities, and Local Government (MHCLG) for this five-month project-all were fulfilled, and often exceeded:

1. Select three universities and three Darul Ulooms: Collaborations and partnerships were established with Ebrahim College and St Mary's University in London, the University of Birmingham, Al-Mahdi Institute and As-Suffa Institute in Birmingham, and the University of Leeds and Jamiatul Ilm Wal Huda (Blackburn) in the North.

2. Provide a list of existing models in the university sector for Darul Uloom graduates.

3. Map Darul Uloom graduates' pathways into higher education.

4. Develop a universal Darul Uloom toolkit that align alimiyyah programmes with the National Qualifications Framework so they can be understood by university admissions officers.

5. Run three workshops with St Mary's University and Ebrahim College: Conducted on the campuses of both institutes, the workshops furthered the process that we expect will lead to Ebrahim College being the first UK Muslim seminary to gain university accreditation for its alimiyyah programme.

6. Run three workshops for Darul Uloom teachers: Participating teachers were introduced to the National Qualifications Framework by Dhorat and Begum and were guided through the process of recasting their Darul Uloom syllabus to align with the National Qualification Framework (NQF). This constitutes the first step of a wider programme of crystallizing learning objectives of each taught text, shifting from a book-based to a subject-based curriculum, and raising pedagogic standards with the eventual goal of achieving accreditation.

7. Work with a women's Darul Uloom to ensure equal access to university courses by mapping the curriculum onto the National Qualifications Framework so that it can be replicated in other women's Darul Ulooms.

8. Interview key women to develop a mentoring programme for women, that will increase their community influence

9. Partner Islamic Studies teachers in universities with Darul Ulooms: A wider goal that will serve Darul Ulooms is our work with St Mary's Catholic University, the University of Birmingham, the University of Leeds, School of Oriental and African Studies (SOAS), and the University of London to consolidate the Common Awards system by analogy with that set up at Durham University by the Church of England. The Common Awards system facilitates parity across religious training in the Church of England. It requires constant diligence to pre-empt universities falling back into older, more conservative habits that retreat from partnerships with Muslims, and to encourage more conservative Darul Ulooms to run such programmes.

\subsection{Accreditation: Ensuring a Contextualized University Curriculum}

The need for the modernization and accreditation of classical Islamic theology courses has been accepted for some time (Gilliat-Ray 2005; Geaves 2012; Geaves 2015; Mukadam et al. 2010). Accreditation is a practical process that will empower young adults from traditional Muslim seminaries to be officially rewarded for their expertise and to enhance their career possibilities. Coexistence in society is the focus: 
'... analysis as a mode of conversation, rather than mastery, can yield a vision of coexistence that does not require making others' lifeworlds extinct or provisional'. (Mahmood 2005, p. 199)

The discourse of 'integration' in much of the British political and cultural sphere focuses upon the responsibility of minority actors to adapt and move toward the majority (Scott-Baumann 2018). As the quote from Mahmood suggests, there may be a loss in this movement, and, in the context of UK universities, there is potential for enrichment through a connection with Muslim seminaries. Young Muslim men and women will no doubt benefit from these developments in terms of academic success, career progression, salary enhancement and understanding of their own and other cultures. We hope to be able to report in a few years that an acceptance of modest Islamic virtues onto campuses may make it possible to offer alternatives to mainstream campus misogyny, related to campus contexts (offline and online) that can be affected by alcohol use and sexualisation of friendships (Phipps and Young 2012). The recent AHRC project confirms in fact that most university students welcome the presence of religion on campus as a benevolent influence (Scott-Baumann et al. 2020).

Indeed it is highly relevant for the elucidation of our current project to accept that cultural recognition of other belief systems is an important goal to strive for: we see this in our work with universities and Darul Ulooms, where it is also necessary to accept that there are significant institutional and cultural differences and that they must be acknowledged and discussed in order to develop clear working relationships (Scott-Baumann 2003, 2017; Cheruvallil-Contractor and Scott-Baumann 2015).

It is necessary that universities acknowledge religious understanding in order to work with people of faith, and it is also necessary that Darul Ulooms recognise secular understanding in order to work with universities. Amongst the approaches adopted by Muslims, some choose to exclude tradition in favour of secular critique, whilst others choose to uncritically accept traditional approaches in favour of pursuing pure lives. All parties will need to make adjustments, to build a society that is moral together, and we hope to facilitate this. We believe that such co-operative approaches will facilitate avoidance of the extreme poles of the debate. As a result, we also expect that in the future more women will be able to participate actively in legal reasoning, thereby bringing female perspectives to Islamic religious authority, and the interpretation (in the modern world) of theological and legal understandings (Naguib 2010). We will show here how this may become possible by changing certain structures to reflect the fact that women may have different views from men on certain topics.

\subsection{Bridging the Gap between Darul Ulooms and Universities: The Toolkit}

One of the key outputs of the project has been to produce a toolkit for universities and Islamic seminaries to understand each other. It was designed by UMSEP researchers with considerable experience in the workings of both Islamic seminaries and the UK's higher education system. The toolkit is a unique exercise in bridging the gap between different intellectual traditions and institutions. Apart from the details it outlines below, this clear exposition of what the seminary does and how it corresponds with university education also creates diverse opportunities for collaboration and partnerships with seminaries. These could aid seminaries develop their curricula to align better with further and higher education frameworks and explore validating partnerships. It can also serve as a reference point for employers to understand the academic background and skills of seminary graduates in the same way that QAA benchmarks and published university syllabi do.

The toolkit will help universities and other stakeholders in the following ways:

1. Understand the full breadth and depth of the seminary curriculum and where it corresponds with their own Islamic studies programmes.

2. Serve as a reference point for universities' admissions departments by providing a full picture of the seminary graduate's academic history at level 3 (AS/A level) and levels 4, 5, and 6 (undergraduate level).

3. Create diverse opportunities for collaboration and partnership. 
4. Facilitate seminaries and universities fully exploring the possibility of validating partnerships.

5. Serve as a reference point for employers to understand the academic background and skills of seminary graduates in the same way that QAA benchmarks and published university syllabi do.

6. Support seminaries in developing their own curricula within the context of British further and higher education frameworks.

\subsection{Helping Universities Understand Muslim Seminaries}

The toolkit also contains the following information about seminaries:

1. A definition of an Islamic seminary,

2. An overview of the key features of UK seminaries,

3. An overview of the seminary curriculum,

4. A detailed explanation of the Islamic sciences, and

5. A list of seminaries that are producing faith leaders and teaching at levels that overlap with higher education.

Another approach was through holding meetings and workshops with key personnel from As-Suffa Institute, Al-Mahdi Institute, a London Women's Darul Uloom ${ }^{1}$, St Mary's University, the University of Birmingham and the University of Leeds.

On each occasion, the activities brought together individuals who would not normally meet:

1. St Mary's (RC, Protestant and other) hosted a workshop with Ebrahim College staff and students (Muslim);

2. Al-Mahdi College (Shi-i Muslim) hosted a workshop with the University of Birmingham (secular), Ebrahim College (Sunni Muslim) and As-Suffa Institute (Sunni Muslim);

3. London Women's Darul Uloom and Ebrahim College hosted meetings and workshops with young Muslim women students who had not previously worked with co-ed or male Islamic seminaries.

In each case, significant barriers were removed. For example, the University of Birmingham and Al-Mahdi representatives were sceptical of Sunni Darul Ulooms academic levels prior to being introduced to Ad Duha Mohammad's sophisticated mapping exercise, and the detailed information of modules run at Ebrahim College.

\subsection{Understanding Career Trajectories of Darul Uloom Graduates}

Because their seminary studies are not recognized by the mainstream, rather than entering graduate-level employment or post-graduate education directly, British Muslim seminary graduates often need to study for undergraduate degrees all over again. With university fees being prohibitive and interest-bearing student loans religiously contentious, the problems extend beyond time and age. In particular, young female graduates may be reluctant to pursue university education, despite a keen desire to do so, due to being unfamiliar with the secular environment, or to respect family wishes. Thus, their educational and economic opportunities-for the duration they wish to engage in them-can be more limited and less rewarding than for their male counterparts (Cheruvallil-Contractor and Scott-Baumann 2015).

The UMSEP survey was collaboratively compiled by the UMSEP team using Google Forms. After piloting it with selected Darul Uloom graduates, it was revised and disseminated to graduates of Sunni Darul Ulooms across the UK, of both Deobandi and Barelwi orientation. Primarily, graduate networks were tapped into via the social media platform, 'WhatsApp,' through personal acquaintances belonging to 'WhatsApp' alumni groups, who also shared the survey widely. The link for the survey

1 The institutional participants wished to remain anonymous. 
was preceded by a message detailing its purpose. The survey questions were mostly open-ended, using short or long answer response fields. Whilst multiple-choice questions on gender and study mode were restricted, other multiple-choice questions, such as the type of activity pursued upon graduating had 'other' as an option, which also invited open-ended input.

To date, the survey has generated 221 responses countrywide, from alumni of male and female Islamic seminaries, who predominantly graduated between the ages of 16 to 25 -thirteen respondents were over 25 , with the eldest being 53 . The number of responses makes this the most extensive survey ever done in this field, and, uniquely, over $35 \%$ of the respondents (81) were graduates of female Darul Ulooms. Coding of the survey data has been done for the following questions: region of home town; which Darul Uloom the individual graduated from; the field and level of education pursued upon graduating; the route to admission to university; the ease of admission to university; the field of employment entered upon graduating from Darul Uloom/from university; subsequent fields of employment; current field of employment; the types of community service performed. Whilst some preliminary findings can be noted, a statistician is yet to conduct a thorough analysis.

The large majority of Muslim seminaries in the UK do not offer any externally validated qualification at the end of their programmes, thus placing graduates at a disadvantage when applying for university or employment (Gilliat-Ray 2005). The survey revealed that access to Higher Education courses, usually run at colleges, have offered a pathway for several graduates. Furthermore, progressing onto further and higher education was a popular route taken upon graduating from Darul Uloom, be it at a college or university, or an Islamic institute. Almost 35\% of respondents (77) graduated with a BA, and $18.5 \%$ with an MA/ PGCE (41). Of the MA/ PGCE holders, close to $8 \%$ (17) enrolled directly onto their programme without a BA, predominantly in the field of religion/Islamic Studies (13). Some would combine their studies with a form of employment. Others would return to studying after other pursuits. The range of subjects studied at BA/BSc level (single honours or combined) included Audiology, Biomedical Science, Building Surveying, Business Management, Business Information Systems, Chemistry, Civil Engineering, Communication Media Studies, Criminology, Computer Science \& Internet Technology, Deaf Studies, English Language \& Linguistics, English Literature, Forensic Psychology, Interdisciplinary Human Studies, Journalism, Law, Optometry, Primary Teaching \& English with QTS, Public Health, Social Studies, Sociology, and TESOL. Subjects studied at MA/ MSc include Accounting, Building Surveying, Engineering, Journalism, Law, Social Care Policy, TESOL, Translation, Pharmacy, Philosophy, Psychology, and Special Educational Needs. From the 77 BA holders $78 \%$ (60) secured employment in professions that were not related specifically to religion (i.e. not religious teaching, chaplaincy, or imaamat). Looking at the $41 \mathrm{MA}$ holders, the percentage rises to $85 \%$ (35). Fields of employment included construction, health, IT, finance, law, management, media, retail and teaching.

Though the survey results seem promising in terms of the ambition and resourcefulness of seminary graduates in seeking out Higher Education and gainful employment, their path is often far from straightforward and may be difficult: for various reasons-including financial—some of those who would aspire to, do not make it onto university degree programmes. Perhaps even more problematic is the constraint on directly applying for grants and then later for graduate-level employment positions. Furthermore, Islamic seminary graduates tend to have instilled in them a sense of duty to serve community and society, and the survey has generated plentiful data on the various forms this takes. Detailed quantitative and qualitative analysis of all these areas is due to be undertaken in the next phase of the project.

\subsection{Emerging Leadership Models}

As long as 15 years ago, Lewis (2006) reflected upon the new social roles emerging among the graduates of the Darul Ulooms. Many of these young graduates (in this case male) were forging paths into community service and leadership that their training did not equip them for, nor even intend. This is in large part because the Dars Nizami syllabus taught at British Darul Ulooms is descended 
from an Indian Muslim intellectual tradition that was geared to producing civil servants for the Mughal Empire, not necessarily youth workers and local mosque Imams in England. Some of the roles, such as interfaith facilitator, media spokesperson, speaker on the campus circuit, prison or hospital chaplain, and others, are quite alien to the bookish emphasis of many Islamic seminaries.

The third major theme of the UMSEP project is to identify and acknowledge some of the new leadership models that young Muslim seminary graduates are taking up and understand the pathways they are pioneering and laying out for future generations. This is particularly necessary for the increasing cohort of female Islamic scholars who are re-establishing traditional roles by entering the Muslim community.

Due to the various exploratory strands of this project, several methodological approaches were adopted. For the survey, we relied upon snowball sampling, which proved very effective considering the hard-to-reach demographic of Darul Uloom graduates. As mentioned earlier, the survey was devised collaboratively and tested before use, and the results will be statistically analysed.

Interviews were undertaken for the project strands related to women leaders and chaplains. In total, 13 interviews were conducted-seven with Muslim women leaders, and six with chaplains, both men and women. Interviews were approximately an hour in duration and questions focused upon the career trajectories of both groups. For the women leaders, questions centred on avenues and obstacles to religious authority in the community. For the chaplains, questions related to understanding the current terrain of chaplaincy work, and the potential for Muslim and female practitioners in that field. At time of writing, analysis of interviews was ongoing. All participants were guaranteed anonymity, confidentiality and right to withdraw at any time. All the interviews were recorded unless participants stipulated otherwise, in which case verbatim notes were taken. Most interview participants requested to be anonymised. Some, who are named here, gave permission for their names to be used. With regard to confidentiality, we made it clear that the taped transcripts would be shared with a transcriber from outside the project team and, as the project is government funded, there was a possibility that parts of the data would be seen by the funders. This required a process of detailed exposition of the research and dissemination process to the participants for the purpose of reassurance. This is understandable considering the difficult relationship between British Muslim communities and recent successive governments, as well as the feeling of scrutiny and surveillance experienced by British Muslims, be it from media or political power.

In other strands of the project, less conventional methods were utilised. One key strand was the curriculum mapping exercise with the women's seminary. This was a unique collaborative and reciprocal activity of direct benefit to participants and researchers. As many of the seminaries can be very private and insular, building trust and credibility was a major obstacle, but the results were fruitful. Finally, the workshops we organised, hosted by various seminaries and mainstream universities, were primarily aimed at the purpose of bringing together: (a) Darul Ulooms from different backgrounds to learn from each other, and (b) Darul Ulooms and universities to start a conversation about collaboration. We used a mapping exercise that involved three sequential steps: identifying key Islamic texts, then mapping them onto the university curriculum for religion and subsequently identifying and explaining the knowledge and skills required for non-experts. This model provided clarity in formulation of objectives, assessments and pedagogy and produced a template that can be used elsewhere. These workshops were highly successful in their primary purpose, and though data collection was not a primary intention of this strand, they did inform our research trajectory and help acquire future partners.

\subsection{The 'Jurisprudence of Reality'}

In all intellectual traditions, be they religious or academic disciplines such as psychology, there is a gap between the theory and the practice. In Islamic discourse, the idea of a jurisprudence of reality, which is a translation of the Arabic fiqh al-waqi', seeks to address this gap and to understand better the ways in which legal rulings work out in Muslim society. The idea of fiqh al-waqi' (in those 
terms) has been used by a number of public Islamic Scholars such as Shaikh Yusuf al Qaradhawi (see Caeiro 2017). However, the idea has been debated and expressed in other ways among Islamic scholars the world over. Though many in the South Asian influenced Darul Uloom world would assert that the fatwa tradition (fatwa is the act of creating new legal opinions) is robust and adequate enough to deal with the ever changing modern world, there are a number of scholars from the tradition who have upheld a more context-led reappraisal ${ }^{2}$. Apart from the Islamic legal approach to applying fiqh (Islamic jurisprudence) to 'facts on the ground', there have been a number of anthropological analyses of this bridging activity: most relevant for this context is the work of Bowen (2016) who studied Sharia courts in Britain.

Resonating with the jurisprudence of reality, one of the key emerging leadership roles for Islamic religious professionals in the modern UK context is that of chaplaincy. How can we create accessible spirituality that facilitates humane conversations and mutual recognition, even if not mutual understanding? Whilst Islamic jurisprudence has developed extensively over the centuries, the idea of an Islamic pastoral theology has not. Yet, more recent institutes, such as Cambridge Muslim College, White Thread Institute and Ebrahim Community College are rebalancing the debate. Indeed, as noted by Ali and Gilliat-Ray (2012), Darul Uloom graduates working in chaplaincy are engaging in legal reasoning-regarding what is haram and halal in the context of British public institutions, as well as inspiring an emerging 'theology of pluralism' and 'theology of pastoral care'.

By analogy, the idea of the jurisprudence of reality can be adopted by those who wish to enhance the capacity of Muslims to find a space in which they can explore alternative views to the formulaic ones, and to facilitate the personal futures that may need to be mapped out for an individual with a question, a dilemma or a problem. This need is identified by women interviewees in our project, who state that there is a need for chaplains to master:

'practical theology to complement their theoretical studies ... and what is needed in chaplaincy is the ability to contextualise theology and adapt to this [workplace] context-Darul Uloom graduates have not been taught to contextualise in this way.' (UMSEP archive 24 June 2019)

\section{7. "Paraguiding" and Chaplaincy}

Our 2019 findings demonstrate a powerful evolution in the perception of chaplaincy which, in the 1980s was often still viewed as a Christian device. This justifies our emphasis in this paper upon chaplaincy as a dominant aspect of the creation of new career pathways for Darul Uloom graduates.

The religious diversity of Britain should surely suggest the need for proper national chaplaincy provision in places of public service and public education. As Aune, Guest and Law show in their 2019 report, there have been developments and we see this evolving in earlier reports (Aune et al. 2019). Gilliat-Ray's Religion in Higher Education: The Politics of the Multi-faith Campus (2000) and Ataullah Siddiqui's valuable report on Islam at Universities in England (2007) both contain helpful chapters on the developing character of chaplaincy among Muslim students. Between 2008 and 2012 Professor Sophie Gilliat-Ray, Mansur Ali and Stephen Pattison conducted the first systematic study of Muslim chaplaincy in the UK (2008-2012, funded by Religion and Society). They found that the appointment of Muslim chaplains in prisons and hospitals since the 1990s has positively influenced chaplaincy and Islam in Britain. Their research, culminating in the book Understanding Muslim Chaplaincy, identified

2 These include luminaries such as Mufti Taqi Usmani and Mufti Khalid Sayfullah Rahmani. The latter has a famous book called (Jadid Fiqhi Masail, i.e., 'new jurisprudential issues') and is also the general secretary of the Indian Fiqh Academy. The first two objectives in the English brochure of the IFA reads as follows: ' 1 . To find solutions for the contemporary problems brought up by the developments and changes in social, political, economic, industrial and technological spheres of life, in the light of the guidelines provided by the Quran and Sunnah and deliberations and interpretations of the companions of the Prophet and other pious classical jurists and scholars. 2. To make collective efforts to find out solutions to the contemporary problems or those problems of past which demand rethinking and research in the changing circumstances in line with the principles and methodology of Fiqh.' 
how much excellent chaplaincy support goes unnoticed and argued for better funding, understanding and appreciation. They also discuss Dr. Ataullah Siddiqui's unique Markfield Institute of Higher Education (MIHE) Certificate in Muslim Chaplaincy (2013, pp. 5-11) and show how the terms 'chaplaincy' and 'pastoral' have been adopted and adapted by Muslim practice. Chaplaincy gives new opportunities to Muslim men, and especially Muslim women, to function in the secular public space as agents of religious caring (Gilliat-Ray et al. 2013, p. 165).

We wish to draw attention to the evolution of this model, related partly to the involvement of Ebrahim College (Ad Duha Mohammad) and Markfield Institute of Higher Education (Ataullah Siddiqui) in developing new and Islamic approaches to chaplaincy. In 2008-2012, Gilliat-Ray's research with Muslim chaplaincy identified that Muslim chaplains often pay close attention to legal rulings of Islam, i.e., practical/correct behaviour, whereas for Christian chaplains, 'correct' practice was not that important (p. 169). In the intervening years, this difference has altered, as argued by Rajput (2015). Yet our work develops a new approach that leads to new practices, neither focusing more upon humanitarian care (Rajput), nor upon theological accuracy (traditional seminary): we show how Muslim chaplaincy can develop a coherent combination of counselling/social work/pastoral support with theological application of key moral tenets.

Our research shows that Muslim chaplaincy is now evolving and is valued by Darul Uloom graduates, especially women, who understand the potential of their faith and their soft skills in this context. Most of the Darul Uloom graduates who were interviewed now see chaplaincy as a logical career progression: they describe Darul Uloom training as really important-without this Muslim chaplains would not have theological resources to turn to as they need to have a good grasp of Qur'an and Hadith. Most importantly, in our view, several also saw a reciprocal relationship between their textual and legal understandings and their work as chaplains: they described chaplaincy as a necessary contextualisation of their Darul Uloom studies: their descriptions evoke fiqh al waqi', the jurisprudence of reality. Some voices are critical. Tim Winter gave us his views on Darul Uloom education in his interview:

'Darul Uloom students usually lack critical skills, comparative approaches, a historical sense of the emergence of Islamic doctrines and laws, and an awareness of wider global and Islamic trends. They are also not trained in essay-writing or the construction of arguments'. (UMSEP archive 2019)

Earlier we mentioned soft skills: by soft skills the chaplains we interviewed understand interpersonal aspects of relationships such as active listening, being non-judgmental yet always moral and having a religious opinion to offer in real situations: they see chaplaincy as both complementary to theology and also going beyond it. This 'going beyond' involves several features that emerged as a theme in interviews and shows understanding of a varied, complementary set of skills that are often reciprocal: in order to give help the one whose help is sought has to learn about the one who seeks help. We present them here (in no hierarchical order because they were intertwined during discussion and show the jurisprudence of reality). First, for a novice chaplain it's necessary to learn the skill of functioning like a counsellor by gaining experience through volunteering - it's wise to give this time and attend training courses in order to understand the context of chaplaincy: this includes the importance of presenting oneself as a professional and also as a moral and spiritual guide. We also have evidence of this perceived need for soft skills from within the Darul Ulooms and unrelated to chaplaincy, as evidenced by a senior woman teacher and Darul Uloom graduate:

'We need counselling as we are expected to be a counsellor too. Not only should we be able to deal with fiqh questions, but we need to help people through emotional times'. (UMSEP archive 2019)

Secondly, it's necessary to come as a 'learner' to this work, to deal with the secular world and not come with a sense of entitlement gained from specialist theological knowledge. In his interview Tim 
Winter explained how the success of the Cambridge Muslim College Diploma in Contextual Islamic Studies and Leadership shows:

'the willingness of Darul Uloom graduates to gain non-traditional skills which will render them more relevant and employable in the UK'. (UMSEP archive 2019)

Thirdly, women have particular strengths in soft skills as we see in the Ebrahim College work and that of Cambridge Muslim College, which the senior Darul Uloom woman teacher also emphasised:

'Leadership skills are vital and how to deal with people of different ages. CEO type training is not useful. Rather it has to be grass roots focused and based on khidma (service).

Such qualifications would help us feel more confident.' (UMSEP archive 2019)

Here, we propose a new model of leadership, paraguiding, to create possibilities for contextualization, for practical wisdom and for challenging secular norms, inspired by the jurisprudence of reality, fiqh al waqi'. Paraguiding includes the skills clearly discernible in chaplaincy, and also encompasses good practice seen in Darul Ulooms. Paraguiding puts the emphasis upon reciprocity, being beside each other and even learning from each other, and we see this in the ethos and approach of Ebrahim College's new chaplaincy model. When interviewed for the UMSEP project, Dhorat described the process of training for chaplaincy at EC to be "Learning to sit with a problem, not just in a text-based way", which she believes is part of a guided process of "finding yourself". This guided process, when facilitated by 'open ended reflections and exploration of students' experiences, has been particularly useful in developing these skills and helping them to understand the work of being a chaplain' (UMSEP archive 24 June 2019).

There is clear understanding in the Muslim chaplaincy sector of the combination of skills and character traits necessary for this type of work. When asked what qualities, skills and qualifications graduates should have when looking into chaplaincy, a workplace chaplain described the exact combination that we envisage for the jurisprudence of reality:

- Academic background-sound knowledge of Islam, confident in interpretation, qualified theologian, good grasp of jurisprudence;

- $\quad$ Ability to contextualise and apply teaching appropriately e.g., what applies in local communities as an imam may not work as a chaplain;

- Ability to tailor guidance to individuals;

- Basic training in chaplaincy e.g., confidentiality, non-judgmental approach;

- Interfaith experience and background as chaplaincy teams tend to be multifaith;

- (UMSEP archive 17.06.19).

We propose that this set of skills requires three crucial moral zones: traditional theology, moral authority and reasonable pluralism. These moral zones reflect the three sides of modern Islamic authority that Masooda Bano captured in her recent project (Munnik 2019). As well as working with traditional institutions that train ulama such as Cairo's al-Azhar and the Darul Uloom in Deoband (Bano 2018a), Bano has also worked with newer institutions and scholars in Muslim-minority countries such as Zaytuna College (USA) and Ebrahim College (England) (Bano 2018b). She avers that authority in Islam comes from three sources: knowledge of Qur'an and Sunna (ilm); the moral authority of the scholar; and the scholar's ability to relate to the realities of the living context (Bano 2018a, pp. 30-31). Specific to the third aspect, she notes how Muslim intellectuals educated in the West are notable for having sought and received education that helps them to recognise arguments that are both spiritually strong and realistically reflective of a specific situation (Bano 2018b, p. 25). For example, in chapter 6 of her book, Bano describes how Ad Duha Mohammad, co-founder of Ebrahim College in East London and lead member of the UMSEP team, uses the juridical history of the term ikhtilāf (disagreement) to propose that reasonable pluralism is a wise approach. In this way, he is thereby precluding relativism, 
and proposing that it is not possible to legislate so that everyone squares their conscience with their social responsibility in exactly the same way. Bano presents Ad Duha Mohammad as an example of a Western-educated Muslim faith leader, brokering reasonable pluralism and this provided inspiration for our project.

\subsection{Paraguiding and Female Leaders}

Historically the narrative of religious authority in Islam has not been a male-only endeavour. Although the primary Prophetic figurehead is male, the official systems of religious knowledge-making and official roles of religious leadership have not unanimously excluded women. Women have been able to access higher religious education (but arguably not equally) and have been able to teach and preach as legal and textual scholars. However, the role of Imam or leader of congregational prayers has been invariably male (Bano and Kalmbach 2012; Hammer and Spielhaus 2013).

There are a number of women-only Muslim seminaries in the UK, which produce alimas (female Islamic scholars). These women are trained in the traditional Islamic textual and legal canon and can also have a stake in religious authority. Most of the women's Darul Ulooms in the UK, however, do not offer a curriculum as advanced as the male seminaries. This is partly due to a perception that female graduates will not choose to take up public leadership roles, or perhaps they are not encouraged to. However, those who do go on to serve in the community often become religious teachers in mosques and supplementary schools. Other emerging pathways for these women include chaplaincy, legal work, mediation, counselling and other forms of religious and community leadership.

However, many female seminary graduates do not pursue a vocation based upon their learning. This may partly be due to structural issues in the Muslim community, which, despite the Islamic tradition being historically open to women pursuing religious qualifications, has not yet sufficiently adapted to cater for the growing number of credible female religious practitioners: as such, opportunities for women to exercise their religious learning and authority tend to have been limited. Furthermore, because female-only seminaries typically, it seems, have opted not to formally emphasize post-seminary education and employment, leadership positions in the British Muslim community taken by women have tended to be by those that are not seminary trained; this may have had a role in undermining the religious credibility of female scholars. Giulia Liberatore's paper in this special issue addresses these aspects of leadership for women (Religions 2019, 10(11), 601; https://doi.org/10.3390/rel10110601). Liberatore placed the issues facing women into a wider societal context, when we interviewed her for this project:

'It's really hard to build a community and to support the women, and that's a really big problem because that's why women might start something but not necessarily continue with it. It's a problem for women in general, there are fewer women in high-end jobs. It's a fundamental structural, societal problem.' (UMSEP archive 2019)

Nevertheless, due to numerous factors including generational changes and the increasingly challenging context of British society and the economy, learned and ambitious Muslim women are beginning to make an increasing impact on their communities and wider society.

How should we articulate the spiritual and the interpersonal components of female leadership that our interviewees identify? To approach this, we draw on the extensive literature dealing with the servant-leader model, which is appropriate since the two concepts of spiritual leadership and servant-leadership are close, and both resonate with paraguiding. However, scholars have noted that the literature has little to say about the motives, values, and conditions that cause one to become a servant-leader (Yukl 2010; Freeman 2011). It has been suggested that spiritual individuals are much more likely to become servant-leaders than those who are not (Freeman 2011). This theory is quite plausible given that possessing spiritual values such as humility, integrity, and empathy/compassion are thought to facilitate servant-leadership (Freeman 2011). 
Reciprocity is the key characteristic that connects these different approaches to human communication and understanding. We use the educational model of the zone of proximal development (ZPD) and the servant-leader model to inform our working practices in this project, and introduce the concept of paraguiding. This approach has allowed us to clarify the ways in which the paraguiding chaplaincy model is unique and based upon a model of reciprocity that makes explicit a dimension to spiritual leadership that is often latent or even absent.

Lev Vygotsky, the renowned Russian psychologist (1896-1934), partially developed a model known as the zone of proximal development, unfinished at his early death (Yasnitsky 2018). It seems that if he had developed it further, he would have elaborated the emotional, cognitive and spiritual aspects of the learner's personality, but it is generally used as a pedagogic instrument: the basic premise is that the teacher must know the level of understanding and competence of the learner in order to teach well. If we take this beyond mere functionality to a richer level of human interaction, it is clearly necessary for teacher and learner to communicate well with each other.

The servant-leader model presented by Greenleaf in 1978 also requires reciprocity in the acceptance by both parties, leader and follower, of the possibility of role reversal, humility and learning from each other, in a deliberate and sometimes risky rejection of traditional hierarchal models of leadership (Greenleaf 1978).

Both these approaches are integrated into the chaplaincy model developed here, because this model involves acceptance of reciprocal learning, and generates the possibility for the spiritual leader to also learn, as well as serving the person who requests their guidance.

Most interestingly, Sendjaya (2007) has even developed and validated a scale for measuring spiritual leadership. Pertinently, interview questions used in the development of the scale included: "Does the term 'spiritual leadership' or 'servant leadership' mean anything to you?"; "How would spiritual/servant leadership be different from other leadership approaches or styles?"; and "Do you think the concept and practice of spiritual/servant leadership in organizations can contribute to better organizational performance? How?" Sendjaya appears to combine the two concepts of spiritual and servant-leadership, but what is missing is the possibility of creating a safe space in the secular world for the religious and also for acknowledging the ethical and societal benefits for women in this career path. In our section on Muslim chaplaincy, we demonstrate the value and efficacy of paraguiding as a way of beginning to understand what it is that women bring to leadership.

As well as ethical, organizational, spiritual and societal reasons for adopting a new model of Muslim leadership as exemplified in chaplaincy, there are pedagogic reasons for advocating paraguiding. This builds on the model of teaching and learning developed by Vygotsky. Underpinning Vygotsky's model is the simple and powerful belief that in order to teach someone something new, it is necessary to first establish what that person knows. This is achieved by drawing attention to a notional 'zone' that exists between what I know and what I do not know, which Vygotsky labelled the 'zone of proximal development' (ZPD). Paraguiding proposes that women in particular, for complex cultural reasons, are often particularly suited to inhabiting a 'zone' with a learner to establish the learner's current expertise, and then propose, negotiate and construct next steps.

We also propose that paraguiding can facilitate the new and growing desire to combine theological wisdom with real-world engagement because of the special combination made possible by introducing chaplaincy skills into a situation hitherto dominated by textual and linguistic analysis and devotional quietude. Chaplaincy training creates the 'zone of proximal development' (ZPD): the 'zone' is the cognitive, emotional and spiritual area where the learner has not previously engaged with secular workplaces and is being guided by a person who, through their chaplaincy experience, has adapted to secular settings and can mediate between pure theological learning and its real world application. Once learnt through training, the Muslim chaplain can take the zoning technique and apply it when attempting to help others who come to seek their guidance, whether Muslim or not. Thus there is in this model a built-in sense of learning in order to teach: the trained chaplain works alongside the trainee chaplain and teaches the trainee skills that achieve two functions: the trainee changes her own 
approach and then also, once she has become a chaplain, uses that new insight of teacher as well as the techniques she has learnt, to support those who seek guidance. We describe this process initially here in transactional terms and, in the context of Muslim leadership, it should also be understood in spiritual terms, because the motivating impulse for the female Muslim chaplain is the wish to animate her faith in order that its energy and goodness can be made accessible to others, even if they are of a different faith or no faith. It is understood both religiously and in terms of counselling traditions that personal agency is crucial. For a person of faith, religious knowledge production is at the core of this process, embodied in expressions of sympathy and solidarity as well as in moral precepts drawn from the prophetic Islamic traditions.

Finally, it is not accidental that the term paraguiding sounds like paragliding, a sport not for the fainthearted that takes the human mind and body out of the comfort zone of both feet planted firmly on the earth. Learning anything new provides a challenge at some level to one's sense of self, and this is especially so for chaplaincy, which constitutes a space for spirituality in a secular system. As a Muslim healthcare chaplain said when interviewed, the key to becoming a good chaplain is to 'Get out of your comfort zone'. However, becoming a chaplain means that Muslim seminary graduates' feet are already on unfamiliar terrain in a professional setting which challenges 'theological understandings around multifaith environments, mixed gender environments (UMSEP archive 20 June 2019). Other challenges commented on by interviewees include the reality that Imams and pastoral officers have 'very different roles, and different qualification sets - the theology qualification equips you for advisory role, not necessarily mental health and wellbeing' and that there needs to be a bridge between theology and mental health wellbeing (UMSEP archive 24 June 2019).

The key is for seminary graduates to be paraguided safely through the experience. And prior to that, for the theological education offered to them to be contextualized through a jurisprudence of reality, combining rulings with reality.

\section{Conclusions}

Through UMSEP, we now have partners in seminaries and universities to enable regional partnerships and share best practice and expertise. As mentioned, we are also working to extend the Common Awards system. We hope that our new partners in seminaries and universities will enhance mutual recognition and understanding within society.

Islamic seminaries and university Islamic Studies departments, or universities teaching Arabic as a language, exist in the same societal space but often do not know enough about one another to work co-operatively. As such, the toolkit has some general information about Islamic seminaries, their purpose and their history. Of greater practical import is the curriculum map that details every subject taught at Islamic seminaries and how each level of teaching approximates to the national qualifications framework. Such practical measures will facilitate mutual understanding of spiritual and educational needs.

The three main themes of the project have already begun to bear fruit; firstly, facilitating accreditation through workshops, curriculum mapping, and the toolkit; secondly, understanding the career pathways of seminary graduates; thirdly, analysing emerging leadership models, with special attention to chaplaincy and female leadership. We have analysed these emerging leadership models through the concepts of jurisprudence of reality, the servant-leader model and Vygotsky's teacher/learner approach. In this conflicted modern world, we share, our project provides powerful evidence of generous reciprocity emerging between mainstream universities, Darul Ulooms and Muslim College higher education models. These models can be expressed by using the neologism of paraguiding which shows the potential combination of the theological understanding of Islam, the servant leader model of leadership and Vygotsky's zone of proximal development. This model includes but is not restricted to new chaplaincy models, which create the ability to interweave three crucial moral zones: traditional theology, moral authority through humility and reasonable pluralism 
as understood when secularism and religiosity communicate effectively through sitting together to learn from each other.

Author Contributions: Conceptualization, A.S.-B., A.E., S.A.D.M., S.B., H.P. and J.S.; Data curation, A.E., S.D., S.B., H.P. and J.S.; Formal analysis, A.S.-B., A.E., S.A.D.M., S.D. and H.P.; Funding acquisition, A.S.-B.; Investigation, A.S.-B., A.E., S.D., S.B. and H.P.; Methodology, A.S.-B., A.E., S.A.D.M., S.D., S.B. and H.P.; Project administration, A.S.-B., H.P. and J.S.; Resources, J.S.; Supervision, A.S.-B. and S.A.D.M.

Funding: Ministry for Housing, Communities and Local Government (MHCLG).

Conflicts of Interest: The authors declare no conflict of interest.

\section{References}

Ali, Mansur, and Sophie Gilliat-Ray. 2012. Muslim Chaplains: Working at the Interface of 'Public' and 'Private'. In Muslims in Britain: Making Social and Political Space, 1st ed. Edited by Waqar Ahmad and Ziauddin Sardar. London: Routledge, pp. 84-100.

Aune, Kristin, Matthew Guest, and Jeremy Law. 2019. Chaplains on campus Understanding Chaplaincy in UK Universities. Coventry: Coventry University, Durham: Durham University, Canterbury: Canterbury Christ Church University.

Bano, Masooda, and Hilary Kalmbach. 2012. Women, Leadership and Mosques: Changes in Contemporary Islamic Authority. Leiden: Brill.

Bano, Masooda. 2018a. Modern Islamic Authority and Social Change Volume 1: Evolving Debates in Muslim Majority Countries. Edinburgh: Edinburgh University Press.

Bano, Masooda. 2018b. Modern Islamic Authority and Social Change Volume 2: Evolving Debates in the West. Edinburgh: Edinburgh University Press.

Bowen, John R. 2016. On British Islam: Religion, Law, and Everyday Practice in Shari'a Councils. Princeton: Princeton University Press.

Caeiro, Alexandre. 2017. Facts, Values, and Institutions: Notes on Contemporary Islamic Legal Debate. American Journal of Islamic Social Sciences 34: 42.

Cheruvallil-Contractor, Sariya, and Alison Scott-Baumann. 2015. Islamic Education in Britain: New Pluralist Paradigms. London: Bloomsbury Academic.

Ebbiary, Alyaa. 2017. Re-examining the Decline Narrative: Cambridge Muslim College and the changing face of Imam training in Britain. In Imams in Western Europe: Developments, Transformations, and Institutional Challenges. Edited by Mohammed Hashas, Jan Jaap de Ruiter, Niels Valdemar Vinding and Khalid Hajji. Amsterdam: Amsterdam University Press.

Freeman, G. Thomas. 2011. Spirituality and servant leadership: A conceptual model and research proposal. Emerging Leadership Journeys 4: 120-40.

Geaves, Ron. 2012. The Symbolic Construction of the Walls of Deoband. Islam and Christian-Muslim Relations 23: 315-28. [CrossRef]

Geaves, Ron. 2015. An exploration of the viability of partnership between dar al-ulum and higher education institutions in North West England focusing upon pedagogy and relevance. British Journal of Religious Education 37: 64-82. [CrossRef]

Gilliat-Ray, Sophie. 2005. Closed Worlds: (Not) Accessing Deobandi dar al-uloom in Britain. Fieldwork in Religion 1: 7-33.

Gilliat-Ray, Sophie, Mansur Ali, and Stephen Pattison. 2013. Understanding Muslim Chaplaincy. Burlington: Ashgate Publishing Co.

Greenleaf, Robert K. 1978. Servant Leader and Follower. New York: Paulist Press.

Hammer, Juliane, and Riem Spielhaus. 2013. Muslim Women and the Challenge of Authority: An Introduction. The Muslim World 103: 287-94. [CrossRef]

Lewis, Philip. 2004. New Social Roles and Changing Patterns of Authority Amongst British 'Ulamâ. Archives de Sciences Sociales des Religions 49: 169-87.

Lewis, Philip. 2006. Only Connect: Can the Ulema Address the Crisis in the Transmission of Islam to a New Generation of South Asians in Britain? Contemporary South Asia 15: 165-80. [CrossRef] 
Mahmood, Saba. 2005. Politics of Piety: The Islamic Revival and the Feminist Subject. Princeton and Oxford: Princeton University Press.

Mukadam, Mohamed, Alison Scott-Baumann, Ashfaque Choudhury, and Sariya Contractor. 2010. The Training and Development of Muslim Faith Leaders: Current Practice and Future Possibilities; London: Communities and Local Government. Available online: https://assets.publishing.service.gov.uk/government/uploads/system/ uploads/attachment_data/file/6155/1734121.pdf (accessed on 19 November 2019).

Munnik, Michael B. 2019. Answering for Islam: Journalistic and Islamic Conceptions of Authority. Religions 10: 435.

Naguib, Shuruq. 2010. Horizons and limitations of feminist Muslim hermeneutics: reflections on the menstruation verse. In New Topics in Feminist Philosophy of Religion: Contestations and Transcendence Incarnate. Edited by Pamela Sue Anderson. Dordrecht: Springer Press, pp. 33-49.

Phipps, Alison, and Isabel Young. 2012. That's What She Said: Women Students' Experiences of 'Lad Culture' on HE Campuses. Sussex: University of Sussex.

Rajput, Asgar H. 2015. The Role of Muslim Chaplains in Higher Education: Should They Be Doing What They Are Doing? Practical Theology 8: 227-44. [CrossRef]

Scott-Baumann, Alison. 2003. Teacher education for Muslim Women: Intercultural Relationships, Method and Philosophy. Ethnicities 3: 243-61. [CrossRef]

Scott-Baumann, Alison. 2007. Collaborative Partnerships as Sustainable Pedagogy: Working with British Muslims. In Greener by Degrees: Exploring Sustainability in HE Curricula. Edited by Carolyn Roberts and Jane Roberts. Cheltenham: University of Gloucestershire: Centre for Active Learning, Section C4.

Scott-Baumann, Alison. 2017. Trust within reason: how to trump the hermeneutics of suspicion on campus. In Muslims, Multiculturalism and Trust, 1st ed. Edited by Amina Yaqin, Peter Morey and Asmaa Soliman. New York: Palgrave Macmillan.

Scott-Baumann, Alison. 2018. United Kingdom. In Yearbook of Muslims in Europe. Edited by Oliver Scharbrodt, Samim Akgönül, Ahmet Alibašić, Jørgen S Nielsen and Egdūnas Račius. Leiden, Boston: Brill, vol. 9, pp. 711-30.

Scott-Baumann, Alison, Matthew Guest, Shuruq Naguib, Sariya Cheruvallil-Contractor, and Aisha Phoenix. 2020. Islam on Campus: Contested Identities and the Cultures of Higher Education in Britain. Oxford: Oxford University Press.

Sendjaya, S. 2007. Conceptualizing and measuring spiritual leadership in organizations. International Journal of Business and Information 2: 104-26.

Sidat, Haroon. 2019. Formation and Training of British Muslim Religious Leadership Muslim Scholars (Ulama): An Ethnography of a Dar al-Uloom in Britain. Ph.D. dissertation, Cardiff University, Cardiff, UK.

Yasnitsky, A. 2018. Vygotsky. An Intellectual Biography. London: Routledge.

Yukl, Gary. 2010. Leadership in Organizations, 7th ed. Upper Saddle River: Prentice Hall.

(C) 2019 by the authors. Licensee MDPI, Basel, Switzerland. This article is an open access article distributed under the terms and conditions of the Creative Commons Attribution (CC BY) license (http://creativecommons.org/licenses/by/4.0/). 
Article

\title{
Assessing Muslim Higher Education and Training Institutions (METIs) and Islamic Studies Provision in Universities in Britain: An Analysis of Training Provision for Muslim Religious Leadership after 9/11
}

\author{
Jawad Shah \\ Department of Arabic, Islamic and Middle Eastern Studies, University of Leeds, Leeds LS2 9JT, UK; \\ ml14j6s@leeds.ac.uk
}

Received: 22 October 2019; Accepted: 6 November 2019; Published: 11 November 2019

\begin{abstract}
The training of Imams and Muslim religious leaders has received much interest in the post-9/11 era, resulting in a vast amount of research and publications on the topic. The present work explores this literature with the aim of analysing key debates found therein. It finds that throughout the literature there is a pervasive demand for reform of the training and education provided by Muslim higher education and training institutions (METIs) and Islamic studies programmes at universities in the shape of a synthesis of the two pedagogic models. Such demands are founded on the claim that each is lacking in the appositeness of its provision apropos of the British Muslim population. This article calls for an alternative approach to the issue, namely, that the university and the METI each be accorded independence and freedom in its pedagogic ethos and practice (or else risk losing its identity), and a combined education from both instead be promoted as a holistic training model for Muslim religious leadership.
\end{abstract}

Keywords: Imam training; Muslim religious leadership; Islamic education; darul-ulums; Islamic studies; British Islam

\section{Introduction}

Few observers would disagree with the Orientalist Bernard Lewis' (1993, p. 263) assertion in his study of Islamic civilisations through the lens of Western Christendom that there is no church or church-like authority in Islam, and that instead the mantle of religious authority in Muslim communities is taken on by individual leadership, which, most visibly in the British context, includes the 'Imams' of the hundreds of mosques scattered throughout the country.

The term 'Imam' is an Arabic word translated by Wehr and Cowan (1993, p. 32) as literally 'guide' or 'leader'; it has been translated by some as 'in front of' (Mukadam and Scott-Baumann 2010), due to, it seems, their mistakenly assigning the diacritic fathah as the first vowel instead of the required kasrah. It has different connotations in Sunni and Shi'ite schools of Islam: Whilst for Sunnis 'Imam' is a title reserved for those who lead congregational prayers and occasionally extended to historically influential jurisconsults, for Shi'ites it is a rank of theological significance and an inherent component of their creedal postulations of prophecy and revelation (Scott-Baumann and Cheruvallil-Contractor 2015, pp. 57-81). However, the Sufi-oriented Barelvis from the Sunni school have also formulated a more complex spiritual hierarchy of Imam al-Kubra ('the greater Imam') and Imam al-Sughra ('the lesser Imam') (Geaves 2008, p. 108).

The roles of regular mosque Imams extend today beyond the traditionally limited confines of a number of congregational duties into 'professional managerial and pastoral' dimensions (Birt 2006). Consequent to this (and the ubiquitous inclination in the academic literature to draw 
Christian parallels) the term 'Imam' had become the de facto term for Muslim religious leadership in the nomenclature of this area of study (Scott-Baumann and Cheruvallil-Contractor 2015, p. 57). It is now being recognised, however, that there exists a whole plethora of platforms from which influence and authority may be exerted within Muslim communities (Mukadam and Scott-Baumann 2010; Scott-Baumann and Cheruvallil-Contractor 2015). There are firstly the ulama, a religious scholarly elite class, many of whom indeed are Imams themselves, and who are hailed by Qasim Zaman (2007) as the 'custodians of change' in Muslim societies. Alongside them are rival Muslim intellectuals mostly trained in universities, who may not have had the same traditional training of the ulama and are becoming a major source of consultation for the government on Muslim-related policy matters (Lewis and Hamid 2018, p. 51). Then there are charity workers, community organisers and campaigners, mosque management committee members, along with the incipient roles of chaplains and social media personalities (the latter of which arguably yield the most far-reaching followings in the digital media age) (Mukadam and Scott-Baumann 2010; Scott-Baumann and Cheruvallil-Contractor 2015).

These leaders, or 'religious professionals' as Sophie Gilliat-Ray (2006) prefers to label them, influence Muslim identity formation and socio-cultural thought, shaping the minds of Muslims of all ages; from children in the maktabs (local schools of religious learning), youth clubs, and on their electronic devices to adults attending Friday sermons, lectures, and counselling sessions. Given the extent of this influence, it should come as no surprise that these individuals, their training, and the institutions that provide the training are of much importance to government policymakers, academic researchers, and the British Muslim public alike.

Consequently, academic and policy research conducted thus far has resulted in the availability of a rich body of material, comprising government reports, academic literature, as well as a number of responses and innovative enterprises from within Muslim communities. Amongst the earliest studies into METIs are those conducted by Geaves, Philip Lewis, and Jonathan Birt, and these focus mainly on Deobandi institutions (Gilliat-Ray 2005, p. 8). Gilliat-Ray $(2005,2006)$, maybe driven by the inaccessibility of the Deobandi institutions, builds on these to produce a detailed and inclusive survey of institutions affiliated to other Muslim groups like the Shi'ites and the Azharis (linked to Al-Azhar University in Cairo). Following the Siddiqui Report, the government-commissioned Mukadam and Scott-Baumann Report was published in 2010, in which the different offerings of 'Muslim faith leadership' training were reviewed. On the other hand, works such as those of Alyaa Ebbiary (2018) and Lewis and Hamid (2018) focus on more recently established Muslim and Islamic 'colleges'. However, the earliest truly comprehensive 'insider' information on METIs comes from their graduates themselves; the likes of Hamid Mahmood (2012), Ebrahim Moosa (2015), and Haroon Sidat (2018), who were able to have much better access as 'insiders'.

This article, through a review of the literature on METIs and Islamic studies at universities, aims to explore and analyse key elements of the debate surrounding the training of Muslim religious leadership and the various forms of education systems available to them within the context of post-9/11 and post-7/7 Britain. It attempts to address the following three questions: (i) How valid are the most common criticisms levelled at shortcomings in the various forms of training provision for Muslim religious leadership in Britain? (ii) How have the institutions providing this training responded? (iii) And what is the effectiveness of the reforms proposed by the different stakeholders to improve it?

It finds that throughout the literature there persists a theme of criticising the inadequacy and incongruity of the training and education provided by METIs and universities for Muslim religious leadership within the British context and that coalescence of the two's pedagogical praxes is often proffered as the elementary characteristic of a comprehensive system. However, though this criticism may be applicable to a certain extent, it does not stand in its entirety as many METIs and universities continue to evolve in line with their environment. Moreover, the proposed reform via synthesis idea has proven ineffectual in several cases, largely due to the contrasting objectives of the two systems. Instead, I put forward an alternative proposal here to allow METIs and universities to push 
forward independently of one another, thus ensuring that they maintain their positive attributes and be able to rethink the shortcomings within their approaches at their own pace and with freedom from external ideological influences whilst also affording aspiring Muslim religious leaders the opportunities to benefit from a holistic training model that combines education from the two in lieu of a corrosive hybridisation.

\section{Terminology and Nomenclature}

\subsection{Defining the Training}

The training of Muslim religious leadership, just like its roles, takes various forms. To use Scott-Baumann and Cheruvallil-Contractor's (2015) 'twin-track system', it may be an education in Islam or about Islam, and in Britain this is currently provided at the highest level by METIs known as Darul-Ulums, Jamias, Hawzahs, and Muslim/Islamic 'colleges' on the one hand and by numerous mainstream universities on the other. From so-called 'faith-based' courses offered at METIs and 'academic', 'secular' ones offered at universities to language courses, online courses, and specialised vocational training for chaplains, there are a range of paths available to prospective Muslim religious leaders.

There is, resultantly, much debate about formulating a succinct terminology to define this training. Scott-Baumann and Cheruvallil-Contractor (2015), following Bernasek and Bunt (2010), attempt to contain the entire field under the label of 'Islamic studies', an 'umbrella term that encompasses a wide range of disciplinary approaches ranging from Islamic theology to sociology of Islam to Islamic finance and also a wide range of geographical areas'. They also reiterate the general assumption that the approach of METIs is a 'confessional' model of 'Classical Islamic Theology' distinct from the 'academic' courses of 'Islamic studies' at universities. Gilliat-Ray (2006, p. 64), in a somewhat nuanced expounding of this popular view, juxtaposes the 'academic rigour' of universities with the 'self-development' focus of METIs. A third binary is proffered by Mukadam and Scott-Baumann (2010, p. 44) that of 'Islamic sciences' in METIs and 'Islamic studies' in the universities. The scope and criteria of 'Islamic studies' at universities is then further debated with regard to whether it falls under religious studies, area or language studies, social sciences, or constitutes a separate discipline on its own-even whether it should be called 'Muslim Studies' instead (Scott-Baumann and Cheruvallil-Contractor 2015, pp. 9-56). During a meeting of leading academics with officials from the former Higher Education Funding Council England (HEFCE), it was concluded that the subject could be split across three areas, language-based studies, social sciences, and a core 'Islamic studies' based on traditional Muslim approaches of studying Islam (Higher Education Funding Council for England 2007). Sahin (2018), on the other hand, distances the Islamic studies courses found in universities, which he describes as 'a Western framing of the study of Islam that came out of the Eurocentric discourse of Orientalism', from a broader and more organic 'Islamic Education'.

Two dichotomous lines are being drawn between these forms of training: firstly, between the 'secular' and the 'religious', and, secondly, between the purely educational and the more pedagogic (in its original Greek meaning) or nurturing. However, as Lewis (1993, pp. 261-74) concludes, the imposition of the Western Christian concept of a secular-religious binary cannot fit well within a Muslim pedagogical framework for the simple reason that it does not carry over the same value in the Muslim imaginary, just as Asad's (2003) genealogical analysis highlights the contingency of this binary considering its historical conception and adoption in the early modern world of emerging European nation states. Therefore, despite the allure of comparing the two religions given all their parallels, constant comparisons between the two may actually present more problems than solutions given their distinct natures. Moreover, as Scott-Baumann and Cheruvallil-Contractor (2015, p. 24) later concede, in reality these lines of bifurcation are not as clearly defined as they are made out to be, especially with the continual changes many of the institutions are undergoing. Such a dichotomy also ignores the manqulat ('traditional sciences')/ma'qulat ('rational sciences') binary, the two halves making up 
the whole that is Islamic learning and paramount to the classical tradition of METIs (Geaves 2008; Mahmood 2012, pp. 12-13).

\subsection{Problematic Terminology: Darul-Ulum and the Seminary}

As argued earlier, METIs have for some time remained largely understudied and they are, therefore, frequently misunderstood. They are often incorrectly linked to unrelated developments in the Muslim world, such as the Taliban movement or Jihadist groups like al-Qaeda and ISIS, and have been branded with pejorative labels such as 'Jihad Factories' (Hefner and Zaman 2007; Birt 2006). Moreover, the default term for METIs in Britain usually is 'Darul-Ulum', defined by Birt and Lewis (2010, p. 93) as 'ulama-led educational institutions training students in the traditional Islamic sciences', for which the English equivalent presented is 'seminary' (Gilliat-Ray 2005). However, in continuing to question the Christian-influenced nomenclature of this area of study, the selection of both terms is questionable.

Firstly, the term 'Darul-Ulum' is associated mostly with Deobandi institutions and, therefore, its use as the term of choice disregards other significant Muslim currents in the country that prefer alternative designations for their own institutions: such as the Barelvi 'Jamias', Shi'ite 'Hawzahs', and METIs that adopt the titles of 'college' or 'institute' (like the Deobandi Ebrahim College or the Markfield Institute) (Scott-Baumann and Cheruvallil-Contractor 2015, p. 35). This also ignores the existence of many informal learning centres providing the same education (Birt and Lewis 2010, p. 93; Geaves 2008, p. 108). Admitted, the largest portion of METIs in Britain are Deobandi-affiliated (approximately 70\%) (Mahmood 2012, p. 50), whilst South Asians make up most of the British Muslim population (around 66\%), which is also reflected in the religious leadership (South Asian Imams made up 83.7\% in the results of a 2008 survey) (Geaves 2008, p. 102); nevertheless, describing these institutions solely through a Deobandi (or even a South Asian) frame of reference will result in the promulgation of views that ironically overlook minority voices and the nuanced ways that British Muslims have gone about disseminating knowledge.

One alternative adopted by writers such as Peter Mandaville (2006), Mahmood (2012), Moosa (2015), and Sidat (2018) is the term 'Madrasah'. Another, chosen by Scott-Baumann and Cheruvallil-Contractor (2015), is the expression 'Muslim institution'. The latter evidently seems like the more suitable choice in this case, avoiding the possibility of mistranslation and adequately covering the broad range of approaches; however, it is too generic to provide the specificity required for the present discussion, so I propose it be qualified further to 'Muslim Higher Education and Training Institutions' (or METIs for short), incorporating both the pedagogic and the vocational provisions of these institutions.

Secondly, 'seminary' as a translation (for darul-ulum or its cognates in Britain) is also problematic as in its original context 'seminary' implies a provision of training solely for religious leadership (Scott-Baumann and Cheruvallil-Contractor 2015, p. 42), which as we shall see in the coming discussion is neither the sole nor principal aim of METIs. This term too is borrowed from a Christian lexicon, emblematic of the perpetual urge to force Western Christian terms on to Islamic cognates that is so prevalent in this field.

\section{Criticisms of the Training}

\subsection{Criticism of METIS}

Throughout the literature, the main criticism brought against METIs is their importation of foreign contexts, resulting in outdated curricula that are irrelevant to British Muslims and communicated to them in a foreign language. Siddiqui says that for the most part these institutions are 'oblivious of the realities around them', while a report from the Muslim Council of Britain deemed their system of education to be 'inadequate' with 'serious shortcomings' (Siddiqui 2007; Mukadam and Scott-Baumann 2010). Musharraf Hussain, himself the director of a METI, asserts that graduates from 'Islamic seminaries' are 
'without sufficient communication skills [ ... ] leadership skills, and without a good understanding of British culture' (Mukadam and Scott-Baumann 2010, p. 9).

The argument is that many British Deobandi and Barelvi institutions remain stuck within their original Indian milieus, relying on a curriculum known as the Dars-e-Nizami, conceived of in pre-colonial India and further developed in the nation's colonial period (Mahmood 2012), and that even today, despite the demand for English-speaking leaders, their language of instruction is usually in Urdu (Lewis and Hamid 2018, pp. 47-48), meaning that even whilst having mastery of English, the conveyance to an English audience of subject matter they had received in Urdu can be difficult for METI graduates. From Geaves' (2008, pp. 107-10), Mahmood's (2012), and Sidat's (2018) work, it becomes evident that even amongst the graduates of these METIs there is some discontent. Mahmood (2012) contends that the Dars-e-Nizami model is imported wholesale from the subcontinent, where it had been formerly transplanted from the Arab world in the aftermath of the sacking of Baghdad in 1258 . He argues that following the uprising against the British Raj in 1857, the approach of some Muslims changed from open reform to preservation, and this along with the resultant stagnation of scholarship carried over into the British context.

Not all METIs are following these trends though. For example, Geaves (2008) demonstrates how Barelvis see too much of a change from their original context in their institutions and would prefer a return to an emphasised spirituality through the shaykh-murid relationship. Gilliat-Ray (2006) touches on the contextualised focus of the Shi'ite and Azhari 'colleges', which are seen to represent the continuous adaptations of METIs to changing contexts, with some of them even awarding accredited degrees. ${ }^{1}$ Furthermore, as Mukadam and Scott-Baumann's (2010, p. 41) report shows, most of the Deobandi darul-ulums too have made several changes to their syllabi to conform to their current environment, and as Sidat (2018, p. 5) insists as well, with the emergence of British-born teachers has come the increasing adoption of English as the language of instruction.

Another major point of concern raised by several authors is that of the opportunities available to the graduates of METIs. The concern is that, with unrecognised qualifications, the only career option for most graduates is to serve as Imams in mosques, but, as Birt and Lewis (2010) highlight, there are too few mosques to accommodate them all, leaving a surplus of graduates looking for work. However, from the existing research, it becomes clear that a future career in Muslim religious leadership is not always the primary motivation for studying at METIs, nor the leading factor in student recruitment. Some parents send their children solely for a Muslim upbringing and education—to make them 'better Muslims' - and see this as a way to ensure the child's protection in adolescence from culture parents perceive as immoral (Scott-Baumann and Cheruvallil-Contractor 2015, p. 37; Gilliat-Ray 2006, p. 68). Ebbiary (2018, p. 332) says the training in METIs is not designed to produce qualified Imams, but rather trainee scholars. It is even suggested that poorer families, as it is the case in the Subcontinent, see these institutions as a place where their children can be 'housed and fed for eleven months of the year for a relatively small cost (Gilliat-Ray 2006, p. 68.). The developing individuation process highlighted by Geaves (2008, p. 108), where older students, influenced by global preachers, seek a religious education as part of their 'reversion', also shows that this form of study is not merely career-oriented. This would mean that, just as Moosa (2015, p. 53) found to be the case in India, not all graduates of British METIs would be contemplating a full-time imamate or teaching position, and would simply aim to apply their knowledge and moral training in their daily lives. The primary purpose of such institutions, therefore, is to cultivate piety and instil religious values in their students, referred to in the literature as a 'self-development focus' (Gilliat-Ray 2006), 'Taqlid-e-Shakhsi' (Mahmood 2012), an 'otherworldly trend' (Moosa 2015), and a 'tarbiyyatic pedagogy' (Sidat 2018).

1 These too can perhaps be better understood in light of their original contexts, e.g., the strong presence of the rational sciences in Persia/Iran, or the Wahhabi and Nahda movements in the Arab world. 
Furthermore, this employability issue would not be an issue for the degree-awarding Islamic/Muslim colleges, though as Gilliat-Ray (2006, p. 63) asserts (in reference to the Muslim College) few students of these colleges go on to become imams. The Shi'ite models are not explored as much in this regard, the results of which would be interesting given their unique structures of religious leadership. On the other hand, although there are fewer female-only or co-educational METIs than male-only ones (six female-only METIs offering a complete Alimah course were identified in the Mukadam and Scott-Baumann Report (2010, pp. 40,71-73), whose student numbers totalled to 1606), because of their larger intake the total number of female students at METIs is almost equal to the number of male students; and so it would be easy to assume that the generally underresearched female graduates of METIs have the worst prospects in terms of employment opportunities for religious leadership roles. There is indeed a commonly held notion that females cannot become Imams, and it has been identified that the leading roles in fields such as teaching at many METIs are held by men (Scott-Baumann and Cheruvallil-Contractor 2015, pp. 121-22); however, more and more Muslim women are challenging these norms by adopting various roles of religious leadership within their communities. There have been several recent examples of female Imams leading congregations (Lewis and Hamid 2018; Petersen 2019); a rising number of Muslim women taking up chaplaincies, where they even have certain advantages over their male counterparts (Gilliat-Ray et al. 2013); and an emerging cadre of female METI graduates realising that they provide unique services of 'personal and collective guidance' to their communities that tend to override the need for conspicuous career paths but nevertheless propel these women forward as authorities within a male-dominated space (Liberatore 2019). Nevertheless, further research is required on the experiences of female alumni of METIs to uncover the extent to which gendered dynamics influence their subsequent career trajectories.

There are several reasons presented for the lack of, or the slow rate of, progress in METIs. Mahmood (2012, p. 45) states that hurdles tend to arise from older members, who, having grown up in the original homeland context, are most inclined to preserve it undiluted. Sidat (2018, p. 9), likewise, points to senior teachers and their eagerness to imitate their 'akaabir (pious ancestors)'. ${ }^{2}$ Mainly though, it is the isolationist tendencies of movements like the Deobandis that are blamed for creating closed-off worlds, meaning that even the new generation of graduates, from whom the most is expected, can end up paradoxically entering mainstream society with their institutionalised, inward-looking weltanschauung (Gilliat-Ray 2006, p. 71). Lewis and Hamid (2018, p. 28) uncover another potential barrier to change in the form of the 'first generation in every generation' phenomenon prevalent amongst some British Muslim communities due to a large percentage of marriages arranged with partners from abroad, meaning that foreign contexts cannot be entirely eliminated and will be renewed in every generation. One further reason is the security-oriented approach of the government towards METIs, which can sabotage the prospects for positive co-operation, even though, as recognised by those who have studied them, these institutions are part of the solution and not the problem (Birt and Lewis 2010; Birt 2006, 2016).

Nevertheless, as most of the research interviews conducted with British Muslims (Siddiqui 2007)—and Moosa's (2015, p. 241) personal admission—make plain, the teaching offered by METIs is still held to be the most 'authentic' and, therefore, cannot be disregarded. If indeed their twin aims are to preserve their heritage and culture and to engage solely or primarily in a 'tarbiyyatic pedagogy', then they can be said to have been highly successful in achieving these aims so far, and, notwithstanding the aforementioned criticisms, there is a general acceptance that these institutions have indeed evolved somewhat with time and continue to adapt slowly at their own pace to their new context.

Moreover, it is never spelt out in detail in the literature what the required rate of 'progress' is supposed to be; nor indeed if this demand for reform falls under the perpetual promulgation of Western

2 Sidat agrees that akaabir may be better translated as 'great elders' in line with Ingram (2018) translation. 
liberalism via a modus operandi resembling a neo-colonial imaginary highlighted by authors such as Joseph Massad (2016), or what Sayyid and Hesse (2006) refer to as the attempted 'assimilation' of the 'ex-colonial ethnically-marked "immigrant"'.

\subsection{Criticism of Universities}

The pressing question in this context about the teaching of Islam in universities is whether or not this would be recognised by the Muslim community as 'legitimate' training for Muslim religious leadership. It seems that the majority of Muslims do not see the study of Islam at a university as sufficient; as the Siddiqui (2007) shows, they would rather go to a METI for that, and, as Geaves (2008, p. 110) notes, 'an Imam trained outside the darul-ulums and without the dars-i-nizami would not be accepted' in their communities. There is also a suspicion of Islamic studies taught in Western universities on the basis of Orientalist biases and hidden agendas (Moosa 2015, pp. 52-53; Larsson 2018, p. 130), evinced in public comments shared on sites like Youtube from globally influential Muslim scholars such as Noman Ali Khan and Yasir Qadhi (whose influence amongst British Muslims is recognised in Geaves' (2008, p. 108) work), which dissuades Muslim students from joining these courses. However, this may well be changing now, for although criticism of Orientalism in Western universities may have been well-founded in previous decades, a growing number of the leading lecturers in these departments are now Muslim scholars, and the numbers of Muslim students taking up these courses are also increasing; whilst there can also generally be seen efforts to decolonise the curriculum (Suleiman and Shihadeh 2007).

The second critique of the universities' provision of Islamic studies almost mirrors that of METIs; that is, a criticism is made of their decontexualised focus on the Arab and Middle Eastern world-and on texts instead of communities. Sources of this bias are said to be the aftereffects of the colonial legacy and Orientalism at a state level, and little to no engagement with local Muslim communities on the local level (Higher Education Funding Council for England 2007, pp. 8-10; Siddiqui 2007). The discussions the HEFCE had with academics, as well as the Siddiqui Report which they were driven by, both highlight the deficient study of South Asian Islam in these degree programmes, a shade of Islam that represents its largest demographic component in Britain and not only the origin of most British Muslims but also of most of the students enrolled on these courses too (the complete non-existence of a study of minority South Asian Muslim cultures such as the Pashtuns makes for a striking example of this issue) (Higher Education Funding Council for England 2007, 2008a; Siddiqui 2007, pp. 23-24). In these discussions, leading British academics of the field, Shuruq Naguib and Hugh Goddard, expressed the need to include the study of Islam in communities outside the Arab world and of what Naguib terms 'living Islam' (Higher Education Funding Council for England 2007, pp. 8-12). Moreover, although the Arabic language features centrally in most university courses-as Robert Gleave (Higher Education Funding Council for England 2007, pp. 6-8) argues it should-Urdu, the language of much South Asian Islamic literature and arguably as prominent a language of Islamic learning as Persian or Turkish, unfortunately remains neglected (Higher Education Funding Council for England 2007). Indeed, as important as the current focus of universities on Arabic is, given its obvious indispensability in any serious study of the formation of Islamic civilisation, there should be due weight given to post-formative iterations of Islam, especially those that are also relevant to the British and wider Western context.

Finally, there is the overarching dilemma of maintaining the 'secular' ethos of the university when it comes to the study of religion-if indeed Islam can be said to be a 'religion' in the Western sense of the word, as it can be argued that it is perhaps coming to be seen as more of a culture or ethnicity in its diasporic form. Can it remain purely academic—or from the point of view of many prospective Muslim students, should it? Goran Larsson (2018) concludes that subjects such as Islamic theology (and all types of theology for that matter), even if they are labelled as 'academic', do not belong in today's Western universities; especially given that, according to him, most Muslim students only choose this subject for faith reasons. Moreover, he cites the argument of Donald Wiebe that academic disciplines in 
this area should not be utilised to achieve religious, cultural, or political goals (Larsson 2018)—though we should remain wary of uncritically applying the context of other European countries to Britain's own idiosyncratic setting. Likewise, Aaron Hughes (2008) avers that the university study of Islam should not comprise a 'colour commentary' on Muslim life and practice, but rather the focus should be exploring Islam as a social construct in line with the broader framework of Religious Studies.

This assumption about the incompatibility of the two systems is a pervasive one as Scott-Baumann and Cheruvallil-Contractor (2015, p. 146) show, pointing towards fears of 'religious students' on 'secular campuses'. However, the veracity of such an assumption may be called into question: Geaves (2013) finds in his research that the differences in pedagogy between the two systems are often overplayed, whilst Sahin (2018) also demonstrates the errors of such a binary. Similarly, Asad's (2003) work expounds upon the complexities of the notion of 'secular' in relation to 'religious' as well as the various historical overlaps between the two. Scott-Baumann and Cheruvallil-Contractor (2015, p. 144) continue to argue that the need for a 'confessional religious education' is for religious leadership in all faiths in pluralist Europe. Siddiqui (2007) too contends that universities have a faith element to them in terms of the religious plurality of their audiences and should cater to this niche.

On the whole, universities too, like METIs, are adapting to changing contexts with a number of collaborations with local Muslim communities and METIs (to be discussed in the next section) as well as the growing inclusion of Muslim academics who can and will change the topography of the field—although as we are currently in the early stages of this paradigm shift it would be premature to assume how far and in what ways this will happen, given that there is already some opposition to what is perceived as a developing Muslim apologist approach in the academic study of Islam post-9/11 (Hughes 2008). The 'Re/presenting Islam on Campus' project headed by Scott-Baumann et al. can be cited as a positive effort in this regard, which will no doubt help in understanding further the relationship between the university and its faith-oriented constituents. ${ }^{3}$ Muslim women are also helped by university programmes, and though their numbers may be low relative to male staff in the teaching positions (Suleiman and Shihadeh 2007), they take up the larger portion of places on undergraduate courses (Higher Education Funding Council for England 2008b) in an experience that is life-changing for them and allows them to rethink the postulates of their tradition in line with their intersectional identities (Scott-Baumann and Cheruvallil-Contractor 2015; Tyrer and Ahmad 2006). Moreover, several graduates of METIs take up study at universities, many of whom go on to bring about positive change in their communities and from whom much is expected (Lewis and Hamid 2018; Birt and Lewis 2010).

\section{Changing Circumstances and Reform}

\subsection{METIs and Reform}

Over the centuries, one of the enduring characteristics of the Islamic civilisation has been the proliferation of its variant localised currents as it acquired local flavour with its geographical spread. The heterogeneity of METIs all over the world is exemplified in Hefner and Zaman's (2007) work, showing how they reflect their localised contexts and are constantly evolving and dealing with change in their own manner. A look into the past shows that internal debate about Muslim pedagogy was rife from the very outset during the formation of these institutions; and ever since there have existed figures who seek to rethink the epistemological and pedagogical frameworks of Muslim societies-the critical and reformist views of some of the early Deobandi ulama being a case in point (Geaves 2008, pp. 106-7; Reetz 2010, pp. 111-22; Mahmood 2012, pp. 42-48; Moosa 2015, p. 47; Sidat 2018, p. 5).

As mentioned earlier, in Britain too, METIs have been updating their systems of education in line with their new context. Many METIs teach core subjects of the National Curriculum (for

3 See https://www.soas.ac.uk/representingislamoncampus/. 
which a large number of them enjoy positive Ofsted reports) with the provision of GCSEs and A-levels as well as BTEC qualifications, thereby opening up the possibility for the re-integration of the ma'qulat element of their original curricula (Mukadam and Scott-Baumann 2010, pp. 42-43; Geaves 2008, p. 111). These curricula have been updated, with English becoming a more common language of instruction, and several young teachers are adopting modern methods of teaching (Geaves 2013, pp. 8-10; Mukadam and Scott-Baumann 2010, p. 41). Of the reasons cited as causes for this change, chief is the emergence of a new generation with different needs and priorities to its elders and which, through seeking employment or further study, sees the inefficacy of its schooling, initiating an internal shift from a migrant-outlook to a citizen-outlook (Mahmood 2012, p. 45; Sidat 2018, pp. 5, 11; Gilliat-Ray 2018).

These changes by METIs represent their own individual and autonomous attempts to rethink their positions in light of the demands of their ever-changing worlds and may indeed be interpreted as expressions of their own modernities - and they should not be disregarded as inadequate on the basis of a Western modernity as the sole standard through which progress can be measured and assessed. As Hefner and Zaman (2007) reminds us, citing the Israeli sociologist Shmuel Eisenstadt, 'modernity is multiple, not singular' and as Mignolo (2009) remonstrates, Western ideas of modernity—shown by Asad (2003) as commonly perceived to be linked with the centralisation of the 'secular' - should not dictate the waves of global change by ignoring 'alternative modernities'.

\subsection{Muslim Colleges: Blurring the Lines of Division}

Amongst METIs in Britain, the 'colleges' are seen as the perfect 'hybrid institutions', reuniting the 'sacred' and 'secular' sciences of the classical Muslim tradition (Ebbiary 2018). If their Darul-Ulum counterparts represent the reactionary split of their tradition's 'sacred' elements in opposition to the dominant 'secular' education system, then these 'colleges', formed afresh in this new context, represent attempts to bring the two back together once more- though each institution varies in its approach.

Although the more traditional METIs (traditional in the sense of opting to prioritise, at least ostensibly, the transmission and preservation of their curricula and pedagogy instead of major reforms of these) and universities have also responded to the demands of the British context, neither can seem to do so as freely as these 'colleges' perhaps due partly to their desire to maintain their original ethos and identities. This is not an issue for METIs adopting the relatively more flexible labels of 'college' or 'institute', which can as a result be more freely situated on the pedagogical spectrum (in between the traditional METI and the university). Evidence of this comes from the fact that in their 2010 report, Bernasek and Bunt (2010, p. 26) listed four of these colleges as offering validated modules and degrees: Al-Maktoum Institute (which was accredited by the University of Aberdeen but no longer exists), the Shi'ite Islamic College (accredited by Middlesex University), Markfield Institute-where Abdullah Sahin has developed the first MEd in Islamic Education (accredited by Newman University and prior to this by the University of Gloucestershire), and the Muslim College (previously accredited by Birkbeck College and now by ASIC). The Cambridge Muslim College has recently managed to obtain validation from the Open University for its BA in Islamic Studies programme; the Al-Mahdi Institute has established a partnership with the University of Birmingham where final year students of its Hawzah programme can receive an MA in Islamic Studies; whilst Ebrahim College has also been working towards developing validated courses, with already existing extensive collaborations with universities and other institutes (Lewis and Hamid 2018, pp. 56-58; Ebbiary 2018). More recent establishments of such institutions include the Cambridge Islamic College and, the first of its kind in the north, the Bradford Muslim College.

Furthermore, these colleges are able to break with cultural norms and allow mixed-gender classes, promote an open door policy untypical of traditional METIs, and employ non-Muslim lecturers on their staff; in addition, they offer more practical vocational training for chaplains and imams, which, as Ali argues, will help curb the pastoral 'liminality' of current Imams given the discharge of pastoral dimensions now expected in their roles (Ebbiary 2018; Ali 2018). Another feature of such 
institutes is the further opening of opportunities for female religious leaders, who can find through these courses alternative careers in chaplaincy, higher education, and so on (Scott-Baumann and Cheruvallil-Contractor 2015, pp. 128-30). Most of the female scholars mentioned in Liberatore's (2019) work for example had studied at Muslim colleges.

\subsection{Universities and Reform}

Universities also seem to show some interest in rethinking their strategies to include collaboration with METIs (Suleiman and Shihadeh 2007, p. 317; Bernasek and Bunt 2008). There have been a number of these, which include-in addition to the ones mentioned above; the University of Winchester with the Khoja Shiite Ithna-Asheri Community's Islamic Institute for Postgraduate Studies in Damascus, Lampeter University with the European Institute of Human Sciences (EIHS), and the University of Cambridge with the Azhar University (as well as with Cambridge Muslim College on an informal basis) (Mukadam and Scott-Baumann 2010, pp. 44-47; Geaves 2013, p. 3). A lasting positive and successful example is the partnership between the University of Middlesex and The Islamic College, which, with its mixture of validated and non-validated modules, could be an efficacious blueprint for other Muslim 'colleges'; whilst a more recent one between MIHE and Newman University also shows promise (Scott-Baumann and Cheruvallil-Contractor 2015, pp. 136-38). The University of Leeds created a certificate course in Islamic Studies as a result of interactions with the local Muslim community (especially women), and has also facilitated the establishment of the nascent 'Iqbal Centre for the Study of Contemporary Islam' (Siddiqui 2007, Appendix D).

\subsection{Bringing the Two Together}

The most ubiquitous calls for reform in the training provision of Muslim religious leadership put forward the demand that as two distinct educational systems, each lacking full capacity on its own, METIs and universities should work together in a complementary fashion. Both would need to update their curricula, whilst universities are charged with 'connecting' to local METIs and assisting them in acquiring accreditation. Analysing the conception of the Dars-e-Nizami as an elite curriculum in Mughal India, several authors point to how it was updated and developed for a specific context much different to that of modern-day Britain, and how the same should be done today by its adherents in the British context (Geaves 2008, pp. 105-7; Birt and Lewis 2010, p. 117; Mahmood 2012, pp. 42-45; Moosa 2015).

The effectiveness of such reform proposals, however, remains to be seen. A major obstacle arises in the form of the numerous METIs that take on students at a younger age (38 such institutions were listed in the Mukadam and Scott-Baumann 2010), where almost all of the curriculum is completed alongside Levels 1-3 of the National Qualifications Framework. It was in response to this problem that this report recommended that the syllabus of METIs be aligned with the NQF, with recognised qualifications to accommodate all levels (1-6) of instruction (Mukadam and Scott-Baumann 2010, pp. 67-68). Nevertheless, as Sahin (2018, p. 3) shows, such initiatives can only be properly formulated and carried out by specialist Education Studies experts who would ideally have experienced both educational systems, but at present such expertise is short in supply. 4

Furthermore, despite a few successful ventures alluded to here, it looks as though there is an impassable barrier prohibiting collaboration. An irreconcilable, and almost civilizational, clash persists between the two systems: The universities' offering is not legitimate in the eyes of Muslims, whereas

4 However, as Gleave (Higher Education Funding Council for England 2007, pp. 6-8) contends in his rejoinder to the Siddiqui report, this would mean complying unwillingly with the demand that Muslim lecturers should teach modules on Islam, as they are the only ones able to access both the 'traditional' METIs and universities, and would result in a recruitment bias; although it may be noted that this issue would easily be resolved now with the many colleges and institutes offering an 'insider perspective' to students from all backgrounds. 
the 'faith-based' curriculum of METIs is not in line with the quality assurance standards of universities (Siddiqui 2007, p. 31; Scott-Baumann and Cheruvallil-Contractor 2015, pp. 133-58). Two of the four partnerships noted by Bernasek and Bunt proved short-lived, and there has been to date no successful collaboration with any British Deobandi darul-ulum (Scott-Baumann and Cheruvallil-Contractor 2015, p. 138; Geaves 2013). ${ }^{5}$

Moreover, it is apparent that whilst METIs are keen to make these collaborations (perhaps because they stand to benefit more immediately in the form of validated courses), universities do not share the same enthusiasm. Scott-Baumann and Cheruvallil-Contractor (2015, pp. 147-48, 157) note several refusals from universities to set up partnerships with METIs between 1998 and 2015, whilst their ESRC-funded project in 2013 exploring collaborative partnerships between METIs and universities saw limited university uptake in comparison to the representation from METIs. Both Siddiqui (2007) and Mukadam and Scott-Baumann (2010) highlight the willingness of METIs to work with universities in order to seek accreditation. Geaves' (2013, pp. 8-12) darul-ulum project discovered that institutions from Blackburn and Bolton had already made attempts to set up partnerships with local universities, and even went so far as to provide alternative facilities to host the courses-in an attempt to placate concerns over 'permitting post-puberty males to travel alone into gender-mixed FE/HE environments'. However, it is important to clarify that this is not the case with all METIs, who in no way form a monolithic bloc, for, as Geaves' (2013) demonstrates and Mahmood (2012, p. 16) emphasises, the Deobandi darul-ulums differ amongst themselves on the merits of HE collaboration-the Deobandi 'mother institute' in Bury being a prime example of some METIs' disinterest in the idea of partnership (though as Birt and Lewis (2010, p. 100) show, Darul-Ulum Bury was bringing about changes in its own way, encouraging its graduates to take up further study at universities).

The main issue for such collaborations, claim Scott-Baumann and Cheruvallil-Contractor (2015, pp. 140-41), arises from the significant amounts of funding required by both types of institutions. Furthermore, they show that changing approaches in today's universities, inclined towards a 'neoliberal managerialism', push the focus towards the economic value of their programmes instead. ${ }^{6}$ There is also the ever-present spectre of Islamophobia and prejudiced counter-terrorism agendas that can inhibit co-operation from both sides, especially with the prevalent suspicions of a link between university campuses and radicalisation (Scott-Baumann and Cheruvallil-Contractor 2015, p. 152; Department for Education and Skills 2006).

The question also remains as to what the ultimate end product would be of such collaborations if they prove successful, for as Scott-Baumann and Cheruvallil-Contractor $(2015$, p. 141) illustrate, each institution will of course try to influence the other, though the validating university will have the upper hand. In that case, would the university swallow the METI completely, as an affiliate body under its authority or even as a fully-integrated department? Both scenarios would force METIs to shed much of their original identities, which surely cannot be the desired outcome for them given that they are all almost exclusively formed on the basis of a distinct Muslim intellectual heritage, pedagogy and ethical formation, which should retain paradigmatic status under conditions of change rather than face assimilation into the secular British HE system.

\subsection{Alternative Possibilities}

It becomes clear that METIs are important centres of authoritative religious learning for many Muslims, providing education that universities do not (and arguably should not) offer. As seen from the literature, the dominant view amongst Muslim students is that only Muslim teachers in METIs can properly communicate the spiritual and confessional elements of their faith. So perhaps such a

5 Professor Geaves was contacted during the research for this essay, and he explained how his efforts in this project to set up partnerships for two Deobandi Darul-Ulums in North West England eventually turned out to be unsuccessful.

6 The importance of funding for private METIs was also expressed in the 'Islam on Campus' report (Suleiman and Shihadeh 2007, pp. 322-24). 
syncretism of the METI and university models is not fitting if it would significantly disrupt, perhaps even fatally, the continued healthy transmission of traditional religious values through the maintenance of viable independent ulama-led educational institutions. It is for this reason that even METIs that have moved away from the traditional system are seen by Michael Mumisa (2014) as struggling with a 'crisis of identity' (referring to 'modern Islamic colleges'); so even if they are described as successful 'hybrid' models by some academics as highlighted earlier, they are not always held in the same positive light by Muslims (Geaves 2008; Gilliat-Ray 2006).

Therefore, instead of trying to fuse together the idiosyncratic worlds of the METI and the university, perhaps it would be better to keep them apart, empowering each to traverse its own trajectory independently and adapt its own pedagogical style over time, and to evolve in its own natural way and at its own pace. This can primarily be achieved if no institution is required to be entirely dependent on another (in most cases the METI on the university) for validation or accreditation, which is where Mukadam and Scott-Baumann (2010) proposals can play a key role in granting METIs their independence. Both approaches, the university and the METI, like the two sides of a coin, are crucial in creating traditionally trained scholars conversant with contemporary realities and therefore must be kept separate - at least for the moment. Moreover, Muslim students of sacred knowledge should be encouraged to study at both in order to benefit from the positives of each, gaining both the 'insider' and 'outsider' perspective to balance the biases of each, whilst also benefitting from Muslim lecturers who have studied under both systems (and are found in both systems too-such as Dr Ibrahim Harvey at Ebrahim College) and present a unique syncretic approach. ${ }^{7}$ However, some level of co-operation should be maintained between METIs and universities through the exchange of ideas and a fluid transfer of students as in the Leeds example, which will promote better awareness, development, and community cohesion.

This approach of integrating the two systems as part of a holistic model of training instead of synthesising them could help in creating a generation of much-needed experts who can develop this field theoretically and internally formulate the most appropriate models for these institutions going forward. Moreover, this would reflect recent positive trends in the field's research methods where Muslim and non-Muslim academics combine to paint a more balanced picture through presenting both 'insider' and 'outsider' perspectives. Lewis and Hamid (2018, pp. 47-90), whose work is an example of this collaboration, have shown in their case studies of two METI graduates the positive results of combined perspectives.

Admittedly, the synthesised Muslim colleges pose a conundrum for such a proposal in that they seem to be the inevitable result of such a twin education; however, the more successful ones amongst them, such as the Shi'ite colleges mentioned earlier, have incorporated more of a combination of the two systems rather than a complete synthesis, and these can, therefore, serve as unique models for similar institutions to follow.

\section{Conclusions}

The resounding impression that becomes apparent from the literature reviewed in the foregoing discussion is that the training of Muslim religious leadership in Britain is in need of further improvement; at either ends of the spectrum, the offerings of the METI and the university are both inadequate, and a blend of the two is what is ultimately required. Though different parties prioritise different demands, the overall insistence is essentially for this training to reflect both intersectional layers of British Muslim identities, the British and the Muslim—which, it is argued, the current provision does not do.

7 The concepts of the 'insider' and the 'outsider' are vague, with undefined boundaries and several overlaps; they are used here solely for lack of better terms. With the 'insider' view there will be the difficulty to detach oneself from something as dear to them as their faith, but on the other hand this could also be over-compensated for in order to appear impartial. Likewise, 'outsiders' may have a negative or suspicious view of a subject that they cannot be as well-informed about, but may also be inclined to compensate for their 'outsiderness' by a bias in favour of their subjects of study. 
However, this essay concludes that whilst this criticism may be well-founded, the METIs and the universities have both indeed responded internally to their changing contexts in their own ways, and the proposed reform of conflating the two systems is not the most felicitous and may be described as an attempt at cultural assimilation. Questions remain about the effectiveness of the suggested reform proposals given their many failures, whilst the generally implicit motives of the university-based academics pushing for reform, who may be unwittingly (or even wittingly) seeking to impress their own Western liberal ideas on entirely dissimilar systems, also need to be scrutinised. Furthermore, there is ironically a discriminatory focus on the Deobandi and South Asian METIs, with an unequal exploration of other groups such as the Barelvis and the Shi'ites, the influx of Salafist views through the internet, or even female METIs. Overall, it can be seen that this area of study is in need of much formulation at the theoretical level, perhaps because it has not yet had enough time and opportunities to develop.

The alternative recommendation proffered here is that instead of continuing conceivably futile attempts at a synthesis of two disparate systems, the provision of the METIs and the universities should be kept separate and each should be integrated individually into Muslim Religious Leadership training instead, thus keeping in line with the aforementioned necessity of respecting their differences and not imposing (upon either) foreign and unrelatable notions. Originating from divergent contexts, they obviously have differing raisons d'être that grants them their identities, and each offers unique benefits that the other cannot provide, but a fusion of the two would ultimately force them to water these down or abandon them.

The best-case scenario would be every institution functioning independently and freely according to its own ideals. For this to come to fruition though the METIs would require a system of validation for their provision that does not mean relying on another institution, and here the recommendations of Mukadam and Scott-Baumann should be developed and utilised. Subsequently, in order to gain a holistic training, Muslim religious leadership would be expected to acquire an equally important education from both the METI and the university.

Most importantly, however, regardless of the shape it takes, change must be allowed to come about organically from within and must not be enforced upon any institution, and especially not through a liberal-assimilationist or counter-terrorism rationale.

Funding: This research received no external funding.

Acknowledgments: I would like to express my sincere gratitude to Riyaz Timol and Sophie Gilliat-Ray for considering my article for publication, to Haroon Sidat for his feedback and comments, and most of all to my supervisor, Ustadh Yahya Birt, without whose excellent guidance this work could not have been completed.

Conflicts of Interest: The author declares no conflict of interest.

\section{References}

Ali, Mansur. 2018. Muslim Chaplaincy as a Model for Imamship: From Liminality to Immanent Spirituality. In Imams in Western Europe: Developments, Transformations, and Institutional Challenges. Edited by Mohammed Hashas, Jan Jaap De Ruiter and Niels Valdemar Vinding. Amsterdam: Amsterdam University Press, pp. 295-314.

Asad, Talal. 2003. Formations of the Secular: Christianity, Islam, Modernity. Stanford: Stanford University Press.

Bernasek, Lisa, and Gary Bunt. 2008. International Approaches to Islamic Studies in Higher Education: A Report to HEFCE. Ashby: Higher Education Academy.

Bernasek, Lisa, and Gary Bunt. 2010. Islamic Studies Provision in the UK: Report to HEFCE by the Higher Education Academy. Ashby: Higher Education Academy.

Birt, Jonathan. 2006. Good Imam, Bad Imam: Civic Religion and National Integration in Britain Post-9/11. The Muslim World 96: 687-705. [CrossRef]

Birt, Jonathan. 2016. Locating the British Imam: The Deobandi Ulama between Contested Authority and Public Policy Post-9/11. In European Muslims and the Secular State. Edited by Jocelyne Cesari and Seán McLoughlin. Abingdon and Oxon: Routledge, pp. 183-96. 
Birt, Jonathan, and Philip Lewis. 2010. The Pattern of Islamic Reform in Britain: The Deobandis between Intra-Muslim Sectarianism and Engagement with Wider Society. In Producing Islamic Knowledge: Transmission and Dissemination in Western Europe. Edited by Martin Van Bruinessen and Stefano Allievi. London: Routledge, pp. 91-120.

Department for Education and Skills. 2006. Promoting Good Campus Relations: Working with Staff and Students to Build Community Cohesion and Tackle Violent Extremism in The Name of Islam At Universities and Colleges; London: Department for Education and Skills.

Ebbiary, Alyaa. 2018. Re-examining the Decline Narrative: Cambridge Muslim College and the Changing Face of Imam Training in Britain. In Imams in Western Europe: Developments, Transformations, and Institutional Challenges. Edited by Mohammed Hashas, Jan Jaap De Ruiter and Niels Valdemar Vinding. Amsterdam: Amsterdam University Press, pp. 315-36.

Geaves, Ron. 2008. Drawing on the Past to Transform the Present: Contemporary Challenges for Training and Preparing British Imams. Journal of Muslim Minority Affairs 28: 99-112. [CrossRef]

Geaves, Ron. 2013. An Exploration of the Viability of Partnership Between Dar Al-Ulum And Higher Education Institutions in North West England Focusing Upon Pedagogy and Relevance. British Journal of Religious Education 37: 64-82. [CrossRef]

Gilliat-Ray, Sophie, Mansur Ali, and Stephen Pattison. 2013. Understanding Muslim Chaplaincy. London: Routledge. Gilliat-Ray, Sophie. 2005. Closed Worlds: (Not) Accessing Deobandi dar Ul-uloom in Britain. Fieldwork in Religion 1: 7-33. [CrossRef]

Gilliat-Ray, Sophie. 2006. Educating the Ulama: Centres of Islamic Religious Training in Britain. Islam and Christian-Muslim Relations 17: 55-76. [CrossRef]

Gilliat-Ray, Sophie. 2018. From "Closed Worlds" to "Open Doors": (Now) Accessing Deobandi darul Uloom in Britain. Fieldwork in Religion 13: 127-50. [CrossRef]

Higher Education Funding Council for England. 2007. Islamic Studies: Current Status and Future Prospects; Ashby: Lion Court Conference Centre, Higher Education Funding Council for England.

Higher Education Funding Council for England. 2008a. Islamic Studies: The Way Forward in the UK; Ashby: Queen Elizabeth II Conference Centre, Higher Education Funding Council for England.

Higher Education Funding Council for England. 2008b. Islamic Studies: Trends and Profiles; Ashby: Higher Education Funding Council for England.

Hefner, Robert W., and Muhammad Qasim Zaman. 2007. Schooling Islam: The Culture and Politics of Modern Muslim Education. Princeton: Princeton Univ. Press.

Hughes, Aaron W. 2008. Situating Islam: The Past and Future of an Academic Discipline. London: Equinox Pub.

Ingram, Brannon D. 2018. Revival from Below: The Deoband Movement and Global Islam. Oakland: University of California Press.

Larsson, Goran. 2018. Studying Islamic Theology at European Universities. In Imams in Western Europe: Developments, Transformations, and Institutional Challenges. Edited by Mohammed Hashas, Jan Jaap De Ruiter and Niels Valdemar Vinding. Amsterdam: Amsterdam University Press, pp. 121-41.

Lewis, Bernard. 1993. Islam in History: Ideas, People, and Events in the Middle East, 2nd ed.Chicago: Open Court.

Lewis, Philip, and Sadek Hamid. 2018. British Muslims: New Directions in Islamic Thought, Creativity and Activism. Edinburgh: Edinburgh University Press.

Liberatore, Giulia. 2019. Guidance as 'Women's Work': A New Generation of Female Islamic Authorities in Britain. Religions 10: 601. [CrossRef]

Mahmood, Hamid. 2012. The Dars-e-Nizāmī and the Transnational Traditionalist Madāris in Britain. Master's thesis, University of London, London, UK.

Mandaville, Peter. 2006. Islamic Education in Britain: Approaches to Religious Knowledge in a Pluralistic Society. In Schooling Islam: The Culture and Politics of Modern Muslim Education. Edited by Robert W. Hefner and Muhammad Qasim Zaman. Princeton: Princeton University Press, pp. 225-41.

Massad, Joseph Andoni. 2016. Islam in Liberalism. Chicago: University of Chicago Press.

Mignolo, Walter D. 2009. Epistemic Disobedience, Independent Thought and Decolonial Freedom. Theory, Culture E Society 26: 159-81. [CrossRef]

Moosa, Ebrahim. 2015. What is a Madrasa? Chapel Hill: University of North Caroline Press.

Mukadam, Mohamed, and Alison Scott-Baumann. 2010. The Training and Development of Muslim Faith Leaders: Current Practice and Future Possibilities; London: Department for Communities and Local Government. 
Mumisa, Michael. 2014. Quranic Hermeneutics and the British Context. Frankfurter Zeitschrift Für Islamisch-Theologische Studien 1: 82-101.

Petersen, Jesper. 2019. Media and the Female Imam. Religions 10: 159. [CrossRef]

Reetz, Dietrich. 2010. From Madrasa to University: The Challenges and Formats of Islamic Education. In The Sage Handbook of Islamic Studies. Edited by Akbar S. Ahmed and Tamara Sonn. Thousand Oaks: SAGE Publications, pp. 106-39.

Sahin, Abdullah. 2018. Critical Issues in Islamic Education Studies: Rethinking Islamic and Western Liberal Secular Values of Education. Religions 9: 335. [CrossRef]

Sayyid, Salman, and Barnor Hesse. 2006. Narrating the Postcolonial Political and the Immigrant Imaginary. In A Postcolonial People: South Asians in Britain. Edited by Nasreen Ali, Virinder S. Kalra and Salman Sayyid. London: Hurst.

Scott-Baumann, Alison, and Sariya Cheruvallil-Contractor. 2015. Islamic Education in Britain: New Pluralist Paradigms. London: Bloomsbury.

Sidat, Haroon. 2018. Between Tradition and Transition: An Islamic Seminary, or Dar Al-Uloom in Modern Britain. Religions 9: 314. [CrossRef]

Siddiqui, Ataullah. 2007. Islam at Universities in England: Meeting the Needs and Investing in the Future. Islamic Studies 46: 559-70.

Suleiman, Yasir, and Ayman Shihadeh. 2007. Islam on Campus: Teaching Islamic Studies at Higher Education Institutions in the UK. Report of a Conference Held at the University of Edinburgh, 4 December 2006. Journal of Beliefs \& Values 28: 309-29. [CrossRef]

Tyrer, David, and Fauzia Ahmad. 2006. Muslim Women and Higher Education: Identities, Experiences and Prospects. Liverpool: Liverpool John Moore University and European Social Fund.

Wehr, Hans, and J. Milton Cowan. 1993. A Dictionary of Modern Written Arabic: (Arabic-English). Urbana: Spoken Language Services.

Zaman, Muhammad Qasim. 2007. The Ulama in Contemporary Islam: Custodians of Change. Princeton: Princeton University Press.

(C) 2019 by the author. Licensee MDPI, Basel, Switzerland. This article is an open access article distributed under the terms and conditions of the Creative Commons Attribution (CC BY) license (http://creativecommons.org/licenses/by/4.0/). 

Article

\title{
Shedding Light on the Modalities of Authority in a Dar al-Uloom, or Religious Seminary, in Britain
}

\author{
Haroon Sidat \\ Centre for the Study of Islam in the UK, School of History, Archaeology and Religion, Cardiff University, \\ Cardiff CF10 3EU, UK; Sidathe@cardiff.ac.uk
}

Received: 25 July 2019; Accepted: 26 November 2019; Published: 29 November 2019

\begin{abstract}
God is the Light of the heavens and the earth ... ' (Quran, 24:35.) This article sheds light on the modalities of authority that exist in a traditional religious seminary or Dar al-Uloom (hereon abbreviated to DU) in modern Britain. Based on unprecedented insider access and detailed ethnography, the paper considers how two groups of teachers, the senior and the younger generation, acquire and shine their authoritative light in unique ways. The article asserts that within the senior teachers an elect group of 'luminaries' exemplify a deep level of learning combined with practice and embodiment, while the remaining teachers are granted authority by virtue of the Prophetic light, or Hadith, they radiate. The younger generation of British-born teachers, however, are the torchbearers at the leading edge of directing the DU. While it may take time for them to acquire the social and symbolic capital of the senior teachers, operationally, they are the ones illuminating the way forward. The paper discusses the implications of the changing nature of authority within the DU is likely to have for Muslims in Britain.
\end{abstract}

Keywords: Dar al-Uloom; Islam in Britain; Deoband; ulama; tradition; authority

\section{Introduction}

During research undertaken for my $\mathrm{PhD}$ thesis, authority emerged as a significant analytical category and became one of the lenses through which I examined the Dar al-Uloom (DU). ${ }^{1}$ Its relationship with the Islamic tradition, that of being anchored in an authentic past, results in intense competition among British Muslims who vie to present themselves as heirs of an authentic interpretation and practice of Islam (Gilliat-Ray 2010). It is the DU that becomes implicated as the institution par excellence for the dissemination and imparting of religious knowledge in Islam. Hence, there has been an interest in madrasas globally (Metcalf 1978; Moosa 2015; Bano 2012) and more recently this significance has grown in the West (Bano 2018; Scott-Baumann and Cheruvallil-Contractor 2017). However, no detailed ethnographic study of a DU in Britain has emerged to date. (Geaves 2015a) did spend a short period in a British DU, but his work was limited to the exploration of pedagogy.

My research, therefore, provides a unique detailed "insider" ethnographic account based on immersion in a DU over one year for the very first time. There are increasing numbers of young, educated British-born Muslims looking to religious scholars (ulama) and imams for religious guidance. ${ }^{2}$ In parallel, there has been an interest in DUs from many stakeholder groups from both within and

1 It is important to note that the meaning of words change with their context. In the nomenclature of modern Britain, the word madrasa refers broadly to supplementary schools that take place in the evening for younger children. The DU is the place for higher learning of Islamic education.

2 In a separate paper, I want to argue that both the imam and the ulama have distinct yet overlapping roles in modern Britain. For example, when it comes to religious guidance and questions, the Muslim public is more likely to go to an alim (singular of ulama) than to an imam. The imam leads the prayer and delivers the sermon (khutba), but may not be sought for questions regarding everyday Muslim concerns. This division of labour is significant and underappreciated. 
outside Muslim communities. This paper, however, describes the various modalities of authority and their interdependency in the DU. Reflective of the broader Asadian notion of a discursive tradition (Asad 1986), it argues that the nature of authority is undergoing change, adaptation and contestation.

The first section provides a brief background and history of DUs in Britain. This is then followed by a section that explores how scholarship has understood Islamic authority and its relationship with tradition. This relationship is tied to the importance of possessing a living intellectual lineage or chain (isnaad) back to the Prophet himself with the notion of a close apprenticeship (suhba) with teachers. Before using this as a theoretical base upon which to elucidate the ways in which modalities of authority operate in the DU, I will provide a summary of my methodology. Finally, the implications of the findings for the broader field of the study of religion and authority in modern Britain will follow. What emerges is that despite the concern over the ability of the traditional religious authority to address concerns Muslims are facing, the ulama remain relevant thanks largely to their ability to engage in a tradition where they are constantly reflecting upon inherited practices in relation to modern circumstances.

\section{Background to Dar al-Ulooms in Britain}

Given the centrality of this institution in the preservation and production of knowledge as well as in the formation of the religious elite, the madrasa is crucial to the construction of religious authority. (Zaman 1999, p. 294)

Zaman's comment points towards the significance of the DU. Knowledge during the formative period of Islam evolved from informal settings to become reified and institutionalised in the madrasa (Berkey 2014; Chamberlain 2002; Zaman 2012). Over time, it became the primary institution for the systematic dissemination of knowledge and remains central to the Islamic tradition today. The DU, following this tradition, emerged in a milieu of waning Mughal power and rising British rule. This brought with it structural secularisation, that is the removal of religion from the institutions of society and, subjective secularisation, which is the removal of the religious consciousness (Berger 1973). In response, a group of reformist ulama sought to revive Islam by training well-educated believers to instruct the community in the true practice of Islam by founding a seminary in the city of Deoband in North India in 1867 (Metcalf 1978). ${ }^{3}$ Within a short period, Deoband became a particular tradition, or maslak, of Indian Islam, that is:

A virtuous temperament embedded in an elaborate narrative, one that etched on their madrasa franchise a distinctive blend of theological convictions, intellectual style, and ascetic pious practice derived from eighteenth and nineteenth century predecessors. (Moosa 2015, p. 104)

Following significant numbers of South Asian Muslims migrating to the UK in the 1960s and 1970s, it was the Deobandis as they became referred to, who were the most active in the 'transplanting' of DUs. Two of the earliest Deobandi seminaries were established at Bury in 1975 and Dewsbury in 1982 (Geaves 1996; Gilliat-Ray 2005). They came to dominate the so-called imam-training field in Britain, producing around eighty per cent of British-trained imams (Birt and Lewis 2011). ${ }^{4}$ However, it is inaccurate to view DUs as solely engaged in producing imams. While students who complete the full course graduate as ulama (not imams), there are alternative ways in which their religious leadership is embodied. In any case, despite the prominence of DUs in Britain, they are arguably

3 The Deoband madrasa was designated as a Dar al-Uloom in 1879.

4 The figure is likely to be much bigger since those that provide formal education to over 16 's are not required to register. There are also increasing numbers of part-time courses being run on weekends, evenings and online that are not accounted for. 
the least researched from among the various organisations that serve the religious needs of Muslims in Britain. ${ }^{5}$

\section{Religious Authority in Islam}

Weber (1947) distinguishes between three types of authority in modern societies: Charismatic, traditional and rational-legal. They are in turn legitimated by another typology of norms or legitimate normative orders which include tradition, effectual attitudes, a rational belief in some form of absolute value, and assent to some form of legal enforceability (Spencer 1970). Both norms and authority are present in a symbiotic relationship in any institutional structure. Relevant to this study is the traditional authority which emerged after the charismatic authority of the Prophet (Dabashi 1993). This was in turn legitimated and circumscribed broadly by the Quran and the Prophetic way, his Sunnah, and synthesised formally through the various legal schools (madhabs). Its interpretation passed into the hands of the ulama who emerged in the absence of a formal institution of authority in Islam (Berkey 2001; Crone and Hinds 2003). Following Abou El Fadl (2013), who distinguishes between "being in authority" and "being an authority", the ulama acquire their authority by virtue of the perceived competence they possess to understand God's law. Authority, then, is based on social perception and trust, while it is circumscribed by a normative tradition (see Figure 1).

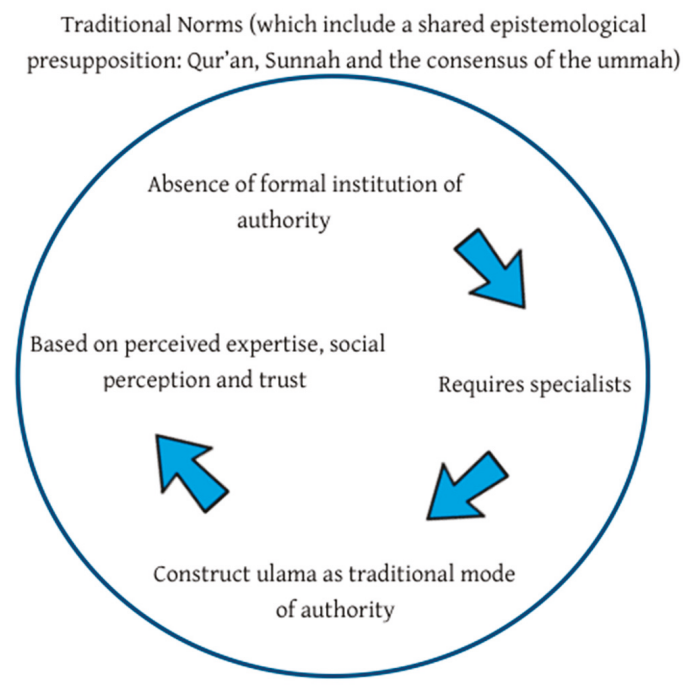

Figure 1. Depiction of how authority emerged in Islam.

As for contemporary trends in modern Europe, Cesari (2003) argues that second generation Muslims are seeking an 'individualised' private Islam, which grants them more autonomy (Peter 2006). Mandaville (2001) points towards the effects of travel and migration. This develops a "critical Islam" where Muslims, in a translocal space, neither completely embrace the host community nor reject their heritage, but form a hybrid outlook. Roy (2004) looks at the influence of the West and towards the perceived inability and social inadequacy which results in Muslims having a greater awareness to deeply reflect on their faith. Media combined with what Eickelman and Anderson (2003) call the 'reintellectualisation of the Islamic doctrine', has led to new challenges for the traditionally trained

5 Gaining access to DUs in Britain has been fraught with many challenges; see (Gilliat-Ray 2005). A handful of authors have written on DUs in Britain (Birt 2006; Birt and Lewis 2011; Geaves 1996; Lewis 2004), but none of them provides a detailed ethnographic account of the DU and young British Muslim experiences first-hand. 
ulama. Finally, as Robinson (2009) and Hamid (2018) argue, thanks to mass education and literacy, especially in the context of modern Britain, imams, mosques and traditionally trained ulama and institutions may become less significant. According to these scholars, the result will be democratisation of Islamic knowledge (not dogma), though not a complete disconnect where a believer constructs their faith anew.

However, Amir-Moazami and Salvatore (2003) see the current trend among young Muslims as a continuation of reform discourses as they emerged in the nineteenth century. They use the notion of Islam as a discursive tradition to argue that any change will occur through "internal interventions" (p. 71), and thus, the role of tradition and the ulama will remain significant. My findings support this view. In essence, this has overturned the "emplotment strategy" (Peter 2006, p. 109) which holds that following large-scale migration of Muslims to Europe successive generations will enable the flourishing of an Islam that is compatible with Europe. A key characteristic of this form of emergent Islam, it is claimed, is an individualised form of religiosity. However, the key arena where the shaping of Muslim religiosity is being welded is within a discursive tradition with religious authorities maintaining an important role.

\section{Authority Through a Living Isnaad and Suhba}

Reflective of the less formal system of education of the past, DU Deoband promoted a close relationship between the teacher and the student (Metcalf 1982). A religious edict (fatwa) issued by the Deoband DU clarified that one could only be called a Maulana, an honorific title signifying that someone had become a religious scholar, if he has studied with a teacher (Metcalfe 1984). Here we see how the tradition of suhba, through an apprentice-based system, grants a graduate authority. ${ }^{6}$ Books are insufficient of themselves to transmit the tradition. In other words, the ulama sought to maintain a focus on an anthropocentric worldview in a world that was increasingly becoming bibliocentric (Ingram 2018). Carroll et al. (1997) describe a similar challenge that Christian seminaries face, in forming the hearts and minds of students towards a pious outlook. The authors conclude that two key factors are important in achieving this: The teachers and the time period the student is exposed to the school's culture. Against the trend to study online or distance-based learning, they thus argue that in seminary training, students' physical presence is essential in shaping them along with the culture of the seminary. In both Christian and Muslims traditions; therefore, spending time with teachers is considered an essential part of the student's learning experience.

The link between knowledge and practice, and the notion of embodiment, combined with an affiliation with the schools of Sufism (the Islamic mystical tradition) helps to explain why there continues to be a great emphasis on developing a deep bond between the teacher and student. The DU Deoband was set up in response to a suggestion by Hajji Imdad Allah (d.1899) who was affiliated with the Chishtiyya-Sabriyya Sufi Order. Its Sufism, however, was closely integrated with Hadith scholarship and legal practices in Islam (Naeem 2004). This "ascetic counterculture" (Moj 2015, p. 59) is important because, with very few exceptions (Geaves 2015b), much recent literature fails to sufficiently acknowledge the important role Sufism played in Deoband. The Deoband seminary was reflective of a broader tradition of authoritative knowledge being transferred from person to person. Others, like Messick (1993) in his study in Yemen, and Berkey (2014) in his study of Cairo under Mamluk rule, argue that the transmission of religious knowledge is a highly personal process: Teachers were responsible for the moral behaviour of their students. The notion of studying at the feet of a teacher still remains a central tenet of learning in Islam, possessing a notion of authenticity and resulting in an individual being recognised as an authority in Islam. This helps to explain why places like the DUs in Britain endure.

6 As Ingram (2018) states "Deobandis believe that the reliability of knowledge itself is inseparable from the embodied ethics of the persons who transmit it" (p. 21). 


\section{Methodology}

Through the ethnographic method of participant observation, I was able to gather rich data about the lived reality within a DU in Britain. This method was complemented with interviews that took place predominantly towards the end of my fieldwork. This helped in crafting my questions based on inferences made during observations. This method is broadly referred to as "grounded theory" (Glaser et al. 1967) where theories and questions emerge inductively from the field and data. Secondly, they were informed by the literature review and the particular research questions that emerged as a result. All three methods, that of the literature review, piloting and inductive data analysis helped refine the interview schedule. The questions were based broadly around collating personal biographical data, exploring motivations and experiences at the DU, pedagogy, identity formation, and questions regarding the nature of knowledge. In the DU, the formality of interviews can cause consternation and unease, and this was something that I wanted to avoid. Having said that, interviews were conducted in a sensitive manner. By including a variety of qualitative methods, methodological triangulation is a way to cancel out the biases of any one method with others (Carter et al. 2014). In total, 41 interviews were conducted —of which 24 were formal, recorded and transcribed. The entire project went through a stringent ethical approval process. The formal interviews lasted on average for $2 \mathrm{~h}$. As for the informal interviews, they all took place in the DU during break and lunchtimes.

My interviewees included students, teachers, management staff and the Principal of the DU and Principals of other DUs in Britain. The first group included students. In order to document their "anticipatory socialisation" (Welland 2000) a number of students who had recently enrolled were interviewed. Other groups of students included those who were progressing through the DU and those who were about to graduate. Students who had graduated were also interviewed. As for the teachers, this included three junior teachers and three senior teachers, including a staff member who had recently left the DU. Given their intimate knowledge of the practical side of the DU, members of management were also included.

The fieldwork took place over 14 months, and it was my identity as a 'trusted' graduate that paved the way for access to the fieldsite (Ahmed 2017). This is because being a graduate of the DU is insufficient in gaining access. The 'trusted' graduate embodies certain acquired characteristics that facilitate and ease access to the DU. Despite graduating in 2006, I have continued to maintain a relationship with the Principal and the teachers at the DU. This includes meeting with them regularly to seek answers to questions from the public, seeking their counsel when it comes to decisions regarding my own personal and spiritual development, and offering to help them whenever I am able to do so. This last point was significant. In 2014, an opportunity arose to pioneer a partnership between the DU and a British University in offering the first two years of a new BA in Islamic Studies. Despite my work commitments at the time, I took on the role of managing this partnership. At the time, I saw this project as the beginning of a broader ambition to address the educational needs of future Muslim scholars in Britain. Despite attempts to compensate for my time and effort by the Principal, I did not accept any financial rewards for my work. The Principal viewed this as sincere on my part, and it ultimately played a significant role in gaining his trust, and thus, access for my doctoral research. As for the senior teachers, being a former student and a fellow imam, I possessed the right cultural capital to gain their trust. Finally, my suhba, that is my ongoing association with some of the senior teachers allowed them to see me as someone who could be trusted. As one teacher stated:

The important thing is that you have an association (nisbat) with the elders. A lot of students don't maintain relationships once they leave. But you have been able to do that which is why we know we can trust you.

It is the relationships maintained, and services rendered post-graduation that are key factors in constructing the 'trusted' graduate. This brief account will be of use to scholars attempting to study communities that can be hard to gain access to and more broadly to those interested in British Muslim studies specifically. 
However, my positionality can carry the risk of over-rapport, while being less critical of the DU leading to what Hodkinson (2005) refers to a becoming a "subcultural spokesperson". ${ }^{7}$ This meant I had to engage in long periods of reflexivity whilst ensuring procedural objectivity (Bourdieu and Wacquant 1992; Hammersley and Atkinson 2007; Abbas 2010). ${ }^{8}$ This was achieved by providing a personal narrative with the inclusion of the ethnographic self, alongside a decade of "distancing" where I had undertaken various career trajectories post-graduation from the seminary. The experiences I have gained in a variety of fields after graduating from the DU have created sufficient distance between myself and the field site, further complicating the claim the I am purely an "insider" (Chryssides and Gregg 2019). Bauman (2000) notion of "liquid identities" of the complexity of simultaneous sameness (being an alumnus in my case) and differences (researcher) led me to consider that my identity is not dialogic, but fluid. Therefore, I was able to achieve both familiarity and strangeness (Coffey 1999; Sara et al. 2010; Collins and Gallinat 2010). Clearly, my work has been conducted within an all-male environment, and so my claims and findings, of course, exclude a 'female' perspective. However, my research will hopefully contribute to methodological discussions about conducting research in these educational environments and may stimulate a subsequent female-led study of a girl's DU in the future. Finally, because this is a community that has generally borne the brunt of sensationalist media reports and conflation with issues to do with securitisation, I struck a delicate balance between robust data collection and a deep sensitivity towards my participants. I have been able to maintain analytical rigour throughout my research by making sure my methods and analysis are transparent.

\section{Modalities of Authority in the Dar al-Uloom}

The teaching staff of the DU can be broadly broken down into two groups: The senior and the junior teachers. ${ }^{9}$ The senior teachers, all of whom are above the age of fifty, have received their religious training in South Asia before migrating to the UK. Alongside this, it is well known-among the ulama and Muslims, they serve more generally—-that they have spent significant time in the suhba of well-known and respected scholars in India. They have not only benefitted from them intellectually, but also spiritually. The acquisition of traditional knowledge comes from studying in the company of teachers who possess a living intellectual lineage or chain (isnaad) back to the Prophet himself. This tradition of discipleship and an uninterrupted chain of pious individuals back to the Prophet remains central in granting a graduate authority. The senior teachers possess a form of charismatic leadership which is likely to be the case for other DUs around Britain. However, since their training and experiences have been formed in a very different socio-cultural setting, this raises questions around whether they are sufficiently familiar with the changing mores of contemporary Britain. ${ }^{10}$ The junior teachers, while not possessing the same level of leadership qualities, are born, raised and trained in Britain. In addition, they are exposed to current debates and challenges facing Muslims thanks largely to social media, which nearly all of them access in various ways. They are more aware of the challenges and context of life here in Britain and share experiences that make them ideally suited to implement considered changes to the way the DU operates. While junior teachers can relate to the contemporary world, some of the senior teachers had more to share in terms of real-life work within their comfort zones, such as their experiences as imams working within Muslim communities, something that has been recognised by others (Lewis and Hamid 2018).

7 While my primary role was of a participant-as-observer, my role was fluid, and I did move along a spectrum between the complete participant and complete observer.

This means that I am a researcher who is conscious that biases and preconceptions can influence the understanding of events.

9 In the actual thesis, I have a further two categories: The Principal and the senior management team (see Figure 2 below).

10 The famous Damascene Hanafi jurist Ibn Abideen (d. 1836) emphasised in his epistle, Nashr al-'arf fi bina' ba'd al-ahkam 'ala'l-'urf (the wafting of perfume concerning building certain judgements on custom) and elsewhere that custom ('urf) and the needs of the people was an important consideration in dispensing religious guidance. 


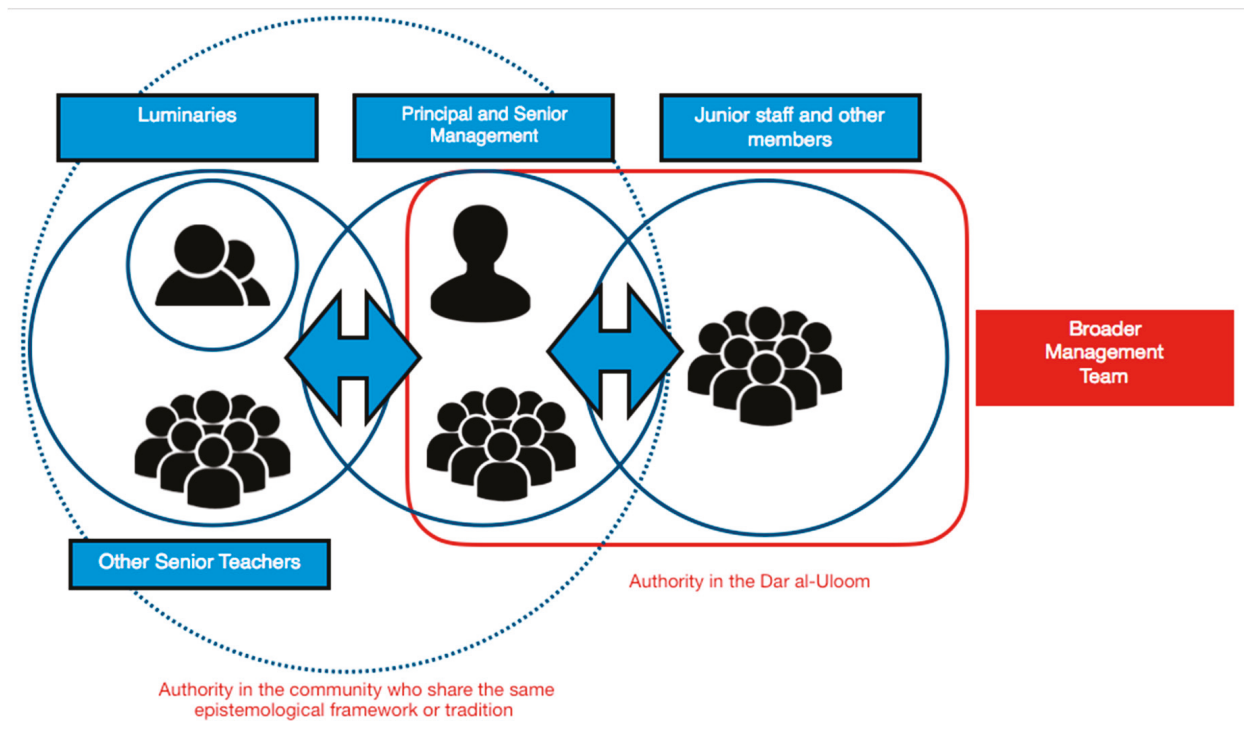

Figure 2. Depiction of how modalities of authority operate within the DU.

\section{The 'Luminaries'}

Within the group of senior teachers, there are two teachers who are significant. This can be seen by the fact that many of the other teachers in the DU refer to them for guidance and advice. They are part of a Chishti Sufi Order (tarigah) and have been granted permission (ijaazah) to provide Sufi guidance to other Muslims. Hence, it is not only lay Muslims who seek them for guidance, but other ulama. However, there are other factors, as one of my participants commented:

Because they are very pious. There is $r u^{\prime} b$ (a sense of being enthralled). I mean you never see them wasting time and they are always engaged in teaching or praying. I have never seen them go out and socialise like other teachers. I'm not saying that's wrong, but we never see them socialising.

$R u^{\prime} b$, though difficult to translate, is used here to describe them in the effect or energy (faiz) which resonates beyond their discursive knowledge on others (Ingram 2018). It is not that they have a personality that is introvertive, but rather that their deep learning, long silences, and reputation for being men who seamlessly combine piety with practice affects and shapes the perception others have of them. Their personality enthrals others. When I probed this further with another teacher he explained:

It's not like other teachers do not have God-consciousness or piety (taqwa) or are less knowledgeable. When you look at the lives of certain teachers you can see very clearly that they are focused on teaching and praying. Nothing else. This means they have a greater level of $r u^{\prime} b$ and I think this is why people have more respect for them.

In essence, they personify for many what knowledge $(\mathrm{ilm})$ is about: It must be practised to be fruitful, while its carriers ought to be disinterested with superficial worldly distractions. The former, referred to as malaka in Arabic, is the enduring ethical disposition or habit that emerges as a result of nurturing and discipline. Therefore, the social perception of sustained piety and religious learning and its embodiment leads to a greater level of public respect from a community who share the same "epistemological framework" (Friedman 1973, p. 83). Social perception is, therefore, a critical ingredient in attributing a higher level of authoritativeness to an alim. It is these luminaries who shine the light on the way for others. The diagram below (Figure 3) theorises the findings, thus far: 


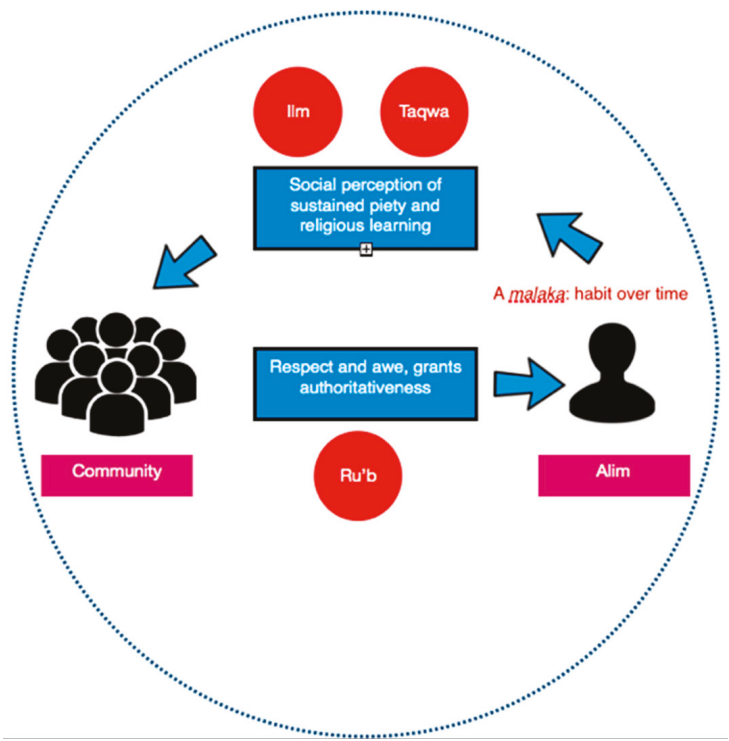

Figure 3. The theorisation of how certain ulama acquire their authority.

\section{Prophetic Traditions (Hadith) as a Guiding Light}

The remaining senior teachers acquire their authority by virtue of the type of texts they teach. Generally, the higher, or the more complex, the level of text they teach, the greater their perceived level of authority. The syllabus, a six-year course, moves from auxiliary sciences, including grammar, syntax, logic and rhetoric through advanced texts in Islamic law (figh) to Hadith, or collections of Prophetic statements and his actions in the capstone year (dawra). In this light, a senior teacher summarises what matters most is the teaching of Hadith:

It all comes down to the [H]adith text you teach. Teaching figh is important but it is teaching $[\mathrm{H}] \mathrm{adith}$ that matters and makes the difference.

The text of the Hadith taught by a teacher possessing an isnad is essentially the blueprint through which to embody the Prophet. Text, teacher and the Prophet form the essential building blocks for the construction of authority. This is enhanced by a combination of teaching a greater number of Hadith and figh texts in the latter years and a lower range of classes in the auxiliary sciences in the earlier years within the syllabus. Beyond the texts, authority is complemented by the fact that having acquired their learning in South Asia, this group of teachers are uniquely positioned to act as the 'authoritative bridge' that are connected to particular tradition-the maslak - both geographically and intellectually. They possess a form of symbolic capital. In the authority of senior teachers, we see how the bibliocentric and the anthropocentric tradition are wedded together. Knowledge is inseparable from the bodies that inhabit that knowledge.

Finally, many of the teachers serve as imams, so they possess a form of social capital. Being well respected and trusted in their communities is a form of capital which in turn legitimises the very institution in the eyes of those they serve. A senior member of management had this insight to share:

The senior teachers are well respected and known. When parents choose to send their children here, or when people send their questions to us, they look at the teachers we have. Lots of time students join here because their parents have relationships with them; they are well-known local imams, and teachers. 


\section{Junior Teachers as Torchbearers}

The junior teachers, under the age of thirty, are all British-born graduates from the same DU. They all teach in the earlier years, but unlike their senior counterparts, have roles beyond teaching. It is this function, that of being intimately engaged with the DU that grants them an alternative form of authority. For example, all of them are school teachers at the secondary school being run at the seminary. Furthermore, their roles can range from administrative tasks involving tracking absenteeism and record-keeping to oversight of the various operational functions in the DU. For example, one teacher is responsible for overseeing the Quran memorisation (hifz) arrangements. This includes regularly monitoring and target setting for portions of the Quran to be memorised and ensuring correct recitation (tajweed) among the students. Despite his young age, he has overall responsibility and manages teachers who are much older than him. However, he does not view this as being problematic. When asked how he manages the relationship with someone who was once his teacher, this is what he had to say:

It is a relationship based on respect. We both agree what matters most is improvement and that students learn. So based on this shared understanding we are able to work together.

As for what he particularly enjoys about the DU, it is to see the students' progress:

I like to see progress. I don't want to waste time. If I waste time I am wasting their time. They should all progress whether they're weak or clever, whatever. They all have to be challenged and I try and get the best out of them.

The same teacher has a pastoral role where he uses any free time in the morning to deal with complaints and other issues:

I go down to the office after teaching and if they want me to speak to a student because of some issues I shall go and find him. I'll try and find out how he's feeling. I don't like to tell them off or anything, just a few good words that make a difference so that's it. I love it. Everyday is a different day.

Another teacher, who has a degree and regularly publishes articles for the public, feels that his responsibilities at the DU have evolved and that he has a greater level of influence in the way things are run. When asked what had been his best experience at the DU, he replied that his influence has increased over the years. This view was echoed by another teacher who has overall responsibility for the syllabus, which means setting targets and exam and lesson planning. He has spearheaded a number of innovative changes primarily focused on facilitating student learning and engagement. This included translating into English and simplifying some of the more technical texts. His reflection on the impact of this particular 'translation movement' shows that this has led to significant improvements in the teaching and learning of students. I asked him what the response has been to changes in language and target setting from the senior staff:

There was some resistance from a handful of teachers who were concerned about being taught in English but once they started seeing the fruits and benefits of it, I think they were okay with it. They saw that we could cover more topics if we arrange things better.

There are other reasons why junior teachers have a greater operational influence. Among them were that they spend most of their day at the DU and being former graduates, are familiar with the values and ethos of the DU. As for the Principal, he feels that the younger generation of teachers brings in ideas to move the DU forward:

The young teachers are born here. They speak English and are educated here. They are completing further education so they bring new ideas that we can use. They are very dedicated and work really hard to help make the Dar al-Uloom a success. 
All of these factors combine to ensure that the younger generation of teachers influences the DU operationally. However, this does not mean that senior teachers are less invested in the DU. As one teacher is quick to remind me:

It's because they're not familiar with the way things work and their time is used better elsewhere. They have other commitments, so they only come, teach and go back to their communities.

Outside of the four walls of the DU, it is the junior teachers with the Principal who are shaping its engagement and relationship with the wider world. This includes working with the local hospital, the Salvation Army, feeding the homeless, inter-faith relations, and liaising with the local police. The inclusion of and the encouragement by the Principal for students to study A-levels and pursue further education is reflective of a broader ethos of the DU. Significantly, the DU has been seeking out opportunities to work with universities. For example, as mentioned above, it has been involved in a pioneering partnership with a British University in offering the first two years of a new BA in Islamic Studies. At the time, this sparked great interest from other DUs and academic researchers. The course being delivered at the DU was oversubscribed, showing that there is certainly an appetite for DUs to work with universities. Students are interested in gaining qualifications that will help them acquire careers post-graduation. The teachers view this engagement as the beginning of a broader project to address the educational needs of future Muslim scholars in Britain. Moreover, many of the younger teachers already have or are acquiring university qualifications and are pushing for accreditation.

This broad shift has been recognised by (Geaves 2015a) and more recently by (Lewis and Hamid 2018) who notes diversity and more openness from some DUs and their graduates. For example, the latter cites the work of Dr Mansur Ali, an academic at Cardiff University and an alumnus of a DU, for his ground-breaking research on the impact of Muslim chaplains. Another example is of Shams Ad Duha who is also a DU graduate and Principal of a madrasa in London, having a more cosmopolitan and inclusive outlook. ${ }^{11}$ (Gilliat-Ray 2018) has recently updated her 2005 paper with a new publication that charts a more promising shift taking place in some DUs towards more outward-facing forms of engagement.

From my research, it was clear that there are not many imam positions available (and may not be an attractive career choice, given the pay and conditions) and careers in publicly funded chaplaincy are very competitive. As a result, students who want to study further and gain qualifications often explore university degree courses. The DU for their part, recognise that the syllabus can benefit from being infused with contemporary realities and other pedagogical methods to enhance their teaching. ${ }^{12}$ While significant strides have been made by certain DUs to partner with universities, it remains to be seen if the latter can display the same level of enthusiasm.

Ultimately, all the decisions in the DU will go through the Principal. He embodies a traditional form of leadership. While it relies on a dominant personality, it is legitimated by the particular tradition. This is because, as we have seen with the senior teachers, their legitimacy is endowed by being part of the Deobandi tradition-by "the belief in the inviolability of that which has existed from time out of mind" (Weber 1968, p. 1008). He is known for being visionary, and his authority is best described as paternalistic. This is because the Principal bases his authority on a form of loyalty. Weber recognised that this is one of the traditional forms of pre-bureaucratic power that is "based not on the official's commitment to an impersonal purpose and not on obedience to abstract norms, but on a strictly

11 In the same work, Lewis cites extensively from the work of Mufti Saiful Islam, who is a graduate of a DU, to draw wide conclusions from a small selection of evidence. Gilliat-Ray (2018) comments that this is "rather unhelpful when these examples are presented as indicative of opinions among a much wider group of ulama" (p. 144).

12 More recently, a report by the Citizens Commission on Islam, Participation and Public life, entitled, The Missing Muslims: Unlocking British Muslim Potential for the Benefit of All, recommended that universities consider pairing with seminaries so that educational schemes for imams become accredited, allowing imams and graduates to receive both an educational qualification along with a religious qualification. See: www.citizensuk.org/missing_muslims (last accessed 3 March 2019). 
personal loyalty" (Weber 1968, p. 1006). Students and teachers alike see the Principal as a father figure. For the younger generation of teachers, he is recognised as someone who maintains a strong relationship with subordinates through his dialogical and consultative form of decision-making.

From an Islamic perspective, this is known as the 'shura' based model where a group of people effectively act as a consultative body in the decision-making process with the final decision being delegated to the amir, or group leader. The Quran also sanctions this form of leadership, "their affair being counsel among them". ${ }^{13}$ As for being a visionary, this is because his shura members consist of young people who are driving change. This is what the Principal had to share:

I want to take this DU forward. And I want the young ulama to make decisions and decide what is best for us. Before our maqsad (purpose) was for students to learn in an Islamic environment and to make it easy to save their imaan [faith]. Now, we want to allow students to serve Muslims in Britain better and to learn how to engage with non-Muslims as well.

This is an acknowledgement of changing circumstances on the part of the Principal and a recognition that the people who will drive this change are the younger generation of teachers. His willingness to allow me to conduct my doctoral research within the DU is a signal of this outward-facing stance, the trust he is placing in younger scholars, and a willingness to see how the institution might benefit from academic research conducted in a university environment. Given the generally conservative character of the Deobandi movement, this makes his style of leadership distinctive. He has been able to balance the need to bring in change, while remaining within the normative system of the particular tradition (maslak). This also serves as a reminder that being conservative does not necessarily imply being impervious to change.

The sociologist Edward Shils (Shils 1981) defines tradition as something that is transmitted from the past to the present. However, in the DU there is much more than just handing down. It includes "a process of evaluation, amplification, suppression, refinement, and assessing the polarity between would-be tradition and indigenous innovations and/or non-indigenous ideas and practices" (Jackson 2002, p. 26, italics original). This process of evaluation is taking place through the "custodians of change' (Zaman 2002), in this case, the junior teachers. In this sense, they have authority as torchbearers maintaining the tradition. The key thing about tradition is whether the particular idea or practice receives an endorsement from the custodial generation. It is the junior teachers who will become senior teachers and will ultimately decide the future direction of the DU, and in many ways the practice of Islam within communities across Britain:

The future of Islam rests where it has rested in the past—on the insight of the orthodox leaders and their capacity to resolve the new tensions as they arise by positive doctrine which will face and master the forces making for disintegration. (Gibb 1947, p. 122)

Tradition is not a simple act of transmission, but an ongoing living process: The receiving generation will decide what stays, what it modifies, and what it strips away. What is clear, however, is that this tradition is in transition, and it will have important implications for the production of future Muslim leaders in Britain.

\section{Conclusions}

My findings align with the broad thrust of Amir-Moazami and Salvatore (2003) argument that the current trajectory among young Muslims is part of a broader continuation of reform discourses. While there may be some truth in the individualisation thesis, it is far from conclusive. My findings indicate that change is taking place through "internal interventions" within the DU at least. The younger graduates and teachers are making significant changes and contributions to the way Islam is transmitted

13 Quran, 42:38. 
in Britain. This signifies that the younger ulama will continue to be relevant, if not important. With reference to Mandaville (2001), the transformation of Islam in a translocal space need not necessarily result in an alternative form of authority. Rather, it is this very translocal space-taken here to be the DU and its connected communities-where transformation is taking place among the young generation of ulama and graduates.

Moreover, the individualisation thesis needs to contend with issues around class and social mobility. Reflective of the general population of Muslims in Britain, most of the students that attend the DU are from a working class background where "one needs to be attentive to the fact that individuals have differing competences/capacities-according to class, gender, generation or, more generally, their socialisation-to engage in the eclectic construction of 'their' belief (compétences bricoleuses)" (Peter 2006, p.110, italics original). Therefore, one of the challenges for the younger generation of ulama will be how to connect with an increasingly young generation of middle-class British Muslims.

Recently, (Bano 2018) deals with, among other things, the issue of class. Her five-year research project titled Changing Structures of Islamic Authority and Consequences for Social Change-A Transnational Review (CSIA), looks at how old and new centres of Islamic learning are adapting to the external environment, in particular, the West. Her broad argument is that the Islamic religious milieu in the West is fertile ground for producing an understanding of Islam that fosters a generation of confident young Muslims that are rooted in the Islamic tradition. She argues that 'affluent' Muslim communities will play a key role in transformative conceptualisations of Islam by reversing the isolation of Islamic and modern knowledge. Importantly, she concludes by stating that Islamic authority in the West lies in the ability "to be able to be reasonable and responsive to the demands of changing times, while respecting the core of the tradition" (p. 28). This, for her, and as my paper confirms, is reflective of the enduring feature of the Islamic scholarly tradition: Internal reform.

The DU in which my research was conducted is situated within a complex and changing nexus of institutional developments in Britain. The authority of the institution and its personnel needs to be appreciated within this broader religious landscape. While movements aligned with the South Asian diaspora remain influential in Britain, second and third generation Muslims are forming their subjectivities in relation to access to higher education, employment, and the broader social/cultural framework of British society. This, along with greater self-reflection among young Muslims, has spurred the growth of new Islamic initiatives in the West (Janmohamed 2016). While indigenising Islam in the West can come from above (for example, between the state and mosques) the most fascinating and productive arena for the study is the initiatives taking place from below.

Given the lacuna in relation to the study of DUs in Britain, this article began by illuminating this often-misunderstood tradition. By building on existing theories of authority in Islam, it enlightened the various modalities of authority within the DU. What emerges is that the authority of particular individuals or groups of teachers is largely consensual in that it is based on social perception, perceived expertise and trust. Tradition and authority are interdependent because the prescriptive informational content of the former is related to how the latter in the present is construed (Klusmeyer 2014). While tradition defines the terms through which such authority is framed: "[T]he past, to the extent that it is passed on as tradition, has authority; authority, to the extent that it presents itself as history, becomes tradition" (Arendt 2005, p. 73).

We observed that the authority of 'luminaries' stemmed from the social perception of sustained piety and religious learning and its embodiment. The senior teachers' authority is based on texts and the particular year groups that they teach, in this case shedding the Prophetic light. In addition, they are chronologically closer to the particular tradition (maslak) and possess social (and spiritual) capital in terms of being imams and senior ulama in the eyes of the wider public. While they may possess a greater level of authority externally, internally, it is the younger generation of teachers who possess operational authority and are the torchbearers of this tradition. Through physical proximity to the Principal and senior management, their background, and their day-to-day involvement in the running of the DU, they exert authority in the DU. However, this is mediated through the management staff 
and the Principal. Their ability to steer the DU in its engagement with wider society, as in the case with universities and seeking accreditation, is likely to move the DU towards horizontal forms of indigenisation with secular institutions.

Despite challenges to traditional Islamic authority, due to wider social changes in the form of inter-generational shifts, an increasingly pluralistic and diverse intra-religious context and the impact of technology, tradition and the authority of the ulama endure. This is largely because it is the younger generation of ulama who are now driving change and are engaged critically in a rethinking of tradition. The evolving face of this tradition and authority will largely depend on how they embody them in modern Britain. The torch is firmly in their hands.

Funding: I would like to thank the Jameel Scholarship Programme for their generous funding and support in completing my research.

Conflicts of Interest: The author declares no conflict of interest.

\section{References}

Abbas, Tahir. 2010. Muslim-on-Muslim Social Research: Knowledge, Power and Religio-cultural Identities. Social Epistemology 24: 123-36. [CrossRef]

Abou El Fadl, Khaled. 2013. Speaking in God's Name: Islamic Law, Authority, and Women. London: Oneworld Publications.

Ahmed, Abdul.-Azim. 2017. The Other Ethical Approval: The Importance of Being "Islamic". Fieldwork in Religion 12: 204-22. [CrossRef]

Amir-Moazami, Schirin, and Armando Salvatore. 2003. Gender, Generation, and the Reform of tradition: From Muslim Majority Societies to Western Europe. In Muslim Networks and Transnational Communities in and Across Europe. Edited by S. Allievi and J. Nielsen. Lieden: Brill, pp. 52-77.

Arendt, Hannah. 2005. The Promise of Politics. New York: Random House Digital, Inc.

Asad, Talal. 1986. The Idea of an Anthropology of Islam. Washington: Center for Contemporary Arab Studies, Georgetown University.

Bano, Masooda. 2012. The Rational Believer: Choices and Decisions in the Madrasas of Pakistan. Ithaca: Cornell University Press.

Bano, Masooda. 2018. Modern Islamic Authority and Social Change: Evolving Debates in Muslim-Majority Countries. Edinburgh: Edinburgh University Press Limited.

Bauman, Zygmunt. 2000. Liquid Modernity. Cambridge: Polity Press.

Berger, Peter. L. 1973. The Social Reality of Religion. London: Faber \& Faber.

Berkey, Jonathan. Porter. 2001. Popular Preaching and Religious Authority in the Medieval Islamic Near East. Seattle: University of Washington Press.

Berkey, Jonathan. Porter. 2014. The Transmission of Knowledge in Medieval Cairo: A Social History of Islamic Education. Princeton: Princeton University Press.

Birt, Jonathan. 2006. Good imam, Bad imam: Civic Religion and National Integration in Britain Post-9/11. Muslim World 96: 687-705. [CrossRef]

Birt, Jonathan, and Philip Lewis. 2011. The Pattern of Islamic Reform in Britain: The Deobandis Between Intra-Muslim Sectarianism and Engagement with Wider Society. In Producing Islamic Knowledge in Western Europe. Edited by S. Allievi and M. V. Bruinessen. London: Routledge, pp. 91-119.

Bourdieu, Pierre, and Loïc J. D. Wacquant. 1992. An Invitation to Reflexive Sociology. Chicago: University of Chicago Press.

Carroll, Jackson W., Barbara G. Wheeler, Penny Long Marler, and Daniel O. Aleshire. 1997. Being There: Culture and Formation in Two Theological Schools. Oxford: Oxford University Press.

Carter, N., D. Bryant-Lukosius, A. DiCenso, J. Blythe, and A. J. Neville. 2014. The Use of Triangulation in Qualitative Research. Oncol. Nurs. Forum. 41: 545-7.

Cesari, Jocelyne. 2003. Muslim Minorities in Europe: The Silent Revolution. In Modernising Islam: Religion in the Public Sphere in the Middle East and in Europe. Edited by J. Esposito and F. Burgat. London: Hurst, pp. 251-69.

Chamberlain, Michael. 2002. Knowledge and Social Practice in Medieval Damascus, 1190-1350. Cambridge: Cambridge University Press. 
Chryssides, George. D., and Stephen E. Gregg. 2019. The Insider/Outsider Debate New Perspectives in the Study of Religion. Sheffield: Equinox Publishing.

Coffey, Amanda. 1999. The Ethnographic Self: Fieldwork and The Representation of Identity. London: Sage.

Collins, Peter, and Anselma Gallinat. 2010. The Ethnographic Self as Resource: Writing Memory and Experience into Ethnography. New York: Berghahn Books.

Crone, Patricia, and Martin Hinds. 2003. God's Caliph: Religious Authority in the First Centuries of Islam. Cambridge: Cambridge University Press.

Dabashi, Hamid. 1993. Authority in Islam: From the Rise of Muhammad to the Establishment of the Umayyads. Piscataway: Transaction Publishers.

Sara, Delamont, Paul Atkinson, and Lesley Pugsley. 2010. The Concept Smacks of Magic: Fighting familiarity Today. Teaching and Teacher Education 26: 3-10. [CrossRef]

Eickelman, Dale F., and Jon W. Anderson. 2003. New Media in the Muslim World: The Emerging Public Sphere. Bloomington: Indiana University Press.

Friedman, Richard E. 1973. Concepts in Social \& Political Philosophy. New York: Macmillan Publishing.

Geaves, Ron. 1996. Sectarian Influences within Islam in Britain. Community Religions Project Paper Series; Leeds: Community Religions Project.

Geaves, Ron. 2015a. An exploration of the viability of partnership between dar al-ulum and higher education institutions in North West England focusing upon pedagogy and relevance. British Journal of Religious Education 37: 64-82. [CrossRef]

Geaves, Ron. A. 2015b. The Contested Milieu of Deoband: 'Salafis' or 'Sufis'? In Sufis and Salafis in the Contemporary Age. Edited by L. Ridgeon. London and New York: Bloomsbury Publishing.

Gibb, H. A. R. 1947. Modern Trends in Islam. Chicago: University of Chicago Press.

Gilliat-Ray, Sophie. 2005. Closed Worlds: (Not) Accessing Deobandi Dar al-Uloom in Britain. Fieldwork in Religion 1: 7-33.

Gilliat-Ray, Sophie. 2010. Muslims in Britain. Cambridge: Cambridge University Press.

Gilliat-Ray, Sophie. 2018. From "Closed Worlds" to "Open Doors": (Now) Accessing Deobandi darul uloom in Britain. Fieldwork in Religion 13: 127-50. [CrossRef]

Glaser, Barney G., Anselm L. Strauss, and Elizabeth Strutzel. 1967. The Discovery of Grounded Theory: Strategies for Qualitative Research. Chicago: Aldine.

Hamid, Sadek. 2018. Sufis, Salafis and Islamists: The Contested Ground of British Islamic Activism. London: IB Tauris. Hammersley, Martyn, and Paul Atkinson. 2007. Ethnography: Principles in Practice. New York: Routledge.

Ingram, Brannon D. 2018. Revival from Below: The Deoband Movement and Global Islam. Oakland: University of California Press.

Jackson, Sherman A. 2002. On the Boundaries of Theological Tolerance in Islam: Abū Hāmid Al-Ghāzalī's Fayșal Al-Tafriqa Bayna Al-Islam Wa Al-zandaqa. Oxford: Oxford University Press.

Janmohamed, Shelina. 2016. Generation M: Young Muslims Changing the World. London: IB Tauris.

Klusmeyer, Douglas B. 2014. Hannah Arendt on Authority and Tradition. In Hannah Arendt: Key Concepts. Edited by P. Hayden. London: Routledge.

Lewis, Philip. 2004. New Social Roles and Changing Patterns of Authority Amongst British Ulama. Archives de Sciences Sociales des Religions 49: 169-87.

Lewis, Philip, and Sadek Hamid. 2018. British Muslims: New Directions in Islamic Thought, Creativity and Activism. Edinburgh: Edinburgh University Press.

Mandaville, Peter G. 2001. Transnational Muslim Politics: Reimagining the Umma. London: Routledge.

Messick, Brinkley. 1993. The Calligraphic State: Textual Domination and History in a Muslim Society. Oakland: University of California Press.

Metcalf, Barbara. 1978. The Madrasa at Deoband: A Model for Religious Education in Modern India. Modern Asian Studies 12: 111-34. [CrossRef]

Metcalf, Barbara. 1982. Islamic Revival in British India: Deoband 1860-1900. Princeton: Princeton University Press.

Metcalfe, Barbara. 1984. Moral Conduct and Authority: The Place of Adab in South Asian Islam. Berkeley: University of California Press.

Moj, Muhammad. 2015. The Deoband Madrassah Movement: Countercultural Trends and Tendencies. Cambridge: Anthem Press, CUP.

Moosa, Ebrahim. 2015. What Is a Madrasa? Chapel Hill: UNC Press Books. 
Naeem, F. S. 2004. A Traditional Islamic Response to the Rise of Modernism. In Islam, Fundamentalism, and the Betrayal of Tradition. Bloomington: World Vision, pp. 79-116.

Peter, Frank. 2006. Individualization and Religious Authority in Western European Islam. Islam and Christian-Muslim Relations 17: 105-18. [CrossRef]

Robinson, Francis. 2009. Crisis of Authority: Crisis of Islam? Journal of the Royal Asiatic Society 19: 339-54. [CrossRef]

Roy, Olivier. 2004. Globalized Islam: The Search for a New Ummah. New York: Columbia University Press.

Scott-Baumann, Alison, and Sariya Cheruvallil-Contractor. 2017. Islamic Education in Britain: New Pluralist Paradigms. London: Bloomsbury Publishing.

Shils, E. 1981. Tradition. London: Faber and Faber.

Spencer, Martin E. 1970. Weber on Legitimate Norms and Authority. The British Journal of Sociology 21: 123-34. [CrossRef] [PubMed]

Weber, M. 1947. The Theory of Social and Economic Organization. Translated by A. R. Henderson and T. Parson. New York: Oxford University Press.

Weber, M. 1968. Economy and Society: An Outline of Interpretative Sociology (Vol. 1). New York: Bedminster Press.

Welland, Trevor. 2000. The 'Real World' of Ordained Ministry: Making Sense of Training for Priesthood. Journal of Beliefs and Values 21: 179-88. [CrossRef]

Zaman, Muhammad Qasim. 1999. Religious Education and the Rhetoric of Reform: The Madrasa in British India and Pakistan. Comparative Studies in Society and History 41: 294-323.

Zaman, Muhammad Qasim. 2002. The Ulama in Contemporary Islam: Custodians of Change. Princeton: Princeton University Press.

Zaman, Muhammad Qasim. 2012. Modern Islamic Thought in a Radical Age: Religious Authority and Internal Criticism. Cambridge: Cambridge University Press.

(C) 2019 by the author. Licensee MDPI, Basel, Switzerland. This article is an open access article distributed under the terms and conditions of the Creative Commons Attribution (CC BY) license (http://creativecommons.org/licenses/by/4.0/). 

Article

\title{
Structures of Organisation and Loci of Authority in a Glocal Islamic Movement: The Tablighi Jama'at in Britain
}

\author{
Riyaz Timol \\ School of History, Archaeology and Religion, Cardiff University, Cardiff CF10 3AT, UK; TimolR1@cardiff.ac.uk
} Received: 29 June 2019; Accepted: 2 October 2019; Published: 14 October 2019

\begin{abstract}
The Tablighi Jama'at (TJ) is widely regarded as the largest grassroots Islamic revival movement in the world, but it remains significantly under-researched. This paper, based on sustained ethnographic fieldwork conducted between 2013 and 2015, provides a comprehensive overview of the movement's organisational structures and loci of authority in Britain. It describes how different levels of the movement interact, from the local and regional to the national and international, to constitute a truly glocal movement. TJ's European headquarters, located in Dewsbury, West Yorkshire, is identified as a centralised hub that for several decades has co-ordinated the movement's activities in the West through the devoted leadership of Hafiz Muhammad Patel (1926-2016) and ongoing contact with the global spiritual centre in Nizamuddin, New Delhi. TJ's simultaneous links with hundreds of mosques across the country, largely — though not exclusively-of Deobandi orientation, are also described. The functioning of its regional centres of operation in Birmingham, Blackburn, Glasgow, Leicester and London is elaborated with reference to key weekly meetings convened on-site and the "routing" of numerous TJ groups to various British mosques each weekend. Although TJ's leadership has recently become embroiled in schism, the paper argues for the successful establishment of a robust institutional infrastructure in Britain which has facilitated the movement's transmission to a generation of British-born activists.
\end{abstract}

Keywords: Tablighi Jama'at; British mosques; Dewsbury Markaz; Hafiz Patel; Nizamuddin; Islamic revival; Deobandi; Muslims in Britain

\section{Introduction}

\subsection{A Quiet Revolution: The Spiritual Soft Power of a Global Islamic Movement}

From humble beginnings in 1920s British India, the Tablighi Jama'at-an apolitical and quietist movement of mass Islamic revivalism-has today developed into "one of the most important grassroots Islamic movements in the contemporary Muslim world" (Reetz 2009, p. 293). With tens of millions of followers across the globe (Mandaville 2010, p. 44), its influence extends across both Muslim-majority as well as diaspora settings, and its large headquarter complexes (markaz) can be seen dotted across numerous continents. Its distinct style of activism seeks to reinvigorate basic Islamic piety among Muslim masses through the constant formation and dispatch of small groups (jama'at) of itinerant lay preachers to sympathetic mosques around the world (Masud 2000). While the movement's core raison $\mathrm{d}^{\prime}$ être is $d a^{\prime} w a$, or Islamic proselytization, it has no formal mechanism for inviting non-Muslims to the faith, but instead focusses its energies on bringing lapsed Muslims (of various denominational affiliations) into the fold. Despite a rigid uniformity of method, recent studies have chronicled its impact in regions as geographically disparate as Australia (Ali 2012), The Gambia (Janson 2014), South East Asia (Noor 2012), Kyrgyzstan (Balci 2015) and Pakistan (Khan 2016). However, its quiet and unassuming style of activism, coupled with its general policy of avoiding publicity and resisting 
research, has allowed it to flourish while frequently escaping the attention of academics and political commentators. In Britain, TJ has-along with its Deobandi cognate-exercised considerable influence in the establishment of Islam since the post-war settlement of Muslim communities from South Asia (Ahmed 2019, p. 154; Lewis 1994). For around 40 years, the movement's European headquarters has operated out of an imposing mosque complex located in Dewsbury, West Yorkshire, which also houses a residential Islamic seminary (dar al-ulum) providing theological training for future imams. However, despite the international furore sparked by the so-called 'London mega-mosque' controversy (Birt and Gilliat-Ray 2010; Pieri 2015), relatively little is known about the movement's internal organisation and modalities of operation in the UK. The most influential piece of research on British TJ-which continues to inform journalistic accounts or those inspired by Christian mission (Bowen 2014; Taylor 2015) — was carried out by Yoginder Sikand in the mid-1990s (Sikand 1998a). This paper, based on sustained and unprecedented ethnographic fieldwork undertaken with British TJ from 2013-2015, therefore aims to fill this lacuna by providing an insight into the movement's structures of organisation and loci of authority in Britain and beyond.

\subsection{A Historical Précis of TJ in Britain}

The history of TJ in Britain may be conceptualised in terms of three distinct phases. The first, chronicled in detail by Sikand (1998b), loosely extends from the time of the movement's arrival in the post-war period to the point at which a British-born generation of activists became increasingly involved in the early 1990s. During this time, TJ helped consolidate the religious identity of freshly uprooted immigrants by recreating, in diaspora, norms of life familiar from the country of origin. Given the mosque-based nature of its activism, TJ also expedited the process of community formation by contributing to the rapid proliferation of new mosques across the country (King 2002). In tandem with its Deobandi cognate, it also developed an institutional infrastructure of Islamic schools and seminaries aimed at preserving Muslim identity in a non-Muslim setting (Gilliat-Ray 2006; Birt and Lewis 2012). The tireless dedication of Hafiz Muhammed Patel, TJ's European amir (leader), was the conduit through which much of the activism of these decades came to fruition (Shaw 2016).

The second phase stretches from the increasing involvement of the British-born generation (although this process began gaining momentum from the late 1980s, I identify 1994 as a watershed year due to the convocation of a huge number of international TJ activists at the Dewsbury headquarters-popularly known as the '1994 World Ijtima'-which catalysed the process of intergenerational transmission (Timol 2017)) until the death of Hafiz Patel in 2016. During these years, thousands of British-born youth spent time with the movement-often visiting the international headquarters in India, Pakistan and Bangladesh on an extended four-month khuruj (outing)—many of whom remain active adherents to this day. While the movement's British core remains firmly in the control of elderly first-generation migrants, the periphery was increasingly appropriated during these decades by large numbers of English-speaking, secular educated youth ${ }^{1}$ who are now in their 40 s and 50s, and who exercise increasing influence in the movement's hierarchy. This phase also saw the increased participation of numerous British converts to Islam and Muslims of non-South Asian ethnic origin although they, in the UK context, remain a minority. Finally, this phase saw the consolidation of British TJ's national presence through the establishment of dedicated regional centres in Birmingham, Blackburn, Glasgow, Leicester and London in addition to the constant dispatch of British TJ groups to destinations across Europe as well as North and South America (Timol 2015). Despite TJ's significance on the landscape of British Islamic youth activism during this period, it remains characteristically under-studied and is often conspicuous by its absence in the academic literature; Sadek Hamid's

1 Janson's (2014) analysis of TJ's support base in The Gambia similarly identifies a core constituency of English-speaking, secular-educated youth. This challenges Sikand's dated assumption, based largely on the impassioned invectives of Gloucester-based pamphleteer Ebrahim Rangooni and the opinions of Hizb ut-Tahrir spokesperson Farid Kassim, that "The Tablighi Jama'at has very little presence among Muslim students in British schools and colleges" (Sikand 1998b, pp. 185-86). 
notable studies of the subject, for example, are resoundingly silent about TJ (Hamid 2011, 2015). ${ }^{2}$ My research therefore provides the first significant insight into the movement's appeal to British-born Muslim youth during these years (Timol 2017).

The third phase commences from Hafiz Patel's death in February 2016. While for many TJ activists this was experienced as an immeasurable loss (Timol 2016), it coincided with an internal schism in the movement's international leadership that came to public prominence after violent clashes were reported at the worldwide Nizamuddin headquarters in New Delhi during Ramadan $2016 .{ }^{3}$ The core issue was one of successorship; following the death in 2014 of Maulana Zubair-ul-Hasan ibn Inamul-Hasan Kandhalwi, one of TJ's global spiritual leaders, disagreement broke out as to whether Maulana Muhammad Sa'ad Kandhalwi, the great-grandson of TJ's founder Maulana Muhammad Ilyas Kandhalwi, should take sole leadership of the movement, or whether a global shura (council) should be formed. Discussions became heated, and eventually a 13-man council was formed in November 2015 despite Maulana Sa'ad's vehement objections. For the first time in its history, the movement's global leadership cleaved into two opposing factions: one supporting Maulana Sa'ad's continued leadership operating out of the historical headquarters in Nizamuddin, while the other pledged allegiance to the council of elders (alami shura) whose de facto base became the Raiwind headquarters in Pakistan. Many of TJ's national chapters thus splintered-a situation that has led to acrimonious disputes at the level of individual mosques and families across the globe. ${ }^{4}$ British TJ certainly has not been immune, and the movement's national council of elders, based in Dewsbury, as well as those managing the various regional centres, became locked in bitter dispute during 2017. The content of this paper, however, is based upon fieldwork conducted between 2013 and 2015-prior to the death of Hafiz Patel. It therefore chronicles the structures of authority and modalities of operation which have characterised the movement in Britain for the great majority of its history.

\subsection{A Methodological Excursus}

The findings of this paper derive from qualitative fieldwork undertaken between 2013 and 2015, which principally examined the appeal of TJ to British-born Muslims. An ethnographic approach was taken in which I immersed myself in the subjective life-worlds of contemporary British TJ activists as a reflexive participant observer for a period of 18 months (Madden 2010; Coffey 1999; Hammersley and Atkinson 2007). This involved several overnight stays at the European headquarters in Dewsbury, participation in a fully-fledged TJ khuruj to Bulgaria for 42 days with experienced British-born activists (Timol 2015), and sustained participation in the daily TJ activities of a single mosque located in the North of England. During Ramadan 2014, I also participated in two ten-day outings to Bradford and Birmingham, respectively, with jama'ats consisting mainly of college and university students on their summer holidays. Additionally, I conducted 59 interviews - 25 formal and recorded, with consent forms, and 34 informal and jotted while in the field-with a wide spectrum of Muslims with differing experiences of TJ, including senior leaders, disillusioned critics and youthful neophytes experimenting with the movement for the first time. My prior familiarity with TJ, to which I was first exposed while studying at college over 20 years ago, coupled with my personal identity as the visibly Muslim offspring of South Asian migrants to the UK, helped me navigate the linguistic and cultural worlds of my respondents with relative ease, quickly developing the trust and rapport necessary for access. My fieldwork was limited, however, to the male experience of TJ given the guidelines of strict gender segregation that govern the movement (Amrullah 2011). Taken together, my fieldnotes and interview

2 Hamid's important book Sufis, Salafis and Islamists does not mention TJ once, while his paper British Muslim Young People: Facts, Features and Religious Trends erroneously states that "The seminary in Bury in North-West England is ... the international headquarters of the international Tablighi Jamaat missionary movement" (Hamid 2011, p. 256).

3 See, for instance, https://www.okhlatimes.com/tablighi-jamaat-members-clash-markaz/ (accessed 21 June 2019).

4 While this development is yet to be captured in the academic literature, it has been widely reported in South Asian media and the subject of much animated discussion within Muslim communities (see, for instance, Iqbal (2018) or Ghazali (2018)). 
transcripts produced a dataset in excess of 800,000 words which I meticulously checked and thematically coded using the qualitative data analysis software NVivo.

The objective of this paper is primarily descriptive. Drawing upon these fieldwork experiences, it seeks to improve our understanding of TJ by documenting its institutional infrastructures in Britain and meticulously sketching its core modalities of operation. It first describes the centrality of the Dewsbury headquarters for the functioning of British TJ before probing the extent to which TJ has managed to access mosques of various denominational orientations. The interaction of TJ's local, regional, national and international dimensions is then described by suggesting a parallel with the "episcopal polity" of British Christianity. The paper then foregrounds a case-study of TJ's Blackburn Markaz to examine how the movement's regional headquarters manage a constant flow of incoming and outgoing TJ groups, especially over peak weekend periods. Lastly, TJ's functioning on the interface of the local and global is described to argue for a normative glocal praxis that resides at the heart of the movement's operational dynamics.

\section{Dewsbury as A Central Hub}

The legal entity under which TJ operates in Britain is the "Anjuman-e-Islahul Muslimeen of United Kingdom" (The Society for the Reformation of Muslims in the United Kingdom) which has been a registered charity since 25 June 1975 . The principal aims of this charity, in its own words, ${ }^{5}$ are as follows:

- $\quad$ “To make provisions for the religious education of Muslim adults and children;

- To arrange and hold religious gatherings;

- $\quad$ To establish mosque and religious education schools;

- $\quad$ To attempt to create understanding of the Muslim religious issues amongst government institutions ${ }^{6}$;

- $\quad$ To make arrangements for groups of persons to visit mosques in the United Kingdom and overseas for the purpose of religious learning and spiritual self-rectification."

The charity is registered at the national headquarters of TJ, which is located on South Street in Savile Town, Dewsbury, in an enormous mosque complex that dominates the skyline (see Figure 1). The existing structure was built between 1978-1982 and was intended, with the approval of international TJ authorities, to be the base of the movement's activities in the West. By 'the West', a broad geographical purview is meant that initially covered Europe and North America but was later expanded, I was told by a long-standing TJ activist, to include South America. The amir (leader) of the Dewsbury headquarters, and by extension of TJ in the West, was- until his death in February 2016 aged 90-Hafiz Muhammad Patel, a dynamic Gujarati who devotedly coordinated TJ's Western activities for over 50 years since migrating to England in the 1960s. I was able to meet Hafiz Patel (as he is invariably referred to) several times during the course of my fieldwork and witnessed first-hand the reverence in which he was held; many regarded him a kaamil wali (fully accomplished saint) and he functioned as a Sufi shaykh for a sizeable number of British TJ activists who had taken the formal Sufi pledge of allegiance (bay'ah) with him (see Figures 2 and 3). ${ }^{7}$

5 Reproduced from the Annual Report filed with the Charity Commission for the year ending 31 December, 2014: http://apps.charitycommission.gov.uk/Showcharity/RegisterOfCharities/CharityWithPartB.aspx? RegisteredCharityNumber $=505732 \&$ SubsidiaryNumber $=0$ (accessed 21 June 2019).

6 Although a stated aim, in practice it appears that the British branch of the Tablighi Jama'at has preferred to eschew all but necessary contact with government throughout its history. This becomes all the more apparent when their approach is contrasted with other organisations such as the Muslim Council of Britain for example.

7 For more on Hafiz Patel, see the series of articles penned by the respected Leicester-based Deobandi scholar Maulana Muhammad Saleem Dhorat (2018). Although the Sufi roots of the Tablighi Jama'at are undeniable, the extent to which it can be considered a Sufi movement today is contested in the academic literature, and the movement has generally preferred to downplay public expressions of Sufism throughout its history. 


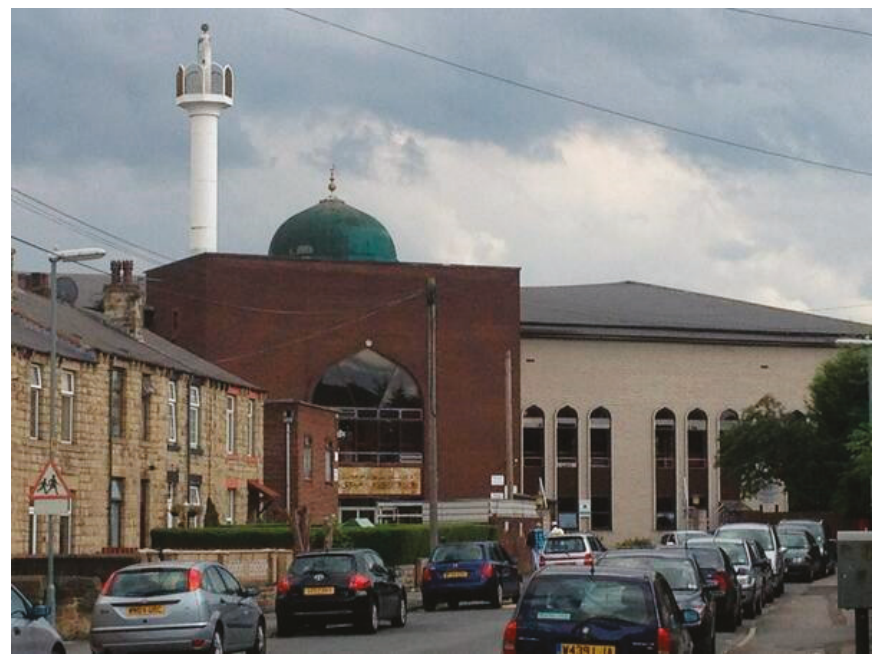

Figure 1. The Tablighi Jama'at (TJ) headquarters in Dewsbury, West Yorkshire. Source: http://www. beautifulmosque.com/Markazi-Mosque-in-Dewsbury-United-Kingdom (accessed on 21 June 19).

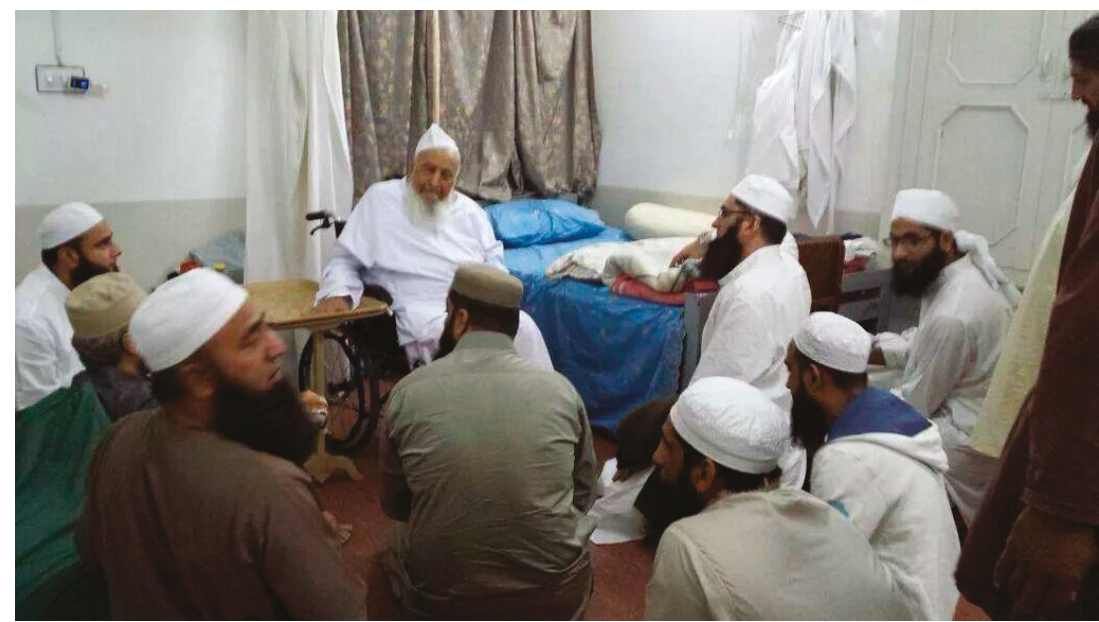

Figure 2. "With one of my favorite elders. Hafiz Patel sahib of Dewsbury UK. Raiwind ijtema 2014. Myself Saeed Yusaf n Sohail". Tweeted by the popular Pakistani popstar-turned-preacher Junaid Jamshed on 19 November 2014 (Hafiz Patel is in the wheelchair) during the annual TJ convocation (ijtima) held at Raiwind, near Lahore. Also visible in the photo are Pakistani cricketing heroes Saeed Anwar and Mohammad Yousuf (formerly Yousuf Youhana), both of whom became dedicated TJ activists through the influence of Maulana Tariq Jameel, a massively popular global spokesperson for the movement whose visits to the UK invariably draw crowds of many thousands. For more on Jameel, see Schleifer (2018, p. 107) and: https://www.asianexpress.co.uk/2014/12/world-famous-islamic-scholarreturns-to-bradford/ (accessed on 21 June 2019)). Source: https://twitter.com/junaidjamshedpk/status/ 535185271126757376 (accessed on 21 June 2019). 

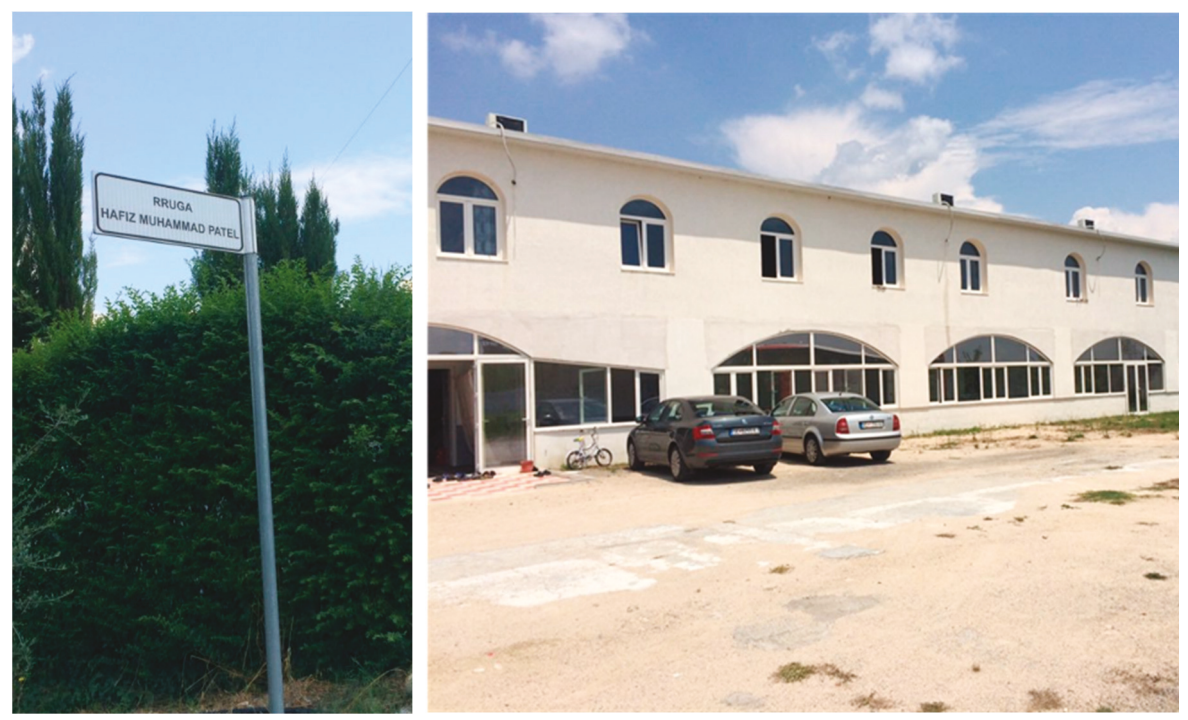

Figure 3. "Earlier today our convoy led by Mufti Muhammad Taqi Usmani and Mufti Ahmed Khanpuri arrived at Tirana Markaz, Albania. The road leading to the Markaz is named after Marhum [Deceased] Hafiz Patel, reflecting his lifelong commitment and dedication to propagating Deen [Religion]." Tweeted by (Mufti) Yusuf ibn (Mufti) Shabbir on 22 June 2018. Source: https: //twitter.com/ibn_shabbir/status/1010196457125707776 (accessed on 21 June 2019).

According to Abubakr, a senior British TJ leader I interviewed for over 5 hours, the decision to locate the movement's national base at Dewsbury was essentially fortuitous:

"So what happened was, Hafiz sahib, initially ... he worked for a few weeks in Preston ... Because the work was in Preston, a factory called Courtaulds ... So Hafiz sahib and Ishaq Patel $^{8}$ — two of the ... founders of Tabligh in this country, they got a job in Courtaulds... then because of the incident in Courtaulds [they were refused time off to offer their Friday prayers] they left and went to Nuneaton. There was no markaz established in Dewsbury at that time, and even though there was a community of Muslims there, Gujarati Muslims, they didn't have an alim (religious scholar), they didn't have a hafiz (somebody who has memorised the Qur'an). But they'd heard about Hafiz Patel, so they said this person in Nuneaton, why don't we bring him over? So they actually sort of head-hunted him to come to Dewsbury, and that's how it all [began] ... He was the imam there and then established the markaz there, so that's how Dewsbury became a foundation... Allah's will that it happened in Dewsbury." ${ }^{\prime 9}$

In addition, Dewsbury's location at the geographic centre of the UK may have been a contributory factor in that it facilitates the frequent travel that $\mathrm{TJ}$ activists make to the national headquarters from around the country. The importance of the Dewsbury headquarters as a centralised hub that co-ordinates international TJ activities in the West can be gauged by the fact that every outgoing TJ tour that exceeds 10 days in length must start and finish its journey in Dewsbury, irrespective of where

8 This seems to be the same Ishaq Patel reluctantly interviewed by Geaves (1996, pp. 171-77) during his visit to Dewsbury Markaz in 1993.

9 Sikand (1998b, p. 180) has essentially the same account, although he makes no mention of the stint in Preston and has Hafiz Patel moving to Dewsbury from Coventry rather than Nuneaton. All respondents I interviewed have been anonymised to protect their identity. 
in the UK the group originates from. For example, a group of Scottish youngsters who decide to spend their summer holidays on a 40-day TJ khuruj would, as the first step, make their way to Dewsbury Markaz, where a group leader (amir) would be appointed and the destination of their tour decided upon. They might spend the first two days at the headquarters where they would be expected to participate in the prayers and speeches delivered throughout the day before being dispatched, for example, to London for the next 37 days. Their first point of landing in London would be the regional TJ markaz (centre) located in West Ham where they might spend a day; regional TJ leaders there would assess the group and accordingly decide, through the core TJ act of mashwera (mutual consultation), the specific boroughs and mosques they should visit for the remainder of their tour. The bulk of the 40-day trip would then be spent travelling through a range of London mosques in which the group would stay for no more than 2-3 days each (so, between 12-15 mosques in total) and, upon completion, they would return to the Dewsbury centre again for the final 24 hours. During this final day, an appointed spokesperson (again, decided internally in the jama'at (group) through mashwera and appointed by the amir) would feed-back (karguzari) the group's experiences to the assembled audience at Dewsbury and, before departing back home, the Dewsbury elders would offer parting advice to the group about establishing TJ activities in their local Scottish mosques and encourage them to return annually for their chillah (40-day outing). Should the outgoing group arriving at Dewsbury comprise of more experienced, dedicated members (usually, those who have already undertaken the signature four-month khuruj to the movement's South Asian headquarters) rather than young neophytes, then it is quite possible that they would be dispatched to an international, rather than national, destination, quite literally anywhere in the world. Again, any incoming TJ group formed in a markaz elsewhere in the world and dispatched to the UK would first make a beeline for the Dewsbury headquarters straight from the airport, where the elders, after the due processes of mashwera, would decide where in the UK to send them for the duration of their tour. We thus see how TJ's national headquarters in Dewsbury is a central transit point both for incoming and outgoing TJ groups, and it is quite usual, when visiting the centre, to meet groups that have just arrived from or are about to depart to far-flung corners of the world (see Figures 4 and 5).

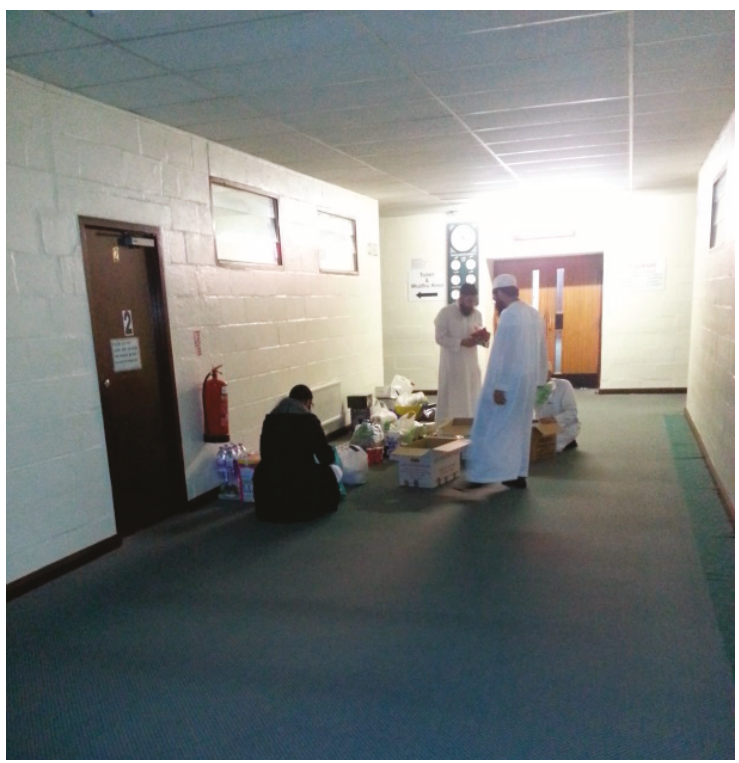

Figure 4. A young British-born TJ group packing their provisions in Dewsbury before departing on an international 40-day TJ excursion in November 2013. Source: author's photo. 


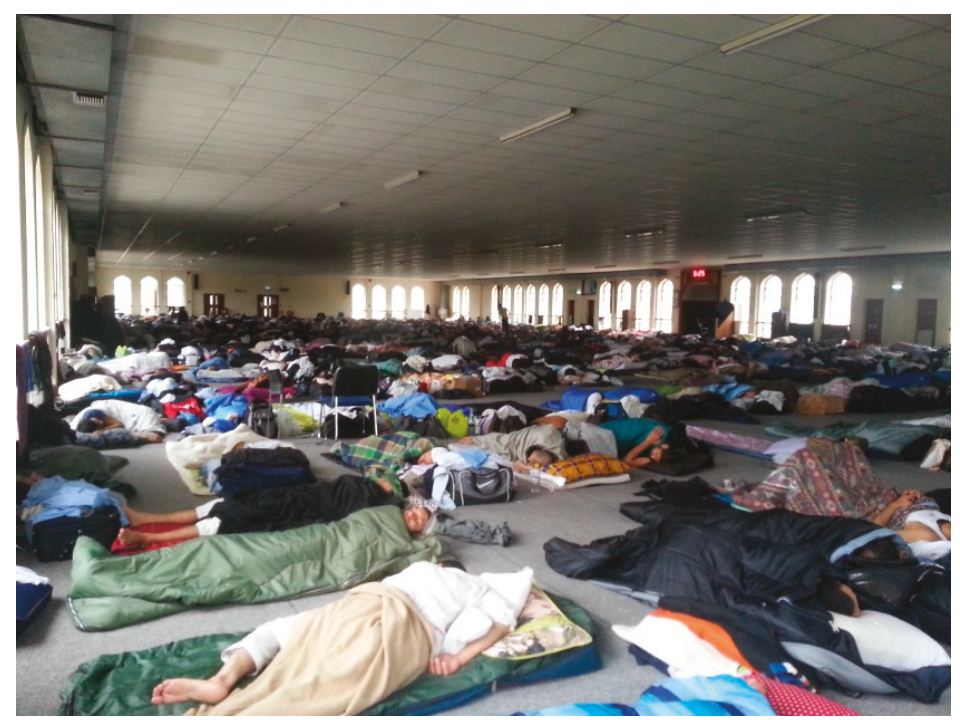

Figure 5. The upper floor of the large TJ complex in Dewsbury strewn, in Ziauddin Sardar's (2004, p. 2) words, with a plethora of "contended logs" taking their sunna siesta nap during the peak summer holiday period in 2014. Source: author's photo.

\section{TJ and the Local Mosques}

\subsection{Accessing Mosques of Different Denominational Affiliations}

While the Dewsbury Markaz functions as a central hub, its national activity depends upon a network of regional maraakiz (plural of markaz: headquarters/centre) and mosques scattered across the country. Sikand (1998a), in his study of the British branch of TJ, made no mention of the five regional headquarters that have operated for some decades now in Birmingham, Blackburn, Glasgow, Leicester and London; these are briefly highlighted by Pieri in his much later study (Pieri 2012b, p. 30). My fieldwork also uncovered the existence of what I have termed "semi-maraakiz" operating in Bristol, Cardiff, Newcastle and Dublin (more on these below). A key distinction should be made here: the maraakiz are exclusively the preserve of $\mathrm{TJ}$ in that they are administered by $\mathrm{TJ}$ authorities and permit only TJ activities and speeches on their premises; the mosques, by contrast, are managed by local committees and permit a range of activities including, though not limited to, TJ. However, not every mosque in the UK allows TJ activities. According to the website meticulously maintained by Mehmood Naqshbandi, there are over 1800 active mosques and Islamic prayer premises in the UK, of which some $797(41.2 \%)$ are affiliated with the orientation of Deobandi Islam. ${ }^{10}$ It is safe to assume that TJ can operate without any resistance in the great majority of these mosques; in fact, it will actively be supported in many by a variety of imams, committee members and regular worshippers (see also King 2002). It is worth noting in this connection that, during the course of my fieldwork, I observed several recently-built British Deobandi mosques that had been architecturally designed to accommodate visiting TJ groups. Specific design features included dedicated sleeping areas, sometimes with their own central heating controls, state-of-the-art kitchens to facilitate jama'at cooking and an easily accessible shower cubicle. Additionally, many British mosques display signs which indicate the movement's entrenchment in the wider ideological architecture (see Figure 6).

10 See www.MuslimsInBritain.org (accessed 21 June 2019). The statistics are derived from a downloadable PDF report compiled on 16 September 2017: http://www.muslimsinbritain.org/resources/masjid_report.pdf. 

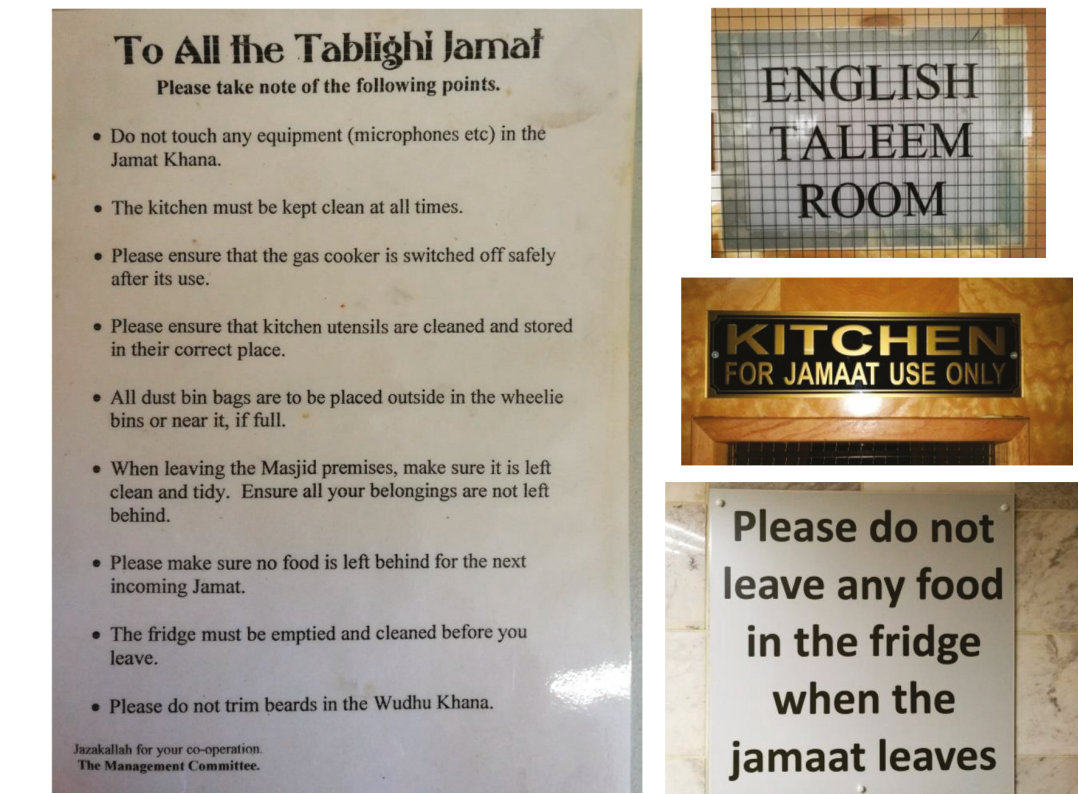

\section{'Please do not leave any food in the fridge when the jamaat leaves}

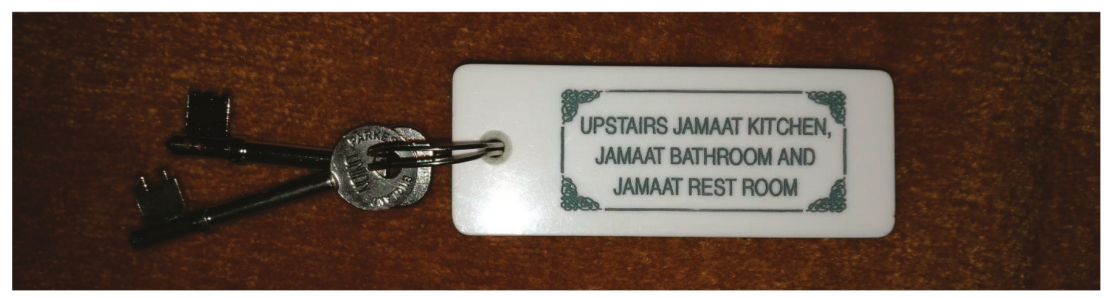

Figure 6. A collection of signs indicating TJ's entrenchment on the landscape of many British mosques. Source: author's photos.

By contrast, due to sectarian differences, TJ will effectively be barred from operating in the majority of Barelwi (459 mosques; 23.7\%) and Salafi-inspired (182; 9.4\%) mosques-although this is not always the case. For instance, while conducting fieldwork in Birmingham during the summer of 2014, I spent a night with a visiting TJ group from Medina, Saudi Arabia ${ }^{11}$ that was staying in an Arab Salafi mosque. Local activists informed me that that regional TJ authorities, based at the Birmingham Markaz, make a point of sending only Arab TJ groups to mosques of this kind as the usual groups of South Asian ethnic origin are more readily objected to. The cosmopolitan Al-Rahma mosque in Liverpool may be cited as another example. Founded (and still managed) primarily by Muslims of Yemeni and Somali extraction, it can in no way be considered Deobandi, yet it has a long history of allowing TJ groups to visit and stay, permitting them to deliver their talks after the daily prayers. According to Mogra (2014, p. 189), TJ has, in some UK cities, also achieved limited success in accessing mosques of Barelwi and Ahl-e-Hadith orientation as well as those founded by non-South Asian Muslims who "tend to be sympathetic towards TJ, especially for bringing change among some wayward youths". Similarly,

11 Although TJ is officially banned in the Kingdom, I was informed by the group it has a discreet yet robust presence-as is the case in several Middle Eastern countries (see the fascinating article published by the Christian Science Monitor: The mysterious Islamic movement quietly sweeping the Middle East (Luck 2015)). 
Siddiqi (2018, p. 125) finds in Cardiff that the Dar ul-Isra mosque, "affiliated with the ideology of Abul Ala Maududi, the founder of the Jamaat-I Islami", 12 permits TJ groups to stay and conduct their activities on-site while the Shahjalal and Jalalia mosques, both catering to Muslims of the Bangladeshi Fultoli tradition, allow TJ groups to visit and preach, though not stay overnight. While this calls into question Pieri's (2012b, p. 9) assertion that "All TJ mosques are Deobandi but not all Deobandi mosques are TJ", I think it would nevertheless be safe to assume that TJ is completely barred from operating in at least a third of the UK's mosques (see Figure 7).

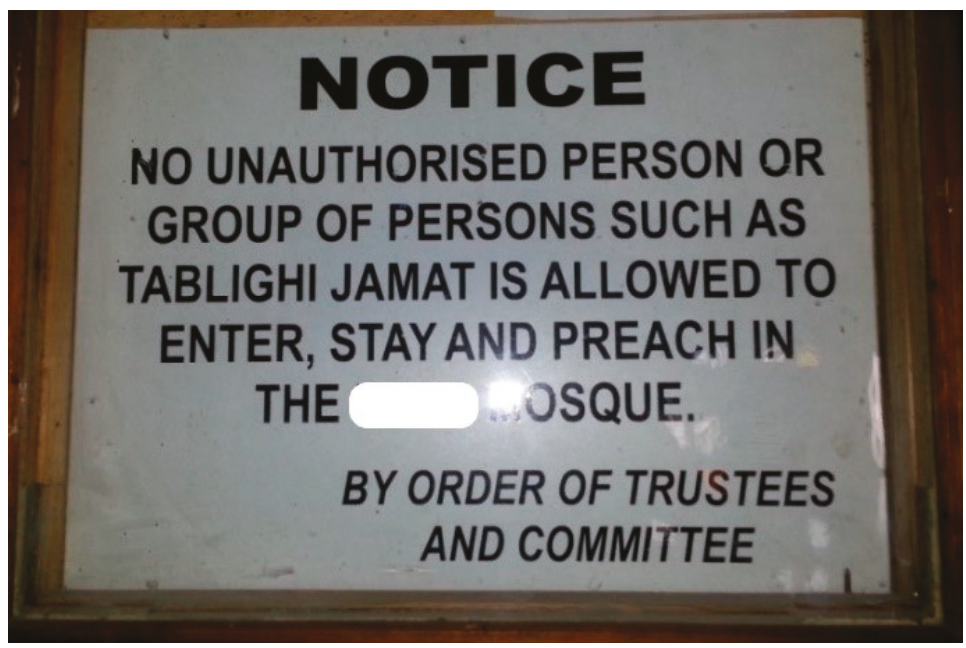

Figure 7. Sign on the noticeboard in a British Barelwi mosque (in terms of the Pakistani context, Ahmad (1991, p. 523) states: "Tablighi Jamaat assemblies are completely banned in the mosques controlled by the Brelvi ulama and their followers"). Source: author's photo.

\subsection{TJ Maraakiz and the Authority of the Sunna}

Where do TJ's large markaz complexes fit on the landscape of British mosques more generally? In a recent paper, Ahmed (2019) deploys the emic terminology of the Islamic tradition to propose a three-tier typology of British mosques. The fard mosque offers no more than the daily (or occasional) prayers, the fard kifaya mosque simultaneously discharges communal obligations pertaining to such matters as rites of passage, while the sunna mosque offers a plethora of additional activities ostensibly rooted in the paradigm of the Prophet's mosque at Medina. The smallest unit of TJ is the itinerant group, united temporarily under an amir, which operates in all three tiers of Ahmed's typology-indeed, in any mosque it will be hosted. However, it is TJ's maraakiz, or headquarters, which would fall within the category of the sunna mosque-not just due to their size, but also because of the volume of personnel and range of activities involved. However, unlike the examples of the East London Mosque or Cardiff's Dar ul-Isra mosque cited by Ahmed, the TJ maraakiz evince virtually no desire to proactively engage with wider non-Muslim society by, for example, holding MP surgeries on-site or hosting interfaith events. Their focus, rather (as elucidated in more detail below), is on managing the activities of large numbers of TJ groups and providing a spiritually charged atmosphere to catalyse the moral

12 However, according to Ahmed (2019, p. 150): “The members of the mosque leadership are equally from Pakistani and Middle-Eastern backgrounds, though its congregation is more diverse..." Having personally visited the mosque on several occasions, I think a more accurate descriptor would simply be "cosmopolitan"—which brings into sharp relief the problems inherent in ascribing labels to people, mosques or organisations that inevitably evolve over time, and the "dynamics of power inherent in the act of naming" (Guenther 2009, p. 412). 
transformation of the individual Muslim. In doing so, and as a movement explicitly geared toward the salvific revival of the sunna (prophetic example), TJ grounds itself in a series of symbolic reference points for which it finds precedence in the lives of the Prophet and his Companions. The grandiose ambition of the "London mega-mosque" project (DeHanas and Pieri 2011), for example, was criticised by a large number of long-standing (and, perhaps tellingly, non-London-based) TJ activists I interviewed for contravening core TJ principles of humility, simplicity and good-neighbourliness-seen to be hallmarks of the sunna. This indicates, as Ahmed suggests, the intrinsic heterogeneity of the sunna category and the way in which it is differently interpreted and mobilised by multiple social actors to infuse with authenticity and authority structures and activities sustained across space and time in the name of Islam.

\section{Ministering the Nation: Regional and Local Divisions of TJ}

Each regional markaz is connected to a network of mosques within which TJ is able to operate to constitute a halqa - translated as area, region or zone-for which it carries ministering responsibility. The UK, for TJ purposes, is therefore divided into six halqas-including, of course, the Yorkshire halqa, whose markaz in Dewsbury also doubles up as the national and European headquarters of the movement. To aid understanding, it may be instructive at this point to sketch a parallel with what is termed the "episcopal polity"13 of traditional Christianity. It is usual for church authorities to map the country along local and regional lines to facilitate administrative and ministering functions. Broadly speaking, the parish comprises the smallest unit of ecclesiastical organisation and roughly equates to the catchment area surrounding a local mosque. Just as numerous parishes taken together constitute a diocese, presided over by a bishop who is properly based in a cathedral, so do numerous mosques taken together constitute a halqa, networked, in TJ terms, to the regional markaz. Similarly, just as the jurisdiction of a particular diocese roughly follows civil boundaries, so does each halqa roughly comprise an amalgamation of a number of British counties. Each markaz, given its size and relationship to the individual mosques in its 'diocese', can be equated analogously to a cathedral-although it is administered not by a single bishop but a council of elders appointed (not elected) by the Dewsbury headquarters. From my interviews with several TJ leaders, it seems that a new regional headquarters can only be established following approval from the movement's spiritual centre in Nizamuddin, New Delhi-with Dewsbury, of course, acting as a conduit. In this, it may be useful to elaborate the parallel further with reference to Roman Catholicism which, in terms of numbers of adherents, is incidentally far closer to the British Muslim population than the dominant Church of England. While the latter operates currently in 41 dioceses ${ }^{14}$-subsumed further into two 'ecclesiastical provinces', York (12 dioceses) and Canterbury (29 dioceses), each with their own Archbishop-the former operates in five ecclesiastical provinces containing a total of 22 dioceses. ${ }^{15}$ Of all Roman Catholic cathedrals in England and Wales, it is the one at Westminster that occupies a special place as the "mother church"; this resembles the special position occupied by Dewsbury Markaz for British TJ (and if we insist on pursuing the parallel even further, it could be suggested that the leadership role exemplified by the recently deceased Archbishop Emeritus Cormac Murphy-O'Connor equates somewhat analogously to that of the late Hafiz Patel). Similarly, just as British Roman Catholicism derives its ultimate authority and directives from the Vatican, so do the top-level hierarchy of British TJ refer back periodically for guidance and advice to the Nizamuddin headquarters in India where the "theoretical, spiritual, and symbolic head of the movement" ${ }^{\prime 16}$ (Reetz 2008, p. 109) resides (see Figure 8).

13 Such an arrangement does not exist in the "congregational polity" of many post-Reformation denominations.

14 With the Diocese in Europe, the total is 42; see https://www.churchofengland.org/about-us/dioceses.aspx (accessed 21 June 2019).

15 See http://catholicfaith.org.uk/Home/Ask-Find/Find-a-church (accessed 21 June 2019).

16 The reference is to Maulana Muhammad Sa'ad Kandhalwi, great-grandson of TJ's founder, although of course this all refers to the situation before the schism outlined in Section 1.2. In recent years, Maulana Sa'ad's authority has been increasingly 

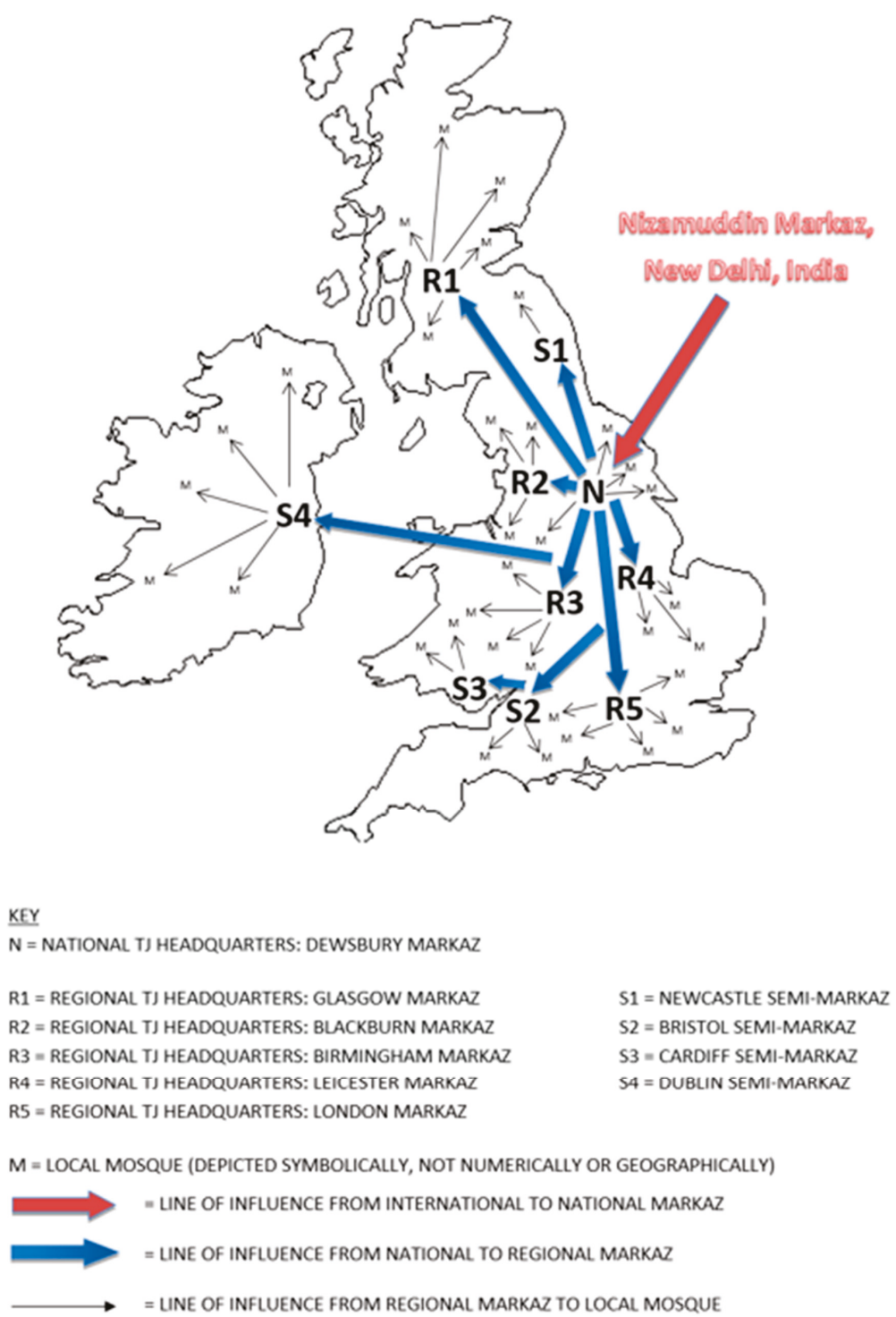

Figure 8. A topography of British TJ.

It is important to specify here the nature of the influence depicted by the arrows in Figure 8 . While the national centre exerts considerable influence on the regional ones (but by no means absolute, as demonstrated by Pieri's (2015) study of the relative autonomy exercised by regional London TJ leaders in their bid to secure planning permission for the proposed "mega-mosque"), the regional

contested, and rejected outright by some, in TJ circles, leading to the undermining of the authority of both the Dewsbury and Nizamuddin headquarters for many British Tablighis. However, as stated in Section 1.2, the content of this paper reflects the situation as it was during the period of my fieldwork over 2013-2015, and fresh fieldwork would be required to accurately map subsequent developments. 
centres exercise far less influence on the local mosques. The nature of this influence is restricted to the coterie of TJ activists that gather regularly in each mosque with a TJ presence and relates in no way to the day-to-day administration of the mosque (whether it is Deobandi or non-Deobandi). This administration is managed by the mosque management committee which operates independently of the regional markaz and makes decisions relating to, for instance, the appointment of imams or the curriculum of the evening madrassa with complete autonomy. Only in mosques with a strong TJ presence might the council of elders at the markaz be consulted (often in a private capacity) on such issues, as might the senior ulema of the Dar al-Ulums due to their popular perception as fonts of piety and wisdom. From the perspective of the regional markaz then, it is sufficient for the local mosque to simply permit visiting TJ groups to stay on their premises and carry out their programme of activities while providing adequate kitchen, heating and shower facilities.

As mentioned, many British mosques also have a small presence of dedicated TJ activists who conduct their daily TJ activities on site and who maintain an ongoing link with both their regional markaz as well as the national markaz in Dewsbury. In practice, as TJ is a normative component of the Deobandi institutional infrastructure, TJ leaders, ulema and mosque committee members usually work in concert to facilitate each other's activities within a single mosque setting in which it is broadly recognised that $\mathrm{TJ}$ is but one among a range of permitted religious offerings. This, however, does not always happen without friction. For instance, a local group of dedicated TJ activists may insist on separately conducting their daily ta'lim (book-reading) session after the Isha prayer at the same time that the imam is conducting his weekly circle on tafsir (Qur'anic commentary). This reinforces the idea that, in some settings, TJ assumes a parochial cliquish identity-as pointed out by the British Deobandi scholar Mufti Muhammad ibn Adam al-Kawthari on the authority of his teacher Mufti Taqi Usmani. ${ }^{17}$ Alternatively, a member of a visiting TJ group might accidentally leave a burn mark on the mosque carpet as he irons his clothes; or a group of youngsters out on a weekend tour might, while playing indoor football at night with a bundle of rolled up socks, damage the expensive chandelier ornamenting the central prayer hall—both of which would, understandably, provoke the ire of the mosque's management committee. Such incidents are not unknown and, in some cases, the regional markaz elders might be called upon to smooth local ruffled feathers and try to facilitate the ongoing visits of jama'ats.

\section{The Functioning of a Regional Markaz}

Two key weekly activities distinguish a markaz from a normal mosque. The first is the "Tuesday evening mashwera" which sees local TJ leaders from across the halqa gather to progress TJ goals. This weekly "synod" attracts a fairly aged crowd of up to 100 long-standing activists, usually with several decades of TJ experience each; every (active TJ) mosque in the halqa is expected to send two or three senior Tablighis to participate in the mashwera. Different regional TJ elders preside over each weekly meeting, and participants offer ideas about how TJ's macro goals can be achieved (see Section 6 for more on these). That a substantial minority of younger, British-born activists are sufficiently experienced to regularly contribute to these meetings now, and sometimes lead them, indicates a level of successful intergenerational transmission within British TJ-a topic I explore in more detail elsewhere (Timol 2017).

The second key activity of a regional markaz is the "Thursday night gathering", which is an open invitation to male Muslims across the halqa to attend an hour-long inspirational lecture, often delivered in Urdu but always with separate English (and, if necessary, Arabic) translation, followed by an appeal (tashkeel) in which assembled audience members are encouraged to volunteer themselves to participate in outgoing TJ tours. Talks are delivered either by committed activists or ulema from across the region, or by members of visiting TJ groups-as determined on a weekly basis by local markaz elders. During

17 See: http://daruliftaa.com/blessed-effort-of-jamaah-al-tabligh (accessed 21 June 2019). 
the course of my fieldwork, I attended several Thursday night gatherings at the Blackburn Markaz (see Figure 9), which invariably attracted a largely youthful crowd of up to 1000 Muslims of mainly South Asian origin from mosques across the halqa including Bolton, Preston, Liverpool, Nelson, Lancaster and, of course, Blackburn. ${ }^{18}$ Following the lecture, many participants proceed downstairs to the bottom storey of the building where a communal meal is served-usually accompanied by much good-natured camaraderie and jovial chatter as TJ activists from across the halqa (who have often spent time together on extended khuruj outings) catch up with each other and newcomers are gently socialised into the movement. The really dedicated (up to 50-100) stay the night each week, only returning home, or going straight from the markaz to their workplaces, after offering the Friday dawn prayer (fajr) in congregation. Given that the night preceding Friday is regarded as being especially blessed, one of the objectives of the overnight stay is to facilitate the rising for the pre-dawn optional tahajiud prayer-a particularly emphasised component of TJ's devotional cosmology.

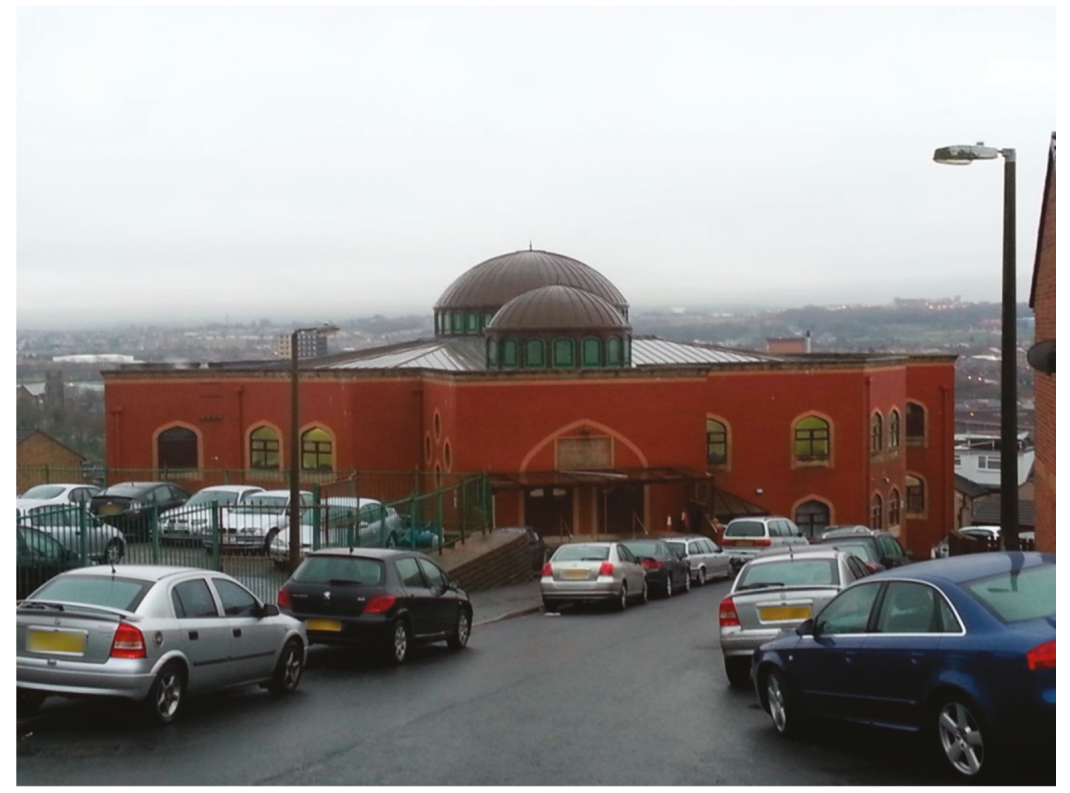

Figure 9. Blackburn Markaz (the number of cars indicating the amount of attendees the weekly programme attracts) Source: author's photo.

Another key activity administered by the regional maraakiz is the weekly management of weekend TJ outings-a staple of the movement's global modus operandi-across the halqa. When attending the Tuesday evening mashwera, it is usual for the TJ leaders of each mosque to inform the markaz elders of the number of jama'ats expected that coming weekend from their local mosque, and whether they are expecting any masturat jama'ats (ladies groups) to be formed. Designated members of the markaz hierarchy then co-ordinate destinations in the halqa for each of the expected groups and write them with a wipe-able marker pen onto a pre-prepared template displayed as one of several oversized noticeboards situated at the administrative hub of the markaz (see Figure 10). Before returning home,

18 The bulk of Pieri's (2012a, p. 39) participant observation consisted of attending the weekly Thursday night gatherings at London Markaz- “ 150 hours (roughly 55 separate sessions) over a period of 18 months were spent attending these talks, followed by further time socialising over a meal in the mosque afterwards" - where he observed that a more ethnically diverse crowd of up to 3000 would gather each week. 
the visiting TJ leaders from the different mosques across the halqa will make their way to the noticeboard to take note of the "routes" given to each of their expected jama'ats. This information will then be relayed to the remainder of the TJ activists in their own mosque, usually at the daily mashwera meeting held after the Fajr prayer the next (Wednesday) morning. Younger activists then often disseminate the destination of that weekend's jama'at to their friends or other potential recruits via WhatsApp or text message (see Figure 11).

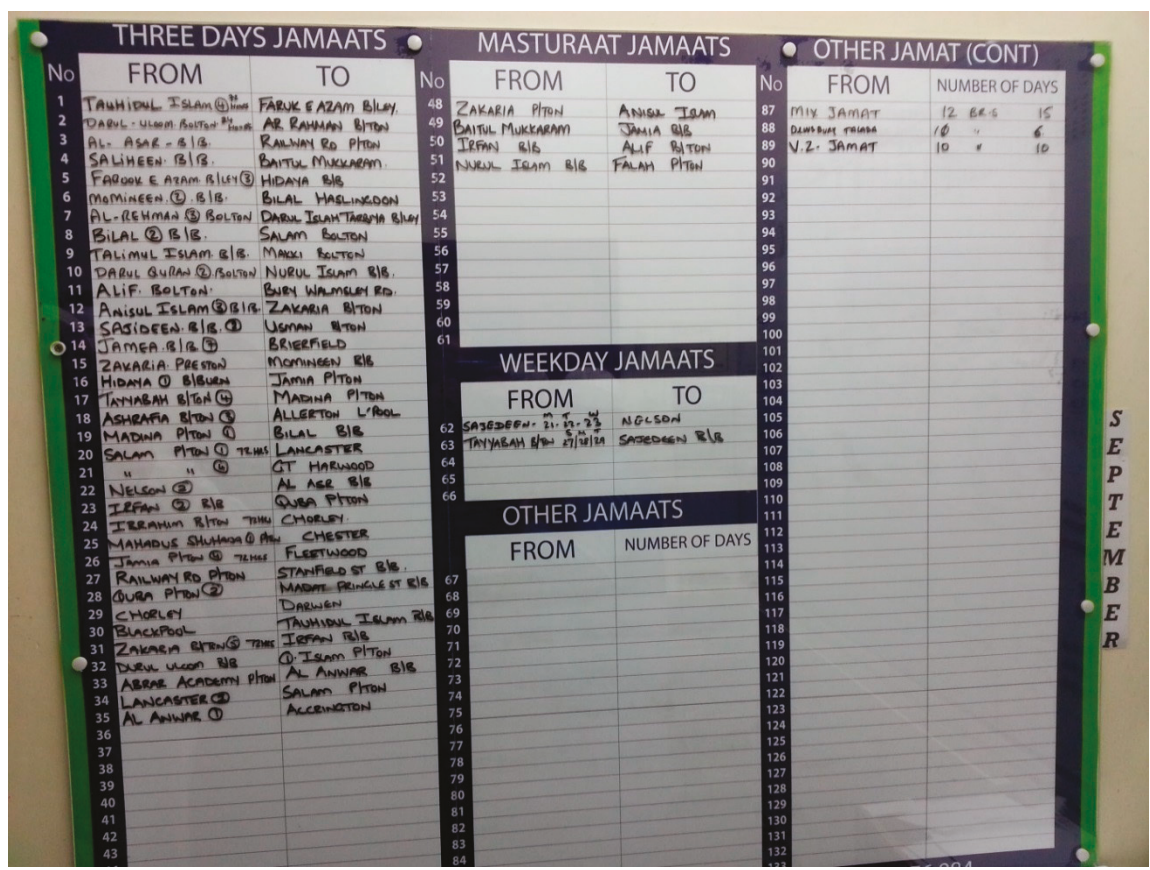

Figure 10. The oversized noticeboard template in Blackburn Markaz, freshly filled out on a Tuesday evening, that displays the "routes" of all the jama'ats operating in the Lancashire halqa on a typical week. Source: author's photo (October 2013).

\section{Salam. Jama'at will be going to Zakariyya Masjid in Bolton this weekend IA. Brothers are requested to be ready with their bedding, etc in Isha salaat on Friday which is at $7.35 \mathrm{pm}$. Jazakallah}

Figure 11. An example of a text message sent out on Wednesday informing potential participants about the coming weekend's jama'at. Source: author's mobile phone.

Figure 10 warrants some commentary. As can be seen: 
- There are 35 men's jama'ats (usually between 8-15 members each) expected that weekend and four ladies' groups (usually comprising 4-6 husband-wife couples each), ${ }^{19}$

- Of the men's jama'ats, five are ready for the full 72 hours (Thursday to Sunday evening), while the majority are for the weekend only (Friday to Sunday evening), and one is only for 24 hours;

- Two weekday jama'ats are also expected (usually consisting of taxi drivers and restaurant workers who find it difficult to join the normal groups due to their occupational commitments over the weekend);

- $\quad$ All the above refer to the weekly 2-3-day TJ outings to be formed, organised and dispatched within the halqa. Additionally, three groups (under the heading 'Other Jamaats') are visiting mosques in Lancashire from outside the halqa. These comprise the following:

1. A "mixed group" (i.e., the individual members hail from different parts of the UK) of 12 people that is probably out for 40 days in total and is spending 15 days in this halqa;

2. A 10-strong group of 'Dewsbury talaba' (i.e., students of the Dewsbury Dar al-Ulum) that is visiting the halqa for 6 days;

3. 'V.Z. Jamat'-i.e., a foreign TJ group from Venezuela visiting the halqa (via Dewsbury, of course) for 10 days and probably in the UK for 40 days in total.

We thus see how 44 separate mosques within the Lancashire halqa were scheduled to host visiting jama'ats on that weekend, chosen at random, in October 2013. Elders at the Blackburn Markaz are therefore evidently required to exercise care to ensure that mosques are not double-booked with more than one visiting jama'at at the same time, and that individual mosques are visited by different TJ groups with fairly uniform frequency. Although the other regional maraakiz (in Birmingham, Dewsbury, Glasgow, Leicester and London) may not follow the same noticeboard system, it is highly probable that they will organise their weekly groups along very similar lines so as to maintain a birds-eye view of the various jama'ats operating within their demarcated zones at any given time.

As mentioned earlier, my fieldwork also uncovered the existence of what I have termed four "semi-maraakiz." These operate in Bristol, Cardiff, Newcastle and Dublin and differ from a full markaz in two important respects. Firstly, they are based in an ordinary mosque (albeit with a strong TJ presence) and not premises exclusively managed by TJ. Secondly, local TJ leaders convene in them weekly only for the Tuesday evening mashwera and to co-ordinate the movement of jama'ats across their local regions; they are not considered strong enough yet-in TJ terms- to host the weekly Thursday-night open programme. The medium-long term goal for each, however, would no doubt be to strengthen the local TJ infrastructure enough to manage this also in dedicated premises, thus establishing another fully-fledged regional markaz.

\section{On the Interface of the Local and Global: TJ's "Glocal" Activism}

Another key institutional activity of British TJ comprises the "mahina mashwera" convened at the national Dewsbury headquarters every 6 weeks or so. It is a weekend-long council attended by several hundred leaders of TJ mosques across the country, thus amalgamating nationally the same long-standing activists who attend the weekly Tuesday evening mashwera in their respective regional maraakiz. Although I did not attend a mahina mashwera, I gauged that it proceeds along a set format in which a large number (around 20 or so) of umoors (agenda items) are discussed over the course of the weekend; it invariably concludes with a tearful supplication $\left(d u^{\prime} a a\right)$ that would historically be offered by Hafiz Patel. Several senior Tablighis informed me that the umoors derive from a higher level "European mashwera" held at the international Nizamuddin spiritual centre every two years

19 Masturat, or ladies TJ groups, in practice comprise of couples. While men stay at the mosque, ladies are hosted in the house of a local volunteer. For more on the female TJ experience, see Amrullah (2011) or Janson (2014). 
(similar continental-wide mashweras are also held biennially there for other global territories such as Africa or South East Asia, for example). Here, national TJ leaders from various European countries (and select others) gather for several days to discuss macro TJ goals which are then broken down and agreed at the country level with the Nizamuddin authorities. The mahina mashwera is a key mechanism designed to facilitate the achievement of these national goals calibrated across a two-year period (that is, between European mashweras). There is also an interim level-between the global and national-in which, every three months, TJ leaders from across Europe gather for a weekend-long mashwera in different European countries selected on a rotation basis where they feed-back on national activities and monitor the progress of the macro European goals decided at Nizamuddin. At the national level, on the next (Monday) evening following a given weekend mahina mashwera held at the Dewsbury Markaz, TJ activists from each "diocese" gather at a pre-stipulated "parish" mosque that is selected on a rotation basis, or alternately gather at the regional markaz. Here, the handful of local elders that attended the Dewsbury gathering relay a condensed version of the discussions to the much larger number of regionally gathered activists, and the national umoors are thus broken down a level further. Ultimately, individual TJ activists return to their own mosques to implement the agreed outcomes at a micro-level, as depicted in Figure 12.

It may be helpful to illustrate the staggered nature of this activism with an example. For instance, at the biennial European mashwera, the Nizamuddin headquarters may have requisitioned (takaza) from the Dewsbury centre six 40-day jama'ats from the UK to tour a specified range of European countries every three months. At the mahina mashwera, this would be one of the many umoors discussed, and each of the regional halqas might take upon themselves the responsibility of contributing one jama'at each (thus making up the required total of six). At the regional Monday evening follow-up, individual mosques might take upon themselves the responsibility of contributing one member each for the jama'at agreed at halqa level. Names of potential candidates would then be discussed and a list drawn up at the local mosque's daily mashwera meeting. Next, individuals would be visited and tashkeeled (encouraged to participate) during the daily gasht (preaching) activity of each local "parish" mosque (see (Reetz 2003) for more on TJ's "Local Mosque Scheme"). Progress would be monitored at a halqa level at the weekly Tuesday evening mashweras held at the regional maraakiz and, ideally, the assembled jama'at would make their way to Dewsbury Markaz within the stipulated timeframe ready to begin their 40-day tour. At the next European mashwera at Nizamuddin, the Dewsbury (and other national) authorities would be required to feed-back (karguzari) on how well objectives were achieved over the preceding two years; accordingly, problems might be brainstormed and fresh macro objectives set for the coming two years.

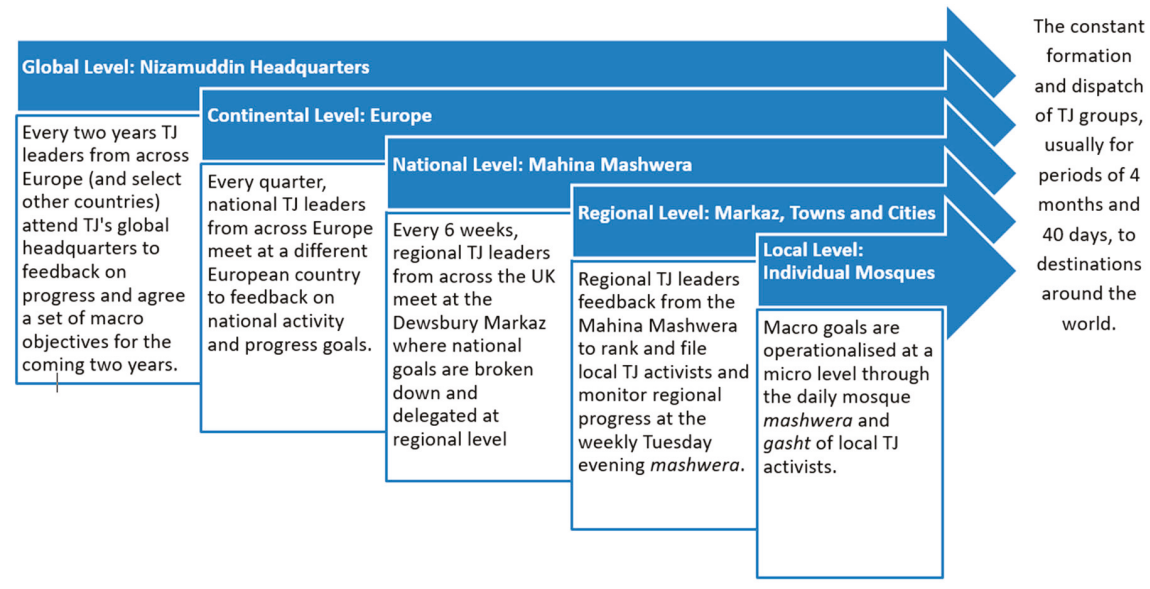

Figure 12. The mechanics of TJ's "glocal" activism. 
This measured and calculated style of activism, which encompasses local, regional, national and international dimensions, is commented upon by Reetz (2008, p. 111) in his analysis of TJ's "faith bureaucracy" in its Indian context: "Thus, a huge map of religious activity and performance is imagined of the country and the whole world. It is not unlike the target map of a huge global corporate enterprise, setting course on expansion" (also see Figure 13). Ali, a 37-year-old English convert to Islam who has spent the last two decades as a dedicated TJ activist, expressed a similar sentiment when describing to me his first international TJ khuruj to the Raiwind headquarters in 1998:

"It was really the next level and masha' Allah, you know, I met so many people from around the world and I did meet committed people so it was a real kind of, the performance bar was increased, you know, you saw people who were giving so many hours a day and they were very devoted to the teachings of Islam and yeah, it was a really good environment to be in ... it felt like a genuine, I mean basically the layout was almost like a business plan which is: this is what we want to achieve, these are the outcomes that we want to achieve, these are the kind of performance indicators, you know, it was like a very clear business plan. How people can benefit from the religion of Islam and how the Muslims can be a source of benefit for mankind and serve mankind and be a source of good for mankind. And again, that resonated with me, and it seemed like a very clear game plan which I've heard lots of other groups of people but I never saw a very practical, clear plan as this."

The practical ramifications of this glocal activism become evident when considering that eight of my formal interviewees who worshipped in a single mosque in the North of England had, between them, visited, over two decades of staunch TJ commitment, the following countries (usually for a minimum 40-day khuruj but sometimes for a longer four-month outing): America, Argentina, Australia, Austria, Bangladesh, Barbados, Belgium, Bosnia, Brazil, Bulgaria, Canada, Denmark, Fiji Islands, Finland, France, Germany, Greece, Holland, India, Indonesia, Italy, Kosovo, Malta, New Zealand, Pakistan, Panama, Romania, Saudi Arabia, South Africa, Spain, Sri Lanka, Sweden, The Philippines, Trinidad \& Tobago and Venezuela. That seven of the eight were British-born further indicates the extent of successful intergenerational transmission of the movement in Britain and exposes the lacuna that exists in extant studies of British Islamic youth activism.
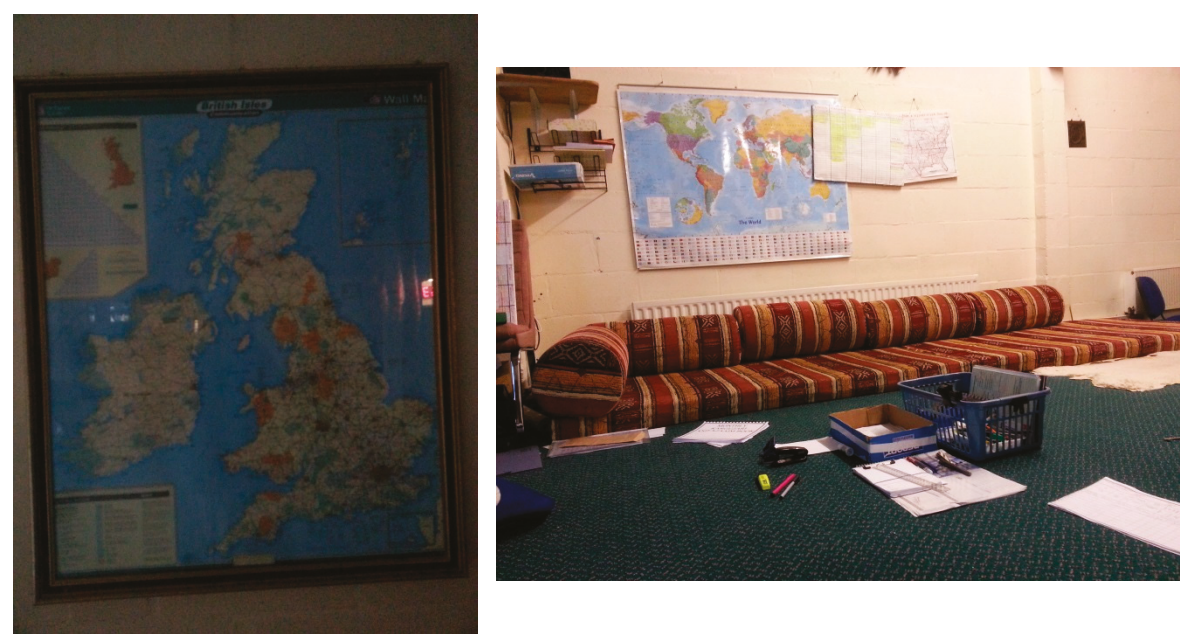

Figure 13. It is noteworthy that national and international maps adorn the walls of the Dewsbury headquarters, although critics maintain that it has failed to engage adequately with the wider society on its doorstep (Lockwood 2012). Source: author's photos. 


\section{Conclusion}

This paper has described the Tablighi Jama'at's institutional organisation and modalities of operation in the British context. In doing so, it has highlighted the systematic manner in which local, regional, national and international levels of the movement interact to produce a truly "glocal" movement. It has also identified the basic geographic sites at which British TJ operates from hundreds of individual mosques scattered around the country to the national headquarters situated in Dewsbury, with various regional maraakiz (in Birmingham, Blackburn, Glasgow, Leicester and London) and semi-maraakiz (in Bristol, Cardiff, Newcastle and Dublin) acting as conduits. While the institutional organisation of the movement in Britain has recently splintered, following the death of its spiritual leader Hafiz Patel in February 2016 and the simultaneous development of a seemingly insoluble schism at the level of the global hierarchy, this paper has captured the ordinary structures of authority that have characterised its operation in Britain throughout the bulk of its history. In this, it has built upon Reetz's $(2003,2008)$ work in the South Asian context and helped fill evident lacunae subsisting in the British context (Sikand 2002; Siddiqi 2018). In particular, the paper fleshes out Pieri's (2015) valuable overview of British TJ's organisational structures with an unprecedented level of detail based on freshly undertaken ethnographic fieldwork. Triangulating the findings with studies conducted elsewhere-such as Janson's (2014, pp. 91-95) description of Gambian TJ's organisational structure-indicates the extent to which TJ has managed to spread its activities across vast geographical expanses whilst maintaining a supranational uniformity of method. However, this global—or glocal—proliferation, as was pointed out earlier, often escapes public attention. According to Mandaville (2001, p. 146), "It is in groups such as the Tablighi Jama'at ... that the umma, in the sense of a community of believers unhindered by geographical or national boundaries, finds its truest expression in Islam today". While there is no doubt that this ethos of radical egalitarianism constitutes a striking element of TJ's normative praxis (as also attested to by Metcalf (1994) among others), this paper has argued that it simultaneously camouflages a structured hierarchy of authority and an elaborate system of organisation crucial to its basic functioning. Not only does the Tablighi Jama'at operate on the interface of the local and the global then, but it also exemplifies a type of regulated fluidity and a distinct "absent presence" (Kinnvall and Svensson 2017) that defies simplistic categorisation.

Funding: I wish to record my gratitude to the Jameel Scholarship Programme which made possible the research upon which this article is based.

Conflicts of Interest: The author declares no conflict of interest. The funders had no role in the design of the study; in the collection, analyses, or interpretation of data; in the writing of the manuscript, or in the decision to publish the results.

\section{References}

Ahmad, Mumtaz. 1991. Islamic Fundamentalism in South Asia: The Jama'at-Islami and the Tablighi Jama'at of South Asia. In Fundamentalisms Observed. Edited by Martin E. Marty and Scott R. Appleby. Chicago: University of Chicago Press.

Ahmed, Abdul-Azim. 2019. Conceptualising Mosque Diversity. Journal of Muslims in Europe 8: 138-58. [CrossRef]

Ali, Jan Ashik. 2012. Islamic Revivalism Encounters the Modern World: A Study of the Tablighi Jama'at. New Delhi: Sterling Publishers.

Amrullah, Eva F. 2011. Seeking sanctuary in 'the age of disorder': Women in contemporary Tablighi Jamā'at. Contemporary Islam 5: 135-60. [CrossRef]

Balci, Bayram. 2015. The rise of the Jama'at al Tabligh in Kyrgyzstan: The revival of Islamic ties between the Indian subcontinent and Central Asia? Central Asian Survey 31: 61-76. [CrossRef]

Birt, Jonathan, and Sophie Gilliat-Ray. 2010. A mosque too far? Islam and the limits of British multiculturalism. In Mosques in Europe: Why A Solution Has Become A Problem. Edited by Allievi Stefano. London: Alliance Publishing Trust-Network of European Foundations. 
Birt, Jonathan, and Philip Lewis. 2012. The Pattern of Islamic Reform in Britain: The Deobandis Between Intra-Muslim Sectarianism and Engagement with Wider Society. In Producing Islamic Knowledge: Transmission and Dissemination in Western Europe. Edited by van Bruinessen and Stefano Martin. London: Routledge.

Bowen, Innes. 2014. Medina in Birmingham, Najaf in Brent: Inside British Islam. London: C Hurst \& Co Publishers Ltd.

Coffey, Amanda. 1999. The Ethnographic Self: Fieldwork and the Representation of Identity. London: SAGE Publications Ltd.

DeHanas, D. N., and Z. P. Pieri. 2011. Olympic Proportions: The Expanding Scalar Politics of the London 'Olympics Mega-Mosque' Controversy. Sociology 45: 798-814. [CrossRef]

Dhorat, Muhammad Saleem. 2018. Hafiz Muhammad Patel Sahib. Riyadul Jannah 27.

Geaves, Ron. 1996. Sectarian Influences Within Islam in Britain with Reference to the Concepts of 'ummah' and 'community'. Edited by Kim Knott. Leeds: University of Leeds.

Ghazali, Abdus Sattar. 2018. Global leadership split in Tablighi Jamaat echoes in San Francisco Bay Area. Available online: https:/countercurrents.org/2018/10/global-leadership-split-in-tablighi-jamaat-echoes-insan-francisco-bay-area (accessed on 21 June 2019)

Gilliat-Ray, Sophie. 2006. Educating the Ulama: Centres of Islamic religious training in Britain. Islam and Christian-Muslim Relations 17: 55-76. [CrossRef]

Guenther, Katja M. 2009. The politics of names: Rethinking the methodological and ethical significance of naming people, organizations, and places. Qualitative Research 9: 411-21. [CrossRef]

Hamid, Sadek. 2011. British Muslim Young People: Facts, Features and Religious Trends. Religion, State and Society 39: 247-61. [CrossRef]

Hamid, Sadek. 2015. Sufis, Salafis and Islamists: The Contested Ground of British Islamic Activism. London: I.B.Tauris $\&$ Co Ltd.

Hammersley, Martyn, and Paul Atkinson. 2007. Ethnography: Principles in Practice, 3rd ed. London: Routledge.

Iqbal, Sajid. 2018. A House Divided. Dawn. Available online: https://www.dawn.com/news/1391624 (accessed on 21 June 2019).

Janson, Marloes. 2014. Islam, Youth and Modernity in the Gambia: The Tablighi Jama'at, The International African Library. Cambridge: Cambridge University Press.

Khan, Arsalan. 2016. Islam and Pious Sociality: The Ethics of Hierarchy in the Tablighi Jamaat in Pakistan. Social Analysis: The International Journal of Anthropology 60: 96-113. [CrossRef]

King, John. 2002. Tablighi Jamaat and the Deobandi mosques in Britain. In Global Religious Movements in Regional Context. Edited by John Wolffe. Bath: Ashgate Publishing Ltd in Association with The Open University.

Kinnvall, Catarina, and Ted Svensson. 2017. Ontological security and the limits to a common world: Subaltern pasts and the inner-worldliness of the Tablighi Jama'at. Postcolonial Studies 20: 333-52. [CrossRef]

Lewis, Philip. 1994. Islamic Britain: Religion, Politics and Identity among British Muslims. London: I.B.Taurus.

Lockwood, Danny. 2012. The Islamic Republic of Dewsbury. Batley: The Press News Ltd.

Luck, Taylor. 2015. The Mysterious Islamic Movement Quietly Sweeping the Middle East. Available online: http://www.csmonitor.com/World/2015/1206/The-mysterious-Islamic-movement-quietly-sweepingthe-Middle-East (accessed on 21 June 2019).

Madden, Raymond. 2010. Being Ethnographic. London: SAGE Publications Ltd.

Mandaville, Peter. 2001. Transnational Muslim Politics: Reimagining the Umma. London: Routledge.

Mandaville, Peter. 2010. Muslim Networks and Movements in Western Europe. Washington, DC: The Pew Forum on Religion \& Public Life.

Masud, Muhammad Khalid, ed. 2000. Travellers In Faith: Studies of the Tablighi Jama'at as a Transnational Islamic Movement for Faith Renewal. Leiden: Koninklijke Brill NV.

Metcalf, Barbara. 1994. Remaking Ourselves: Islamic Self-Fashioning in a Global Movement of Spiritual Renewal. In Accounting for Fundamentalisms: The Dynamic Character of Movements. Edited by Martin E. Marty and Scott R. Appleby. Chicago \& London: University of Chicago Press.

Mogra, Imran. 2014. The Tablighi Jama'at in the UK. In Islamic Movements of Europe: Public Religion and Islamophobia in the Modern World. Edited by Frank Peter and Rafael Ortega. London: I.B. Tauris \& Co. Ltd.

Noor, Farish. A. 2012. Islam on the Move: The Tablighi Jama'at in Southeast Asia. Amsterdam: Amsterdam University Press. 
Pieri, Zacharias. 2012a. The Contentious Politics of Socio-Political Engagement: The Transformation of the Tablighi Jamaat in London. Ph.D. thesis, University of Exeter, Exeter, UK.

Pieri, Zacharias. 2012b. Tablighi Jamaat_Handy Books on Religion in World Affairs. London: Lapido Media.

Pieri, Zacharias. 2015. Tablighi Jamaat and the Quest for the London Mega Mosque: Continuity and Change. New York: Palgrave Macmillan.

Reetz, Dietrich. 2003. Keeping Busy on the Path of Allah: The Self-Organisation (Intizam) of the Tablighi Jama'at. In Islam in Contemporary South Asia. Edited by D. Bredi. Rome: Oriente Moderno.

Reetz, Dietrich. 2008. The Faith Bureacracy of the Tablighi Jama'at: An Insight into their System of Self-organization. In Colonialism, Modernity, and Religious Identities: Religious Reform Movements in South Asia. Edited by Gwilym Beckerlegge. Oxford: Oxford University Press.

Reetz, Dietrich. 2009. Tablighi Jama'at. In The Oxford Encyclopaedia of the Islamic World. Edited by John Esposito. Oxford: Oxford University Press.

Sardar, Ziauddin. 2004. Desperately Seeking Paradise: Journeys of a Sceptical Muslim. London: Granta Books.

Schleifer, Abdallah, ed. 2018. The 10th Anniversary Edition, The World's 500 Most Influential Muslims, 2019. Amman: The Royal Islamic Strategic Studies Centre.

Shaw, Martin. 2016. 'At least 5000' mourners turn up to funeral of respected Muslim leader in Yorkshire town. The Mirror. Available online: http://www.mirror.co.uk/news/uk-news/at-least-5000-mourners-turn-7404184 (accessed on 21 June 2019).

Siddiqi, Bulbul. 2018. Becoming 'Good Muslim': the Tablighi Jamaat in the UK and Bangladesh. Singapore: Springer. Sikand, Yoginder S. 1998a. The origins and Development of Tablighi-Jama'at (1920-2000): A Cross-Country Comparative Study. Ph.D. thesis, University of London, London, UK.

Sikand, Yoginder S. 1998b. The origins and growth of the Tablighi Jamaat in Britain. Islam and Christian-Muslim Relations 9: 171-92. [CrossRef]

Sikand, Yoginder S. 2002. The Origins and Development of Tablighi-Jama'at (1920-2000): A Cross-Country Comparative Study. Hyderabad: Orient Longman.

Taylor, Jenny. 2015. Understanding and Engaging with the Tablighi Jamaat. Lausanne Global Analysis 4. Available online: https://www.lausanne.org/content/lga/2015-11/understanding-and-engaging-with-thetablighi-jamaat (accessed on 21 June 2019).

Timol, Riyaz. 2015. Religious Travel and the Tablighī Jamā'at: Modalities of Expansion in Britain and Beyond. In Muslims in the UK and Europe I. Edited by Yasir Suleiman. Cambridge: Centre of Islamic Studies, University of Cambridge.

Timol, Riyaz. 2016. Obituary: Hafiz Patel (1926-2016) -'A Spiritual Giant in an Age of Dwarfs'. Available online: http://www.onreligion.co.uk/blogs/obituary-hafiz-patel-a-spiritual-giant-in-an-age-of-dwarfs/ (accessed on 28 February 2016).

Timol, Riyaz. 2017. Spiritual Wayfarers in a Secular Age: The Tablighi Jama'at in Modern Britain. Ph.D. thesis, Cardiff University, Cardiff, UK.

(C) 2019 by the author. Licensee MDPI, Basel, Switzerland. This article is an open access article distributed under the terms and conditions of the Creative Commons Attribution (CC BY) license (http://creativecommons.org/licenses/by/4.0/). 



\title{
Article \\ "I Feel as Though I'm Doing the Job of the Imam for Them": Considering 'Tactical' Muslim Leadership Through the Case of 'Muslim RE Teachers'
}

\author{
Matthew Vince \\ Centre for the Study of Islam in the UK, School of History, Archaeology and Religion, Cardiff University, \\ Cardiff CF10 3EU, UK; vincem@cardiff.ac.uk
}

Received: 24 May 2019; Accepted: 5 July 2019; Published: 9 July 2019

\begin{abstract}
Although Muslim leadership in Britain has long been the focus of scholarly attention, discussion has tended to prioritise "official" Muslim leaders (Birt 2006; Geaves 2008; Ahmad and Evergeti 2010). However, what constitutes a "Muslim leader" is increasingly contested, revealing instead a diversity of authoritative 'claim makers' and representative positions (Jones et al. 2015). These contestations were a recurring theme throughout the Leadership, Authority and Representation in British Muslim Communities conference (Gilliat-Ray and Timol 2019). Building upon these debates, this article considers how Muslim teachers can be considered Muslim leaders within their local contexts. This paper draws on qualitative research with 21 'Muslim RE teachers' across England to consider how their experience and positioning as 'role models' for Muslim and non-Muslim pupils brought considerable influence to represent Muslims, affect school policy and practice, and shape "official" Islamic discourses in their local communities. I argue that their experience reflects what can be considered as 'Muslim leadership' on the broader scholarly terrain, but as a form of 'tactical' Muslim leadership by virtue of existing within the confines of "secular" institutions. As such, this article concludes by calling for the recognition of Muslim leadership beyond national, 'strategic' forms to more 'tactical', contextually bounded cases.
\end{abstract}

Keywords: Muslim leadership; Muslim teachers; Muslims in Britain; education; religious education; RE teachers; tactical religion; strategic religion

\section{Introduction}

Although Muslim leadership in Britain has long been the focus of scholarly attention, discussion has tended to prioritise "official" forms and sites of leadership, such as the imam and Muslim umbrella bodies (Birt 2006; Geaves 2008; Ahmad and Evergeti 2010). However, critics have argued that the concept of a 'Muslim leader' is problematic. The notion evokes the sense of a monolithic Muslim community that in turn fails to reflect the diversity of voices and conflicting positions within Muslim communities (Jones et al. 2015). An emphasis on religious authority, authenticity, and praxis, also presents a narrow view of leadership (Gilliat-Ray 2010, p. 54). These contestations emerged as a recurring theme throughout the Leadership, Authority and Representation in British Muslim Communities conference (Gilliat-Ray and Timol 2019), which asked, who exactly are Muslim leaders in Britain today?

In the wake of these contestations, new and alternative forms of Muslim leadership are being articulated. Jones et al. (2015, p. 213) argue for the recognition of a diversity of Muslim 'claim-makers' that utilise different modes of representation for different groups and individuals. Gilliat-Ray et al. (2013) posit that Muslim chaplaincy has led to the development of a new form of professional leadership, in their capacity to shape Islam to secular policy frameworks of British public institutions. Discussions of Muslim leadership in relation to education has restated the importance of Islamic scholars: alims and alimahs, and Dar Ul Ulooms, as contemporary sources and sites of authority 
(Scott-Baumann and Cheruvallil-Contractor 2015; Sidat 2018). Moreover, as Bano (2017) writes, education has been a particularly important sphere for female Muslim leadership.

The presence of Muslim 'role models' has been side-lined in these debates, neglecting its potential as a form of Muslim leadership and representation in contemporary Britain. Burdsey $(2007,2016)$ has highlighted, and problematised, the importance of sports personalities like Amir Khan and Mo Farah within discourses surrounding multi-ethnic and post-racial Britain both as 'role models' and 'palatable representations' of the 'British Muslim', primarily for non-Muslim Brits. Similarly, Nadiya Hussain, of Great British Bake Off fame, has become a symbol of both (Muslim) female agency and postcolonial assimilation (Casey 2018; Lagerwey 2018), to such an extent that Ted Cantle has remarked that Nadiya has done 'more for British-Muslim relations than 10 years of government policy' (Wiseman 2018). But, again, these notions of role modelling have been criticised because of their orientation toward a white, British audience.

Yet, the promotion of Muslim role models seems to be occurring from within Muslim communities. Jones et al. (2015, pp. 218-19) highlight 'standing' as a type of 'surrogate' representative position: 'how public prominence can enable an individual to speak out on topics that have relatively little to do with the reason why that person is in the public spotlight'. They discuss how Muslim MPs, like Sajid Javid and Sadiq Khan, as well as Amir Khan, have used their prominence, power, and Muslim identity to 'speak for' Muslims, even though this may go beyond their expertise-both politically and 'religiously'. Like Nadiya Hussain, this kind of leadership seems to be especially important for Muslim women, with individuals challenging prevailing discourses within and outside Muslim communities. Elsewhere, Khan (2018) photography counters stereotypical 'misrepresentations' of Muslim women in the media by drawing attention to their engagement in a wide variety of activities and fields. The Women Like Us series by British Muslim TV (Choudhry 2018) also champions this narrative, featuring interviews with Muslim women who are leading within a diverse array of fields whilst also emphasising their identities as Muslims. However, whilst role models exhibit the potential for leadership and representation for Muslims, their capacity to act as "Muslim leaders" remains largely unexplored.

It struck me during my doctoral research how 'Muslim RE teachers' occupied many of these representative positions. On a micro level, specific to their community and school contexts, these teachers were often positioned as 'role models' and 'community leaders' by Muslim and non-Muslim pupils, parents, and staff. This article therefore re-considers Muslim leadership through the case of Muslims working as non-confessional Religious Education (RE) teachers across secondary schools in England, or 'Muslim RE teachers'. Drawing on qualitative research with 21 participants, I consider how their experience as role models for Muslim and non-Muslims brought considerable influence to represent Muslims, affect school policy and practice, and engage with "official" Islamic discourses in their local communities. I argue that they reflect what is considered as 'Muslim leadership' in the broader scholarly terrain, but that their leadership is more subtle and 'hidden' by virtue of existing primarily within the confines of a local "secular" institution. Doing so reveals a new kind of 'tactical', interlocutory Muslim leadership that complements and contrasts with the national, 'strategic' forms of leadership that have already been articulated. This article concludes by calling for the renewed recognition of leadership below the 'strategic' level to more contextually bounded, 'tactical' cases.

\section{Representative Positions and Muslim Leadership}

Given the increasing diversity of what can be considered 'Muslim leadership' the concept itself is nebulous and hard to define. Recognising this multiplicity, Jones et al. (2015, p. 214) provide a way to conceptualise Muslim leadership in terms of representational positions. They write that

According to Saward ... accepting the fact that the British Muslim population is diverse and divided does not mean jettisoning the idea of Muslim representation entirely, as the critics mentioned above appear to believe it does. Representation can be taken on a claim-by-claim 
basis. Groups can speak for Muslims—or Muslim women, Muslim converts and so on-on some issues and not on others, at sometimes and not others.

This claims-focused approach is useful because it allows 'Muslim leadership' to be considered as something that is complex, contested and reflects a constellation of voices (Jones et al. 2015, p. 220). Muslim actors can be leaders in different ways, for different groups, based on varying claims to represent and lead, made by either themselves or by others. Although their analysis is focused on Muslim leadership within proximity to governance, such as the Muslim Council of Britain (MCB), they recognise that such claims are also made by those in other arenas, such as at the local level (Jones et al. 2015, p. 215). Therefore, the typology of representative positions that Jones et al. (2015) provide offers a useful theoretical foundation from which to explore the capacity for 'Muslim RE teachers' to be considered as leaders. In turn, the case of 'Muslim RE teachers' serves to support further research and development of this typology.

Their typology of representative positions consists of four modes of representation. These are:

- Delegation: 'the building up of 'grass roots' support from community institutions or voluntary associations and using that to try and establish credibility and ultimately influence policy' (Jones et al. 2015, p. 215).

- Authority: meaning 'religious authority, and the role that religious authority can play in allowing individuals a public voice and access to government' (Jones et al. 2015, p. 216).

- Expertise: 'expertise in a given field-such as discrimination law-has given Muslim individuals the opportunity to enter governance spaces in which they can then speak for the interests of an identity group' (Jones et al. 2015, p. 217).

- Standing: 'how public prominence can enable an individual to speak out on topics that have relatively little to do with the reason why that person is in the public spotlight' (Jones et al. 2015, p. 218).

Whilst this typology is limited to forms of representation that exist in proximity to governance, Jones et al. (2015) leave open the possibility for their expansion. Accordingly, through this article I argue that these characteristics map onto more micro-level forms of 'Muslim leadership', namely the roles and work that 'Muslim RE teachers' engage in in their schools. Throughout their work they occupy these various modes of representation within their school contexts, and act as leaders for the Muslims (typically pupils and parents) in their school communities. In turn, I propose that role modelling may be added to this typology as a type of representative position; akin to standing.

I also argue for a distinction between 'tactical' and 'strategic' forms of leadership, to further nuance the above analytical approach. As Woodhead (2016, p. 15) writes, where strategic modes 'impose' from above using their institutional authority and power, tactical modes work from within and in response to power;

This does not mean that they are powerless, but that their power operates in a different mode from that of the powerful-a tactical rather than strategic mode. They duck and dive, think on their feet, turn and weave. A tactic, according to de Certeau (1984), 'is determined by the absence of power just as a strategy is organized by the postulation of power'. But contrary to a narrow Foucault-inspired position, the tactical does not merely practice arts of 'resistance': it can be highly creative and constructive in what it does with the structures and strategies in terms of which it operates: 'sly as a fox and twice as quick: there are countless ways of "making do"'.

In the discussion, the use of 'tactical' leadership reflects the participants occupying representative positions from within and between the policy frameworks and practices of their school contexts and traditional sources of authority within their local Muslim communities. I claim that this is distinct from 'strategic' modes of Muslim leadership and representation, explored by Jones et al. (2015), that exist in proximity to national governance and seek change from above. 


\section{The Research}

Considering the growth of Muslim actors in education surrounding Preventing Violent Extremism policies and the promotion of Fundamental British Values, Muslim teachers remain surprisingly under-researched. Given their unique positioning as interlocutors between the state and Muslims in schools, and tasked with embodying both, their experiences and perspectives are valuable to exploring how Muslims manage their identities in schools. 'Muslim RE teachers' are a particularly pertinent case because their role as teachers of non-confessional RE means that much of their work explicitly deals with matters of religion within school, more so than in other subjects. As Freathy et al. (2016) state, notions of RE teacher professionalism include unique ontological and epistemological expectations to manage one's own faith and appear 'neutral' in the classroom (see also Jackson and Everington 2017). Therefore, the experiences of 'Muslim RE teachers' can bring to light processes of identity-work that remain more implicit for Muslim teachers more generally.

Conducted from 2015 to 2018, my research explored the personal and professional identities of 'Muslim RE teachers' through a total sample of 21 teachers working in secondary schools across England. The study employed a qualitative methodology and research design in order to elicit 'thick descriptions' from the participants about their faith and professional identities (Flick 2009). Although this research is not intended to be representative, and currently no information regarding the religious identification of RE teachers in England is available, the sample is the largest qualitative study involving Muslim RE teachers to date.

\subsection{Methods}

The research used two data collection methods.

\subsubsection{Semi-Structured Interviews}

A total of 21 one-to-one, semi-structured interviews formed the primary data collection tool—one with each participant. The interviews were designed to explore the ways participants understood their identities as 'Muslims' and as 'RE teachers', and how these two identity-attributes came together in their everyday work. Most of the interviews were conducted face-to-face in the participants' schools, a smaller number were conducted in other sites, over Skype and by telephone. All the interviews were recorded on a dictaphone and were transcribed verbatim.

\subsubsection{Participant Shadowing}

The interview data was enriched by three periods of participant shadowing. Shadowing is 'observation on the move', with the researcher following a participant whilst they work (Czarniawska 2014, p. 43). Shadowing was used to supplement the interview data because, as Gilliat-Ray (2011) writes, 'being there' allows the researcher to 'share the experiences' with participants to elicit data of a qualitatively different kind. The concept of shadowing another's work is also part of teaching culture, with teaching observations a common practice in teacher training and development. Here, shadowing was used to supplement the interview data by allowing me to experience how the participants' identities played out moment-by-moment in their schools.

Three participants were shadowed over a period of ten weeks during the Spring and Summer terms of 2017. I spent two or three days a week with each participant, totalling 24 days of observation overall. My observations and reflections were recorded in a fieldwork journal, which were also transcribed along with the interviews. These participants were selected from the wider sample based on their willingness to participate further, and their identification as a significant case on the basis of the interview data.

A 'lived religion' approach was adopted that allowed for analysis to consider the participants' faith and professional identities together. 'Lived religion' considers how the narratives and practices of everyday experience shape the construction of identity (Ammerman 2016). Within this approach, 
religion is 'constituted by the practices people use to remember, share, enact, adapt, create and combine the stories out of which they live', rather than by "official" religious discourses (McGuire 2008, p. 98). As such, "lived religion' has been fruitful in de-centring foci on "official" forms and sites of religion to religion 'at the edges' (Bender et al. 2013). Similarly, 'Everyday lived Islam' has also drawn attention to scholarship's preoccupation with "official", often hypervisible, forms of 'Muslimness' (Dessing et al. 2016; Werbner 2018). Hence, the use of this framework helped my analysis to look beyond "official" discourses and practices, which is pertinent to the present discussion.

\subsection{Sample}

Biographical data of the sample are worth noting as this is an indication of the diversity of Muslim identities amongst the participants. Participants were selected based on: their self-identification as 'Muslim', holding Qualified Teacher Status (QTS), and were working as, or had worked as, an RE teacher in a secondary school, as identified by job title, job description, or that RE was one of the principal subjects that they taught. The sample consists of 14 self-identified Sunni Muslims, 2 Shia Muslims, 2 Sufi Muslims, 1 Ahmedi Muslim, and 2 who described themselves as 'cultural' and 'political' Muslims. The sample was also mainly of Asian ethnicity $(n=20)$, and there was one white male Muslim convert. Thus, under the category 'Muslim' diverse intersections of race and denominational identifications feature within the participants' narratives, along with their varied professional understandings of 'RE teaching'.

Participants taught in a variety of secondary academies and Local Education Authority (LEA)-controlled secondary schools across England, located in the North West, Midlands, South East and South West. None of the schools were Muslim faith schools, and a minority $(n=4)$ were Christian-ethos schools. There was a tendency for these schools to have ethnically diverse student bodies; a tendency that has been noted elsewhere in terms Black and Minority Ethnic (BME) teachers (Cunningham and Hargreaves 2007), but the majority of these could not be said to be Muslim majority. Amongst these there was only one all-girls school. Thus, no generalisations can be made from the data based on the schools of the participants, other than the ethnic diversity of the area, which emphasised themes of race, racism and representation.

The gender of the participants also turned out to be significant in terms of intersecting identity-attributes. They were predominantly female $(n=15)$, reflecting the higher proportion of women in secondary teaching generally (Department for Education DfE), although this seems to be overrepresentative with regards to ethnicity (Department for Education DfE). This gendered dynamic was not intended and emerged naturally through the sampling procedure. In this way, the data primarily reflects the experiences of Muslim women in teaching, which can be linked to themes of hypervisibility (Jeldtoft 2016), especially surrounding wearing visible Muslim dress in school: with ten of the 15 female participants wearing the hijab in work (no teachers wore the niqab). Also gendered interpersonal relations, particularly with other Muslims in their school communities, were highlighted. The analysis of the data therefore reflected this gendered aspect, emphasising the embodied dimension of teaching in the underlying theoretical framework (see Estola and Elbaz-Luwisch 2003). In the present discussion, the focus on leadership includes specific consideration of the capacity of female Muslim leadership also.

\subsection{Ethics, Positionality and Presentation of Data}

The research was ethically approved by Cardiff University's School of Social Sciences Ethics Committee and designed according to the British Educational Research Association's ethical guidelines (British Educational Research Association BERA).

Being a white, male, non-Muslim researcher 'outside' of the community presented certain challenges to the research. Bolognani (2007, p. 282) has documented a 'general sense of mistrust' toward researchers investigating Muslim communities, especially those perceived to be 'outsiders', which can present barriers to access (see also Gilliat-Ray 2005). Issues with misrepresentation have also 
been noted as a common criticism of such research, especially where the researcher may not be sensitive to differences in ethnic, cultural or religious positions (Spalek 2005). My experience of RE teaching (two years) was a point of commonality with the participants, and in a way provided an 'insider' perspective on aspects of their experience, which significantly helped with recruitment and access. Within this research I have tried to remain attentive to the limitations of my perspective by giving significant space for the participants' own voices, here in the form of extended quotations. Although this is no guarantee to capture the 'secret knowledges' of marginalised groups (Spalek 2005, p. 414), this idea of 'giving voice' has been widely used in feminist research (McDowell 2016). Additionally, all names and places have been changed to protect anonymity, but continue to reflect the participants' denominational identification, gender and ethnicity (Guenther 2009).

\section{Results}

Black and Minority Ethnic (BME) teacher research has drawn attention to the leadership potential of BME teachers (Haque and Elliot 2017; McNamara et al. 2009; Osler 1997, 2003). Notably, their positioning as role models has been long been highlighted as a significant characteristic of BME leadership in education (Carrington and Skelton 2003; Haque and Elliot 2017; McNamara et al. 2009; Pole 1999). Other roles to support the needs of BME pupils, such as acting as translators for BME pupil communities, have also been identified as roles that are earmarked for BME teachers (Coleman and Campbell-Stephens 2010; Ghuman 1995; Haque and Elliot 2017). Recently, Shah $(2016,2018)$ has argued for the inclusion of Islamic notions of education and leadership into British state educational leadership to better attend to the needs of Muslim pupils. Thus, notions of leadership already surround Muslim teachers, but primarily as a case of BME actor.

Although not a specific line of inquiry, leadership was a consistent theme that underlined many of the participants' narratives, echoing this wider literature. In addition to their teaching, notions of leadership were tentatively associated with other roles and responsibilities that they had adopted during their careers. These other roles ranged from more implicit forms of leadership: acting as ambassadors and "Muslim" role models, to more explicit modes of representation: as Muslim representatives and religious authorities.

\subsection{Ambassadors}

The participants primarily spoke of their capacity as leaders in terms of being ambassadors and role models. All the participants in this study saw themselves as role models. Their role modelling centred on the impact of their Muslim identity in the classroom, often in conjunction with their visible 'Muslimness', reflecting an intersection between their faith, race, and their professional identity. There were two distinct facets to role modelling: role modelling for non-Muslims in an ambassadorial capacity, and role modelling for Muslims in a more typical role modelling sense.

The main way these teachers spoke of being a role model was in their capacity to "break stereotypes" about Muslims for non-Muslim pupils. Given the nature of RE, it was felt that their work-involving explicit discussion of religion and religious believers in the world today-put them in a privileged position to shape what others thought about Muslims and Islam. This kind of role modelling reflects an ambassadorial mode. They occupied a representational position through the authority bestowed on them as teachers over non-Muslim pupils. As Miss Meer reflected

I guess, in a classroom, they can't walk away from you. You know, they're in front of you whether they like it or not, and you have enough time to win them round, in a way. (Interview $17,12: 24-17: 53)$

This commitment to "breaking stereotypes" became an integral part of many of the participants' pedagogy. Often this was through sharing their 'personal life knowledge' as Muslims in discussions in the classroom (see Everington 2012). By sharing their own experiences of being Muslim, and correcting common misconceptions that non-Muslim pupils had, they worked to challenge the frequently racist, 
Islamophobic perceptions of these students. Another feature was that they broke stereotypes by simply being visibly Muslim in school. As a hijab-wearing Asian Muslim woman teaching RE, Miss Meer added that

I think it's important for people to see that there are individuals out there that want to be nice, that are decent ... But they're also Muslim, because it's this idea of Muslims are the bad people. And I wanted to be, sort of, the walking, talking evidence against that. (Interview 17, 12:24-17:53)

Thus, as 'Muslim RE teachers', they acted in an ambassadorial role for non-Muslim pupils as part of their embodied experience of RE teaching. In doing so, the participants occupied a representative position by acting as an example for non-Muslim pupils about what Muslims are really like.

"Breaking stereotypes" extended beyond the classroom, toward challenging the anti-Muslim sentiment of staff and parents. Often the participants were among the only Asian and Muslim staff members in school and so immediately "stood out". For Mrs Iqbal, being visibly Muslim enabled her to challenge the assumptions of the wider staff body, as she remarked in the following incident,

Yeah because they always assume that ... that you must have had an arranged marriage and that you've done this and you've done that, and I'm like NO.

(Interview 1, 46:00-46:12)

For Miss Sumar, this involved contending with the views of pupils' parents,

Their parents were saying stuff like y'know all Muslims are terrorists, that sort of stuff ... I felt like I had this additional responsibility in a sense ... I felt like I had to try and be the best that I could. (Interview 7, 39:10-41:28)

This kind of ambassadorial role modelling, through "breaking stereotypes", echoes the influence of representatives like Mo Farah and Nadiya Hussain. On the one hand, something like these celebrities' capacity to present a 'palatable' Muslim for white, non-Muslims was arguably present here. Yet, Everington (2015) has noted how the use of 'personal life knowledge' by Muslim teachers can bridge ontological gaps with non-Muslim pupils to challenge their views. By sharing their experiences, they were able to act as interlocutors between their world (as Muslims) and the worlds of their non-Muslim students and staff. So, whereas these celebrities are "walking, talking evidence" on television, these teachers were able to incorporate local narratives into their teaching. Doing so meant they were able to challenge to prevailing racist, Islamophobic discourses surrounding Muslims in Britain by relating specifically to the pupils as part of their community.

Acting as ambassadors was especially important if they worked in predominantly white schools or local contexts, adding a demographical dimension to their sense of leadership. Some participants noted that they were "the only chance" that non-Muslims would have to speak to a Muslim (Mr Chowdhury, Interview 18, 27:17-37:32). As the only "brown Muslim" in the area, Mr Chowdhury explained this further

Well, you know, I made it very clear, you see, from when ... When I got my feet in, you know, I became more established, you know, I would share personal stories with students. I was very explicit with my experiences ... To make [RE] real, I had a huge advantage of being a brown Muslim who had experienced it, than just a normal, white RE teacher who is referring to examples. (Interview 18, 27:17-37:32)

Here Mr Chowdhury had configured his experience of being a Muslim in a predominantly white area as a pedagogical resource in the classroom. These experiences reveal an entanglement of race and faith in their experience of ambassadorship, almost being forced to occupy ambassadorial role modelling positions in predominantly white contexts given their obvious racial differences. Basit et al. (2007) have also noted this entanglement in the experience of BME teachers more widely. 
Yet, in the case of 'Muslim RE teachers' their lack of representation both in teaching and within their local contexts almost necessitates that they act as ambassadorial role models, reifying the hypervisibility of 'Muslimness' and the unique professional discourses surrounding the RE teacher that explicitly incorporates aspects of faith and race into the role. Furthermore, this was even the case for those working in more ethnically diverse contexts, in terms of "Muslim" role modelling (discussed later).

As such, their position as ambassadors for non-Muslims reflects an important representational authority at this local level. In many ways this kind of representative position reflects Jones et al. (2015, p. 218) description of standing: where individuals use their prominence to represent the Muslim community to others and 'speak out' on their behalf. In the case of 'Muslim RE teachers', their prominence comes from their proximity and the authority of being a teacher- they meet many non-Muslim pupils who have to listen to them. Equally for Muslim pupils, this combination of teacher authority and proximity, in conjunction with their visible 'Muslimness', encouraged these 'Muslim RE teachers' to occupy various representative positions.

\section{2. "Muslim" Role Modelling}

Many of the participants also felt that they were role models for, and seen as role models by, Muslim pupils. Their shared faith identity evoked feelings of the Ummah in their relationships with Muslim pupils (Mrs Khan, Fieldnotes 16, March 2017, p. 76). This sense of shared identity was also reified by shared experiences of racism. These feelings of being part of a shared faith community, coupled with their position as teachers of religion (even though non-confessional), led to the participants being positioned as "Muslim" role models by Muslim pupils.

The participants' idea of role modelling for Muslim pupils primarily centred around a more typical understanding of being an example to follow. This kind of influence was most apparent in the case of female teachers becoming role models for Muslim girls. Given that most of the participants in this study were Asian Muslim women, 'role modelness' reflected their own biographies. They empathised with Muslim girls, sharing their experiences of growing up, wearing the hijab, and going through the British education system;

I felt it because it was a school ... [with a] Muslim majority, Bengali background, just like me-home situation just like me, a lot of girls who were literally like how I was when I was in Sixth Form, so they used to come to me and be like "Oh Miss how was Uni? How did you cope with this?"- they saw me as somebody who had already gone through it and had come out of it still with my faith intact, and so they wanted to know. (Miss Sumar, Interview 7, 1:18:29-1:20:21)

Mrs Iqbal's response when asked if she considered herself as a role model hints at the extent of influence that these teachers had as role models for their female Muslim pupils. She alludes to some adopting the hijab due to her example;

Yeah definitely, like especially for the girls, I mean there's been quite a few of the girls that have started wearing hijab, which I thought was interesting. (Mrs Iqbal, Interview 1, 19:34-21:23)

Mrs Iqbal's account is a powerful statement of the participants' potential influence in how Muslim pupils understood and embodied their faith. I would tentatively suggest that a (perceived) lack of female Muslim leadership more widely contributed to the importance that these teachers placed on being role models for Muslim girls, and so these teachers moved in to fill this gap. Specifically, their role modelling resonates with the examples I previously highlighted-Khan (2018) photography and the Women Like Us tv series (Choudhry 2018) - with a message to Muslim girls that they can be Muslim and do these things (like go to University and go into teaching). As such, the experience of female 'Muslim RE teachers' seems to reveal a gap in contemporary Muslim leadership: role models for young British Muslim girls. 
However, the participants were also positioned as role models by Muslim pupils, whether they wanted to take on this leadership role or not. Mr Ali explained this process;

When I became a teacher, I made it absolutely clear that I refused to be a role model because that's too much pressure for me, because one mistake can be magnified. But it's happened. I notice it all the time. Moreso in the last couple of years of my teaching, and I first feared it quite a lot. I'm like 'pppfffttt' this is a big burden on my shoulders, but actually it's made me think about what I say and do a bit more-which is a positive thing. And if I want to be a mirror of what I want my [Muslim] students to be-in terms of the character and the way they think, then I'm like okay no problem then. (Interview 8, 45:24-47:15)

Evident in Mr Ali's account is a conflation from Muslim pupils of these participants' teacher and faith identities, constructing them as 'Muslim RE teachers' and then positioning the teachers as role models. It is possible that, in part, this reflects the pupils' blurring the boundaries between their state education and any supplementary Islamic education, through a shared construction of 'Muslim teacher'. This brought with it, willingly or unwillingly, a commitment to dealing with matters of religion as part of their teaching role, as they ended up dealing with Muslim pupils' religious needs and concerns.

Despite the general willingness from the participants to become role models for Muslim pupils in this way, for some there was apprehension. There were an array of concerns surrounding the 'religious' appropriateness of offering guidance, and the potential eschatological implications of this for themselves and for the Muslim pupils who acted on their advice. Above, Mr Ali spoke of a "fear" and "pressure" that came with role modelling, along with the "magnification" of mistakes. Similarly, Miss Noor expressed her reservations surrounding being a source of sex and relationships advice for a Muslim girl who was brought to her attention from another staff member;

I know for a fact that she didn't want me to know, and I wouldn't even know how to deal with that. 'Cos I'm a Muslim doesn't mean I'm going to be able to say to her "Oh you're going to Hell" - it's out of my league! I can come to her in terms of religious knowledge-as to what to say-but like I can't give fatwas, like that's not within my control. (Interview 10.2, 20:09-24:12)

These apprehensions begin to show the contours of role modelling as a representative position by exposing some theological and eschatological limitations. As Mr Ali and Miss Noor expressed, there was an implicit understanding that the kind of guidance they should provide should be restricted in relation to other sources of guidance for Muslim children-such as their parents and traditional Islamic authorities. Their apprehensions and concerns are important here considering the responsibilities that Muslim pupils seemed to put upon them, which blurred the boundaries between religious and non-religious authority. Yet, these apprehensions did not stop either Mr Ali or Miss Noor from giving advice or acting as an example for Muslim pupils.

It is worth noting an interesting proximal element to this relationship. Unlike other local or national Muslim leadership, Muslim pupils would have access to these teachers consistently for many hours throughout the week during the school year, usually discussing explicitly religious topics (as part of RE). Hence, there is simply more time and opportunity for these teachers to affect, influence and act as examples for Muslim pupils to follow, even though their teaching was non-confessional. This point is particularly pertinent given some participants' explicit positioning alongside, or even against, other Muslim leaders, which is discussed later in the paper. Additionally, being in proximity begins to reveal the importance of 'tactical', local forms of Muslim leadership.

Furthermore, the impact of hypervisibility, and the underpinning intersections of race, gender and faith, also affected the positioning of 'Muslim RE teachers' as leaders in this way. As a white male convert working in a predominantly white school, Mr Jones discussed being able to "hide" his Muslim identity whilst in school, even after his 'outing' by another staff member (Interview 6, 39:06-44:23). 
Although his faith was known by some staff, he did not feel encouraged to draw upon his Muslim identity, nor was it known to his pupils. Elsewhere, Mrs Khan, who did not wear the hijab and worked in a Muslim-majority school, faced questions from Muslim pupils over her sartorial choices (Fieldnotes 16, March 2017, p. 23). The notion of ambassadorship and role modelling, then, seems to be somewhat predicated on 'looking Muslim' as a catalyst, and operates within Muslim school communities. Future research into the intersections of 'whiteness' and Muslim leadership in the case of Muslim converts could elucidate this further.

Thus, participants' positioning as role models for Muslim pupils brought with it a whole aspect of their non-confessional work that was explicitly concerned with matters of faith, bringing added responsibility to their role. In the main, by acting as role models in this capacity the participants seem to be filling an important space between traditional sources of authority and guidance: parents and the mosque. Writing in a Swedish context, Berglund (2012) has also noted the tendency for Muslim pupils to use (Muslim and non-Muslim) teachers as sources of guidance, given their proximity and authority as educators. Thus, I would argue that the participants seemingly inevitable positioning as role models for Muslim pupils reveals a significant space for Muslim leadership between traditional sources of authority and representation. Moreover, there seems to be a need for Muslim leaders that Muslims, especially young Muslim girls, can just approach to share their concerns. In a way, the non-confessional aspect of these teachers' teaching of religion was seen to be a benefit here, creating the sense that they were not there to judge, unlike Muslim parents or the imam, even though their influence and guidance may have a normative effect.

Therefore, I would argue that the experiences of 'Muslim RE teachers' reveals role modelling to be an important representative position and form of leadership for Muslims at a local level. Role modelling here is distinct from the ambassadorial mode, discussed previously, as it is leadership for Muslims, but it is also distinct from what can be understood as religious authority because their authority does not come from within traditional sources and sites. Rather, the position of role model itself comes from being an accepted example to follow as an interlocutor between tradition and everyday life. As such, I suggest that role modelling should be added to the typology of representative positions, reflecting its importance as an interlocutory form of leadership in this way.

\subsection{Muslim Representatives}

The participants' expertise as teachers was also recognised by Muslim parents, reflecting this mode of representation. Some participants spoke of how Muslim parents had approached them to "represent them" within school (Mrs Iqbal, Interview 1, 21:42-21:51). For Muslim parents, they seemed to have this authority by virtue of their positions within their schools, their knowledge and responsibilities as teachers of religion, ${ }^{1}$ and, to some extent, the reputation they had gained as role models for their Muslim pupils. As such, they were seen to be able to bring "Muslim issues" to the table of their school's Senior Leadership Teams (SLTs).

As such, some of the participants were able to use their professional expertise to effect policy and practice in their schools. Their knowledge and position allowed them to navigate their school's policy frameworks and bring "Muslim issues" to the attention of the school's SLT. As a result, some had affected institutional change by leading faith-based initiatives in their schools, such as Miss Aziz's "lunchtime Ramadan club" (Fieldnotes 19, July 2017, p. 17), or Miss Ahmed's "faith talk" series (Interview 3, 43:52-47:48). It was also common practice for these teachers to facilitate lunchtime prayers in their classrooms for Muslim pupils (Miss Memon, Interview 15, 1:17:52-1:25:00). Additionally, this recognition also seemed to be supported by their school SLTs, as part of their job was "something to do with religion", despite their role being ostensibly "secular" (Mr Jones, Fieldnotes 6, June 2017,

1 With a possible conflation of the participants as 'Muslim RE teachers' with teachers of Islam-those who taught in the madrassah. Several participants mentioned that this kind of conflation was commonplace amongst Muslim parents. 
p. 9). In a field interview with Miss Aziz's headteacher, she made it clear that the 'lunchtime Ramadan club' only happened because Miss Aziz had taken the lead on the initiative, as the head neither had the time or knowledge to implement such support (Miss Aziz, Fieldnotes 19, July 2017, pp. 25-26). This kind of representation has been noted in wider BME teacher literature: as a consequence of role modelling BME teachers can become spokespeople for BME needs and issues within their schools, which is especially valuable given the 'whiteness' of SLTs (Coleman and Campbell-Stephens 2010).

Therefore, their positioning as experts, both as Muslims and as teachers of Religious Education, allowed some of the participants to act as interlocutors to affect policy and practice within their school. Their capacity to shape institutional policy and practice through expertise is identified by Jones et al. (2015) as a representative position. Yet, it is interesting to consider how successful these participants were in relation to attempts to change educational policy by "official" representative bodies and external experts. There seems to be a sense that, by virtue of being part of the school, these teachers were able to better frame "Muslim needs" as educational and just get on and make these changes, especially if they were able to take the lead and implement them. In contrast, recommendations made by the Muslim Council of Britain (2007) were perceived by schools as 'demands' (Baker 2007), and which 'cut across' the guidance of other representative groups (Jones et al. 2015, p. 215). This seems to suggest that there is a difference in the form and effectiveness of leadership at the local level. Like Muslim chaplains (Gilliat-Ray et al. 2013), their professional expertise allows them to bring change from within the policy frameworks of these ostensibly 'secular' institutions.

I suggest that the capacity for 'Muslim RE teachers' to effect policy and practice reflects an important distinction between 'tactical' and 'strategic' modes of Muslim leadership. To illustrate this here, whereas the MCB tried to affect change from above, 'Muslim RE teachers' were able to creatively and tactically bring change from within, at ground level, arguably to greater effect. The presence of 'tactical' forms of Muslim leadership are therefore potentially important for bringing the change that wider, 'strategic' Muslim leaders also seek to implement by being able to operate within the established powers and frameworks of British institutions. If so, this highlights a significant analytical problem for looking at Muslim leadership solely at the 'strategic' national level or in 'traditional' religious authorities, where this focus misses these more creative and 'hidden', yet potentially impactful forms of Muslim leadership.

\subsection{Religious Authority}

Alongside these more 'tactical' expressions of Muslim leadership, participants tentatively had claims to be a religious authority within their local Muslim communities. Even though their job as RE teachers is 'non-religious', and despite the reservations some felt around role modelling, the other representative positions that they occupy seemed to coalesce and culminate in their positioning in relation to other Muslim leaders, by themselves and other Muslims. What is fascinating is how their professional expertise as RE teachers and knowledge of World Religions from a Western academic perspective became understood, by themselves and others, as evidence of their religious credentials, constructing them akin to alims and alimahs.

Where Gilliat-Ray (2010, p. 54) highlights claims to authenticity as an important mode of religious authority, these credentials and positions seemed to give some participants the authority to make such claims. For example, their commitment to "breaking stereotypes" extended to "traditional" Islamic stereotypes held within their wider communities, further reinforcing their authority through claims of authenticity surrounding what was, or was not, "Islam". Several participants made clear a distinction between what was "culture" and what was "actually Islam" in their teaching, especially about Muslim women. Breaking down stereotypes in this instance concerned breaking down the "cultural" norms that pupils espoused as correct Islamic beliefs. Miss Ahmed spoke of using her "faith talks" for this purpose;

I mean I used to do lots of different things, different activities, I took about 200 girls, it was like a proper assembly every week for half an hour, so sometimes I got some girls to 
do a role play, or take part in different things-just imagine there is no-one there and just speak-because you need to learn what Islam is and what culture is. Because it is a shame. And the reason that it happens in [area] is because then they get married to people from back in Pakistan. It was never, what can you say, they wouldn't ever question what Islam is, and what religion actually is. (Interview 3, 1:06:50-1:10:14)

Miss Meer recounted challenging the views of Muslim parents:

So, you know, even stereotypes within the Muslim community is something that I wanted to battle. What I have found lately, and it is something that really frustrates me, is even getting respect from men in the Muslim community is sometimes ... If you're not wearing a hijab, then, you know, go home, sort yourself out, or come back with a gentleman, come back with your husband or your Dad. And that's the way it is. And that's something that's always frustrated me. (Interview 17, 12:24-17:53)

The authority of the participants afforded by their role as RE teachers allows them to engage with, and challenge, prevailing narratives within their communities, in a variety of ways that are arguably hidden from "official" sources of authority outside the school gates. Miss Meer's account is particularly powerful, demonstrating the capacity for Muslim women to deploy their state-given authority as teachers to challenge the views of Muslim men in the classroom and at parents' evenings. Through their Muslim pupils, this is coupled with their position as "Muslim" role models to shape the beliefs and values of their local Muslim communities beyond the school gates. Again, the potential impact of their voice, given that these participants were at the heart of many Muslim pupils' education about religion through their statutory RE lessons, cannot be understated.

As such, several participants tentatively recognised themselves as Muslim leaders within their communities in this way. Miss Meer remarked that teaching "gave her a voice";

And my Mum's always said, keep your mouth shut, keep your mouth shut, because the community aren't going to look at you well. And I thought, no. And I guess teaching gives me that voice. (Interview 17, 12:24-17:53)

Others explicitly put themselves, or were put, in competition with the "local imam", like Mr Shah;

Because sometimes I feel as though I am doing the job of their imam for them, where I'm actually exposing, not exposing them [pupils], I'm enabling them to understand that Islam is much more than just a religion of rituals and practices and growing beards and covering your head and hitting the ground with your forehead and throwing pebbles in Mecca. (Interview $13,50: 34-57: 20)$

Mr Jones took this further;

I think the biggest problem ... is this fear of infection by ideas that we couldn't counter. Y'know that we-I don't know if Muslim parents do withdraw their kids from RE-they might feel that that's putting their head above the parapet, but there's certainly a sense of real guardedness about engaging with RE for fear that you'll ... like somehow the pristine pure theology that we're so carefully curating in the mosque will get undermined. And who is it who says - the sign of an educated man is that he can entertain a thought without believing it? And I just feel that the community, if we can call it collectively, is very bad at doing that-they don't think you can do that, there's almost an a priori impossibility that if I'm entertaining a thought-“'Oh I must believe it!" (Interview 6, 1:24:40-1:27:00)

These accounts powerfully suggest that these teachers represent a different kind of authority to that of the local imam, in turn putting them on the leadership map. Their commitment to exploring the meaning of Islamic beliefs, not just the "rituals and practices, especially with a critical edge, and 
awareness of other worldviews, resonate with wider critiques of Islamic education (Gilliat-Ray 2006, p. 67; Sahin 2013). In turn, they attend to this gap by bringing their Islamic knowledge into the professional and pedagogical frameworks of RE teaching. Again, this reflects a kind of 'tactical', interlocutory leadership that sits between what is traditionally understood as Muslim authority and leadership, by incorporating more 'secular' modes and frameworks.

Therefore, by working at the 'tactical' level some of these participants are seemingly able to subvert "official" authorities and discourses. Particularly for the female participants, they are using their authority 'on the ground' to challenge and subvert traditional norms within their Muslim communities. Others are subverting what they see is being taught in their local mosque, encouraging critical reflection and emphasis on the meaning of beliefs and practices, in turn highlighting the shortcomings of their local imam. They can do so because they are given time and space within their RE classrooms and are recognised as authorities within the daily lives of Muslim schoolchildren.

\section{Concluding Discussion}

This article has argued that 'Muslim RE teachers' can be considered as a case of Muslim leadership that represents a localised, 'tactical' form. Their experience being ambassadors to non-Muslim pupils, parents, and staff, "breaking stereotypes" encountered within their school contexts, acting as role models for Muslim pupils, changing school policy and practice to represent the needs of Muslim pupils, to actively engaging with Islamic discourses with their communities, reflects their capacity to adopt various representational positions that broadly correlate with the wider forms of leadership outlined by Jones et al. (2015). Yet, in contrast to more 'strategic' modes of Muslim leadership, their modes of representation manifest in 'tactical', interlocutory forms that operate within and between the policy frameworks and practices of British 'secular' state education and "official" sources of religious leadership within their local Muslim communities. Role modelling seems to be a particularly significant manifestation of this kind of representative position-as someone who can bridge the gap between tradition and everyday life in contemporary Britain. So, whilst their sphere of influence is largely felt directly in their local contexts, their impact on Muslim and non-Muslim pupils and parents, and on schools' professional communities, is potentially far reaching.

Given the potential of 'tactical' forms of Muslim leadership, there is a pressing need to reflect on which 'claim makers' are being prioritised. As Jones et al. (2015) admit, analyses of Muslim leadership tend to prioritise the "official", the national, and those orientated toward policy-'strategic' forms of Muslim leadership. Although these actors and groups are important on the national stage, this gaze can miss how Muslims are affecting change and leading from within various 'secular' British spaces on the ground. Considering the influence of these 'Muslim RE teachers' and the impact of Muslim chaplains, as highlighted by Gilliat-Ray et al. (2013), these kinds of actors could represent this kind of 'tactical' Muslim leadership, as individuals that are leading from within both British institutions and Muslim communities, and blending, the frameworks of British institutions, Muslim communities, and Islamic traditions. This is particularly important given the potential of these 'tactical' leaders to augment or subvert the discourses coming from "official" sources through their work with Muslims 'on the street' in their everyday lives.

Finally, 'tactical' Muslim leadership seems to have been taken up by Muslim women in this instance, potentially revealing new spaces for female Muslim leadership in Britain. Scholars have highlighted how Muslim women are using education to challenge existing leadership structures and create their own (Bano 2017; Scott-Baumann and Cheruvallil-Contractor 2015), but these discussions have emphasised traditional sites of Islamic education. Yet here, in the case of Muslim chaplains (Gilliat-Ray et al. 2013), and arguably like Baroness Sayeeda Warsi, Muslim women seem to be occupying leadership positions beyond these traditional sites based on wider educational and professional authority, which then allows them to engage in religious debates. Where the 'tactical' works around and in response to power, I suggest that this is the case here with Muslim women working around and between the "official" hierarchies of power to shape Muslim identity from the ground up. 
Funding: This research was generously funded by the Jameel Scholarship Programme (http://sites.cardiff.ac.uk/ islamukcentre/jameel-scholarships/).

Acknowledgments: The author would like to thank the teachers who gave up their precious time to take part in the study, as well as colleagues at the Islam-UK Centre and Harriet Walker for their feedback on this paper and their support throughout the course of this research.

Conflicts of Interest: The author declares no conflict of interest.

\section{References}

Ahmad, Waqar, and Venetia Evergeti. 2010. The making and representation of Muslim identity in Britain: Conversations with British Muslim 'elites'. Ethnic and Racial Studies 33: 1697-17. [CrossRef]

Ammerman, Nancy. 2016. Lived religion as an emerging field: An assessment of its contours and frontiers. Nordic Journal of Religion and Society 29: 83-99. [CrossRef]

Baker, Mike. 2007. Was Muslim Guidance Reasonable? BBC News. February 24. Available online: http: //news.bbc.co.uk/1/hi/education/6391271.stm (accessed on 24 May 2019).

Bano, Masooda. 2017. Female Islamic Education Movements: The Re-Democratisation of Islamic Knowledge. Cambridge: Cambridge University Press.

Basit, Tehmina, Olwen McNamara, Lorna Roberts, Bruce Carrington, Meg Maguire, and Derek Woodrow. 2007. 'The bar is slightly higher': The perception of racism in teacher education. Cambridge Journal of Education 37: 279-98. [CrossRef]

Bender, Courtney, Wendy Cadge, Peggy Levitt, and David Smilde. 2013. Religion on the Edge: De-Centering and Re-Centering the Sociology of Religion. Oxford: Oxford University Press.

British Educational Research Association (BERA). 2018. Ethical Guidlines for Educational Research. London: British Educational Research Association.

Berglund, Jenny. 2012. Teachers only stand behind parents and God in the eyes of Muslim pupils. Journal of Beliefs \& Values 33: 357-67. [CrossRef]

Birt, Jonathan. 2006. Good Imam, Bad Imam: Civic Religion and National Integration in Britain Post-9/11. The Muslim World 96: 687-705. [CrossRef]

Bolognani, Marta. 2007. Islam, Ethnography and Politics: Methodological Issues in Researching amongst West Yorkshire Pakistanis in 2005. International Journal of Social Research Methodology 10: 279-93. [CrossRef]

Burdsey, Daniel. 2007. Role with the Punches: The Construction and Representation of Amir Khan as a Role Model for Multiethnic Britain. The Sociological Review 55: 611-31. [CrossRef]

Burdsey, Daniel. 2016. One Guy Named Mo: Race, Nation and the London 2012 Olympic Games. Sociology of Sport Journal 33: 14-25. [CrossRef]

Carrington, Bruce, and Christine Skelton. 2003. Re-thinking 'role models': Equal opportunities in teacher recruitment in England and Wales. Journal of Education Policy 18: 253-65. [CrossRef]

Casey, Emma. 2018. From Cookery in Colour to The Great British Bake Off: Shifting gendered accounts of home-baking and domesticity. European Journal of Cultural Studies, 1367549418810083. [CrossRef]

Choudhry, Sabah. 2018. Women Like Us. Wakefield: British Muslim TV.

Coleman, Marianne, and Rosemary Campbell-Stephens. 2010. Perceptions of career progress: The experience of Black and Minority Ethnic school leaders. School Leadership \& Management 30: 35-49. [CrossRef]

Cunningham, Mark, and Linda Hargreaves. 2007. Minority Ethnic Teachers' Professional Experiences: Evidence from the Teacher Status Project. London: DFES.

Czarniawska, Barbara. 2014. Social Science Research: From Field to Desk. London: SAGE.

de Certeau, Michel. 1984. The Practice of Everyday Life. Berkeley: University of California Press.

Dessing, Nathal, Nadia Jeldtoft, and Linda Woodhead. 2016. Everyday Lived Islam in Europe. London: Routledge. Department for Education (DfE). 2018a. School Teacher Workforce: Ethnicity. London: Crown.

Department for Education (DfE). 2018b. School Workforce in England: November 2017-Table 3a. London: Crown.

Estola, Eila, and Freema Elbaz-Luwisch. 2003. Teaching bodies at work. Journal of Curriculum Studies 35: 697-719. [CrossRef]

Everington, Judith. 2012. 'We're all in this together, the kids and me': Beginning teachers' use of their personal life knowledge in the Religious Education classroom. Journal of Beliefs \& Values 33: 343-55. [CrossRef] 
Everington, Judith. 2015. Bridging separate communities: The aspirations and experiences of minority ethnic religious education teachers in England. Journal of Beliefs E Values 36: 165-74. [CrossRef]

Flick, Uwe. 2009. An Introduction to Qualitative Research. London: SAGE.

Freathy, Rob, Stephen Parker, Friedrich Schweitzer, and Henrik Simojoki. 2016. Professionalism, professionalisation and professionality in Religious Education. British Journal of Religious Education 38: 111-13. [CrossRef]

Geaves, Ron. 2008. Drawing on the Past to Transform the Present: Contemporary Challenges for Training and Preparing British Imams. Journal of Muslim Minority Affairs 28: 99-112. [CrossRef]

Ghuman, Paul. 1995. Asian Teachers in British Schools: A Study of Two Generations. Clevedon: Multilingual Matters.

Gilliat-Ray, Sophie. 2005. Closed Worlds: (Not) Accessing Deobandi Dar ul-Uloom in Britain. Fieldwork in Religion, 1. [CrossRef]

Gilliat-Ray, Sophie. 2006. Educating the c Ulama: Centres of Islamic religious training in Britain. Islam and Christian-Muslim Relations 17: 55-76. [CrossRef]

Gilliat-Ray, Sophie. 2010. Muslims in Britain: An Introduction. Cambridge: Cambridge University Press.

Gilliat-Ray, Sophie. 2011. 'Being there'the experience of shadowing a British Muslim Hospital chaplain. Qualitative Research 11: 469-86. [CrossRef]

Gilliat-Ray, Sophie, and Riyaz Timol. 2019. Leadership, Authority and Representation in British Muslim Communities. Cardiff: Cardiff University.

Gilliat-Ray, Sophie, Stephen Pattison, and Mansur Ali. 2013. Understanding Muslim Chaplaincy. Farnham: Ashgate Publishing Company.

Guenther, Katja M. 2009. The politics of names: Rethinking the methodological and ethical significance of naming people, organizations, and places. Qualitative Research 9: 411-21. [CrossRef]

Haque, Zubaida, and Sian Elliot. 2017. Visible and Invisible Barriers: The Impact of Racism on BME Teachers. London: National Union of Teachers, Available online: https://www.teachers.org.uk/sites/default/files2014/barriersreport.pdf (accessed on 24 May 2019).

Jackson, Robert, and Judith Everington. 2017. Teaching inclusive religious education impartially: An English perspective. British Journal of Religious Education 39: 7-24. [CrossRef]

Jeldtoft, Nadia. 2016. The Hypervisibility of Islam. In Everyday Lived Islam in Europe. Edited by Nathal Dessing, Nadia Jeldtoft and Linda Woodhead. London: Routledge.

Jones, Stephen H., Therese O'Toole, Daniel Nilsson DeHanas, Tariq Modood, and Nasar Meer. 2015. A 'System of Self-appointed Leaders'? Examining Modes of Muslim Representation in Governance in Britain. The British Journal of Politics \& International Relations 17: 207-23. [CrossRef]

Khan, Ayesha. 2018. The Everyday. Cardiff: Ffotoview, Available online: http:/ffotoview.org/ayesha-khan/ (accessed on 24 May 2019).

Lagerwey, Jorie. 2018. The Great British Bake Off, joy, and the affective potential of Nadiya Hussain's amateur celebrity. Celebrity Studies 9: 442-54. [CrossRef]

McDowell, Linda. 2016. Reflections on Research Practice: Writing Difference. Australian Feminist Studies 31: 355-62. [CrossRef]

McGuire, Meredith. 2008. Lived Religion: Faith and Practice in Everyday Life. Oxford: Oxford University Press.

McNamara, Olwen, John Howson, Helen Gunter, and Andrew Fryers. 2009. The Leadership Aspirations and Careers of Black and Minority Ethnic Teachers. Birmingham: National Association of Schoolmasters Union of Women Teachers, Available online: http://www.equitableeducation.co.uk/uploads/1/5/5/9/15597724/the_leadership_ aspirations_and_careers_of_black_and_minority_ethnic_teachers.pdf (accessed on 24 May 2019).

Muslim Council of Britain. 2007. Towards Greater Understanding: Meeting the Needs of Muslim Pupils in State Schools. London: Muslim Council of Britain, Available online: http://www.religionlaw.co.uk/MCBschoolsreport07.pdf (accessed on 24 April 2019).

Osler, Audrey. 1997. Education and Careers of Black Teachers. Buckingham: Open University Press.

Osler, Audrey. 2003. Muslim women teachers: Life histories, identities and citizenship. In Muslim Women in the United Kingdom and Beyond: Experiences and Images. Edited by Tansin Benn and Haifaa Jawad. Leiden: Brill.

Pole, Christopher. 1999. Black teachers giving voice: Choosing and experiencing teaching. Teacher Development 3: 313-28. [CrossRef]

Sahin, Abdullah. 2013. New Directions in Islamic Education: Pedagogy and Identity Formation. Markfield: Kube Publishing. 
Scott-Baumann, Alison, and Sariya Cheruvallil-Contractor. 2015. Islamic Education in Britain: New Pluralist Paradigms. London: Bloomsbury.

Shah, Saeeda. 2016. Education, Leadership and Islam: Theories, Discourses and Practices from an Islamic Perspective. London: Routledge.

Shah, Saeeda. 2018. "I Am a Muslim First ... ": Challenges of Muslimness and the UK State Schools. Leadership and Policy in Schools, 1-16. [CrossRef]

Sidat, Haroon. 2018. Between Tradition and Transition: An Islamic Seminary, or Dar al-Uloom in Modern Britain. Religions 9: 314. [CrossRef]

Spalek, Basia. 2005. A Critical Reflection on Researching Black Muslim Women's Lives Post-September 11th. International Journal of Social Research Methodology 8: 405-18. [CrossRef]

Werbner, Pnina. 2018. Between Islamic piety, agency and ethical leadership: Paradoxes of self-transformation. Contemporary Levant 3: 79-90. [CrossRef]

Wiseman, Eva. 2018. Nadiya Hussain: 'This is more than a job-It's important to be out there'. The Guardian. December 16. Available online: https://www.theguardian.com/food/2018/dec/16/nadiya-hussain-bake-offwinner-this-is-more-than-a-job (accessed on 24 May 2019).

Woodhead, Linda. 2016. Tactical and strategic religion. In Everyday Lived Islam in Europe. Edited by Nathal Dessing, Nadia Jeldtoft and Linda Woodhead. London: Routledge.

(C) 2019 by the author. Licensee MDPI, Basel, Switzerland. This article is an open access article distributed under the terms and conditions of the Creative Commons Attribution (CC BY) license (http://creativecommons.org/licenses/by/4.0/). 


\title{
Article \\ Conflicting Paradigms of Religious and Bureaucratic Authority in a British Mosque
}

\author{
Amin El-Yousfi \\ University of Cambridge, Cambridge CB2 1TN, UK; ae375@cam.ac.uk \\ Received: 16 May 2019; Accepted: 20 September 2019; Published: 30 September 2019
}

\begin{abstract}
This article analyses an on-going conflict between two groups (Bargil and Kardal) over the management of a mosque located in an area near London. Based on fourteen months of intensive fieldwork, including participant observation, informal chats and semi-structured interviews, this article offers an in-depth and original account of the transformations taking place in mosques concerning the role of imams and mosque committee members. By analysing the object of conflict, the organisational structure, the dynamic of the groups and its leaders, as well as the process of bureaucratisation of mosques as a material condition, I intend to scrutinise the role and status of the imam and mosque committee members. The primary aim of this article is to re-examine and challenge the narrative of decline in religious authority (in Western mosques) propounded by some scholars as being the result of individualisation and the rise of new religious figures outside traditional institutions. I suggest that rather than experiencing a decline in imams' religious authority, mosques have become controlled by the bureaucratic authority of the committee members. In other words, imams' religious authority is still exercised, yet only within the bureaucratic framework set by the committee members.
\end{abstract}

Keywords: mosque; conflict; imam; committee members; religious/bureaucratic authority

A common narrative in the literature surrounding mosques is the decline of religious authority (Peter 2006; cf. Sunier 2018). ${ }^{1}$ Scholars argue that this decline is due either to the process of individualisation among the younger generations (Cesari 1998, 2003; Hervieu-Léger 1999; Roy 2005) or to the emergence of a new religious authority instead of the traditional authority of imams (Mohsen-Finan 2003) - the reference here is primarily to 'conference speakers' ${ }^{2}$ who act outside traditional institutions and whose legitimacy is often charismatic and mediatic (Frégosi 2004, p. 140). However, there has been no significant work on the process of institutional deregulation which

1 Despite the epistemological problems surrounding the concept of "religious authority," I use it in this article primarily due to its constant presence in the works of scholars who propound the narrative of decline that I intend to challenge here. On the one hand, Asad (1993) has sharply demonstrated the way in which the abstract category of "religion" is historically constructed based on the protestant idea of inner belief- making its unquestionable (and almost instinctive) usage to study Islam highly problematic. On the other hand, the concept of "authority" which is still shaped by the famous Weberian tripartite classification (traditional, charismatic and legal-rational) is mainly based on its opposition to "persuasion." As explained by Blau (1963, p. 307), "In persuasion, for example, one person permits the influence of another to influence his decisions or actions. Authority is distinguished from persuasion by the fact that people a priori suspend their own judgment and accept that of an acknowledged superior without having to be convinced that his is correct." In the case of imams, such an understanding is overly misleading: Not only the imam's opinions expressed to members of the congregation have an "ethical authority" as showed by Agrama (2010) in his study of Al-Azhar mosque in Egypt, in the sense that both $m u f t \bar{i}$ (scholar answering the question) and questioner "find their way together" by sharing a "responsibility rooted in reciprocal conditions of perplexity and uncertainty-perplexity of the fatwa seeker about what to do, and uncertainty of the mufti about what to say" (p. 13), but also the role of emotions, sensibilities and temporalities is central in the Muslim's reception of the imam's fatwas (legal opinion)-what can be called the "authority of the heart" based on the prophetic hadith (saying) "istafti qalbak (... ) wa in aftäka an-nās wa aftū $k$ " (consult your heart ... even though people give you their opinion and continue to do so) (hadīth 27 in An-Nawawī's Forty Hadith (An-Nawawī 1997)).

2 For example, Frégosi (2004) studies the case of Tariq Ramadan. 
supports the claim of a fragmentation of religious authority, including the loss of imams' influence. That is, we often explain the decline of religious authority exclusively by diverse exogenous factors rather than through the analysis of the internal power dynamics within mosques. Regarding this development, although there has been important research on the role of imams in mosques in Europe (Khosrokhavar 1997; Frégosi 1998; Gaborieau and Zeghal 2004; McLoughlin 2005; Birt 2005, 2006; Hashas et al. 2018), only a few scholars have distinguished between the role of imams inside/outside the mosque and that of the mosque committee members (e.g., Jouanneau 2013; Sèze 2013; Vinding 2018) who, far from being necessarily knowledgeable in religious matters, have the task to look after the management of the mosque. More importantly, only a few studies have analysed conflicts inside mosques as part and parcel of the process of fragmentation of religious authority: Geaves (1996a), McLoughlin $(1998,2005)$ and Werbner (1996; Werbner and Anwar 1991) tackle denominational conflicts in the UK, Van Bruinessen (2010) studies conflict between committee members and imams regarding Islamic knowledge, while Minganti (2012) analyses women's striving for "gender complementarity" through "tactical orthodoxy" in Swedish mosques.

In this paper, I suggest that rather than experiencing a decline of religious authority, mosques have become controlled by the bureaucratic authority ${ }^{4}$ of the committee members. The aim of this paper is to challenge the popular narrative of 'decline' characterised by the loss of imam's influence who was, for many years, portrayed as an important and multifunctional figure in diasporic contexts (Gaborieau and Zeghal 2004, p. 18). For this purpose, relying upon a "relational ethnography" (Desmond 2014) which gives primacy to configurations of relations and studies multiple actors and agencies engaged with one another, this paper looks at the conditions and functions of a conflict inside one mosque in an area near London. As argued by Matthew Desmond, in order to carry out a relational ethnography, we need to study cultural conflict rather than group culture. Hence, between May 2016 and September 2017, I immersed myself in the field of local Muslim leadership as a relational ethnographer who is an "in-betweener" i.e., "neither entirely inside or outside" (Milligan 2016). ${ }^{5}$ Using participant observation, informal chats and semi-structured interviews with the old and new imams, two madrassah (Islamic school) teachers, previous and current committee members and various members of the congregation, I observed "in real time fight and struggle, cooperation and compromise, misunderstanding and shared meaning-making between actors occupying different positions" (Desmond 2014, p. 556) inside the mosque. During the same period, after more than thirty years of service, the imam of this mosque resigned under the pressure of the committee who recruited a contractual imam whose sole role is to lead the five daily prayers.

In what follows, drawing on both the work of Simmel (1955) who developed a theory of social conflict that presents conflict as a form of socialisation and Coser (1956) who built on it by looking at its multiple functions, I will examine four aspects of the internal power dynamics within mosques: (a) emergence of the conflict and definition of its object, (b) the organisational structure of the mosque, (c) the actors' dynamic and interests, and (d) the functions of the conflict both in terms of division of roles inside the mosque and 'weaponisation' of rules by the committee members in order to control the

3 These studies have focused on conflicts mainly from a denominational perspective, for example: Deobandi Vs Barelvis, Shi'a Vs Sunni, etc.

4 I prefer to use 'bureaucratic authority' instead of the famously Weberian category of 'legal rational authority' primarily because of the implied coercive character of the "legal" (Schauer 2015) and its absence in the "authoritative" (Kramer and Schmidtke 2006). Hence, my contention finds roots in the oxymoron that lies behind the conceptualisation of law and authority in its relationship to coercion, which was minutely examined by Agrama (2010, p. 6) who concludes: "if law is distinguished mainly in terms of its coercive character and authority is defined as willing obedience irreducible to coercion, the concept of legal authority becomes something of a contradiction in terms."

5 I use the category "in-betweener" not only because I agree with Milligan (2016, p. 240) that "the boundaries both between insider and outsider and other identities were often messy and difficult to define" but also because it is the way I was perceived by members of congregation due to the entanglement of various racial, religious, national and linguistic factors which I cannot detail here. 
imam's role. The analysis of the conflict will help us to assess the narrative of decline and propose an alternative direction in the study of local Muslim leadership.

\section{Facets of Religious Authority}

In this mosque built in 1982 by a group of Kashmiris led by Haji Salim, ${ }^{6}$ two groups emerged based on the villages of origin: Bargil and Kardal. Both villages were impacted by the construction of the Mangla Dam in 1966 which obliged many habitants of the larger area of Mirpur District in Azad Jammu and Kashmir (AJK) to migrate to the UK. With a work permit in hand, male Bargilis and Kardalis came with the obvious intention to return. But after several years and due to various endogenous and exogenous factors, the intention started to take the form of a myth (Anwar 1979) by moving from "sojourners to citizens" (Haddad 2002). In 1971, the UK passed the Immigration Act that allowed Commonwealth citizens already in the UK to remain, while holders of British passports born overseas could settle. Family reunification means the start of a 'mourning of return' illustrated in a socio-demographic rejuvenation, community formation and the quick development of housing investment in the host country.

One of the most important symbols of this mourning is the mosque to which "British Muslims have devoted more energy and resources [ ... ] than perhaps to any other institution" (Gilliat-Ray 2010, p. 181). The only other place which has an equivalent symbolism of "rootedness" is the burial ground for Muslims (Ansari 2007). Hence, undoubtedly, the mosque is a place that responds to the community members' need of worship, but also a cherished space where the tradition of Barelvism or "ahl-i Sunna wa al-jamā'a" (adherents to the prophetic tradition and the community of followers $)^{7}$ that people from Bargil and Kardal belong to is revived and embodied by the youth who believe in their belonging to the land where they were born (where the mosque was built by their parents) more than any other land. It is therefore a place with a deep sense of both belonging and ownership that results sometimes in conflicts that go beyond any tribal or ideological belonging. ${ }^{8}$

In this context, the imam plays an important role: he is the umbilical cord between the tradition and the host culture, between the first generation and the second one, between the text and the context. It is true that back home (in the whole South Asian region), the imam occupied a low functionary status with little capital (Lewis 1994, p. 82), but in many cases in the UK, particularly among the Barelvi community, the imam demanded considerable respect-not only because the majority of babas (elderly men) were illiterate and used to see him as an "samandar (ocean) of knowledge" (Usman, previous committee member, 71), but because he was generally appointed by a $p \bar{\imath} r$ that the members of the community venerate and have probably bay'at (allegiance) to. This is what happened with Imam Mahboob in 1983 when he was recommended by a famous $p \bar{i} r$ to the five committee members who founded the mosque. He was neither from Bargil, nor from Kardal, but he had an important religious authority. According to Ahmad (69), one of the early members of the current committee, the babas could not make any decision without his agreement. They regarded the imam, Ahmad says, as "the khaliffa (vicegerent) of the $p \bar{\imath} r$ " who is "the epitome of the prophet's characteristics; loving, kind, handsome and of generous nature" (Khan 2006, p. 23). ${ }^{9}$

$6 \quad$ All the names of people, groups and villages have been changed to preserve confidentiality.

7 This appellation is used by practitioners to oppose the derogatory use of Barelvi by people from other denominations (particularly Deobandis and Ahl-I Hadith) in the sense of being outside the sunna (tradition) of the prophet.

8 Previous studies refer to conflicts in mosques to point out the damaging role of "sects" or that of baradaris in which the categories of class and race are entangled. In my research, I demonstrate that conflicts can be also linked to the process of confronting tradition-based imaginaries with the bureaucratic transformation of mosques in the West.

9 This was not always the case. Drawing on his insider experience, Khan (2006, p. 24) says: "the norm for most imams from the Indian subcontinent, including the Barelvis, [was] to shout during sermons. In my view the imams generally lacked the dignity and the sophistication of the pirs. The pirs had charisma whereas most of the imams did not." However, even in this case, they were still respected if recommended by a $p \bar{i} r$. 
Often social scientists talk about the decline of imams' religious authority in Europe without defining its nature (Cesari 1998; Frégosi 2004; Mohsen-Finan 2003). In order to demonstrate the impact of individualisation which is "meant to signify primarily an Islam lived in the private sphere [ ... ] where the believer decides autonomously which elements of Islam (s)he considers to be binding or not" (Peter 2006, p. 106), these scholars tend to point out the emergence of "new leaders" (Roy 2004) as well as novel Islamic spaces created by second generation actors (Mandaville 2001, p. 124; Özyürek 2014) which lead directly or indirectly to the loss of imam's influence and the decline of religious authority. In this sense, Mohsen-Finan (2003, p. 133) explains for example the success of Tariq Ramadan among Muslims in France and the UK as "less due to the rigour and strictness of his message than to the absence of religious authorities." In other terms, "the new generation appears often reluctant towards the traditional teaching" of imams (Cesari 1998, p. 27). It is undeniable that the second and third generation has changed the Muslim-based organisational landscape not only in the UK but in various other Western countries, but to what extent does this constitute a decline of the imams' religious authority? Before considering this, it is necessary to examine what is meant by religious authority and what are its components?

Clearly in the context of Barelvism which represents $23.7 \%$ of British mosques ( 459 mosques), ${ }^{10}$ the religious authority of the imam is based on the embodiment of a tradition that goes back to the sunna of the prophet through various discourses - in the case of this mosque, primarily through the hanafi madhhab (legal school) and the naqshabandi tariqa (sufi path). The imam has authority not only over the figh $\bar{\imath}$ (legal) discourse but also over the process of embodiment via the transmission of popular devotional practices such as milād sharif (Prophet's Birthday) and 'urs shariff (death anniversary of a saint), na't sharif (devotional poem in honour of the Prophet) and dhikr (remembrance of God) (Khan 2006). This makes Imam Mahboob the protector of a discursive and embodied tradition (Asad 1986) in a place created primarily for this purpose. His authority is based on meeting the religious needs of a particular lay audience, it represents in this sense "the aspiration, effort, and ability to shape people's belief and practice on recognizably 'religious' grounds" (Zaman 2012, p. 29).

Moreover, unlike some Barelvi imams in the UK, Imam Mahboob did not fail to defend the devotional practices from the attacks of other groups such as Hizb al-Tahrir, particularly during the 90 's. Many kakas (youngsters) who "were rejecting both assimilation into the mainstream indigenous culture and the ethnocentricity of their parents" (Geaves 1996b, p. 59) were attracted by the doctrine of the movement. Imam Mahboob's role was crucial in challenging these ideas that were regarded by the babas as part of the broader emic category of "wahhabism." This ideological clash resulted in a "fitnah" (strife) between parents and children within many families" says Faruq (39), head of an active youth foundation in the district, "a fitnah that transformed Imam Mahboob into a psychologist." He adds:

Imam Mahboob was my saviour in a difficult time. While attending his class on Bukhari Sharif from Kitäbul adab mufrad, ${ }^{12}$ I used to ask him all sorts of questions and he used to listen to me contrary to the elders. I used to challenge him, but his knowledge in the four madhabs, his knowledge of the context and his charisma-bear in mind! he was one of the few Barelvi imams who were able to speak English fluently during 80s and early 90s, until recently actually. So, he was capable in many regards to intervene positively in family conflicts but also in accompanying youth intellectually, and I was one of them.

Faruq's case illustrates the importance of Imam Mahboob's capacity in "bridging social capital" (Lewis 2006, p. 273) as a way to help youth in their aspiration for coherence (Asad 1986, p. 17) within

10 http://www.muslimsinbritain.org/index.php (link accessed on 5 April 2019).

11 This use of the term fitnah here refers to the Qur'anic verse: "wa l-fitnatu ashaddu mina l-qatl" (And fitnah is worse than killing) (Qur'an 2: 191).

12 It is the seventy eighth book of Imam Bukhari's collection of sahìh (authentic hadiths-prophetic sayings). It concerns the question of perfecting Muslim manners. 
the British context ${ }^{13}$ where Pakistani Muslim adolescents have a stronger ethnic identity compared to Indians for instance (Robinson 2009). He was clearly an exception to other imams in terms of his ability to nurture a "cultural capital" to engage in civil society (Gilliat-Ray 2010, p. 163) even if it "takes time [to] accumulate" (Bourdieu 1986, p. 241). He is the one who advised Faruq to create an institution outside the mosque to offer a space for discussion and blossoming to other kakas instead of aiming to change babas.

Of course, the role of Imam Mahboob did not stop the influence of the sum of reformist 'neo-orthodox' ideas which are observable today in almost all Barelvi mosques in the UK despite the persistence of what Geaves (2009) accurately calls the "cultural binary fission" of Sufism in Britain-a metaphor borrowed from cellular biology to refer to the way in which tariqas in the UK reproduce continuously to create a duplicate of themselves which is ethnically and locally bounded. However, in the midst of the youth's "creative, empowering, stimulating, inspiring and arousing" everyday struggle (Threadgold 2018, p. 22), Imam Mahboob accompanied them in developing a post-Barelvi understanding of the tradition primarily by seeking sufi practices beyond Kashmiri circles, particularly among internationally active scholars like the Habä'ib (plural of Habīb-referring to scholars/sayyids originated from Yemen) such as Habib Ali Jafri or Habib Umar bin Hafiz, and some American or British convert scholars such as Hamza Yusuf and Abdal Hakim Murad. ${ }^{14}$ In other words, he was able to canalise the youth's "individualised" quest of truth through a form of Barelvism which can discursively embrace novel sufī practices.

Bano (2018a) proposes measuring the scholar's Islamic authority according to three components: (1) his textual knowledge of Islamic sciences and command over Arabic, (2) his moral authority i.e., "the scholar's way of life, as reflected in his adab (Islamic norms of behavior), uprightness, and conduct on material matters. [ ... ] The persona of the Prophet and his Sunnah become the model against which the scholar is judged; in the spirit of the Prophet's tradition, the scholar is expected to live by what he teaches" (p. 31), and (3) his knowledge of everyday social realities. Drawing on my fieldwork, these three dimensions represent Imam Mahboob's religious capital (Iannaccone 1990), or rather spiritual capital (Verter 2003). Regardless of the problematic use of the adjectives 'religious' and 'spiritual' that I cannot discuss here, ${ }^{15}$ Verter's conceptualisation is interesting not only because it draws on Bourdieu's notion of cultural capital in its three forms, i.e., the embodied state, the objectified state, and the institutionalised state (Bourdieu 1986, pp. 243-48), but mainly because it helps to sketch the three aspects of Imam Mahboob's religious authority. Firstly, the embodied state means that the spiritual capital is embodied in the habitus, it is not only about Imam Mahboob's position but also about his dispositions and inward/outward capacities. Secondly, the objectified state refers to the fact that Imam Mahboob holds a set of objects, texts and vestments (Bourdieu 1986, pp. 246-47) such as the 'amāma (turban) that he appropriated from his master and which can be "consumed" by disciples and members of the congregation. Finally, the institutionalised state is related to Imam Mahboob's qualifications from various renowned Islamic institutions in Pakistan and elsewhere, including al-Azhar in Egypt where he spent one year.

Drawing on this understanding of Islamic authority and spiritual capital, is it accurate to talk about a decline of religious authority in Imam Mahboob's case? What is the process taking place in mosques if it is not a decline of religious authority? What is the role of conflict in this process? What are its functions regarding the mosque's internal dynamics and what is its impact on the role of local Muslim leaders (imam and mosque committee members)? I intend to explore these questions in the following sections.

13 To know about the British youth aspiration, see Franceschelli and O'Brien (2015) and Hamid (2016).

14 This move is already old now, McLoughlin (2005, p. 1063) reports that in February 2003, Shaykh Hamza Yusuf was invited to speak to almost 6000 people in Bradford. This post-tarīga sufism and the absence of pīr-murīd relation is also described by Geaves (2012).

15 For a thorough theoretical discussion of these concepts, see Ahmed (2016). 


\section{The Analysis of Social Conflict}

\section{a. Emergence of the conflict and definition of its object:}

According to Adnan (66), a previous chairman from the Bargil group, ${ }^{16}$ the two groups started to emerge in 1983, when the committee decided to fire Mufti Hasan while he was in Kashmir for holiday. Mufti Hasan was a member of the community who volunteered himself to lead the five daily prayers and deliver the jum'a khutbah (Friday Sermon). He was known for his forthrightness, that is, "he was never hesitant to tell some members of the committee that their commerce of alcohol is harām (illicit)," says Adnan. Hence, many worshipers including his peers in naqshabandī tarīqa stood firm against the decision to fire him, which resulted in organising the first elections in 1983. Other informants who joined the mosque during the 90 s trace the formation and the proper engagement of the two groups to their diverse responses to the new constitution drafted in 2001. They refer to the conflict arising from the process by which the management committee was to be appointed. The Kardal group defended an election mechanism while the Bargil one preferred selection. Although the latter accepted the use of elections for many years, disagreement over how to organise and nominate mosque committee members reinforced the conflict between the various protagonists.

It might be argued that the two groups were formed based on belonging to the same tarīqa, or to the village of origin based on the network of baradari, ${ }^{17}$ or to the ethnicity and class that derives from the caste system, but none of these explain the current constitution of the two groups. In both groups, we find people named Raja and others named Chaudhary (names referring originally to castes), we find also people coming from Bargil/Kardal and from other villages such as Solu or Pilan. The composition of each group does not derive necessarily from the migration ties, whether interpersonal, organisational or composite (Granovetter 1973; Poros 2011).

Taking all the narratives into considerations, there is a constellation of interests and motivations behind the groups' formation. The only certainty here, is that the conflict could not emerge without what Coser (1956, p. 38) called the high frequency of conflictual occasions due to the closeness of relations, i.e., "the closer the relationship the more intense the conflict." Members of both groups were living in the same district where habitat is grouped, and where the mosque represents the centre of everyday interaction. This connection was not only centred on mosque management, but on all sorts of personal and community affairs.

\section{b. The organisational structure of the mosque:}

Originally, along with the imam, only five people used to oversee the management of the mosque after its construction in 1982. Under Imam Mahboob's guidance, these people continued to manage the mosque's logistic affairs until 1992 when they succeeded to collect the necessary amount of money to buy the next door's warehouse and extend the mosque. The project included adding additional floors reserved to women in the old building as well as the construction of a madrassah (used also as a prayer space during Fridays and other celebrations), a larger wudu (ablution) area and a minaret on the new site. As a result, the mosque's capacity has almost doubled from 220 people in 1982 to 500 in 1992. This has engendered an important shift in management: in addition to the important financial involvement of some members who expressed their interest in joining the management committee. The extension resulted in the proliferation of everyday managerial tasks that led to increase the number of committee members.

16 After the formation of the two groups in conflict, the name of the villages of origin became officially used to design the two parties taking part in mosque's internal elections. 'Bargil group' and 'Kardal group' is an emic designation that I will use in the rest of the article.

17 It derives from the Persian word baradar meaning 'brother,' and it means an extended kinship group that "perpetuates itself through the institution of arranged marriage". 
The management committee is composed currently of 25 directors who work on a voluntary basis and who are elected every two years to manage the mosque. The nomination is completed through a process of informal preselection within the two groups which intensifies kinship and the role of baradari, while the voting system is based on an open-list proportional representation (PR) which increases polarisation between the two groups. Lardeyret (1991) says "PR is dangerous" when "faced with ethnic or cultural divisions" (p. 32), it "tends to reproduce ethnic cleavages in the legislature" (p. 35). Hajji Salim (69), the current chairman describes the process by saying:

You are campaigning for your group and I am campaigning for mine. But in order to present 25 people, I and you have to go and find those people who can get more votes, family, friends, etc. It doesn't matter if they can't read the namaz, if they can't do their prayer properly, if they don't come to the mosque, more than that, if they do illicit jobs ... like selling alcohol ... they can be in the management committee! So when we come to vote, I tick 25 Bargil and you tick the 25 Kardal.

Therefore, the work of this mosque's committee is within a functional organisational structure, where we find a management committee, education committee, maintenance committee, and fundraising committee. Although the management committee is composed of nine people, the main tasks are shared mainly between the chairman and the secretary, who is also head of the education committee and spokesman of the mosque. Members of both groups acknowledge the need for a harmony between the chairman and the secretary in order to assure a satisfactory governance of the mosque, yet they all point out the "danger" when they both have full power. In this regard, the Bargil group points out also the importance of the imam's presence in the decision making as the "religious and spiritual leader" of the mosque, independently of his belonging to the same tariqa or village of other members in the committee.

c. The actors' dynamic:

Right before 2001, due to the intensification of the polarisation between the Bargil and Kardal parties, Imam Mahboob, who arrived in 1983 to replace Mufti Hassan, intervened to resolve the dispute. A new committee composed of 25 people was formed: twelve from each group and one neutral person appointed by the imam. Although the imam divested conflict situations of "non-realistic elements of aggressiveness" so as to allow the contenders to deal realistically with the divergent claims at issue (Coser 1956, p. 60), the committee dissolved ten months later, and another election took place because the imam's role itself was an object of conflict. After this first internal attempt at mediation, which failed to reach a compromise, the Bargil group (which is close to the imam) resorted to a legal mechanism for conflict resolution in 2003. One of its members sued the Kardal committee in a commercial court. The judge suggested signing an agreement between the two groups and to find an external mediator.

After a few days, both groups communicated the problem to an important religious figure in the UK and proposed him as a mediator due to his scholarly renown and authority among all Barelvis. He accepted reluctantly and appointed a new committee (eleven from each group) and asked three barristers to draft a new constitution. The first two drafts were refused because of their similarity to the 2001 constitution, and the third one was refused by the Kardal group for allegedly preparing the ground for establishing a selection process. Fawaz (56), one of the current committee members describes this third draft by saying:

The barrister said "select a panel from the community which will act as a jury. This panel that you can name 'advisory board' might include the imam as well. Then, call for applications ... for all positions except the chairman. Forget about a chairman position! During meetings, you simply propose a person to chair. Then, interview the applicants and choose the best ones. The selected team will act as the new executive committee."

Between 2006 and 2009, the conflict sharpened, and the object of conflict became clearly defined: the Bargil group defended selection as a process of nomination and the protection of Imam Mahboob's active 
role in management while the Kardal group advocated election and the permanent marginalisation of the imam as an employee. In 2010, members of the Kardal group decided to go to the court and challenge the external mediation. After one year, the judge decided that the mediation was not binding in the light of the constitution of 2001. He also ordered a secret ballot and considered anyone who participated in the election of 2001 and 2003 as a full member of the mosque.

\section{d. Functions of the conflict:}

The enrolment in "judiciary quarrels" (Coser 1956) led to three things: an intensification of the conflict, a division of roles and a weaponisation of rules. First, the boundaries between the two groups were never clear as such. Before, people who are not originally from Bargil or Kardal used to move between the two groups for various political and social reasons. The court's decision resulted in a clear separation between the two groups in terms of social and political participation. It reinforced both a form of 'ethnicisation' (Rajesh 2000) that was much more porous back home (Gandotra 2011), and a clear-cut political partisanship.

Second, the process resulted in a division of roles through several bureaucratic procedures and policies. The role of the imam now became circumscribed within the framework of the constitution and the contract of employment; in other words, the imam's daily activities were distinctly arranged by the committee. In this sense, the imam had no role in the management of the mosque anymore. He was in charge of the ritual tasks only, while the management committee were responsible for all what is perceived by them as profane that is, which "does not require a religious expertise" (Fawaz, 56). The exercise of religious and spiritual authority by the imam became controlled by the bureaucratic authority of the committee members.

Finally, the organisational policies are weaponised by a group versus the other, notably because of the centralisation of power in the hands of the chairman and the secretary. ${ }^{18}$ The imam who was close to the Bargil group was obliged to resign after more than thirty years of service under the pressure and control exercised by the chairman and secretary who were both members of the Kardal group. The imam was no longer able to exercise his role inside and outside the mosque which allows for his religious authority to flourish and his spiritual capital to be displayed. Appointments of new staff were organised in a way to distance the imam from the congregation: his courses of Arabic and Hadith were stopped because the committee recruited a new madrassah teacher who teaches in the same hall where the imam used to. Moreover, a new imam was recruited to give a second khutbah entirely in English during jum'a, which obliged Imam Mahboob to give the first khutbah only in Urdu as it is attended mainly by the elders. The fact that "many mosque committees still seem reluctant to employ such British trained imams" (Lewis 2014, p. 238) was used by this committee as an argument to justify its so-called "progressive change" (Imran, Secretary, 49). Furthermore, an attendance record has been established by the committee as a way to control the imam's presence for all five daily prayers in the mosque making his duties vis-à-vis the community both in the local area and beyond often unachievable.

Activities such as participation in interfaith dialogue initiatives, whispering the adhān (first call for prayer) and iqāma (second call for prayer) in the newborn baby's ears, counselling regarding marriages and divorces, reading Qur'an and $a l-B u r d a^{19}$ to a sick person in hospital and so forth are today extremely controlled bureaucratically. Instead of going to visit members of the community flexibly in person, the imam is obliged to stay between prayers in his office to respond to people's questions and take notes of the various requests expressed by members of the congregation which are later transferred to the secretary. His preliminarily role is henceforth to respond bureaucratically to Muslims' "everyday

18 I asked the secretary Imran about his role, he said: "I manage everything. I might delegate some tasks but I manage everything. The external actors such as the police, county council, schools, and churches will contact me if they need anything; I am the spokesperson of the mosque."

19 Famous poem "Ode of the Mantle" praising the prophet and written by Imam al-Būsīri (d. 1294). 
concerns" (Sartawi and Sammut 2012). His religious authority is still exercised, yet only within the bureaucratic framework set by the committee members.

\section{Discussion and Concluding Remarks}

So far, I have analysed the conflict in which the imam's role within the management of the mosque is the main object of conflict. To explain the conflict, I scrutinised the organisational structure of the mosque as well as the dynamic of the groups and their leaders. During fourteen months of intensive fieldwork, I was able to observe that his religious authority and spiritual capital remained intact. His decision to resign in the tenth month of my fieldwork was even supported, not to say proposed, by many members of the congregation from both groups, Kardal and Bargil, who were ready to help him create another institution. The day after his departure, Imam Mahboob had still to officiate a nikāh (marriage) in the groom's house, lead a janāza (funeral) and attend a khatam (in honour of a deceased relative). Two months after he left the mosque, his daily schedule was still full, babas and kakas were still coming to his house asking all sorts of questions. Undoubtedly, he is still Imam Mahboob.

However, it is important to analyse what happened in the last ten to fifteen years inside the mosque, ${ }^{20}$ it is not a decline of religious authority but rather the rise of bureaucratic authority. This is not to argue that conflicts between imams and committee members were inexistent before: Werbner (1996) has well described the tripartite caste-driven polarisation both in South Asian and British mosques between "saints, scholars and lay preachers." It is rather to point out the move from inter and intra-denominational conflicts analysed by scholars such as Ron Geaves, Sean McLoughlin and Pnina Werbner to bureaucratic conflicts that transcend the denomination and ethnicity of the congregation members. Not only is a displacement of power witnessed, but also a control of religious authority through bureaucratic mechanisms.

A strong argument in the narrative of decline is that 'technological advancement' has reinforced individualisation (particularly among youth) and therefore led to the decline of religious authority. Inspired by the work of Francis Robinson on the impact of the printing press in the Islamic world as "attacking the very heart of Islamic systems for the transmission of knowledge" (Robinson 1993, p. 134), Eickelman and Piscatori (2004) are at the front stage of this position. They talk about the process of fracturing of Islamic authority. As I said earlier, it is impossible to deny the influence of social media in the so-called Islamic revivalism in the West and elsewhere; however as explained by Bano (2018a, pp. 11-22): "The technological advancements of the last three decades have indeed, therefore, led to increased competition among Islamic authorities, but increased literacy and access to higher education have at the same time re-centered traditional Islamic scholarly authority, instead of eroding it." In other terms, technological advancement has also rendered the institutionalised state of religious authority central. This can be demonstrated in some of the post-Barelvi actions such as taking part in spiritual trips (e.g., Rihla program and al-Ghazāli retreat) ${ }^{21}$ with scholars ${ }^{22}$ to various parts of the world, actions in which imams and madrassah teachers take an important role as well. Also, Imam

20 Which coincides with the same period when the main academic works arguing for the decline of mosques' role and imams' religious authority were published.

21 Drawing heavily on the work and life-legacy of al-Ghazālī (d. 1111), the Rihla program is an annual retreat initiated by Hamza Yusuf under the Deen Intensive Foundation fifteen years ago, it took place in various parts of the world (Morocco, Turkey, Malaysia, etc). The al-Ghazālī retreat is organised every year in Spain and it is led by Tim Winter (Abdal Hakim Murad) and Umar Faruq Abd-Allah. Both retreats attract participants from various schools of thought and from both Western and Muslim majority countries as observed by Bano (2018b, pp. 13-15).

22 Bano (2018a, p. 11) recalls in this regard one of her interviewees' position regarding his participation in al-Ghazālī retreat: "Islam has a rich scholarly tradition in all fields be it fiqh, theology or philosophy. In fact, Islamic theology if properly studied is intellectually very powerful. Yet, to acquire that depth of understanding, we need to go back to work of great Islamic legal scholars, theologians, philosophers, and mystics and it is simply not possible to study those dense texts on your own. You need to be guided by a teacher and ideally a teacher who has very sound proficiency of Arabic grammar in addition to knowing that specific text. [ . . . That is why I like to attend such retreats. I don't have time to pursue study of Islam full time, but participation in these short retreats acts as a good reminder that there is much intellectual depth to Islamic scholarly tradition." 
Mahboob is today using social media to reach his congregation which is increasingly literate-his Facebook page is constantly consulted by members of the congregation. In this sense, the argument that the role of mosques is declining because of technological advancement is increasingly caducous.

In this article, rather than focusing on exogenous factors such as individualisation either as a critical juncture i.e., generational change (Cesari 1998) or as part of a reformist discourse that is having an important impact on the role of imams and mosques (Amir-Moazami and Salvatore 2003), my objective is to point out the internal organisational transformation and its impact -as part of the historical condition of 'bureaucratisation'- on the possibility of an imam to maintain or to lose his religious authority. The point is not to claim that the mosque is a space of hierocracy or an essential site of struggle over the "principles of hierarchization" (Bourdieu 1993), but rather to allude to the internal transformation taking place under the modern nation state apparatus in the West. As Peter (2006, p. 112) remarks "one misses an exploration of how intra-Muslim relations influence the shaping of structures of religious authority." In this article, I add to this important point that one misses the historical conditions that shape intra-Muslim relations. Hence, to go back to the argument of individualisation, I agree with Peter who asserts that "any study of individualization needs to be based on a certain understanding of institutionalized Islam" (Peter 2006, p. 113).

My concern is not whether the individualisation of Islam and the fragmentation of religious authority will lead to the liberalisation of Islam (Mandaville 2001; cf. Roy 2005). Such affirmation has shown to be precipitous not only because of the fallacy of the secularisation thesis that puts 'Western Islam' in a trajectory of progress towards liberalism, ${ }^{23}$ but also because recent studies have shown the attachment of Muslim youth to imams and 'ulamas in various religious institutions in France (Van Praet 2019), Belgium (Groeninck 2017), and so forth. Rather I am interested in demonstrating the dynamic created by bureaucratisation both as a discourse shaped by secularism and neoliberalism and a material condition that transforms the role of local Muslim leaders (imams and mosque committee members).

Scholars need not only focus on the role of committee members as part and parcel of the field of local Muslim leadership -instead of focusing on imams only-, but also and more crucially, to study the role of local Muslim leaders as an "object of observation" rather than an "object of study" shaped by political and mediatic doxa. Differentiating the object of observation (local Muslim leaders) and the object of study (in this case, bureaucratisation of mosques) would help "to attend to wider patterns of power relations-that is, the historical processes and global flows that produce our objects of observation in the first place" (Fernando 2014, p. 24). In the West, the field of local Muslim leadership is one of the interesting "shadows" (Asad 2003, p. 16) and "lenses" through which one can understand the dynamic of the secular today. Such a shift is crucial irrespective of the denomination, nationality or ethnicity of the congregation. It must occur beyond any "substantialist perspective," that is, a perspective that focuses on "internally homogeneous and externally distinctive and bounded objects" (Desmond 2014, p. 551). While I make this call, surrounded by youngsters and other members of the congregation, Imam Mahboob is creating his own institution based on his religious authority which did not decline. However, in an "age of total bureaucratisation" (Graeber 2015, p. 17) which includes the bureaucratisation of mosques as I showed in this paper, it is only a matter of time before he exercises in turn a bureaucratic authority.

Funding: This research was generously funded by the Cambridge Trust, the Woolf Institute, the IJURR Foundation and the Leche Trust.

Acknowledgments: I would like to thank anyone who gave up his precious time to be part of this study. Thanks also to Sami Everett, Nadia Fadil and my anonymous reviewers for their comments on various versions of this article. Thanks to the organisers and attendants of the "Conference on Leadership, Authority and Representation in the Muslim Community" (particularly Sophie Gilliat-Ray and Riyaz Timol) at Cardiff University (21 January 2019),

23 For further discussion, see Massad (2015). 
and the panel "Research on Islam and beyond around the world" at the 117th Annual Meeting of the American Anthropological Association (AAA) in San Jose (16 November 2018) for their helpful feedback.

Conflicts of Interest: The authors declare no conflict of interest.

\section{References}

Agrama, Hussein Ali. 2010. Ethics, tradition, authority: Toward an anthropology of the fatwa. American Ethnologist 37: 2-18. [CrossRef]

Ahmed, Shahab. 2016. What Is Islam? The Importance of Being Islamic. Princeton and Oxford: Princeton University Press. Amir-Moazami, Schirin, and Armando Salvatore. 2003. Gender, generation, and the reform of tradition: From Muslim majority societies to Western Europe. In Muslim Networks and Transnational Communities in and across Europe. Edited by Stefano Allievi and Jorgen Nielsen. Leiden: Brill, pp. 52-77.

An-Nawawī, Yahya. 1997. An-Nawawī's Forty Hadith. Translated by Ezzeddin Ibrahim, and Denys Johnson-Davies (Abdul Wadoud). Cambridge: Islamic Texts Society.

Ansari, Humayun. 2007. Burying the dead': Making Muslim space in Britain. Historical Research 80: 545-66. [CrossRef]

Anwar, Muhammad. 1979. The Myth of Return: Pakistanis in Britain. London: Heinemann.

Asad, Talal. 1986. The Idea of an Anthropology of Islam. Qui Parle 17: 1-30. [CrossRef]

Asad, Talal. 1993. Genealogies of Religion: Discipline and Reasons of Power in Christianity and Islam. London: Johns Hopkins University Press.

Asad, Talal. 2003. Formations of the Secular: Christianity, Islam, Modernity. Stanford: Stanford University Press.

Bano, Masooda. 2018a. Modern Islamic Authority and Social Change (Volume I). Edinburgh: Edinburgh University Press.

Bano, Masooda. 2018b. Modern Islamic Authority and Social Change (Volume II). Edinburgh: Edinburgh University Press.

Birt, Jonathan. 2005. Locating the British Imam: The Deobandi Ulama between Contested Authority and Public Policy Post- 9/11. In European Muslims and the Secular State. Edited by Jocelyne Cesari and Sean McLoughlin. Aldershot: Ashgate Publishing Limited, pp. 183-96.

Birt, Yahya. 2006. Good Imam, Bad Imam: Civic Religion and National Integration in Britain post-9/11. The Muslim World 96: 687-705. [CrossRef]

Blau, Peter M. 1963. Critical Remarks on Weber's Theory of Authority. The American Political Science Review 57: 305-16. [CrossRef]

Bourdieu, Pierre. 1986. The Forms of Capital. In Handbook of Theory and Research for the Sociology of Education. Edited by John G. Richardson. New York: Greenwood Press, pp. 241-58.

Bourdieu, Pierre. 1993. The Field of Cultural Production: Essays on Art and Literature. Edited and Introduced by Randal Johnson. Cambridge: Polity.

Cesari, Jocelyne. 1998. Musulmans et Républicains: les Jeunes, l'Islam et la France. Brussels: Editions Complexe.

Cesari, Jocelyne. 2003. Islam, Citizenship and European Integration. London: Routledge.

Coser, Lewis A. 1956. The Functions of Social Conflict. London: Routledge.

Desmond, Matthew. 2014. Relational Ethnography. Theory and Society 43: 547-79. [CrossRef]

Eickelman, Dale F., and James Piscatori. 2004. Muslim Politics. Princeton: Princeton University Press.

Fernando, Mayanthi. 2014. The Republic Unsettled: Muslim French and the Contradictions of Secularism. Durham: Duke University Press.

Franceschelli, Michela, and Margaret O'Brien. 2015. Being modern and modest': South Asian young British Muslims negotiating multiple influences on their identity. Ethnicities 15: 696-714. [CrossRef]

Frégosi, Frank, ed. 1998. La Formation des Cadres Religieux Musulmans en France: Approches Socio-Juridiques. Paris: L'Harmattan.

Frégosi, Frank. 2004. L'imam, le conférencier et le jurisconsulte: Retour sur trois figures contemporaines du champ religieux islamiques en France. Archive de Sciences Sociales des Religions 125: 31-46. [CrossRef]

Gaborieau, Marc, and Malika Zeghal. 2004. Autorités religieuses en Islam. Archive de Sciences Sociales des Religions 125: 5-21. [CrossRef]

Gandotra, Hema. 2011. Migration and marginality: a sociological insight of Kashmiri Pandits. Madhya Pradesh Journal of Social Sciences 16: 11-17.

Geaves, Ron. 1996a. Cult, charisma, community: the arrival of Sufi Pirs and their impact on Muslims in Britain. Journal of Muslim Minority Affairs 16: 169-92. [CrossRef] 
Geaves, Ron. 1996b. Sectarian Influences Within Islam in Britain with Reference to the Concepts of 'Ummah' and 'Community'. Leeds: Community Religions Project.

Geaves, Ron. 2009. A Case of Cultural Binary Fission or Transglobal Sufism? The Transmigration of Sufism to Britain. In Global Networking and Locality: Sufis in Western Society. Edited by Ron Geaves, Markus Dressler and Gritt Klinkhammer. London: Routledge, pp. 97-112.

Geaves, Ron. 2012. The Transformation and Development of South Asian Sufis in Britain. In South Asian Sufis: Devotion, Deviation and Destiny. Edited by Clinton Bennett and Charles Ramsey. London: Continuum, pp. 181-96.

Gilliat-Ray, Sophie. 2010. Muslims in Britain. Cambridge: Cambridge University Press.

Graeber, David. 2015. The Utopia of Rules: On Technology, Stupidity and the Secret Joys of Bureaucracy. Brooklyn: Melville House.

Granovetter, Mark S. 1973. The Strength of Weak Ties. The American Journal of Sociology 78: 1360-80. [CrossRef]

Groeninck, Mieke. 2017. Politics of 'ilm: Islamic religious knowledge transmission among female Maghrebian Muslims in the region of Brussels. Ph.D. dissertation, Katholieke Universiteit Leuven, Leuven, Belgium.

Haddad, Yvonne. 2002. Muslims in the West from Sojourners to Citizens. Oxford: Oxford University Press.

Hamid, Sadek. 2016. Young, Muslim and British: Between Rhetoric and Realities. London: Routledge.

Hashas, Mohammed, Jan Jaap de Ruiter, and Niels Valdemar Vinding. 2018. Imams in Western Europe: Developments, Transformations and Institutional Challenges. Amsterdam: Amsterdam University Press.

Hervieu-Léger, Danièle. 1999. Le Pèlerin et le Converti. La Religion En Mouvement. Paris: Flammarion.

Iannaccone, Laurence R. 1990. Religious Practice: A Human Capital Approach. Journal for the Scientific Study of Religion 29: 297-314. [CrossRef]

Jouanneau, Solenne. 2013. Les Imams en France: Une Autorité Religieuse sous Contrôle. Marseille: Agone.

Khan, Muzamil. 2006. Devotional Islam in Kashmir and British Diaspora. Ph.D. dissertation, University of Liverpool, Liverpool, UK.

Khosrokhavar, Farhad. 1997. L'Islam des Jeunes. Paris: Flammarion.

Kramer, Gudrun, and Sabine Schmidtke. 2006. Speaking for Islam: Religious Authorities in Muslim Societies. Leiden: Brill. Lardeyret, Guy. 1991. The problem with PR. Journal of Democracy 2: 30-35. [CrossRef]

Lewis, Philip. 1994. Being Muslim and Being British: The Dynamics of Islamic Reconstruction in Bradford. In Desh Pardesh: The South Asian Presence in Britain. Edited by Roger Ballard and Marcus Banks. London: Hurst, pp. 58-87.

Lewis, Philip. 2006. Mosques, 'Ulama' and Sufis: Providers of Bridging Social Capital for British Pakistanis? Contemporary South Asia 15: 273-87. [CrossRef]

Lewis, Philip. 2014. Imams in Britain: Agents of De-Radicalisation. In Islamic Movements of Europe. Edited by Frank Peter and Rafael Ortega. London and New York: I.B. Tauris, pp. 237-40.

Mandaville, Peter. 2001. Transnational Muslim Politics: Reimagining the Umma. London: Routledge.

Massad, Joseph Andoni. 2015. Islam in Liberalism. Chicago and London: University of Chicago Press.

McLoughlin, Sean. 1998. The Mosque-Centre, Community-Mosque: Multi-functions, Funding and Reconstruction of Islam in Bradford. The Scottish Journal of Religious Studies 19: 211-27.

McLoughlin, Sean. 2005. Mosques and the Public Space: Conflict and Cooperation in Bradford. Journal of Ethnic and Migration Studies 31: 1045-66. [CrossRef]

Milligan, Lizz. 2016. Insider-outsider-inbetweener? Researcher positioning, participative methods and crosscultural educational research. Compare: A Journal of Comparative and International Education 46: 235-50. [CrossRef]

Minganti, Pia K. 2012. Challenging from Within: Youth Associations and Female Leadership in Swedish Mosques. In Women, Leadership, and Mosques. Edited by Masooda Bano and Hilary Kalmbach. Leiden: Brill, pp. 371-92.

Mohsen-Finan, Khadija. 2003. La mise en avant d'une 'citoyennete' croyante': Le cas de Tariq Ramadan. In De la Citoyenneté Locale. Edited by Rémy Leveau, Khadija Mohsen-Finan and Catherine Wihtol de Wenden. Paris: Institut Français des Relations Internationales, pp. 87-96.

Özyürek, Esra. 2014. Being German, Becoming Muslim: Race, Religion, and Conversion in the New Europe. Princeton: Princeton University Press.

Peter, Frank. 2006. Individualization and religious authority in western European Islam. Islam and Christian-Muslim Relations 17: 105-18. [CrossRef] 
Poros, Maritsa V. 2011. Modern migrations: Gujarati Indian Networks in New York and London. Stanford: Stanford University Press.

Rajesh, Gill. 2000. "Cities and Ethnicity: A Case of De-ethnicization or Re-ethnicization”. Sociological Bulletin 49: 211-28.

Robinson, Francis. 1993. Technology and Religious Change: Islam and the Impact of Print. Modern Asian Studies 27: 229-51. [CrossRef]

Robinson, Francis. 2009. Crisis of Authority: Crisis of Islam? Journal of the Royal Asiatic Society 19: 339-54. [CrossRef]

Roy, Olivier. 2004. Globalised Islam: The Search for a New Ummah. London: Hurst \& Company.

Roy, Olivier. 2005. La Laïcité Face à l'Islam. Paris: Editions Stock.

Sartawi, Mohammed, and Gordon Sammut. 2012. Negotiating British Muslim identity: Everyday concerns of practicing Muslims in London. Culture and Psychology 18: 559-76. [CrossRef]

Schauer, Frederick. 2015. The Force of Law. Cambridge: Harvard University Press.

Sèze, Romain. 2013. Etre Imam en France. Paris: Cerf.

Simmel, Georg. 1955. Conflict and the Web of Group-Affiliations. New York: The Free Press.

Sunier, Thijl. 2018. The making of Islamic authority in Europe. In Imams in Western Europe: Developments, Transformations and Institutional Challenges. Edited by Mohammed Hashas, Jan Jaap de Ruiter and Niels Valdemar Vinding. Amsterdam: Amsterdam University Press, pp. 51-68.

Threadgold, Steven. 2018. Youth, Class and Everyday Struggles. Abingdon: Routledge.

Van Bruinessen, Martin. 2010. Producing Islamic Knowledge in Western Europe: Discipline, Authority, and Personal Quest. In Producing Islamic Knowledge: Transmission and Dissemination in Western Europe. Edited by Martin van Bruinessen and Stefano Allievi. Abingdon: Routledge, pp. 1-27.

Van Praet, Younes. 2019. Socio-Anthropologie De L'enseignement De L'islam Dans L'agglomération Rouennaise: Rapports De Genre Et Évolutions Des Légitimités. Ph.D. dissertation, Rouen Université de Rouen, Mont-Saint-Aignan, France.

Verter, Bradford. 2003. Spiritual Capital. Theorizing Religion with Bourdieu against Bourdieu. Sociological Theory 21: 150-74. [CrossRef]

Vinding, Niels Valdemar. 2018. The making of Islamic authority in Europe. In Imams in Western Europe: Developments, Transformations and Institutional Challenges. Edited by Mohammed Hashas, Jan Jaap de Ruiter and Niels Valdemar Vinding. Amsterdam: Amsterdam University Press, pp. 231-54.

Werbner, Pnina. 1996. The making of Muslim dissent: hybridized discourses, lay preachers and radical rhetoric among British Pakistanis. American Ethnologist 23: 102-22. [CrossRef]

Werbner, Pnina, and Mohammad Anwar. 1991. Black and Ethnic Leaderships in Britain: The Cultural Dimensions of Political Action. London: Routledge.

Zaman, Muhammad Qasim. 2012. Modern Islamic Thought In A Radical Age: Religious Authority And Internal Criticism. Cambridge and New York: Cambridge University Press.

(C) 2019 by the author. Licensee MDPI, Basel, Switzerland. This article is an open access article distributed under the terms and conditions of the Creative Commons Attribution (CC BY) license (http://creativecommons.org/licenses/by/4.0/). 



\title{
Obituary \\ Fuad Nahdi, $Q-N e w s$, and the Forging of British Islam: Some Personal Reflections
}

\author{
Yahya Birt \\ The School of Philosophy, Religion and History of Science, University of Leeds, Leeds LS2 9JT, UK; \\ J.J.Birt@leeds.ac.uk or yahya.birt@gmail.com
}

Received: 17 April 2020; Accepted: 23 April 2020; Published: 29 April 2020

\begin{abstract}
This obituary offers some personal memories of Fuad Nahdi (1957-2020), based on my interactions with him, as well as some reflections on the historic importance of Q-News, the British Muslim periodical Nahdi founded, which was published between 1992 and 2006, partly based on short impromptu interviews done with some who worked on the magazine with Nahdi. In Q-News, Nahdi created the most consequential UK Muslim publication of its day and helped shape how a whole generation of young Muslims saw their identity and faith. He should be remembered alongside Abdullah Quilliam (1856-1932) and Dr Kalim Siddiqui (1931-1996) as among the great journalists-cum-activists that British Islam has produced.
\end{abstract}

Keywords: British Muslims; Media Studies; Religious Studies; Islamic Studies; religious leadership; British Islam; identity; Fuad Nahdi; Q-News; religious authority; Sufism

\section{Introduction}

It is hard to think of life as a Muslim in Britain without recalling the presence of Fuad Nahdi (1 June 1957-21 March 2020) within it, may God have mercy on him, as he touched so many of our lives, directly and indirectly. His passing is devastating for myself and for countless others, including my wife Dr Fozia Bora (b. 1972), who had worked with Fuad at Q-News in the early 1990s and for whom he was an important mentor. We can only imagine the depth of grief felt by Fuad's family, his wife, the activist Humera Khan, his son Nadir and his daughter Ilyeh.

On the day that Sidi Fuad passed away, Saturday, 21 March 2020, once I steadied myself after the initial wave of shock and grief, I joined others in trying to ensure that his passing was marked in an appropriate way. That evening, I wrote a rather impersonal brief, slightly updated and expanded here, to send around to media outlets (which was later kindly retweeted, with permission, by Dr Hisham Hellyer). It went like this:

Fuad Nahdi was the éminence grise of British Islam. The founding figure of modern British Muslim media, Fuad and the talented young journalists he mentored at Q-News (1992-2006), helped to define "British Muslims" and "British Islam" in the 1990s.

Fuad was a prominent figure in interfaith circles, playing an active role in the Christian-Muslim Forum, established in 2005, was awarded the Interfaith Gold Medallion by the Three Faiths Forum in 2012, and was the first Muslim ever to address the General Synod of the Church of England in 2014. He was particularly close to the Archbishop of Canterbury Rowan Williams.

He was also active in policy issues from the 1990s onwards, as an influential figure in Whitehall. The "Radical Middle Way" he established in December 2005 was a flagship outreach programme to promote a positive British Islam that was confident, and not afraid to be outspoken when required. 
Growing up in Kenya, of mixed Yemeni-Indonesian ancestry, Fuad traced his descent back to the Nahdi tribe of the southern Yemen. He came to London in 1983 to train at City University as a journalist and had an incredible career.

He worked and wrote for Reuters, Los Angeles Times, Arab News, The Nation, ABC News, Crescent International, Africa Events, and the BBC World Service. He contributed journalism and commentary to The Economist, The Independent, The Guardian, The New York Times, The New Statesman, Arab News, Mail \& Guardian (South Africa), the BBC, Arabia Magazine, Asahi Shimbun, Channel 4, Canadian Broadcasting Corporation and others. His opinion pieces were taken seriously by the British establishment.

A larger-than-life character with a wicked sense of humour, Fuad loved young people and did much to mentor them. Entrepreneurial and a capable networker, he put together many seminal events, such as the grand national celebration of the Prophet's birthday, "Uniting for the Prophet", at the Wembley Arena in May 2005.

Fuad Nahdi was a catalytic figure who helped to inspire a confident, outward-looking, progressive, and yet cosmopolitan British Islam.

He had been ill for several years and was among the first of the Muslim community's elders to be diagnosed with the Covid-19 infection.

Such then are the bare bones of an amazing life. But I wanted to follow up on this skeletal note with a more personal and considered remembrance, as the hastily-formulated briefing I wrote and sent out does not do justice to the unquantifiable scope of Fuad's varied contribution to British Muslim life, to what he meant to me personally or to his significance in the history of Islam in Britain. I attempt to rectify this somewhat by offering some reflections here, with a focus on Fuad and Q-News. It certainly does not attempt to capture the whole of Fuad's complex and multifaceted life, but only my memories and reflections of him, peppered with some of those who worked with him on the magazine.

\section{How I Got to Know Fuad Nahdi}

I first met Fuad and Humera through my marriage to Fozia Bora in 1997; they joked that it was the first $Q$-News marriage, as we had met while she was on a journalistic assignment. Before the wedding, I went to their home in Wembley for an evening interview. Ostensibly, they were going through a marriage contract they had drawn up for us. They were concerned that this contract should reflect higher Islamic values — not just the legalities of wedded life-informed by an egalitarian ethos of mutual respect and care, which they palpably embodied in their own marriage. They were equals, and as such were unafraid to air their own differences on issues of the day before guests around their famous dining room table of hospitality and conversation in Wembley (see Figure 1). In retrospect, it seems obvious to me now that Fuad and Humera were making sure that one of their protégés at Q-News had picked a safe bet. Later on, Fozia's younger brother, Musab, would marry another Q-News editor in Shagufta Yaqub in 2002, which strengthened my connection to Fuad's circle. 


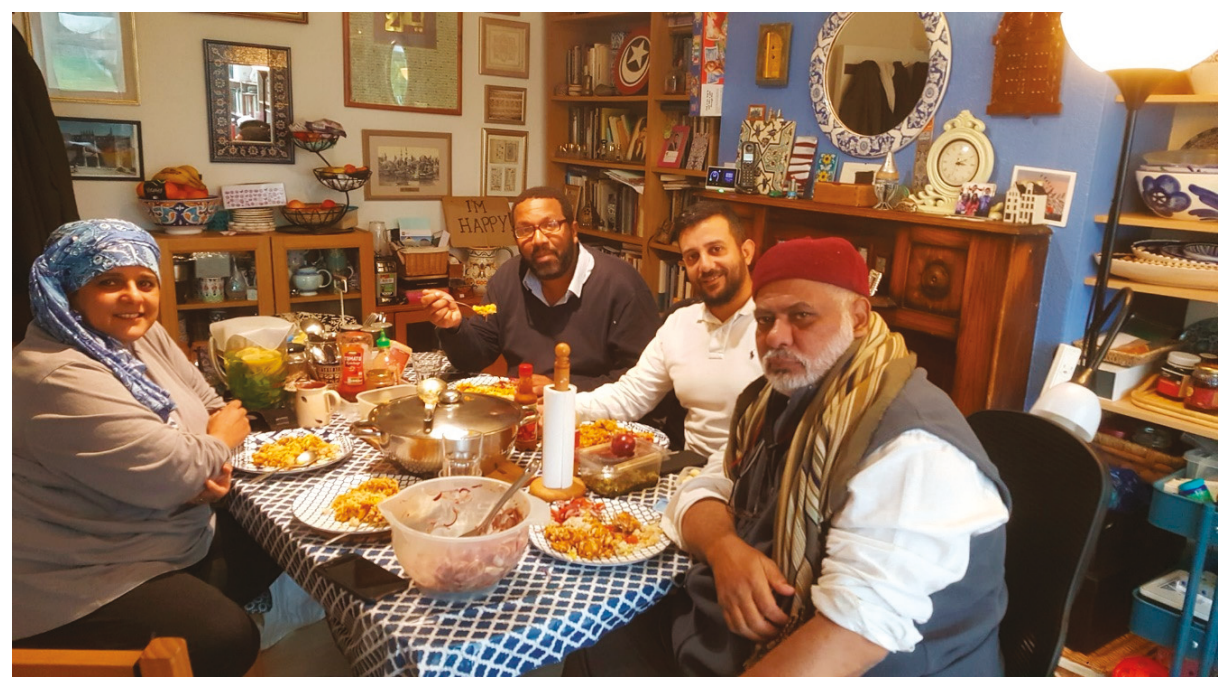

Figure 1. Humera Khan (far left) and Fuad Nadhi (far right) hosting guests around their famous dining table at their Wembley home, well-known for great food and good conversation, in 2018. With them is Ismail Lea South (centre) of the Salaam Project and, to the right of him, Shuaib El-Nahla of Rumi's Cave. (Photo courtesy of Ismail Lea South.)

Like so many others, I was quickly adopted into Fuad and Humera's extended family—really a microcosm of the creative vanguard of the umma (the global Muslim community). Fuad, with typical generosity, threw himself into organising entertainments at our wedding celebration, including munshidin (singers of devotional odes) from the Sudan and Bosnia, and we were honoured to have him act as our master of ceremonies, looking stately in a gorgeous blue Nigerian kaftan (see Figure 2). Fuad encouraged me, as he had so many others, to write my first published comment pieces and reviews for Q-News (from 2000) and I contributed to the magazine thereafter. We saw less of Fuad and Humera than we would have liked once we moved north from Oxford to Leicester and then later to Ilkley in West Yorkshire, but—as many others have attested—he had a gift for friendship and once he accepted you into his circle, he would neither forget you nor allow you to drift away.

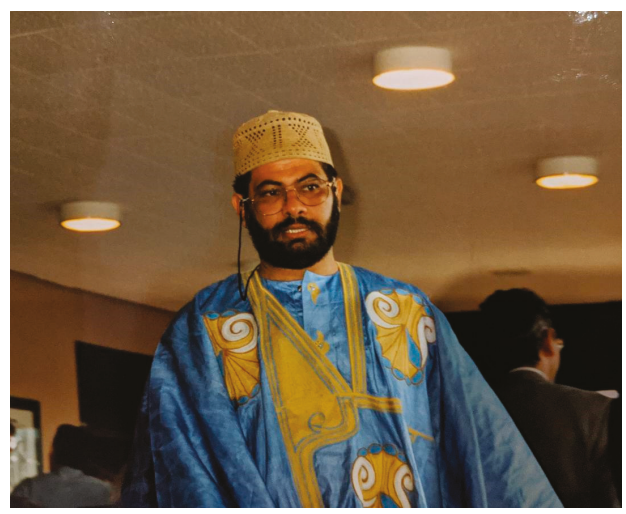

Figure 2. Fuad Nahdi, officiating at the wedding of Yahya Birt and Fozia Bora in 1997, with his usual style and aplomb. (Author's collection.) 
When Fuad would call me up out of the blue, with that inimitable Kenyan accent, saying, "As-salāmu alaykum, Yahya. It's Fuad," I always wondered what kind of trouble I'd gotten myself into. Famously, Fuad wasn't someone whom you wanted to be on the wrong side of an argument with. He wasn't one to suffer foolishness lightly. What had I done to provoke his ire? What had I written or said?

Equally, he could just as easily be ringing to ask for my comments or feedback on a piece he was drafting for the press or to chew over the latest cause célèbre in the Muslim community. He was always warm and personally generous. He loved to catch up with your news, pass on his news, his latest idea or project, or chew over what was going on in British politics, in the Muslim community nationally or around the world.

\section{Q-News: A Brief History}

In terms of expressing Islam in a British idiom, Fuad embodied the outlook that he put forward in Q-News, and its short-lived precursor, MuslimWise (est. 1988), a satirical monthly inspired by Private Eye. Q-News started out as a news-driven weekly with its first issue on 3 April 1992 (see Figure 3), but in later years it became a glossy monthly magazine with longer features (see Figure 4). It was always targeted at young Muslims, so to cater to them, Fuad mentored a young British Muslim team, passing on his considerable skills in journalism, public relations, community organising and event management. This cohort of young Muslim journalists then went on to help define the outlook of their generation that came of age in the 1990s-Fareena Alam, Faisal Bodi, Fozia Bora, Zeeshan Khan, Abdul-Rehman Malik, Roshan Salih, Shagufta Yaqub, Saba Zaman and many others.

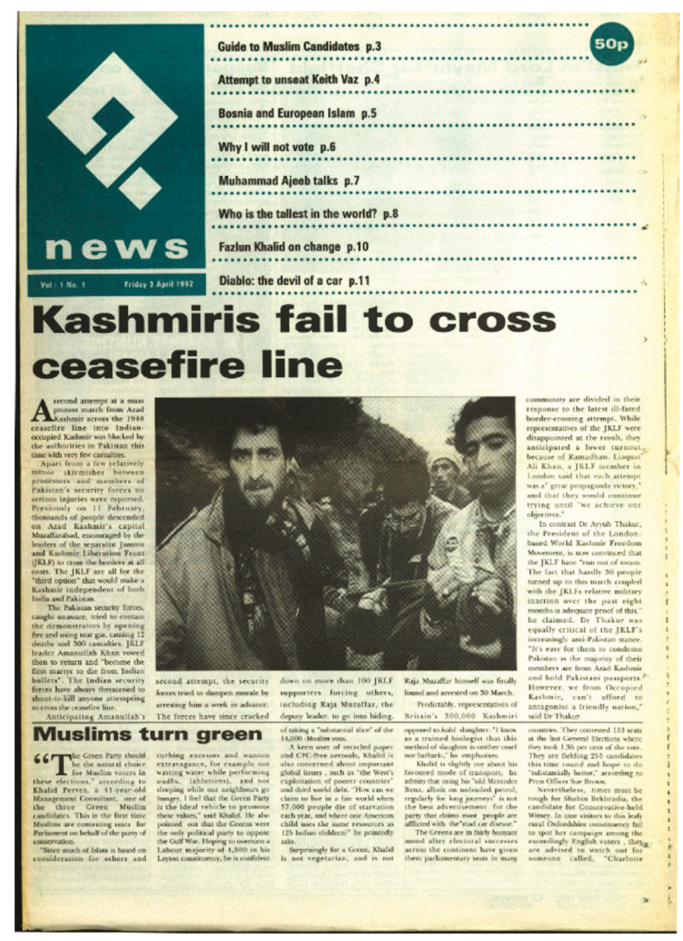

Figure 3. The first issue of $Q-N e w s$, then a weekly newsmagazine, published from London on 3 April 1992. (Image courtesy of the Convergence Trust.) 


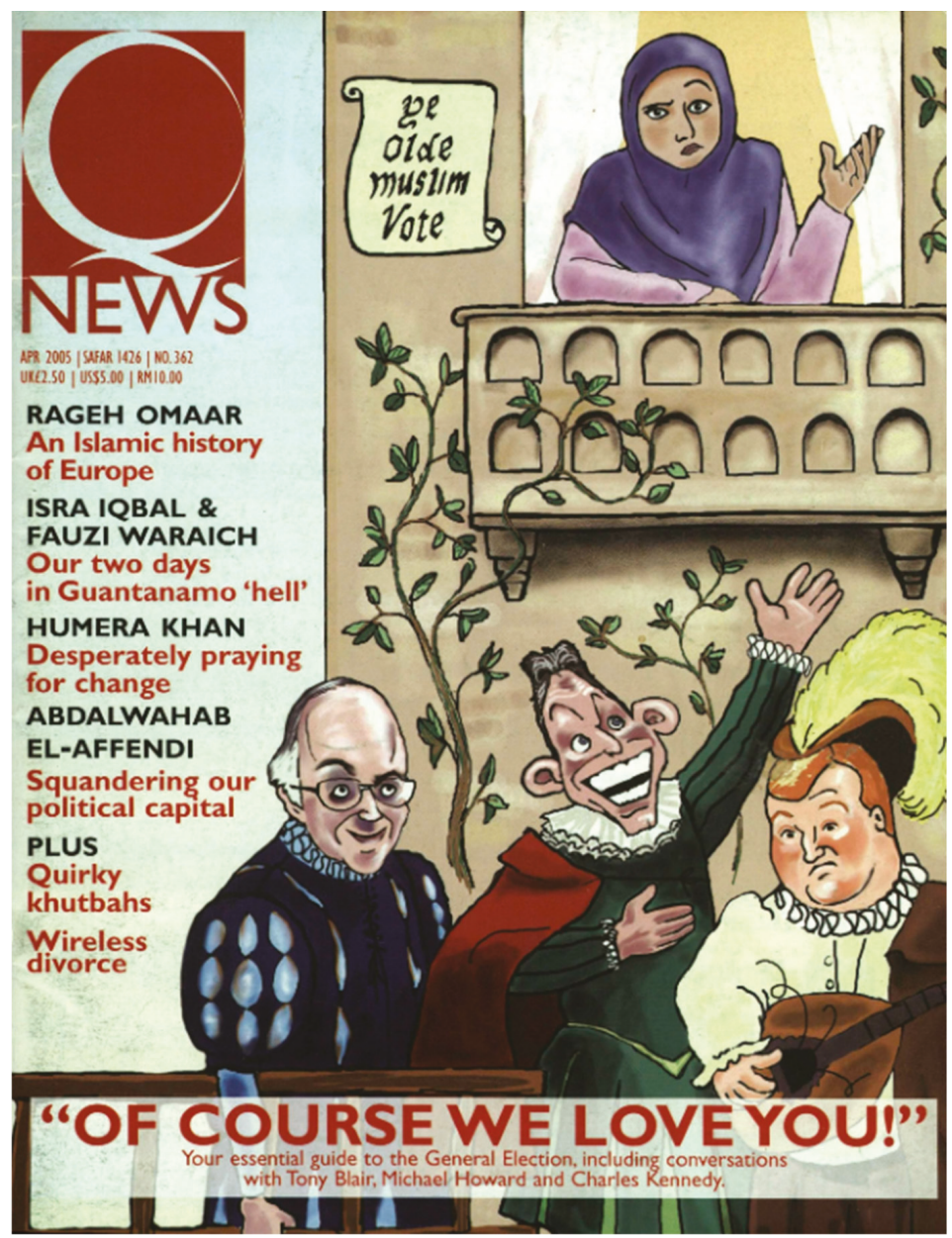

Figure 4. A cover of $Q$-News in its later years, when it had become a glossy monthly magazine with longer feature articles. This is issue No. 362, from April 2005, covering the general election campaign of that year. (Image courtesy of the Convergence Trust.)

With Q-News moving beyond beards, hijabs and halal meat (an early tagline), Fuad wanted to identify positively what it meant to be Muslim and British long before it became fashionable or even commonplace, as it is today. Fuad as a person and $Q-N e w s$ as a publication could be summed up in four ways: as progressive, cosmopolitan, attentive to context, and respectful but never deferential let alone obsequious towards religious and political authority. For Fuad and $Q$-News, being respectful included being unafraid to be maverick, even contrarian or satirical at times, and standing outside any easy or cosy consensus when it was necessary.

When Q-News was launched as a weekly newsmagazine, its location near Oxford Circus reflected both its quirky Britishness and its connection to the affairs of Muslims worldwide. Its busy offices at 44 Conduit Street were sandwiched between the flagship store of the famed British fashion designer associated with the punk movement, Vivienne Westwood, and the Embassy of Bosnia-Herzegovina on the second floor-and this was during the Bosnian War of 1992-1995. The office was dank and dingy, Faisal Bodi recalls, with no hot water, filled with old Macs and fan heaters to stop the staff freezing in 
the winter. The state of its finances was so parlous that the staff didn't know if they would get paid from one month to the next. But that didn't matter, Bodi says, because the staff "believed in the vision and mission of $Q$-News, it almost inspired you more because it was a smaller struggle within a bigger and wider struggle." In Bodi's view, that vision and struggle was to give an independent voice to young second-generation British Muslims, distinct from the vernacular and cultural Islam of parents or the competing currents of Islam on offer to young Muslims in the large cities.

Ibrahim Hewitt, who came to work at Q-News as a sub-editor for two weeks and stayed for six months, recalls that Fuad ran a relaxed office that became increasingly frenetic as publication day loomed. Instead of finishing at 5 or 6 pm on press day, the staff would often find themselves putting the magazine to bed in the early hours or after an all-nighter. Faisal Bodi prefers to describe it as "organised chaos", remarking that "it was only the sense of purpose and belief in what we were doing that made it work." With the frenzy that came with putting the issue to bed, Fozia Bora, then a features editor at the paper, recollects that a huge picnic lunch would be assembled, consisting of baguettes, hummus, and cherry tomatoes, to keep tired brains ticking over and keyboard fingers nimble. "It was enjoyable," Bodi recalls, "and there was a great sense of camaraderie. It was fantastic. I loved it."

Even in his radical student days, Fuad was never one to fall into any single camp, defying easy pigeonholing - he had posters of both Mao and Khomeini hanging up on his college room door. Q-News would reflect this nonconformist spirit with its agenda-setting coverage on issues of Islamophobia and race, the Bosnia conflict and many others.

For Bodi, it gave a voice to a Muslim community that was voiceless, poorly understood and demonised at the time. $Q$-News articles were commonly cited in the national press. Fleet Street editors would often call up for the staff's perspectives on the news of the day. It was not that the magazine had the resources to pursue scoops-rather, its value lay in the fresh and new articulation it gave to British Muslim perspectives and priorities on current affairs.

At $Q-N e w s$, Fuad and his young team worked to define a new expression of Islam in Britain, revolutionary at the time-the early 1990s-but perfectly timed to meet the needs of this second generation that was coming of age and finding its feet. How much we could still do with a Q-News now; it has often been sorely missed since it ceased publication in 2006.

The particular Islam that Q-News sought to nurture in Britain was urbane, reflective of Islamic diversity in Britain, intent on building a new sense of Muslim solidarity, and attuned to British cultural idioms. In that sense, the newsmagazine captured the zeitgeist of nineties British Islam, a decade now all-to-often only recalled for birthing extremism. But for those of us who lived through it as adults, the radical nineties was a decade of unfettered creativity, freedom and political incorrectness, which is now deeply missed, living as we do with a securitization of British Muslim cultural and intellectual life that has paralysed us over time like a slow-motion car-crash we cannot escape.

The veteran activist Massoud Shadjareh recalls Fuad in those years:

Fuad Nahdi and his career should be looked at in the round. Foremost, he was a journalist and activist, acting as a genuine alternative voice of Muslims. His true work dealt with issues like the Rushdie Affair, Bosnia, Islamophobia and Muslim identity. His ability to work with and recognise the Muslim community as a whole made him pan-Islamic.

It should also be remembered that $Q$-News was the first British Muslim periodical to centre the voices, concerns, thoughts and agendas of Muslim women-and this was driven by the tireless and pioneering activism of Humera and Khalida and Aisha Khan, the women who had founded the Muslim gender equality organisation, the An-Nisa Society, established in May 1985. It was also the second British Muslim periodical to appoint a Muslim woman as editor: Shagufta Yaqub, in 2000; Sarah Joseph preceded her at Trends in 1994.

Yaqub, who edited the magazine between 2000 and 2003 (see Figure 5), recalls that the magazine's nonconformism and independence left $Q$-News with its fair share of detractors, determined to prove it was a front of some kind: 
Nobody could quite place $Q-N e w s$. The conspiracy theories about who was funding us or what our secret agenda was were hilarious - as was the speculation about what $Q$ really stood for. In reality, we barely had any funds and certainly no blind loyalties. Fuad gave me the freedom to publish articles he disagreed with and then publicly defended my right to publish them. Those who weren't used to a free media couldn't get their heads around this. Nor did some of the older male Muslim leadership of that era like being held to account by a young female-led magazine backed by a strong and irreverent character like Fuad.

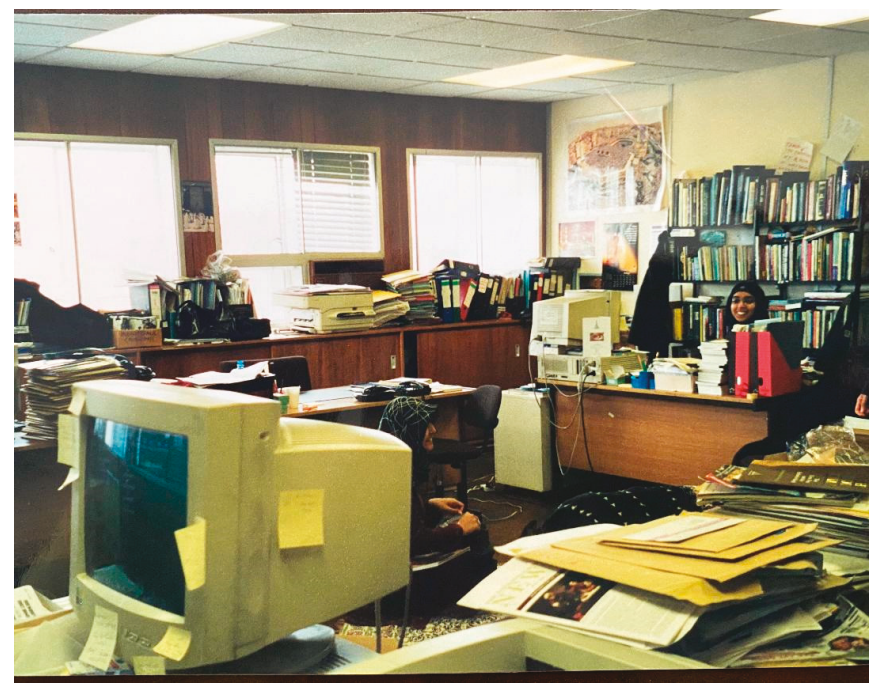

Figure 5. Shagufta Yaqub, Editor of Q-News between 2000-2003, at her desk in the Dexion House office in Wembley with Fareena Alam, News Editor, seated, packing the magazines for subscribers. The Muslim Council of Britain later moved in down the corridor in the same office block. (Photo courtesy of Shagufta Yaqub.)

\section{A Son of the Indian Ocean Forging Cosmopolitan British Islam}

Fuad was a true citizen of the world, a son of the Indian Ocean, sired of those ancient maritime circuits that Islam linked through religion and trade from East Africa, Southern Arabia, India to Southeast Asia. Born in Arusha, Tanzania, and growing up in Mombasa, he had Yemeni-Indonesian ancestry, and later married Humera in 1989, herself of British-Pakistani heritage, six years after moving to London. He and his family embodied globality, something much augmented by his tireless community organising and journalism that took him around the world many times. In his very bearing and person, Fuad was an argument against all kinds of parochialism. He wanted Muslims in Britain to embrace their biryani-like richness, to recognise and acknowledge each other's unique flavours and to marinate together to cook up something beautiful and new. ${ }^{1}$

Fuad was schooled in the scholarly and spiritual traditions of the Bā-'Alawiyya of the southern Yemen, a lineage of pious and holy men descended from the Prophet Muhammad (sādāt), famous for their historic role in spreading Islam in many countries over the centuries (see Figure 6). His spiritual mentor was the famed Habīb Ahmad Mashhūr al-Haddād (1907-1995). Fuad was at the forefront of the first culturally impactful wave of the Bā-'Alawiyya in Britain in the early 1990s, along with Shaykh Abdal Hakim Murad (Dr Timothy J. Winter) (see Figure 7).

1 Biryani is a South Asian Muslim dish that combines cooked rice with spiced vegetables or meat. 


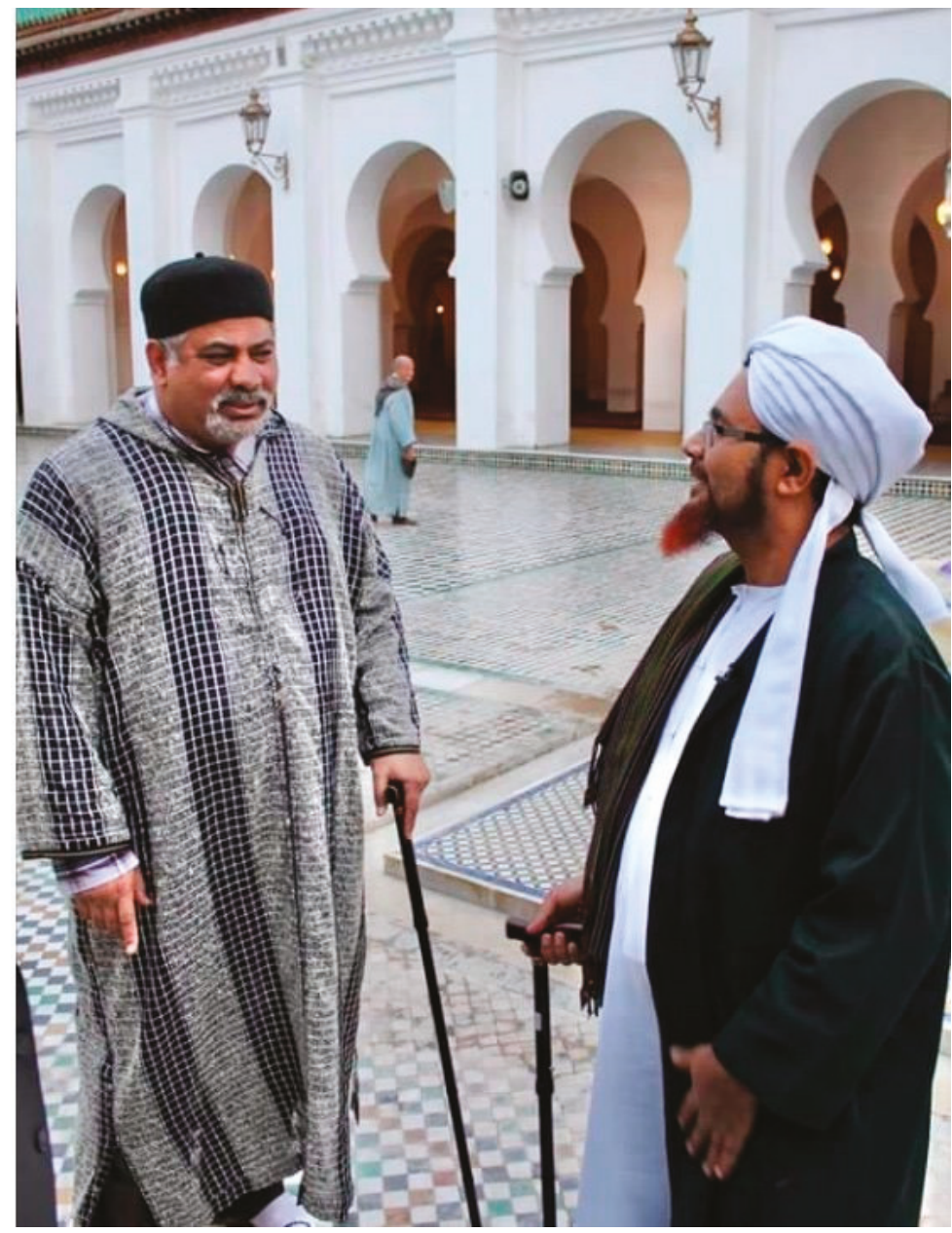

Figure 6. Fuad Nahdi (left) with Habīb Umar ibn Hafīz (b. 1963, right), Dean of Dār al-Mustafā in Tarīm, Hadramawt in the southern Yemen. (Photo courtesy of Shaukat Warraich.) 


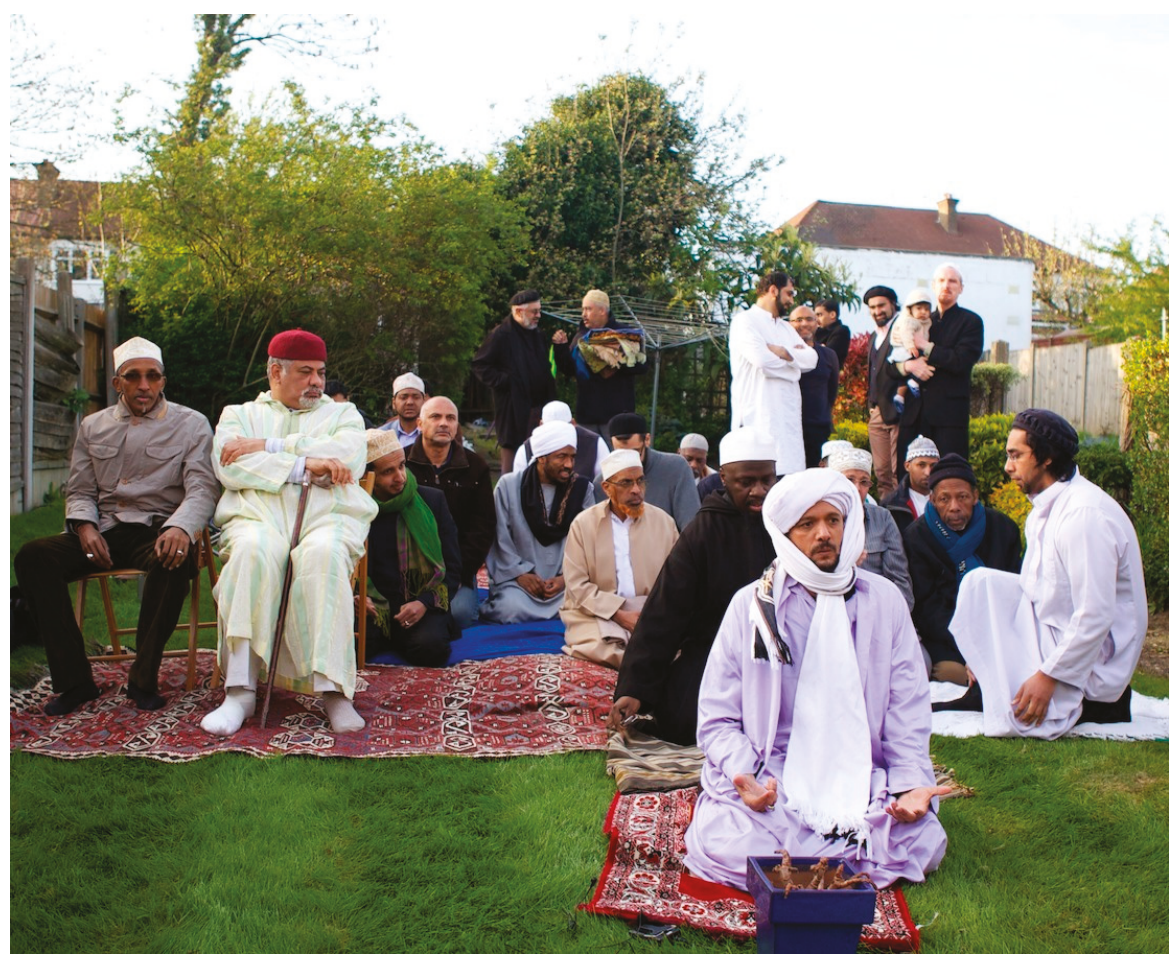

Figure 7. Prayers in Fuad Nahdi's back garden at his home in Wembley, circa 2014, with members of the Bā-'Alawiyya and other close friends. (Photo courtesy of Nadir Nahdi.) ${ }^{2}$

Fuad was always attentive to centring the early British converts to Islam like Muhmmad Marmaduke Pickthall (1875-1936) and Quilliam, just as he was to all converts to Islam whom he knew, drawing them closely to him as mu'allafat al-qulüb (those whose hearts must be drawn closer or reconciled). He was among the first to look at Shaykh Abdullah Quilliam's Crescent, the first Muslim newspaper to be published in Britain between 1893-1908, in the British Library and at one point considered doing a doctorate on him, wanting to think through how British Muslims could relate to the legacy of the early converts, and how it could be furthered today.

2 Habīb Kāzim Saqqāf (b. 1967) leads the prayers, who first began visiting Britain in 2007. The Habā'ib, the religious leaders of the Bā-'Alawiyya, when visiting Britain would often pay their respects by visiting Fuad at his home.

Front row (L to R): (1) Omar "Omareeto" Sayid, a British-Somali Qādirī devotee (2) Fuad Nahdi, (3) Sh. Ibrahim Ossi-Efa, co-founder of the rihlas (neotraditionalist educational retreats) in the West, and the regular host of Habīb Kādhim in the UK, sat directly behind Habīb Kāzim.

Second row (L to R): (1) Sayyid Tahir Bunumay, grandson of Habīb Umar ibn Sumayt, with a green scarf, (2) Sayyid Shams al-Haddād, Kenyan-born, London-based, with the henna-dyed beard, (4) Sh. Muhammad Mlamali Adam (d. 2019), Zanzibari intellectual and editor of Africa Events, a close mentor of Fuad's in London, with a blue scarf.

Third row (L to R): (1) Tariq Khan, Fuad Nahdi's brother-in-law, (2) Sh. Babikr Ahmed Babikr, British-Sudanese Sam'ān̄̄ Sufi shaykh and Director of Rumi's Cave, (3) Wael Zubi, British-Libyan translator for the Habā'ib, partially obscured behind Sayyid Shams al-Haddād.

Standing at the back (L to R): (1) Edris Khamissa, South African educationist, (3) Shahid Hanif, Cambridge Central Mosque project volunteer, (4) Dr Mustaqur Rahman, (6) Sauqab Ashraf, Blackstone Architects, (7) Sh. Abdal Hakim Murad, Dean of Cambridge Muslim College and Shaykh Zayed Lecturer in Islamic Studies at University of Cambridge, holding baby Ibrahim Hanif. (Photo by Nadir Nahdi.) 
At the same time, he was opposed to the argument of some white converts that Islam can only be authentically British if it is defined by them (Birt 2017b, pp. 142-48). He understood that while white converts were an integral part of enculturing Islam, the faith was always going to be generous and inclusive rather than parochial in Britain, a sum greater than its parts, an outcome to be carefully cultivated and nurtured. For Fuad, Islam in Britain was not something to be dishonoured and diminished by exclusivist white British ethno-nationalism or smothered by revanchist ethnocultural expressions of Islam from Asia, Africa or the Arab world. It had to resemble biryani or kushari more than mushy peas. ${ }^{3}$

In his work, Fuad formed important partnerships with converts like Ibrahim Hewitt, Daud Rosser-Owen, Yusuf Islam, Abdul-Azeem Saunders, Abdul-Lateef Whiteman, Martin Abū Bakr Sirāj al-Dīn Lings (1909-2005), Hasan le Gai Eaton (1921-2010), and_in a sustained way-with Shaykh Hamza Yusuf, Shaykh Nuh Keller, Dr Umar 'Abd-Allah, Imam Zaid Shakir, Shaykha Halima Krausen, and, in the deepest way, with Shaykh Abdal Hakim Murad (see Figure 7), who was also close to Habīb Ahmad Mashhūr al-Haddād. When Abdal Hakim returned from his studies in the Arab world, he and Fuad would support each other on many projects over the next thirty years.

Besides the spiritual influence of the Bā-'Alawiyya, another important early set of influences on Fuad was at the University of Nairobi studying economics, where he picked up an abiding love of nonconformist political activism; he was arrested for his role as a leading student protestor against Kenyan president Daniel arap Moi (1924-2020). He ran the Muslim student association there and started a student newspaper. It was an intellectually important time at the university in those days: key figures included the famous Kenyan novelist Ngugi Wa Thiong'o, who taught English Literature to Fuad, and the Marxist political scientist Ahmed Muhiddin, who also advised Julius Nyerere. Other important journalist-cum-activist mentors for Fuad after he came to London to study journalism were the political scientist and former-Guardian writer and sub-editor Dr Kalim Siddiqui, founder of the Muslim Institute in London in 1974, who had relaunched Crescent International in 1980 as the "newsmagazine of the global Islamic movement" (see Figure 8), and Zanzibari intellectual and ex-BBC journalist Mohamed Mlamali Adam, who edited the political monthly, Africa Events (see Figure 7). Fuad wrote and worked for both periodicals in the 1980s. (Bakari 2020; O'Sullivan and Malik 2020).

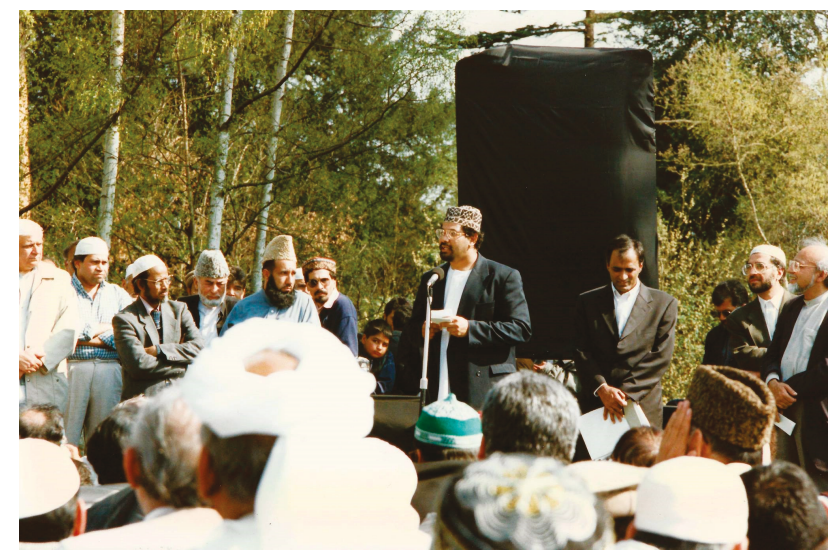

Figure 8. Fuad Nahdi (centre) speaking at the funeral of Dr Kalim Siddiqui (1931-1996), who mentored him in both journalism and political activism when he first came to Britain. (Photo courtesy of Muhammad Ahmedullah.)

3 Kushari is an Egyptian dish, combining Italian, Indian and Middle Eastern elements, bringing together rice, lentils, and macaroni. 


\section{Respect and Irreverence towards Religious and Political Leadership}

Fuad demonstrated how to be respectful towards authority, religious or political, without ever being obsequious or deferential. He was like this with everybody. He was a singular personality with an infectious sense of humour, charm and warmth that did not mask his underlying seriousness of purpose. Whether it was renowned shaykhs, archbishops or chief rabbis, leading politicians, civil servants or diplomats, Fuad was always himself. If he felt that something was nonsensical or ill-advised, he would say so. But not in a way that alienated people, for, with Fuad, it was always criticism with love, with concern, with compassion.

Fuad was the opposite of a hypocrite. He never liked to attack from behind; rather, if he had to criticise you for something then his preferred method was the frontal attack. Face to face, as befitted his ancestry, which Fuad traced back to the Nahdi Tribe of the Southern Yemen, who acted as protectors to the peoples of the Hadramawt Valley. Such then was his intent in protecting upfront what he saw as the best interests of his community or society at large. Yet behind the charm and humour lay a steeliness towards those whom he thought threatened those interests. Fuad's old colleague, the human rights campaigner Massoud Shadjareh, reflects upon these qualities when he observes, "I worked with him on many projects and sometimes we fundamentally disagreed with each other but this didn't impact our brotherhood and friendship negatively."

He loved being around people. After Friday Prayers in Wembley, he would have a kebab and a chat with local Muslims there. His corner of northwest London-Wembley, and more generally Brent-was a nexus for the cutting edge of Islam in Britain in the late 1990s. The Muslim Council of Britain and Q-News shared the same office block. Fuad would, despite their rivalries, lend the Council his interns. His neighbours included figures like the exiled Saudi dissident Muhammad al-Mas'ari, Massoud Shadjareh and Arzu Merali of the Islamic Human Rights Commission, Sarah Joseph and Mahmud al-Rashid of the Islamic Society of Britain and Emel, Dr Abdul Wahid of Hizb-ut-Tahrir UK, and, of course, Humera, Khalida and Aisha Khan of the An-Nisa Society, among so many others. Intellectuals important to the articulation of this new zeitgeist like Tariq Modood and Salman Sayyid also had longstanding connections with Brent.

Behind the scenes in Fleet Street and Whitehall, Fuad fought a patient rear-guard battle against the maligning of Muslim organisations and individuals, even some of those who were his rivals, saving them when he could from some of the worst savagery that the national press could dish out. But, of course, that was a lonely struggle and a losing battle in the end, because of the post-Murdoch tabloidization of British newspapers, and the effective merger between government spin and the 24-h rolling news media machine.

Fuad was the finest political tactician of his generation in the British Muslim communities. He was always about three to five steps ahead of anybody else in the Muslim community, and, lacking the support networks and resources of the established Islamic revivalist movements, relied instead on his own agility and wits to stay ahead of the curve. It is no surprise that he was a trusted mentor to anyone in the next two generations of British Muslim community organisers who were coming through the ranks. His tactical acumen and sagacity were invaluable for young, ambitious Muslim activists who were navigating the choppy and dangerous waters of British public life for the first time. Fuad always gave freely of his time, despite, as his son Nadir has remarked, the serious illnesses he had to contend with in later life. He gave so much of himself but hid his own grave underlying health issues for the last thirteen years of his life, diverting well-wishers when he was laid low in hospital with a smile, a joke or a well-deserved bit of admonition.

Let me share an example of Fuad's political nous. After the 7/7 attacks of 2005, the Blair government put together a consultation, "Preventing Extremism Together", that September with the Muslim community, comprised of the activist circuit and its own Labour Party contacts. Typically, Fuad was aware from the beginning that the government was uninterested in the myriad suggestions that Muslims would come up with about Islamophobia, foreign policy, youth issues, or media bias (not that these weren't important in their own right). But, being the informed realist that he was, 
Fuad knew the government was only really interested in what we British Muslims would do in our own communities to address political violence and how they could best support it. So, it was unsurprising that Fuad's Radical Middle Way became one of the three New Labour government's flagship projects to emerge directly after the London attacks, and before Prevent became an established policy.

However, it would be falsifying history to portray Fuad as a government patsy. Far from it. Civil servants and SPADs (Special Political Advisors)—so often used as gatekeepers by ministers-would think twice about getting in his way. How typical it was of Fuad to try and reclaim the term "radical" positively so early on, and to work behind the scenes to negotiate hard for the project's independence from Whitehall interference.

It is noteworthy that as soon as its autonomy was threatened, Fuad moved the Radical Middle Way away from any UK government funding streams in 2011, just after the Conservative-led Coalition came to office. He knew when to engage and when to disengage; in his last decade, he focused his attention abroad on Islam outside the Arab world and at home on interfaith. As Abdul-Rehman Malik, who knew him as well as anyone, observed shortly after his death, Fuad came to believe in later life that renewal would come not from the shattered twenty-first-century heartlands of Islam, but from its peripheries where Islam's cumulative tradition had not been disrupted in regions like West Africa or Southeast Asia in partnership with the Muslim communities of the West. He dubbed his envisioned alliance a crescent of hope.

Over these last ten years, when I worried aloud to him that the perception of compromised collaboration with state soft power would trump his good intentions and safeguards, and that focusing too much on theological correction diverted us from some of the real issues we faced, Fuad always gave me a courteous hearing. Yet he stayed true to his modus operandi of principled yet savvy engagement and shifted his field of endeavour when he felt his independence might be threatened.

Fuad honoured and respected the shuyūkh (authorities in Islamic moral education and spiritual guidance) and the ulama (the class of Muslim scholars specialised in Islamic theology, jurisprudence and other scholastic disciplines) in their role as inheritors of the prophets, as befits the Bā-'Alawiyya tradition that he came out of. Yet, at the same time, he always could be frank with the shuyūkh, in ways that would never come easily to British Muslims brought up in traditions of deference and sometimes of unquestioning loyalty. Fuad would always prefer honesty with respect over disquiet with deference. He could be blunt with the shuyūkh when he felt they had stepped out of their lane of religious learning and were opining on some other matter they knew little about, whether it was public relations, or media, or the British political situation. He trusted his own counsel, his own insights, his own experience in navigating these domains for the benefit of British Muslim communities-and rightly so. At the same time, he gave the ulama full respect for their competence and expertise in the religious sciences.

He demonstrated how to have an adult relationship with learned religious authorities in Islam, which is not meant to be obsequious or unduly deferential but should be a relationship of mutual respect, mutual learning, and the sharing of expertise and experience in pursuit of the common good in any challenge facing Muslim communities. In short, it should be a collaborative relationship based on benefitting from each other in positive ways, casting aside either vituperative disowning of the ulama and their learned tradition or alternatively a childish obsequiousness that encourages mediocrity, complacency and moral cowardice in our religious scholars. Fuad was an exemplar to me in how he walked this fine line.

After the Arab Spring, we shared our profound disappointment at our teachers and their loyalist activists and students who sided with the counter-revolutionary monarchies and republics trying to crush democracy at birth. But, unlike me, Fuad judged that it was better to offer private counsel. He always respected my decision to go public with my criticisms (Birt 2017a), even if he went through its contents and its reception with me after publication with a fine and exacting toothcomb. I would have expected nothing less of him.

Fuad had the social confidence and ease to be with leaders or the people, and be just the same, just like Malcolm X or Kalim Siddiqui. He was singular in that way, and as such he made a doughty 
champion for the British Muslim community in the corridors of power. He stood out for his confidence, ease and flair in a generation of community organisers who were often awkward and stolid, oscillating between reaction and obsequiousness in their dealings with government. His assurance, aplomb and style were qualities that younger Muslims could relate to and be inspired by. He gave us hope that the future could be different and could be better.

May Sidi Fuad rest in peace, may God forgive him, and grant him the company of the martyrs, the righteous, the veracious and the prophets in Paradise. And may God's blessings be upon the Beloved our Master Muhammad and his family, whom Sidi Fuad loved and honoured and served. And may God give us the ability to build upon Fuad Nahdi's vast legacy for our own welfare and benefit, and for his everlasting and perpetual reward in the Hereafter. Āmin.

Funding: This research received no external funding.

Acknowledgments: I would like to thank Sophie Gilliat-Ray and Riyaz Timol for approaching me to put this obituary into their special issue on "Leadership, Authority and Representation in British Muslim Communities". Special thanks should go to Faisal Bodi, Fozia Bora, Shagufta Yaqub, Humera Khan, Massoud Shadjareh, and Abdul-Rehman Malik for sharing their memories of Fuad and Q-News; Fozia Bora and Shagufta Yaqub for editing earlier drafts; and to Muhammad Ahmedullah, Shagufta Yaqub, Ismail Lea South and Nadir Nahdi for sharing their photographs.

Conflicts of Interest: The author declares no conflict of interest other than a deep love for the late Sidi Fuad Nahdi, may God have mercy on him.

\section{References}

Bakari, Mohamed. 2020. Fuad Nahdi: An Appreciation. Hekaya Arts Initiative. April 14. Available online: https://hekaya.co.ke/2020/04/14/fuad-nahdi-an-appreciation/ (accessed on 16 April 2020).

Birt, Yahya. 2017a. Blowin' in the Wind: Trumpism and Traditional Islam in America. Medium. February 14. Available online: https://medium.com/@yahyabirt/https-medium-com-yahyabirt-blowin-in-the-windtrumpism-and-traditional-islam-in-america-40ba056486d8 (accessed on 16 April 2020).

Birt, Yahya. 2017b. Preachers, Patriots and Islamists: Contemporary British Muslims and the Afterlives of Abdullah Quilliam. In Victorian Muslim: Abdullah Quilliam and Islam in the West. London and New York: Hurst and Oxford University Press, Available online: https://www.oxfordscholarship.com/view/10.1093/oso/ 9780190688349.001.0001/oso-9780190688349-chapter-009 (accessed on 17 April 2020).

O'Sullivan, Jack, and Abdul-Rehman Malik. 2020. Fuad Nahdi Obituary. Guardian. April 1. Available online: https://www.theguardian.com/world/2020/apr/01/fuad-nahdi-obituary (accessed on 16 April 2020).

(C) 2020 by the author. Licensee MDPI, Basel, Switzerland. This article is an open access article distributed under the terms and conditions of the Creative Commons Attribution (CC BY) license (http://creativecommons.org/licenses/by/4.0/). 



\section{Afterword}

\section{Ron Geaves}

School of History, Archaeology, and Religion, Cardiff University, Cardiff CF10 3EU, Wales, UK; geavesr@cardiff.ac.uk

Received: 9 October 2020; Accepted: 13 October 2020; Published: 23 October 2020

It is not possible to read the excellent articles that are contained in this Special Issue of Religions without reflecting on the development of the study of British Muslim religious life over the past 30 years. When I began my academic career in 1988, the Community Religions Project based in the Theology and Religious Studies department at the University of Leeds was beginning to explore the presence of religions that had primarily arrived in Britain through migration and were beginning to transform the landscape of British religious life. The literature on British Muslims was small, and very few scholars in the study of religion were researching "lived religions". The Muslims inBritain Research Network created by Jørgen Nielsen existed in its infancy with less than a dozen scholars. Many of the contributions in this collection have been written by scholars with a connection to the Centre for the Study of Islam in the UK, and there can be no doubt of the important contribution of the Centre to furthering the development of the study of Muslim religious life in Britain. What is notable about the studies contained in the collection is that so many have been written by British Muslims keen to own and reclaim their own narratives and to bring an emic insight to balance the rigours of etic methodology. It is also refreshing to read a significant collection of articles that engage with topical concerns of interest to government bodies, policy makers, and the media; avoid the pitfalls of securitisation in the subject area; and, in particular, avoid the posing of simple binary oppositions such as liberal/orthodox, enabling/constraining, or resistance/compliance that can often dominate public and academic debate on the topic. As stated by Liberatore (2019, p. 2), "this multiplicity and fluidity of subjectivities means that they can never be fully captured by 'strong' theoretical frameworks, binaries or the linear arguments of academic debate".

Throughout the articles, one theme that reoccurs repeatedly is that of representation, revealing a complex and creative intermingling of traditional religious authorities, individual rationalising, and the practice of Islam. It would have been easy for the authors to draw conclusions based on a binary contradiction between Islamic orthodoxies and the disruptive inroads of modernity. This trap too is avoided by the contributors. There are no essentialised, overly linear models of orthodoxy and heterodoxy in the development of Islam; instead, the authors acknowledge that it is has been the norm over the centuries for Muslim civilisations to demonstrate flexibility and transformation, as their rapid spread led to a multitude of variant localised currents that gave a local flavour. The development of diverse representation, authorities, and leaderships is not new to the 21st century minority British context, and any study undertaken of the "subjectivities" that form the religious life of British Muslims has to be undertaken from within the context of Islamic traditions reworked into the British context. As noted by Munnik (2019, p. 12), the studies suggest that "this is a normal state of affairs and one that can be absorbed in the continuum of history".

Funding: This research received no external funding.

Conflicts of Interest: The author declares no conflict of interest. 


\section{References}

Liberatore, Giulia. 2019. Guidance as 'Women's Work': A New Generation of Female Islamic Authorities in Britain. Religions 10: 601. [CrossRef]

Munnik, Michael B. 2019. Answering for Islam: Journalistic and Islamic Conceptions of Authority. Religions 10: 435. [CrossRef]

Publisher's Note: MDPI stays neutral with regard to jurisdictional claims in published maps and institutional affiliations.

(C) 2020 by the author. Licensee MDPI, Basel, Switzerland. This article is an open access article distributed under the terms and conditions of the Creative Commons Attribution (CC BY) license (http://creativecommons.org/licenses/by/4.0/). 
MDPI

St. Alban-Anlage 66

4052 Basel

Switzerland

Tel. +41616837734

Fax +41 613028918

www.mdpi.com

Religions Editorial Office

E-mail: religions@mdpi.com

www.mdpi.com/journal/religions

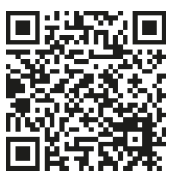



MDPI

St. Alban-Anlage 66

4052 Basel

Switzerland

Tel: +4161 6837734

Fax: +41 613028918

www.mdpi.com 